Mr. Malcolm Burn, with tor Compliments of the further.

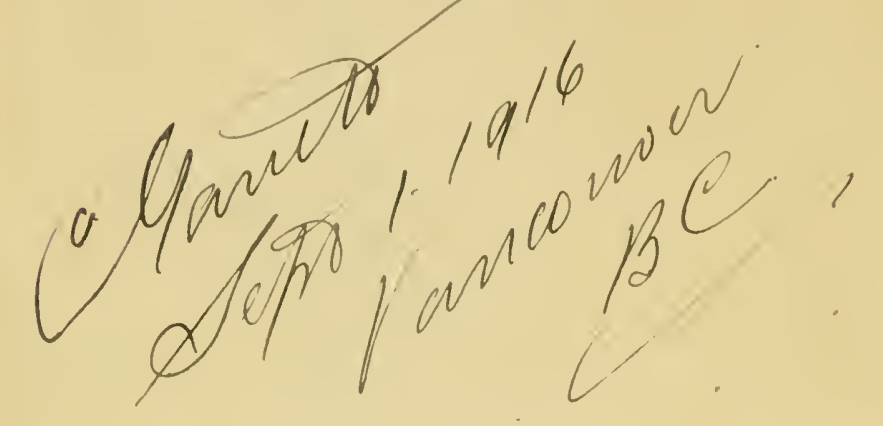





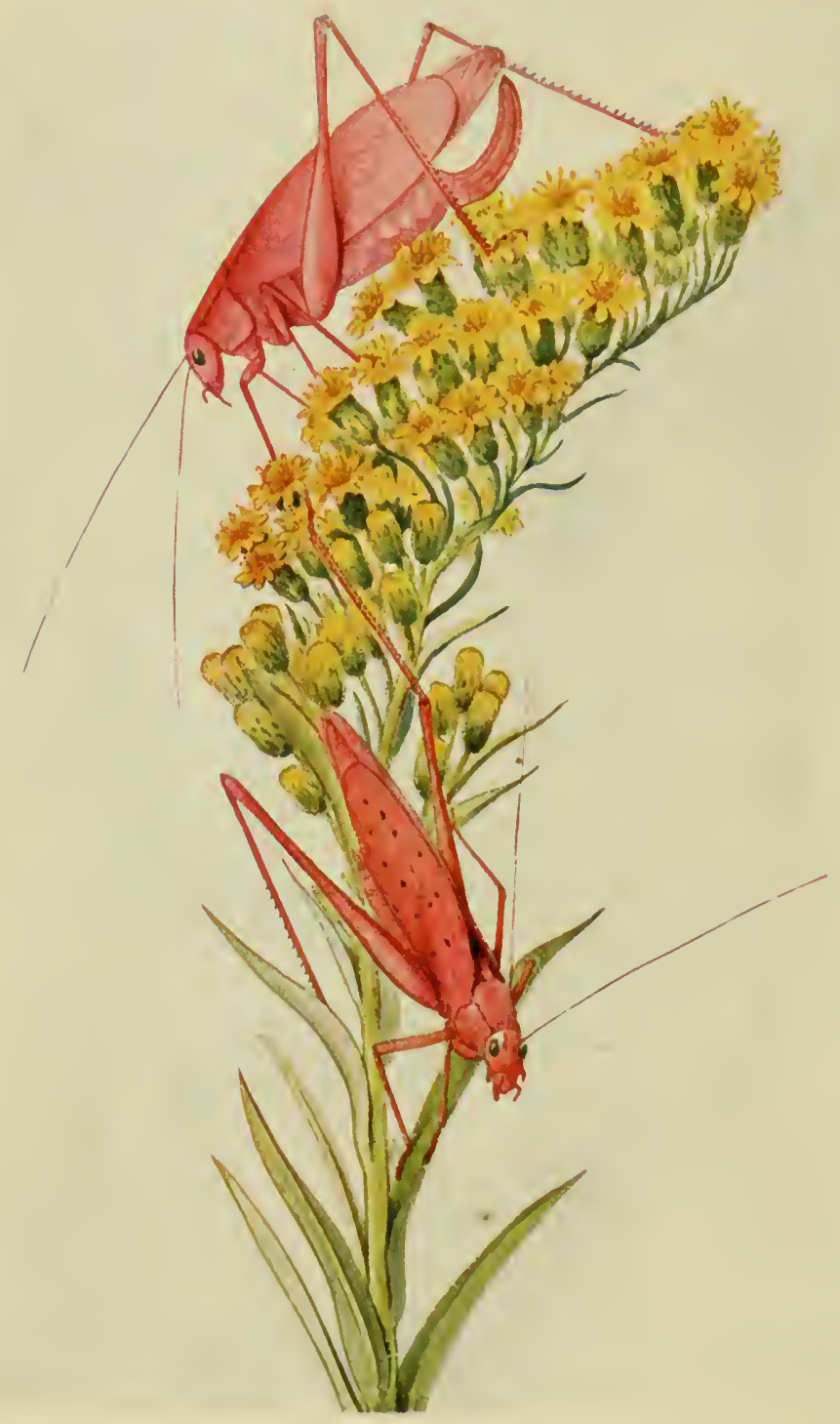

AMBLYCORYPHA OBLONGIFOLIA

PINK KATYDID. (see page 351.)

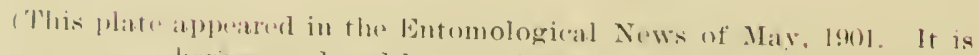
herex reproduced by permission of the Editor, 


\section{THE ORTHOPTERA OF INDIANA.}

From the 27th Annual Report of the Department of Geology and

Natural Resources of Indiana, 1902.

Author's Separates issued September 5, 1903.

BY W. S. BLATCHLEY,

Indianápolis, Ind. 

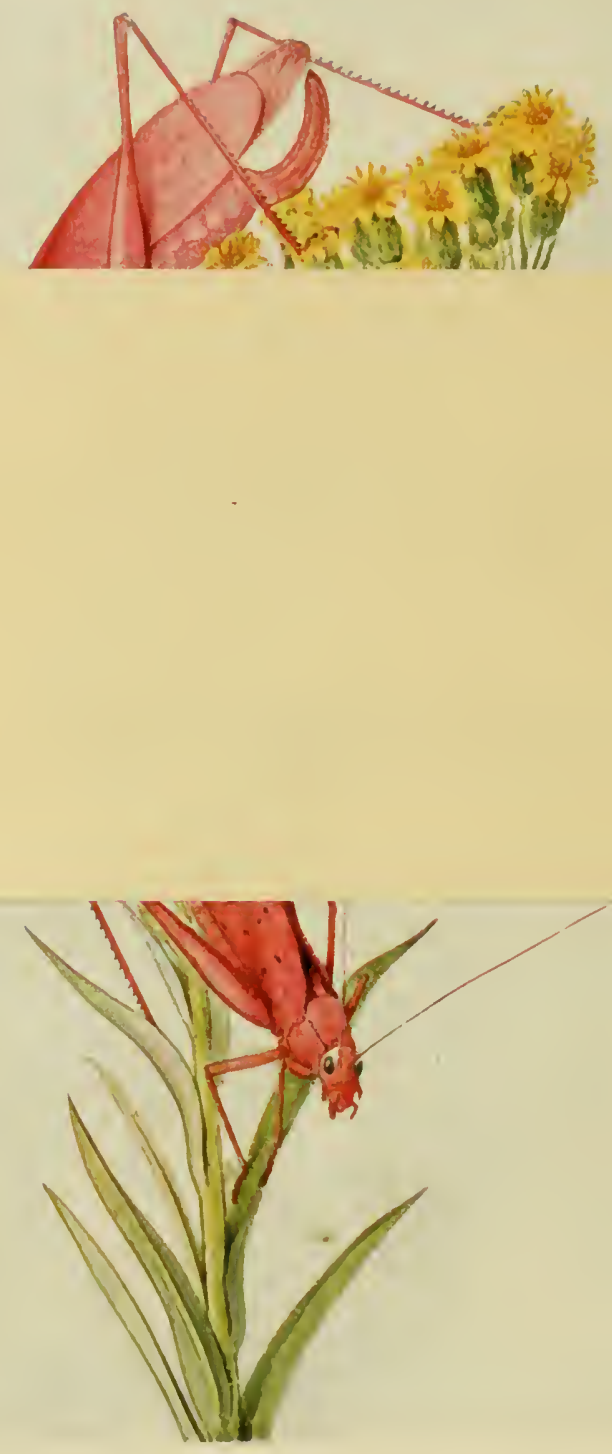

AMBLYCORYPHA OBLONGIFOLIA

PINK KATYDID. (See page 351 ,)

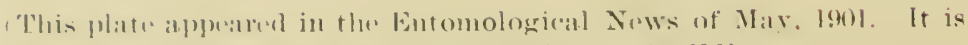
here reproduced by permission of the Editor. I 


\section{THE ORTHOPTERA OF INDIANA.}

An Illustrated Descriptive Catalogue of the Species Known to Occur in the State, With Biblography, Synonyyy and Descriptions of New Species.

\section{BY W. S. BLATCHLEY, Indianapolis, Ind.}





\section{INTRODUCTORY.}

One August evening in 1901 I was seated in the lobby of the St. George Hotel, at Evansville, Indiana, when a large "lubberly locust" -Mélanoplus differentialis Thos.-attracted by the light, flew into the room. Several of the guests, men of intelligence, saw me pick it up, and immediately surrounded me and asked me what it was. I told them that it was a locust or grasshopper, and that fifty or more species of the same family of insects occur in Indiana. All seemed much surprised and a number of them made the statement that they thonght there was but one kind of grasshopper in the State. Such is the opinion of most persons who pay little or no attention to the forms of animal and plant life which surround them. Verily, the most common things about us are those of which we know the least.

For eighteen years I have been more or less interested in that group of insects known as the Orthoptera. During that time I have collected them in the different parts of the State which I have visited and have made many notes upon their habits and their distribution. This information 1 have concluded to bring together into a form suitable for the use of the student in the public schools of the State, or for the boys and girls on the farms, who daily eome in contact with some of these interesting insects. While the information which they will gain from the study of such a group may not be of great monetary value, i. e., may not add many "almighty dollars" to the future wealth of the student, it will add to his powers of observation, upon which much of his future knowledge will depend. It may scrve to bring him in closer contact with nature, and teach him something of the mutual relationships existing between all of her objects, himself included.

The first thing which any one asks concerning a bird, an insect or a stone, is "What is it?" It must have a name-a handle-to hold it by, while we talk of its habits, the benefits or injuries which it does, the means for its protection or extermination. Each of the insects treated in this paper has a double Latin name by which it is or may be known to students of the Orthoptera in all parts of the world. In order that the student may determine this name for himsclf, "keys" or "tables of determination" have been inserted, which, if carefully followed and compared with the different characters of the insect in hand, will lead up to its scientific name. The common name by which it is generally known is also added, but the common name varies greatly in different localities. 
While collecting has not been done in all the different counties of the State, enough of them have been visited to make the collection mpon which the paper is based a representative one. Those localities in which collecting has heen done are markerl with small X's on the accomplnying ontline comnty mat) of the state.

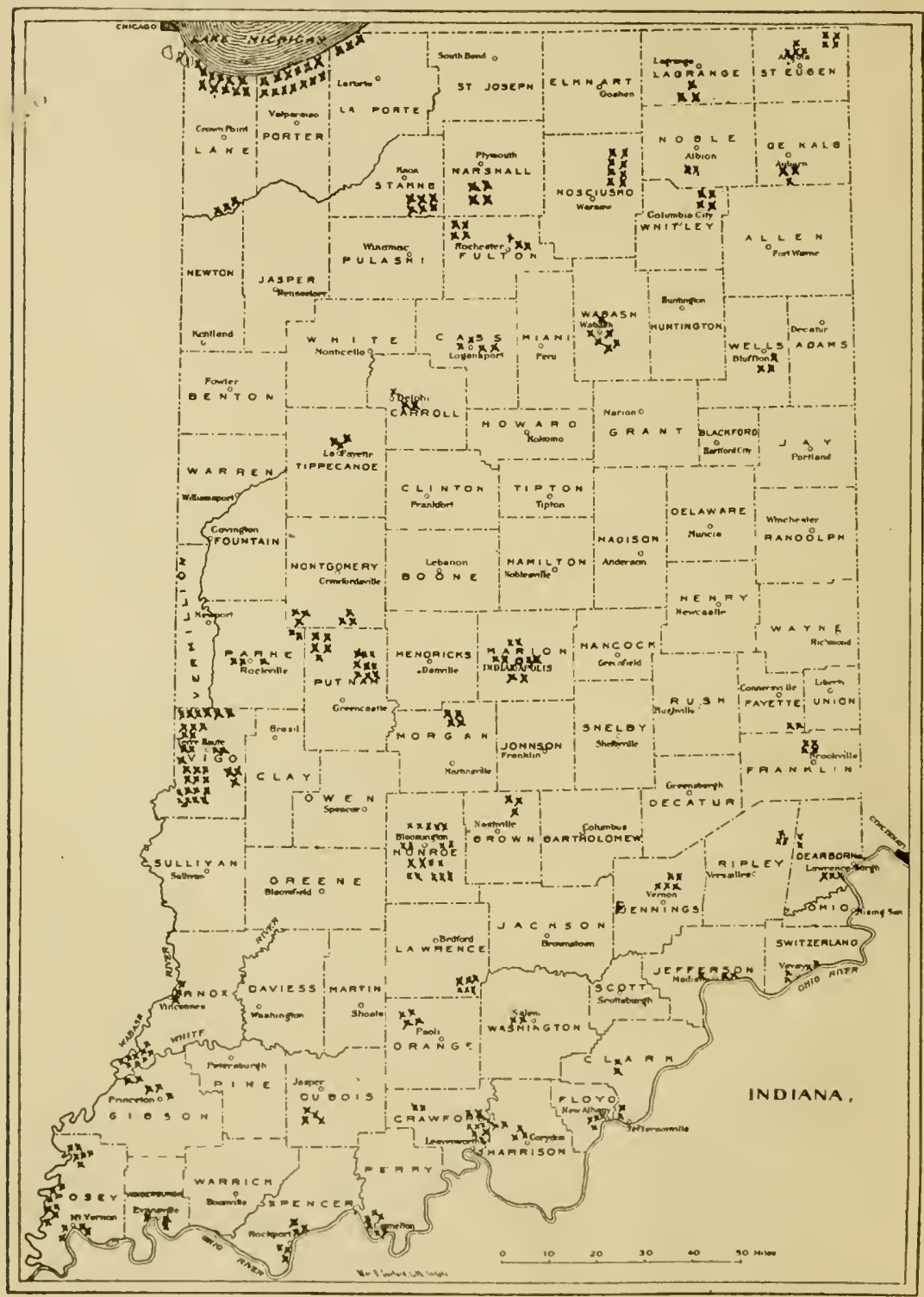

Fig. 1. Sketch maj of Indiana showing loenlities in which collections of Orthoptera have been made. 
ACKNowlEmexts.-During my study of the Orthoptera and in the preparation of the present paper I have been greatly aided by that nestor of orthopterological students, Mr. S. H. Scudder, of Cambridge, Massachusetts. To him, more than to all others combined, is due our present knowledge of the elassification and distribution of North American Orthoptera. Always willing to answer questions and ever interested in any new form which wa discovered, his counsel has been to me both inspiring and helpful. IIis many works upon the subject have been freely nsed in preparing the present paper. Profs. Lawrence Brumer, of Lincoln, Nebraska, and $\Lambda$. 1 Morse, of Wellestey, Massarhusetts, who, next to Mr. Sendder, are the leading anthorities on the gronp, have also rendered me much air in comparing and rerifying specimens sent to them for examination. Only a perom situaterl as I have been, far from any great reference collection, can duly appreciate such kindness as they have shown. To Dr. J. I. Hancock, of Chicago, and Mr. A. N. Caudell, of Washington, 1). ('.. I am also indebted for favors shown; the former having pased in review the collection of Tettiginæ made in the State. Other arknowledgments are marle in the borly of the paper.

Ildestratioxs.-The illistrations used have. for the most part. heen taken from the late Prof. Otto Jugger's "Third Annual Report of the Entomolngist of the State Experiment Station of the University of Minmesota:" permission to use them having been kindly granted hy the present State Entomologist. Prof. F. L. Washburn. A number of original drawings have, however, been made expressly for the paper, by S. Fred Prince of Lincoln. Nebraska, and Miss Lillian Howenstein. of the I. S. Department of Agrieulture. The Seeretary of the Smithonian Institution has also kindly granted the use of the figures illustrating the abdominal appendages of the Melanopli, which are from Mr. Aculder's "Revision of the Orthopteron Group, Melanopli," published in Vol. XX, of the Proceedings of the U. S. National II useum. 



\section{THE EXTERNAL ANATOMY OF A LOCUST.}

Before taking up the description and classification of the insects treated in this paper, it is thought best to deseribe briefly the external parts of a typical nember of the order Orthoptera. The beginner may thus the more readily grasp the name and loeation of the parts used in classification, as well as the meaning of many of the technical terms which, of neciessity, have to be usẹl in such a paper.

If we compare the body of a locust or grasshopper with that of any rertebrate animal, as a fish, bird or squirrel, we find at onee great

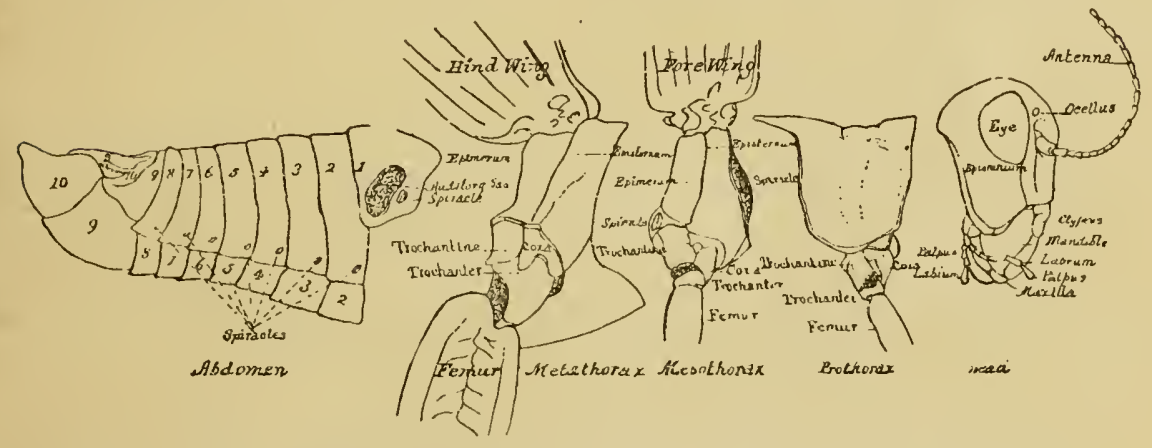

Fig. 2. Body of a locust, sile view, showing the thorax separated from the head and abdomen, and livided into its three segments.

(After Packard.)

and important differences. The vertebrate is an animal with an imer bony skeleton, two pairs of jointed limbs or appendages, and breathes by means of lungs or gills, aceording as it dwells in air or water. The inseet is an animal which has no inner skeleton or bones whatever, but only a hard crust on the surface which surrounds the muscles and vital organs. 'This erust is eomposed of separate rings, $1 \%$ in number, placed end to end. These rings, as well as the legs and wings attached to them, are composed of a euticle or skin hardened by a substance ealled "chitin," which is secreted or exuded by the cells which eompose the cuticle. Chitin itself is insoluble and is not composed of cells, but consists of fine, irregular plates. It hardens the cuticle and thus aids the latter in protecting 
the delicate vital organs within, and also in forming a framework to which the musches of movement maty be attacherl. Between the joints the enticle is deroid of rhitin and is thin, delieate, and flexible, thess allowing the neressary liendem of motion.

The adults of insects, and in mest (alsts. the youmg. have six true lege, and the former menally, thenght not alwaly, have wings. Moreover, insects breathe by a system of tubes ralled trachear, which branch and ramify through erery portion of the body. and which open externally in ahout ten places on eiteh side of the body, instead of at the front end. A locelset could. therefore be held with its head beneath the water lor an hour, without drowning it. In the true inseets, the rings of the bonly are grouped in three regions: the head,

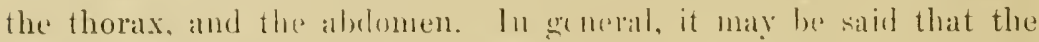

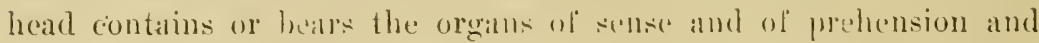
mastication of the fored: the thomax the megans of foremotion; and the abdomen those of erproduction.

\section{THE HEAD.}

The head of the loenst is composed of four or more segments or rings, solidly fuesed together into a (apsule or hared box of ehitin, known as the "pricrenium," which eontains the hrain and associated ganglia, and the mouth. It bears or gives support to the antenne, mouth parts, eyes and ocelli: also intermally to the muscles moring the mandibles or jaws. The brosul batsil portion of the epieranium back of the eyes is known als the "ore iput:" the narrower portion be-
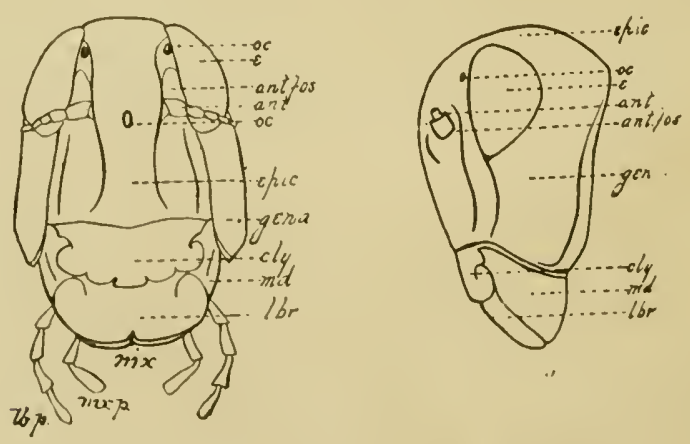

Fig. 3. (a) Front view of the beasl of a luenet

(b) Lateral view of the head of $a$ loctet. (After l,ugger 1

tween the eyes, the "rertex." whil: the long fromtal portion as far down at the frominent trallstere suture is the "front" or "face." 
The short plate $(c l y)$, below or in front of the epicranium, is the "clypeus." Below this and hinged to its front edge is a movable flap known as the "labrum (lbr) or upper lip, to which are attached a pair of jointed "labial palpi." This forms the roof or covering of the front part of the mouth, within which are the large, black-tipped, toothed jaws or "mandibles" ( $m d$ ), which are so attached to the epicranium as to move only in and out or to and from a median line. Beneath the labrum and arched orer the tongue will also be found a

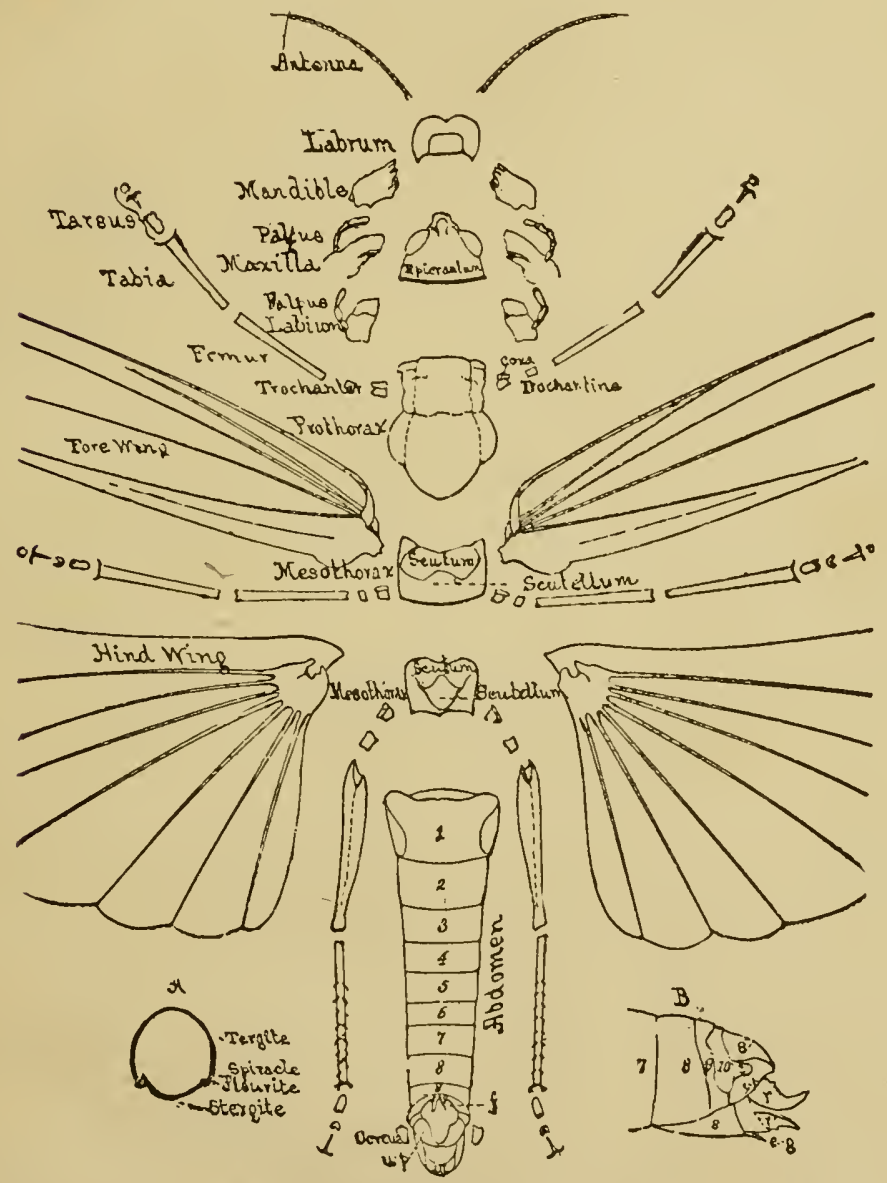

Fig. 4. External anatomy of a locust, showing the hear and thorax disjointed. (After Packard.)

pair of accessory jaws, the "maxille" ( $m x$ ), each of which is composed of three pieces, the most important, used in classification, being the jointed "maxillary palpus." 
Above the elypeus, is a ridge extending upward along the median line of the face to the rertex. "This is the "frontal cosla;" and its characters are often used in classification. In one species it may be sulcate or grooved; in another, flat. Its edges, or "carince" may be parallel the full length or may diverge or converge. Its width and prominence are also often mentioned.

'The region on the side of the hatd, behind the eye, and above the base of the mandibles is the eheek or "gena" (yen.). "To its inner wall is at tached the large muscle which moves the mandible.

The eyes of a locust are five in number; two large compound ones. and three small, simple ones. The compound eyes are present in all Orthoptera. In the locust they vary in shape, but for the most part are oval, and are located on the upper portion of the sides of the head. Each is made up of many thousands of six-siderl facets or lenses, in carch of which a single filament of the optic nerve ends. The simple eyes or "ocelli". (oc.) are absent in some Orthoptera, as the Locuslida, but are present in the locust. 'Two of them are situated just above the base of the antenna close to the inner margins of the compound eyes; while the third is located near the middle of the frontal costa. Their position varies in the different families of Orthoptera. These ocelli are thought to be inherited from the obscure eyes of the worm-like ancestry of the locust, while the many facetted compound eyes of insects and crustaceans have been evolved to satisfy the needs of the more recent existence of these groups.

The antenne (ant.) of the locust are simple, many jointed appendages, located on the face between the eyes and articulating with the

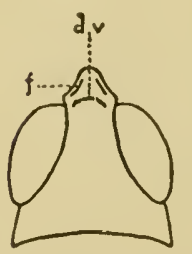

Fig.5 Showing fasligi u m, disk and foveola of vertex.

(Atter lugger.) hearl by a ball and socket joint. They are principally organs of touch, lout are also supposed to contain the nerves of smell. They vary mueh in length and form among the different families of Orthopteri, the variation being the result of adaptation to their peculiar surroumdings and habits. For instance, in those Loeustide which dwell in cares they are very much longer than in those members of the same genus which dwell albore ground. Chararetere pertaining to their form, length, and point of union witle the hearl. are much userel in classitimations. Such terms as "filiform." "clatrate," "setaceous," ete., relating to their form, are definer in the aeenpanying glossary.

Characters pertaining to the vertex, or that part of the epicranium between the eyes, are much used in separating the different species of Orthoptera. The central portion of the rertex, known as the "disk," 
(dv.) or "scutellum," (sv.) is often depressed, or separated from the remainder. Its bounding walls are termed "lateral carine" and often a "median carina" divides it into two parts. The front portion, or apex, often called the "fastigium," is variable in form, and its characters are also much used. On the outer side of, and a little below the front half of each lateral carina of the vertex, there is, in inany Orthoptera, a little space or concavity bounded by elevated ridges. These spaces are the "laleral fovcole," (f.) and their variations in size and form also afford characters much used in classification.

\section{The Thorax and Its Appendaties.}

The middle region of the body is called the "thorax." To study its parts aright, the wings and legs attached to it should be removed; when it will be seen to consist of three rings or segments. These are known as the "prothorax," "mesothorax" and "metathorax." Within these rings are located the muscles for moving the wings and legs; as well as some of the digestive oroans.

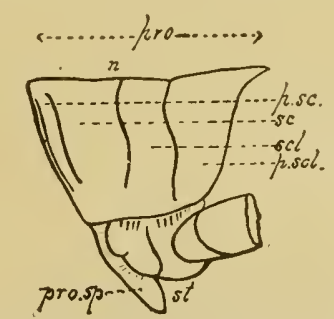

Fig. 6. Lateral view of the prothorax of a lor:ust. (After Lugger.)

The Prothorax of the locust (Fig. 6) has its sides and dorsal surface covered by a large, sun-bonnet shaped piece known as the "pronotum" (pro.). This varies much in shape and size in the different families of Orthoptera. Its upper surface is called the "disk," and its sides, the "lateral lobes." Raised lines known as "lateral carince" usually separate the disk from the sides, while a third line, the "median carina," runs lengthwise through the middle of the disk. This may be "high" or "low," "crested," "arched," "listinct," "aborted," etc. It is usually ent by one or more notches formed by shallow grooves or "sulci" which cross the disk of the pronotum and extend down its sides. The hindmost of these sulci, or grooves, divides the disk of the pronotum into two parts known as the "prozonc" (pz.) and "metazona" (mz.). The fore and hind margins of the lisk of pronotum may be "truncate," "rounded," "angled," 
"notehed," etc. 'The surface of the disk is often smooth, but sometimes "wrinkled" and may be "rugose" or roughened with numerous tubereles.

The under or "ventral" sile of the protborax is a marrow, somewhat movable piece called the prostermmu. On its eenter it often

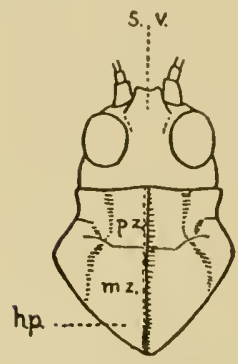

Fig. 7. Showing "prozona" and "metirona" of jronotum, and "scutellum" of vertex.

(After Lugger.) bears a tooth or spine (pro sp.), the presence or absence, and shape of which form character's used in classification. Near the outer concls of the prostermum are shallow sockets in which are attached the front pair of legs.

The Mesothorax and Metathokax, the second and third segments of the thorax, are, in the loewst, rather firmly united with the basal abdominal serment of the abdomen to form a firm walled hox; though in the Blattider they are distinct. The upper portion of these seguents is, in many Orthoptera. partly or wholly cosered by the pronotum. In the mesothorax are attached the first or outer pair of wings and the second or mirdle pair of legs. To the metathorax are joined the inner wings and the third or hind pair of legs. The under or ventral portion of these segments are called respectively

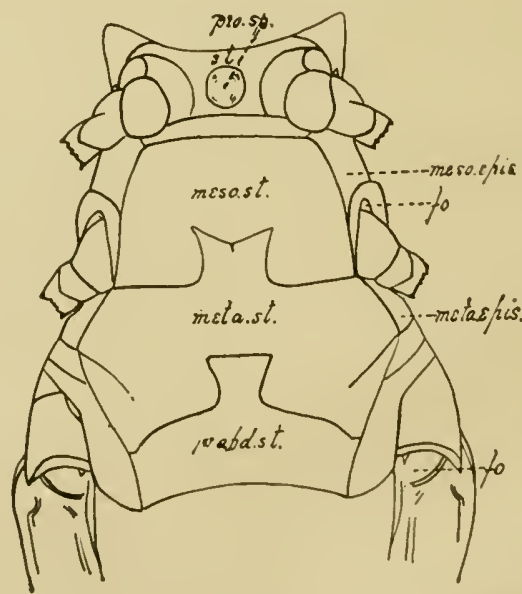

Fig. 8. Lower or ventral view of the thorax of a locust.

(After Jugger.)

the "mesosternum" and "metastermmm." 'Tlue former, in the locust, is composed of a front transverse portion, with two nearly rectangular lobes projecting batekwart. Between these lobes is dovectailed 
a squarish tongue or forwarl prolongation of the metasternum. The latter is united with the basil abdominal segment by the dovetailing of a similar but narrower tongue between its lobes. The side pieces of the mesothorax and metathorax are called "pleurites" and bear the prefixes "meso" and "meta."

'The Wixgs.-These are thin, broad, more or less leaf-like folds of the integument or body covering, which are joined to the thorax and moved by powerful muscles located within the thoracic cavity. The first or outer pair of wings of the locust and other Orthoptera serve as shields or covers for the more delicate inner pair. In the text which follows they are called "wing covers" or "tegmina." Each wing cover is a thin, more or less transparent, leathery or parchmentlike plate of chitin; strengthened by a network of tubes called "nerves" or "veins." The spaces enclosed by the veins and their cross branches are called "cells." When folded and at rest upon the body the onter faces of the tegmina of a locust are vertical, with the front or costal margin below, and the posterior or sutural margin lying along the back; that of the left wing cover slightly overlapping the right.

The principal veins of the tegmina of a locust diverge from the basal end and are seren in number. The one nearest the front or lower margin of the wing cover is the "sub-marginal" or "costal

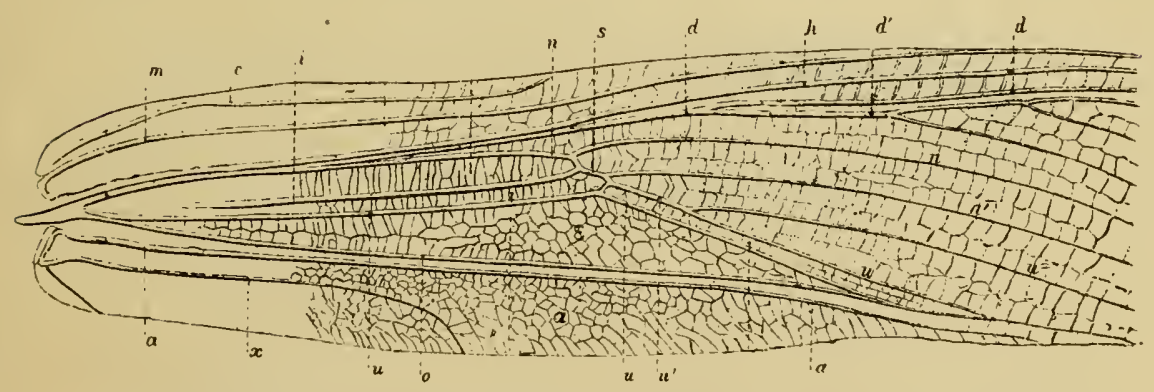

Fig. 9. Right tegmina of a locust, showing the venation. The names of the veins designated by the letters are given in the text.

(After Saussure.)

rein" (c). It is molivided, and may usually be traced for a little more than half the length of the tegmina, though in some locusts it is" lacking. The second and longer vein, also undivided, is the "mediastinal" $(m)$. The third and nuch larger vein is the "humeral" (h), sometimes called the "sub-costal." It gives rise to several large branches, the sub-divisions of which form the framework of the greater part of the wing cover. 'The larger of these branches 
(d), is known as the "discoidal rein," its branches being designated as $\left(d^{\prime}, d^{\prime \prime}\right)$. cte. 'The fourth or "median vein" $(n)$ is much smaller" and soon divides into branches of nearly equal size. Above or behind the median vein is sometimes present a short, mulvided vein

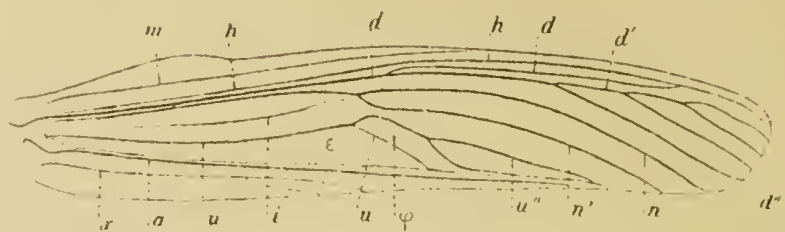

Fig. 10. Right tegmina of the lorust. Dissosteira rarulina (L.) Showing the venation. (Alter sinssure.)

(i), known as the "intercalary rein." Text in order is the "uhnar rein" (u), which gives ofi several branches (u', $u^{\prime \prime}$, etr.). The upper division of this rem (o) is known as the "posterior ulnar" or" the "sub-median vein." Close to and parallel with it near the uplece or hind margin of the wing corer is the undivided anal rein (a); while the uppermost rein of the wing cover, also undivided, is the "axillary rein" $(x)$.

The temina is divided by these reins into three areas: The "costal" or "malrginal area" (M) forms the lower or front edge of the wing corel and is bounded above and behind by the humeral vein.

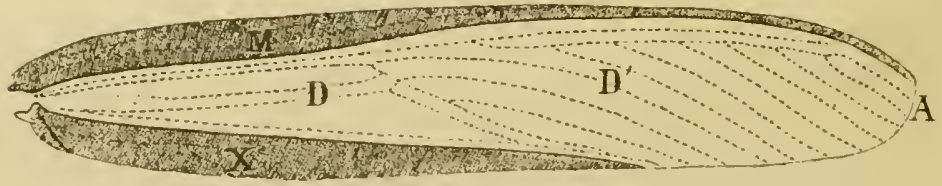

Fig. 11. Right tegmina of a locust, showing the "areas" designated in the text. (After saussure.)

"The "median" or "discoidal area" (I) is much the largest and lies between the humeral and posteriol uhar veins. The "anal" or "Alorsal area" $(X)$ is the free maregin lying alomg the back above and hehind the anal rein. The posterior end of the wing corer $(\lambda)$ is known as the "apicasl margin."

'The imner or second pair of wings are joined to the metatherax, and when at rest lie folded beneath the tegmina. Il, in allesh example. the dark coloped marewal rein be pulled outward or forward with a pair of foreeps, it will be secen that the wing is a thin. parehment-like membrane. witl a still front elge, which is nearly straight, whike the rounded onter and hind margins are thin and flexible. When in tlight, the wing is fully extended, its upper surface being 
convex, while its front margin is rendered still more rigid by being overlapped by the internal margin of the upper wing or tegmina. The numerous veins radiating from the base are so arranged that their elasticity causes the wing to fold upon itself like a fan as soon as its margin is released. The principal veins correspond in position to those of the tegmina, and have the same names. Both tegmina and wings are wanting in a number of species of Orthoptera, while in others the tegmina are present and the wings absent.

THE Legs of a locust are six in number, arranged in pairs, one pair being joined to each of the divisions of the thorax. The first and second pairs are mich smaller than the third, but the number and name of the joints is the same. They unite with the body at a different angle from the hind or third pair, and are therefore adapted to erawling and clinging to grass stems or other support, rather than to leaping.

The hind pair or leaping legs of the locust are composed of five parts:

The "coxa" (c), or basal division, which is joined to the thorax; a small segment, the "trochanter," $(t r)$, immovably joined to the upper apical portion of the coxa; the " $f e$ mur" (f.), a long, swollen, clubshaped segment, which makes up nearly half the length of the limb. When the animal is at rest, it extends upward and backward, with its apical end above the dorsal surface of the body. This joint contains powerful leaping muscles. The "tibia" (ti), is about as long as the

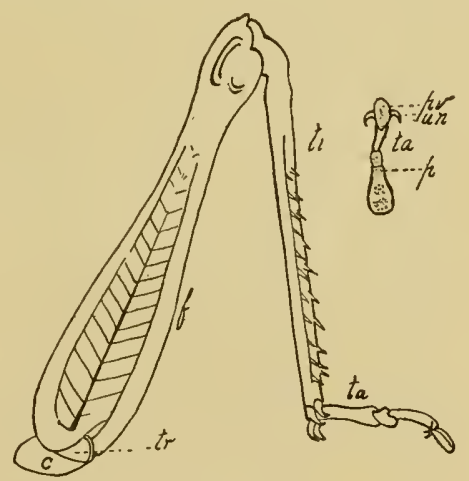

Fig. 12. Hind leg of a locust.

(After Lugger.) femur, but is very slender and of uniform diameter. When at rest it extends downward and backward, at an acute angle from the apex or knee of the femur, but in the act of jumping it is thrown backward and the limb becomes straight. It bears on each of its lower outer margins a row of spines, and at the end, one or more pairs of longer spines or spurs known as "calcaria." The tibiæ of the fore legs of many Orthoptera are much modified for use in burrowing or prehending food. The "larsus" (la) or foot of the locust is made up of three movable joints. The first and longest has upon its lower surface a soft pad $(p)$ which, by its adhesion to foreign bodies, serves as a point of resistance in leaping. The second 
joint is much shorter and carries a smaller pad. The third joint is long and slender, with two curved, pointed elaws or "ungues" (un); between which is a concave sucking disk or pad, known as the "pulvillus" $(p v)$. In some families of Orthoptera the tarsus is made up of four or fire joints instead of three.

\section{The Abdonen.}

The abdomen or hind portion of the body of the locust (See Figs. 2 and 4) is composed of ten more or less complete segments, so united as to be movable in a small degree. Each segment is composed of two parts, a "lergum" or upper portion, and a "sternum" or under piece. "The tergum is crested or bent in the median line to form a ridge, the two sides, sloping downward, being known as "lergites." The sternum of the first or basal abdominal segment is united firmly to that of the metathorax. The tergites of this segment, in the locust, each contain a large opening closed by a membrane, the "auditory organ" or ear. However, the ears of

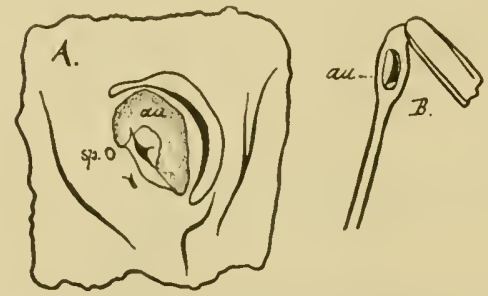

Fig. 13. Auditory organs or ears-(A), of a locust; (B), of a katydid. (After Lugger.) many Orthoptera are borne upon the basal portion of the front tibia. Eight of the abdominal segments of the locust have a small opening on the lower margin of each "tergite." These are "spiracles" or external openings of tubes which serve as air passages. The ninth and tenth abdominal segments of the locust

are more or less modified in both sexes. The abdomen of the female ends in a double pair of short eurved horny plates, known as the "valves of the oripositor." In the other families of Orthoptera in which the ovipositor is visible. these plates vary greatly in form and size. The valves in the female locust are used in foreing the earth aside, thus forming a pit in which the eggs are deposited. Between and hidden by them is the oripositor proper.

The ventral portion of the last abdominal segment of the male locust is a large, upenred, spoon-shaped piece known as the "subgenital plate." Attached to the tergum of the next to the last segment are a pair of appendages known as the "cerci." In the male locust these are unjointed, and in the different species vary much in size and shape, affording valuable characters for elassification. In many of the other families they are jointer, and more or less hairy. 
The cerci of the female are much smaller than those of the male, and in other Orthoptera are often wanting. The tergum or upper portion of the tenth abdominal segment is a triangular, often thick solid plate, known as the "supra-anal" plate. At the base of this plate and resting upon it, a pair of small projections, known as "furcula" are usually present. In certain genera of locusts the shape, size and relative position of these afford valuable specific characters.

The above constitute the more important external parts of the locust, the characters of which are used in determining the name of a member of the order Orthoptera. As will be seen in the pages which follow, these different parts vary much in size and in form, but the names given to them apply as well to the members of one family as to another. By referring to the accompanying figures, and by observing carefully the parts of the specimen in hand, the beginner need have little hesitation in deciding as to whether the description agrees with that specimen.

\section{INSECTS OF THE ORDER ORTHOPTERA.}

All true insects can be separated into two great groups, based upon the kind of changes or transformations which they undergo before reaching the adult or winged stage. To one group-the Metabolabelong those insects which undergo what is termed a complete metamorphosis. In this group there are four distinet stages-the egg, larval, pupal and imago-in the order named. No insect is hatched from the egg with wings, and when an insect reaches the winged stage it is adult, and never grows thereafter. Thus the gnats and midges are not the sons and daughters of the larger flies, but are full grown insects of themselves, which are undergoing the fourth or last stage of their lives. The second, the larval or wormlike stage, is the one in which the insect of this group is commonly the most injurious, for then it eats voraciously, and then is the only period of its life when it grows in size. The pupal, or third stage, is usually a quiescent one, the insect eating nothing and not increasing in size, but undergoing great changes of form. Thus the homely and often repulsive grubs, maggots and caterpillars, which are the larval forms of the beetles, flies and butterflies, respectively, enter the third stage as wormlike crawling creatureŝ, and emerge from it as beautiful winged forms, sometimes glistening and gleaming with all the colors of the rainbow. This change of life and form is undoubtedly of great advantage to the most of this group of insects, as it tends to prevent the extinction of the species; since, if at a given moment the parents were swept out of existence, the young, living in a different station, would continue to represent the species. 
The second group, the IIeleromelabola, comprises those insects in which the metamorphosis is ineomplete; the young, when hatehed from the egg being wholly wingless and of the same general form as the parent. As the insect grows it moults its skin a number of times and wings develop gradually, there being no sharp line defining the

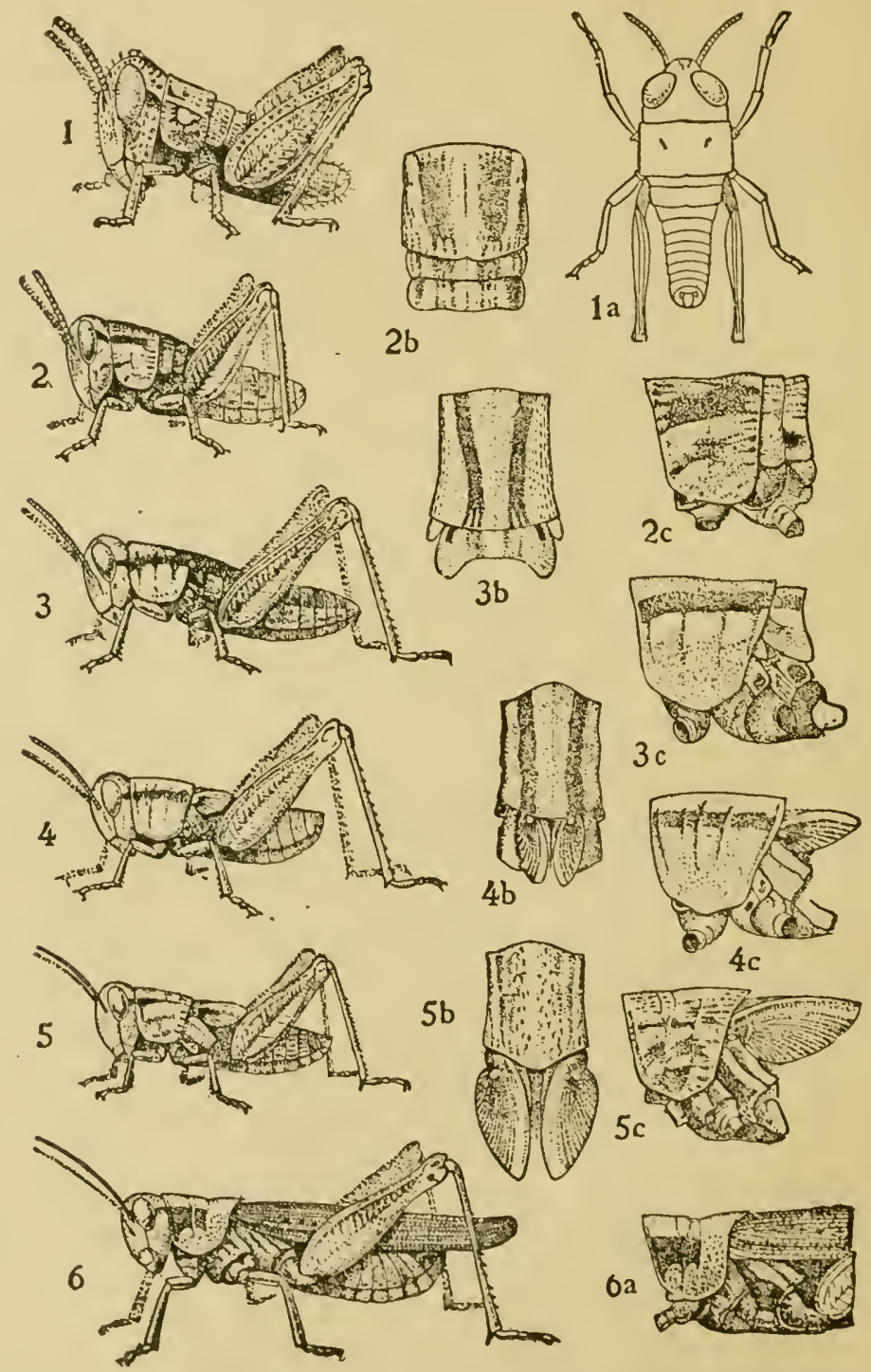

Fig. 14. Partial metamorphosis of Melanoplus femur-rubrum, showing the five nymph stages and the partial growtl of the wings, which are first visible externally in $3,3 \mathrm{~b}, 3 \mathrm{c}$. 
larval and pupal stages. The young of all stages are called "nymphs;" they continue active and feed from the time of hatching until they reach the final moult and emerge therefrom mature or in the imago stage.

It is to this latter gromp, whose members undergo an incomplete metamorphosis, that the Orthoptera, the order of which this paper treats, belong. From other orders of the group, they may be known by their biting mouth parts and by the fact that the wings, when present, are four in number, the first pair being thick, leathery or parchment like, and usually overlapping when at rest. They form protective covers for the second pair, which are thinner, more delicate, and folded in plaits like a fan. The name Orthoptera, is derived from two Greek words, orthos, straight, and pteron, a wing; and refers to the longitudinal folding of the hind wings. The fore wings. or tegmina, are not used in flight, the hind pair alone being used for that purpose. The wings of some species of Orthoptera are wholly wanting, while a few others have only the front pair present.

About 900 species of Orthoptera are known from the United States. Of these 148 have been taken in Indiana; specimens of all but two being in the writer's collection. Of one of these, a large field cricket, Gryllus firmus Scudder, a single female from Franklin Connty served as one of the types and is now in the collection of Mr. Scudder at Cambridge, Massachusetts. Of the other, an earwig, Forficula auricularia L., four specimens taken at Lafayette are in the U. S. National Museum.

\section{ENEMIES OF ORTHOPTERA.}

- With the exception of the Mantids, all our Orthoptera are injurious, most of them being vegetable feeders. Were it not for the many natural enemies which prey upon them, they would abound each season in such vast numbers as to prove a reritable scourge. These enemies are many of them parasites which live only upon Orthopterous forms, and when the latter are abundant the parasites also increase in number, and soon devastate the hordes of insects. Besides these parasites, many predaceous or beneficial insects feed upon locusts and crickets; and birds, both wild and domesticated, are exceedingly fond of them. These parasites, predaceous insects and birds are, therefore, of great benefit to the farmer, and he should do all in his power to increase their number, in order to keep within bounds the different species of Orthoptera. 
Vegetable Parasites.-Among the most common parasites of locusts is a regetalle fungus. which in wet seasons attacks them, saps their veins and in time destroys many of their tissues. One often finds, after a long damp spell in late summer, many dead specimens of our larger locusts clinging to the tops of weerls. A close examination will show that their bodies are soft, and issuing from them in many places are the ends of fungous tubes. This locust fungus, Empusa grilli Fres, for some unexplained reason, impels the insects

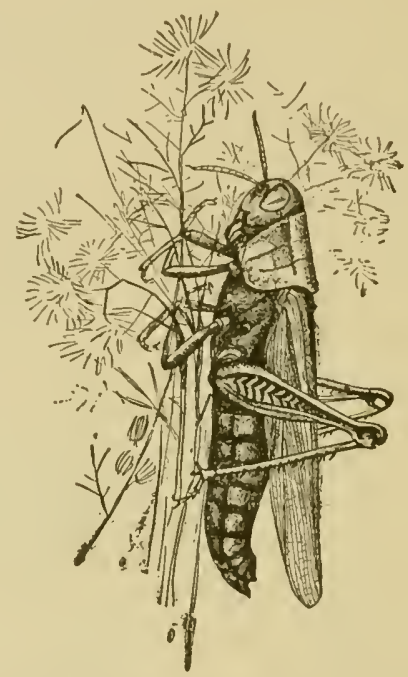

Fig. 15. Locust-Melanoplus bivittatus Say-killed by a fungus.

(After Lugger.)

affected with it to climb some tall weed or grass stem and cling to it with such tenacity that the body remains long after death. The spores given off from the fungus of the diseased or dead locust, are more widely seattered by this peculiar habit which the host insect has of climbing tall weeds, as they can the more readily be dispersed over wide areas.

Besides this fungous parasite other vegetable bacteria attack locusts in favorable seasons. But this takes place only in long warm, damp spells; during which the locust has sought shelter and been deprived of food. Many are then often congregated together and one individnal affected by the disease may inoculate hundreds. In dry seasons, the locnsts and green grasshoppers are much more healthy and abundant and the damage which they do is much greater than in a wet season. 
Upon the character of the winter of any year depends largely the number of Orthoptera and other insects which will be present the next summer. Most insects pass the winter in either the egg or the pupal stagc; since these forms can readily withstand long and severe cold weather, in fact may be frozen solid for weeks and retain life and vigor, both of which are shown when warm weather and food appear again. Indeed, it is not an unusually cold winter, but one of successive thawings and freezings, which is most destructive to insect life. A mild winter encourages the growth of mold which attacks the hibernating larvæ and pupæ as soon as, from excess of rain or humidity, they become sickly; and it also permits the continued activity of insectivorous mammals and birds. Thus, moles, shrews, and field mice, instead of burying themselves deeply in the ground, run about freely during an open winter and destroy enormous numbers of pupæ; while such birds as the woodpeckers, titmice and chickadees are constantly on the alert, and searching in every crevice and cranny of fence and bark of tree for the hibernating eggs and larvæ.

Animal Parastees.-A number of parasites belonging to the animal kingdom use as their chief hosts the bodies of locusts and other members of the order Orthoptera. Chief among these animal parasites is the red locust mite, Trombidium locustarum Riley. On the first warm, sunny days of spring, as soon as the surface of the earth is fairly dry and warm, scores of minute "red spiders" can be seen

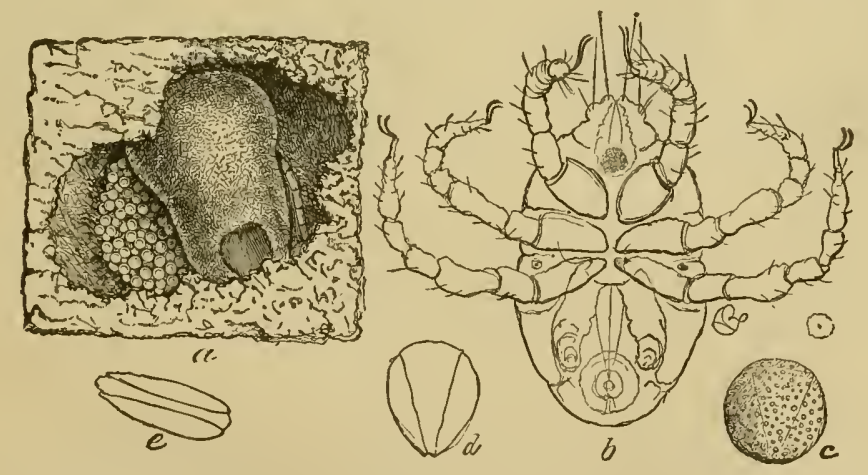

Fig. 16. Trombidium locustarum.- $a$, female with her batch of eggs (after Emerton); $b$, newly hatched larva, natural size indieated by the lot within the eircle; $c$, egg; $d$, e, vacated egg shells. (After Riley.)

along any pathway in the woods and fields. They are especially common if locusts were abundant the year before. These red spiders are in fact mature red mites, the two sexes of which are shown in Fig. 1\%. Soon after appearing in spring, the sexes mate and the fe- 
male soon deposits 300 or more small, globular eggs at a depth of a few inches in the soil. From each of these eggs there hatches, about the time the young locusts appear, a minute six-legrged mite, which runs actively about in search of some host to which it may attach itself. When it happens upon a young locust, it fastens itself to the wings, wing pads or abdomen and uses its month parts to suck up the fluid portions of its host. In a short time its body inereases in size, the legs grow smaller, and the mite resembles a small, globular mass of blood attached to the locnst. Sometimes as many as twenty mites can be counted on a single host. When thus infested, the locust often becomes disabled, and drags itself about in a clumsy fashion, eats less and dies early, often before the mating and egg-laying season has arrived. In the swollen and almost legless condition which the mite soon attains, it can not move about, and so remains in one position until full grown, when it drops to the ground and enters the pupal stage from which it emerges as the "red spiderkin" of spring. It often becomes mature in late autumn and passes

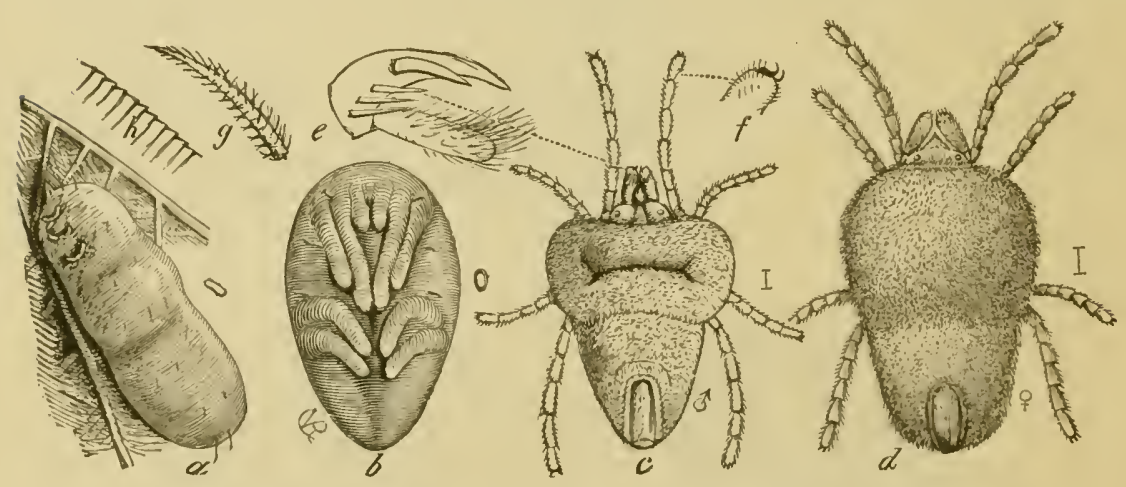

Fig. 17. Irombidium locustarum. $-a$, mature larva when about to leave the wing of a locust; $l$, pupa; c, male adult when just from the pupa; $d$, femalc-the natural sizes indi; cated to the right; $e$, pupal claw and thumb; $f$, peclal claws; $\theta$, one of the barbed hairs $h$, the striations on tho larval skin. (After Riley.)

the winter in the ground where it is not idle, except when the tenperature sinks below the freezing point. It feeds upon all sorts of soft food, and whenever it has access to the eggs of locusts it greedily eats them. In soil containing eggs of locusts large numbers of these mites congregate. 'They creep into every hole in search of these eggs and thrive upon such rich food. The great advantage of fall plowing over all other remedies against locusts is seen in regard to these red mites, as the plowing of fields in which the eggs of locusts have been deposited will destroy the young locusts hatching from them, 
but not the mites, which can easily work their way toward the surface.

Other parasitic animals besides these mites often attack the different species of Orthoptera. On a number of occasions I have found protruding from the abdomens of green grasshoppers and crickets a slender "hair worm" or "horse-hair snake," a species of Gordius. If the body of snch grasshopper or cricket be cut open the interior is often found to be almost filled with this parasite, which is many times longer than its host, and it will be seen that all the important organs of the latter are pressed to one side and mable to perform their necessary functions. Locusts so affected are seldom able to propagate their kind.

Among insect enemies of the Orthoptera, which aid largely in keeping down their numbers, are "Tachina Flies," "Flesh Flies," "Bee Flies" and "Blister Beetles." Tachina flies are mostly of a gray color, and resemble large house flies. In fields where locnsts are abundant, one of these flies may often be seen hovering over a large specimen, awaiting a favorable opportunity to deposit one or more of its eggs on the neck or beneath the wing. These eggs hatch into larvæ or maggots which eat their way into the body of the locust. There they seem to avoid the most vital parts, but feed upon the fatty secretions stored up for future use of the reproductive organs. Locusts so affected have a soft, flabby body, and can often be readily canght by the hand. They never mate, and perish much sooner than the healthy, unaffected individuals.

The flesh flies attack locusts, katydids and grasshoppers in much the same manner as do the tachina flies, and their maggots are often found existing as true parasites upon the vitals of these orthopterous insects. When the maggots of either of these flies become full grown, they burrow through the body wall of the locust and drop to the ground, where they enter the earth and pass through the pupal stage from which they emerge as fully winged insects, ready for attack upon a new generation of locusts.

The egg clusters of locusts, crickets and other Orthoptera in the ground are often attacked by the larval forms of bee flies and blister beetles. The bee flies are of a blackish gray color, densely covered with pale yellow hairs, and in Tune and July may often be seen hovering above the ground, or feeding upon the honey of various species of wild flowers. Their eggs are laid among or close to the egg masses of the locust, and their larvæ feed upon and destroy myriads of the eggs of the locnsts and crickets. 
Three or four species of blister beetles or "old-fashioned potato beetles" exist in Indiana, and in the winged or full grown stage are often very injurious to potatocs ant allied plants. The eggs of the blister beetle are laid in the ground in late summer, and the larva soon hatch and move actively about in search of animal food, in the form of egg masses of other insects. 'They have often been found feeding upon the eggs of locusts and other Orthoptera and are undoubtedly of much aid in keeping within bounds these injurious forms.

Many of the ground beetles or Carabide feed, during both their larval and mature stages, upon locust eggs. Abont 350 species of this family of beetles ocenr in Indiana, and all are beneficial. In the mature stage they are long legged. rapiel moving forms, which mostly hide by day beneath logs and rubbisl and run actively about at night in seareh of some form of flesh upon which they may make a meal. Since insect life is the most common form which they find on or beneath the ground, it is but natural that most of their food is composed of it. The species of Amara and Calosoma. two of which are

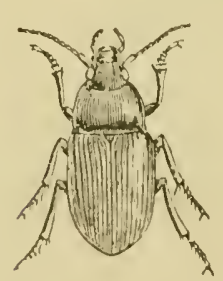

Fig. 18. Amara obesn Sny. Twice natural size. (Aftor Riley.)

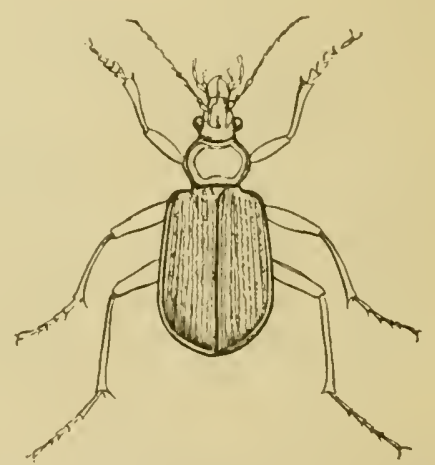

Fig 19. Oalosoma serutritor Fab. Natural size.

figured herewith, are anong the most common and beneficial of this family of beetles. The larre of Amara may, in autmmn, often be found fecding on the egrg masses of the locust.

ITigher in the scale of aninal life are many forms which are among the best friends the farmer possesses. yet many of them he destroys on sight through ignorance of their beneficial habits. Chicf among these are shrews, moles. salumanders and smakes. Both shrews and moles are burrowing mammals which feed almost wholly upon insect life. True, the latter sometimes destroy the sects of corn and regetables, but the good which they do in destroying the eggs and larvæ 
of injurious insects far outweighs the bad. Salamanders, or ground puppies, live beneath logs and chunks and burrow into the surrounding region in search of eggs and larvæ, while snakes feed largely upon the young and mature of grasshoppers and locusts, yet all are destroyed at sight.

Many species of birds use as food both the young and full grown of all kinds of Orthoptera. The Division of Ornithology at Washington, and other authorities, have made investigations of the stomachs of many species of birds, and have found that the following species which occur in Indiana feed largely upon locusts, grasshoppers and other forms of Orthoptera.

\section{LIST OF INDLANA BIRDS WIIICH ARE KNOWN TO FEED UPON ORTHOP'TERA.}

Franklin's Gull.

Black Tern.

American Bittern.

Least Bittern.

Ǩing Rail.

Sora.

Wilson's Snipe.

Golden Plover.

Red-tailed Hawk.

Red-shouldered Hawk.

Broad-winged Hawk.

Black Hawk.

American Sparrow Hawk.

Yellow-billed Cuckoo.

Black-billed Cuckoo.

Red-headed Woodpecker.

Night Hawk.

Phoebe.

Prairie Horned Lark.

Blue Jay.

Commou Crow.

Bobolink.

Cowbird.

Red-winged Blackbircl.

Meadow Lark.
Killdeer.

Quail.

Ruffed Grouse.

Prairie Hen.

Wild Turkey.

Mourning Dove.

Marsh Hawk.

Baltimore Oriole.

Common Blackbird.

Vesper Sparrow.

Chewink.

Dickcissel.

Scarlet Tanager.

Butcher Bird.

Red-eyed Vireo.

Yellow-throated Vireo.

Water Wagtail.

Yellow-breasted Chat.

Mockingbird.

Catbird.

lirown Thrasher.

Hermit Thrusl.

Robin.

Bluebird.

Of the foregoing list, those which feed mainly on Orthoptera during the summer season are the hawks, blackbirds, crows, blue jay, prairie chicken, mockingbird and bluebird. All of these birds are, however, beneficial in the highest degree and all should, at all times, be protected from their enemies, chief among which is the youth with his shotgun, or the small boy with egg-hunting proclivities. 
About the best remedy for Orthoptera on a farm is a large flock of turkeys. Under the leadership of an experienced gobbler, almost their entire time during the summer and fall months is spent in wandering orer the fields and pastures in search of the fat and juicy nymphs of locusts, grasshoppers and crickets. Indeed, most of the luscious white and brown meat of our Thanksgiving and Christmas dinners was onee grass, then grasshopper, and finally turkey. No better and more practical remedy can be devised, for the damage which the insects do is, especially in these days of "turkey trusts," often more than compensated by the value of the pounds of flesh which this domesticated fowl stores up from its favorite food of locusts.

\section{Biblogliaphy ANi STNONYMY.}

In the preparation of this paper, the following papers and general works on Orthoptera have been consulted or are referred to in the synonymy which follows the scientific name of each species.* In order to save space the titles of the papers and works are not given in the synonymy, but each is known by a certain number, printed in open space figures, which, in the snyonymy, immediately follows the name or abbreviation of the author, and all references to that paper bear the same number. For example, Scudder's "Materials for a Monograph of North American Orthoptera," in Vol. VII of the Journal of the Boston Society of Natural IIistory, bears the number 141 in the Bibliography, and whenever Scudd. is followed by the open space number 141 , reference is made to the paper mentioned. Thus, on page 242, under Orphulella speciosa (Scudder), we find in italics the name Stenobolhrus speciosus Scudd., 141, VII, 1862, 458. This shows that on page 458 of the "Materials for the Monograph of North American Orthoptera" there is, under the name Stenobothrus speciosus, a description or important notice of the species now known as Orpluulella speciosa (Scudder). In this particular instance the original description is referred to. When in the original description a species was placed by the author in a genus different from that to which it is now referred, the name of the author is placed in parenthesis. In the example referred to, the locust described as speciosus was placed in the genus Stenobothrus by Mr. Scudder. It is now reeognized as belonging to the genus Orphullela as at present limited. IIence Scudder's name is placed in parenthesis.

*An asterisk (") preeding the number in the Bibliography denotes that the paper referred to has not been seen by the nuthor, the title being quoted from seudder's "Index to North Aucrican Orthoptera." All papers not preeeded by an asterisk are in the author's library. 
Most of the species of Orthoptera found in Indiana liave been mentioned in so many different works that it is impossible to make reference to them all. I have therefore cited in the synonymy only such works as include descriptions or figures of the species in question or important information regarding its habits and life history. I have thus excluded most of the local lists, but have inchded papers which contain previous references to its occurrence in Indiana. I have also, in all instances, given the page of Scudder's "Catalogue of North American Orthoptera" on which the species is mentioned, as this catalogue is, in the main, used as the basis for the arrangement of families and genera, and for the synonymy adopted. Special students who wish a more extended synonymy are referred to Scudder's "Index to North American Orthoptera," which includes every known reference to each species up to the close of the year 1900.

\section{BIBLIOGRAPHY.}

1. Bethune, C. J.- "Insects of the Northern Part of British America, compiled from Kirby's Fauna Boreali-Americana: Insecta. IT, Orthoptera," in Canadian Entomologist, VII, pp. 129-131. London, Ontario, $18 \% 5$.

2. Beulenmüller, Wm.- "Notes on some Species of North American Orthoptera, with Descriptions of New Species," in Bulletin American Museum of Natural History, VI, pp. 249252. New Iork, 1894.

3. Beutenmüller, Wm. - "Descriptive Catalogue of the Orthoptera Found Within Fifty Miles of New York City," in Bulletin American Museum of Natural History, VI, pp. 253-316, Figs. 1-15, Plates V-X. New York, 1894.

4. Blatchley, W. S.- "Some Indiana Acrididx. I," in Canadian Entomologist, XXIII, pp. “4-81, 98-100. London, Ontario, 1891.

5. Blatchley, W. S.- "The Gryllidæ of Indiana," in Proceedings of the Indiana Academy of Science, 1891, pp. 126-144. Indianapolis, 1892.

5a. Blatchley, W. S.- "Two New Orthoptera from Indiana," in Canadian Entomologist, XXIV, pp. 26-2\%. London, Ontario, 1892.

6. Blatchley, W. S.- "Some Indiana Acrididx. II," in Canadian Entomologist, XXIV, pp. 28-34. London, Ontario, 1892. 
7. Blatchley, W. S.- "The Locustida of Indiana," in Proceedings of the Indiana Academy of Science, 1892, pp. 92-153. Indianapolis, 1893.

S. Blatchley, II. S.- "The Blattidx of Indiana," in Proceedings of the Indiana Academy of Science, 1892, pp. 153-165. Indianapolis, 1893.

9. Blalchley. W. S.- "An Unusual Appearance of Schistocerea Americana," in Psyche, VI, pp. 465-466. Cambridge, 1893.

10. Blatchley, II. S.- "Some New Locustidie from Indiana," in Camadian Entonologist, XXV, pp. 89-93. London, Ontario, 1893.

11. Blalchley, W. S.- "Some Indiana Acrididx. III," in Canadian Entomologist, XXYT. pp. 21\%-223, 2+1-245. I.ondon, Ontario, 1894.

12. Blatchley. W. S.- Notes on the Winter Insect Fauna of Vigo County, Indiana," in i'syche, VII, pp. 248-250. Cambridge, 1895.

13. Blatchley, W. S.- "Miscellancous Notes," in Canadian Entomologist, XXVIIJ, pp. 265-266. London, Ontario, 1896.

14. Blatchley, W. S. - "Indiana Cares and Their Fauna," in 'Twenty-first Anmual Report of the Department of Geology and Natural Resources, 1896, pp. 121-212, Plates IV-XII. Indianapolis, $189 \%$.

15. Blatchley, W. S.- "Some Indiana Acrididas. IV," in Canadian Entomologist, XXX. pp. 5t-6t. London, Ontario, 1898.

16. Blatchley, W..S.- "Katydids and 'Their Kin; or the Orthoptera of Indiana," in Gleanings from Nature. pp. 19\%-2.t. Figs. 41-ro. Indianapolis, 1899 .

1\%. Blatchley, W. S.- "On the Species of Nemobius Known to Occur in Indiana," in Psyche. IX, pp. 51-5t. Cambridge, 1900 .

1.. Blatchley, W'. S.-A Nature Wooing. P'p. 1-24.;. Plates I-XII. Figs. 1-63. Indianapolis, 1902.

19. Boliear. Ignacio.-Essai sur les Aeridiens de la tribu des Tettigida. Ip. 1-139, Plates I-II. Bruxelles, 1S8\%.

20. Brmuer. Lawrence.- "New Species of Neblaska Acridide," in Canadian Entomologist. VIII. pl. 123-125. London. Ontario, $18 \approx 6$.

21. Bruner, Lanrence. - "Two New Myrmecophila from the United States," in Canarian Entomologist, XVI, pp. 41-43, Fig. 4. Tondon, Ontario, $18 s 4$. 
22. Bruner, Lawrence.- "First Contribution to a Knowledge of the Orthoptera of Kansas," in Bulletin Washburn College of Natural History, I, pp. 125-139. Topeka, 1885.

23. Bruner, Lawrence.- "Report of the Entomologist," in Annual Report of the Nebraska Board of Agriculture, pp. 84-130. Lincoln, 1888.

21. Bruner, Lawrence. - "New North American Acrididx found North of the Mexican Boundary," in Proceedings of the U. S. National Museum, XII, pp. 4\%-82, Plate. Washington, 1890.

25. Bruner, Laurence.- "Ten New Species of Orthoptera from Ne" braska, with Notes on the IIabits, Wing Variation, etc.," in Canadian Entomologist, XXIII, pp. 36-40; 56-59; 70-73. London, Ontario, 1891.

26. Bruner, Lawrence. - "Teport on Destructire Locusts," in Bulletin U. S. Division of Entomology, XXVII, pp. 9-33. Washington, 1892.

27. Bruner, Lawrence. - "A Change in the Name of a Recently Described Species of Orchelimum," in Entomological News, III, pp. 264-265. Philadelphia, 1892.

28. Bruner, Lawrence. - "The More Destructive Locusts of America North of Mexico," in Bulletin U. S. Division of Entomology, XXVIIT, pp. 1-40. Washington, 1893.

29. Bruner, Lawrence. - "A List of Nebraska Orthoptera," in Publications of Nebraska Academy of Science, III. pp. 19-33. Lineoln, 1893.

30. Bruner, Lawrence.--"The Insect Enemies of Small Grains," in Report Nebraska State Board of Agriculture, pp. 359-468, Figs. 1-111. Lincoln, 1893.

31. Bruner, Lawrence.- "Insect Enemies of the Apple Tree and its Fruit," in Report Nebraska State Horticultural Society, pp. 153-224. Lincoln, 1894.

32. Brumer, Lawrence.- "Insect Enemies of the Grape Vine," in Nebraska State Horticultural Report, pp. 68-162, Figs. 1-96. Lincoln, 1895.

33. Bruner, Lawrence._- "Directions for Collecting, Preparing and Preserving Specimens of Orthoptera for the Cabinet," in Special Bulletin Department of Entomology, University of Nebraska, II, pp. 1-8. Lincoln, 189.5.

34. Bruner, Lawrence.- "The Grasshoppers that Occur in Nebraska," in Annual Report Nebraska State Board of Agriculture, 1896, pp. 105-138, Figs. 1-35. Lineoln, $189 \%$. 
35. Bruner, Laurence.-- "Insect Enemies of the Apple Tree and its Fruit," in Annual lieport Nebraska State Horticultural Society, pp. 119-212, Figs. 1-108. Lincoln, 1899.

36. Bruner, Lawrence.- "Report of the Entomologist. A Preliminary Report on the Insect Enemies of Clover and Alfalfa," in Anmual lieport Nebraska State Board of Agriculture, pp. 239-28.), Figs. 1-(i\%. Lincoln, 1899.

3\%. Brunner ron Wallenwyl, Carl.-Nouveau système des Blattaires. Pp. 1-426, Plates 1-13. Vienna, 1865.

38. Brunner ron Wallenwyl, Carl._- Monographie der Phaneropteriden." in rer K. K. Zoölogisch-Botanischen Gesellschaft in Wien, pp. 1-401, Plates I-VIII. Vienna, $18 i 8$.

39. Brunner ron Wallenwyl, Carl.- "Monographie der Stenopelmatiden und Grillacriden," in VerhandIungen ZoölogischBotanischen Gesellschaft, XXXVIII, pp. 2ti-39t, Plates V-VIII. Wien, 1888.

39a. Brunner ron Wallenwyl, Carl-D Monographie der Psendophylliden. Pp. 4+282, Plates I-X. Wien, 1895.

40. Burmeisler, Hermann.-Handbuch der Entomologie, II. Pp. 459- 756. Berlin, 1838.

40a. Caudell, A. N. - "The Phasmidx or Walking-Sticks of the United States," in Proceedings of the U. S. National Museum, XXVT, 863-885, Plates LVIII-LIX. Washington, 1903.

40). Caudell, 1. N.- "Notes on the Nomenclature of Blattidx." in Proceedings Entomological Society of $\mathrm{W}^{\mathrm{r}}$ ashington, V, 232234. Washington, 1903 .

41. Comstocli, J. H._- "Orthoptera," in An Introduction to Entomology, T. pp. 8\%-122, Figs. 83-110. Ithaca, 1888.

42. Comstock. J. II and A. B.-A Manual for the Study of Insects. Pp. 12+i01, 6 plates. Ithaca, 1895.

43. Daris, II'm. T.- "The Song of 'I'hyreonotus," in Canarlian Entomologist, XXV. pp. 108-109. I.ondon, Ontario, 1893.

44. Dodge, Chas. R.- "Notes of a Coweateher Ride Through Nebraska," in Canadian Entomologist. IV.pp. 11-16. I.ondon, Ontario, 18:2.

45. Dodge, G. M-- "New Species of Acridide from Nehrakka," in Canarlian Entomologist. VIII. pp. 9-12. Lonion, Ontario, $18 \% 6$.

46. Dodge, (r. Mr- "New Species of Orthoptern," in Canadian Entomologist, 1X, pp. 111-113. London, Ontario, $18 \%$. 
47. Doran, Edwin W.- "The Life History of the Northern Mole Cricket," in Canadian Entomologist, XXIV, pp. 270-273. London, Ontario, 1892.

*48. Drury, Dreu.-Dllustrations of Natural History. I, pp. $28+130$, Plates 1-50; II, pp. $7+92$, Plates $1-50$; III, pp. $26+\% 6$, Plates 1-50. London, 17\%0-1782.

49. Emmons, Ebenezer.-Agriculture of New York. V, pp. 8-272, Plates $3+4 \%$. Albany, 1854 .

*50. Fabricius, Johann C.-Systema entomologix, sistens insector$\mathrm{nm}$ classes, ordines, genera, species, arjectis synonymis, locis, descriptionibus, observationibus. Pp. $32+832$. Flensburgi et Lipsia, $17 \% 5$.

*51. Fabricius, Johann C.-Species insectormm exhibentes eorum differentias specificas, synonyma anctormm, loca natalia, metamorphosin adjectis observationilous, adumbrationibus. I, pp. 8+552; II, pp. 2+494. Hamburgi et Kilonii, 1 r81.

*52. Fabricius, Johann C.-Entomologia systematica emendata et ancta, secundum classes, ordines, genera, species, adjectis synonymis, locis, observationibus, descriptionibus. II, pp. 1-62. Hafnix, 1793.

53. Fernald. C. H.-The Orthoptera of New England. Pp. 1-61, Figs. 1-22. Boston, 1888.

54. Fletcher, James._-"The Northern Mole Cricket," in Canadian Entomologist, XXIV, pp. 23-25. London, Ontario. 1892.

*55. Fischer, L. II. - Orthoptera Europæa. Pp. 20+454, Plates 1-18. Lipsia, 1853.

56. Fitch, Asa.- "Third Report on the Noxions and Other Insects of the State of New York," in Transactions of the New York State Agricultural Society, XVI, pp. 321-50\%. Albany, 18.56 .

*5\%. Geer, Karel de.-Memoires pour servir à l'histoire des insectes. Orthoptera, III, pp. 399-554, Plates 21-25. Stockholm, $17 \% 3$.

58. Germar, Ernest F.-In Burmeister's Handbuch der Entomologie, II. Berlin, 1838.

*.59. Gerstreclier, Carl Edward. - Ueber die Locustinen-gattung Gryllacris. Wiegm., Arch. naturg., XXVI, pp. 215-2i8. Berlin, 1860.

60. Glorer, Townend.- "Report of the Entomologist." in the Annual Report of the T. S. Department of Agriculture, 18\%0, pp. 65-91. Washington, $18 \% 1$. 
61. Glover, Townend.- "Report of the Entomologist," in Annual Report of U. S. Department of Agriculture, 18:1, pp. 69-Ss. Washington, $18: 2$.

62. Glorer, Townend.-Illustrations of North Ameriean Entomology-Orthoptera. T'p. 5+11. Plates 1-18. Washington, $18 \div 2-18 \% 4$.

63. Glover. Tounend.-- "Report of the Entomologist," in Annual Report of the U. S. Department of Agriculture, 1871, pp. 122-146. Washington, 1875.

*64. Gray. Geo. R.-Synopsis of the Species of Insects belonging to the Family of Phasmida. Pp. 4+18. Tondon, 1835.

65. Haldeman, Samuet S-_Description of Some New Species of Insects. with Ohservations on Tescribed Species," in Proceedings of the Academy of Natural Scicnee of Philadelphia. TI. pp. 861-36..). P’hilatlelphia. 1853.)

66. Hancocti, Joseph L._- "Unusual Flights of the Grouse Jocust. (Tettigidea lateralis Say) in Northeastern Jllinois," in American Naturalist, XXVIII, pp. $483-48 \%$ Plate 13. Philadelphia, 1 S94.

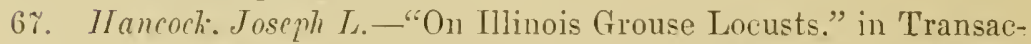
tions American Entomological Society, XIIIT, pp. 23.j-24t. Plates VI-IX. Philadelphia, 1896.

6S. Hancoct. Joseph l.-_"Some T'ettigian Studies," in Entomological News. X, pp. 2\%,-282. Philadelphia. 1899.

69. Mancock. Joseph T.-The Tottiginea of North America. Pp. viit1SS. Plates I-XI. Figs. 1-13. Chicago, 1902.

*ro. Marris, Thaddeus II.-A Catalogue of the Animals and Plants in Massachusetts. VIII. Insects in ITitcheock, Fdward, Report of the Geologist of Massachusetts, pp. 566-595. Amherst, 1833: Second edition, pp. 553-602. Amherst. 1835.

71. Harris. Thaddeus W.-A Report on the Insects of New Fugland Injurious to Vegetation. Pp. viiitt59, First edition. Cambridge, 1811.

72. Harris Thaddeus WY-A Treatise on some of the Insects of New Fngland which are Injurious to V'egetation. Pp. $12+$ 640. Figs. 1-2 \%S. Plates I-VIII. Third edition. Edited by Chas. Tuwis Flint. Boston, 1862 .

\%3. IIart, Chas. A.- "On the Species of Ecanthus Serv.." in Entomologieal News. III, pp. 33-34. Figs. 1-6. Philatelphia. 1892.

74. Howard, I. O._ "A Genus of Mantis Egg-Parasites," in Insect Life, IV, pp. 242-245, Figs. 2S-31. Washington, 1892. 
75. Howard, L. O.- "Damage by the American Locust," in Insect Life, VII, p1. 220-229, Figs. 19-22. Washington, 1895.

\%6. Howard, L. O.-The Insect Book. Pp. xxvii+429, Figs. 1-264. New York, 1901.

7\%. Hyatt \& Arms.-Guides for Science Teaching. Insecta. Pp. xxiii+300, Figs. 1-223, Plates I-XIII. Boston, 1890.

78. Kellogg, V. L.-Common Injurious Insects of Kansas. Pp. S+ 126. Lawrence, 1592 .

*y9. Kirby, William.-Fanna boreali-americana. The Insects, IT, pp. 39+325, Plates I-Y'III. London, $183 \%$.

*80. Linnceus, Carl von.-Centuria insectorum rariorum. Pp. 6-32. Upsaliæ, 1 r63.

*81. Linneus, Carl von.-Systema naturæ. Editio decima reformata. Orthoptera, I, pp. 423-434, 1\%58. Editio duodecima reformata. Orthoptera, II, pp. 686-\%03. Holmiæ, $176 \%$.

82. Lintner, J. A._-"Chimarocephala viridifasciata (DeG.)," in Second Report on the Injurious and other Insects of the State of New York, p1. 187-198, Figs. 54-59. Albany, 1885.

83. Lintner, J. A.-Report of the State Museum of New York, XLVIII. Pp. 440-443, Fig. 19. Albany, 1895.

84. Lugger, Otto.- "The Orthoptera of Minnesota," in Third Annual Report of the Entomologist of the State Experiment Station of the University of Minnesota for the year $189 \%$ Pp. 1-296, Figs. 1-18\%. St. Paul, 1898.

85. Marlatt, C. L.- "The Principal Household Insects of the United States," in Bulletin 4, new series, U. S. Division of Entomology, pp. 1-130, Figs. 1-6t. Washington, 1896.

86. Marlatt, C. L._CCockroaches," in Circular 51, second series, U. S. Division of Entomology, pp. 1-15, Figs. 1-5. Washington, 1902.

8\%. McNcill, Jerome._-Dissosteira carolina," in Canadian Entomologist. XIX, pp. 58-59. London, Ontario, 188\%.

88. McNeill, Jerome.- "A List of the Orthoptera of Illinois," in Psyche, VI, pp. 3-9, 21-27, 62-66, \%3-\%8. Cambridge, 1891.

89. McNeill, Jerome.- "Revision of the Truxalinæ of North America," in Proceedings of the Davenport Academy of Natural Sciences, VI, pp. 179-2 \%4, Plates I-VI. T)avenport, $189 \%$.

90. McNeill, Jerome._ "Orchelimum Serville," in Canadian Entomologist, XXXII, pp. 7\%-83. London, Ontario, 1900.

91. MeNeill, Jerome.- "Review of the Orthopteran Genus Trimerotropis," in Proceedings of the U. S. National Museum, XXIII, pp. 393-449, Plate XXI. Washington, 1901. 
92. Morse, Albert P.- " $\triangle$ New Species of Stenobothrus from Connecticut, with Remarks on other New England Species," in Psyche, TI, pl. 477-479, Figs, 1-6. Cambridge, 1893.

93. Morse, Albert P.- A Prelininary List of the Acridida of New England," in P'syche, VII, pp. 102-10s. Cambridge, 1894.

94. Morse, Albert P.- "Notes on the Acrididre of New England. I. 'Tettigina," in Psyche, VII, pp. 14\%-15t, 163-167, Plate 6. Cambridge, 1894.

95. Morse, Albert P._-Spharagemon; A Study of the New England Species," in Procecdings of the Boston Society of Natural History, XXVI, pp. 220-2 10, Figs. 1-9. Boston, 1894.

96. Morse, Albert P.- "New North American Tettigine. 1," in Joumal of the New Tork Entomological Society, III. pp. 14-16; "II," pp. 10\%-110. New York, 1895.

9\%. Morse, Albert P. - "Revision of the Species of the Genus Spharagemon," in Psyche, VII, pp. 287-299, Figs. 1-6. Cambridge, 1895.

98. Morse, Albert P.- "Notes on the Acrididx of New England. II. Tryxaline," in Psyehe. VII, pp. 323-32\%, 3t2-3t4, 382$38+402-403,407-411,413-122,443-145$, Plate \%. Cambridge, $1896-' 9 \%$.

99. Morse, Albert P._. "Notes on New England Acrididie. III. Oedipodina," in Psyche, VIII, pp. 6-8, 35-3\%. 50-51. 61-6i6. 80-\$2, 8\%-89, 91-11t, Plate 2. Cambridge, $189 \%$.

100. Morse, Albert P.- Notes on New England Acrididr. IV. Acridina," in Psycle, VIII, pp. 2t\%-2ts; 255-260, 26!)273, 279-282, 292-296, Plate \%. Cambridge. 1898.

101. Morse, Albert P.- "New North American 'Tettigina. III." in Journal New Tork Entomological Society. TTT, pp. 198201. New York, 1899.

102. Morse, Albert P.—"Variation in 'Tridactylus," in P'syche. ІХ. pp. 19\%-199, Figs. 1-5. Cambridge. 1901.

103. Murlfeldt, Mary E._- "The Carnivorous Habits of Tree Crickets," in Insect Life, II, pp. 130-132. Washington, 1889.

104. P'actiard, Alpheus S.- "Orthoptera," in Guide to the Study of Insects and a Treatise on Those Injurious and Beneficial to Crops. P1. 5j6-rir. Salem. 1869. Also edition of 1883.

10\%. Perlicard, Alpheus S._- "On the Care Fauna of Indiana," in Anmul Report of Peabody Academy of Science, V. pp. 93-9\%. Saleu, $18 \% 3$.

106. P'artard. Alpheus S.- "The Cave Fauna of North Ameriea, with Remarks on the Anatomy of the Brain and Origin of 
the Blind Species," in Memoirs National Academy of Science, IV, pp. 3-156, Plates I-XXVI. Washington, 1888.

10\%. Packard, Alphens S.- "On Insects Injurions to Forest and Shade Trees," in Report of the U. S. Entomological Commission, V, 8+958, Plate I. Washington, 1890.

*108. Palisot de Beaurois, A. M.-Insectes recueillis en Afrique et en Amérique dans les royaumes d'Oware à Saint-Domingue et dans les Etats-unis pendant les années 1786-179\%. Pp. $16+2 \approx 6$, Plates 1-90. Paris, 1805-1821.

109. Rathion, S. S.- "Entomology and its Relation to the Vegetable Productions of the Soil, with Reference to Both the Destructive and Beneficial Insects," in Report of the U. S. Department of Agriculture, pp. 3\%2-390, 4 plates. Washington, 1862.

110. Redtenbacher, Josef.- "Monographie der Conocephaliden," in Verhandlungen der K. K. Zoölogisch-Botanischen Gesellschaft in Wien, pp. 315-562, Plates 3-4. (Author's Separate, pp. 1-248.) Wien, 1891.

111. Rehn, James A.--"Schistocerca alutacea and rubiginosa," in Entomological News, XIII, p. 89. Philadelphia, 1902.

112. Rehn, James A.- "Records of New Jersey and Pennsylvania Orthoptera," in Entomological News, XIII, pp. 309-316. Philadelphia, 1902.

112a. Rehn, James A.- "Notes oll Some Interesting Species of Forficulidæ and Blattidæ from the Eastern United States," in Entomological News, XIV, 1903, pp. 125-126.

113. Riley, Chas. V.-First Annual Report on the Noxious, Benefieial and other Insects of the State of Missouri. Pp. 1-181, Figs. 1-98. Jefferson City, 1869.

11t. Riley, Chas. V.-Fifth Annual Report on the Noxious, Beneficial and other Insects of the State of Missouri. Pp. 1-160, Figs. 1-75. Jefferson City, $18 \% 3$.

115. Riley, Chas. V.- "Katydids," in the Sixth Annual Report on the Noxious, Beneficial and other Insects of the State of Missouri, pp. 150-169, Figs. 43-55. Jefferson City, $18 \% 4$.

116. Riley, Chas. V.-Seventh Annual Report on the Noxious, Beneficial and other Insects of the State of Missouri. Pp. viii+ 196, Figs. 1.39. Jefferson City, 1875.

11\%. Riley, Chas. V.-Eighth Annual Report on the Noxious, Beneficial and other Insects of the State of Missouri. Pp. 1-185, Figs. 1-55. Jefferson City, $18 \% 6$. 
118. Riley, Chas. V.-Ninth Ammul Report on the Noxions, Beneficial and other Invects of the State of Missonri. Pp. vi+129, ligs. 1-33. Jeflerson City, 18:\%.

119. Riley. Chas. V.-The Locust Pague in the United States: being more particularly a treatise on the Rocky MIomntain locust or so-called grasshopper, as it occur's cast of the Rocky Mountains, with practical recommendations for its destruction. P'p. 1-236, Plates 1-3. ('hieago, 18:\%.

120. Riley, Chas. V.- "The 'Thick-thighed Walking-stick," in Report U. S. Tepartment of Agriculture, 1S:s, p). 2\$1-2t5, Plate III. Nashington, $18: 9$.

121. Riley, Chas. V.- General Index and Supplement to the Nine Reports on the Insects of Missouri," in Bulletin U. S. Entomological Commission, VI, pp. 1-1\%s. Washington, 1881.

122. Riley, Chas. V.- "Orthoptera," in The Standard Natural History, II, pp. 167-203, plate. Boston, 1884.

123. Riley, Chas. V.- "Report of the Entomologist," in Annual Report of the U. S. Department of Agriculture, 1885, pp. $10+$ 13\%, Plates I-IS. Washington, $18 S 6$.

12t. Riley, Chas. V.- "Our Shade Trees and their Insect Defoliators," in Bulletin U. S. Division of Entomology, X, pp. 1+69. Washington, 188\%.

125. Riley, Chas. V._- Injury done by Roaches to the Files in the 'I'reasury iu Washington," in Insect life, I, pp. 67-\%0, 190191. Washington, 1888.

126. Riley, Chas. T.- "Some Insect Pests of the Houschold, IV, Cockroaches," in lnsect Life, II, pp. 266-269. Washington, 1890.

12\% Riley, Chas. V.-. Destructive Loeusts. A Popular consideration of a few of the more injurious locusts of the United States. together with the hest means of destroying them," in Bulletin 25, U. S. Division of Entomology, pp. 1-62, Plates 1-12, map. Washington, 1891.

128. Saussure, Henri D.-Orthoptera Nova Americana (Diagnoses Pracliminaires) I, pp. 1-16; II, I). 1-33; III, pp. 1-17. Paris, 1859-186:2.

*129. Sunssure, Henri 1).-Orthopteres de l'Amerique moyenne. Pp. 1-279, Plintes 1-2. Genera and Paris, 186i-1869.

130. Saussure, IIenri D._- Essai d'un Systeme des Mantides," in Mittheilungen der Schwiez Entomological Gesellschaft, I11, pp. 49-73. Schafllausen, 1869.

131. Saussure, Henri D.-Synopsis des Mantides Amerieains. Pp. 1-18t, Plates 1-2. Genere et Bale, 18 r. 
132. Sanssure, Henri D.- "Ntudes sur les insectes Orthopteres," in Mission Seientifique au Mexique et dans l'Amerique Centrale, pp. 6+533, Plates $7-8$. Paris, 18\%0-1879.

133. Saussure, IIenri D.-Melanges Orthopterologiques. I, pp. 1460, Plates 1-\%; II, pp. 1-831, Plates 1-29. Geneva, 18\%\%1878.

134. Saussure, Henri D.- "Prodromus Oedipodiorum Insectorum ex ordine Orthopterorum," in Memoir de las Societe de physique et d'histoire naturelle de Genève," XXVIII, pp. 1-254, Plate I. Geneva, 1884.

135. Saussure, ILenvi D. and Zehntner, Len-—"Orthoptera genuina. Blattidæ, Mantidæ," in Biologia Centrali Americana. Orthoptera, pp. 13-197, Plates I-X. London, 1893-1894.

*136. Saussure, ILenri D. and Pictel, Alphonse. "Orthoptera gennina. Locustida," in Biologia Centrali Anericana, Zoölogia Orthoptera. Pp. 285-458, Plates 14-22. London, $189 \%-1899$.

13\%. Say, Thomas. American Entomology, or Descriptions of the Insects of North America. I, pp. 8+112, Plates 1-18; III, pp. 1-138, Plates 37-54. Philadelphia, 1824-1828.

138. Say, Thomas.-"Description of new Hemipterous Insects collected in the Expedition to the Rocky Mountains, performed by order of Mr. Calhoun, Secretary of War, under Command of Major Long," in Journal Academy of Natural Science of Philadelphia, IV, pp. 307-345. Philadelphia, 1825.

139. Say, Thomas. The Complete Writings of Thomas Say on the Entomology of North America. Edited by John Lawrence Le Conte, M. D. I, pp. 24+412, Plates 1-54: II, pp. $4+814$. New York, 1859.

140. Scudder, Samuct H.- "On the Genus Raphidophora Serville; with descriptions of four species from the Caves of Kentucky, and from the Pacifie Coast," in Proceedings of the Boston Society of Natural History, VIIl, pp. 6-14. Boston, 1861.

141. Scudder, Samuel H.- "Materials for a Monograph of the North American Orthoptera, including a Catalogue of the Known New England Species," in Journal of the Boston Society of Natural IIistory, VII, pp. 409-480. Boston, 1862.

142. Srudder, Samuel H.- "The Songs of the Grasshoppers," in American Naturalist, II, pp. 113-120, Figs. 1-4. Salem, 1868. 
113. Scudder, Samuel II.- "Notes on the Stridulation of some New Fingland Orthoptera," in Proceerlings of the Boston Society of Natural History, XJ. pp. 306-313. Boston, 1868.

141. Scudder, Samuel 1 .- " $\Lambda$ Century of Orthoptera, Decade I. Gryllides," in Proceedings of the Boston Society of Natural History, XIJ, pp. 139-113. Boston, 1868.

145. Scudder, Samuel II.- "Revision of the Large, Stylated Fossorial Crickets." in Memoirs of the Peabody Academy of Science, I, pp. 1-2S, J'late I. Salem, 1869.

116. Scudder, Samucl II.- "Descriptions of new species of Orthoptera in the collection of the American Entomological Society," in Transactions of the American Entomological Society, II, pp. 305-30\%. Pliiladelphia, 1869.

147. Scudder, Samuct II.- "Notes on the Orthoptera collected by Dr. F. V. Hayden in Nebraska," in Report of the U. S. Geologieal Survey of Nebraska and Portions of Adjacent Territories, pp. 247-261. Washington, 1872.

148. Scudder, Samucl H.- "The Distribution of Insects in New Hampshire," in Hitcheock's Report on the Geology of New Hampshire, I, pp. 331-380, Plates A-C. Coneord, 1874.

149. Scudder, Samuel H.- "Spharagemon,-A Genus of Oedipodidx; with a Revision of the Species," in Proceedings of the Boston Society of Natural History, XVII, pp. 467-471. Boston, $18 \% 5$.

150. Scudder, Samucl H.- "Revision of two American Genera of Oedipodidx," in Proceedings of the Boston Society of Natural History, XVII, pp. 478-48. Boston, 1875.

151. Scudder, Samuel H.- "A Century of Orthoptera. Decade II. -Locustarix," in Procecdings of the Boston Society of Natural Jistory, XVII, pp. 454-462. Boston, $18 \% 5$.

1.52. Scudder, Samucl H.- "A Century of Orthoptera. Decade III. -Acrydii (Pezotcttix Caloptenus)," in Proceedings of the Boston Society of Natural History, XVII, pp. 472-478. Pioston, 1875.

153. Scudder, Samuel H.-Entomological Notes, IV. Pp. 1-91. Boston, 1875 .

15t. Scudder, Samuel II.- "The Chirp of the Mole Cricket," in The Ancrican Naturalist, X, pp. 97-98. Salem, 1876.

15.5. Scudder, Samuet 1I.- "Brief Synopsis of North American Earwigs, with an Appendix on the Fossil Species," in Bulletin of the U. S. Geological and Geographical Survey of the Territories, II, No, 3, pp. 249-260. Washington, 1876. 
156. Scudder, Samuel H.- "List of the Orthoptera Collected by Dr. A. S. Packard in Colorado and the Neighboring Territories During the Summer of 18:5," in Bulletin of the U. S. Geological and Geographical Survey of the Territories, II, No. 3, pp. 261-26\%. Washington, $18 \% 6$.

15\%. Scudder, Samuel H.- "Synoptical Tables for Determining North American Insects. Orthoptera.-U. S. Forficularia," in Psyche, I, pp. 17\%-178. Cambridge, 18\%6.

158. Scudder, Samuel II.- "Critical and Historical Notes on Forficulariæ, including descriptions of new Generic forms, and an Alphabetical Synonymic List of the Described Species," in Proceedings of the Boston Society of Natural History, XVIII, pp. 287-332. Boston, 1876.

159. Scudder, Samuel HI.- "Report on the Orthoptera Collected by the U. S. Geological Survey West of the One-hundredth Meridian, under the direction of Lieut. Geo. M. Wheeler, during the Summer of 1875," in Annual Report of the Chief of Engineers for 1876. Appendix JJ, pp. 498-515. Washington, 1876.

160. Scudder, Samuel H.- "New Forms of Saltatorial Orthoptera from the Southern United States," in Proceedings of the Boston Society of Natural History, XIX, pp. 35-41. Boston, $187 \%$.

161. Scudder, Samucl H.-Entomological Notes, VI. Pp. 1-55. Boston, $18 \% 8$.

162. Scudder, Samuel H.- "The Florida Orthoptera collected by J. H. Comstock," in Proceedings of the Boston Society of Natural History, XIX, pp. 80-94. Boston, 18\%\%.

163. Scudder, Samuel H.--"Remarks on Calliptenus and Melanoplus, with a Notice of the Species foumd in New England," in Proceedings of the Boston Society of Natural History, XIX, pp. 281-286. Boston, 1878.

164. Scudder, Samuel H.-A Century of Orthoptera. Pp. 1-84. Boston, 1879.

165. Scudder, Samuel H.- "A Few Notes on North American Acridii," in Canadian Entomologist, XII, pp. 75-76. London, Ontario, 1880.

166. Scudder, Samuel H.- "A List of Orthoptera Collected by Dr. Alpheus S. Packard in the Western United States in the Summer of 187\%," in Report of the U. S. Entomological Commission, II. Appendix 2, pp. 23-28, Plate 1\%. Washington, 1880. 
167. Scudder, Samuel II.- "The Orthopteran Genus Iippiscus," in Psyche, V1, pp. 265-27+, 285-288, 301-30+, 317-320, 333-336, $3+7-350,359-363$. Cambridge, 1892.

168. Scudder, Samuel H.- "The Songs of our Grasshoppers and Crickets," in Twenty-third Ammual Report of the Entomological Society of Ontario, 1892, pp. 62-7S, Figs. 36-5t. Toronto, Ontario, 1893.

169. Scudder, Samuel H.-_Walking-sticks," in Harper's Magazine, LXXXVIII, pp. 45 4-461, 11 figures. New York, 1894.

1\%0. Scudder, Samuel II.- "A Preliminary Review of the North American Decticidæ," in "Canadian Entomolngist, XXVI, pp. 17\%-18t, London, Ontario, 1894.

171. Scudder, Samuel II.- "The North American Ceuthophili," in Proceedings of the American Academy of Arts and Sciences, XXX, pp. 17-113. Boston, 1894.

172. Scudder, Samuel H.-."Summary of the United States Phasmidæ," in Canadian Entomologist, XXVII, pp. 29-30. London, Ontario, 1895.

173. Scudder, Samuel H.- "Index to the Mantidæ of North America North of Mexico," in Canadian Entomologist, XXVIII, pp. 207-215. London, Ontario, 1896.

174. Scudder, Samuel II.--"Some American Crickets," in Harper's Magazine, XCIII, pp. 691-696. New York, 1896.

175. Scudder, Samuel H.- "North American Specics of Nemobius," in Journal New York Entomological Society, $I T^{\top}$, pp. 99-10\%. New York, 1896.

176. Scudder, Samucl 1I.- "The Species of Nemobius found in North America," in Psyche, VII, pp. 431-431. Cambridge, 1896.

17\%. Scudder, Samuel H.- "The Genera of North American Melanopli," in Proceedings of the American Academy of Arts and Sciences, XXXII, pp. 193-206. Boston, 189\%.

178. Scudder, Samuel II.- "Diapheromera femorata," in Psyche, VIII, pp. 30-31. Cambridge, 189\%.

179. Scudder, Samuel H.- "The Species of the Genus Melanoplus," in Proceedings of the American Philosophical Society, XXXVI, No. 154, pp. 5-35. Philadelphia, 1897.

180. Scudder, Samuel H.- "Biological and other Notes on American Acrididæ," in Psyche, VIIT, pp. 99-102. Cambridge. 189\%. 181. Scudder, Samuel II.- "Revision of the Orthopteran Group Melanopli (Acridida), with Special Reference to North American Forms," in Proceedings U. S. National Mruseum, XX, Pp. 1-121, Plates I-XXVI. Washington, $189 \%$. 
182. Scudder, Samuel H.- "The Orthopteran Group Scudderiæ," in Proceedings of the American Academy of Arts and Sciences, XXYIII, No. 15, pp. 2r1-290. Boston, 1898.

183. Scudder, Samuel H.- "The Described Species of Xiphidium in the United States and Canada," in Canadian Entomologist, XXX, pp. 183-184. London, Ontario, 1898.

184. Scudder, Samuel II.--"The Orthopteran Genus Schistocerea," in Proceedings of the American Academy of Arts and Sciences, XXXIV, pp. 4t1-4\%6. Boston, 1899.

185. Scudder, Samuel H.- "The North American Species of Orphulella," in Canadian Entomologist, XXXI, pp. 177-188. London, Ontario, 1899.

186. Scudder, Samuel H._. "Short Studies of North American Tryxaline," in Proceedings of the American Academy of Arts and Sciences, XXXY, pp. 39-5\%. Boston, 1899.

18\%. Scudder, Samuet H.- "The Species of Myrmecophila in the United States," in Psyche. VIII, pp. 423-428. Cambridge, 1899.

188. Scudder, Samuel H.- "Catalogue of the Described Orthoptera of the United States and Canada," in Proceedings of the Davenport Academy of Natural Sciences, VIII, pp. 1-101, Plates I-III. Davemport, 1900.

189. Scudder, Samuel H.- "A List of the Orthoptera of New England," in Psyche, IX. pp. 99-106. Cambridge, 1900.

190. Scudder, Samuel H.- "The Distribution of Leptysma marginicollis Serv.," in Psyche, IX, p. 116. Cambridge, 1900.

191. Scudder, Samuel II.- "The Species of Diapheromera (Phasmidæ) found in the United States and Canada," in Psyche, IX, pp. 187-189. Cambridge, 1901.

192. Scudder, Samuel II.- "Miogryllus and Its Species in the United States," in Psyche, IX, pp. 256-258. Cambridge, 1901.

193. Scudder, Samuel H.- "The Species of Gryllus on the Pacific Coast," in Psyche, IX, pp. 267-270. Cambridge, 1901.

194. Scudder, Samuel H.- "The Species of Gryllus found in the United States East of the Sierra Nevadas," in Psyche, IX, pp. 291-296. Cambridge, 1902.

195. Scudder, Samuel H.- "On the United States Orthoptera which have been referred to the Genus Tridactylus," in Psyche, IX, pp. 308-310. Cambridge, 1902.

196. Serville, J. G. Audinel.-IIistoire naturelle des Insectes. Orthopteres. Pp. xviii+777, Plates 1-14. Paris, 1839. 
197. Smilh, John B.- "Grasslioppers, Loeusts and Crickets," in Bulletin New Jersey Agricultural College Experiment Station, XC, pp. 1-3t. New Brunswick, 1892.

198. Smith, Sidney I.- "On the Orthoptera of the State of Maine," in Proceedings of the Portland Society of Natural History, I, pp. 143-151. Portland, 1868.

199. Smith, Sidney I.- "Report of the Entomologist," in Annual Report of the Comnecticut Board of Agrieulture, 1872-1873, pp. 345-383. Hartford, $18 \div 3$.

200. Stal, Carl--Recensio Orthopterorum; Revue ('ritique des Orthopteres decritis par Linné, de Geer et Thumburg. I, pp.

4+154; II, pp. 4+121; III, pp. 4+105. Stockholm, 1873-18\%5.

*201. Stoll, Caspar.-Representation exactement colorée d'apres nature des spectres ou phasmes, des mantes, des sauterelles, des grillons des eriquets, et des blattes, qui se trouvent dans les quartres parties du monde, l'Europe, l'Asie, l'Afrique et l'Amerique, rassemblées et décrites. I. Spectres et mantes, pp. 6+79, Plates 1-25. Amsterdam, 178\%-1813.

202. Thomas, Cyrus.- "Insects Injurious to Vegetation in Illinois," in Transactions of the Illinois State Agricultural Society, V, pp. 401-468. Springfield, 1865.

203. Thomas, Cyrus.- "Descriptions of Grassinolpers from Colorado," in Proccedings of the Academy of Natural Sciences of Philadelphia, pp. 74-84. Philadelphia. 18\%0.

20t. Thomas, Cyrus.-."A List and Descriptions of new species of Orthoptera," in Annual Report of the U. S. Geological Survey of the Territories, II, $18 \% 0$, pp. 26\%-2S. Washington, $18 \% 1$.

205. Thomas, Cyrus.- "Notes on the Saltatorial Ortheptera of the Rocky Mountain Regions," in Preliminary Report of the U. S. Geological Survey of Montana and Portions of Adjacent Territories. 18:1, pp. 423-466. Plates I-II. Washington, 1872.

206. Thomas, Cyrus.-"Synopsis of the Acrididx of North America," in Hayden's Report of the U. S. Geological Survey of the 'Territories, V, 1873, pp. 1-258, plate. Washington, $18 \% 3$.

207. Thomas, Cyrus.- "Descriptions of some new Orthoptera, and Notes on some Species but Little Known," in Bulletin U. S. Geological and Geographical Survey of the Territories, I, No. 2, pp. 63-71. Washington, 1874. 
208. Thomas, Cyrus.- "Report upon the Collections of Orthoptera made in Portions of Nevada, Utah, California, Colorado, New Mexico and Arizona, during the Years 1871, 1872, 1873 and 18\%4," in Wheeler's Report upon the Geological and Geographical Explorations and Surveys West of the One Hundredth Meridian, V, pp. 813-908, Plates XLIII-XLV. Washington, 1875.

209. Thomas, Cyrus.- "A List of the Orthoptera of Illinois," in Bulletin Illinois Museum Natural History, I, pp. 59-69. Springfield, 1876.

210. Thomas, Cyrus. - "A List of Orthoptera Collected by J. Duncan Putnam, of Davenport, Iowa, during the summers of 1872, 1873,1874 and $18 \% 5$, chiefly in Colorado, Utah and Wyoming Territories," in Proceedings Davenport Academy of Natural Sciences, I, pp. 249-268, Plate XXXVI. Davenport, $18 \% 6$.

211. Thomas, 4 Cyrus. - "The Acrididx of Illinois," in Report of the State Iintomologist on the Noxious and Beneficial Insects of the State of Illinois, IX, pp. 73-140, Figs. 1-24. Springfield, 1.880 .

212. Uhter, P. R.- "Orthopterological Contributions," in Proceedings of the Entomological Society of Philadelphia, II, pp. 543-555. Philadelphia, 1864.

213. Uhler, P. R.-In Harris's Treatise on Insects Injurious to Vegetation, third edition.

211. United States Entomological Commission (C. V. Riley, C. Thomas, A. S. Packard). First Annual Report for the Year $187 \%$ relating to the Rocky Mountain Locust. Pp. 16+477+ 295, 3 maps, 5 plates, 111 figures. Washington, 1878.

215. United States Entomological Commission (C. V. Riley, C. Thomas, A. S. Packard). Second Report for the Years 1878 and 1879 , relating to the Rocky Mountain Locust and the Western Cricket. Pp. $18+322+80,9$ maps, 17 plates, 10 figures. Washington, 1880.

216. United Stales Entomological Commission (C. V. Riley, C.. Thomas, A. S. Packard). Third Report relating to the Rocky Mountain Locust, the Western Cricket, the Army Worm, Canker Worms, and the Hessian Fly. Pp. 14+347+ 12, 4 maps, $6 \pm$ platcs, 13 figures. Washington, 1883.

21\%. Waller, E. MI.- "Notes on some Ontario Acrididæ," in Canadian Entomologist, XXX, pp. 122-126. London, Ontario, 1898. 
218. Walker, E. M.- "The Canadian Speeies of 'Trimerotropis," in Canadian Fintomolngist, XXXIY. pp. 1-11. Jondon. Ontario, 1902.

219. Huller, Francis.-Catalogue of the Specimens of Dermaptera Saltatoria and a Supplement to the Blattarie in the Collection of the British Musemm. I. pp. 1-22t: IV. pp. 605-809. London, 1869-18\%0.

2201. Walsh. B. D.- - The Snowy 'Tree Cricket." in Practical Entomologist, I, p. 126. Philadelphia, 1866.

221. Walsh, B. D._- Mabits of the 'Tree Cricket (CEanthus niveus), in Practical Entomologist, II, pp. 54-94. Philadelphia, $186 \%$.

22:. Heed, Clarence M.-Life IIistory of American Insects. Pp. 12+2i2, Plates 1-21. New Iork, 189\%.

223. Wheeter, IT. M.- "Notes on the Oviposition and Embryologic Development of Xiphidium ensiferm Scudder." in Insect Life, 1I. pp. 222-225. Washington, 1890. 


\section{A DESCRIP'TIVE CATALOGUE OF THE ORTHOPTERA KNOWN TO OCCUR IN INDIANA.}

The order Orthoptera may be subdivided into two classes or suborders, which in turn are subdivided into seven families. The suborders may be distinguished by the following table:

KEY TO SUB-ORDERS OF ORTHOPTERA.

a. Legs of equal or nearly equal size, the hind femora not being enlarged for leaping. Organs for producing sound absent. Tegmina and wings of nymphs, when present, in a normal position. Ovipositor concea?ed by the sub-genital plate. .Non-Saltatoria, p. 167 a a. Legs of unequal size, the hind femora fitted for leaping, being much thickened and swollen, and usually much longer than the middle femora. Organs for producing sound usually present. Tegmina and wings of nymphs, when present, in a reversed position. Oripositor usually exserted so as to be plainly visible.............

SALtatoria, p. 210

\section{NON-SALTATORIA.}

To this class or sub-order belong four of the seven recognized families of Orthoptera. These may be distinguished one from another by the following table:

KEY TO FAMILIES OF NON-SALTATORIAL ORTHOPTERA.

a. Body short, narrow, more or less flattened. Head horizontal, the mouth in front. 'Tegmina leathery, very short, without veins; meeting in a straight line down the back. Tarsi tluree-jointed, without pulvilli or pads. Abdomen of both sexes terminating in horny

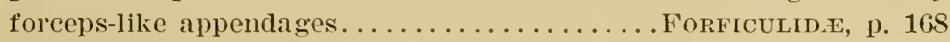

aa. Body either short and wide, or elongate and narrow. The mouth at either lower or back portion of head (depending upon the position of the latter when at rest). Tegmina usually parchment like, thickly reined. Tarsi five-jointed. Abdomen terminating in cerci, but these nerer distinctly forceps-like.

b. Body short, broad, oval, depressed. Head almost wholly concealed beneath the pronotum; the mouth posterior (at back portion when at rest). Ocelli generally two. Pronotum shield shaped, transverse. Legs compressed. Insects of

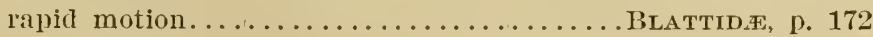

bb. Body elongate, narrow. Head, free, not covered by pronotum; the latter longer than broad. Ocelli three or wanting. Legs slender, not compressed. Insects of slow motion.

c. Head oblique; mouth inferior. Ocelli three. Antenna short. Pronotum generally longer than any other segment. Front pair of legs, raptorial, fitted for grasping. Cerci jointed..................... 
cr. Head sub-horizontal: mouth sulu-inferior. Ocelli often wanting. Antenna senerally fonger than the body. Pronotum but little longer thin heid. Front pris of

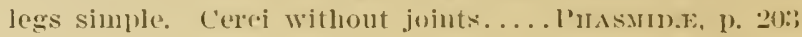

\section{Family FORFICUIAI) R.}

This family of the order Orlhoptera comprises those short, narrow. flattened insects, with legs of equal size, commonly known as "carwigs." 'They are so different from the langere and better known Orthoptera that many writers hare placed them in a distinct order, the Dermaptera or Euplexoplera.

The Forficulide have the head flattened and horizontal with the mouth in front. 'The thorax is short and narrower than the head. The tegmina or wing covers are leathery or horny in texture, meet in a straight line down the back; are without reins and cover only a portion of the abdomen. 'The inner wings, when present, are rery large, and bear numerous radiating reins which act as the bars of a fan in folding and unfolding the wings. When at rest, these wings are folded both lengthwise and crosswisc beneath the protecting tegmina. The abdomen ends in a pair of appendages which somewlat resemble forceps. Were it not for these, the carwigs would resemble rery closely the Staphylinide or rove beetles of the order Coleopteri. Those spe(ies which possess inmer wings use these loreeps to aid in folding and unfolding those organs, and they are also used as clisping orgins during the mating of the sexes. Is the carwgs never leap. the hind femora are not enlarged. The tarsi are never mole than threejointed and have no pads between the claws. No organs for prodncing sound are present, and, as far as known, hearing organs are also alsent.

The name "carwig" was given to these insects in burope. where they are abundant and better known than in this enmtry. It is a common belief among peasants and the medncated masses, that these inseets will, when opportunity oflers, enter the ears of hmman heings and injure the sense of hearing. Such belief is, of course, wrong and nonsensical, the insects being wholly lantuless. Tike the members of the next family, the Blallide or cockroaches, they lire in cracks and ramuies in walls and floors, bencath rubbish and the bark of logs and stumps. From these retreats they rome forth only by night to feed upon dead insects and mpon suall snails and other sluggish moring forms. Like other nocturual insects they are attracted by light. and on the ground bencath the electric lights of cities in Florida and Old Mexien, I have fomnt them in numbers. The female is said to 
brood over the eggs, but to abandon the young as soon as hatched. In this she resembles some of our common myriapods of the genus Lithobius, which are often found beneath logs and rubbish curled up around their eggs, but which are never seen in company with the young.

Earwigs are common in the cities along the seacoast, especially those of the Southern States and tropical and semi-tropical countries. Inland, especially in temperate and cold regions, they are scarce. The family is not, as yet, divided into sub-families. Six genera and fourteen species are listed by Scudder from the United States. Of these, three species, representing two genera, have been taken in Indiana. They belong to that division of the family in which the sixth joint of antennæ is as long as, or very nearly as long as, the first. The following key will serve to separate the two genera:

\section{KEY TO GENERA OF INDIANA FORFICULIDA.}

a. Sixth joint of antenna cylindrical, many times longer than broad; second tarsal joint produced beneath the third..............

I. Forficula, p. 169

aa. Sixth joint of antennæ plainly obconic, about three times as long as broad. Second tarsal joint minute, simple, compressed.........

II. LABIA, p. 171

\section{Forficula Linnæus (1758).}

Size, medium; whole body more or less flattened, rather long and slender. Antenrix a little more than half as long as the body, 10 to 14-jointed, the joints cylindrical, more than four times as long as liroad. Abdomen not expanded in the middle; all the dorsal segments before the last, of nearly equal length in both sexes. First tarsal joint a little longer than the third; the seeond short, dilated at the apex and lobed, passing beneath the third joint.

This genus is the richest in species of any of the family, and is more widely spread than any, being found wherever earwigs occur. Six species belonging to it are known from the United States, two of which have been taken in Indiana. These may be separated by the following:

IEY TO INDIANA SPECIES OF FORFICULA.

a. Wings wanting; antenne 12 -jointed............ aculcata, p. 170

aa. Wings protruding beyond the tips of tegmina; antenus 14-15-jointetl. 


\section{Forficula aculeata Scudder.}

Forficula aculeata Scudd., 156, II, 1876, 254, 256; Id., 157, I, 1876; 177; Id., 1 58, XVIII, 1876, 262, 310; Id., 164, 1879, 41; Id.. $188,1900,5$; Beut., 3, VI, 1894, 256.

Antema 12-jointed. Pronotnm longer than broad, narrower than the head. 'Jegmina nearly twice as long as the pronotum, truncate. Inner wings wanting. Furceps of male, three-fourths as long as the abdomen, slender, arcuate, bent downward a little at apex of basal third; becoming again horizontal a little before the tip; a slight pointed tooth present at second bend. Forceps of female shorter than those of male, nearly straight, the inner edges touching for most of their length, the tip incurved.

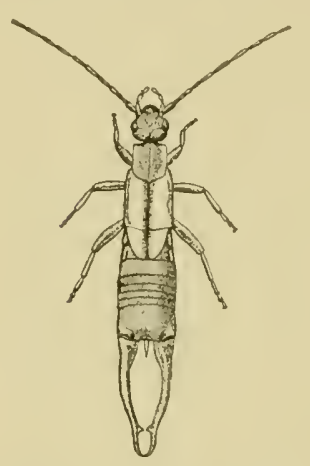

Fig. 20. Forficula aculeata Scudiler. Male, two and onehalf times natural size. (Original.)

Color, dark chestnut brown. Palpi, legs, edges of pronotum and outer two-thirds of tegmina, yellow.

Measurements: Length of body, male, 10 mm., female, $11 \mathrm{~mm}$.; of antennx, male, 7.5 mm., female, $7 \mathrm{~mm}$.; of tegmina, male and female, $3 \mathrm{~mm}$.; of forceps, male, $5 \mathrm{~mm}$., female, $3.5 \mathrm{~mm}$.

This earwig was taken a mile southwest of Mit. Vernon, Posey County, on April 9, 1901. It was found to be fairly common beneath rubbish and leaves in some woods along the bank of the Ohio River. It has not been noted elsewhere in the State, though it is liable to be found anywhere within its bounds as its range includes the northern United States cast of the Mississippi River. The type specimens came from northern Illinois and sonthern Michigan.

\section{Forficula aurioularia limmeus.}

Forficula anrimlario L., 81 , Ed. X, I, 1758, 42:3: Scudd., 15 5, Ш, 1876, 254; Id., 15 7, I, 1876, 177; Id., 158 , XVIII, 1876, 311; Id., 188 , І9к0, 5; Beut., 3, VI, 1894, 256; Brum., 35, 1s99, 133; Relm., $112^{\text {a }}$, XIV, 1903, 125.

"Fusco-ferlugrinous; antemne 14-15-jointed; basal joint, sides of pronotum, and legs testaceous; tegmina and wings dull luteous, the former half as long again as the pronotmm; foreeps of male usually as long as the abdomen; horizontal, depressed, and lilated at the base, and beyond rather strongly arcuate, tapering to a point, the extreme base of inner odge tubereulato-denticulate, with a distinet immer tooth 
at base of arcuate portion. Body (average), $11 \mathrm{~mm}$; forceps, male, 4-8 mm.; female, $3 \mathrm{~mm} . "-S c u d d e r$.

I have not seen this earwig in Indiana, but Rehn, loc. cit., states that four males, collected by F. M. Webster, at Lafayette, Indiana, about May 15, 1889, are in the collection of the U. S. National Museum. It is an introduced species, which has before been recorded in the United States from New York and New Jersey.

\section{LABIA Leach (1815.)}

Size, small. Body, flattened and slender, the abdomen slightly widened in the middle. Antenna about half as long as the body, 10 to 13 -jointed, the joints moniliform, or of equal size thronghout, obconic, about three times as long as broad. Both tegmina and wings present in our species. First and third tarsal joints equal, the second minute, simple, compressed. Forecps seldom more than half as long as the abdomen; in the male, simple, arcuate, horizontal; in the female, simple, straight, incurved at the tip, unarmed.

This genus differs from the preceding principally in the simple character of its middle tarsal joint, and in the shorter obconic joints of the antenna. Four species are aceredited to the United States, one of which occurs in Indiana.

3. LabIa MINoR (Linnæus.) The Little Earwig.

Forficula minor L., 81, Ed. X, I, 1758, 423; Burm., 4 0, II, 1838, 754; Fisch., 5 5, 1853, 52, 70, Plate VI, Fig. 7.

Labia minor Glov., 62, 1872, Plate X, Fig. 3; Scudd., 155, II, 1876, 257; Id., 157 , I, 1876, 178; Id., 158, XVIII, 1876, 320; Id., 188, 1900, 6; Comst., 41, 1888, 91 ; Fern., 53, 1888, 53; Bent., 3, VI, 1894, 257; Lugg., 84, 1898, 86, Figs. 49, 50.

Lubia minuta Scudd., 14 1, VII, 1862, 415; Pack., $104,1869,507$; Glov., 62, 1872, Plate I, Fig. 10.

Antennæ 10-12-jointed. Pronotum narrower than the head, scarcely longer than broad. Tegmina nearly twice as long ás the pronotim, the wings, when at rest, extending fully half their
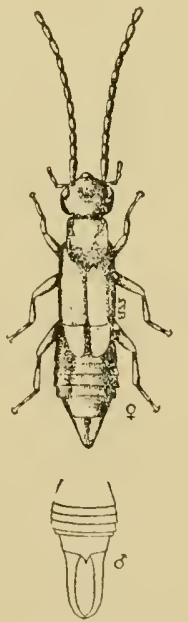

Fig. 21. Labia minor (L.) Female. Four times natural size. Abdomen of male showing form of forceps. (After Lugger.) length beyond the tip of tegmina. Forceps of male about threefourths the length of abdomen, rather heavy, minutely toothed on 
the inner edge. Last ventral segment of male with a slender, apical, compressed, upcurved tubercle. The entire body is covered with fine, soft, yellowish hairs.

Color: Head and sides of abdomen nearly black; mouth parts, antenria, thorax, tegmina, exposed parts of wings and middle of upper side of abdomen, yellowish brown; last segment of abdomen and forceps, reddish brown; legs and last two joints of the antenna, honey yellow.

Measurements: Male, length of body, $5 \mathrm{~mm}$; of antennx, $3.2 \mathrm{~mm}$.; of tegmina, $2 \mathrm{~mm}$.; of forceps, $2 \mathrm{~mm}$.

Although the range of this little earwig is said to cover Europe and the United States, and Canada east of the Rocky Mountains, I failed to detect it in Indiana until May 12, 1903, when I took a single male from beneath the bark about the base of a sweet gim tree near Grand Chain, Posey County. It doubtless occurs throughout the State, but is overlooked on account of its small size. A close search about electrie lights in the eities and towns of the State will donbtless reveal its presence in numbers.

\section{Family BLATTIDA.}

The members of the family Blattide, commonly known as cockroaches, may be known from the other families of Orthoptera by their depressed, oval form; by their nearly horizontal head which is bent under and almost concealed by the broad pronotum, so that when at rest the mouth projects back between the bases of the first pair of legs; by their slender depressed legs of equal length and size; and by the absenee of either ovipositor or forcipate appendages at the end of the abdomen. 'The ocelli are usually but two in number and the tarsi are 5-jointed.

The pronotum is generally transverse or shield-shaped, with rounded angles. The rings of the abdomen overlap each other and are eapalyle of great extension and depression, so that these insects seem to be pre-cminently fitted for living in the narrow erevices and cracks which they inhaloit. The legs are of peculiar structure in that they are long and more or less flattened, thus enabling the cockroaches to run with surprising swiftness, so that the family has been placed by some writers in a separate sub-order, the Cursoria, or runners. 'I'he wing covers, or tegmina. are leathery, translucent, and when well developed, orerlap when at rest; while the wings never excced the tegmina in lengtl, and in some cases are rudimentary or even wanting. 
From the other Orthoptera (except the Mantide) the Blattidee differ widely in the manner of oviposition, as the eggs are not laid one at a time, but all at once in a peculiar capsule or egg case called an ö̈theca. These capsules vary in the different species as regards the size, shape, and the number of eggs they contain, but they are all similar in structure. Each one is divided lengthwise by a membranous partition into two cells. Within each of these calls is a single row of cylindrical pouches, somewhat similar in appearance to those of a cartridge belt, and within each pouch is an egg.

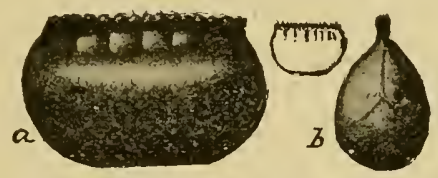

Fig. 22. Oötheca of Blatta orientalis; $a$, sile; $b$, end view. Natural size indicated by outline figure. From "Housebold Insects", published by U.S. Div. of Entomology.

The female cockroach often runs about for several days with an oötheca protruding from the abdomen, but fiually drops it in a suitable place and from it the young, in time, emerge. While this method of oviposition is the one practiced by all the species of common occurrence in the United States, there seem to be exceptions to it, as Dr. C. V. Riley has recorded the fact of an introduced tropical species, Panchlora poeyi Sauss., being viviparous, the young emerging alive from the body of the parent, and a careful dissection of the latter showing no trace of either eggs or oötheca.

All young cockroaches resemble the parents in form but are wholly wingless, the wings not appearing until after the fifth or last moult. The young are often mistaken for the mature by persons who have not made a careful study of the life history of the insects; and those of one or two well-known and common forms have, in the past, even been described or figured as distinet wingless species by some of the leading entomologists of the country.

To the paleontologist, interested in traeing back the ancestry of insects, the Blaltide become at once a group of surpassing interest, for some of the oldest known insects are eoekroaches from the Silurian and Carboniferons rocks. Between 130 and 140 fossil species of the family are known from the Paleozoic rocks of the United States, principally from the Carboniferous formations, but some from all the ages as far back as the middle Silurian. Mr. S. H. Scudder, of Cambridge, Mass., the most eminent authority on insect paleontology, says of the cockroach: "Of no other type of insect can it be 
said that it occurs at every horizon where insects have been found in any numbers; in no group whatever can the changes wrought by time be so carefully and completely studied as here; none other has furnished more important evidence coneerning the phylogeny of insects."

The Blattidx are pre-eminently tropical insects, and though abundantly represented in individuals, the number of species inhalsiting the United States is comparatively few, but 34 being listed in Seudder's Catalogue. These are divided among seven sub-families and eighteen gencra. Aside from two or three sub-tropical species which are often introduced in bananas and other fruit, but which soon die, and are not, therefore, considered in the present paper, nine species have been taken in Indiana. These represent but two of the sub-

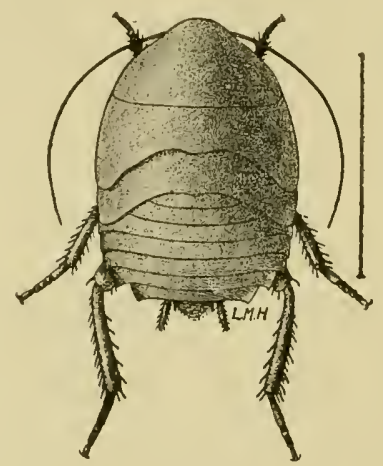

Fig. 23. Nymph of Nyctobora holosericea Kilug. One of the more common tropieal reaches introduced on fruit." (After Lugger.)

families and five of the genera, belonging to that division of the family in which all the femora, or at least the middle and hind pair are spined on the under side. These sub-families may be separated by the following table:

A BYYOPSIS OF THE SUB-FAMILIES OF BLATTID.E KYOWX TO OCCUR IX INDIANA.

a. Last ventral segment of the fomale alulomen plane, not compressed and nut dividerl; fore fomoral rally armed beneatl on the inner margin wilh many distinct spines; if so armed, then the sub-

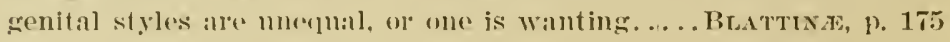

Nymphs of this sub-tropical roach have been taken in Indianapolis and Terro Haute A mature male wasent me from IIt. Carmal. Illinois, by Dr. J. Schneck. It was an inch and $a$ fourth in length, a uniform dark brown in color, with numerous small hairs on the pronotum and tegmina. 
aa. Last ventral segment of the female abdomen compressed so as to form a carina or ridge on its under side, and divided so as to be bi-valved; fore femora armed beneath with many spines on the immer margin........................ 191

\section{Sub-family BLATTINAE.}

In this sub-family the body of the male is elongate; that of the female usually distinctly broader. The head is strongly depressed and almost wholly covered by the pronotum. The antennæ in our species are setaceous. The posterior border of the pronotum is truncate or rounded. Both pronotum and tegmina are free from hairs. The tegmina are coriaceous or membranaceous, rarely corneous, in texture. The median vein of the wings sends but few branches to the apex; while the radial vein emits many parallel, simple veinlets to the costal margin. The tarsi are without pulvilli or pads. The last ventral segment of the female is relatively plane, not compressed or divided. The supra-anal plate of both sexes is but little produced, triangular, entire. The sub-genital plate of the male (exeept in the genus Blattella) bears a pair of minute styles.

To this sub-family belong all the native species of roaches found in Indiana, and one common introduced species, Blattella germanica L. The native species, as far as synonymy goes, are a badly mixed lot - so badly mixed, in fact, that more time has been spent upon them than upon any other group treated in this paper, and in the end the results are more unsatisfactory and less certain than in any other. This is due to the fact that the sexes differ so widely in appearance that they have been described as different species, and often placed in wholly different genera. Most of the descriptions have been made by foreign entomologists, who never saw a specimen in the field, and for that reason knew nothing of the relationship of the diflerent individuals before them. However, the two sexes are so seldom found mating, that even the field naturalist can not be certain as to their relationship. I have collected Indiana Blallidee for 15 years, and, as yet, am only positive as to the sexes of one of our native speciesTemnopteryx deropeltiformis Brmn. The conelusions at which I have arrived regarding the others are based mainly upon finding both-sexes at the same time beneath the same hiding places on a number of occasions. This, however, is not positive proof that the sexes belong where I have placed them.

Saussure, followed by Scudder, has stated that the tegmina in both sexes of the genus Temnopteryx are abbreviated, yet this is not true of $T$. deropeltiformis Brunn., the only one of the United States spe- 
cies in which both sexes are known. Prof. Lawrence Bruner, an acknowledged anthority on North American Orthoptera, writes me that, as far as he knows, "all the females of Temnopteryx are shortwinged, and all the males long-winged like the majority of the species of Ischnoptera." Prof. A. P. Morse kindly examined Mr. Scudder's collection for me, and states that, as far as he was able to ascertain, it contains no short-winged males of Temnopteryx.

Saussure and Scudder, in their "Keys to Genera of Blattinæ," also state that in the genus Ischnoptera the "tegmina are completely developed or in the female rarely abbreviate." In all my collecting, I have never seen a long-winged female of Ischnoptera. Bruner has written me that he does not possess a long-winged female or a shortwinged male of the genus, and Morse also states that Scudder's collection contains no long-winged females of Ischnoptera. From these facts, and from others"gathered in the field and mentioned under the different species, I have concluded that the species of Phyllodromia and Temnopteryx listed by Scudder in his Catalogue* are but the females of certain species of Ischnoptera and have so placed them in the present paper. As a result, representatives of but three genera of the sub-family Blattince oceur in the State. These may be separated by the following

\section{KEY TO GENERA OF INDIANA BLATTINE.}

a. Sub-genital stylets present in the males. Tegmina of females abbreviate, reaching lout little, if any, beyond the middle of the broad ahdomen.† (Native species.)

b. Tegmina corneous; those of fomale obliquely truneate at apex. Uhar vein of wings of male without branches to the rena dividens........................ Tennoptersx, p. 176

b). Tegmina membranaceous or somewhat coriaceous; those of female usually loroadly rounded at apex; sometimes angulate, but not truncate. Ulnar vein of wings of male emitting complete branches to the apical margin and incomplete branches to the reua dividens............. I IschNorTERA, 11. 17 ar. Sub-genital stylets absont in the males. Tegmina of both sexes fully developel. Size smill, body narrow. (Introduced speeies.)

V. PILATTILIA, H. 1ST

\section{Temnoptenix Brumner (1865).}

Body oblong, that of male rather slender; that of female stouter, with the abdomen broader than the thorax. IIead large and flattened; the vertex swollen. Antenna longer than the body, rather stout. Ocelli wanting. Pronotum and tegmina somewhat corneous

- If does not list T. deropeltiformis Brunn.

tIn the females of $I$. pennsylvanica they sometimos cover throe-fourths of abclomen, but nevor roach its tip. 
in texture, quite flat, the former nearly semi-orbicular in shape, much the broader in the female, the hind border a little rounded in the male, truncate in the female. Tegmina fully developed and much surpassing the abdomen in the male (of our species); abbreviate and with the apex obliquely truncate in the female. Abdomen very flat above, convex beneath. Supra-anal plate of the male, transverse, rounded; that of the female triangular. Sub-genital plate of the male, narrow, bearing two stylets; the one on the left usually the larger. Cerei rather long and stout, 10-jointed. Last ventral segment of the female abdomen broadly rounded, entire.

As noted above, I consider that certain species heretofore ascribed to this genus are females of species of Ischnoptera. This eliminates the nominal species T. major Sauss.-Zehnt. and T. virginica Brunn. of Seudder's Catalogue, representatives of which occur in Indiana, and leaves T'. deropelliformis Brunn. as our sole representative of the genus.

\section{Tennopteryx deropeltiforms Brumer.}

Temnoptery.r deropeltiformis Bruun., 37, 1865, 87; Bl., 8, 1893, 160.

Main characters as given above. Disk of male pronotum with three impressions, one shallow, median and longitudinal, the other two deeper, semicircular and lateral. Tegmina of female covering about one-third of the abdomen, their inner edges meeting; those of male much surpassing the abdomen.

Color, a uniform dark mahogany brown, except the tibiæ and tarsi of all the legs, which are a light reddish brown, the contrast between the two colors, in living specimens, being very striking. Wings of male transparent, slightly infuscated, the veins and anterior border light brown.

Measurements: Iength of body, male, 14 mm., female, $15 \mathrm{~mm}$; of pronotum, male, 3.5 mm., female, $4.5 \mathrm{~mm}$; of tegmina, male, 15.5 mm., female, $5 \mathrm{~mm}$.; width of pronotum, male, $4.5 \mathrm{~mm}$., female, $6 \mathrm{~mm}$.

In Indiana this handsome roach has, as yet, been noted only in Vigo and Crawford counties. In the former it was found in but one locality, the border of a marsh in a low sandy woods three miles east of Terre Haute. A single pair were taken on May 28, 1893, and on June 18 , probably a dozen specimens were se-

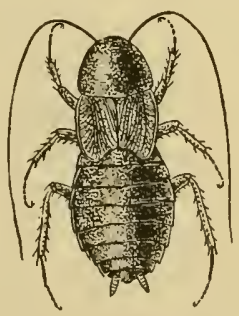

Fig. 24. Temnopteryx deropeltiformis Brunner. Female one and one-tbird times natural size. (Original.) cured. They were hiding beneath small $\operatorname{logs}$ and sticks, and the males, when deprived of their shelter, flew actively away, while the 
females conld but crawl, and that rather sluggishly for a Blattid, towart a new hiding place. A mature male was taken in the same place on May 12, 1894. In Jume, 190\%, a number were found in Crawford county beneath flat stones and rublish on the tops of high hills near Wyandotte Cave. A single female was also captured while feeding npon a species of fleshy fungus (1 garicus) in dense woods in Marshall County, Illinois, about eight miles west of Terre Hante. Brunner (loc. cit.) recorded it from "Amerique du Nord," and I can find no other note of its occurrence in the United States.

\section{Iscmoptera Burmeister (1838).}

Body of male rather narrow, oblong; that of female broader, orbicular. Antenne nearly or fully double the lengtl of the body. Pronotum small, orbicular or of the form of an ellipse; in the male often much narrowed in front. Tegmina membranaccous, more or less translucent, longer than the abdomen in the males, abbreviated (in our species) in the females. Wings hyaline; "the discoidal (ulnar) vein, instear of sending longitudinal branches exclusively to the apieal nuargin, sends also small oblique branches to the anal vein (vena dividens)." Cerei long and relatively stout, 12-jointed. Supraanal plate of the male broad, the apex either truncate or rounded; that of female narrower, triangular and obtuse. Sub-genital plate of male bearing two rather long stylets which are often deflexed. Last abdominal plate of female entire.

Five species of our native roaches belong to this genus. They may be separated as follows:

\section{KEY TO INDIANA SPECIES OF ISCHNOPTERA.}

(1. Size large; length of body of male, 19 or more mm. of body, including tegmini, 25 or more $\mathrm{mm}$.

b. General color fuscous or ehestunt hrown; the center of disk of pronotum dark, the silles yellow.

c. I'ronotum elliptieal, nearly as wide in front as hehind, the sides flaring, but little deflexed; the center of disk

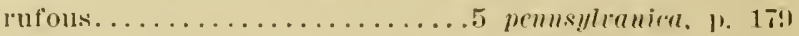

cc. Pronotum notalily narrower in front than behind, the sides strongly deflexed: the center of disk black...........

(i incqualis. 1). 182

bb. General color light rerdlish or yellowish brown; the sides of pronotum not markedly different in color from the center of disk............................ major, p. 183 
aa. Size medium; length of body of male, less than $15 \mathrm{~mm}$; of hody, including tegmina, less than $20 \mathrm{~mm}$.

d. General color of male, light reddish or yellowish brown; of female, reddish brown, the abdomen darker; inner edges of tegmina of female meeting or slightly overlapping........... \& uhlcriann. p. 184

dd. General color of male, dark reddish brown or chestnut; of female, piceous; inner edges of tegmina of female widely separated.........9 intricata, p. 186;

5. Ischnoptera Pennsylyanica (De Geer). The Pennsylvania Cockroach. Blatla pennsylanica De G., 57, III, 1773, 537, Plate 44, Fig. 4; Thom., 202, V. 1865, 440. (Male).

Platamodes pennsylianica Scudd., 14 1, VII, 1862, 417; Glov., 62, 1872, Plate I, Figs. 1, 3; Riley 122; II, 188t, 172; Comst., 4 1, 1888, 93.

Ischnoplera pennsylvanica Brumı., 37, 1865, 135; Sauss., 132, VI, 1870, 63, Plate II, Fig. 35; Bl., 8, 1893, 158; Id., 16, 1899, 202, Fig. 43; Beut., 3, VI, 1894, 259; Lugg., 84, 1898, 96, Fig. 58; Scudd., $188,1900,7$.

Blatta borealis Sauss., 128, 1862, 4, (Female).

Phyllodromia borealis Brumn., 37, 1865, 101 ; Scudd., 188, 1900, 8; Id., $189, \mathrm{IX}, 1900,100$.

Ectobia flavocincta Scudd., 141, VII, 1862, 419; Brumn., 37, 1865, 57; Comst., 41, I, 1888, 93; Bl., 8, 1893, 161. (Female).

Blatta flarocincta Fern., 5 3, 1888, 51.

Ectobia lithophila Scudd., 14 1, VII. 1862, 418 (Immature).

Male: Size, large. Pronotum elliptic, the front border slightly the narrower, its margin straight; the hind border rounded; an ob-

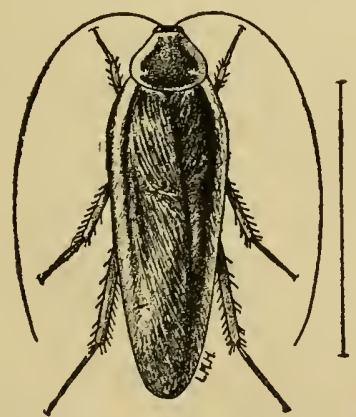

Fig. 25. Ischnoptera pennsylvanica (De Geer). Male. (After Lugger).

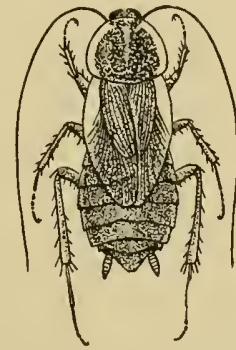

Fig. 26. Ischnoptera pennsylvanica (De Geer).=Phyllodromia borealis Sauss.= Ectobia flavocincta Scudd.

(Female. Original.)

lique depression on each side, near the base. Tegmina membranaceous, more or less transparent, long and rather narrow, extending 
much beyond the tip of abdomen. Wings as long as tegmina. Subgenital styles deflexed.

Female: Size medium, the abdomen broader than thorax, its greatest breadth contained less than twice in its total length. Pronotum much wider and of firmer texture than in the male; the disk a little convex and with no impressions; the hind margin nearly truncate; the front margin narrower, rounded; the lateral margins somewhat flaring, their posterior third slightly upturned. 'I'egmina broad, overlapping, covering from a half to three-fourths of abdomen, their apices rounded; the veins prominent. Inner wings narrow, about half the length of tegmina.

General color, chestnut brown to fuscous, the females the darker. Antennæ dusky; face reddish brown in center, the margins yellow. Disk of pronotum chestnut brown, margined on sides, and sometimes nearly in front, with whitish yellow. Tegmina of male smoky brown, lighter in freshly moulted specimens; those of female dark reddish brown; the outer basal two-thirds (male) or onc-half (female) rather broadly margined with yellowish. Upper surface of female abdomen very dark brown. Legs of both sexes pale yellowish brown.

Measurements: Length of body, male, $21 \mathrm{~mm}$., female, $16 \mathrm{~mm}$; of antennix, male, $28 \mathrm{~mm}$., female, $18 \mathrm{~mm}$; of pronotum, male and female, $5 \mathrm{~mm}$.; of tegmina, male, $22 \mathrm{~mm}$., female, $6-10 \mathrm{~mm}$.; width of pronotum, male, $5.5 \mathrm{~mm}$., female, $7 \mathrm{~mm}$.

While I have never taken the sexes in coitu, there is no doubt in my mind but that the female of pennsylvanica is the roach heretofore known as Blatta or (Phyllodromia) borcalis Sauss., and Ectobia flavocincta Scudd. That these last two names are synonymous has been shown by Seudder.*

As far back as May 2\%, 1894, I made the following entry in my ficld note book: "Platamodes pennsylvanica and Eclobia flavocincla, both mature and very common beneath the bark of red oak stumps and dead trees. Are the latter the females and the former the males of the same species? I often think so, but as yet have no positive proof." I have since on many occasions taken the two forms together, but have never seen a female of pennsyleanica nor a male of flavocincta, unless the latter be the female of the former. I can find no mention or description of the female of pemsylianica in any work at my command. All illustrations of the species which have been published are of the male.

On the other hand, all mention and descriptions of $P$. borealis which note the sexes, with a single exeption, relate to the female.

"Psyche, IX, 1900, 100. 
The exception noted is that of Saussure who, in his original description of borealis, mentions the male, stating that the elytra are short, the supra-anal plate triangular, acuminate and sub-carinate. This is true of all the specimens of borealis in my collection. Several of them havc oötheca partly protruding from the abdomen and the genital organs of all are similar. Prof. Morse has compared specimens of what I have called flavocincta with Scudder's types, and pronounces them the same.

I. pennsylvanica is the most common of our native roaches, having been taken in the State wherever collections have been made, beneath the loose bark of logs and old stumps. It is usually seen in the wingless stages, the mature individuals being common only from May 5 th to October. The half grown young, described by Scudder as Ectobia lithophila, are of a shining, dark brown color, the dorsal surface of thoracic segments often lighter. As the long-winged males are attracted by light, country houses are often badly infested with them; and where food is scarce, the wall paper is sometimes much injured for the sake of the paste beneath. What the hordes of young which dwell under the bark of logs live upon is a question as yet unsettled, but the larvæ of other insects undoubtedly form a portion of their food, as in two instances I have found them feeding upon the dead grubs of a Tenebrio beetle; while living as well as decaying vegetable matter probably forms the other portion. The mating of the imagoes probably occurs in late spring and early summer, the newly hatched young being most abundant from mid-August until December. Females with oötheca protruding have been taken as early as May 19th and as late as September 3 d. The young in various stages of growth survive the winter in the places mentioned, they being the most common insects noted in the woods at that season. Cold has seemingly but little effect upon them, as they scramble away almost as hurriedly when their protective shelter of bark is removed on a day in midJanuary with the mercury at zero, as they do in June when it registers $100^{\circ}$ in the shade.

The empty oötheca of this species are very common objects beneath the loose bark of logs and especially beneath the long flakes of the shellbark hickory. They are chestnut brown in color, from 5 to 9 $\mathrm{mm}$. in length by $4 \mathrm{~mm}$. in breadth, and are much less flattened than those of Blattella germanica described below. The dorsal or entire edge is slightly curved, or bent inward, after the fashion of a small bean, while the other edge is minutely serrate. The young, after hatching, evidently escape in the same manner as do those of the Oriental cockroach, as no break is visible in the empty capsule. The 
general range of pennsylvanica is given by Seudder as "Northern United States and Canada east of the Rocky Momntains."

\section{ISCINOPETRA IN EQUALIS Sauss.-Zehnt}

Ischnoptera inxerpulis Sauss.-Zehnt., 135, 1893, 36, Plate 6, Figs. 1417 ; Scudd., $188,1900,7$.

Male: "Fuscous or fusco-ferruginous, with brownish antennæe. Head with face testaceous; in middle and on vertex, black. Pronotum elliptical, with distinct impressions, the disk slightly convexed, smooth, wholly black or fuscous or castancous, with lateral margins testaceous, translucent. Tegmina fuscous or slightly rufous in color, basal area with anterior margin hyaline. Wings subvitreous, with anterior and apical margins rather broadly infuscated. Vena ulnaris with six or seven branches; besides this, with incomplete branch and other rudimentary ones, not reaching the vena dividens.

Fiemale: "Pronotum horny, parabolic, with anterior and lateral nargins semi-elliptical, and the posterior margin transverse, broad, subangular, with lateral angles slightly rounded. Disk a little convex, with no impressions; fuscous-black in color, with yellow lateral margins. 'Tegmina abbreviate, covering first segment of the abdomen, blackish-fuscous in color with distinct veins, apex widely rounded and costal area yellowish in color. Wings rudimentary, yellowish, not covering medial segment, with apex fuscous or spotted."

Measurements: Length of body, male, $21 \mathrm{~mm}$, female, $16 \mathrm{~mm}$; of pronotum, male, $5.2 \mathrm{~mm}$., female, $5 \mathrm{~mm}$; of tegmina, male, 23 mm., female, $8 \mathrm{~mm}$; width of pronotum, male, $6.3 \mathrm{~mm}$., female, 6.5 miı.; of tegmina, male, $6.8 \mathrm{~mm}$., female, $5.2 \mathrm{~mm}$.

Specimens from Crawford County, Indiana, were identified for me as this species by Prof. T. Bruner. I have since secured a copy of the description of Sauss.-Zehnt.-the only one extant-quoted above, with which the Indiana examples fairly agres. The species is very close to $I$. pennsylianica, and may prove only a rariety. The measmements are very nearly the same. 'The general color of the pronotum and teguina is darker, approaching a fuscous. The pronotum is proportionally narrower in front, with the sides more distinctly deflexed and the sub-basal impressions more distinct. The females of the two are even more difficult to distinguish than the males.

'The Crawford County specimens were taken in late June beneath flat rocks and chmnks on high hills near Wyandotte Cave. Sauss.Zchnt., like many other foreign systematists, give a rery general range to the species they describe, recording this one from "North America, Texas, North Mexico." 


\section{IsCHNOPTERA MAJOR (Sauss.-Zehnt.)}

Temnopteryx: major Sauss.-Zehnt., 135, 1893, 54; Scudd., 188, 1900, 8.

Male: Size, large. Pronotum broadly elliptic, larger than in either of the two preceding species, membranaceous, the sides flaring, translucent; two deep oblique impressions on either side near the base. Tegmina membranaceous, hyaline, longer than albdomen. Wings as long as tegmina.

Female: Body, stont, broad. Pronotum, short and wide, hornlike, with no impressions; the hind margin nearly straight, the front margin rounded. Tegmina, abbreviated; covering only the basal segment of abdomen; rather broad, their inner edges overlapping, their apices broadly rounded. "Sulcus analis deep, scarcely curved anterior to the apex, reaching to three-fourths of the sutural margin." Wings rery small, narrow, pointed. Supra-anal plate large, triangular, keeled, with apex bluntly rounded.

Color: Male, a nearly uniform, light reddish brown. Two basal joints of antennx yellow, the remaining portion, as also the cerci, dark brown. Lateral margins of pronotum and of basal half of tegmina translucent whitish. Abdomen and legs pale yellowish brown. Fente: Pronotum reddish brown, the lateral margins indistinctly yellowish or paler than the disk. Tegmina darker brown, their outer margins dull yellowish. Abdomen and cerci piceous. Antennæ as in male; the legs darker.

Measurements: Length of body, male, $21 \mathrm{~mm}$., female, $1 \% .5 \mathrm{~mm}$.; of pronotum, male, $5.5 \mathrm{~mm}$., female, $5.3 \mathrm{~mm}$.; of tegmina, male, 21 $\mathrm{mm}$., female, $6.5 \mathrm{~mm}$.; width of pronotum, male, $6.3 \mathrm{~mm}$., female, 7 mm.; of tegmina, male, $6.2 \mathrm{~mm}$., female, $5 \mathrm{~mm}$.

This roach has been taken in Indiana only in the vicinity of Wyandotte, Crawford County. Immature females were first found May 9 , 1899 , and mature individuals of the same sex on July 7th of that year. In 1902 more persistent searching proved the females to be common during the last week of June and the first one of July, sevcral being taken with oötheea protruding. A single male, the only one seen, was secured on July 3d. There is little donbt but that it is one of the same species as the female, as it was found with two of them, and differs from any other roach taken in the State. It is of the exact color of I. uhteriana Sauss., described below, and is verry likely to be taken for an unusually large form of that insect. It may be possible that it is a light form of $I$. couloniana Sanss., of which the females are unknown, as it agrees very well, except in color, with the deseription of that species. If so, that name would have priority over major, of which the males have not hitherto been found. There is no 
doubt of its being a true Ischnoptera. The female somewhat reserbles that of the common I. pennsylvanica, but is broader bodied, with the front half not tapering. The yellow margin of pronotum and tegmina is much less distinct. 'The tegmina do not vary in length, as do those of the female pennsyluanica.

In the region mentioned $I$, major oceurs beneatlı flat rocks on the sides and erests of the higher hills, especially in limestone glades where the red cediar abounds. It has heretofore been reeorded only from 'Temmessec.

8. Iscinoptera UHLeriana Saussure.

Isthopdere uhterima Sanss., 128, III, 1862, 8; Id., 129, 186t, 82; Id., 132, VI, 1870, 55; Sauss.-Zehnt., 135, 1893, 36, Plate 3, Figs. 21-23; Scudd., 188, 1900, 7; Id., 189, IX, 1900, 100. (Male.)

Plutumules unicolor Scudd., 14 1, VII, 1862, 417; Fern., 53, 1888, 53.

Isclunptera nuimlor Brumn., 37, 1865, 134; Sauss., 133, VI, 1870, 56; B1., 8, 1893, 160; Bent., 3, VI, 1894, 259; Lugg., 84, 1898, 97, Fig. 59; Scurld., 188, 1900, 8. (Male).

Trmmiptry.r rirginier Brumu., 37, 1865, 86; Beut., 3, VI, 1894, 261; Scudd., $188,1900,8$. (Female).

Male: Size, small, body narrow. Antennæ slender, tapering, slightly longer than the body. Pronotum, small, elliptical; the hind

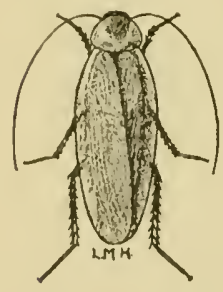

Fig. 2i. Ischnoptera uhleriona Sauss. Male. (After Lugger.) margin rounded, the sides somewhat deflexed, translnecut: the impressions near base of disk, distinct, oblique. 'T'egmina fully developed, longer than the abdomen, rather wide. Wings as long as tegmina; the ulnar vein with five or six apical branches and several shorter ones. supra-anal plate triangular.

Female: body broader than that of male. I'ronotum semi-orbientar, sub-corneons. the hind margin nearly straight, the disk sub-eonvex, the inupressions less distinet. T'egmina albreviated, covering less than half the abdomen, their inner edges stightly orerlapping. their apices roumded; usually slightly emarginate near the inner or sutural angle. Wings short and narrow, covering only first ahdominal segment. Supra-anal plate triangular.

Color: Male, usually a uniform light reddish brown. Head and posterior margin of pronetum sometimes a little darker. Eyes, black. Wings, sub-vitreous, with reddish brown veins. Female, darker, the head, pronotum and usually the tegmina dark reddish brown, the 
tegmina sometimes chestnut brown. Top of abdomen fuscous brown to piceous. Legs pale reddish brown.

Measurements: Length of body, male, $12 \mathrm{~mm}$., female, $11 \mathrm{~mm}$; of pronotum, malc, $3 \mathrm{~mm}$., female, $3.3 \mathrm{~mm}$.; of tegmina, male, 16 mm., female, $3.7 \mathrm{~mm}$; width of pronotum, male, $4 \mathrm{~mm}$., female, $3.7 \mathrm{~mm}$.

This light colored roach probably occurs throughout the State, having been taken in numbers in Crawford, Vigo, Putnam, Marion, Kosciusko and Lake counties. The males are often seen about eleetric lights in the cities; but when first reaching maturity abont May 10, they are gregarions beneath the bark of logs and under chunks and rubbish in open woods. The females appear fewer in numbers, but are probably overlooked, their tegmina being so short that they resemble the nymphs of their own or other species.

The first record of the female in the State was made June 2, 1894, as follows: "In a flat woods, seven miles east of Terre Haute, I found a new species of cockroach quite common beneath the bark of oak stumps. The wings short, covering less than one-half abdomen. It may be the female of $I$. unicolor Scuctl, as several of the longwinged forms of the latter were beneath the same shelter." Since then, I have usually found this short winged form in company with the nuales of $I$. unicolor; and have taken them with oötheca protruding in the first week of July. Some of the first ones taken were sent to Scudder, who pronouneed them $T$. virginica Brunner, and they agree in all respects with the original description of that species, which was made from a single female, and of which the male is unknown. Since no female of $I$. unicolor has been described exeept by Sauss.-Zehnt. under the name of I. uhleriana, I believe the $T$. virginica to be the female of $I$. unicolor. Scudder, in Psyche (IX, 100), states that he has compared the types of uhleriana and unicolor and that they are identical. He had previonsly seen Indiana specimens of unicolor and pronounced them that species. Prof. L. Bruner has recently sent me specimens of both sexes of uhleriana from $\mathrm{Ne}$ braska under the name of $I$. borealis Brunn. It is very probable that that species is also a synonym of uhleriana, though only a comparison of the different types will decide. Brumner states that $I$. unicolor may be distinguished from $I$. borealis by the much lighter color and the disposition of the nerves of the wings; but the color varies much with age; while Saussure has shown that in certain species of Ischnoptera, the venulation of the wings is also very variable.*

"Miss. Seientif. Mex., p. 64. 


\section{ISCHNOPTERA INTIRICATA sp. nov.}

Female: Size, small; body, short and broad. Antennæ slender, about as loug as body; the joints with numerous short hairs. Pronotum sub-orbicular, smootlu, shining; the disk convex, its sides sloping; the hind margin straight or nearly so. Tegmina abbreviate, reaching only to second abdominal segment, their inner edges separated by a space equal to half their breadth; and gradually tapering obliquely on apical third to the sub-acute apex. Wings minute, narrow, reaching only to first abdominal segment. Abdomen notably

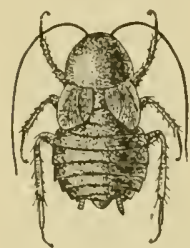

Fig. 28. Ischnoptera intricata sp. nov. Fomale. One and onethird times natural size.

(Original.) broader than thorax; its width equaling twothirds the total length. Supra-anal plate short, triangular, obscurely keeled; the preceding segment, smaller and more distinctly keeled. Subgenital plate broadly convex, entire.

Color: A nearly uniform shining piceous; the outer margins of tegmina sometimes chestmut brown. Legs dark reddish brown; wings light brown.

Male: Size small, body narrow. Pronotum elliptical, sub-corneous, the lateral margins strongly deflexer; the hind margin but little convex; the disk with an irregular distinct depression on either side. 'Tegmina much longer than the abdomen, rather wide, the veins distinct.

Color, dark reddish brown to piceous, the tegmina and legs lighter. Antenna light wood hrown, the joints rery hairy. Head and under side of thorax piceous. Pronotum reddish brown, the posterior margin darker. 'Tegmina and legs dull yellowish or golden brown. Under side of abdomen reddish brown.

Measurements: Leugth of body, male, $14.5 \mathrm{~mm}$., female, $12 \mathrm{~mm}$.: of pronotum, male, $3.5 \mathrm{~mm}$., female, $4 \mathrm{~mm}$.; of tegmina, male, 15.5 mm., female, $4 \mathrm{~mm}$.; width of pronotum, male, $5 \mathrm{~mm}$., female, $6 \mathrm{~mm}$.; width of tegmina, male, $5 \mathrm{~mm}$., female, $3.5 \mathrm{~mm}$.

The single male which I refer to this species was taken beneath a flat rock on the slope of a high hill near Wyandotte, Crawford ('ounty. May 9. 1899. The females were found to be quite common in the same locality in the last week in June, 1902. Sereral females were also sccured beneath chunks in oak woods near Lake James, Stenben County, on August 7th, two of which had oötheca protruding. I am by no means certain that the male belongs with the females; if not. the name applied will be referred to the latter sex. 


\section{Blattelia Candell (1903).}

The members of this genus have the body elongate; the head almost completely hidden by the pronotum, which is small and suborbicular; the eyes large and reniform, the ocelli more or less distinct. Antemnx setaceous, sparsely ciothed with long hairs, unicolorous and much longer than the body. Tegmina and wings reaching to or beyond the tip of abdomen, membranaceous or slightly coriaceous. Inner wings with the ulnar vein undivided and without incomplete branches to the rena dividens. Supra-anal plate of male elongated, either triangular or broadly rounded, sometimes almost orbicular; sub-anal plate of the same sex with the styles rudimentary or wanting. Last abdominal sternite of the female, large, triangular, obtuse but not notched.

This gemus is represented in Indiana by but one introduced species which is cosmopolitan in its range.

10. Blattella germanica (Limæus). The German Cockroach. The Croton Bug. The Water Bug.

Blatte germunice L., 81, II, 1767, 688; Sauss., 132, VI, 1870, 28; Comst., 41, 1888, 93, Fig. 87; Fern., 53, 1888, 50, Fig. 20; Kell., 78, 1892, 108, Fig. 59; Lugg., 84, 1898, 90, Fig. 53; Scudd., $188,1900,8$.

Ectobia gemanica Scudd., 141, VII, 1862, 418; Pack., 104, 1869, 576, Fig. 569; Glov., 62, 1872, Plate 1, Fig. 4; Id., 63, 1874, 132, Fig. 3; Riley, 122, II, 1884, 171, Fig. 247; Id., 125, I, 1888, $68,191$.

Phyllodromia germanicu Brumn., 37, 1865, 90; Pack., 104, 1883, 576, Fig. 569; Riley, 126, II, 1890, 266, Fig. 57; BI., 8, 1893, 162; Id., 16, 1899, 204, Fig. 44; Beut., 3, VI, 1894, 258.

Ectobia (Phyllodromia) germanica Marl., 85, 1896, 92, Fig. 42; Id., 86, 1902, 10, Fig. 5.

Blattella germanica Caud., $40 \mathrm{Ob}, \mathrm{V}, 1903,234$.

Ischnoptera bicittata Thom., 21 0, I, 1876, 250, Plate XXXVI, Figs. 1, 2.

This is one of the smallest and, at the same time, one of the most common of the Blattida known to occur in the State. The general color is yellowish brown, the females often darker; all the limbs much lighter than the body; the pronotum with two dark brown, longitudinal bands separated by a yellowish stripe. The tegmina and wings of the male extend to the end of abdomen, those of the female are a little longer. Antennæ dark brown, exceeding slightly the tips of the closed tegmina. The body of the male is longer and narrower than that of the female.

Measurements: Male-Length of body, $13 \mathrm{~mm}$.; of tegmina, 10 mm.; width of body, $4 \mathrm{~mm}$.; Female-Length of body, $10 \mathrm{~mm}$.; of tegmina, $11 \mathrm{~mm}$; of antennæ, $13 \mathrm{~mm}$. 
The "Croton bug," so called because it made its appearance in New York City in numbers about the time the Croton Aqueduct was completed, is a native of Central Europe, but like the Oriental roach, has become cosmopolitan. It seldom if ever occurs in numbers in the country, but is one of the worst insect pests with which the inhabitants of the larger cities of the United States have to deal, and is found in every town of any size in Indiana. It is the most fecund of all the roaches and the seasons of mating and hatching of the young are, perhaps, more irregular than in any other species. Adult forms are evidently to be found at all seasons of the year, as I have taken them in December, April and October. It is not so much a lover of filthy surroundings as is the Oriental roach, and hence frequents more

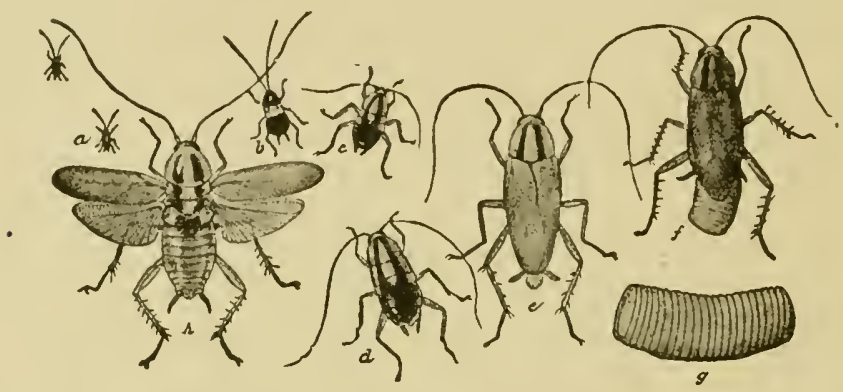

Fig. 29. Blattelle germanica L.; $a$, first stage; $b$, second stage; $c$, thiril stage: $d$, fourth stage; $e$, arlut; $f$, adult female with egg ease; $g$, egg case, enlarged; $h$, alult, with wings spread. All natural size except g.-Trom "Household Inseets," published by U. S. Div. of Entomology,

often than that species the dwellings of the better class of people. It delights in warm, moist places, and is especially abundant and destructive in buildings which are heated by stcam.

As an evidence of its abundance under favorable conditions, I will mention that a single person captured for me over thirty adult specimens and fully half that number of young, in less than ten minutes in the kitchen of the leading hotel of the city of 'Terre Haute. Where it once obtains a foothold and the surroundings of temperature and food supply are favorable, it is almost impossible to eradicate, as its small flattened form enables it to hide and breed in cracks and crevices which none of the other roaches ean enter.

Like many other omnivorous animals, Croton bugs find in wheaten flour a food substance which is rich in nutrition and easily digested, and so they prefer wheat breads and starehy materials to all other foods. On account of this liking they often do much harm to cloth bound books ly gnawing their eovers in search of the paste beneath. 
They also seem to have a peculiar liking for paints of various kinds, and in the office of the U. S. Coast and Geodetic Survey, at Washington, have done much damage by eating off the blue and red paints from the drawings of important maps. Glover, loc. cit., states that in his office "They made a raid on a box of water colors where they devoured the cakes of paint, vermilion, cobalt and umber alike; and the only vestiges left were the excrements in the form of small pellets of various colors in the bottom of the box."

The oötheca of the Croton bug is very light brown, a little over twice as long as broad, $7.5 \times 3.5 \mathrm{~mm}$., with the sides somewhat flattened and the edges parallel. Within it the eggs, thirty-six in number, are arranged in the usual two rows. It is carried about by the mother roach for several days with from half to three-fourths of its length protruding from the abdomen, and when dropped in a favorable place the young, evidently very soon, emerge from it; for in a bottle in which a female with protruding oötheca was placed at eleven o'clock p. m. the young were found to have emerged on the following morning at eight. They were then wholly white, except the lateral edges of the abdomen, where a blackish tinge was evident. By five o'clock in the afternoon of the same day, having meanwhile eaten their fill of moistened wheaten bread, they had become too large for their skins, and had moulted for the first time. They then measured $3 \mathrm{~mm}$. in length, and the head, pronotum, abdomen, and apical half of antennw were black, while the other two thoracic rings and the basal half of antennæ were a grayish white. The half grown young are very dark brown, with the first four or five segments bordered with yellow, and with traces of a lighter median stripe.

In giving a remedy for this and other roaches I can not do better than to quote from Mr. Marlatt's excellent bulletin as follows:

"Like the crows among birds, the roaches among insects are apparently unisually well endowed with the ability to gnard themselves against enemies, displaying great intelligence in keeping out of the way of the irate housekeeper and in avoiding food or other substances which have been doctored with poison for their benefit. 'Their keenness in this direction is unquestionably the inheritance of many centuries during which the hand of man has ever been raised against them.

"Fumigation.-A thoronghly effective and simple means of ridding one's premises of roaches has been found, lowever, and is in fumigating with hydrocyanic-acid gas. The experience of the last year or two has demonstrated that this gas, formerly employed for disinfecting mursery stock and orchard trees (notably citrus) from scale and 
other insects, is equally effective against houschold insects, and is particularly applicable and satisfactory against all species of house roaches. The gis is extremely poisonous to human beings, but by abscring the proper precantions, may be employed with complete safety. A special (ircular (No. tfi, Second Series, U. S. Div. Ent.) has been prepared by Dr. 1. O. Howard, giving the steps of the process in detail.

"In addition to the hydrocyanic-acid gas treatment noted above, two or three other forms of fumigation may be employed against house roaches. Wherever roaches infest small rooms or apartments which may be sealed up nearly air-tight, and also on shipboard, the roach nuisance can be greatly abated by the proper use of poisonous gases, notably bisulphide of carbon. This substance distributed about a pantry or room in open ressels, will evaporate, and, if used at the rate of one pound to every-1,000 cubic feet of room space, will destroy roaches. Unless the room can be very tightly sealed up, however, the vapor dissipates so rapidly that its effect will be lost before the roaches are killed. The hatches of ships, especially of smaller coasting vessels, may be battened down, a very liberal application of bisulphicle of earbon having been previously made throughout the interior. If left for twenty-four hours the roaches and all other vermin will unquestionably lare been destroyed. In the use of this substance it must he always borne in mind that it is riolently explosive in the presence of fire, and every possible precantion should be taken that no fire is in or about the premises during the treatment. It is also deadly to higher animals, and compartments should be thoroughly aired after fumigation.

"Poisons and Repellenls.-As just noted, roaches often seem to display a knowledge of the presence of poisons in food, and, notwithstanding their practically omnivorous habits, a very little arsenic in baits seems to be readily detected by them. In attempting to eradicate roaches from the Department storerooms, where doth-bound books are kept, various paste mixtures containing arsenic were tried, but the roaches invariably refused to feed on them in the least. This applies particularly to the German roach, or Croton bug. and may not hold so strongly with the less wary and perhaps less intelligent larger roaches.

"A common remedy suggested for roaches consists in the liberal use of pyrethrum powder or buhach, and when this is persisted in considerable relief will be gained. It is not a perfect remedy, however, and is at best but a temporary expedient. while it has the additional disadrantage of soiling the shetres or other oljects orer which 
it is dusted. When used it should be fresh and liberally applied. Roaches are often paralyzed by it when not killed outright, and the morning after an application the infested premises should be gone over and all the dead or partially paralyzed roaches swept up and burned. Flour of sulphur dusted about where roaches abound has proven very effective as a repellent.

"There are many proprietary substances which claim to be fairly effective roach poisons. The usefulness of most of these is, however, very problematical, and disappointment will ordinarily follow their application. The only one of these that has given very satisfactory results is a phosphorus paste, also sold in the form of pills. It consists of sweetened flour paste containing 1 to 2 per cent. of phosphorus, and is spread on bits of paper or cardboard and placed in the runways of the roaches. It has been used very successfully in the Department to free desks from Croton bugs, numbers of the dead insects being found in the drawer's every day during the time the poison was kept about. It is also a repellent."

For no other insects have so many quack remedies been urged and are so many newspaper remedies published. Many of them have their good points, but the majority are worthless. In fact, rather than put faith in half of those which have been published, it were better to rely on the recipe which T. A. Janvier gives (in his charming article on "Mexican Superstitions and Folk-lore," published in a recent number of Scribner's Magazine) as emrrent among the Mexicans:

"To Get Rid of Cockroaches. - Catch three and put them in a bottle, and so carry them to where two roads cross. Here hold the bottle upside down, and as they fall out repeat aloud three credos. Then all the cockroaches in the house from which these three came will go away.".

\section{Sub-family PERIPLANETINA.}

The two Indiana members of this sub-family are our largest roaches. Both are introdnced species which have become thoroughly naturalized, and one of them is better known than any of our indigenous or native forms. The main distinguishing character of the sub-family is that pertaining to the last ventral segment of the female, which is keeled or boat-shaped, and divided into two valves. The head is large, flattened or slightly concave and not wholly covered by the pronotum. The antemn are setaceous, more or less pubescent, the joints obconie and very short. The tegmina and wings are variable in the different species, being fully developed, abbre- 
riated, or wholly wanting. The sub-anal plate of the male is furnished with two small styles on its apical margin. In our species the first joint of the hind tarsi is as long as, or longer, than the other joints combined.

Two genera of the sub-family, each represented by a single species, occur in Indiana.

KEY TO GFNERA OF INDIANA PERIPLANETINA.

a. Tegmina of neither sex reaching tip of ahdomen, those of the female much shorter. Distance between the eyes greater than lengtl of last joint of maxillary palpus............. BI. BLAтtA, p. 192 au. Tegmina of both sexes much smpassing the abdomen. Distance between the eyes less than the length of last joint of maxillary

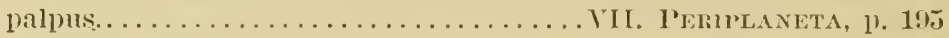

\section{BL.1TTA* Timmeus (1758).}

In this genus the cyes are farther apart than the serobes or pits in which the antemn are inserted. The tegmina of the female are very short in both sexes and their outer border is less rounded than in Periplaneta.

11. Blatta ORentalis Limmeus. The Oriental cockroach. The "Black Beetle."

Blatta orimtalis L., 81 , I, 1758, 434; Harr., 72, 1862, 145, Fig. 66; Ratliv., 109, 1ی62, 374, Figs. 4, 5: Caud., 40b, V, 1903, 234.

Periplanta wirntalis Burm., 40, II, 18:38, 504; Brum., 37, 1865, 226;

Riley, 122, II, 1884, 172, Figs. 246, 248; Id., 126, II, 1890, 267; Comst., 41, I, 1888, 93; Fem., 53, 1888, 52, Fig. 21; Hyatt and Arms., 7 7, 1890, 102, Plate IV, Figs. 5t, 55; Bl., 8, 1893, 156; Isl., 16, 1s99, 199, Fig. 41; Marl. 85, 1896, 91, Fig. 41 ; Il., 86, 1902, 9, Fig. 4; Lugg., 84, 1898, 92, Figs. 51, 54.

Kukerlar mirnfuli: Serv., 196, 1839, 72.

Sifylopygre mimtalis Seudll., 141, VII, 1862, 416; Irl., 188, 1900, 9; Glov., 62, 1872, Plate I, Figs. 5, 6; Plate VII, Fig. 12; Id., 63, 1874, 132, Fig. 4; Beut,, 3, VI, 1894, 260, Plate V, Figs. 2, 3.

General color dark mahogany brown, the limbs lighter, the pronotum without a yellow margin. Female with rudimentary tegmina which do not execed $5 \mathrm{~mm}$. in lengih. Male with the tegmina and wings well developed, the former covering three-fourths of the abdomen, the latter almost as long. Supra-anal plate of the male truncate; that of the female romded with a shallow noteh at the enr.

* Mr. A. N. Caulell has recently shown (1'roe. Ent. Sor., Wash., V, 1903, 234), that orientalis L., is the type speeies of the genus Blatta; hence, the generie name Blatla is here used instead of Stylopyoa of Sendiler's Catalogue. 
Measurements: Length of body, male, $22.5 \mathrm{~mm}$., female, 27.5 $\mathrm{mm}$.; of tegmina, male, $14 \mathrm{~mm}$., female, $4.5 \mathrm{~mm}$.; of pronotum, 6 $\mathrm{mm}$.; width of pronotum, $\mathrm{S} \mathrm{mm}$.

In Indiana the Oriental roach is found in all the larger towns and eities, and is one of the most noisome and disagreeable insects with which certain elasses of their inhabitants have to contend. It seldom oecurs in honses in thinly settled localities, and never, as far as my observation goes, beneath the bark of logs and stumps.

As its name indicates, it is a native of Asia, but has been carried from one country to another by shipping. It delights in filth and darkness, and hence in the holds of vessels, the cellars and basements

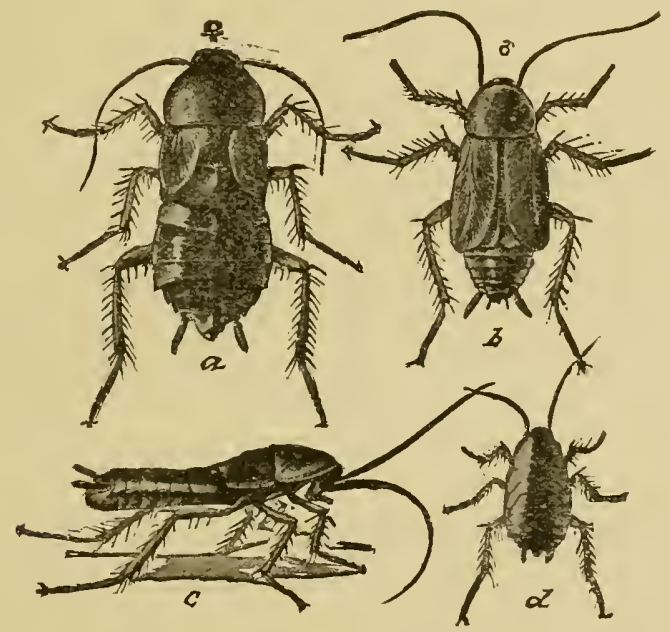

Fig. 30.-Blatta orientalis; $a$, female; $b$, male: $c$, side view of female; $d$, half grown specimen. All natural sizes. From "llouseholı Insects," published by U. S. Div. of Entomology.

of tenement houses, and in all damp, dirty places it swarms by thousands, undoubtedly doing much good as a scavenger. but infinitely more harm on account of its omnivorous and insitiable appetite. Like most other members of the family, it feeds mainly at night. appearing to detest and avoid the light, as one can readily prove by taking a lighted lamp suddenly into its haunts, when a hurried scrambling will take place toward its daylight retreats, and but a few moments will elapse before the last of the busy maraulers will have disappeared. Of this and other species Mardatt has written:

"The damage they do is not only in the produets aetually consuned, but in the soiling and rendering nauseous of everything with which they come in contact. 'they lave. wherever they occur in any 
numbers, a fetid, nauscous odor, well known as the roachy' orlor, which is persistent, and can not be removed from shelves and dishes without washing with soap and boiling water. Food supplies so tainted are beyond redemption. 'This odor comes partly from their excrement, but chicfly from a dark colored fluid exuded from the nouth of the insect, with which it stains its runways, and also in part, donbtless, from the scent glands, which occur on the bodies of both sexes between ecrtain segments of the abdomen, and which secrete an oily liquid possessing a very eharacteristic and disagrecable odor. It frequently happens that shelves on which dishes are placer become impregnated with this roachy odor, and this is imparted to and retained by dishes to such an extent that everything served in them, particularly liquids, as coffee or tea, will be noticed to have a peculiar, disgusting, foreign taste and odor, the source of which may be a puzzle and will naturally be supposed to come from the food rather than from the dish."

The Oriental roach is probably the most carnivorous of all our Blattida, though, like most others, it is fond of starchy food. It is known to feed mpon meat, cheese, woolen clothes, and even old leather, and is said to be especially fond of the festive "bed-bug," Acanthia leclularia $I_{\text {., }}$ which soon disappears from a house infested with the Oriental roach. 'This roach is, however, far too great a nuisance in itself to be introduced as a means of eradicating even the bed-bug.

The eggs of the Oriental roach are sixteen in number, and the large, horny capsule or oötheca in which they are packed is carried about by the mother for a week or longer when she drops it in a warm and sheltered place. Along one side of the capsule, which resembles in form and color a diminutive seed of the papaw, Asimina tritoba Duval, is a seam where the two edges are cemented closely together. When the young are hatehed they excrete a liquid which dissolves the ecment and enables them to escape without assistance, leaving their infantile receptacle as entire as it was before they quitted it.

This species is notably gregarious in habit, the individuals living together in colonies in the most friendly way, the small ones being allowed by the larger ones to sit on them, run orer them and nestle beneath them without a show of resentment. The young pass through a variable 11 miber, sometimes as many as seven, moults, the skin splitting along the back and the insect emerging white and soft, but soon hardening and assuming its normal color.

Besides the remedies given on a previous page for roaches in general, a simple trap has been tried by Mr. Marlatt which was fairly 
successful in lessening the numbers of the Oriental roach. This "consists of any deep ressel or jar, against which a number of sticks are placed, and bent over so that they project into the interior of the vessel for a few inches. The vessel is partially filled with stale beer or ale, a liquid for which roaches seem to have a special fondness. In the morning these vessels are found charged with great quantities of dead and dying roaches which have climbed up the inclined sticks and slipped off into the vessel."

Another remedy which may be used for any of the household species is a mixture of plaster of Paris, one part, and flour, three or four parts, in a saucer, and placed where the roaches abound, with another flat plate nearby containing pure water, both supplied with several bridges to give easy access, and one or two thin boards floating on the water touching the margin. The insects readily eat the mixture, become thirsty and drink, when the plaster sets and clogs the intestines. The insects disappear in a few weeks, the bodies no doubt being eaten by the survivors.

\section{Periplaneta Burmeister (1838).}

The members of this genus have the eyes closer together than the scrobes or pits of the antennæ. The tegmina of both sexes reach much beyond the abdomen, and the inner wings are as long as the tegmina.

But one species has as yet been taken in the State, thongh another may occur here, so. that the following key is given for their separation:

KEY TO SPECIES OF PERIPLANETA.

a. Tegmina much exceeding the ablomen; their outer margin of the same color as the remainder of the wing......12 americant, p. 19 .

a. Tegmina but little exceeding the abdomen; a bright yellow stripe along the basal half of their outer margin..........anstralasice.

12. Periplaneta americana (Linnæus). The American Cockroach.

Blatta americana L., 81 , I, 1758, 434; Rathv., 109, 1862, 375 (in part) ; Pack., 2 16, 1883, 309, Plates XXV-XXXV.

Periplaneta americana Burm., 40, II, 1838, 503; Scndd., 14 1, VII, 1862, 416; Id., 188, 1900, 9; Brunn., 37, 1865, 232; Glov., 62, 1872, Plate I, Fig. 2; Riley, 122 , II, 1884, 172; Id., 125 , I, 1888, 68, 190; Id., 126 , II, 1890, 266 ; Fer1., 53, 1888, 51; BI., 8, 1893, 157; Id., 16, 1899, 202, Fig. 42; Bent., 3,VI, 1894, 259, Plate V, Fig. 4; Marl., 85, 1896, 90, Figs. 38, 39; Id., 86, 1902, 8, Figs. 1, 2; Lugg., 84, 1898, 93, Fig. 55.

Kukerlac umericana Serv., 196, 1839, 68. 
Guncral color, light reddish brown. Pronotum broadly margined on the sides and narrowly in front with yellow, thus enclosing a large, bi-lobed brown spot. Tegmina and wings reaching much beyond the abutomen in both sexes. Supra-anal plate of female more pointed and median notely narrower and deeper than in R. orientelis.

Measurements: Lemgth of hody, male, 29 mm., female, $30 \mathrm{~mm}$; of promotmm. \& mm.; of tegmina, male and female, $27.5 \mathrm{~mm}$; widtl of promot.mm, $10.5 \mathrm{~mm}$.
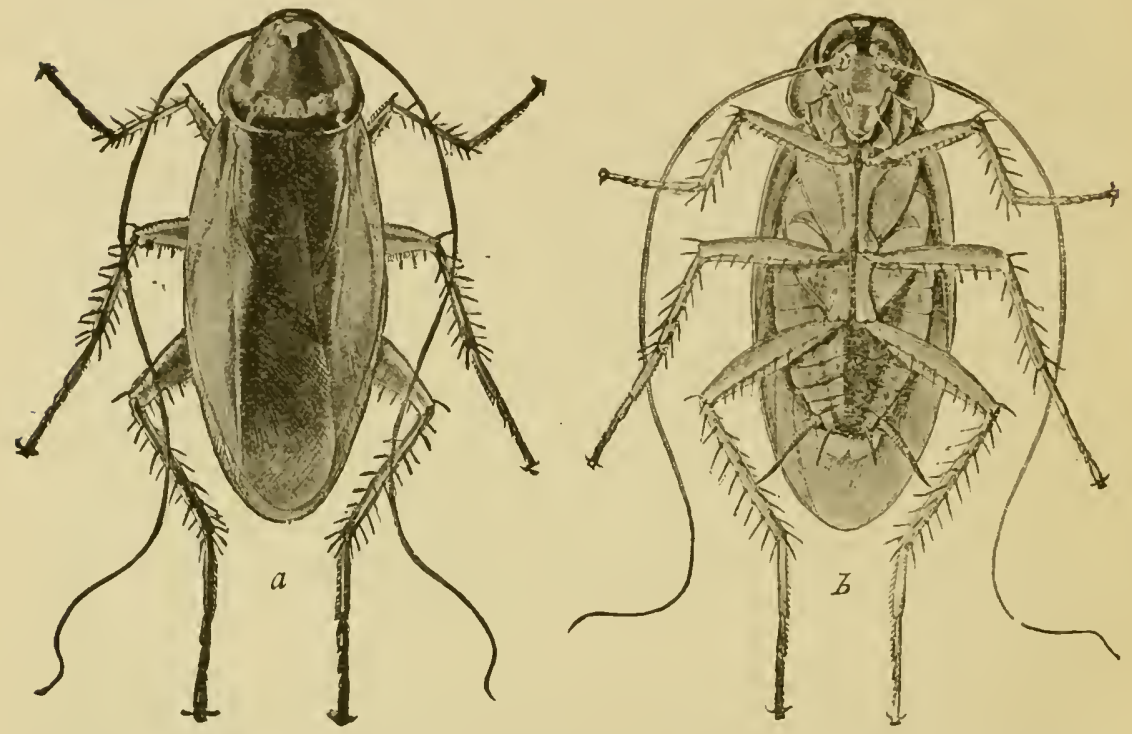

Fig. 31. Peripluneta americma; $a$, view from ahove; $b$, from beneath: both enlarged one-third. From "Ilousohold Insects," Published by I". S. Dir. Entomology.

The American cockroach is, as its specific name indicates, a native of tropical and sub-tropical America; but, like B. orientatis, it has spread to the four corners of the earth. It is by far the largest species found in the State, but is much less common than orientalis, as I have specimens from but two counties, Putnam and Marion. It doubtless occurs, however, in all the larger towns of the State. It is found in numbers in some of the leading lotels of Indianapolis, but usually confines iteclf to the basement and first floor, and appears to be inuch more cleanly in its choice of an abiding place than does the closely allied Oriental roach.

Catesby, as far back as 17.18, wrote of this species in Carolina as follows: 
"The Cockroach.-These are very tronblesome and destructive vermin, and are so numerous and voracious that it is impossible to keep victuals of any kind from being devoured by them without close covering. They are flat, and so thin that few chests or boxes can exclude them. They eat not only leather, parchment and woolen, but linen and paper. They disappear in winter and appear most numerous in the lottest days in summer. It is at night they commit their depredations, and bite people in their beds, especially children's fingers that are greasy. They lay innumerable eggs, creeping into the holes of old walls and rubbish, where they lie torpid all the winter. Some have wings and others are without-perhaps of different sexes."*

Catesby's wingless examples were in all probability the young, as, like most other insects, the wings are not acquired until the final moult. Marlatt says that the "domesticity of the American roach resulted from ages of association with the aborigines. It has now become thoroughly cosmopolitan, and is unquestionably the most injurious and annoying of the species occurring on vessels. It is sometimes numerous also in greenhouses, causing considerable injury to tender plants. It is a notorious house pest, and occasionally vies with the German roach in its injuries to book bindings. The backs, sometimes entirely, of both cloth and leather bound books, are eaten off to get at the starchy paste used in the binding."

The young of the American roach require about a year to reach maturity. The rate of growth of it and other species depends, however, largely on the food and temperature conditions, and uncter unfavorable circumstances the nymph stage is much prolonged. "The abundance of roaches is, therefore, apparently not accounted for so much by their rapidity of multiplication as by their unusual ability to preserve themselves from ordinary means of destruction and by the scarcity of natural enenies."

Periplaneta australaste Fab. The Australian Roach.

This species will doubtless be found to inhabit the State, as it has been recorded from Florida, Nebraska and Mimnesota. It is a little smaller than $P$. americana, from which it can be separated by the characters given in the key. Iike the last two species, it inhabits houses, and in the Southern States it is more abundant and troublesome than either of them.

${ }^{k}$ Natural History, Carolina, 1748, Vol. II, p. 10. 


\section{Family MANTID E.}

This family is composed of elongate, slow moving insects, the most noticeable character of which is the possession of a long, slender prothorax with the first pair of legs so modified as to be fitted for grasping and holding their prey. The old name given to the group was therefore liaploria or graspers. The head is large, oblique, loosely joined to the prothorax in such a manner as to be freely movable; the antennie are slender, and rarely as long as the body. The neelli are present and three in number. The pronotum is longer than any other segment. The abdomen of the female is much broader than that of the male, and is withont a visible ovipositor. 'The forelegs are stout, raptorial and terminate in a single elaw which, with the five-jointed tarsi, is placed in a groove on the under side of the spinous tibia when at rest. The middle and hind pairs of legs are long, slender, and fitted for slow motion. Tegmina and wings are present, but in the female are often abortive. As with the other non-saltatorial families, ears and organs for producing sound are absent.

The members of this family have numerous popular names, the most common of which is the "praying mantid," given them on account of the position which they take when at rest or when waiting to grasp another insect. The knees are then bent. and the front legs held as though in supplication. In the sonthern States they are often called "mule killers," from the common belief that the brownish liquor which they give off from the month is fatal to mules. This name is, however, often also applier to the "whip-scorpion," a large member of the order Arachnida, which inhahits the Southern States. The mantids are all carnivorons, feeding prineipally upon the different forms of other insects. They are thus in the main beneficial, in this respect differing widely from all other members of the order Orthoptera, mless it be the tree crickets of the genus (Écanthus, which feed upon plant lice. They capture their prey by stealth, crawling upon it very slowly, and when within reaching distance, seizing it with a subden and rapid morement. Tike other preslatory insects, they have very roracions appetites. A member of a European species, Mantis religinsa, which was introduced on nursery stock in New York State, was olserved to eat, in one kay, three large grasshoppers and a daddy-long-legs and then tackided another mantis from which he was separated with difficulty. The eggs of mantids are lait in a curiously formed egg casc or "oötheca," which is secreterl by the female. 
Only two of the six known sub-families are represented in the United States, and one of these only by a single genus and species along the sonthern border. The other is the

\section{Sub-family MANTINA.}

The insects belonging to this sub-family have the upper surface of the middle and fore femora and tibire rounded, insteal of carinate. The head is unarmed, whereas, in the other sub-family, the Vatine, it bears on the middle an erect process, as long as the rest of the head. To the Mantince belong eleven known genera and sixteen species from the United States. Of these two species, belonging to different genera, have been taken in Indiana.

\section{KEY TO GENERA OF INDIANA IIANTINAE.}

a. Broadest portion of pronotum far in advance of the middle; the sides in front distinctly tapering. Fore femora armed on the lower outer margin with large spines only........ VIII. Stagmomantis, p. 199

aa. Broadest portion of pronotum but little, if any, in advance of the middle; the sides in front parallel, or nearly so. Fore femora armed on the lower outer margin with minute spines between the large

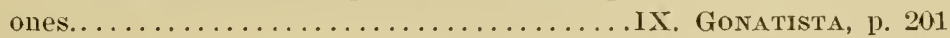

\section{Stagmomantis Saussure (1869).}

Body of male narrow, of female much broader. Head large, compressed, triangular. Antenne short and fine, inserted about the middle of the face below the center of the eyes. Vertex narrow, transverse, a little elevated above the eyes. Pronotum very long, in our species forming two-fifths the whole body; the apical third wider, the edges carinate and armed with minute, distant teeth. Tegmina of female shorter than abdomen, opaque and bearing a distinet spot or stigma of different texture near the center. Tegmina of male, in our speeies, longer than abdomen with stigma often indistinct or wanting. Wings of the female, when expanded, of the form of a quarter circle; those of the male longer and narrower. Abdomen of female, large, more or less dilated; that of male narrow, the subgenital plate large.

Two species oceur in the United States, one of which is found in the southem half of Indiana. 
13. Stamomantis carolina (Limmens). The Carolina Mantis. The

Rearhorse.

Gryllus carolinus L., 80, 1763, 13.

Mantis carolina L., 81, II, 1767, 691; Rathv., 109, 1862, 376, Figs. 8-10;

Riley, 1 13, I, 1869, 169, Figs. 94, 95; Id., 2 16, III, 1883, 37,

Figs. 19ab; Id., 124, X, 1887, 4t, Figs. 20ab; Glov., 62, 1872, Plate II, Figs. 1-16.

Stugmommantis corolime Sauss., 130, III, 1869, (6i); Irl., 131, 1871, 46;

Id., 132, VI, 1872, 247, Plate T, Fig. 5; Plite VI, Fig. 12;

How., 74, IT, 1892, 243, Figs. 29, 31; Id., 76, 1901, 326, Figs.

215, 216; Scudd., 173, XXVIII, 1895, 210; Id.. 188, 1900, 12;

Bl., 13, XXVIII, 1896, 265; Ir., 16, 1899, 209, Fig. 46.

Phasmomantis retrolina Riley, 122 , II, 1884, 173, Fig. 249.

Color: Male, grayish brown. Tegmina semi-transparent, grayish, more or less mottled with smoky brown; sometimes almost wholly of the latter color. Body and feet often greenish yellow. Female, either wholly green or of the color of the male; the stigmatic patch black bordered with pale yellow, more distinct in the green form.

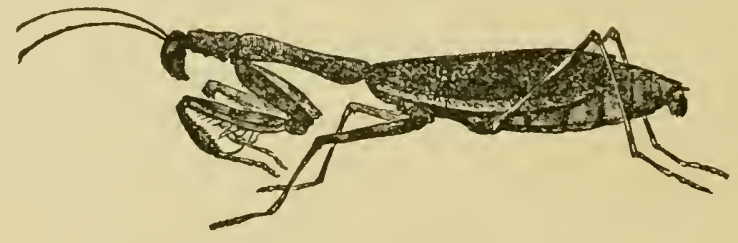

Fig. 32. Stagmomantis curolina L. Female.

Measurements: Length of body, male, $49 \mathrm{~mm}$., female, $52 \mathrm{~mm}$; of pronotum, male, $17 \mathrm{~mm}$., female, $20 \mathrm{~mm}$; of tegmina, male, 32 , mm., fernale, $23 \mathrm{~mm}$.

This mantid is a species of southern range and in Indiana occurs only in the south half, being quite common in the counties bordering the Ohio River. It extends as far north as Marion and Putnam counties, where it is found sparingly. I have taken it in Floyd, Perry and Lawrence counties, and have had a dozen or more specimens bronght to me in Indianapolis, all of them females. Mr. S. G. Evans, of Evansville, in a letter says: "The Mantids are found here of all sizes and colors, the eggs and young being almost as common as mosquitoes. I liave, on several occasions, placed male and female together in a glass jar, and the female always devoured the male, and generally while in the act of copulating, the bodies remaining together until the male was almost consumed." At Indianapolis the females evidently reach maturity about September 1st, most specimeus being brought in about that date or later. The green and 
brown forms of the female are about equally numerous. In Putnam County it has been noted by Mr. John S. Michaels near Bainbridge.

When in the presence of its prey the Carolina mantis moves almost imperceptibly along, stealing toward its victim like a eat approaching a mouse. When sufficiently near, the foreleg is suddenly extended to its full length and the mnlueky insect is immediately eanght and impaled by the spines between the tibix and tarsi, earried to the mouth and deliberately eaten piecemeal while yet alive and struggling to escape. When the two sexes are eaptured and placed together the female soon begins to feed upon her liege lord, and finally derours all portions of him which are in the least degree digestible.

The eggs of the Carolina mantis are laid in tough cases about an inch long which are attached to the twigs of trees. The ease is tough and homy, and the eggs are laid in parallel rows, perhaps forty in a row, issuing from a common longitudinal middle line. All of the eggs stand on end and are inclined somewhat toward the central channel. A cluster of eggs has a braided appearance, but consists simply of a contimuous ribbon of mucus folded in elose flutings and having an egg deposited in the bight or angle of each fold. The eggs are deposited simultaneously with the deposition of this ribbon by the mother insect, and the whole mass is at first soft and flexible, but rapidly hardens by exposure to the air. In this manner the speeies survives the winter and in May, when inseet life begins to abound, the young emerge and use their prominent, staring eyes to good adrantage in seeking plant lice and other minnte forms which furnish them their first of many meals. The eggs are frequently parasitized by a very peculiar chalcis fly, Podagrion manlis which penetrates the tough egg mass with its long ovipositor, and whose larve feed upon the eggs. Thus egg masses taken by the observer in the winter and kept for the hatching of the young will frequently in the spring give out those parasites instead of the young mantids.

\section{Gonatista Sanssure (1869).}

Body short and broad. Ifead short, compressed. Antenna inserted opposite the base of the eyes, hair-like, of considerable length. Eyes very large, globose, prominent. Ocelli large in the male, smaller in the female. The face, in appearanee, somewhat exeavated on aceount of the prominenee of the eyes. Crest of vertex a straight transverse line a little elevated above the eyes. Pronotum of medium length and breadth; the disk depressed, but with an elevation or 
hump on the front and middle thirds with a depression between and with two small tubercles on the lind margin; widest about the middle; the front margin truncate; the sides of the front half parallel, those of posterior half a little converging. 'Tegmina of female broad, corering three-fourths of abdomen; the reticulation dense and irregular; the stigma small, narrow, often indistinct. Those of male narrower; surpassing the abdomen, more membranaceous. Wings ample, about as long as tegmina; those of the female forming a quarter of a circle, colored; those of male transparent or a little spotted. Fore limbs rather stout, the tibie with five or six large spines on the lower outer border, with numerous small ones intervening; the inmer border with twelve or more strong spines. Abdomen depressed, of medium width in the male; large and broad in the female, the border coarsely serrate or lobed.

One species is known from the southern United States and West Indies.

14. Gonatista Grisea (Fabricius). The Grizzled Mantis.

Mantis yrisea Fab., 52, II, 1793, 22.

Gonatista grisea Sauss., 131 , 1871, 23; Id., 132, VI, 1872, 231, Plate 5, Figs. 1, 2; Scudd., 173, XXVIH, 1896, 211, 214; Id., 188 , 1900,$13 ;$ B1., 13, XXVII, 1896, 26.

Mantis plungganoides Serv., 196, 1839, 198.

Gonatista cubensis Sauss., 130 , III, 1869, 61.

Color: Female, grayish, more or less mottlerl with fuscous. The tegmina with two oblique fuscous crossbars on apical half. Inner wings bluish black. Fore legs gray tinged with greenish and sprinkled with fuscous. The middle and hind legs with narrow fuscous crossbars.

Measurements: Female, length of body, $36 \mathrm{~mm}$; of pronotum, $11 \mathrm{~mm}$.; of tegmina, $20 \mathrm{~mm}$.

$\Lambda$ single female of this sonthern mantid was taken in Vanderburgh County loy Mr. S. G. Evans and by him sent to the Agrieultural College of Michigan, from which it came into my possession. Mr. Erans writes that he must have supposed it to be a short bodied form of Slagmomanlis carolina and has no recollection of the exact date, or the place in the county in which it was found. It may possibly, therefore, have been introduced on tropical fruits. It is common in Cuba and San Domingo and has been taken in Georgia and at Key West and Fernandina, Florida. 


\section{Family PHASMIDA.}

To this family of non-saltatorial Orthoptera belong the insects commonly known as "walking-sticks." The body is long and exceedingly slender; the head nearly horizontal, not covered by the pronotum and usually quadrate or four sided: the antenne long and rather coarse; the eyes small; the ocelli often wanting. The pronotum is very short. The tegmina and wings are wanting in our species, though present and rudimentary in some tropical forms. The legs are long, slender and of equal size, the fore femora being often bowed and the fore tarsi terminating, like the others, in a pair of claws.

Our species of Phasmido are remarkable for their resemblance to twigs of different plants; while some of the tropical species are so modified as to resemble leaves; frequently bearing so close a resemblance to the foliage as to deceive a keen observer. Their movements are, in general, very slow, though the males can run with some rapidity when in pursuit of the opposite sex. They feed during their entire lives upon leaves, being especally fond of those of oak and wild cherry. The eggs are dropped loosely and singly upon the ground by the mother, where they remain through the winter, thus tiding the insect over the cold season. The outer case or shell of the egg is hard and often sculptured, and those of our common species resemble small beans. The young, when hatched, trust to chance and their peculiar shape to escape those higher animal forms which are ever ready to prey upon every moving object which promises them a bit of sustenance.

The family is, in the main, a tropical one, and is very feebly represented in the United States, where but four of the dozen known sub-families are represented by seven genera and sixteen nominal species. Two of these sub-families are each represented in Indiana by a single genus and species.*

KEY TO SUB-FAMILIES OF PHASMIDA OCCURRING IN INDIANA.

a. Tibia not furnished at apex with a short sunken space to receive the base of the tarsi when bent upon them. Mesothorax never less than fom times as long as the prothorax, generally more. Hind femora armed beneath near the apex with one or more spines.......

BACUNCULind, p. 204

ar. Tibia furnished on the under side at apex with a siort, sunken space to receive the base of the tarsi when bent upon them. Mesothorax never more than three times as long as the prothorax, generally less. Hind femora withont spines.........ANisomorpIIN. p. 207

*Mr. A. N. Caudell has recently published a monograph of the U. S. species of Phasmide in the Proceedings of the U.S. National Muscum, XXVI, 1903, the nomenclature of which I have followed. 


\section{Sub-family PACUNCULINT.}

This sub-fimily comprises the longest and most slender of the Lnited States walling-sticks. The mesothorax is nsually five or more times as long as the prothorax. The antenna. except in the genus Sermyle, are more than twice as long as the front femora. The tibie are withont a sunken areola beneath the apex.

Four of the United States genera belong to this sub-family. Of these, two are represented only in the Gulf and arljoining states; and a third only in the Rocky Mountain Region and California. The species of the other genus, Diapheromera, are widely distributed. Anong them belongs our most common Indiana "walking-stick."

\section{Diapheromera Gray (1835).}

Body long, slender and cylindrical. Head smooth, longer than broad; olliquely attached to the thorax; the eyes small. Antenner inserted in front of the eyes, more than twice as long as fore femora, furnished with 30 or more segments. Pronotum about the length of head. Mesonotum longer than any other segment; metanotum threefourths the length of the mesonotum. Median segment much shorter than metanotum, transverse, quadrate. Legs very long and slender, the femora of the middle pair in the male of our supecins much swollen; armed, like those of hind pair, on under side noar the apex with an acute spine, most prominent in the male. Cerei of the male long, terete and incurved; those of the female short, straight.

Five species oceur in the United States, of which the most common and widespread is

15. Drapheromeri fexorata (Say). The Thick-thighed Walking-stick. Siperfum femorulum Say, 138, II, 1824, 297; Id., 137, III, 1828, Plate 27 ; Id., 139, 1859, I, 82, 197, Plate 37 ; Emm., 49, T, 1854, 142, Plate 7, Figs. 1, 2; Ratliv., 109, 1862, 377, Fig. 11.

Dinphlomene femomen. Harr., 71, 1841, 119; Id., 72, 1862, 146, Fig. 67; Pack., 104, 1869, 573, Fig. 566; Glov., 62, 1872, Plate I, lig. 7; Plate X, Fig. 1; Id., 63, 1574, 134, Fig. 6; Scudd., 148 , I, 1874, 379, Plate A, Fig. 3: Id., 172, XXVII, 1895, 30; Id., 169 , LXXXVIII, 1894, 456, 460; Id., 178, VIII, 1897, 30 : Id., 188, 1900, 14; Id., 191 , IX, 1901, 187; Riley, 120, 1878, 241, Plate 3, Figs. a-c; Irl., 122 , II, 1884, 176 , Fig. 253 ; Comst., 4 1, 1888, 95, Fig. 91; Id., 42, 1895, 108, Fig. 118; Fern., 53, 1885, 49, Fig. 19; Bent., 3, VI, 1894, 262, Plate 10, Fig. 10; Weed., 222, 1s97, 6, Plate 5; Lugg., 84, 1898, 100, Fig. 61; Bl., 16, 1899, 208, Fig. 45; How., 76, 1901, 323, Fig. 214; Caud., 40, 1903, S74, Figs. 4 , 6. 
Color variable, being either gray, brown or greenish brown. The body of the male is usually greenish brown, sometimes almost wholly green; the head yellowish with three lengthwise fuscous stripes; the front legs and the tibix of the others usually green. The female is duller, generally grayish brown, often with paler specks and mottlings on the head and back.

The male is easily distinguished by the shorter and more slender body; longer legs and antennix; the narrower and less dilated front femora; the swollen middle femora and by the greater stoutness of the spines near the ends of the middlo and hind femora.

Measurements: Length of body. male, $70 \mathrm{~mm}$., female, $7 \% \mathrm{~mm}$; of antennæ, male, $65 \mathrm{~mm}$., female, 45 mm.; of hind femora, male, $21 \mathrm{~mm}$., female, $16 \mathrm{~mm}$.

The thick-thighed walking-stick is a rather common insect thronghout the State, though the average observer will probably see but one or two of them a year. They reach maturity in August, and may often be found upon the leaves of oak or wild cherry, especially on isolated trecs along fence rows. One of my students at Terre Haute once brought in on Oetober 15th, 100 or more which he had gotten from a wild cherry tree on whose leaves they had been feeding. It moves

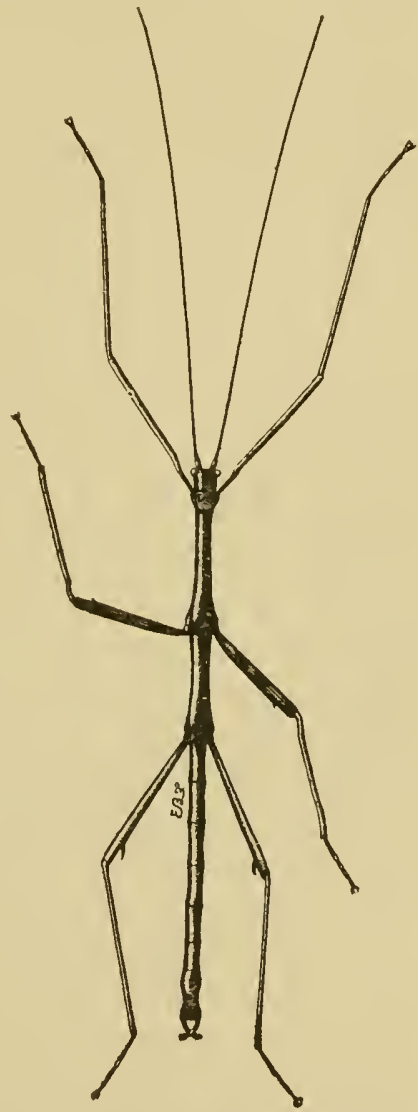

Fig. 33. Diapheromera femorata (Say). Male. very slowly and has a habit of remaining motionless and apparently dead for a considerable length of time. On such occasions it usually stretches itself ont from a twig, with its front legs and antennæ extended, and then can scarcely be distinguished from a prolongation or branch of the twig. Many people who see them thus for the first time and afterwards watch them moving slowly away, can scarcely be persuaded that they are not real twigs, gifted in some mysterious manner with life and motion. 
In feeding, they eat the edges of a leaf, preferably those of an oak or wild eherry, usually straddling it with their legs, and in an hour will derour a picce an inch long by a third of an inch wide. Riley records that on occasions they are so numerous as to do much damage to oak, hickory, locust and other trees. In Yates County, New York, in 1878. Dr. Riley found them very abundant in a woodland of 50 acres, which they had attacked in numbers two and four years previously. He states that: "By the middle of Angust the bulk of the pests were going through their last moult, and by the end of autumn they had stripped most of the trees, showing, however, a decided preference for the black, red and rock-chestnut oaks, over the white oaks and hickories, which they affect but little until after the first mentioned trees are stripped. The underbrush was also rery effectually cleancd of its foliage, and the insects hung froin and clung to the bare twigs and branches in great clnsters. They settle to roost on the witch-hazek, but do not defoliate it until the other trees mentioned are pretty bare. Sumach and thorn are also little affected, while peach and apple in an adjoining orchard were untonched. Whenerer they have entirely stripped the trees and shrubs they move in bodies to fresh pastures, crowding upon one another and covering the ground, the fence rails, and cverything about them so that it is impossible for a person to enter the woods without being covered by them. The timber affected ean be recognized by its seared and leafless appearance from a great distance, and npon entering the woods the ear is greeted by a peculiar secthing noise, resulting from the motion of the innumerable jaws at work on the leaves. Their depredations first begin to attract attention soon after wheat harrest, and are most noticeable in September. The injury to the trees done in 1874 and 1876 was manifest in the death of most of the hlack oaks, and, according to the owner's observations, trees die in three years after the first attack."

The eggs, of which each female lays about 100. are a little less than $3 \mathrm{~mm}$. in length, long oval in shape and of a polished black color with a whitish stripe on one side. They resemble a small, plump bean or seed of other leguminons plant. "They are simply dropped loosely upon the ground from whatever height the female may happen to be, and, during the latter part of autumn where the insects are common, one hears a constant pattering, not unlike drops of rain, which results from the abundant dropping of these eggs, which in places lay so thick among and under the dead leares that they may be scraped up in great quantities. From general observations of specimens kept in confinement, it would appear that each female is 
capable of laying upwards of 100 . The eggs remain upon the ground all through the winter and hatch for the most part during the month of May. Some of them, however, continue hatching much later, so that all through the summer and even into the fall, young individuals may be found. The insect changes very little in appearance from birth to maturity except so far as color is concerned, and moults but twice. Growth is rapid, averaging, under favorable circumstances, about six weeks from birth to maturity. With age the green color gives way to various shades of gray and brown. In this way we find great correspondence with its surroundings. While the vegetation is green, the walking sticks are green also; when the foliage turns in autumn, they change color correspondingly, and when the foliage is stripped they so closely resemble, in both appearance and color, the twigs upon which they rest - the habit of stretching out the front legs and feelers greatly enhancing the resemblance-that when they are few in number it is difficult to recognize them. A few green specimens, more particularly of the males, may always be found, even among the mature individuals."

This Walking-stick appears to be abundant in any certain locality only every other year. This is in part due to an increase of the insect's natural enemies on those years in which they are most abundant. These enemies are several species of true bugs (HemipteraHeteroptera) crows and other birds. The main reason for the greater number of Walking-sticks on alternate years is, however, thought to be due to the fact that the larger proportion of the eggs, especially those laid late in the antumn, take two years in hatching. If at any time the inscet threatens to become injurious in the woodlands of the State, it can be held in check by burning the leaves on the ground in the winter scason, thus destroying the hibernating eggs.

\section{Sub-family ANISOMORPHINÆ.}

In this sub-family the antennæ are more than twice as long as the anterior femora. The tibia are furnished with a sunken areola beneath the apex, which receives the base of the tarsi when bent; coxæ visible from above; tarsi distinctly five-jointed. Mesothorax not more than three times as long as the prothorax. Intermediary segment invisible.

A single genus of this sub-family is represented in the United States. 


\section{Anisomonitia Gray (1835).}

Body of male elongate, slender; that of the female mueh larger and more robust. Head short, quadrate, horizontally attached to the thorax; and eyes larger than in Diapheromera. Antenne shorter anl stouter than there, though longer than the fore femora; the basal joint but little longer and little stouter than the seeond. Pronotum the length of the head. Mesonotum twiee as long as pronotum and a third longer than metanotum. Front segments of abdomen but little longer than broad. Legs of nearly equal length, stout and thick, shorter than in the preceding genus, unarmed. Cerei of both sexes short, stout, cylindrieal, projecting a little from beneath the large supra-anal plate.

Two species occur in the southern United States, one of which extends northward into Indiana.

16. Anisomorpha ferrugined (Palisot de Beaurois). The Lesser Twostriped Walking-stick.

Phasma ferrugincum Pal. de Beauv., 108, 1805-1821, 167, Plate XIV, Figs. 6-7.

Anisomorpha ferruginea Gray., 64, 1835, 18; Burm., 40, II, 1838, 570; Scudd., 172, XXVII, 1895, 30; Id., 188, 1900, 15; Candell 40ª XXVI, 1903, 880, 882, Plate LIX, Fig. 2.

Color: Fuscous or ferruginons, ineonspicuonsly striped with narrow dusky dorsal and lateral stripes; these in the female less distinet, and often obsolete on a portion of the abdomen. Antennæ dull reddish brown. Under side of body dull elay yellow, brownish when dried. Legs brownish red.

Head but little longer than broad. Body of female six to six and a half times longer than broad; of male, about twelve times as long as broad.

Neasurements: T.ength of head, male, $3 \mathrm{~mm}$., female, $5.5 \mathrm{~mm}$.; of body, male, $30 \mathrm{~mm}$., female, $56 \mathrm{~mm}$.; of antennæ, male, $22 \mathrm{~mm}$., fenale, $31 \mathrm{~mm}$.; of hind femora, male, $9 \mathrm{~mm}$., female, $12 \mathrm{~mm}$.

This southern Walking-stick has been taken in Indiana only near Wyandotte, Crawford County, and Grand Chain, Posey County, being found in large numbers in both localities. 'The first ones taken were in Crawford County, on June 2S, 1902, when the young about an inch and a half long were found beneath loose flakes of bark on oak and other trees. In the first week in September I again risited the locality and found scores of pairs of them, all mating, beneath the loose bark of old oak snags and stumps. A half-dozen or more 
pairs were often found within an area of a foot or two square, the large, heavy bodied female bearing her diminutive liege lord upon her back.

When picked up by the fingers, there is exuded from glands on the sides of the thorax a vapor from the male and a white milky fluid from the female. This possesses a peculiar, though somewhat pleasing odor, which has been likened to that of the common Everlasting, Gnaphalium obtusifolium L. The secretion is doubtless used as a de-

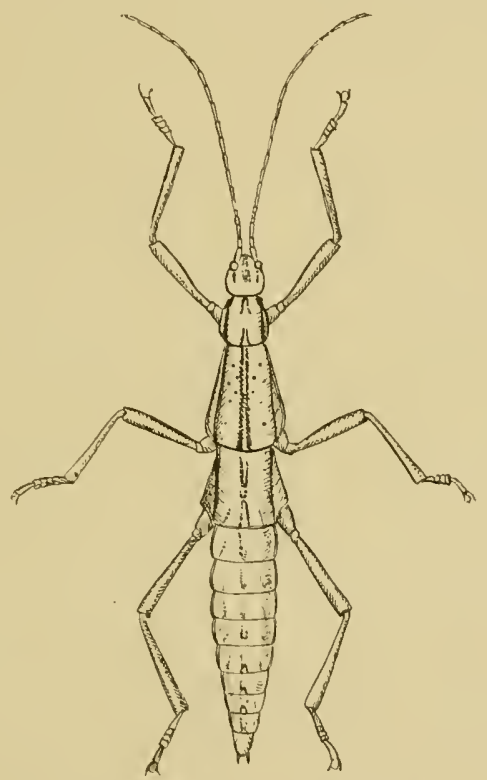

Fig. 34. Anisomorpha ferruginea (Pal de Beauv). Female. Natural size. (After Caudell.)

fense against certain enemies, being probably very distasteful, and perhaps harmful, to birds and rapacious insects. Scudder (Psyche I) has noted this secretion, and concludes that the Phasmidee with their slender form and sluggish movements have especial need of such a weapon as these glands furnish.

Nonc of the specimens of ferruginea noted were feeding, though they probably lire upon the leares of oak and other trees. The species was later found in numbers in Posey County, and probably occurs in most of the counties bordering the Ohio River. It is but one of many forms of insect and plant life which have their most northern habitat in the southern third of Indiana. Specimens in the U. S. National Museum are from Florida, Louisiana, Kentucky and Pennsylvania."

* Sinee the above was in type a ferruginea has been taken as far north as Medora, Jackson County. 


\section{SALTATORIA.}

Belonging to this class or sub-order, are three families which comprise the great majority of our best known Orthoptera. They are the true "hoppers" or leapers of the order; their hind limbs, in the course of ages, having become so modified as to be adapted in the highest degree to the life which they lead. Possessing. also, in many instances, ample organs of flight, which enable them, when disturbed, to move rapidly to a distance, the males have evolved in connection therewith organs of sound, by which they may call the members of the opposite sex to them. Were it not for these calling organs the two sexes would, during their varied movements, often be widely separated, and perhaps be unable to locate one another after'settling in a new position. The males alone possess these organs of sound, and they only when wings are present. All the wingless forms lack also "auditory organs" or ears, since these would be uscless unless some means of producing sound were present. "The families belonging to this group may be separated by the following table:

\section{KEY TO FAMULIES OF SALTATORIAL ORTHOPRERA.}

a. Antenna much shorter than the body, variable in form. Ocelli three. Tarsi three-jointed. Calling ormans of male, when present, sitiated on the hind femora and lower border of tegmina. Organs of hearing, when present, located on the basal segment of the abolomen. Oripositor composed of two pairs of slort, horny, more or less eurved plates, whose tips diverge............ Acrinid... 1) 211

aa. Antemna much longer than the hody, bristle shaped, delicately tapering. Ocelli often wanting. Tarsi four or three-jointed. Calling organs of male, when present, situated on the dorsal field of the tegmina. Organs of hearing, when present, located near the base of the fore tibia (rarely on the prosternum). Oripositor (except in certain crickets) an elongated blacle or needle; its parts compact.

7. Ocelli generally wanting. Tarsi four-jointed. 'Tegmina with the sides sloping. Calling organ of male, when present, located on basal half of tegmina and limited to the aual area. Ovipositor, when exserted, forming a strongly compressul, generally sword-shaped blade, the tip not expanded.........

LOCUSTID E, 1. 340

bb. Ocelli variable. Tarsi three-jointed. Tegmina flat above, the sides bent abruptly downward. Calling organ of male. when present, extending across both anal and median areas of the tegmina. Ovipositor, when exserted, forming a nearly eylindrical straight or upeurved needle, the tip often enlarged...... 


\section{Family ACRIDIDA.}

To this family of saltatorial Orthoptera belong those short-horned grasshoppers or locusts which are so common in our meadows and pastures and along our roadsides from mid-April until after the heavy frosts of late autumn. Their antennæ are, with few exceptions, much shorter than the body, filiform, clubbed or ensiform in shape, the joints distinct, and often, especially toward the base, depressed. The head is usually short, and in the leading sub-families is extended horizontally. Ocelli are always present, and foveola usually so, the variations in form and size of the latter affording characters much used in classification.

The pronotum is variable in form and size, but in most species forms a buckler or saddle-shaped shield covering the three segments of the thorax. In one sub-family, the Tettigince, it extends back over the abdomen. The tegmina and wings, when present and in repose, rest partly horizontal on the dorsal surface of the abdomen and partly reflexed against its sides. The auditory or hearing organ, when present, is located on the side of the basal ring of the abdomen. The anterior and middle legs are equal or nearly so in size, and much smaller and shorter than the hind legs; the femora of the latter being, as in the other Sallatoria, very much enlarged in their basal halves. The tarsi are three-jointed and similar in structure on all the legs; the first joint, usually the longest, has the under side marked with two cross impressions which, when seen from below, give the impression that it is composed of three segments. The third or apical segment of the tarsus ends in a pair of curved claws which enable the insect to catch and cling to blades of grass and other objects on which it may alight. Between these claws there is in the species of all the sub-families except those of the Tettigince a circular pad or cushion, called the pulvillus or arolinm. The ovipositor consists of four short, horny pieces, the so-called valves, projecting from the tip of the abdomen, two of which curve upward and two downward.

The call notes made by the males of the Acrididae are produced in two ways. In one group, whose members call only when at rest, the sound is produced by rubbing the inner surface of the lind femur against the outer surface of the tegmina. Landois has shown that in this group, the inner surface of the femur is furnished along the lower margin with a longitudinal row of minute, lancet-shaped, elastic teeth, ranging in number from 85 to 93 , which are scraped across the veins of the tegmina, thus producing a low, buzzing sound. Those 
which stridulate in this manner mostly belong to the sub-families Tryxaline and Acridince.

The members of the sub-family (Edipodine nsually sount their call during flight by rubbing together the upper surface of the front edge of the wings and the under surface of the tegmina, thus pro-
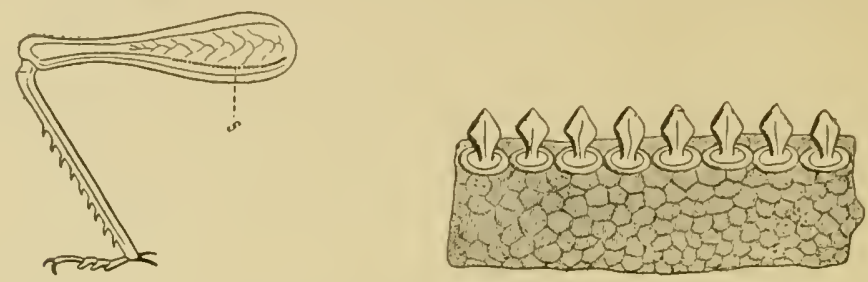

Fig. 35. Inside of hind femora of a loeust. 8 , ridge with teeth. Ridge and teeth greatly enlarged. (After Landois.)

ducing a sharp, crackling sound which has been likened to that of burning stubble. By paying close attention the observer ean soon learn to know each species by its peculiar eall. Like the other fanilies of Orthoptera, the males alone of the Acridide have musical organs, which is quite the reverse among some animals higher in the seale of life, where the females make most of the music and oftentimes much of the noise.

The great majority of Indiana Aeridide pass the winter in the egg stage, the eggs being deposited by the mother insect in early

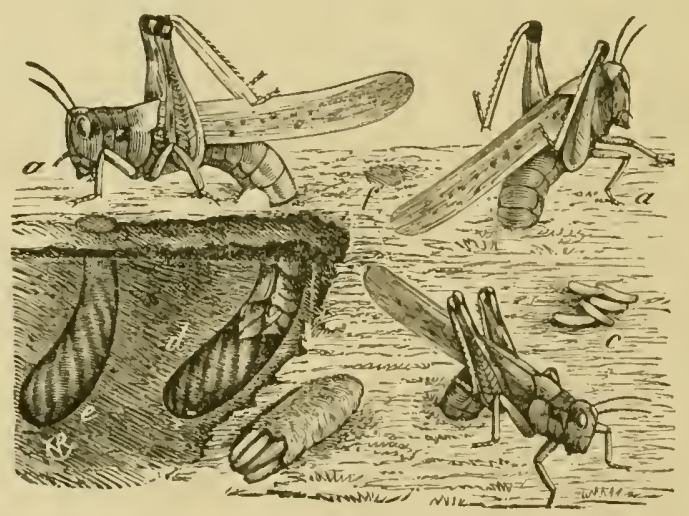

Fig. 36. Loeust in the act of laying eggs. (After Riley.)

autumn. When ready to oviposit, she forms a hole in the ground or other nitus to a depth corresponding to the length of her abiomen. The eggs are then deposited one at a time to the number of 30 to 60. being placed in regular order in this hole. During the process a 
glutinous fluid is emitter around them which at length hardens and binds them together, thus forming a bean-shaped mass. The hole abore the mass is then closed with dirt intermixed with this fluid which, when it hardens, renders it partially impervions to water. However, if the winter is an open one with many changes of temperature, many of the eggs are apt to be destroyed. By far the larger number of eggs are deposited in the earth in the manner shown in the accompanying ent. A few species, however, oviposit in rotten or
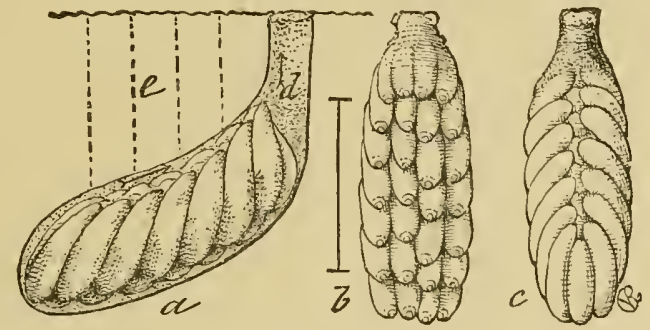

Fig. 37. Egg mass of locust. $a$, from the side, within bnrrow; $b$, from heneath; $c$, from above; enlarged. (After Riley.)

decaying wood. Abont mid-April the eggs begin to hatch and the sprightly little insects, devoid of wings but otherwise like their parents, are soon seen on erery hand.

Sorm with one earthly desire - a voracious appetite-and witl one valuable possession-a pair of strong, broad jaws, which move in and ont like the blades of a pair of scissors-the little hopper soon begins to use the latter to appease the former, and for twenty-four hours a day and seven days in a week, he gnaws away at the soft, green, succulent grass which surrounds him on every side. Such a procedure can have but one result. IIis body soon becomes too big for its surround-

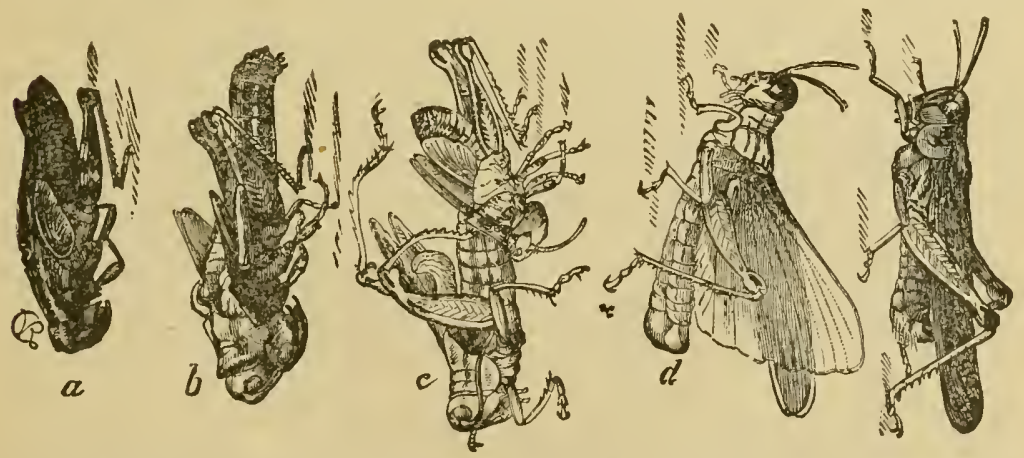

Fig. 38. Molting of a locust. a, nymph ready to change: $b$, the skin split along the back and the arlult elnerging; $c$, continues the process; $d$, the adult insect drying out;

e, perfect adult. (After Riley.) 
ings. Something must give way, and that something is his skin. He casts it aside, however, with but little ruluetanee, for a new one is ready to take its place, and immediately begins to satiate his appetite once more. Five successive times his skin gets too small for his body and is cast aside. Between each of these moults the wings are growing, and when the fifth skin is shed he emerges a mature and full fledged insect.

Howerer, all locusts do not pass the winter in the egg state. Three or four species hatch in early antumn and the young in various stages can, in suitable localities, be seen jumping vigorously about on any warm sunny day in mid-winter. If their presence at such a season comes to the attention of a newspaper reporter, the press of the entire State is apt to teem with warnings of a coming "grasshopper" plague," of which the youngsters are thought to be the advance guard. These hibernating young are the first to reach maturity the next spring, usually becoming-full grown about the 20th of April.

A number of species of Acridida, especially of those belonging to the genus Melanoplus, possess, in the adult stage, only rudimentary tegmina and wings, and resemble immature insects or nymphs in appearance. A close examination will show, however, that these adults have the tegmina in the proper position, while in the immature stages of these and other forms, the tegmina and wings are inverted, being twisted abont so that the faces and-margins are just the opposite of what they are in the perfect insect.

About 5 to species of Acridide are known from the United States. These are divided among four sub-families, all of which are represented in the Indiana fauna, 63 species having becn taken in this State. These sub-families may be separated by the following table:

A SYXOPSIS OF TIE SUB-FAMILIES OF ACRIDID.E KNOWX TO OCCUR IX IXIDINA.

a. Size, very small; pronotum extending to or beyond the end of alydomen; tegmina represented by small seales or lobes on the sides of the body; claws of tarsi withont a pad or enshion hetween

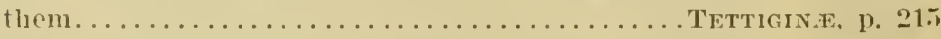

111. Size, larger: pronotum never axtendiug over the abdomen; tegmina nsually well developed. but sometimes abbreviated or even wanting: claws of tarsi furnished with a small eushion or pad between them.

b. No spine or tubercle on the prosternum between the front pair of legs.

c. Face or front head rery oblique, usually meeting the rertex at an acute angle; the fastigium horizontal or a little 
ascending; foreole usually present and well dereloped; median carina of the pronotum nerer raised in the form of a crest, or cut by more than one sulcus.........

TRYXaline, p. 232

cc. Face or front of head nearly or quite rertical and rounded where it meets the rertex; the fastigium almost always sloping sharply downward; foreolie generally obscure; median carina of pronotum often crested and usually cut by more than one stilcus............ (EDIPOdinde, 1. 251

6b. A distinct conical or cylindrical spine present on the front margin of the prostermum................'Aldin.E, p. 285

Sub-family TET'TIGIN.T.

The members of this sub-family, known as the "grouse locusts," are our smallest Acridians. They are readily known from all other locusts by having the pronotum prolonged and tapering backward to such an extent that it reaches to or beyond the tip of the abdomen. The tegmina are rudimentary, being represented only by small oval lobes or scales, placed on the sides of the body and usnally covering a small portion of the base of the wings. The wings are usually present and well developed, especially in their anal area, though both they and the tegmina are, in a few instances, wanting. The prosternum is prolonged in front by a half circular "chin piece" which enrelops the maxillix and other mouth parts like a muffler; no arolia or pads are present between the terminal claws of the tarsi. The males of most of the species are much narrower bodied than the females; their sub-anal plate, viewed from the side, is conical or triangular; the supra-anal plate lanceolate or triangular. The valves of the ovipositor are armed with small rounded teeth on their outer edges, and their extremities sharply diverge.

These little gronse locusts are the only member's of our Indiana Acrididx which pass the winter in the imago or mature stage. On the approach of winter they hide beneath chunks, chips, rubbish, the loose bark of logs, or beneath the bottom rails of old fences. Sometimes a warm sunny day in mid-winter tempts them forth in numbers, and on such occasions, the earth seems to swarm with them as they leap before the intruder, their hard bodies striking the dead leaves with a sound similar to that produced by falling hail. If the winter is an open one, with alternate periods of thawing and freezing, many of them doubtless perish. On the first warm days of spring they can be collected by hundreds from any grass-covered hillside having a sunny southern exposure, or from the boggy places along the margins 
of lakes and streams. Haneock has written entertainingly of their habits as follows:

"I'he jump of the grouse locust is peculiar in that it is quick and inconspicuous and in this that it alights alnost invariably on the ground. The young of the larger Orthoptera ustally alight on grass or stems of plants, flodging buhind them for protection. The remarkable color of these little Acridians, hamonizing in erery instance with the soil, makes it sometimes diflicult to locate them. 'This protective resemblance is earried out to perfection, the little inserets hinge on the soil seattered with heloris faded out be the hot sum, and the lights and shatows in whateser way they play, are "opicel exartly. No shade. color or arrangement of markings seems impossible of simulation, and every individual is a sturly in color harlurony.

-.The grouse locusts feed mpon the regetable mold or decomposing soil sonetimes nixed with alge, or on the lichens. mosses, tender spronting grasies, sedges, germinating seeds of plants and debris found in such siluations. Particularly songht-after morsels are the varions colored surface elays and the black muck, consisting of rich regcetable mold. They are ravenous eaters, as one might infer-from the dietary list just mentioned, and the foreal excerement, on reaching the end of the abdominal appendages, is thrnst away from the body by a rapid kick of the lind tibia.

"In the middle of May (Illinois) the first eggs are laid in the wround, the fomale accomplishing this act by making a shallow burrow with her ovipositor. The young larve, hatehed from this brood, mature by fall, passing the following winter in the adult state. The bronds hateded in late . June and early July are often immature by the time winter arrives, and we find them hibernating in the pupa state. 'Thus it is that the Tettimine are about the earliest insects to be found in the spring, appearing as early as March. The time of inculation aries with the temperature, the early broods of Tellix hatching in twenty-three days, but as the days heenme warmer this period is shortened to sixtech days. The number of eags of T'eltix: and P'aralellir vary rensiderably, lout there are more often 10,13 or 16 in cath burrow: in Telligiten rarying from 12 to 2 (i.

"I)uring the life of these litte 'Tettigians they are more or less constantly in danger of enemies among the arachnida, insceta. and some of the vertebrata. The larva of a red mite (Trombidian) is one of the most frequent sourees of annoyance. Arting as a parasite the 'Trombidian larva clingse on the body and attaches itself out of the reach of the victim. There it remains to sap the juices of the host's 
body. It is found on many species. Among insect pests, ants and bugs are sometimes deadly to them. In a wet ditch in June the writer found a number of small dark-brown ants dragging along the ground a female Tellix ornatus which had just been killed by them. When endearoring to capture some Tettix at the same place my attention was drawn to a colony of these ants acting in a panicky state of excitement, the cause of this being that they had darted upon the insect the author was pursuing, tumbling it over and biting it savagely about the neck. The little locust finally escaped by a vigorous jump.

"According to P. R. Uhler, Galgulus oculatus, a true bug, is a serious enemy. 'This insect may often be seen,' says Uhler, 'in the month of May walking about between the stones on the low banks of brooks and streams, where Tcllix and Paratettix abound, watching an opportunity to seize one of these insects, and when the favorable moment arrives, leaping suddenly upon one of them, clasping it with tight embrace between the front femora and tibie and then sucking ont its vital juices." "

Toads, fishes and birds also feed upon them when opportunity offers.

Nine genera, 45 species and numerous varieties of these grouse locusts are described from the United States in the latest monograph of the group.* Of these 12 species, representing five genera, have been taken in Indiana. The genera found in the State may be separated by the following table:

KEY TO GENERA OF INDIANA TETTIGINA:

a. Antenne with 12 to 14 joints; front femora more or less compressed, carinate above.

$b$. Vertex of head extending beyond the front of eyes, wider than one of them; its front angulate or rounded, not truncate.

c. Front dorsal margin of pronotum when trumcate not advanced upon the head to the eyes; facial ridges not forked; front of vertex, when viewed from the side, angulate or sub-rounded.

d. Pronotun with its median carina raised in the form of a crest and more or less arched lengthwise; the front margin produced in an angle over the back of the head. Upper notch or sinus on the hind margin of lateral lobe of pronotum shallow, about

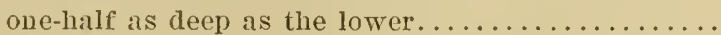

XII. NomotetTix, p. 218

*"The Tettigida of North America," by Dr. J. L. Hancock, Chicago, 1902. 44-Geol. 
di. Pronotum with its median earina low, not arehed; its front not produced forward. Upper noteh or sinus on hind margin of lateral lobe of pronotum nearly as deep as the lower.... XIII. TetT1x, p. 219

cc. liont dorsal margin of pronotum truncate and advanced upon the head to the eyes; facial ridges with their lower lialyes strongly forked; frout of rertex, when viewed

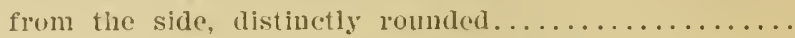

XIV. Neotettix, p. 226

bb. Vertex of head not extending beyoud front of eyes, usually narrower thin one of them; its front usually trmeate.......

XV. Paratettix, p. 227

aı. Antemne witlı 21 or 22 joints; front femora distinctly and broadly grooved or sulcate abore............. Xvi. Tettraidea, p. 2:S

\section{Noyotettix Morse (1894).}

The members of this genus can be easily distinguished from the other 'lettigians by the characters given in the key. The high arched crest of the pronotum, and (in our species) its projection forward in an angle over the back of the head, are especially notable. Between the posterior portion of the eyes and the median line of the pronotum a pair of nipple-like tubercles are usually present. The antenna are short and filiform with 12, rarely 13 , joints. 'The pronotum in most specimens reaches only to end of abdomen, the inner wings then being rudimentary. An occasional example of some of the species is found in which the pronotum is prolonged and the wings well developed. 'These, according to Morse, are examples of a reversion to the earlicr long-winged type of females. The hind femora are wider and stouter proportionally than in the other genera.

Seven nominal species of Nomotettix have been described from the United States. Of these, but one has, as yet, been taken in Indiana.

17. Nomotettix compressus Morse. The Crested Grouse Loenst.

Tomotellic rompmrssus Morse, 96, III, 1895, 15; Scudd., 188, 1900, 15; H:111, , 69, 1902, 55, 58.

Jistruchintece eristute B1., 4, XXIIT, 1\$91, 100 (not Harris).

Batrachiden eqrinetu B1., 6, XXIV, 1892, 33 (not Scudd.).

Borly small, compressed, gramulate: grayish or fuscous brown in color, the sides of pronotum often ornamented with one or two irregular shaped velrety black or black and white spots. Vertex nearly twice as wide as one of the eyes, a little higher than the eyes and cxtending in front of them, its front border sub-rounded. Pronotum strongly compressed, its front dorsal margin advanced in an angle over the hear to the posterior third of the eyes. Median carina of 
pronotum strongly crested and arcuate; so compressed and thin in section that the punctulitions of its surface appear translucent when held against the light. In the shorter and more common form the pronotum exceeds but slightly the tip of abdomen and the wings do not reach its apex; in the long form the pronotum extends $3 \mathrm{~mm}$. and the wings $4 \mathrm{~mm}$., beyond the tip of abdomen.

Measurements: Length of body, male, $7.5 \mathrm{~mm}$., female, $8 \mathrm{~mm}$.; of antennæ, $3 \mathrm{~mm}$; of pronotum, male, $\% .3 \mathrm{~mm}$., female, $8 \mathrm{~mm}$; of hind femora, male, $4.3 \mathrm{~mm}$., female, $5 \mathrm{~mm}$. Length of pronotum, $\operatorname{long}$ form, $10 \mathrm{~mm}$.

This crested grouse locust probably occurs in most portions of Indiana, having been taken by the writer in Perry, Monroe, Vigo and Lake counties, while Dr. Hancock has found it abundant at Dune Park, Porter County. In the southern portion of the State it makes its home on the sides of dry sunny banks in pastures where the grass is scant or has been cropped short, and where the species of "Everlasting," Antennaria and Anaphatis, delight to grow. In such places it nuy be taken by the score in late autmm or early spring. In the northern counties it lives, says IIancock, "on dry, sandy soil, lightly covered by fragments of twigs, leaves, and varions fine debris accumulated from past scasons. It frequently seeks retreat among prickly pear cactus on mossy covered ground, slightly sheltered by trees, among sand dunes. It is a curious little species, and though sometimes quite common locally, it requires the exercise of tact on hands and knees to capture the sprightly little insects. In the cool October morning they did not appear to jump firr, but as the sunlight warmed the ground they became more active. Some were in the last pupa stage, but the majority were adult."

But two specimens of the long-winged form have been taken among the hundreds of short-winged ones collected in this State, a male in Vigo County and a female in Perry County. On account of the greater length of the pronotmm, its median crest does not appear so prominent nor so strongly arched in the long-winged form as in the more common one. Dr. Hancock, in a recent letter, has giren the varictal name atavus to this long-winged form.

\section{XIII. 'Tettix Charpentiel' (1841).}

In this genus the median carina of the promotum is distinct but not arched or raised in the form of a crest. The vertex is wider than one of the eyes, and its front projects beyond them. Antemm short, stout or slender, usually composed of 14 joints. Pronotum with its 
front margin truncate, or suarecly angulate, but little produced forward upon the head, reaching to end of abdomen in short-winged forms and much beyond it in long-winged forms of the same species; the upper lateral notch or sinus nearly as deep as the lower. Eleven species of the genus have been described from the United States, five of which are known to oecur in Indiana. These may be distinguished by the following

IEY TO INDIANA SI'ECIES OF TETTIX.

a. Median carina of pronotum more or less distinctly elevated along its entire length; dorsal surface of pronotum higher in the middle. sloping on the silles; its surface rugose or wrinkled, as well as gramulated.

b. Body slender, the posterior portion of pronotum long drawn out; vertex riewed from ahove, obtusely angulate, its median carina not projecting beyond the sides....1s gramulatus, p. 220

b. Body less slender; pronotum less prolonged posteriorly; front of vertex rounded, its median carina distinctly projecting... .

c. Front half of pronotum with its median earina but little raised; middle femora of male but slightly enlarged, the expanded portion but one-third as long as broad........

19 ornatus, p. 222

c.c. Front half of pronotum with its median carina compressed and more elevatel, more or less arcuate; middle femora of male enlarged, their expanded portion nearly or quite onc-half as long as broad..........20 hancocki, p. 22:3

ar. Median carina of pronotum indistinct, being not at all or rery little elerated; dorsal surface of pronotum flat, or nearly so, the surface granulated, rarely if at ali rugose.

(l. body rather slender, the posterior portion of pronotum prolonged, acute; vertex distinctly dejuessed in front; exes prominent; frontal costa straight and narrowly sulcate..........

21 areuosus, 1). 224

dd. Body more robust, the pronotum less prolonged posteriorly; vertex but little deplessed in front; eyes of medium size; frontal costa, when riewed from the side, distinctly sinuite.........

2.2 obscurus, 1). 22.5

18. Tettix gRanulates (Kirbr).

Amydium gramulutum Kirhy, 79, 1837, 251.

Tellir gramululus seudd., 141, VII, 1862, tit; Ill., 188, 1900, 16; Thos., 206, V, 1si3, 182; Riley, 117 , VHI, 18if, 150, Fig. 47; Ir., 1 19, 18т7, 2:30, Fig. 42; Icl., 214 , I, 1s78, 256, Fig. 11; Id., 122, II, 18st, 192, Fig. 268; Lint , 82, II, 18s., 197, Fig. 59; Bol., 19, 1887, 91; F(rn., 53, 18s8, 46, Fig. 18; Morse, 94, VII, 1894, 15t, 163, Plate 6, Figs. 3, 3a; Bl., 1 1, XXTI, 1894, 220; Beut., 3, VI, 1894, 309; Hanc., 67, XXIII, 1896, 237, Plate VI, Figs. 3, 3a; Plate IX, Fig. 28; In., 68, X, 1899, 279; Ir., 69, 1902, 69, Plate IY, Figs. 2, 2a ; Lugg., 84, 1898, 107, Fig. 63.

Tettix mersci Hanc., 68, X, 1899, 280. 
Color variable, usually wholly grayish or reddish brown, sometimes blackish, often with a whitish median band along the full length of the pronotum. Surface of pronotum and legs finely granulated; the dorsal surface of pronotum also rugose with numerous short ridges or

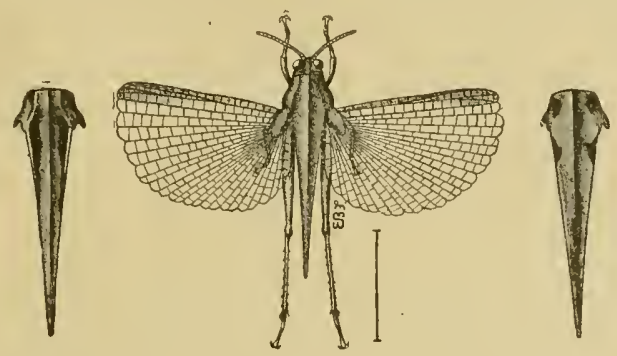

Fig. 39. Tetix granulatus (Kirby). (After Lugger.)

wrinkles. Anterior border of vertex considerably advanced in front of eyes, obtusely angulate or very slightly rounded, the mid-carina projecting but little if any beyond the sides. Face very oblique, eyes small. Body, especially that of male, very slender. Pronotum with front margin trmeate, its posterior portion long drawn out, the apex acute, passing the hind femora; its median carina prominent throughout but not crested. Inner wings reaching to or slightly beyoud tip of pronotum; in life bluish or bottle green in color. A form with the pronotum and wings more or less abbreviated is oceasionally found with the common form. To it Hancock has given the varietal name rariegalus.

Measurements: Length of body, male, $8.5 \mathrm{~mm}$., female, $11 \mathrm{~mm}$; of fronotum, male, $11 \mathrm{~mm}$. female, $13.5 \mathrm{~mm}$; of hind femora, male, $6 \mathrm{~mm}$., female, $7 \mathrm{~mm}$.

This slender gronse locust doubtless occur's throughont the State, having been taken in Lake, Porter, Fnlton, Narshall, Marion and Franklin counties. It is probably much more abundant in northern than in sonthern Indiana, as its general range is northerly, extending from ocean to ocean and northward through British America. It has an especial liking for marshy and boggy tracts about the margins of lakes and tamarack swamps, though it is likely to occur anywhere in low wet woods. In Vigo County I found it hibernating beneath logs along the sandy border of a large river bottom pond. The light band along the middle line of pronotum is in a high degree protective when the loeust dwells among the grasses and sedges of marshy tracts, as it harmonizes with the dried blades of these plants. Inancock has found granulalus in Wisconsin on the ground "about 
prostrate tree trunks, which were molding in decay and covered with greenisly lichens and moss. 'The yellowish and brownish fallen leaves were everywhere suttered over the bed of the forest. Occasionally, when the wind was not blowing, the author was able to mark the presence of Tettigids by the somnd made as they jumped upon the dried leaves." Morse says that "in New kngland this species prefers sedgy meadow lands and swales on sandy soil occasionally flooded by rains or freshets and perpetually moist. The bulk of my specimens were taken on a boggy swamp which had been filled in with sand, and on which water stood more or less of the time."

19. Tetrix oknates (Say). The Ornate Gronse Locust.

Acrylium monclum Say, 137, I, 182t, Plate Y.

Acrillum ornalum Say, 139, I, 1859, 10, Plate 5, Fig. 1.

Tetrit omatus Harr., 70, 1835, 577; Id., 72, 1862, 186.

Tettix ornatus Scudd., 141 , VII, 1862, 474; Id., 188, 1900, 17; Glov. 62, 1872, Plate T, Figs. 1, 2; Plate XII, Fig 10; Thos., 206, V, 1873, 183; Riley, 122, II, 1884, 192; Lint., 82, II, 1885, 197; Bol., 19, 1857, 90; Ferm., 53, 1888, 46; Bl., 4, XXIII, 1891, 100; Irl., 11 , XXTI, 1894, 220; Id., 16, 1899, 236, Fig. 62; Morse, 94, VII, 1894, 152, Plate 6, Figs. 2, 2a-c; Beut., 3, VI, 1894, 310; Hanc., 67, XXIII, 1896, plate TI, Figs. 1, 2; Plate VIII Fig. 20; Plate IX, Fig. 29; Irl, 69, 1902, 78, Plate III, Fig. 4; Plate XI, Fig. 3; Lugg., 84, 1898, 108, Fig. 64.

Trlli, lrianguluris Semdld, 14 1, VII, 18ti2, 475; Thos., 206, T, 1s73, 185; Bol., 19, 1887, 91; Fer11., 53, 188s, 47; Bent., 3, VT, 1894, 310; Lugg., 84, 1898, 109; Hanc., 69, 1902, 80.

Body of moderate size; color extremely rariable; usually dark grayisl, sometimes rusty brown or fuscous; often ormamented with two or iour irregular velvety brown spots on dorsal surface of pronotum, more rarely a large whitish spot in front of these; the hind

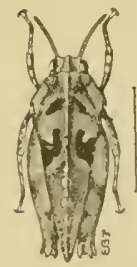

Fig. 40.

Tettix ornatus (Say). (After Lugger.)

fenora often with one or two white blotches on its outer face. Surface of pronotum and legs ererywhere fincly gramulate; the posterior half of the pronotum usually rugose, with numerons short, oblique wrinkles or ridges. Tertex extending in front of 'yes, somewhat rounded in front, its median carina projecting forward beyond the sides. P'ronotum variable in length, in the long form less prolonged backward than in granulatus, its dorsal front margin truncate; the median carina distinet but not as high as in granulatus. Inner wings fully developed, extending a little beyond the apex of pronotum. The form with pronotum and wings shorter is, as shown by the symonymy, the one formerly known as $T$. triangularis Seudd. 
The two forms have been proven by Hancock to interbreed and the measurements intergrade, the following table showing the extremes:

Measurements: Length of body, male, 8.5-12.5 mm.; female, 9$13.5 \mathrm{~mm}$; of pronotum, male, $7.5-10.5 \mathrm{~mm}$., female, $8-12 \mathrm{~mm}$; of hind femora, male, 4.5ั-5.5 mm., female, 5-7 mm.

The ornate gronse locust seems to be rather common in Indiana, having been taken in Crawford, Posey, Marion. Putnam, Lake, Porter and Laporte counties. It may be taken any month in the year but in late autumn and early spring is most abundant, being then usuilly found along the edges of dry open woods and on gravelly hillsides, while in summer it is occasionally found in company with Paratettix cucullatus about the borders of streams and ponds. It sometimes makes its home in grassy plots and lawns, especially those which are wooded, in the outskirts of cities, and is then often seen sumning on the cement and other sidewalks along their margins. The form triangularis more often oceurs in sandy localities, and in some places far outnumbers the typical form.

On a bright sumny afternoon in Tate November, I once found both forms of ornatus very common on a sloping hillsicle two miles north of Indianapolis. A clover field was here adjoining an open woods pasture, and the second crop had been eut in Oetober for the seed. Many of the dead stalks had fallen elose along the fence row separating the fields, and here the Tettix were in abundance, their bodies all grayish brown, and corresponding very closely to the thend elorer stems: so closely. indeed, that they were not visible until they hopped, and then had to be "marked down" before they were captured. Beneath the bottom rails of the old fence they had found a comfortable abiding place and winter retreat, and on this bright afternoon had been tempted forth to bask in the sunlight and perchance to feed mpon the green clover leaves which were yet abundant in places among the dead and fallen stems.

20. Tetrix Hancockr Morse. Hancock's Grouse Locust.

Tettir huncorli Mor'se, 101, TII, 1899, 200; Scudd., 188, 1900, 16; Hanc., 69, 1902, 81, Plate IV, Fig. 4 ; Plate XI, Figs. 5, 5a.

This species is allied to T. ornatus Say, with which it agrees in color, granulation and rugosity of surface, hut differs in its more robust form with wider and generally more projecting vertex, slightly more prominent mid-carina; in the generally more abruptly forked and wider facial costa, and notably in the enlarged middle femora: the expanded portion of the latter in the male being nearly or quite one-half as broad as long (in ornatus seldom more than one-third); 
in the female the difference is less noticeable. The humeral angles of the promotmm are more pronounced and the mid-arina is a little more elevated in its anterior portion.

Forms with both long and short pronotum oceur, the varietal name abbreriatus having been given to the shorter onc. In the long examples the pronotum and wings pass the hind femora about $3.5 \mathrm{~mm}$.

Mensurements: Length of body, male, 8.3-12 inm., female, 9-13 mmm.: of pronotum, male, $8.5-11 \mathrm{~mm}$., female, $8-12 \mathrm{~mm}$.; of hind fumora, male, $5 \mathrm{~mm}$., female, $5.5-6 \mathrm{~mm}$.

This species has been taken only in Marion and Vigo counties. From the latter locality some of Morse's type specimens were secured. It frequents the same localities as T. ornalus, the species to which it is most closely allied. In the localities where it has been found, short forms have, up to the present, proven more abundant than the long ones. It will probably be found to occur more commonly in the northern half of the State, as its range is northerly, being given by Scudder as "Nlontreal to S. Dakota and Nebraska."

21. Tetrox anexosus Burmeister. The Gramulated Grouse Locust.

Tettrit arewer Burm., 40, II, 1838, 659.

Tetti, "rensuse, Bol, 19, 1887, 95; BI., 11, XXVI, 1894, 219 (in part); Scurld., 188, 1900, 16; Hanc., 69, 1902, 68, 85, Plate III, Fig. 3; Plate IT, Figs. 5, 5l).

Teltir omete Thom., 206, V, 1873, $18+$ (in part).

Body rather slender; the pronotum everywhere minutely granulate but little rugose or wrinkled. Color grayish or blackish, often with a large squarish white spot on the dorsal surface between the humeral angles; this spot usually with traces of black on its hind margin. Vertex, viewed from above, nearly twice the width of one of the eyes, depressed in front; extending but little beyond the front of the eyes, its front margin sul,tuncate. the median carina indistinct, scarcely if at all projecting. Eyes, when viewed from above, prominent. Antenne slenler, the joints elongate. Pronotum with its front margin truncate, its posterior portion prolonged, and extending much beyond the hind femora, its dorsil surface flat, the modian carina indistinct, scarcely or not at all elevated. Inner wings fully developed, a little surpassing the pronotum.

Measurements: Length of body, male. $8 \mathrm{~mm}$., female, $9 \mathrm{~mm}$; of promotum, male, 10.5 mm., female. $13 \mathrm{~mm}$; of hind femora, male, 5 mm.. female, $5.5 \mathrm{~mm}$.

'This is a Specimens in my collection are from Posey, Orange, Crawford, Monroe, Vigo. Putnam and Koscinsiso connties. From ornalus it may be 
readily known by its more slender form, flatter pronotum with less prominent median carina, and by its evenly aud finely granulated surface. The annulations of antenna and legs are much less distinct than in ornatus and the general color is not so variable. It frequents upland woods which are dry and open, being seldom found in the vicinity of water. It was criginally described from South Carolina, and its general range is southern.

22. Tetrix obscurus Hancock: The Obsenre Grouse Locust.

Trttix olscume Hanc, 67 , XXIII, 1896, 239, Plate VII, Figs. 9, 9a, 10, 10a; Plate IX, Figs. 23, 25; Irl., 69, 1902, s7; Scudd., 188, $1900,17$.

Tettix influtus Hanc., 67, XXIII, 1896, 238; Sicudrl., 188, 1900, 17.

Tettix angustus Hanc., 67, XXIII, 1896, 238; Scudd., 188, 1900, 16.

Allied to arenosus, with which it agrees in color; body more robust. Vertex, viewed from above, twice the width of one of the eyes, but little depressed in front; extending beyond the front of eyes to a distance equal to one-fourth the diameter of one of them; its median carina but little distinct, not advanced beyond the sides. Frontal costa distinctly sinnate between the lower portions of the eyes, forming a small protuberance at the junction with the median carina of the vertex. Eyes of medium size. Pronotum truncate in front, strongly constrieted before the shoulders, less prolonged backward than in arenosus; the median carina indistinet through most of its length, a little raised on anterior third. Inner wings extenrling slightly beyond tip of pronotum.

Measurements: Isength of body, male, $11 \mathrm{~mm}$., female, $13 \mathrm{~mm}$; of pronotum, male, $10.5 \mathrm{~mm}$., female, $12 \mathrm{~mm}$; of hind femora, male, 5 mm., female, $5.5 \mathrm{~mm}$.

Among a number of grouse locusts sent to Dr. Hancock were numerous examples from Vigo, Marion and Lake counties which he referred to this species. They were taken in company with $T$. arenosus and were by me considered that species. In my opinion time will show that obscurus is but a form of arenosus, as Dr. Hancock wrote me, when returning the specimens, that some of those labeled by him as obscur"us "shade off into forms approaching arenosus."

Hancock's T. gibbosus, representatives of which he also found among the "lot of arenosus" I sent him from Vigo and Marion counties, I consider only a shorter and wider form of arcnosus, having the pronotum a little more constrieted than usual in front of the shoulders. The other characters given by him in his key to the species of Tettix are not distinctive. 


\section{Neotererix Haneock (1898).}

The members of this genus hare the body short and thick set. Vertex wider than one of the eyes, the front margin convex or rounded; viewed from the side, a little advaneed in front of the eyes. Frontal costa convex, their lower halves. viewed in front, strongly divergent or forked. Intemme rather stout, short, composed of twelve or, rarely, thirteen segments. I'ronotum with its front dorsal margin truncate, advanced over the head to the eyes, the sides of dorsal surface sloping a little downward between the shoulders; the median carina distinct, usually a little elevated between the shoulders. Hind femora enlarged, rather short. Hind tarsus with the first segment distinctly longer than the second and third together, the pad between the claws of last segment acute but more or less flat below.

Five species of this genus are known from the United States. One of these occurs in Indiana.

23. Neotettix ImACocki sp. noy.

Body short, robust; color dirk gray, the tibix and tarsi annulate with light and dark, the oripositor brown. Vertex nearly twice as wide as one of the eyes; its median carina visible only on front half; its front border rounded. Frontal costa, viewed from the side, strongly convex between the bases of antemne, tlie lower halves, as in other species of the genus, widely dirergent. Eyes prominent, subglobose. L'ronotum with its dorsal front mirerin truncate. reaching the eyes; the lateral carine on the portion in front of shonlders high and distinct; the posterior portion with the sides converging gradually to a rather sharp apex, which terminates just above the base of ovipositor; the median carina distinct throughout, more or less undulate, highest between the shoulders; the posterior lateral carina prominent throughout; the dorsal surface with a number of prominent oblong tubercles on its front half: those on posterior half shorter and more rounded; tegmina oblong. the apical half rounded. Wings abbreviated, three-fourths the length of posterior portion of pronotum.

Measurements: Length of body, female, $10 \mathrm{~mm}$; of pronotum, $8.5 \mathrm{~mm}$; of hind femora, $(\mathrm{m} \mathrm{mm}$.

From $N$. botivari, its nearet ally, this species is easily recognized by its more bulky forn, by the more convex and prominent frontal costa, the larger eyes, the higher lateral earina of pronotum behind the eyes, and especially by the prominent tubercles on the surface of the front dorsal half of pronotum. The tegmina are shorter and 
broader, the upper posterior notch of lateral lobe of pronotum is deeper and the median lobule more rounded than in bolivari.

A single female, now in the collection of Dr. Hancock, was taken from the border of a large cypress swamp in Knox County, on July 6,1902 . It was not recognized until Dr. Hancock made a careful examination of the Indiana material of the sub-family. A second visit was made to the place on April 23, 1903, but a careful search resulted only in the finding of four half-grown nymphs. The whole swamp was corered with water several fect in depth, and the young of hancocki were found in company with the young and adults of other Tettigids on the higher ground bordering the water, within ten feet of its margin, and only a few rods from the nearest cypress trees. All other known members of the genus are from the southern states. and it is interesting to note that this single northern species makes its home among the isolated cypress swamps of Indiana-the cypress being a tree whose main distribution is far to the south.*

\section{Paratettix Bolivar (1S8\%).}

From the other grouse locusts the members of this genus may be readily known by the short and narrow vertex which does not extend beyond the eyes, its front margin being truneate. Frontal costa more or less prominent between the antennæ, declined toward their base, rarely a little sinuate. Eyes prominent, sub-globose. Antennæ of 14 segments. Pronotum with its dorsal surface flat, its front margin truncate, and, in our species, advanced forward upon the head to the eyes; its posterior portion moderately prolonged; the median earina low. Tregmina oval or elongate, punctate. Inner wings usually fully developed, rarely abbreriated. Hind tibiæ with their apical third grathally enlarged, the pads between the spurs of last joint of hind tarsi covered with numerous fine points or spicules. Five species of the genus are known from the United States, one of which occurs in Indiana.

24. Paratettix cucullatus (Burmeister). The Hooded Grouse Locust. Tetrit cucullate Burm., 40, II, 1838, 658.

Tettix rucullata Scudd., 141, TII, 1862, 475; Thom., 206, V, 1873, 185.

Tettix encullutus Bol., 19, 1887, 259, 266; Fern., 53, 1888, 47; Bl., 6, XXIY, 1892, 33; Bent., 3, VI, 1894, 309.

Paratettir mucullatus Morse, 94, VII, 1894, 163, Plate 6, Figs. 4, 4a; Hanc., 67, XXII, 1896, 241, Plate VII, Figs. 11, 11a; Id., 69, 1902, 111, Plate VIII, Figs. 6, 7; Lugg., 84, 1898, 110, Fig. 65; Bl., 16, 1899, 236, Fig. 62; Scudd., 188, 1900, 17.

* Two additional females of $N$.hancock $i$ were taken in the cypress swamp on $\mathrm{July} \mathbf{1}, 1903$, by one of my assiatants. The male has, however, not yet been diseovered. 
Color usually a uniform yellowish gray; sometimes a russet red or dull black, the tibix ammulate with light and rlark. Borly rather long, depressed, smoothly and evenly granulate. Tertex viewed from above, but little wider than one of the large and prominent eyes; not adranced in front of them, its front margin slightly hollowed. Pronotum truneate in front, adraneed upon the head to the eyes (whence the specific name), the medina earina wanting or indistinct - on the front portion; low on the elongated posterior portion, which

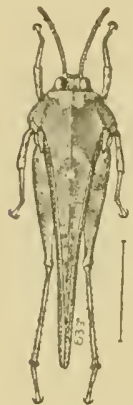

Fig. 41. Paratettix cucullatus (Burm.). (After Lugger.) extends about 3 mm. beyond the apex of hind femora. Inner wings excecding the pronotum by $2 \mathrm{~mm}$.

Measurements: Length of body, male, $9 \mathrm{~mm}$., female, $12 \mathrm{~mm}$.; of pronotum, male, $10.5 \mathrm{~mm}$., female, 13 1mm.; of hind femori, male, 5.5 mm1., female, 7 nmm.

The "looded grouse locust" doubtless occurs throughont the State, haring been noted in Spencer, Knox, Monroe, Vigo, Putnam, Marion and Marshall counties. It is most always found along the damp sandy or muddy banks of ponds, lakes and streams, usually in company with Calgulus oculalus and other semi-aquatic insects. Its modest hnes agree admirably with such surroundings, thus furnishing the insect valuable protection against its foes. When disturbed it more often flies than leaps, its flight being more prolonged than any other of our Indiana Tettigians. It often alights upon the water, where it swims with ease, its dilated hind tibix being then of much aid to its onward progress.

\section{rVI. 'Tetrigidea Sendder (1862).}

The grouse locusts belonging to this genus are more robust and clumsy in form than those we have previonsly treated, and possess a larger head and less oblique face. They may also be readily distinguished by their 2?-jointed antenne and by the fore femora being suleate or grooved along their upper margin. 'The crown of the heald has a small lobe on each side which encroaches upon the upper inner border of the eyc. 'The rertex is wider than one of the eyes and lias its front forder more or less rounder. Pronotum with its dorsal surface finely gramulate and usually more or less rugose or wrinkled; its sides sloping downward between the shoulders. the posterior portion flat and either long drawn out or abbreviate; the anterior margin rounded, angulate or acute and more or less projected forward upon the head; the median carina distinct. As in the previons genera, the males are much more slender than the females and both the prono- 
tum and inner wings vary much in length in the same speeies, much confusion of synonymy haring therefore resulted. Eight nominal species have been described from the United States. Of these four occur in Indiana.

KEY TO INDIANA SPECIES OF TETTIGIDEA.

(. Front margin of the pronotum produced on the head and between the eyes nearly to their front in the form of an acute angle or sharp eusp.

b. Body rather stout; vertex but little projecting beyond the eyes; the pronotum broad across the shoulders, its dorsal surface strongly rugose or wrinkled, its median and lateral carina well developed....................25 armata, p. 229

bu. Body slender; vertex more projecting, the pronotum narrow aeross the shoulders, its dorsal surface finely wrinkled, its earins but slightly developed...........26 spicutu, p. 230

aa. Front margin of pronotum obtuse angulate or rounded, produced on the head only to front of posterior third of eyes.

$c$. Vertex of head rather strongly adraneed in front of eyes, the union of its median carina and frontal costa, prominent; front margin of pronotum obtuse angulate; eyes of average size; antemme stout.......27 parripemis, p. 230

cc. Vertex of head but little produced in front of eyes; the union of its median earina and frontal costa less prominent; front margin of pronotum broadly rounded; eyes prominent, antenna more slender....2s literalis, p. 231

25. Tettigidea armata Morse.

Telligidea armuta Morse, 96, UI, 1875, 107; B1., 15, XXX, 1898, 60; Scudd., 188, 1900, 18; Hanc., 69, 1902, 142, Plate X, Fig. 6.

Tettigideu armate depresse Morse, 96, III, 1895, 107; Bl., 15, XXX, 1898,60 ; Hane., 69, 1902, 142.

C'olor dark gray or brown alove, blackish on the sides, the tegmina with a white spot on their apical third; the hind femora usually more or less mottled with whitish on their outer face. Body rather robust; vertex but little projecting beyond the front of the eyes; the frontal costa, when riewed from the side, prominent. Pronotum with its front dorsal margin projecting forward between the eyes in the form of an acute tooth or cusp; its median carina distinct, sharp, nearly horizontal, its dorsal surface distinctly roughened with rather long wrinkles, the sides in front of the shoulders a little excavated. In the long form the wings and pronotum pass the hind femora. In the short form, T. armula depressa, the pronotnm is abbreviated and the wings more or less abortire.

Neasurements: Length of body, long form, male, $11 \mathrm{~mm}$., female, $15 \mathrm{~mm}$; of pronotum, male, $11.5 \mathrm{~mm}$., female, $1+\mathrm{mm}$.; of hind fe- 
mora, male, $6 \mathrm{~mm}$., female, $7.5 \mathrm{~mm}$. Short form, length of body, male, $8.5 \mathrm{~mm}$. fernale, $11.5 \mathrm{~mm}$.; of pronotum, male, $7.5 \mathrm{~mm}$., female; $11.5 \mathrm{~mm}$.; of hind femori, male, $5.5 \mathrm{~mm}$., female, $7.5 \mathrm{~mm}$.

Morse's type specimens of this species were in part secured by me in Vigo County, where it occurred in small numbers along the wooded margins of a large lowland pond. It has also been taken in Monroe County, along the margins of a lake near Waterloo, Dekalb County, and by Dr. Hancock near Dune Park, Porter County, so that it probably oceurs throughout the State in low, damp, wooded localities. Outside of Indiana it has been recorded from Youisiana, Texas, Florida and Illinois. In my experience the short winged form is much less common than the long winged.

26. TetTimidea spicata Morse.

Trethigitea spicate Norse, 96, III, 1895, 108; Scndd., 188, 1900, 18; Hanc., 69, 1902, 144, Plate X, Fig. 5

Borly small, slender; vertex more projecting than in armala; the body narrower between the shoulders; the lateral carina of pronotum but slightly developed; the median carina less distinct; the dorsal surface more fincly rugulose.

Measurements: Luength of body, female, 14.5 mm.; of pronotum, $14 \mathrm{~mm}$.; of hind femora, $7.5 \mathrm{~mm}$.

Among the specimens of this genus submitted to Dr. Hancock for cxamination he found a single female of this species, taken near Grand Chain, Posey County, April 26, 1901. Several additional specimens were taken along the margin of the Cypress Swamp, Knox County, April 23. 1903. Spicata is a form of southern range, having hitherto been recorded only from Georgia and Florida. Its presence in Posey and Knox counties is but another link in the chain of proof that the snuthern third of Indiana is a portion of the territory in which the sub-tropieal and boreal forms of the eastern United States ovcrlap and merge.

27. TetTIGIDEA PARTIPExis (Harris).

Tetrie jurripemis Harris 70, 1833, 783; It., 72, 1862, 187, Fig. 82.

Tittigitere furripumis Norse, 96, III, 189., 108; Hanc., 67, XxuI, 18:6, 242, Plate VII, Figs. 12, 12a ; I 1., 69, 1902, 148; Walk., 217, XXX, 14:8, 124; seudr., $188,1900,18$.

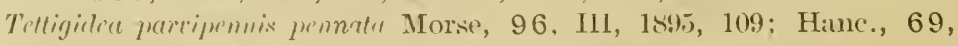
190)2, 146, Plate X, Fig. T.

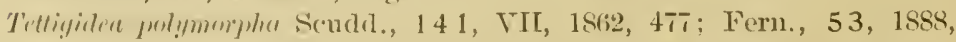
4s; B1., 4, XXIII, 1s:1, 100 (in part); Morse, 94, VII, 1894, $16+$ (nec. Burm.); and doubtless many other authors nnder the same name.

Telligiter luterulis sendd., 141, VII, 1862, t77; Fern., 53, 18ss, 48; B1., 4, XXIII, 1891, 100 (in part); Morse', 94, VII, 1894, 164, Fig. 5 (nec. Sily); and other authors under the same name. 
Color, grayish, light brown or fuscous above; the sides blackish, the tip of pronotum with a small white spot; the male with the lower part of face, mouth parts, and the lower sides of pronotum in front of legs, ivory white; the female with the last two joints of palpi, and often a spot on the upper outer half of hind femora, white. Body robust; vertex about twice the width of one of the eyes, projecting rather strongly in front of eyes. Frontal costa straight, the upper half, when viewed from the side, prominent; the lower half sloping gradually. Antennæ slightly flattened, the joints of the middle third not over two and a half times as long as broad. Pronotum with its front dorsal margin terminating in an obtuse angle which reaches opposite the posterior third of eyes; its dorsal surface rugose with distinct, branching vein-like wrinkles; its median carina distinct, but little elevated; its posterior portion slightly surpassing the tip of abdomen; or, in the long form, $T$. parvipennis pennata, passing the tip of hind femora. Inner wings either aborted or in the form pennata equaling or slightly exceeding the pronotum in length.

Measurements: Long form, length of body, male, $12.5 \mathrm{~mm}$., female, $15 \mathrm{~mm}$.; of pronotum, male, $10.5 \mathrm{~mm}$., female, $14 \mathrm{~mm}$.; of hind femora, male, $5.7 \mathrm{~mm}$., female, $7.2 \mathrm{~mm}$. Short form, length of body, male, $9.5 \mathrm{~mm}$., female, $13 \mathrm{~mm}$.; of pronotum, male, $8.5 \mathrm{~mm}$., female, $12.5 \mathrm{~mm}$; of hind femora, male, $5.4 \mathrm{~mm}$., female, $7 \mathrm{~mm}$.

This is a very common grouse locust throughout Indiana, frequenting both dry upland woods, fence rows, and low marshy tracts. Its mating season appears to be the whole year round, as I have taken specimens in copulation in nearly every month, even on sunny days in mid-winter. It hibernates ustally in small colonies or groupsas many as eleven having been found huddled together within the space of a few square inches on the under side of a log or chunk. F. M. Walker has found it hibernating in a beetle-boring in a log, the hole being completely hidden by the bark. The general color of the pronotum varies grcatly in different examples, each insect seemingly seeking that local habitat which corresponds closely to its hie.

\section{Tettigidea lateralis (Say).}

Acrydium laterale Say, 137, I, 1824, 10, Plate 5; Id., 139, I, 1859, 10, Plate 5.

Tettigidea lateralis Scudd., 141, VII, 1862, 477 (in part); Id., 188, 1900, 18; Thos., 206, V, 1873, 187 (in part); B1., 4, XXII, 1891, 100 (in part); Id., 16, 1899, 236, Fig. 62; Hanc., 66, XXVII, 1894, 483, Plate XIII; Id., 69, 1902, 149, Plate X, Fig. 9; Morse, 96, III, 1895, 108; Lugg., 84, 1898, III, Fig. 66 (in part). 
Color as in T. partipennis; vertex less projecting in front of eyes than in that species. Frontal costa, viewed from the side, less prominent. Eyes larger. Antenne filiform, the joints of the middle third, three to four times as long as broad. Pronotum with its front dorsal margin more or less rounded, but little prodneed forward upon the head; its dorsal surface rugose as in parripennis; its posterior portion surpassing the tip of hind femora in the long form; reaching

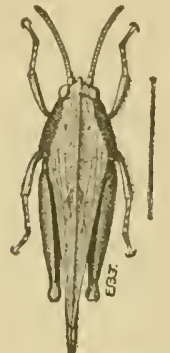

Fig. 42. Tetrigidea lateralis (S:ay). (After Lugger.) the end of abdomen in the short form, $T$. polymorpha Burm. (?). Development of inner wings, as in other species, depending upon the length of pronotum.

Measurements: Length of body, male, $12 \mathrm{~mm}$., female, $14.5 \mathrm{~mm}$; of pronotum, male, $9.5 \mathrm{~mm}$., female, $12 \mathrm{~mm}$.; hind femora, male, $5.5 \mathrm{~mm}$., female, $7 \mathrm{~mm}$.

This is a species of southern range which in Indiana has been taken so far only in Vigo, Putnam, Monroe, Crawford, Floyd, Knnox and Posey counties-all in the southern half of the State. It frequents the same localities and has the same habits as T. parvipennis. Hancock has described a form as variety medialis to which he referred many of the specimens submitted to him from Indiana. This appears to be, in part, a connecting link between parvipennis and lateralis, and an examination of a large series of specimens from all parts of the Eastern United States will probably show that the two species are the same. In that case lateralis wonld have the priority in name.

\section{Sub-family TRYXALIN.T.}

In the members of this sub-family the vertex is horizontal or a little ascending; the face is decidedly oblique and usually meets the vertex at an acute angle; the lateral foveole are usually present and well developed, thongh in a few genera they are absent or invisible from above. 'The eyes are usually longer than that portion of the checks lying below their orlits. The antennæ are variable, being often depressed, acuminate or clavate, and inserted between the middle or below the middle of the cyes. 'The dorsal field of the pronotum has its front and hind margins of nearly equal width; the lateral carinæ usually distinct; the median carina eut by but one sulcus and never crested, and the surface smooth. The tegmina and wings are often short and imperfectly developed. Tong and short winged forms of the same species are not uncommon. The wings are generally transparent, never bright colored or with a black band. 
Our members of this sub-family for the most part frequent the borders of marshes and damp prairie meadows, making their homes among the tall rank grasses and sedges which there abound. 'They usually move by flying, making no noise while on the wing. One or two species, however, delight in sandy or clayey places, where clumps of bunch and wire grass furnish them protection and food. Their inner wings are never bright colored and showy as in the next sub-family, and their tegmina have remained a green or straw color in order to harmonize with their chosen abiding places. The males stridulate, or call the opposite sex to them, only when at rest by rubing the inner surface of the hind thighs against the outer surface of the wing covers. No one of our species occurs in sufficient numbers to do much damage to vegetation, and some of them are among the least common of the Acrididx. The winter of all is passed in the egg stage.

Thirty-eight genera and 90 species of Tryxalince are listed by Sendder from the United States, mostly from the region west of the Mississippi River, and one or two additional species have been described since his catalogne was issued. Of these, but nine species, representing eight genera, have as yet been taken in Indiana, though several others may in time be found to inhabit limited areas of the State. Our genera may be separated by the following table:

KEY TO INDIANA GENERA OF TRYXALINA.

a. Foveolæe of the vertex wanting or invisible from above; face very oblique.

b. Sides of the fastigium strongly rounded, so that the apex is in no way acuminate; antenna strongly flattened at the base; pronotum with the lateral lobes vertical and straight and the lateral carine parallel; median carina of the pronotum cut much behind the middle: tegmina fully developed, acuminate or angulate at apex.............. xviI. Tryxalis, p. 234

13. Sides of the fastigium straight or gently rounded so that the apex is more or less acuminate; antenna variable; pronotum with the lateral lobes less distinctly vertical; the lateral carina gently or strongly sinuate near the middle (except in Dicromorpha); median carina of the pronotum cut in or but little behind the middle; tegmina rounded at apex.

c. Hind tibia armed with 18 to 21 spines on the outer mar-

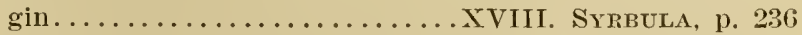

ce. Hind tibia armed with not over 15 spines on outer margin.

d. Antennæe relatively short, at most but little longer than head and pronotum together; fastigium of vertex with no distinct median carina. 
c. Pronotum with the sides elongate, the length on dorsal margin greater than the depth; the disk of one color; lateral carlna parallel throughout ........ XIX. DICROMORPHA, p. 238

ce. Pronotum witl the sides not elongate; the disk particolored; the lateral carinze direrging botls before and behind the middle..............

XX. Orinulelia, 1. 239

dd. Antenne long, ahout or more than half as long again as head and pronotum together; fastigium of restex with a modian carina. .XXI. CnL(EALtus, p. 24: uII. Foveola of the vertex always present; visible from above; face less oblique than in the Ireceding genera.

f. Tegmina without well developed elevated intercalary vein. Median carina of pronotum not high and sharp, never cut plainly in front of middle by the princi-

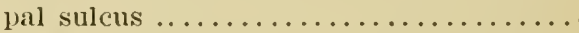

y. Apical spurs on inner side of hind tibire equal in length; lateral carina of pronotum distinct throughout their full length; broadest part of male tegmina lying beyond the middle....xxis. Stenobotinus, p. 246

9!\%. Apical spurs on inner side of hind tibire very unequal in length, the inferior twice, or nearly twice as long as the superior; lateral carinx of pronotum distinct only on metazona; broadest part of male tegmina lying at the middle............

xxiII. Ageneotettix, p. 248

ff. Tegmina with strongly developed, elevated, intercalary vein. Median carina of pronotum rather high and sharp, cut plainly in front of middle by principal sulcus. ..... XXIV. MecosteTHus, ]. 249

X'TT. 'T'RYxalis Fabricius (17\%5).

Vertex horizontal, semi-elliptical, projecting in front of the eyes to a distance about equal to that between the eyes; furnished with a delicate median carina. Tateral foveola wholly wanting. Face, viewed from the side, sloping strongly backward. Antennæ flattened at the base, acmminate, about as long as the head and pronotum. Disk of pronotum plain, the three carinæ parallel, distinct, the median cut by one sulcus much behind the middle. Lateral lobes of the pronotum perpendicular and parallel, a little longer than high, with 
both the front and hind margins oblique; the former straight, the latter sinuate. Tegmina much longer than the abdomen; acuminate or angulate at apex. Hind femora slender, the apex reaching (female) or exceeding by nearly half their length (male) the abdomen. But one species belongs to the genus as at present restricted.

29. Tryxalis brevicornis (Limmus). The Short-horned Locust.

Gryllus (Acrida) brevicornis L., 81, II, 1767, 692.

Truxalis brevicoinis Fabr., 50, 1775, 279; Thom., 211, 1880, 97; McN., 88, VI, 1891, 66; Id., 89, VI, 1897, 211, Plate I, Fig. 5; Bl., 4., XXIII, 1891, 75; Id,, 11 , XXVI, 1894, 221 ; Id., 15, XXX, 1898, 61; Bent., 3, VI, 1894, 291, Plate VIII, Figs. 1, 2. Tryxalis brevicomis, Burm., 40, II, 1838, 607; Morse, 98, VII, 1896, 325, 382, Plate 7, Figs. A, Aa; Scudd., 188, 1900, 19.

Pyrgomorpha brevicomis Glov., 62, 1872, Plate IV, Fig. 14; Thom., 206, V., $1873,67$.

Opsomala punctipennis Serv., 196, 1838, 590; Thom., 202, V, 1865, 447.

Pyrgomorpha punctipennis Thom., 206, V, 1873, 68.

Opomala munctipennis Thom., 206, V, 1873, 196.

The females of this species are dimorphic as regards color, being either a pale green more or less dotted with brown on the tegmina, or a uniform rusty brown. The green form has the lateral carina of pronotum, antennæ and edges of vertex brown. The males, which

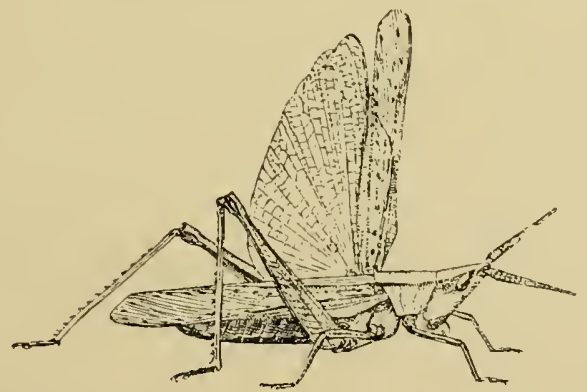

Fig. 43. Tryxalis brevicornis (L.) Female, natural size. (After Beutenmiuller.)

are much smaller, usually have the dorsal surface, face and tibiæ of fore and middle legs, bright green, the remainder of the body dark brown. Inner wings transparent, with the veins greenish. The structural characters are given above under the generic heading.

Measurements: Length of body, male, $20 \mathrm{~mm}$., female, $33 \mathrm{~mm}$; of antennæ, male, $10 \mathrm{~mm}$., female, $11 \mathrm{~mm}$.; of pronotum, male; 4.5 mm., female, $6.5 \mathrm{~mm}$; of tegmina, male, $20 \mathrm{~mm}$., female, $31 \mathrm{~mm}$; of hind femora, male, $14 \mathrm{~mm}$., female, $20 \mathrm{~mm}$. 
This curious long headed locust oecurs in suitable localities throughout Indiana, though Scudder in his catalogue gives its range as the "southern United States." It has been taken both in Steuben and Iake counties, in the extreme northeastern and northwestern corners of the State, as well as in nearly every other county where collections have been made. Walker has recently taken a few specimens near Point Pelee. Ontario. It is found only in the tall grasses and sedges along the margins of lakes, ponds, streams and swales, and in such localities is usually locally ahundant. It reaches maturity in central Indiana about July 20, and in the northern part of the State a fortnight later. The hind legs are very slender as the inseet seldom leaps when disturhed, hut uses the wings in strong, zig-zag, noiseless flight, usually alighting on a stem of grass or sedge a dozen rods away. Frank IIay, living on the north shore of Bass Lake, Starke County, reports a flight of this species after dark on the evening of Angust 13, 1901. Large numbers flew onto the porch and against the house and many were captured and used for fish bait.

\section{Syrbula Stal (1S\%3).}

Head nearly as long as the pronotum, the oceiput moderately rounderl and distinctly aseending. Vertex sub-triangular, the front margin sub-aeuminate, the sides rather prominent, the median carina distinct. Lateral foveole very small or wanting; when present, invisible from above. Antennæ flattened at the base and acuminate in both sexes; expanded apically in the male. Pronotum with the three carina distinct; the lateral gently or strongly sinuate, so that the disk is plainly narrower in the middle; all the carinæ eut by one suleus a little behind the middle. The lateral lobes of pronotum about as high as long, their front and hind margins moderately oblique, the latter a little sinnate; the lower margin more or less undulate. Tegmina and wings well developed, exceeding the abdomen in both sexes. Hind femora unusually long and slender, surpassing the tips of the togmina in our species. Hind tibix armed on the outer margin with 19 to 21 rather small spines. Last ventral segment of male acutely conical. Three species are known from the United States. Of these, one oceurs in Indiana.

30. Syrbuld abmrabils (Uhler). The Handsome Locust.

Stenolwhthus arlmiralitis Uhl., 212 , II, 1864, 553; Glov., 62, 1872, Plate IV, Fig. 13; Thom., 206, T, 1873, 84.

Syrbula admimbilis Thom., 21 1, IX, 1880, 100; Bl., 4, XXIII, 1891, 76; McN., 89, VI, 1897, 222; Scudd., 188, 1900, 19.

S.yrbula leurorema Stal., 200, I, 1573, 102. 
Male much smaller and more slender than the female; its general color olive brown and yellowish. Face yellowish, the corners of the mouth pitch brown. Antennæ with basal two-thirds yellowish, the apical club-shaped portion black on one side and pale on the other. A narrow line running obliquely backward from each eye to the pronotum and the lower third of lateral lobe of pronotum, yellowish. Tegmina brownish, the disk more or less dusky near the base. Hind femora yellowish with two or three oblique dusky bars on the upper outer face, apex black; hind tibiæ pale, the spines tipped with black.

Female: Face and sides of the head green; antennæ pale at base, the apical half dusky. A pale reddish brown stripe extends from the tip of vertex backward to the hind margin of the pronotum; this bordered on each side by a black stripe which is much narrower on the head. Sides of the pronotum green with a fuscous bar across the middle. Tegmina smoky brown, the dorsal and anal fields each with a bright green stripe; the latter notched above by the serrations of a fuscous stripe, which lies between the two green areas; the wings, smoky brown, tinged with greenish yellow at the base. Hind femora with the upper lateral carina whitish; the upper outer face green, the lower, reddish brown; hind tibiæ as in male. The ground color of the female is rarely brown, and that of the male rarely green. The structural characters are given above under the genus heading.

Measurements: Length of body, male, $22 \mathrm{~mm}$., female, $35 \mathrm{~mm}$.; antennæ.male, $9.5 \mathrm{~mm}$., female, $10 \mathrm{~mm}$.; of pronotum, male, $4.5 \mathrm{~mm}$., female, $6 \mathrm{~mm}$.; of teginina, male, $18 \mathrm{~mm}$., female, $27 \mathrm{~mm}$; of hind femora, male, $17.5 \mathrm{~mm}$., female, $24 \mathrm{~mm}$.

This prettily colored locust is nowhere common in Indiana, and as yet has been taken only in the southern half of the State, in Vigo, Putnam, Marion, Monroe, Crawford, Floyd, Knox and Posey counties. It frequents, for the most part, high, open uplands, where the soil is poor and covered with scant vegetation, though it is sometimes found in timothy meadows and along roadsides where the grass has been cropped short. But few individuals have been noted in any one locality. It reaches maturity about August 1. The males differ so much in size and color from the other sex that they are very apt to be considered a distinct species. As the slender legs indicate, the movements are made mostly by the wings, the flight being rapid and noiseless. The range of admirabilis is given by MeNeill as "United States east of the Rocky Mountains, extending as far north as Nebraska and northern Illinois, and on the Atlantic coast to Maryland." 


\section{Dicromorpha Morse (1896).}

Vertex much shorter than broad; the lateral carina distinct, elevated, and meeting in front in a blunt point: median carina and lateral foveolæ wholly wanting. Antennæ about the length of the head and pronotum together, the joints moderately flattened. Disk of the pronotum flat, the carinx distinct, straiglit and parallel, all cut behind the middle by the principal sulcus. Lateral lobes of the pronotum perpendicular, longer than deep, the front and hind margins strongly oblique; the latter plainly sinuate; the lower margin more strongly sinuate. 'Tegmina usually more or less aborted, rarely reaching the end of abdomen. Hind femolia stout and not banded. Two species are known from the United States, one of which occurs in Indiana.

31. Dicromorpina viridis (Scudder). The Short-winged Green Locust.

Chlrealtis viridis Seudrl., 141, VII, 1862, 455; (rlor., 62, 1872, Plate VI, Fig 11; Plate X, Fig. 5; Thom., 211 , IX, 1880, 92, 99; Feru., 53, 1888, 36; McN., 88, VI, 1891, 64; Beut., 3, VI, 1894, 292, Plate VII, Fig. 10.

Chinsochaon viritis Thom., 206, V, 1873, 75; Bl., 4, XXII, 1891, 75; Id., 11, XXVI, 1894, 221.

Dicomorpha rividis Morse 98, VII, 1896, 326, 383, Plate 7, Figs. 7, 7a; McN., 89, VI, 1897, 231; Lugg., 84, 1898, 124, Fig. 71; Bl., 16, 1899, 241, Fig. 67; Seudd., 188, 1900, 25.

Chlrealtis punctulata Scudrl., 141 , VII, 1862, 455; Fern., 53, $1888,36$. Chrysochraon punctulata Thom., 206, T, 1873, 76.

Opsomala brevipennis Thoul., 202, T, 1865, 451.

Truralis angusticomis Stal., 200, I, 1873, 105.

Color of male dull brown, the top of head, disk of pronotum and dorsal field of tegmina usually bright green, rarely hrown: face pale yellowish brown. Female, either bright green or dirty brown; often with a narrow dark line beginning behind the eye and rumning along the upper portion of lateral lobe of pronotum. T'ommina ovate lanceolate, about half the length of aldomen in the female, threefourths its length in the male. Ilind femora reaching tip of abdomen in the female, exceeding abdomen one-third their length in male. Very rarely the tegmina reach to or beyond the tip of abdomen: this form luaving been described as punclulata.

Measurements: Idongtl of body, make, $16 \mathrm{~mm}$, female 22 : of antenna, male and female. S.5 mm.; of promotum, male, 1 mm., female, 6 mm. of tegmina. male. $8.5 \mathrm{~mm}$. female. $9 \mathrm{mmn}$; of hind femora, male, $11.5 \mathrm{~mm}$. female, $15 \mathrm{~mm}$. 
This is a common loeust throughout the State, frequenting the borders of open woods, fence rows, roadsides, and especially the vicinity of the coarse grasses which grow along the margins of lakes, ponds and other wet places. There, as long as motionless, they are invisible, and there they flourish in peace and countless numbers. In southern Indiana $D$. viridis reaches maturity by July 1 st, and the sexes may be found mating from then until after heavy frost. The brown female far outnumbers the green one in this State, especially during the autumn days, when their hues correspond so closely to the dead leaves which cover their haunts of the summer months. The green backed males are, however, the prevailing form of that sex at all seasons. The long winged form has not, as yet, been taken in Indiana. The wings of the other form are too short for flight, and it tries to escape when disturbed only by leaping clumsily.

When the late spring and early summer have been more than usually damp, hundreds of dead and dying specimens of this species and of Melanoplus bivitlatus Say, are often to be seen in late July in the tops of iron weeds. They are principally females, and their death is probably due to the insect fungus, Entomophthora calopteni Bessey;

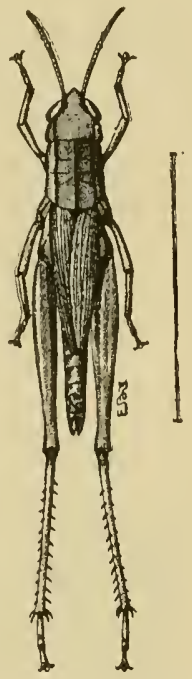

Fig.44. Dieromorpha viridis (Scudd.). Female, one and one-half times natural size.

(After Lugger.) an interesting account of which appeared in Bull. 22, U. S. Dept. Agr., 1890, 104. The disease is, perhaps, more abundant on account of the young being exposed to so much dampness in May and June. In two instances females of the Iubberly locust, Melanoplus differentialis Thos., have been discovered feeding upon the dead bodies of $D$. viridis, the abdomen and soft portions of thorax having been wholly devonred.

\section{Orphulehla Giglio-Tos. (1894).}

Vertex nearly horizontal, never extending in front of the eyes a distance greater than its own width. Merlian carina, if present, very faint. Lateral foreola usually present on side margins of vertex, but small and not visible from above. Antenn: filiform, sometimes depressed and acmminate. Pronotum with the median carina sharp; cut in or behind the middle; the lateral carinæ generally diverging both before and behind the middle, so that the center of disk is 
noticeably narrower than the front and hind margins. Lateral lobes of pronotum no longer than hroad, the front border decidedly oblique, and nearly straight; the hind border less oblique and more or less sinuate: the lower margin plainly angulate near the midrle. 'Tegmina and wings well developed, a little shorter or much longer tham the abdomen; the former very narrow, the intercalary vein wanting. Hind femora of medium size.

T'welve species are known from the United States. two of which have been taken in Indiana. 'These may be separated as follows:

KEY TO IXDIANA SIECHES OF ORPHULELLA.

a. Vertex of head rectangular in female; a little acute in the male. Foveola distinct, narrowly triangular. Lateral carine of pronotum strongly incurved, the distance between them at hind margin much greater than at front margin. Prozona and metazona about equal. Tegmina passing lind fenora..............30 pelidna, p. 240

a $a$. Vertex of head blunt, rounded, obtuse in female, rectangular in male; foreole indistinet. Lateral carince of pronotum less incurved, the distance between them at hind margin being but little greater than at front margin. Prozona longer than metazona. Tegmina rarely exceeding the abdomen..................... speciosa, p. 242

32. Orphulella pelidxa (Burmeister). The Smaller Spotted-winged Loeust.

Ciomplacernes pelichus Burm., 40, II, 1838, 650.

sitenoluthrus jelirlnus: Thom., 206, V, 1873, 95; Morse, 98, VII, 1894, 104.

()ipluala pelidina MeN., 89, VI, 1897, 234, 235; B1., 15, XXX, 1898, 54; Lugg., 84, 1898, 125, Fig. 72.

Oiphulella pelidna Seudd., 185, XXXI, 18!99, 179, 187; Id., 188, 1900, 24.

Simoluthrus meculipenmis Scudd., 141, VII, 1852, 458; Glor., 62, 1872, Plate V, Fig. 14; Thom., 206, V, 1873, 87; Id., 211 , IX, 1880, 88, 102, Figs. 12, 16; Riley, 122, II, 188t, 202, Fig. 282; Lint., 82, II, 1885, 196, Fig. 58; Feru., 53, 1888, 37, Fig. 14; Morse, 92, VI, 1893, 478, Figs. 3, 4; Bent., 3, VI, 1894, 293, Fig. 7, Plate VIII, Fig. 4.

(H) Mnlu muruligunis Morse, 98. VIr, 1896, 326, 408, Plate 7, Figs. 8, 8a.

Simuluthrus propimpnems Seudd , 141 VII, 1862, 461; Thom., 206, V, $1873,90$.

Vertex with the margin distinctly raised above the disk; the median carina absent; its central depression removed from the apex one-third to one-fourth the width of the vertex. Antenna but little depressed, slightly longer than head and pronotum, the middle joints three to four times as long as wide. Median carina of pronotum cut 
very near the middle by the principal sulcus. In the male the hind femora extend about $2 \mathrm{~mm}$. beyond the end of the abdomen, and are slightly exceeded by the tegmina. In the female, both hind femora and tegmina are about equal, and exceed the abdomen less than in the male. Other structural characters are given in the key.

Color: Head and disk of pronotum either brown or green. A broad reddish brown or black band behind the eye reaches back to hind margin of pronotum; this limited above by the lateral carinx of pronotum, which are whitish, but partially crossing the carinæ onto the posterior third of disk. Sides of pronotum below the band brownish. Tegmina either brown or green, with a median band of equidistant square black spots along their full length; in addition a few black spots below the median band. Abdomen reddish brown, the sides spotted with black. Hind femora brownish red, with traces of fuscous cross bars; hind tibix pale brown, annulate with whitish near the base.

Measurements: Length of body, male, $17 \mathrm{~mm}$., female, $21 \mathrm{~mm}$.; of antennæ, male and female, 7.5 $\mathrm{mm}$.; of tegmina, male, $16 \mathrm{~mm}$., female, $18 \mathrm{~mm}$.; of hind fenora, male, $10 \mathrm{~mm}$., female, $12 \mathrm{~mm}$.

Although this small spotted locust is said to occur in abundance in the United States east of the Rocky Mountains, I have met with it but once in Indiana during 15 years' collecting. This was July 27, 1897, when $I$ found it in abundance about the margins of a small lake in one of the valleys among the sand dunes near Millers, Lake County.

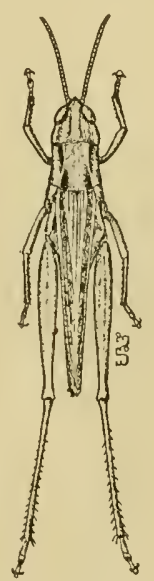

Fig.45. Orphulella pelidna (Burm.). Female, one and one-half times natural size. (After Lugger.)

It uses both the wings and legs in flight, and when close pressed often burrows into the fallen grass in an attempt to escape detection. Of 21 specimens taken, but three were females, and they were of the green variety. Five of the males were also partly green, the remainder being brown and fuscous. Morse states that in New England this species "begins to appear about the middle of July, being a week or two later than speciosa, and may be found during the remainder of the season. It is an active and alert species, leaping well and also flying freely and well, sometimes for two or three rods. It is found on the drier portions of the land adjoining salt marshes, on the more densely grassed portions of ground just inshore of the sandy beaches, and on sandy or loamy soil farther inland." It will probably be found to occur in insolated localities thronghout northeru Indiana. 
33. Orphulella speciosa (Scudder).

Stenobothrus speriosts Scudd., 141, VII, 1862, 458; Thom, 206, V, 1873,87 .

Oiphula sperinse McN., 89, VI, 1897, 235, 240, Plate 4, Fig. 17c; Jugg, 84, 1898, 126, Figs. 73, 74 .

Opphutella speriusa Scudd., 185, XXXI, 1899, 178, 183; Id., 188 , $1900,24$.

Stenobothms arpalis Scucld., 141 , VII, 1862, 459; Thom., 206, V, 1873, 89; Lint., 82, II, 188;, 196; Norse, 92, VI, 1893, 478, Figs. 5, 6; Bent., 3, VI, 1894, 294, Fig. 9.

Orphula xqualis Morse, 98, VII, 1896, 326, 409, Plate 7, Figs. 9, 9a; Bruu., 34, 1897, 128, Fig. 28.

Stenobothrus bilineatus Scurdd., 141 , VII, 1862, 460; Thom., 206, V, $1873,90$.

Stenobothrus gracilis Scudd., 147, 1872, 250; Thom., 206, V, 1873, 94.

Vertex broader and blunter than in pelitna; the margins scarcely raised above the disk; a faint median carina on its front half; the central depression close to apex. Antemia about as long as the head and pronotum, plainly flattened, the middle segments abont twice as long as broad. Median carina of pronotum cut a little behind the middle by the principal sulcus. Tegmina reaching tip of abdomen in the female and tip of hind femora in the male; often shorter.

Color: Either green or brown, much as in pelidna, but the median row of spots on tegmina smaller and fewer in number. and sometimes wanting. The dark bar behind the eye is more faint than in that species, and seldom crosses onto the basal third of pronotal disk. Hind femora greenish or brownish, not banded. Find tibire. dull brown or yellowish, without paler ring near their base.

Measurements: Length of body, male, 14 mm., female. $18 \mathrm{~mm}$.: of antennæ, male and female, $6 \mathrm{~mm}$. : of tegmina, male, $12 \mathrm{~mm}$, female, $13 \mathrm{~mm}$; of hind femora, male, $9 \mathrm{~mm}$., female $11 \mathrm{~mm}$.

This species is also known in Indiana only from Lake Comnty, a single pair having been taken July 21, 1902, from the side of a railway a mile southeast of Hammond. It is liable to be found anywhere in the State as its range is given as "Nova Scotia to Texas." In northern Mllinois MeNeill found it confined to the tops and sides of hills. Morse has written of it as reaching maturity in New England the first week in July, and being "one of the most plentiful and widespread of our locusts, but owing to its small size and non-migratory habits it does not attract the attention given to the larger and consequently more destructive spereics. While somewhat local, it is found nearly everywhere on dry. sandy or loamy soils. It moves chiefly by leaping, but readily takes wing on occasion, flying, however, but a few feet. Active and alert in the hot sunny weather of midsummer, 
it can best be secured by sweeping the net rapidly over the ground, a dozen or more specimens being the result of a few minutes' work."

\section{XXi. Chlealtis Harris (1841).}

Vertex triangular, the lateral carina but little elevated; the median earina more or less distinct; the foveolæ wholly wanting. Antenne long, those of male twice, and of female one and a half times the length of head and pronotum together; the joints of basal half strongly flattened. Pronotum with the three carinæ equally distinet, and eut much behind the middle by the principal suleus; the lateral carina more or less curved, especially in the female, so that the middle of disk is plainly narrowed. Lateral lobes of pronotum a little longer than high, the fore and hind margins straight and strongly and equally oblique, the lower margin with its posterior half nearly horizontal, its anterior half strongly ascending. Tegmina of female abortive (rarely fully developed), those of male well developed, the costal area being dilated and strongly reticulate. Hind femora of medium size; banded on the upper onter face. Ovipositor short, little exserted, the upper valves enlarged and strongly toothed at base. Two species represent the genus in the United States. Of these, one oecurs in Indiana.

34. Chlealtis conspersa Harris. The Sprinkled Locust.

Locusta (Chlocaltis) consperse Harr., 71, 1841, 149; Id., 72, 1862, 184. Chlocaltis consperse Smith, 198, I, 1868, 145; Glov., 62, 1872, Plate VI, Fig. 10, Plate X, Fig. 12; Scudd., 148 , I, 1874, 370, Figs., 55, 56; Id., 168, XXIII, 1893, 75, Figs. 50, 51; Id., 180, VIII, 1897, 99; Id., 188, 1900, 25; Thom., 211 , IX, 1880, 99; Fern.. 53, 1888, 36; McN., 88, VI, 1891, 65; Id., 89, VI, 1897, 228, Plate III, Figs. 14, 14a; Bl., 11 , XXVI, 1894, 222; Beut., 3, VI, 1894, 293, Plate VII, Fig. 9; Morse, 98, VII, 1896, 327, 419, Plate 7, Figs. 11, 11a; Lugg., 84, 1898, 121, Figs. 69, 70; Walk, $217, \mathrm{XXX}, 1898,124$.

Chrysochraon conspersum Thom., 206, V, 1873, 76; Coms., 41, 1888, 102, Fig. 92; Id., 42, 1895, 111, Fig. 122; Bl., 4, XXIII, 1891, 75.

Locusta (Chlecaltis) abortive Harr., 7 1, 1841, 149; Id., 72, 1862, 184. Stenobothru: melanoplen'u. Scudd., 14 1, VII, 1862, 456. (Male.)

Color of male usually light-brown above with always a broad shining black bar covering the entire-lateral lobe of pronotum; the tegmina without spots or with a few faint dusky ones; the hind tibiæ red or yellowish, the knees black. The female varies from dull elay yellow to dark brown. with the tegmina usually more or less sprinkled 
with small black spots, and with only traces of the dark bar on sides of pronotum.

Tegmina of female covering half of the abdomen, those of male reaching nearly to its tip; imner wings shorter. The ovipositor is
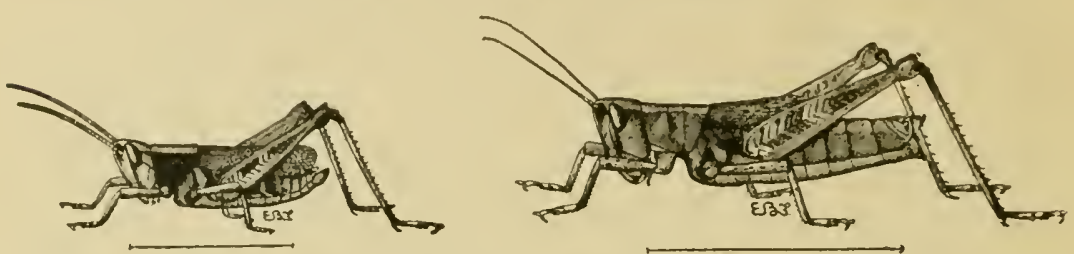

Fig. 46. Chlcraltis conspersa Harr, Male and female. One and one-half times natural size. (After Lugger.)

of peculiar structure, being fitted for boring in wood, its upper valves being short, broad and toothed like a saw on the posterior edge, while the lower ones bear a strong hooked tooth at the tip. For other structural characters see above under the genus heading.

Measurements: Length of body, male, $20 \mathrm{~mm}$., female, $24 \mathrm{~mm}$.; of antennie, male and female, $11.5 \mathrm{~mm}$; of tegmina, male, $11 \mathrm{~mm}$., female, $9 \mathrm{~mm}$; of hind femora, male, $13.5 \mathrm{~mm}$., female, $16 \mathrm{~mm}$.

This handsome wood brown locust oceurs throughout Indiana, but nowhere in numbers. It makes its home in thickets, in the borders of open woods, in grassy plots alongside old rail fences, and oftentimes along the borders of streams in woodland pastures, but is seldom seen in damp localities. In such places its hues correspond so closely with those of the dead leaves, fallen grass stems and other surroundings that it is scldom the insect is noted until it leaps clumsily to one side. Mature males have been taken in Vigo County on June 19th, an carly date for locusts which have hatched from the egg in spring. $\Lambda$ single female with tegmina reaching slightly beyond tip of abdomen is in my collection from Vigo County. The ordinary short winger female is apt to be confused with the brown females of Dicromorpha viridis, but can be readily distinguished by the presence of the median earina of vertex, and the curved lateral (arina of pronotum.

Interesting acenunts of the egrg-laying labits of the female of conspersa have been given by both Smith and Scudder. I have, on a mumber of occasions, noted the females with the aldomen inserted in soft or deenying wood, and on August 11, 1893, I diseovered a female in the art of boring a hole in the npper edge of the topmost board of a six-plank fence. The abdomen was curved downward, and the tonthed foreipate valves of the ovipositor used as pinehers with which small picees of the wood were broken off. When dis- 
covered, the abdomen was inserted nearly one-half an inch in the pine board, and the upper edge of the opening about the sides of the abdomen was covered with small pieces of wood, just as the dust or borings will accumulate about the edge of a hole which a carpenter is boring.

I stood by and watched her work for ten or more minutes, when she suddenly stopped, withdrew her ovipositor and hopped away. Along the fence, within a distance of 30 feet, I found 15 other holes, 11 of which were fresh, while the others had evidently been bored the previous year. Most of these holes were on the upper edge of the top board, which was in all cases of pine and perfectly sound. None of the holes contained eggs, most of them being less than half an inch in depth.

On July 21st, and September 21st, I have found them with the abdomen inserted full length in stumps or logs, and when removed, eggs were found in the lower horizontal portion of each cavity. On the former date the female was ovipositing after dark in an oak $\log$ which served as part of a bridge across a stream. Smith has suggested that the reason for so few holes being finished is, that the wood proves too hard, and the insect tries for a softer place, or, many of them may be disturbed during the process of oviposition. Scudder says that "the wood must be firm enough to retain the eggs well in place, and soft enough to absorb much moisture in the spring. Upright pieces of timber are never chosen, but ratlier short sticks of decaying, charred or pithy wood, which can not easily be broken or blown against the rocks. Holes are frequently made three-quarters of an inch deep, and abandoned because the spot proves unsuitable. In a stick about a foot and a half long, and two or three inches wide, I counted 75 borings, only three or four of which had been used as nests. The number of imperfect to perfect holes must be as 25 to one. When a good piece of wood is discovered, the nests are crowded thickly together; and a stick less than two inches in diameter and five inches in length contained 13 completed nests. The holes are pierced at a slight angle to the perpendicular, away from the insect; they are straight for about a quarter of an inch, then turn abruptly and run horizontally along the grain for about an inch. The eggs (from 10 to 14 in number) are almost always laid in the horizontal portion of the nest; they are cylindrical, tapering toward the ends, but not at all pointed, and measure from five to five and a half millimeters in length, by one and one-eighth in breadth; the ends are equally and regularly rounded. They vary in tint, some being almost colorless, and others of a faint yellow. After the eggs have been carefully packed away in the sawdust made by the abrasion of 
the sides of the hole, they are covered above with a whitish froth, and the hole is sealed up just below the surface of the wood with a black glutinous seeretion, excessively hard, smooth and shiny, and the upper surface slightly concave. In the spring the moisture doubtless softens these coverings so that the young grasshoppers can easily escape. Many old nests may be found uncovered and filled with the shells of the eggs, but none in which the cover is still retained."

\section{Stenobotinus Fischer (1843).}

Vertex triangular, obtuse in female, acute in male; the foveolæ visible from above, as narrow, oblong, or linear impressions; the median carina absent, or at most a colored line. Antennæ filiform; much longer than head and pronotum in the male. Pronotum with the median carina distinct, eut a little behind the middle by the principal sulcus; the lateral carine sinuate or curved, so that the middle of disk is narrower than the fore and hind margins. Lateral lobes of pronotum about as long as deep, the front margin straight, the hind and lower margins sinuate. Tegmina variable in length, usually fully developed in male. Wings a little shorter than tegmina. Hind femora rather slender; not transversely barred. Valves of ovipositor short, but plainly exserted.

This European genus formerly ineluded a number of United States species, Thomas having described no less than 16 species (a number of them synonymous) under it in his Acridide of North America. As at present limited, but two are listed from the United States. one of which occurs in Indiana.

35. Stenobothrus curtipennis (Harris). The Short-winged Brown Locust.

Locusta (Chlereltis) curlipemis Harr., 7 1, 1841, 49; Id., 72, 1862, 184, Plate III, Fig. 1; Rathv. 109, 1862, 386, Fig. 28.

Stemobrulums curtipemis Scudd., 141, VII, 1862, 456; Id., 142, II, 1868, 118; Id., 148, I, 1874, 372, Fig. 57; Id., 168, XXII, 1893, 76, Fig. 52; Id., 180, VIII, 1897, 99; Id., 186, XXXV, 1899, 50; Id., 188, 1900, 26; Smith, 198, I, 1868, 147; Glov., 62, 1872, Plate VI, Fig. 15; Plate VII, Fig. 10; Plate X, Fig. 4; Plate XII, Fig. 18; Thom., 206, V, 1873, 91 (in part), Id., 211 , IX, 1880, 104; Riley, 122, II. 1884, 202; Lint., 82, II, 1885, 196; Comst., 41, 1888, 102; Fern., 53, 1888, 37; McN., 88, VI, 1891, 65; Id., 89, VI, 1897, 260; Beut., 3, VI, 1894, 294; Morse, 98, VII, 1896, 327, 420 Plate 7, Fig. 12; Lugg., 84 , 1898,128 , Figs. $75,76$.

Chlealtis emertipemis Bl., 4, XXIII, 1891, 76; Ir., 11, XXVI, 1894, 222.

S'lenoluthrus longipemis Sculd., 141, VII, 1862, 457; Glov., 62, 1872, Plate V, lig. 15. 
Color exceedingly variable, but in Indiana specimens usually a light brown above, with a black bar extending back from the eye along the upper half of the lateral lobe of pronotum; beneath yellowish, the sides of abdomen spotted with black and the hind knees of the same color. Sometimes the face and lower sides of pronotum are gray, or even green. Antennæ brownish yellow at base, the apical halves brown or black.

The tegmina of curtipennis are, in most females, about threefourths the length of the abdomen, while in the males they usually reach to the tip of the abdomen; though they may be longer or shorter in either sex. The males are apt to be mistaken for those of Chlcaltis conspersa, but may be distinguished by the presence of the foveolæ, by the narrower black bar on sides of pronotum and by the smaller and more slender body.

Measurements: Length of body, male, $14.5 \mathrm{~mm}$., female, $21 \mathrm{~mm}$.; of antennæ, male, $9.5 \mathrm{~mm}$., female, $7.5 \mathrm{~mm}$.; of tegmina, male, 11 $\mathrm{mm}$., female, $10 \mathrm{~mm}$.; of hind femora, male, $11 \mathrm{~mm}$., female, $13 \mathrm{~mm}$.

This is a very common locust throughout northern Indiana, but as yet has not been taken south of Putnam and Vigo counties. It abides in low, wet prairies, swales, damp meadows, and especially in the vicinity of tamarack swamps. These conditions of local habitat are common in the northern half of the State, but scarce or wanting in the southern half, except in the extensive lowlands along the Wabash River in Knox and Gibson counties, but there the locust seems to be wanting. In Putnam County it occurs in blne-grass pastures along the banks of streams in open woodland. It begins to reach maturity about June 20th. By July 1st, it has become fairly common, and it may be taken until mid-October or even later, if the frosts are not too severe. The males seem everywhere less abundant than the females. The former is an active and noiseless flier, but the female, being usually shorter winged, endeavors to escape by leaping and tumbling, and, says McNeill, "its astonishing facility as a tumbler and contortionist generally discourages all but the most determined efforts for its capture." Scudder has given a description of the song habits of curtipennis as follows: "When about to stridulate, these insects place themselves in a nearly horizontal position, with the head a little elevated; they then raise both hind legs together, the hind tibiæ bent back snugly against the femora during the movement, and grate the thighs against the outer surface of the tegmina. The first one or two movements are frequently noiseless or faint. In sunny weather the notes are produced at the rate of about six a second, are continued from one and a half to two and a half seconds, 
and when undisturbed are repeated with intermissions of from five to six seconds. When the sky is overeast the movements are less rapid."

\section{Agennotertix MeNeill (1897).}

Vertex, somewhat declivent, the sides sharp and meeting in front almost at a right angle; the median carina wanting; lateral foveolæ rectangular or four sided, about twice as long as broad, very distinct. Face moderately oblique. Antenne filiform, longer than head and pronotum together. Pronotum with the median carina distinct, cut once behind the middle by the principal sulcus; the lateral carinæ indistinct; strongly sinuate or curved inward; the hind margin of disk broadly rounded. Lateral lobes of pronotum higher than long, their front and hind margins nearly straight and vertical, the lower margin with its front half inclined strongly upward. Tegmina and wings well developed, equaling the abdomen in the female, usually slightly surpassing its tip in the male. Ifind femora rather stout, surpassing the tip of abdomen in the male, equaling it in the female. Hind tibie with the spurs on the immer side at apex, much elongated and very unequal. Valves of ovipositor but little exserted, the tip only being visible. Two speeies are known from the United States, one of which has been taken in Indiana.

36. Ageneotettix scudderi (Bruner).

Aulocare scudderi Brun., 24, XII, 1890, 63; Bl., 11 , XXVI, 1894, 217. Eremnus scud́deri McN., 89, VI, 1897, 268; Lugg., 84, 1898, 132, Fig. 77.

Ageneotettix scudderi Scudd., 188, 1900, 28.

Plitobostroma parre McN., 88, VI, 1891, 64.

General color, dull brown, the tegmina with numerous small darker brown. quadrate spots, sonetimes almost confined to a median band.

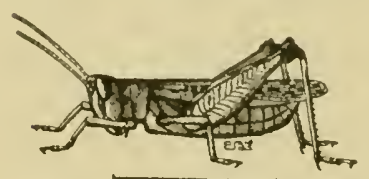

Fig. 47. Agenentellix scudderi (Bruner). Ma!e. (After Lugger.)
In most specimens a dull yellowish band reaches from the vertex backward across the middle of occiput and pronotum to the tips of the tegmina. An indistinct. blackish bar extends from eye back across the upper half of lateral lobes of pronotum; and a triangular spot of black on each side of basal third of pronotal disk, plainest in the male. Hind femora dull reddish brown with three blackish crossbars on the upper outer face. Hind tihia bright coral red, with a whitish basal ring; the knees deep black. Antenna dull reddish, sometimes lighter. Lower surface, dirty yellowish white. 
Measurements: Length of body, male, $15 \mathrm{~mm}$., female, $20 \mathrm{~mm}$.; of antennæ, male $10 \mathrm{~mm}$., female, $7.5 \mathrm{~mm}$.; of tegmina, male, $9 \mathrm{~mm}$., female, $13 \mathrm{~mm}$.; of hind femora, male, $10.5 \mathrm{~mm}$., female, $11.5 \mathrm{~mm}$.

This small dull colored locust has been taken in Indiana only from the sandy bed of the old Wabash and Erie Canal, five miles north of Terre Haute, Vigo County. Here it was first taken on July 6, 1892, and afterward in September and October, 1893. On one side of the canal, at the point mentioned, is a large pond, ocenpying perhaps 50 acres of the Wabash River bottoms, and on the other side is a sandy hill or bluff of the river, which is covered with typical prairie grasses and plants. The locust has been found only in an area of about five acres, on the side of the hill, and in the bed of the canal. When disturbed it leaps vigorously, and without noise, for several times in succession; then settling down on a sandy spot, it will allow a close approach, evidently relying upon the similarity of color between its body and the sand to shicld it from observation. Aceording to Bruner, loc. cil., it is a very common species west of the Mississippi; but east of that stream has been taken only at Moline and Cordova, Illinois; and in Vigo County, this State. It will probably be found to oceur over the sand-covered portions of southwestern Indiana.

\section{Mecostetuus Fieber (1853).}

Vertex horizontal; the lateral carina distinct, straight, the apex truncate or slightly rounded; median carina distinct; lateral foveolæ small, shallow, triangular. Antennæ filiform, longer in the male than the head and pronotum together. Pronotum with all the carinæ distinct, the median rather sharp, and cut in front of the middle by the principal sulcus; the lateral (in our species) with their posterior halves distinctly divergent; the disk rugose, the metazona longer than the prozona; the hind margin of the former obtusely angled. Lateral lobes of pronotum about as high as long. their front margins perpendicular, the hind ones a little oblique, the lower margin with its front half obliche. 'Tegmina and wings well developed, surpassing the abdomen in both sexes, the discoidal area furnished with a very prominent intercalary vein, which in the male is provided with a rasp for stridulating. IIind femora, rather long and slender, exceeding the abdomen in the male. The sub-anal plate of male is acutely produced, being at least twice as long as its greatest depth. Valves of ovipositor strongly exserted, the upper pair, with minute teeth along their upper margins. 
'Three species are known from the United States, one of which oceurs in Indiana.

37. Mecostethus lineates (Scudder).

Aryptera lineatu Scudd., 14 1, VII, 1862, 462; Id., 142, II, 1868, 118 (song of); Id., 143, XI, 1868, 313 (note of, set to music); Smitl, 119, 1872, 381; McN., 88, VI, 1891, 66.

stetheophyma lineata Thom., 206, V, 1873, 98; Id., 211, 1880, 104; Glov., 62, 1874, Plate XVIII, Fig. 9; Fern., 53, 1888, 38.

Mecostethus lineatus Morse, 98, VII, 1896, 327, 4t4, Figs. 13-13b; McN., 89, 1897, 254, Figs. 22a, 22b; Bl., 15, XXX, 1598, 55; Scndd., $188,1900,29$.

General color, dark brown. A narrow yellowish line extends from the upper border of the eye to the pronotum, bordered below by an indistinct dark band which extends along the upper half of lateral

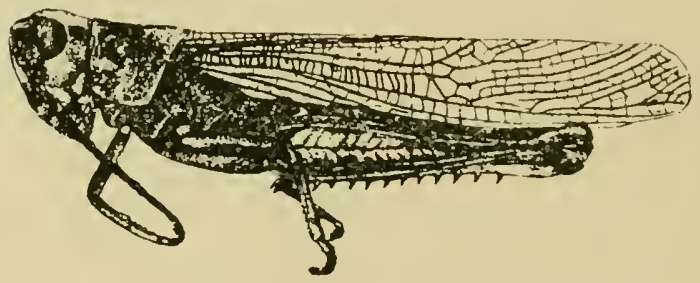

Fig.48. Mecostethus lineatus (Scudd.). (After MeNeill.)

lobes of the pronotum. The tegmina with a distinet pale or yellowish streak two-thirds their length, along the scapular area. Hind femora with the outer face yellowish or reddish brown, darker above, the lower face either yellowish or bright coral red, the knees black. Hind tibiæ yellowish, annulate with paler near their base, the spines black. The females usnally much darker than the males with the yellow line on head and tegmina often obseure. The structural characters are given above under the genus heading.

Measurements: Length of borly, male, $26 \mathrm{~mm}$., female, $35 \mathrm{~mm}$; of antennæ, male, $11.5 \mathrm{~mm}$., female, $10.5 \mathrm{~mm}$; of tegmina, male, 25 mm., female, $30 \mathrm{~mm}$.; of hind femora, male, $1 \% \mathrm{~mm}$., female, $20 \mathrm{~mm}$.

'This large and handsome locust oeems in isolated areas in the nortlern third of the State, having been taken in Fulton, Lake, Starke, Marshall, Kosciusko and Steuben counties. It is fonind only in low boger meadows bordering lakes or tamarack swamps. The males seem to far outnumber the females, and are much more wild and active, taking to flight when a person is a dozen yards distant. They use the wings only in escaping, flying swiftly and noiselessly for 50 to 100 fect and alighting on the stems of the tall grasses and 
sedges among which they have their homes. The only way in which I have been able to effect their capture was by running after them and swooping them with the net as they arose or before they had time to arrange their legs for the upward impetus at the beginning of a new flight. The females are more bulky and lubberly than the males, and are usually seen in more open places, where the grass is shorter, and hence are more easily taken. The earliest date at which mature specimens have been seen was July 13th, in Fulton County, and the latest, October 25th, near Bass Lake, Starke County, though they may occur both before and after these dates. In the United States lineatus has been recorded only from Maine, Massachusetts, Connecticut, northern Illinois and eastern Nebraska.

\section{Sub-family CEDIPODINA.}

This sub-family includes those genera of Indiana locusts which have the prosternum unarmed with tubercle or spine, the face nearly vertical, instead of oblique, and the head rounded at the point of union with the vertex and face. The fastigium or front of vertex slopes sharply downward; the foveolæ are present but are usually small and shallow. The antennæ are linear or sub-linear and are usually inserted above the middle of the eyes, sometimes almost above the eyes themselves. The eyes are shorter than in the sub-family Tryxalina, being rarely longer than that portion of the cheeks below their orbits. The dorsal field of the pronotum has its hind margin much wider than the front margin; the lateral carinæ usually wanting; the median carina (except in the genus Arphia) cut by one or two sulci, and often raised in a sharp ridge or crest, and the surface generally wrinkled or covered with small tubercles. The tegmina and wings are always fully developed and the latter, in most species, are brightly colored. All of our genera belong to the division or tribe Edipodini of Saussure, in which the ocelli are placed near the eyes and in which the outer margin of hind tibiæ lacks an apical spine next the spurs.

Our members of this sub-family are, when at rest with the tegmina closed, dull brown or grayish in color, and hence dwell, for the most part on bare clayey slopes, or stretches of sand; along roadsides and railways, or in closely cropped timothy meadows. Twelve of our 16 species have the inner wings black, yellow or red and hence are very conspicuous objects when in flight, being often taken for butterflies by persons who have given little attention to nature. These bright colors, are, says Morse, "in no sense protective and bear no 
relation to the environment of the insects, but are probably of value in the mating of the sexes." The color of the inner wings often varies much in the same species, shading from dull white, through yellow and orange to vermilion red. 'The greater intensity of color is in part due to age, and perhaps in part to higher temperature, though other factors doubtless enter into its cause.

The members of this sub-family are peculiar in that the males of most of them and the females of a few stridulate while on the wing; a rather harsh, crackling or rattling note being produced by rubbing the under surface of the tegmina against certain veins on the upper surface of the inner wings. The sound seems to be under control of the insect, for they often make it when suddenly alarmed, or cease making it if too greatly frightened. Some of them produce a uniform rattling note during the entire period of flight, which is generally in a straight course. Others make the call only during certain intervals of flight. These change the direction of flight at will, and at every turn emit two or three short, rattling sounds. A number of species also sound a different call when at rest, in the same manner as do the Tryxalince, by rubbing the hind femora against the intercalary vein of the tegmina, which is toothed or roughened to aid as a sounding organ.

This sub-family is also notable among our Indiana Acrididæ by having three or four species which pass the winter as nymphs or half grown young. These nymphs reach maturity about mid-April and are the first Acridians of large size to be scen in the spring. The majority of our species, however, pass the winter, as do most other locusts, in the egg stage.

T'wenty-six genera and 1.54 species were listed by Scndder in his "Catalogue," and about 10 species have since been described. Of these, ten genera and sixteen species have been taken in Indiana. These genera may be separated by the following table in which, however, I have made use of many characters not of generic importance, in order that the beginner may the more readily determine the specimous in hand.

KEY TO GFNLRA OF INDIANA GEDPODINE.

1. Modian ririna of pronotum raised in a distinct crest, which is entire, or not ('ut by the principal suleus; tegmina sul-coriaceous, or leath(ry, in texture, densely and irregularly reticulate; inner wings briglitly colorel, red or yellow at base....... X. V. Anrmia, p. 254

ar. Median cariun of pronotum less prominent and in female always cut by one or more sulci; tegmina with the apical half membranaceous and regularly reticulate. 
b. Median carina of pronotum cut by but one sulcus.

c. Disk of inner wings pellucid or transparent, not distinctly bounded by a blackish border.

d. Promotum with its disk roof shaped, the sides sloping downward; its dorsal frout margin plainly angulate. Hind femora without dark cross bar's...... XXVI. Chortophaga, p. $25 \bar{T}$

dd. Pronotum with its disk flat; its dorsal front margin truncate. Hind temora with dusky cross bars on their outer face.

c. Frontal costa of male strongly sulcate throughout their full length; median carina of pronotum distinct, higher on prozoua than on metazona, distinctly cut by the principal sulcus........... XXVit. Encortolophus, p. 260

ee. Frontal costa of male but slightly sulcate just below the ocellus; median cariua of pronotum low, of equal height throughout, faintly cut by principal sulcus....XXVIII. Cannula, p. 261

cc. Disk of inner wings opaque, red, or'ange, black or yellow' in color; when not black, distiuctly bounded with a blackish border.

$f$. Body, especially that of female, robust. Pronotum with the lateral carinæe extending in front of the principal sulcus and not cut by that sulcus; its disk often with numerous tubercles; inner wings red or yellow; tegmina usually with a number of large dark colored spots......

XXIX. Hippiscus, p. 263

ff. Body more slender, often compressed. Pronotum with the lateral carina extendiug only to the principal sulcus and cut by it; its disk with but few if any tubercles; inner wings black or pale yellow; tegmina with numerous small dark spots which are sometimes united into cross bars.

g. Inner wings black with a yellow border...... Xxx. Dissosteira, p. 272

gg. Iuner wings yellow, with a fuscous curved median band.............

XXXi. Spharagemon, p. 275

b). Median carina of pronotum ent by two sulci, the front notch

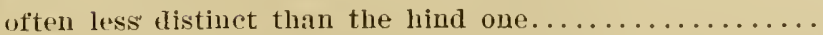

h. Antenne of male shorter than hind femora, the basal joints not strongly flattened. Frontal costa at all points above the ocelhs, wider than the basal joints of antenna. 
i. Lower margin of lateral lobe of pronotum straight, its front half not curved upward. Median carina of pronotum about as high on metazonil as on pro\%ona; its hind notch but little in front of the middle of pronotum.....XXXil. Mestobregua, p. 279

ii. Lower margin of lateral lobe of pronotum with its front half curved upward. Median carina of pronotum very faint on metazona; its hind noteh much in front of the middle, the metazona at least one and a half times as long as the prozona........

XXXiI. Trimerotropis, p. 280

hh. Antennae of male longer than hind femora, the basal joints strongly flattened. Frontal costa at its widest point above the ocellus narrower, and at the vertex much narrower, than the basal joints of antennie............

XXXIV. Psinidia, p. 283

\section{Arphia Stal (18\%3).}

Vertex horizontal, either sub-pentagonal or triangular, its disk with a distinct, nsually deep, transverse curved impression a little behind the middle; lateral carina distinct; the median carina present, but terminating at the impression; the foveolæ present, rather large, but shallow and more or less rhomboidal. Frontal costa rather broad, strongly sulcate in the region of and below the ocellus. Antenne about as long as head and pronotum together. Pronotum with its front margin bluntly angulate, produced forward upon the posterior third of occiput; the median carina compressed, and higher than usual, not notched by the transverse sulcus; the lateral carina rounded, distinct only on the metazona. Lateral lobe of pronotum deeper than long, the front margin a little sinuate, the hind margin more or less oblique, the lower margin with its front half curved upward, the posterior angle rather broadly rounded. Tegmina somewhat leathery in texture, densely and irregularly reticulate, the apical third only with the cells, or spaces between the venules, distinct; the intercalary vein eloser to the median than to the ulnar vein. Inner wings brightly colored, yellow or red at base. Hind femora stout, their basal halves depressed and dilated. Ovipositor with its valves moderately cxserted; the upper ones with their apical halves a little inturned and narrowly spoon-shaped.

Sixteen specics are accredited by Scudder to the United States. Of these but two have, as yet, been taken in Indiana. These may be separated by the following: 
KEY TO INDIANA SPECIES OF ARPHIA.

a. Upper third of frontal costa with the sides converging, meeting at the point of union with the front of vertex; median carina of pronotum lower and less curved; hind margin of pronotum ending in a right angle, or obtuse angle.................... silphurea, p. 255

aa. Upper third of frontal costa with the sides scarcely converging; distinct at the point of meeting with the front of vertex; median carina of pronotum, viewed from the side, high and arched, crestlike; hind margin of pronotum ending in an acute angle.........

39 xanthoptera, p. 256

38. Arphia sulphurea (Fabricius). The Sulphur-winged Locust.

Gryllus sulphureus Fab., 5 1, I, 1781, 369.

Locuste sulphurea Harr., 70, 1833, 583; Id., 72, 1862, 177, Plate I, Fig. 6; Emm., 49, V, 1854, 146; Ratliv., 109, 1862, 386, Fig. 27.

Edipoda sulphwea Burm., 40, II, 1838, 643; Scudd., 141 , VII, 1862, 470; Glov., 62, 1872, Plate V, Fig. 6.

Tomonotus sulpluereus Thom., 206, V, 1873, 105; Id., 211 , IX, 1880, $89,107$.

Arphia sulphurea Stal., 200, I, 1873, 119; Sauss., 134, 1884, 71; Ferm., 53, 1888, 39; Bl., 4, XXIII, 1891, 77; Beut., 3, VI, 1894, 296, Plate VIII, Fig. 10; Morse, 9 9, VIII, 1897, 36, 51, Plate 2, Fig. 17; Lugg., 84, 1898, 136, Figs. 78, 79; Scudd., 188, 1900,30 .

Color, varying from dark brown, almost blackish in some males, to pale yellowish brown. The tegmina of males often with a pale yellowish band along the dorsal or hind margin; those of the lighter colored females often thickly sprinkled with small fuscous spots. Inner wings with their basal two-thirds a bright sulphur yellow. A dusky curved band covers the outer third; from which a distinct dark ray runs nearly to the base of the wing, near the front or costal margin. Hind femora with the outer face either uniform dark brown with a pale ring near the knee, or with alternating bands of black and white, which are more plainly visible on the inner face. Hind tibiæ dusky black, or blue black, with a pale ring near the base. Abdomen reddish brown or yellowish. Many of the young and a few of the adults which appear in spring, or those. which live on high, rocky woodland slopes where lichens are abundant, often have the pronotum and hind femora prettily marked or spotted with grayish and greenish in imitation of those lowly plants.

Neasurements: Length of body, male $22 \mathrm{~mm}$., female $32 \mathrm{~mm}$.; of antennæ, male and female, $\gamma \mathrm{mm}$. ; of tegmina, male $23 \mathrm{~mm}$., female $26 \mathrm{~mm}$; of hind femora, male $14.5 \mathrm{~mm}$; female, $18 \mathrm{~mm}$. 
The yellow winged locust is a common inseet throughout Indiana, making its home in dry upland pastures and meadows, along roadsides and on gravelly and rocky slopes. It passes the winter in the nymph stage sheltered beneath logs, chunks and rubbish and begins to reach maturity in central Indiana about May 1st (May $3 \mathrm{~d}$ being the earliest date it has come to my notice). being preceded only by Chortophaga viridifasciata. It is most abundant in June, and about July 15th begins to be replaced by its congener, A. xanthoptera. However, examples have been taken in Marion County as late as September 10th. The male, when disturbed, moves in short, jerky flights, sounding its cymbals while in the air, at every turn. The sound is a sharp crackling note, and is seemingly under the control of the insect.

39. Arphia xanthoptera (Germar.)

(Erlipoda ranthopter Germ., 58, II, 1838, 643; Scudd., 14 1, TII, 1862, 469 ; Smith, 199, 1872, 372, 381, Fig. 10.

Tomonotus xunthoptemis Thom., 206, V, 1873, 10\%.

Tommetus sutphurens monthopterus Thom., 211 , IX, 1880, 107.

17phim muthoptere Sauss., 134, 1884, 67; Fern., 53, 1888, 39; B1., 4, XXIII, 1891, 7т; Beut., 3, VI, 1894, 297, Plate VIII, Fig. 11; Morse, 99, VIII, 1897, 36, 50, Plate 2, Figs. 16, 16a; Lugg., 84, 1898,138 , Fig. 80 ; Scudd., 188, 1900, 31.

Arphia amthoptera carinata Bl., 4, XXIII, 1891, 78 (not A. corinata Scudd.)

('olor varying from a very dark to a bright reddish brown, the head and pronotum usually lighter than the tegmina; the latter in the female often sprinkled with numerous darker brown spots. Inner wings with the basal two-thirds either deep yellow or orange red, the

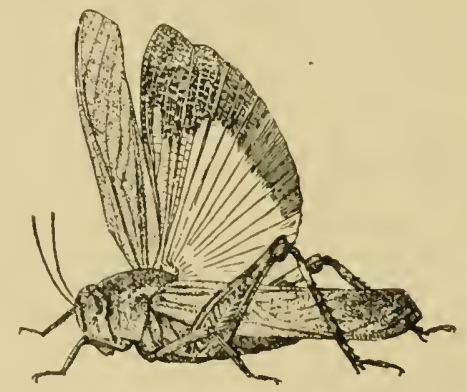

Hig. 49. Arphin xanthoplera (Germar). Malo. Natural Size. (After Beutenmïller).

onter third with the curved fuscous har as in sulphurea, but the dark ray near costal margin not much longer than the width of the fuscous band, and always extending less than one-half the distance to base of wing. Hind femora dull grayish brown, the upper outer face with 
two or three oblique blackish bars; a pale ring near the knee. Hind tibiæ dusky, the spines black.

This species differs from sulphurea by having the disk of the vertex truncate in front, its lateral carina not meeting, but continuous with the frontal costa; the latter with the sides not converging to an acuminate apex. 'The median carina of pronotnm is higher and more distinctly arched and the posterior margin of pronotum is more acute. It is usually larger than sulphurea.

Measurements: Length of body, male $2 \% \mathrm{nmm}$., female $34 \mathrm{~mm}$. ; of antennæ, male and female, 10.5; of tegmina, male, $26 \mathrm{~mm}$., female, $30 \mathrm{~mm}$.; of hind femora, male, $18 \mathrm{~mm}$., female, $19 \mathrm{~mm}$.

This is also a common locust throughout Indiana, beginning to reach maturity in the central part of the State, from eggs hatched in the spring, about July 20th, and existing until November 1st, or later. It frequents the stubble of wheat, clover and timothy fields, the banks along railways and the borders of high, dry, open woodlands and roadsides. One-third or more of the males have the inner wings a deep orange yelluw, but not more than one-sixth of the females have the wings so colored. The orange winged males are usually darker in color, and their stridulation is seemingly louder and more prolonged than in the yellow winged forms. The sound is made as the insect rises from the gromnd, and at times at the points of turning in its zigzag flight. Tanthoptera is a stronger and more active flier than sulphurea and its note is londer and readily distinguished from that of the latter.

\section{Chortophaga. Saussure (1884).}

Body rather slim, compressed, punctate or fine wrinkled, green or brown in color. Vertex horizontal, triangular; the apex truncate; the lateral carinæ not prominent, the median carina wanting; the foveolæ very shallow, elongate, triangular. Frontal costa prominent, rather narrow, punctate, sulcate below the ocellus, the margins of upper fourth slightly converging to meet those of the vertex. Antennæ no longer than head and pronotum together, the joints short and somewhat flattened. Pronotum with its disk roof shaped, its front margin bluntly angulate, projected slightly forward on the occiput, the hind margin acute angled; the median carina not prominent, straight and but faintly notched a little before the middle by the principal sulcus; the lateral carinæ visible only on the metazona, rounded and indistinct in the female, plainly visible in the male. Lateral lobes of the pronotum as in Arphia, the posterior angle less 
rounded. Tegmina narrow, extending beyond the abdomen; the apical half membranaceous, the intercalary vein running midway between the median and ulnar veins. Inner wings pellucid, the veins but shightly swollen. Hind femora of medium size, surpassing the abdomen in the male, a little shorter in the female. Ovipositor as in Arphia.

'Two specics of the genus occur in the United States, one of which inhabits Indiana.

40. Choltopiana viRmfasciata (DeGeer). The Green-striped Loenst. Irrydium viridifusciutum DeG., 57, III, 1773, 498, Plate 42, Fig. 6.

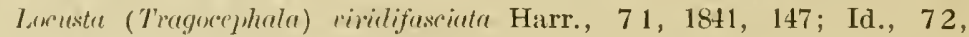
1862, 182, Plate III, Fig. 2.

Tragerephater viridifasciute Sendd., 141, VII, 1862, 461; Id., 150 , XVII, 1875, 481; Id., 153, IV, 1875, 80; Glov., 62, 1872, Plate V, Fig. 9; Thom., 206, V, 1873, 103, Plate I, Fig. 3; Id., 211 , IX, 1880, 105, Figs. 13, 17; Stal., 200, I, 1873, 119; Riley, 117, VIII, 1876, 149, Fig. 46; Id., 214 , I, 1878, 255, Fig. 94; Iri., 122, II, 1884, 203, Fig. 285.

Churtophaga rividifusciate Sanss., 134, 1884, 72, Plate I, Figs. 7, 12; Fern., 53, 1888, 40, Fig. 15; Bl., 4, XXIII, 1891, 76; McN., 88, VI, 1891, 62; Beut., 3, VI, 1894, 295, Plate VIII, Fig. 9; Morse, VII, 99, 1897, 35, 64, Plate 2, Fig. 18; Lugg., 84, 1898, 144, 147, Figs. 83-85; Scudd., 188, 1900, 31.

Locusta (Tiagorephala) infusente Harr., 72, 1862, 181.

Tragorephala infusecta Scudd., 14 1, VII, 1862, 461; Glov., 62, 1872,

Plate X, Fig. 10; Thom., 206, V, 1873, 102, Plate I, Fig. 7.

Tragorephala viridifasciata infuscale Scudd., 150, XVUI, 1875, 481;

Thom., 211, IX, 1880, 106.

(Thortophaga viridifasciata infuscata Bl.. 4, XXIII, 1891, 76.

Locusta (Tragorephalu) valiata Harr., 72, 1862, 183.

Tomonotus zimmermanni Sanss., 128, II, 1861, 23.

Color dimorphic, either largely green with a small amount of brown upon the tegmina (viridifasciata) or wholly brown (infuscata). Specimens are common, however, which can be referred to either

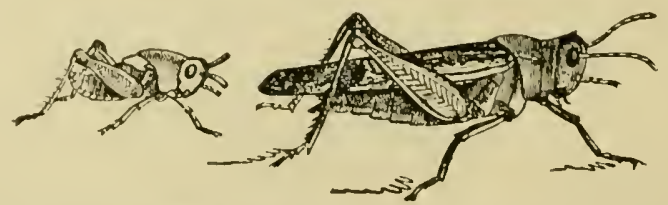

Fig. 50. Chortophaga viridifarciata (DeGeer). Nymph and adult female. (After Riley).

form, the color being a mixture. In the more promounced green examples, the head, pronotum, outer face of hind femora and the basal two thirds of the median field of the tegmina are grass green; the 
upper dorsal field, and apical third of tegmina, as well as a narrow stripe along their lower or costal margin are ash brown; the abdomen reddish brown. Rarely the head, pronotum and hind femora are reddish purple instead of green. In the brown form the apical halves of the tegmina are darker and their sides often contain a few light spots. The inner wings of both forms are transparent and yellow at base, the apical two-thirds fuliginous or smoky, the apex paler; an opaque dark bar is present along the middle of front margin. Hind tibiæ brown or pale blne with a white ring near the base.

Measurements: Length of body, male, $20 \mathrm{~mm}$. female, $26 \mathrm{~mm}$.; of antennæ, male, $8 \mathrm{~mm}$., female, $r \mathrm{~mm}$.; of tegmina, male, $18.5 \mathrm{~mm}$., fenale, $23 \mathrm{~mm}$.; of hind femora, male, $13 \mathrm{~mm}$., female, $15 \mathrm{~mm}$.

This is the first locust to reach maturity in spring from hibernating nymphs, specimens having been taken in Vigo County as early as April 15th. It is a common species throughout the State, making its home in blue-grass pastures, and especially in the grassy tracts along rail fences between upland woods and cultivated fields and meadows. It also occurs on sunny sloping hillsides and railway embankments. In fact, mature individuals may occur anywhere in dry grassy places from mid-April till November 1st. In such localities the young, in company with those of Arphia sulphurea, may be seen on all sunny winter days when the mercury is above the freezing point. At such times they often climb or leap upon the lower rails of fences or sides of stumps, there resting in and apparently enjoying the sunshine. The species is said to be double brooded in some localities, but in Indiana, as far as known, it is single brooded, the young hatehing in August and September and undergoing three or four moults before winter.

In this State, as elsewhere throughout its range, which includes the United States and Canada east of the Rocky Mountains, green females and brown males are the predominating forms, not more than 20 per cent. of the females in Indiana being brown, and a much smaller proportion of the males being green. The male of viridifasciata, when disturbed, usually flies but a few rods, moving in a circling or zigzag course, and producing a low but distinct shuffling or rattling noise during the whole of its flight. The female moves noiselessly and more directly to a greater distance. 


\section{XXYll. Lincoptolopus Scudder (1875).}

Body a litfle shorter and stomter than in Chorlophaga, but compresied as there: 1he head more swollen. Vertex broadly triangular, the apical half sloping a litule downward, the disk noticeably lower than the occiput, the lateral carinx low; the median present but terminating at middle of disk; the foveolae distinct, elongate triangular. Frontal costa narrow, strongly sulcate throughout in the male, but only above ocellus in the female. Antemne equaling the head and pronotum together in the female, a third longer in the male; the joints of apical half moderately flattened. Pronotum with its disk nearly flat, the front margin truncate, the hind margin forming a rather sharply marked right angle; the median carina distinet, a little higher on the prozona. cnt into two nearly equal halves, by a distinet notch: the lateral carina plainly visible only on the metazona. Tateral lobes of pronotum deeper than long, their disks concave and much wrinkled, their front and hind margins nearly vertical, the lower margin with its posterior half rounded, the anterior oblique, ascending. 'Tegmina rather broad and short, the apex broadly rounded, slightly surpassing the abdomen in both sexes; the intercalary vein distinctly nearer the ulnar than the median vein. Inner wings short and broad, poilneid or nearly so, the veins next the costal margin distinctly swollen. Hind femora a little shorter than the abromen in the female; slightly surpassing it in the male.

Fonr species of Encoplotophus are known from the United States. of these, one occurs in Indiana.

41. Excoptolophus somines (Burmeister'. The Clonded Loenst.

Edipodu sondidlı Burm., 40, II, 1838, 643; Glov., 62, 1872, Plate X, Fig. 11; Thom., 206, V, 1873, 116; Pack., 2 15, II, 1880, 179, Plate I, Fig. 4.

Trayorephula somlirlu Stal, 200, I, 1873, 119; Thom., 211 , IX, 1880, 107.

Encoptolophus sorlichus Scudd., 150, XVII, 1875, 479; Id., 153, IV, 187i, 78; Id., 188, 1900, 32; Sauss., 134, 1884, 77; Comst., 4 1, 18s8, 103, Fig. 93; Id., 42, 1895, 110, Fig. 121 ; Fern., 53, 1888, 41, Fig. 16; Bl., 4, XXIII, 1891, 77; Bent., 3, VI, 1894, 296, Plate X, Fig. 2; Morse, 99, VIII, 1897, 35, 66, Plate 2, Fig. 19; Lugg., 84, 1898, 147, Fig. S6.

Locusta milulosc Harr., 71, 1841, 146; Id., 72, 1862, 181; Emm., 49, $\mathrm{V}, 1854,146$, Plate 9, Fig. 7.

Color, dull rnsty, yellowish or smoky brown, varied with small mottlings of the darker and lighter shades. Pronotum in living specimens often with a distinct pinkish buff $\mathrm{X}$-shaped mark on its 
disk. Antenne pale brown at base, the apical half darker. 'Tegmina with two pale transverse bars on the middle of sides, which contrast plainly with the larger dark patches between and on either side of them. Inner wings transparent yellowish at base: the apical half smoky brown, the apex darker. Hind femora indistinctly banded with dull yellowish and dark brown. Hind tibia dusky brown with a pale ring near the base.

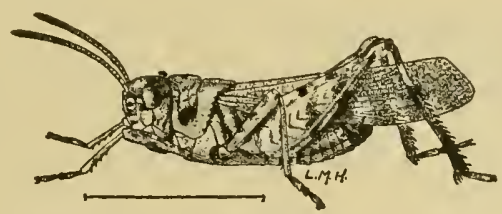

Fig. 51. Encoptolophus sordidus (Burm.). Male. (After Lugger.)

Measurements: Length of body, male, $22 \mathrm{~mm}$., female, $29 \mathrm{~mm}$.; of antennæ, male, $10 \mathrm{~mm}$., female, $9 \mathrm{~mm}$.; of tegmina, male, $19 \mathrm{~mm}$., female, $24 \mathrm{~mm}$.; of hind femora, male, $13.5 \mathrm{~mm}$., female, $16 \mathrm{~mm}$.

The clouded locust is common thronghout the State, maturing in the central portion about August 1st, from eggs liatehed in the spring, and existing till December 1st, provided the antumn is a favorable one. It frequents only dry upland timothy and clover meadows, blue-grass pastures, roadsides, etc. When living in woorlland pastures it frequents the sumy spots, seldom alighting in the shade when flushed. The male stridulates on the wing during short flights, seldom, if ever, in the more prolonged ones, which it makes when frightened. The note is a harsh droning or buzzing sound, somewhat resembling that of a bumblebee, but louler. It is begun after the insect has risen three or four feet above the ground, and is continued until it begins to deseend, being kept up continuously while it is flying horizontally. The females usually leap for the first two or three times they are disturbed, but if flushed a number of times they use the wings in endeavoring to escape.

\section{XXYiII. Cannula Stal (1873).}

Body short, the size below the average for the Oedipodina, the head compressed. Vertex with its disk ovate-oblong in male, broader in female, its front half sloping downward, the apex rounded, the lateral carinæ distinct, the median carina very faint in the female, absent in the male: the fovenle indistinct, narrowly triangular. Frontal costa, not prominent, flat or nearly so, a little sulcate just below the ocellus. Antennæ short, filiform. Pronotum with its disk 
flat, not rugose, the front margin truncate, the hind margin obtuse angled, the median earina low, of equal height throughout, cut with a small noteh a little in front of the middle; the lateral earinæ distinet on both prozona and metazona. Iateral lobes of pronotum, deeper than long, the front margin nearly vertical, the hind margin oblique, the lower margin as in Encoptolophus. Tegmina narrow, surpassing the abdomen; the apical third remotely reticulate, the cells quadrate. Inner wings pellucid with dusky venules. Hind femora equaling or slightly exeeeding the abdomen; their upper margin sharp and somewhat crested. Valves of ovipositor strongly exserted. One species is found throughont the morthernmost United States and Canada from the Atlantie to the Pacific. It oeeurs rarely in northern Indiana.

42. Camputa pelltcida (Scadder). The Clear-winged Locust.

Edijoda pellurida Scudd., 141 , VII, 1862, 472; Glov., 60, 1870, 78; Id., 62, 1872, Plate XII, Fig. 20; Thom., 206, V, 1873, 137. crmmula pellucida Scudd., 148, I, 1874, 378; Id., 188, 1900, 32; Thom., 211 , IX, 1880, 118; Id., 215 , II, 1880, 242, Fig. 10; Riley, 127, XXV, 1891, 32, Fig. 10; Sauss., 134, 1884, 81; Fern, 53, 1888, 41, Fig. 17; Brun., 26, XXVII, 1892, 12; Id., 28, XXVIII, 1893, 34, Fig. 18; Ir., 30, 1893, 463, Fig. 107; Id., 34, 1896, 123, Figs. 25, 26; Morse, V'III, 99, 1897, 35, 80, Plate 2, Fig. 20; Lugg., 84, 1898, 148, Figs. 87, 88.

Edijmela atror Scudd., 147, 1872, 253; Glov., 60, 1871, 77, Fig. 10; Id., 62, 1872, Plate VIII, Fig. 3; Id., 63, 1874, 137, Fig. 10; Thom., 206, T, 1873, 136; Riley, 2 14, I, 1878, 454, Fig. 109.

General color, light brown; face, reddish brown. Antennæ yellowish at base, the apieal half dusky. A dark triangular spot behind eye, and an oblong vertical black spot on the front half of lateral lobe of pronotum. Tegmina smoky brown, with several darker rounded spots on sides; these separated by lighter yellowish blotches; the dorsal surface dark brown, with a yellowish brown stripe along each humeral angle. Inner wings transparent, with dark nervules. Hind femora yellowish brown, with two or three blackish bars on the onter face; the knees fuscous. Hind tibix yellowish brown; the basal fourth lighter. Abdomen yellowish beneath, the sides darker.

"In the markings of the tegmina, form and color, pellucida looks like a diminutive Hippiscus. It varies much in size and tegminal markings."

Measurements: Length of body, male, $19 \mathrm{~mm}$., female, $22 \mathrm{~mm}$; of antenn $x$, male and female, $7 \mathrm{~mm}$.; of tegmina, male, $17 \mathrm{~mm}$., female, $20 \mathrm{~mm}$; of hind femora, male, $12 \mathrm{~mm}$., female, $13 \mathrm{~mm}$. 
As noted above, this is a species of northern range. It has been taken in Indiana but once, near Bass Lake, Starke County, on August 21, 1902. Here a half dozen specimens, all that could be found during a two-hours' search, were secured from a low, marshy tract, on which the grass had been cropped short. When flushed, the males flew noiselessly 30 to 50 feet, then dropped down and squatted low between the grass blades. The single female was more clumsy and did not take to wing; all were found within an area of 100 square feet. It is probable that the species occurs in isolated localities throughout the northern third of the State. In New England Morse says that it begins to mature about July 1 st, and may be found during
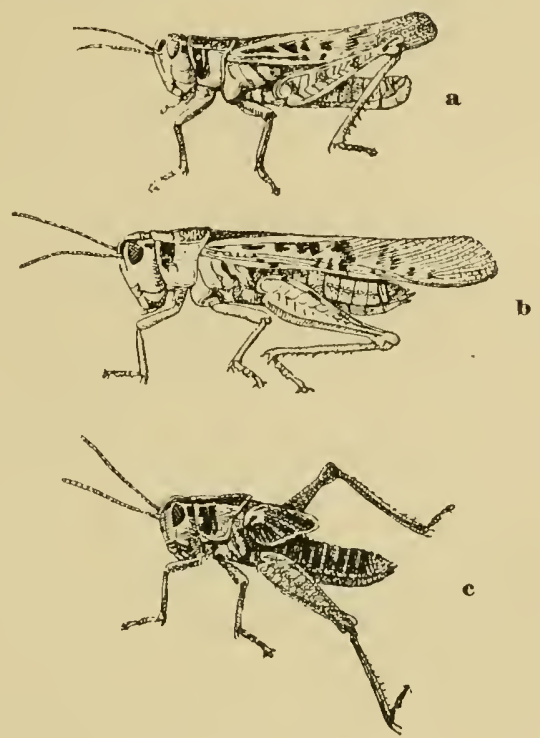

Fig. 52. Camnula pellucida (Scudd.). a, adult male; $b$, female; $c$, nymph; slightly enlarged. (After Simpson.)

the rest of the season. "It is extremely common, even abundant locally, throughout the northern part of New England, being probably the most numerous in point of individuals of any of our Oedipodince. It is found in dry grassy pastures and other untilled lands, preferably on high ground. Its flight is silent or slightly rustling, usually low, short and direct, resembling that of a large Melanoplus; when with the wind, however, it is occasionally prolonged for several rods in a straight line."

\section{Hippiscus Saussure (1861).}

Species of large size and robust form. Head large, sub-globose, the cheeks swollen. Vertex with the disk usually broadly triangular, the apex rounded or obtusely angulate and sloping more or less downward; the lateral carinæ distinct, but not sharp; the median carina present, at least on posterior half, and continued back over the occiput in the form of a small central ridge; the foveolæ present, but not prominent, usually triangular in form. Antennæ but little, if any, longer than head and pronotum together, filiform, the joints of 
apical halves a little flattened. Pronotum with its disk flat, usually rugose and bearing a number of rounder or oblong tubereles; the front margin truncate, the hind margin usually obtuse, or right angled; the median carina rather prominent, and wat once by the principal sulcus: the lateral carina extending a short distance in front of 1his sulcus. lut not ent hy it. Iateral lobes of the pronotum about as loug as deep. constricted near the middle: the front margin a little sinuate, the hind margin oblique; the lower margin with its posterior half rounderl, the anterior half oblique, directed upward, the posterior angle usually broadly rounded. 'Tegmina considerably exceeding the abdomen; their sides nswally with a number of large rounded or squarish dark spots. Inner wings with their basal lialves red or yellow, the apical halves with a broad fuscous arcuate band, narrowing toward the anal angle. Hind femora stout, depressed, dilated.

Thirty-seven of these heavy bodied locusts are catalogued by Sendder as oceurring in the United States, most of them being found only west of the Mississippi River. Four are known from Indiana, and proluably one or two others will, in time, be found to inhabit the State.

\section{KET TO INDIANA SPECIES OF HIPPISCUS.}

1. IIind margin of pronotum acutely angled; the prozona much shorter than the metazona; vertex with the front half of disk prolonged, narrowing gradually; the nlnar area of tegmina dark, but without listinct spots; inner wings pinkish red at base.............

43 tuberculutus, p. 265

a11. IInd margin of pronotum right angled or obtuse angled; the prozona nearly as long as the metazona; vertex with the front lialf of disk not prolonged, narrowing rapidly; the ulnar area of tegmina distinctly spotted; the inner wings (except rarely in haldemanii) yellow or orange red at base.

b. Frontal costal strongly suleate below the oceluns, and distinetly nalrowed at its upper extrenity; vertex with the disk, not or lut faintly divided ly cross enrina into four sub-equal parts; spurs at opposite sides of apex of hind tibia nearly equal.

c. 'T'ubereles on disk of metazona rounded or oblong, not forming ridges parallel to tlse hind margins: inner face of hind fomolat banded with black, blue at base.......

44 phonicopterus, p. 20ii

ce. 'Tubercles on disk of metazona more or less united to form oblique ridges parallel to the lind margin; inner face of hind femora miform yellowish.....45 haldemanii, p. 26i!

bu. Frontal costa but little sulcate below the ocellus and not narrowed at the npper extremity; vertex with the disk divided hy trinsverse and lengthwise carinse into four sub-equal parts: spurs at opposite sides of the apex of hind tihice rery unequal in lengtlı. A distinet broad, buff X-shaped mark usually present on disk of pronotum.......44; rugosus, p. 270 
43. Hippiscus tuberculatus (Palisot de Beauvois). The Coral-winged

Locust.

Acrydium tuberculatum Pal. de Beauv., 108, 1805, 200, Plate 4, Fig. 1. Hippiscus tuberculatus Sauss., 134, 1884, 87; Feru., 53, 1888, 42; Scudd., 167, VI, 1892, 269, 303; Id., 188, 1900, 33; Beut., 3, VI, 1894, 297, Plate X, Fig. 3; Mor'se, 99, VIII, 1897, 36, 81, Plate 2, Fig. 21; Brum., 34, 1897, 131, Fig. 31; Bl., 15, XXX, 1898, 61; Id., 16, 1899, 235, Fig. 61; Lugg., 84, 1898, 153, Figs., 89-91.

Lucusta corallina Harr., 7 1, 1841, 142; Id., 72, 1862, 176; Emm., 49 , $\mathrm{V}, 1854,146$.

Edipoda pheniropterce Scurdd, 14 1, VII, 1862, 468; Glov., 62, 1872,

Plate V, Fig. 4; Thom., 206, V, 1873, 135; Riley, 117 , VIII, 1876, 104, Fig. 41 ; Id. 214 , I, 1877, 228, Fig. 7.

Hippiscus phenicopterus Scudd., 148, 1874, 377; Thom., 21 1, 1880, 95, 117, Fig. 18; Bl., 4, XXIII, 1891, 79.

Edipoda obliterate Burm., 40, II, 1838, 643.

Vertex prominent, its front half prolonged, the lateral carinæ distinct, not uniting, but continuous with those of the frontal costa; the median carina reaching center of disk; the foveolæ triangular, very small. Frontal costa sulcate below the ocellus; the upper third a little narrowed. Antennæ short, equaling the length of head and pronotum; the joints a little flattened. Pronotum with its disk flat, but little wrinkled; granulate and bearing a few small rounded black tubercles; the hind margin acute angled, sometimes right angled in the male; the median carina low, but distinct, cut much in front of the middle by the principal sulcus; lateral carinæ distinct. Hind femora very broad, the upper and lower carinæ prominent and areuate.

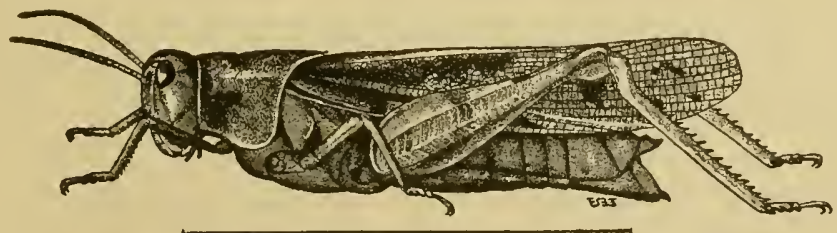

Fig. 53. Hippiscus tuberculatus (Pal. de Beauv). Female. (After Lugger).

General color, ash brown, darker above; the cheeks paler. Antennæ yellowish at base, the apical two-thirds gradually darkening to fuscous. Pronotum with a short, dark brown, lengthwise bar on middle of lateral lobes, below which the lobe is usually lighter than above. Tegmina blotched with fuscous and black, the humeral angle light brown; the dark color of discoidal and ulnar areas usually unbroken; some scattered dark blotches on apical third. Wings bright 
coral red (rarely yellow) at base, bordered without by an arcuate fuscous band which reaches the anal angle; a broad marginal ray of fuscous extends long the front or costal margin, nearly to base. Hind femora with the basal half of inner face black (prussian blue in life), the apical half yellow with a median black bar; the outer face with indistinct bars of black. Hind tibie dull yellow, sometimes with an orange tint.

Measurements: Length of body, male, $30 \mathrm{~mm}$., female, $43 \mathrm{~mm}$; of antenns, male, $13 \mathrm{~mm}$., female, $14 \mathrm{~mm}$.; of pronotum, male, $8 \mathrm{~mm}$., female, $11 \mathrm{~mm}$.; of tegmina, male, $31 \mathrm{~mm}$., female, $41 \mathrm{~mm}$.; of hind femora, male, $18 \mathrm{~mm}$., female, $23 \mathrm{~mm}$.

The female of the coral-winged locust is the largest and most bulky of our Indiana Oedipodince. The males, as the measurements show, are much smaller. This locust probably oceurs throughout the State, but is most abundant in the southern or driftless portion, where the soil is poor and the hills high; and in the northwest portion, where the sand-covered area is extensive. It has not been noted

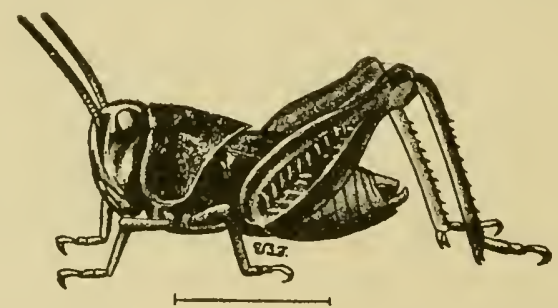

Fig.54. Hippiscus luberculatus. Young. (After Lugger).

1

by me in the rieher and more level regions of the central and eastern portions of the State. The winter is passed in the mymph stage, the young being "curious little depressed. toad-like objects" of a dull leaden color. Mature examples have been taken in Monroe County as carly as April 20th, and in Crawford ('ounty as late as July 10 th. The northern examples are smaller, darker colored, and may probably be found a month later.

This locust frequents, for the most part. timothy meadows, upland pastures, roadsides, and especially bare or scantily regetated slopes and sandy plains. When in flight it is very conspienous, owing to its large size and bright-colored inner wings. The males are ready and active flyers, moving rapilly for quite a distance, making, meanwhile. a lond rattling note which can be heard at a distance of several rods. The females seldom take to wing, but leap clumsily when approached, and are more readily captured. The general range of tuberculatus 
is given by Scudder as "North America, east of the Roeky Mountains, rare southwardly."

44. Hippiscus Phenicopterus (Germar). The Orange-winged Locust.

Edipoda phonicoptere Germ., 58, II, 1838, 643.

Hippiseus phonicopterns Sauss., 134, 1884, 87; McN., 88, VI, 1891, 63;

Scudd., 167, VI, 1892, 267, 274, 285; Id., 188, 1900, 33; Beut.,

3, VII, 1894, 298, Plate IX, Fig. 4.

Erlipoda discoidea Serv., 196, 1839, 724; Glov., 62, 1872, Plate III,

Figs. 3, 7; Thom., 206, V, 1873, 133.

Hippiscus discoidens Stal, 200, I, 1873, 121; Thom., 211 , IX, 1880, 89, 116; Comst., 41, 1888, 104.

Vertex prominent, the basal two-thirds broad, the lateral carinæ distinct, suddenly converging opposite the front half of eyes, but not uniting in front; the median carina low, reaching center of disk; traces of a cross carina on posterior half of disk in female; foveolæ small, elongate U-shaped. Frontal costa rather narrow, sulcate from a little above the ocellus to the base; the upper third narrower, punctate. Antenne a little shorter than head and pronotum in the female; equaling their length in the male; filiform, the joints a little flattened. Pronotum with its disk flat, a little wrinkled on the prozona, covered somewhat regularly with small rounded tubercles, these more prominent in the female; the hind margin right-angled in the male, obtuse-angled in the female; the median carina low but distinct, cut in front of middle by the principal sulcus, the lateral carine distinct only on metazona. Tegmina of both sexes surpassing the abdomen; the basal lobe of lower margin noticeably expanded, especially in the female. Hind femora broadly dilated; the upper and lower carine much elevated and sharp.

General color, ash or reddish brown; the males darker. Face ash brown or clay yellow. Oeciput and disk of pronotum dark brown. All of these parts, as well as the upper and lower onter faces of the hind femora are often prettily tinged with greenish. Tegmina, ash brown, with numerous large dark brown or blackish spots; those of the female more distinet, the light interspaces being wider; the largest of these spots on the lower third being just behind the expansion noted above. Wings deep orange (rarely yellow) at base; outside of this and just beyond the middle a curved black band crosses from the costal margin to the anal angle; the apieal fourth transparent and smoky, the extreme tip with one or two fuscous blotches in the male; a humeral bar or stripe of black reaches nearly to the base of the front portion. Inner face of hind femora deep blue, with an orange bar near the apex; outer face reddish or yellow- 
ish brown, with three black bars on the upper half. Hind tibia yellowish, often tinged with orange, the spines tipped with black.

Measurements: Length of body, male, $31 \mathrm{~mm}$., female $44 \mathrm{~mm}$.; of antennx, male, $12.5 \mathrm{~mm}$., female, $13.5 \mathrm{~mm}$; of pronotum, male, 8.5 min., female, $11 \mathrm{~mm}$; of tegmina, male, $31 \mathrm{~mm}$., femalc, $40 \mathrm{~mm}$.; of hind femor:t, male, $18 \mathrm{~mm}$., female, $23 \mathrm{~mm}$.

This is a locust of southern range which has been taken in Indiana only in Crawford, Lawrence and Jennings counties. In the vicinity of Wyandotte Cave, Crawford County, it is, in the latter half of June and first part of July, one of the most common of the Oedipodine. It occurs only on the uplands, where it frequents grain ficlds, open bare places in the woods, roadsides and timothy meadows. 'The male, when flushed, flies rapidly for a long distance, making a low rattling note while in the air; the female, as in kindred species, is too heary bodied to take to wing gracefully, and thercfore more often moves by leaping. In the vicinity of North Vernon and Mitchell, males only were seen. This locust probably occurs throughout the southern third of the State, and perhaps winters in the nymph stage. Its general range includes the southern United States east of the Great Plains.

\section{Hippiscus haldenanil (Scudder). Haldeman's Locust.}

Frtipoda haldemanii Scudd., 147, 1872, 251; Glov., 62, 1872, Plate XIII, Fig. 3; Thom., 206, T, 1873, 130.

Hippiscus huldemanii Scudd., 156, II, 1876, 264; Id., 167, VI, 1892, 267, 286: Irl., 188, 1900, 32; Lugg., 84, 1898, 156, Fig. 93.

Hipriens nemus. Sauss., $134,1884,86$.

Vertex broad, its disk sub-quadrate, often containing several minute tubercles, the lateral carine low, distinctly rounded; the median carina reaching the center, with sometimes traces of a cross carina; the foreole small but distinct, triangular. Face nearly vertical, the frontal costa broad, sulcate from a little above the ocellus downward, less so in the female, the upper third distinctly narrowed. Antennæ slender, about the length of head and pronotum together. Pronotum short; the prozona sub-cylindrical, constricted; the disk much wrinkled and rugose, bearing numerous elongate tubercles which lic obliquely and more or less parallel to the hind margin; the latter rightangled in the male, obtusc-angled in the female; the median carina low, indistinct on the prozona, cut a little in front of the middle by the principal sulcus; lateral carine distinct on hind part of prozona and front half of metazona. Tegmina surpassing the abdomen about nne-fourth their length. Hind femora relatively slender, much narrower proportionally than in any other of our species of Ilippiscus, 
reaching the tip of the abdomen in the female, slightly passing it in the male.

General color, grayish brown varied with numerous dark spots. Face, ash gray, the cheeks and a spot back of the eye, lighter; the vertex, occiput and disk of pronotum darker. A black bar on middle of lateral lobe of pronotum. Tegmina with a narrow yellowish line along each humeral angle, the dorsal area, brownish, unbroken; the sides with a number of oblong dark brown spots, separated by irregu-

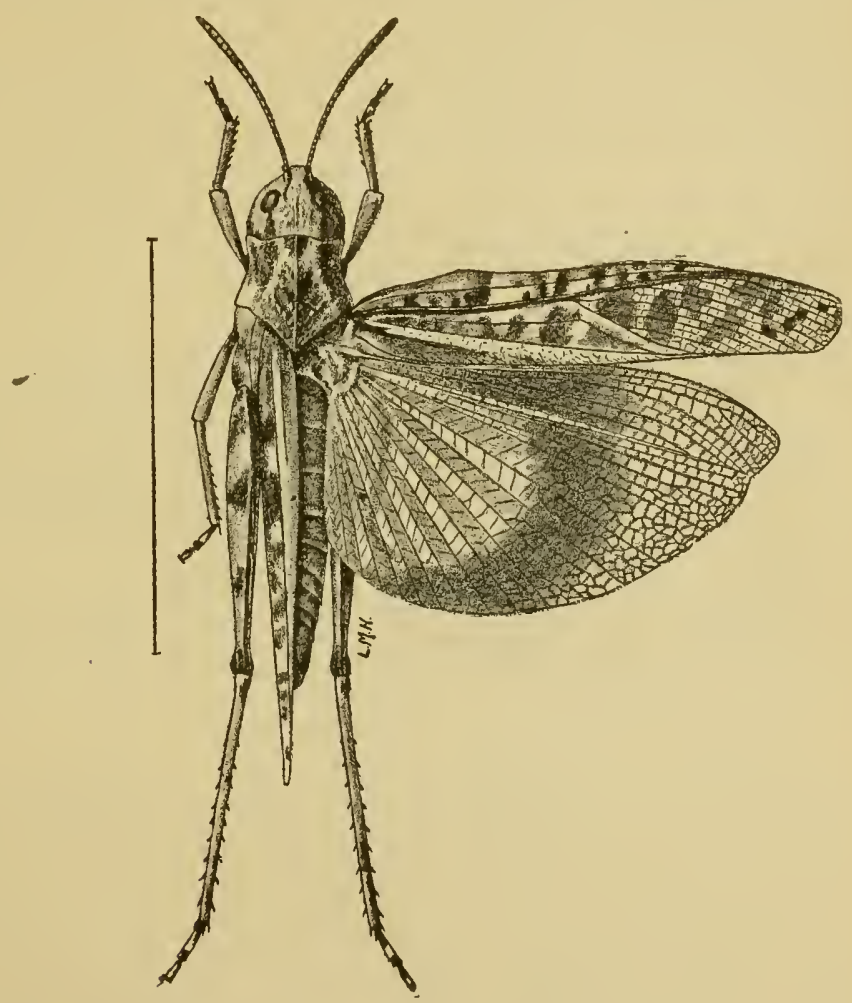

Fig. 55. Hippiscus haldemxnii (Scudder). Female. (After Lugger).

lar grayish bars; those on apical third smaller and rounded. IVings with the basal half lemon yellow, orange red, or, rarely, pinkish; the remaining portion as in phonicopterus. Hind femora with the imner face bright yellow; $*$ the outer face brownish yellow with traces of three very oblique cross bars. Hind tibix light yellow, tinged with orange in the male.

* Thomas says: "Inside of posterior femora and the posterior tibie a bright coral red," but this does not hold good of Indiana specimens. 
Measurements: Iength of body, male, $27 \mathrm{~mm}$, female, $44 \mathrm{~mm}$; of antenna, male, $12 \mathrm{~mm}$., female, $14 \mathrm{~mm}$.; of pronotum, male, $7 \mathrm{~mm}$, female, $10 \mathrm{~mm}$; of tegmina, male, $27 \mathrm{~mm}$., female, $38 \mathrm{~mm}$; of hind femora, male, $16 \mathrm{~mm}$., female, $22 \mathrm{~mm}$.

This species has been taken in Indiana only near l'ine, Lake County, where my assistant, Mr. L. E. I)aniels, took eight specimens on June 20, 1902. They were found on open, sparsely regetated sandy tracts, about a fourth of a mile back from the shore of Lake Michigan. Nothing distinctive of their habits was noted. One of the females taken has the inner wings pinkish or coral red, as in tuberculatus; two have them orange red, the others, yellow. Of the four males, two have yellow and two orange colored wings. This is the most eastern record for the species, its range, according to Scudder, being from Moline, Illinois, westward to the Rocky Mountains. It probably occurs in this State only in the sand-covered area of the northwestern portion.

46. Hippiscus Rugosus (Scudder). The Lubberly Locust.

Edipoda rugosa Scudd., 14 1, VII, 1862, 469; Glov:, 62, 1872, Plate .XII, Fig. 8; Thom., 206, V, 1873, 132.

Hippiscus rugorns Scudd., 148, I, 1874, 377; Id., 167, VI, 1892, 268, 287; Id., 188, 1900, 33; Sauss., 134, 1884, 85; Fern., 53, 1888, 42; Bl., 4, XXUI, 1891, 78; Morse, 99, VIII, 1897, 36, 81, Plate 2, Fig. 22; Lugg., 84, 1898, 149.

Hippiscus corallipes rugosus Thom., 211 , LX, 1880, 89, 115.

Hippiscus rariegatus Scudd., 167, VI, 1892, 268, 301; Id., 188, 1900, 33; Brun., 34, 1896, 131; Id., 36, 1899, 271 ; Lugg., 84, 1898, 157, Fig. 94.

A rather bulky and short-bodied form. Tertex convex, the disk indistinct, and sloping downward, broader than long in both sexes, the lateral carina dull, low; the median carina cxtending to front border, and with a cross carina dividing the disk into four sub-equal portions, the front pair being the more distinct; lateral foveolæ, shallow, elongate triangular. Frontal costa broad, flat, punctate, slightly suleate just below the ocellus. Antenna about as long as head and pronotmm in the female, a third longer in the male. Pronotum with the disk flat or nearly so, the metazonal portion not greatly widened, the hind margin obtuse-angled, the surface bearing numerous low, oblong or longitudinal, glistening tubercles; the median carina low. cut very near the middle by the principal suleus; the lateral carino distinct on the metazona: the lateral lobes of metazona densely punetate. Tegmina relatively broad, exceeding the abdomen in both sexes. Hind femora moderately slender, equaling or surpassing the abdomen by one-fourth their length, the basal half depressed, dilated. 
General color, light to dark brown, the face and abdomen brownish yellow; the disk of pronotum with a pale, $\mathrm{X}$-shaped stripe, not always present in the female. Antennæ yellow at base, the apical half reddish fuscous. Tegmina ash gray, often darker in the male, the sides and dorsal area with numerous dark brown or fuscous oblong or rounded spots, those on center of sides larger; the apical third often semi-transparent, with the spots much smaller and more irregular in shape. Wings with the basal half varying from a pallid tint through pale lemon yellow to deep orange; the outer half with the curved black band and transparent apex as in phonicopterus. Hind femora bright yellow within, with three transverse bars of black; dull clay yellow without, with three more or less distinct, very oblique fuscous bars. Hind tibiæ yellow, with a paler ring near the base.

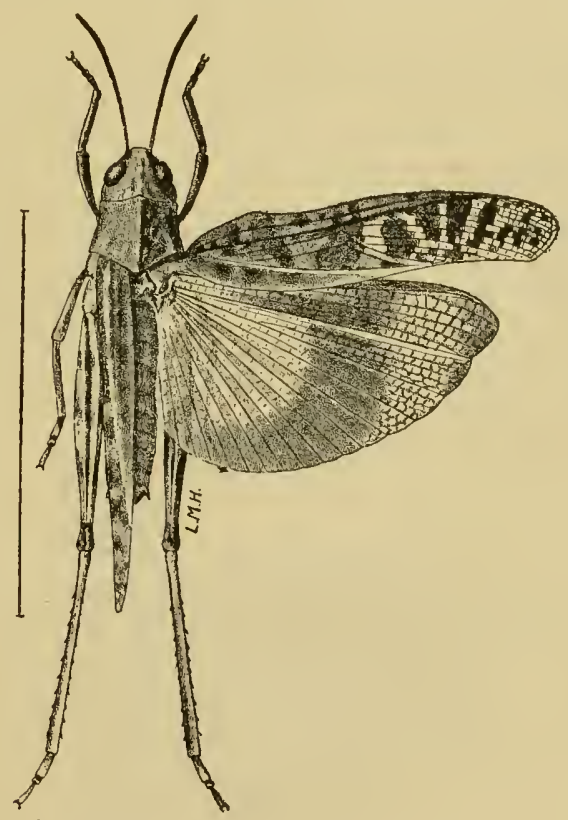

Fig. 56. Hippiscus rugosus (Scudder). Male. (After Lugger.)

Measurements: Length of body, male, $28 \mathrm{~mm}$., female, $37 \mathrm{~mm}$.; of antennæ, male, $13 \mathrm{~mm}$., female, $12 \mathrm{~mm}$.; of pronotum, male, $7 \mathrm{~mm}$., female, $9 \mathrm{~mm}$.; of tegmina, male, $27 \mathrm{~mm}$., female, $34 \mathrm{~mm}$.; of hind femora, male, $18 \mathrm{~mm}$., female, $22 \mathrm{~mm}$.

This is the most common species of Hippiscus in the State, being especially abundant in the central and southern portions, but scarce in the north, where it has been collected only in Fulton and Marshall 
counties. In central Indiana it begins to reach maturity about July 20th, from eggs hatched in the spring. Like others of its kind, it frequents only dry, upland localities, being especially abundant in open woodland pastures, timothy and elover meadows, along roadsides and rail fences. The males are shy, usually taking to flight when an intruder is a rod away and moving in a straight line in the direction they liappen to be headed, without noise, save the rustling of their wings. The females are very clumsy, being readily picked up with the fingers. I have often placed one of them on the palm of one hand and with the other stroked gently its back and antennæ without having it attempt to escape.

Mating takes place in late August and September, and the males then mostly perish, while the females are to be found much longer, sometimes as late as November 5th. Orange-winged females of rugosus are more common than males; probably one third of then having the wings of that hue. It ranges over the eastern United States east of the Rocky Mountains.

From the study of type specimens of Scudder's so-called II. variegalus and of a large number of examples taken in the field, I have concluded that it is but a little stonter bodied, lighter colored form of rugosus, and have therefore combined the two species under the latter name. Intermediate specimens, varying in length of tegmina and size and position of tegminal spots are common. With numerous examples at hand it is impossible to separate the two forms.

\section{Dissostelra Scudder (18\%6).}

Body slender, compressed. Vertex with the disk sub-pentagonal or orate; the front half a little downward sloping, its front margin angulate; the lateral carine low; the median carina present but indistinct; the foreole short. triangular. Frontal costa suleate, a little narrowed below the ocellus. Pronotum with disk of prozona sloping. that of metazona flat: the front margin truncate, the hind margin obtuse-angled; the medim carina high and sharp, and on the metazona strongly arehed, eut in front of the middle by a deep but narrow notch; lateral carinæ rounded, cut by the principal suleus and olssolete in front of it. Lateral lobes of pronotum deeper than long. the front margin vertical, the hind margin oblique, the lower margin with its posterior half rounded, the anterior half oblique. Tegmina broad, much exceeding the abdomen; the whole of apical third membranaceous; the interealary vein very distinet and nearly intermediate between the median and ulnar veins. Inner wings long and wide, 
black, with a narrow yellowish outer border; the apex fuscous. Hind femora'slender, a little shorter than abdomen in both sexes.

Four species of the genus are accredited to the United States. Of these, one occurs in Indiana.

47. Dissosteira oarolina (Linnæus). The Carolina Locust. The Blackwinged Locust.

Gryllus (Locusta) carolinus L., 8 1, I, 1758, 433.

Locusta carolina Harr., 70, 1833, 583; Id., 72, 1862, 176, Plate 3, Fig. 3; Emm., 49, V, 1854, 145, Plate 9, Fig. 9; Rathv., 109, 1862, 386 , Figs. 26, 26 a.

Edipoda carolina Burm., 40, II, 1838, 643; Serv., 196, 1839, 722; Glov., 62, 1872, Plate V, Fig. 3; Thom., 206, V, 1873, 117; Id., $211, \mathrm{IX}, 1880,88,111$.

Dissosteira carolina Seudd., 159, 1876, 511; Id., 180, VW, 1897, 100; Id., 188, 1900, 36; Sanss., 134 , 1884, 137; McNeill, 87, XIX, 1887, 58; Fern., 53, 1888, 43; Bl. 4, XXIII, 1891, 78; Id., 16 , 1899, 242, Fig. 69; Smith, 197, XC, 1892, 6, 12, 3t, Plate 1, Fig. 4k; Beut., 3, VI, 1894, 298, Plate X, Fig. 6; Morse 99, VIII, 1897, 35, 87; Lugg., 84, 1898, 158, Fig. 95.

General color varying from light grayish yellow through bright reddish brown to dark fuscous; usually dull ashy brown, sprinkled with numerous small dusky spots; these most numerous on the pronotum and tegmina, on the latter sometimes forming three more or less distinct cross bands. Wings deep black except the outer border,

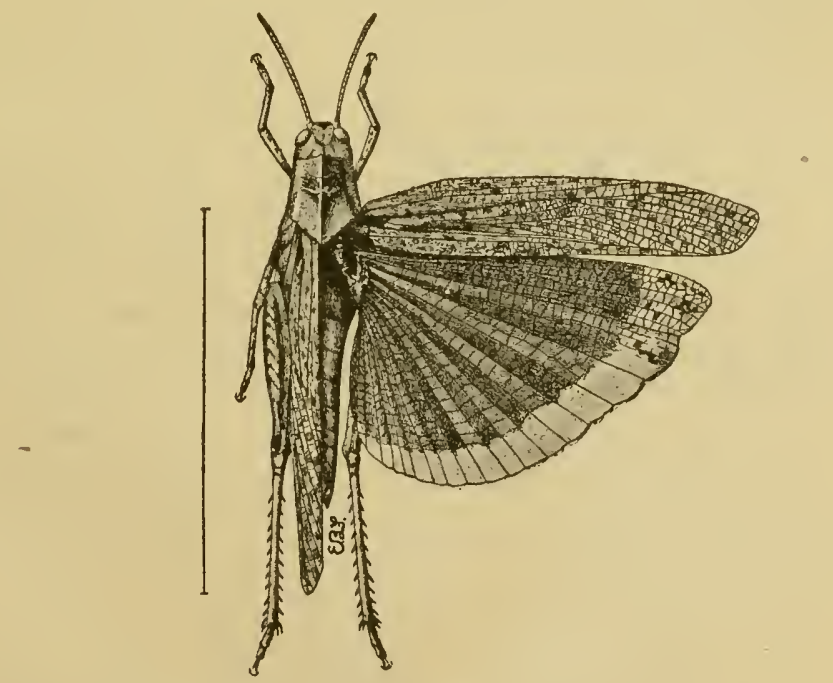

Fig. 57. Dissosteira carolina (Linn.). Female. (After Lugger.)

which is pale greenish yellow; the apex smoky gray with a few darker spots. Hind femora with three broad black bands on the inner face. Hind tibiæ yellowish or dusky. 
Measurements: Length of body, male, $30 \mathrm{~mm}$., female, $35 \mathrm{~mm}$.; of antenna, male, $11 \mathrm{~mm}$., female, $13 \mathrm{~mm}$; of pronotum, male, 7 nm., female, $10 \mathrm{~mm}$; of tegmina, male, $34 \mathrm{~mm}$., female, $41 \mathrm{~mm}$; of hind femora, male, $16 \mathrm{~mm}$., fermale, $18 \mathrm{~mm}$.

The black winged locust occurs everywhere throughout the State and to the casual observer appears to be our most common species, but there are a dozen which are more abundant. Its numbers appear multiplied beeause it frequents the highways and by-ways of man rather than the pastures and meadows where other grasshoppers are wont to congregate. Moreover, when disturbed, it more often betakes itself to the bare earth than to the green grass. Why this absurd taste? asks the person uninitiated in the doings of nature's objects. For the simple reason that the dust of the roadside and the gravel ballast of the railway correspond so closely with the color of its back that its best friends and worst enemies will overlook it if it will only remain quiet. Yea, even that sharp-eyed connoisseur of grasshopper tid-bits, the turkey gobbler, oftentimes walks right over it, mistaking it for a wayside pebble.

Mature specimens of this "carolina locust," hatched from eggs in spring, have been taken in Vigo County as early as June 14th and as late as November $22 \mathrm{~d}$. It is usually common and mating by July 5 th. Either there are two broods each year, or else the eggs hatch at irregular interrals, as freshly moulted individuals have been observed on a number of dates in September, and as late as October 14th. On one occasion, while passing through a wheat field in late September, I observed clinging to the stems of weeds, several specimens of what appeared to be the bodies of grasshoppers with the wings of the common sulphur-yellow butterfly attached to them. Such a combination aronsed my curiosity, but a closer examination proved them to be specimens of this common black-winged locust which had just moulted for the last time, and spread out their soft wings to dry. The inner wings, instead of being black, were light yellow, but in three or four hours thereafter had changed to their usual color.

This locust is often seen along the walks and in the yards of our larger cities and I have seen specimens about the base of the Soldiers' Monument in the very center of the city of Indianapolis. Both sexes use the wings almost wholly in their travels, and fly in a noiseless zigzag manner for quite a distance when flushed. Their hind legs are used only in giving themsclves an upward impetus from the ground, and hence are mich smaller proportionally than are those of such locusts as leap rather than fly, while their wings are much longer and stronger. 
The range of $D$. carolina is a most extensive one, embracing the United States and Canada from ocean to ocean.

\section{Spharagemon Scudder (1875).}

Body slender, more or less compressed. Head rather swollen above, the vertex shaped much as in Dissosteira, but the lateral carinæe converging more rapidly; the median carina and angled front margin absent, the foveolæ wider and more distinct. Frontal costa narrow, sulcate, at least below the ocellus. Antennæ in both sexes about as long as hind femora; filiform, the joints of basal third a little flattened. Pronotum with the disk of metazona flat, that of prozona with the sides sloping; the median carina high and strongly compressed, cut a little in front of the middle by a deep but narrow notch; the lateral lobes as in Dissosteira. Tegmina relatively shorter than in Dissosteira, the intercalary vein less distinct and nearer the median than the ulnar vein. Inner wings yellow, with a dark curved median band. Hind femora rather stout and short, equaling, or a little exceeding, the tip of abdomen. Hind tibiæ, in our species, with at least the apical half red. Valves of ovipositor short; but little exserted.

This genus is closely related to Dissosteira, and Saussure, in his Prodromus, has placed it as a sub-genus under that one. Eight species are known from the United States. Of these, two have been taken in Indiana.

\section{KEY TO INDIANA SPECIES OF SPHARAGEMON.}

a. Size, large; the notch of median carina of pronotum vertical. Hind tibia with a distinct pale ring on basal third, followed by a black one of equal width, the apical half coral red.......48 bolli, p. 275

aa. Size, small; notch of median carina of pronotum distinctly oblique. Hind tibire coral red, sometimes paler at base, but without distinct white and black rings...............49 wyomingianum, p. 277

48. Spharagemon bolli Scudder. Boll's Locust.

Spharagemon bolli Scudd., 149, XVII, 1875, 469; Id., 153, IV, 1875, 68; Id., 168, XXII, 1893, 77; Id., 188, 1900, 37; McN., 88, VI, 1891, 64; Bl., 6, XXIV, 1892, 30; Morse, 95, XXVI, 1894, 227, 236, Figs. 6, 7; Id., 97, VII, 1895, 290; Id., 99, VIII, 1897, 37, 88, Plate 2, Fig. 26; Beut., 3, VI, 1894, 300, Plate X, Fig. 1; Lugg., 84, 1898, 163, Fig. 98.

Dissosteira (Spharagemon) bolli Sauss., 134, 1884, 140.

Dissosteira bolli Fern., 53, 1888, 43.

Spharagemon balteatum Scudd., 149, XVII, 1875, 469; Id., 153, IV, 1875, 68; Bl., 4, XXIII, 1891, 78. 
Ground color variable, that of the male being usually grayish or fuscous, that of the female rusty brown or pale buff; the face grayish or yellowish. Antennie brownish or grayish at base, fuscous at apex. 'Tegmina sprinkled throughout with minute blackish spots. In the males these spots are aggregated into three more or less distinct dark cross bars; in the female only faint traces of these bars are visible. Inner wings light greenish yellow at the basc, with a broad median curved hand of blackish or piceous which stops a little short of the anal angle; from this band near the front margin a black bar reaches

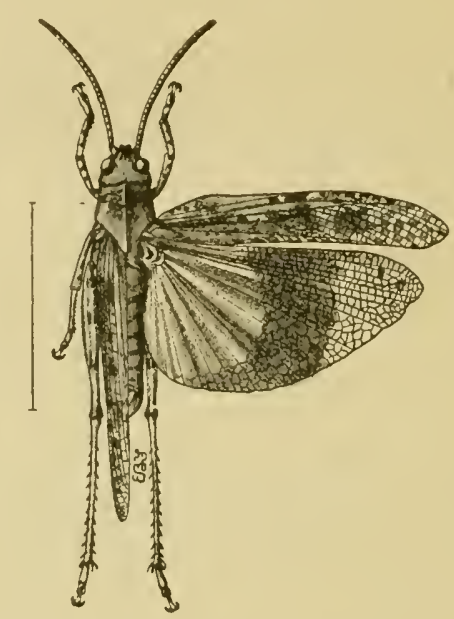

Fig. 55. Sipharagemon bulli sculder. Mule.

(After Iugrger.)

back half way through the yellow. Apical third of wing transparent smoky, the extreme tip in the male being often of the same hue as the median band. IIind femora with alternating bars of black and yellow, three each, on the inner face; the outer face dull yellowish or grayish brown with three or four oblique indistinet dark brown bands.

The median carina of pronotum in the male is higher than in the female, that portion on the metazona being more elevated in front than behind. Other structural characters are given under the generic heading.

Measurements: Length of body, male, $25 \mathrm{~mm}$., female, $33 \mathrm{~mm}$; of antenna, male, $1 . \mathrm{mm}$., female, $16 \mathrm{~mm}$; of pronotum, male, 7 mm., female, $9 \mathrm{~mm}$.; of tegmina, male, $27 \mathrm{~mm}$., female, $32 \mathrm{~mm}$.; of hind femora, male, $16 \mathrm{~mm}$., female, $19 \mathrm{~mm}$. 
This is a common locust throughout the central and southern thirds of the State, but is less numerous northward, where it seems to be replaced in part by the next species, though it has been taken in Starke and Lake counties. It frequents paths and bare places in dry upland woodland pastures, especially those which include the slopes of high hills, roadsides and stubble fields. In the northern counties it is found most abundantly along the sandy edges of woodlands and in old fields. In Crawford County mature specimens from eggs hatched in spring, have been taken on June 25th; in Vigo County, on June 30th. The males fly much farther than the females and on arising from the ground emit a short and rather low rattling note. The females are clumsy in their movements, and prefer, after being flushed once or twice, to lie still when approached, as close to the ground as possible, relying upon their protective coloration to prevent discovery.

Individuals of both this species and $D$. carolina have, in late summer, a peculiar habit of sustaining themselves in the air, about three feet above the ground, for several minutes. While poising in this manner above one spot, they make a dry, rustling note, which is purhaps a call to some nearby member of the opposite sex. S. bolli ranges from New England to Georgia, Texas and Nebraska.

49. Spharagemon wyominginum (Thomas): The Mottled Sand Locust. Edipola wyomingiana Thom., 205, 1872, 462; Id., 206, V. 1873, 113;

Glov., 62, 1874, Plate XIV, Fig. 1; Plate XV, Fig. 2.

Splaaragemon wyomingianum Scudd., 149, XVII, 1875, 468; Id., 153, IV, 1875, 67, 69; Id., 188, 1900, 38; Bl., 15, XXX, 1898, 61.

Spharagemon collare wyomingianum Morse, 97, VII, 1895, 298.

Spharagemon collare McN., 88, VI, 1891, 64.

Spluaragemon oculatum Morse, 95, XXVI, 1894, 232, 239, Fig. 8; Bl., 11, XXVI, 1894, 218; Scudd., 188, 1900, 37.

General color, pale yellowish or pinkish brown, everywhere sprinkled and spotted with darker brown or fuscous. Face ash gray or yellowish, sprinkled with minute darker spots. Antennæ fuscous at tip, lighter toward base. Sides of pronotum with two indistinct dusky bands, the upper in the place of the lateral carinæ on the prozona. Tegmina with three transverse bars of fuscous spots; the dorsal field often brownish red. Inner wings similar to those of bolli, the median black band narrower toward the anal angle which it reaches. Hind femora pale brown or gray on outer face with traces of four fuscous cross bars; within sulphur yellow, with four more or less complete black bars. Hind tibiæ coral red or pinkish, paler at base; spines with extreme tips black. 
The eyes of male of this species are larger and more prominent than usual. The vertex, viewed from above, is about as broad as the eye, with a faint trace of median cinina on the posterior half. Pronotum with the disk flat on metazona, somewhat sloping on prozona, slightly angulate in front, acute angled behind; median earina high, compressed, arched, especially on metazona, the prozona in the male with crest of carina distinetly sloping toward the head; the notch plainly oblique and very narrow. Tegmina surpassing the femora by about one-third their own length. In most specimens the legs and the ventral portion of body are very pubescent, with rather long: grayish hairs.

Measurements: Length of body, male, $19 \mathrm{~mm}$., female, $24 \mathrm{~mm}$.; of antenna, male, $12 \mathrm{~mm}$., female, $11.5 \mathrm{~mm}$; of pronotum, male, 5 mm., female, $6.5 \mathrm{~mm}$; of tegmina, male, $19 \mathrm{~mm}$., female, $23 \mathrm{~mm}$.; of hind femora, male, $11 \mathrm{~mm}$., female, $13 \mathrm{~mm}$.

This small but handsome locust is quite common in the sand covered areas of the northern third of the State, having been taken in Fulton, Marshall, Lake, Porter, LaPorte, Starke, Kosciusko and Steuben countics. The carliest date at which it has been taken is July 14th, in Fulton County, when it was found in numbers and had probably been mature for a week or longer. It oceurs most abundantly along the thinly vegetated sandy tracts twenty rods or more back from the water margin of lakes, in old sandy cultivated fields and along railways and roadsides. In such localities it is often found in company with Psinidia fenestralis and less frequently with S. bolli. It seldom leaps when disturbed, but uses the wings to propel itself in a flight of about 30 yards; the males making a faint crackling noise as they clear themselves from the earth, while the females are noiseless. In a corn field near Lake Maxinkuckee. I found wyomingianum very common on August $1 \%, 1893$, over abont two acres of the most sandy portion. Resting on the soil between the rows. they were rery difficult of detection, and eight times out of ten were not seen until flushed. unless they had previously been "marked down" as they alighted. A few were also taken from the sandy margin of the lake. but careful search over a wide extent of territory failed to reveal them elsewhere. It will probably be found in the ricinity of most of the lakes of the State. It is more frequent northward and westward, but lias been taken in Maryland and New York, and may possibly occur in the sand corered area of southwestern Indiana. 


\section{Mestobregma Scudder (18\%6).}

Size small. Body slender, compressed. Disk of vertex with its posterior portion short and broad, the front portion narrowing rapidly and sloping strongly downward to form the sides of the frontal costa; the lateral carinæ high and sharp, the median carina wanting; the foveolx, in our species, rather prominent, triangular. Frontal costa narrow, sulcate throughout, a little constricted above the ocellus. Antennæ about as long as hind femora, the basal joints so depressed as to form one sharp edge. Pronotum moderately constricted in the middle, the front margin truncate, the hind margin right-angled, the disk wrinkled, and bearing a number of small, oboblique tubercles; the median carina sharp, slightly higher on the prozona, notched twice in front of the middle; the lateral carinæ rounded, visible only on the metazona. Lateral lobes of pronotum deeper than long, the front margin almost vertical, the hind one a little concave, the lower margin oblique but straight, the posterior angle thereby enlarged. Tegmina narrow, the apical half membranaceous and transparent. Inner wings with the basal half yellow. Hind femora slender, reaching tip of abdomen in female, much surpassing it in male.

Nine species of the genus occur in the United States, one of which has been taken in Indiana.

50. Mestobregma cinctum (Thomas). The Ash-brown Locust.

Edipoda cincta Thom., 203, 1870, 80; Id., 204, II, 1871, 275; Id., 205, 1872, 464; Id, 206, V, 1873, 122; Glov., 62, 1872, Plate XII, Fig. 13.

Mestobregma cinctum Thom., 21 1, IX, 1880, 90, 113; Lugg., 84, 1898, 164, Fig. 99; Scudd., 188, 1900, 39.

General color ash gray, or yellowish brown, spotted with fuscous. Face ash gray, with minute dark spots. Occiput and disk of pronotum darker, with often a yellowish line extending back from eye along the sides of the disk. Lateral lobes of pronotum with traces of alternate lengthwise bars of pale and fuscous, the former the narrower. Tegmina yellowish brown or grayish, often darker in the male, the lower field with two squarish dark spots separated by an oblong whitish spot; the apical half transparent, often with a few small dark spots along the costal margin. Inner wings with the basal third greenish or lemon yellow; a narrow curved fuscous band on middle third; the apieal third smoky transparent, with a few fuscous dots near the tip. Outer face of hind femora ash gray or yellowish with three more or less distinct black spots on the upper margin. 
mina much exceeding the abdomen in both sexes, in our species grayish or light brown in color, sprinkled with many small dark spots. Inner wings with the basal half light yellow; the apical third transparent; a narrow curved black band intervening. Hind femora of average width, reaching or exceeding the tip of abdomen in both sexes.

McNeill, in the latest monograph of this genus, describes and gives keys to 54 nominal species belonging to it. Of these, 49 are from the United States, 16 of which are confined to California; while but three occur east of the Mississippi River. Of these, two have been taken in Indiana.

KEY TO INDIANA SPECIES OF TRIMEROTROPIS.

a. Hind tibire yellow or greenish yellow; width of dark band of inner wing seldom more than one-sixth the length of wing............

51 maritima, p. 281

aa. Hind tibix red; width of dark band of inner wing, broader, about one-fourth the length of wing.............52 citrina, p. 282

51. Trinerotropis maritina (Harris). The Maritime Locust.

Locusta maritima Harr., 7 1, 1841, 143; Id., 72, 1862, 178.

CEdipoda maritima Uhl., $213,1862,178$; Glov., 62, 1872, Plate XII, Fig. 17; Thom., 206, V, 1873, 124.

Trimerotropis maritima Stal, 200, I, 1873, 135; Scudd., 148, 1874, 378; Id., 188, 1900, 42; Thom., 211 1880, 113; Sauss., 134 , 1884, 172; Fern., 53, 1888, 45; Bl., 11, XXVI, 1894, 218; Id., 15, XXX, 1898, 61; Bent., 3, VI, 1894, 299, Plate X, Fig. 5; Morse, 99, VUI, 1897, 37, 112, Plate 2, Fig. 29; Lugg., 84 , 1898, 168, Figs. 101, 102; McN., 91 , XXIII, 1901, 399, 410; Walk., 218 , XXXIV, 1902, 2.

Size, medium. Pronotum with the median carina low throughout; the metazona about twice as long as the prozona, its disk flat, with a number of scattered minute rounded tubercles, the hind margin obtuse angulate. Inner wings twice as long as wide.

General color, light to dark gray or reddish brown mottled with brown or fuscous; the sides of head, lower parts of thorax and abdomen and the legs, often nearly white. Tegmina brownish yellow, sprinkled with fuscous dots, which are sometimes, especially in the darker male, arranged so as to form three irregular but distinct transverse bands; more often the spots are scattered along the sides, being most abundant on the basal third. Inner wings with disk light yellow; the width of curved black band rarely more than one-sixth the length of wing; the apex transparent. Inner face of hind femora pale yellow with three black bands; the lower sulcus pale with a black 
spot near the apex; the outer face without distinct spots or bands. Hind tibia obseure yellowish.

Measurements: Length of body, male, $21 \mathrm{~mm}$., female, $28 \mathrm{~mm}$.; of antennæ, male, $10 \mathrm{~mm}$., female, $11 \mathrm{~mm}$; of pronotum, male, 5 mm., female, $6 \mathrm{~mm}$.; of tegmina, male, $24 \mathrm{~mm}$., female, $28 \mathrm{~mm}$; of hind femora, male, $11.5 \mathrm{~mm}$., female, $15 \mathrm{~mm}$.

This species has been taken in Indiana only along the south shore of Lake Michigan, in Lake, Porter and Laporte counties, where it is common. It flies rapidly and noisclessly for long distances and, unless carefully marked down, is very diffieult to detect. The darker specimens are always found at some distance from the lake, where there is a scattering vegetation; the light colored ones on the pure sand of the immediate shore. It has been seen nowhere more than a half mile back from the water margin, and then only on the bare crests of the highest sand ridges and dunes. The carliest date on which mature specimens have been taken was July 25th, and the latest October 15th, though they are doubtless to be found both before and after those dates. Its general range is given by McNeill as "Atlantic States from Virginia northward and along the shores of the Great Lakes west to Illinois."

52. TRIMEROTROPIS CITRINA Scudder.

Trimerotropis citrina Scudd., 147, II, 1876, 265; Id., 168, XXII, 1893, 77; Id., 188, 1900, 41; Sauss., 134, 1884, 169; McN., IX, 1900, 31, 35; Id., 91 , XXII, 1901, 401, 426; Walk., 218 , XXXIV, 1902, 1, 4 .

Size, medium or large. Pronotum with the median carina very low; the metazona but little more than one and a half times as long as prozona; the disk flat, except on the prozona, where the sides are raised moderately, and smooth or nearly so; the hind margin decidedly obtuse angled, the tip rounded. Wings one and three-fourths times as long as broad.

General color ash gray or yellowish brown, sprinkled more or less with fuscous. The face usually light gray; the tegmina yellowish brown, the dark spots aggregated into thrce dark crossbars, indistinct in the female, plainly visible in the male. Wings pale lemon yellow at base, the fuscous band broad, the width being from onefourth to one-fifth the length of wing: the sub-marginal ray short, extending less than half way to base. Inner face of hind femora yellow. with three fuscous bands; the lower suleus yellow with a distinet sub-apical fuscous spot and traces of two others: the outer face plain yellowish brown or gray. Hind tibiæ pinkish red, paler at base. 
Measurements: Length of body, male, $22 \mathrm{~mm}$., female, $30 \mathrm{~mm}$; of antennæ, male, $11 \mathrm{~mm}$., female, $12 \mathrm{~mm}$; of pronotum, male, 5 mm., female, $6.5 \mathrm{~mm}$.; of tegmina, male, $2 \% \mathrm{~mm}$., female, $34 \mathrm{~mm}$.; of hind femora, male, $13 \mathrm{~mm}$., female, $15.5 \mathrm{~mm}$.

This is a somewhat larger and more bulky insect than Indiana examples of $T$. maritima, the male being nearly as large as the female of the latter. In general appearance the two closely resemble one another and are apt to be confounded when they occur together.

I have taken this species in but one locality in Indiana. This was on a long sand and gravel bar, along the north shore of the Ofio River, a half mile below Vevay, Switzerland County. Here it was common on September 23, 1898, but having no net, I was able to capture but three specimens. Its flight along this gravelly bank was much less prolonged than that of maritima on the more extensive sand beach of Lake Michigan. When approached it would rise straight upward a few feet, and then move lazily and without noise eight to 15 feet, and alight again, always on the bare sand or gravel. The gravel bar was at the foot of a terrace 30 feet or more in height and a quarter of a mile wide, the surface of which was cultivated. No trace of citrina was found on this area, though other locusts were abundant. It has been recorded heretofore from Maryland, Arkansas, Texas, Colorado and Nebraska, and therefore is to be regarded as a southern form, which may be found all along the gravelly banks of the Ohio River.

\section{Psinidia Stal (18:3).}

This genus is elosely allied to Mestobregma, the general appearance of our species being very similar. Head with the occiput much elevated, the vertex much as in Mestobregma, but the lateral carinæ more nearly converging in front; the foveolæ smaller, sub-circular. Frontal costa sulcate throughout, the upper half very narrow, the lower half gradually expanding. Antennæ, especially those of the male, long; the joints of basal half strongly flattcned, the edges higher than the center. Pronotum strongly constricted in the middle, the disk nearly smooth, the front margin truncate, the hind margin acute angled; the median carina sharp, straight and of equal height throughout, cut by two notches in front of the middle; the lateral carinæ rather sharp and distinct on the metazona; sub-distinct on the prozona. Lateral lobes of pronotum, with the front and hind margins as in Mestobregma, the lower margin with its front half arcuate, strongly directed upward. Tegmina narrowed, exeeeding 
the abdomen about one-fourth their length; their basal half densely coriaceous; many of the cells in the front half of the middle third two to four times as long as wide. Inner wings with the basal third usually orange red; otherwise as in Mestobregma, except that the black curved median band is broader. Hind femora reaching tip of abdomen in female, slightly exceeding it in male. Hind tibiæ ringed with dusky and yellowish white.

One species of Psinidia occurs in the United States and Canada east of the Mississippi River.

53. Psinidia fenestralis (Serville). The Long-horned Locust.

Edipoda fenestralis Serv., 196, 1839, 726; Thom., 206, V, 1873, 118.

Prinidia fenestralis Stal, 200, I, 1873, 133; Sauss., 134, 1884, 161; Fern., 53, 1888, 44; Beut., 3, VI, 1894, 303, Plate VIII, Fig. 3: Morse, 99, VIII, 1897, 37, 111, Plate 2, Fig. 28; B1., 15, XXX, 1898, 56; Lugg., 84, 1898, 166, Fig. 100; Scudd., 188 , 1900,40 .

Locusta sucerata Harr., 70, 1833, 583; It., 72, 1862, 180.

Edipoda encerata Scudd., 141, VII, 1862, 472; Glov., 62, 1872, Plate III, Figs. 1, 2; Plate V, Fig. 13; Plate VI, Fig. 23; Thom., 206, V, 1873, 119.

General color varying widely according to environment, from pale clay yellow to bright reddish brown or even blackish. Face yellowish brown, the cheeks grayish, the occiput and disk of pronotum darker. A narrow yellowish stripe extends back from eye on to disk of pronotum; the sides of latter with a fuscous bar near the middle. Teg-

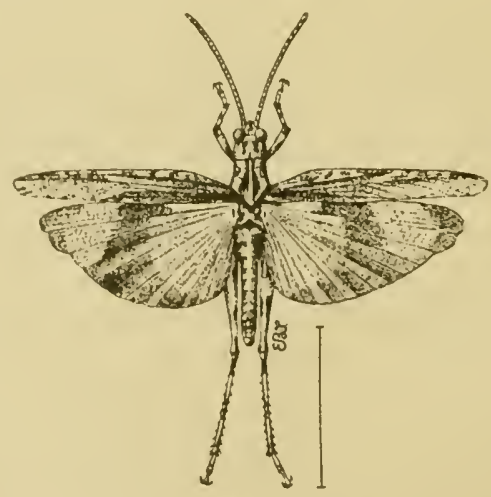

Fig. 60. Psinilia fenestralin (serv.). Male. One and one-laalf times natural size. (After lagger.)

mina yellowish or reddish brown, the lower half of sides with numerous small alternating light and dark spots; the upper half unspotted. Wings with the basal third usually orange or vermilion red, some- 
times yellow; the middle third with a broad curved black band which reaches nearly to the anal angle; the front margin with a dusky bar reaching nearly to the base; the apical third pellucid. Onter face of hind femora reddish brown, with three dark, oblique bars on the upper half; inner face with alternating bands of black and yellow. Hind tibiæ whitish, with a dark ring at each end, and a broad one of the same color just above the middle; the apical halves of spines black.

Measurements: Length of body, male, $17 \mathrm{~mm}$., female, $22 \mathrm{~mm}$; of antennæ, male, $12.3 \mathrm{~mm}$., female, $11 \mathrm{~mm}$.; of pronotum, male, $4.5 \mathrm{~mm}$., female, $5.5 \mathrm{~mm}$.; of tegmina, male, $19 \mathrm{~mm}$., female, $21 \mathrm{~mm}$.; of hind femora, male, $11.5 \mathrm{~mm}$., female, $12.5 \mathrm{~mm}$.

In Indiana the "long-horned locust" has been noted only in Lake, Porter and Laporte counties in the sandy area bordering Lake Michigan, where it was first taken July 2\%, 189\%. It is most common along the beach within one-half mile of the lake, in company with Trimerotropis marilima (Harris) and Spharagemon wyomingianum (Thom.), though a few specimens were taken on sandy ridges five miles from the lake shore. It has a quick, short flight, and al ways chooses a bare, sandy spot on which to alight. Unless it is carefully "marked down" it is then very difficult to distinguish, since its colors harmonize so perfectly with its surroundings. By keeping an eye on it, and stealthily approaching it can readily be taken by throwing the net quickly over it just as it is in the act of rising. The male makes a slight rattling sound as it flies, but the movement of the female is noiseless. The majority of the specimens taken had the inner wings a bright red at base, though variations in color, from light yellow to deep red, were frequent. It may possibly be found to occur on the sand covered areas throughout the northern third of Indiana, though it is probable that it is limited to the area immediately adjoining Lake Michigan.

\section{Sub-family ACRIDINE.}

The Indiana species of this sub-family may be easily recognized by the presence of a distinct spine or tubercle on the prosternum between the front pair of legs. They vary much in size and general appearance, and among them are found our most injurious insects of the order Orthoptera.

The head is, in gencral, smaller and less swollen than in the two preceding sub-families. The face (except in Leptysma) is rarely very oblique. often nearly perpendicular. The disk of vertex is never 
sunken or concave, the lateral carine being low and rounded, or often obsolete. The forcola are often wanting or indistinct. The disk of pronotum is always free from tubereles and prominent wrinkles; has its hind margin usually broadly rounded, and never acute angled; the median carina always low and of nearly equal height throughout; and the lateral carina, with few cxceptions rounded or obsolete. The tegmina arc usually well devcloped, but in a number of species are very short, and in some extra-limital forms wholly wanting. The inner wings are never brightly colored as in the Oedipodince, but are usually transparent.

The prevailing color of most species of the sub-family is dull olivaceous brown; though a number of them are so striped or mottled with yellow, green or fuscous as to be decidedly handsome. Among the members of the principal genus (Melanoplus) there is considerable rariation in color locally, "according to the character of the station where found, and also seasonably, whether collected early or late in the fall. As a rule specimens collected after a number of hard frosts are duller, darker and more suffused than summer examples, the coloration of the individual being apparently considerably modified by such exposure."

With one or two exceptions, all of our species pass the winter in the egg stage, and begin to reach maturity about June 1st, though most of them are not common until July. The Kentucky blue-grass and the different linds of meadow grasses are then a darker green and, when rank, turn brown early in the autumn. The different species of Melanoplus and other locusts whose hues are olive green or brown, find in the fallen clumps of these grasses places of hiding well suiting their color, as well as an abundance of food well suiting their taste.

The males of Acridince rarcly stridulate, and then only when at rest, by rubbing the inner surface of the hind femora against the outer surface of the tegmina.

Scudder, in his recent Catalogue of United States Orthoptera, lists 32 genera and 241 species as belonging to this sub-family. Of these, six genera and 26 species have been taken in Indiana. The genera may be distinguished by the following key:

KEY TO GENERA OF INDIANA ACRIDINE.

a. Face very oblique. Head as long as or longer than the pronotum; the vertex being prolonged and more or less acuminate. Antennæ acuminate, the joints flattened...........XXV. Leptrsma, p. 287

aa. Face nearly vertical. Head shorter than the pronotum, the vertex advanced but little in front of the eyes. Antennx filiform, the joints cylindrical. 
b. Size large, the length of tegmina of female 27 or more mm. Lobes of mesosternum longer than broad, the inner margin straight. Sub-genital plate of male with a distinct $\mathrm{U}$ or $\mathrm{V}$. shaped notch on its upper side. .XXXVI. ScIIISTOcERCA, p. 289

$b b$. Size small or medium, the tegmina never over $25 \mathrm{~mm}$. in length. Lobes of mesosternum transverse or equally long and broad, the inner margin usually rounded. Apex of sub-genital plate of male without a notch on its upper side.

c. General color when living, a bright, pale green, with a conspicuous purple line along the top of pronotum and dorsal part of closed tegmina. Vertex at its narrowest point between the eyes less than one and one-half times the width of second joint of antennre. Sub-genital plate of the male with a more or less distinct sub-apical tubercle ............xхx VII. Hespenotetix, p. 297

cc. Color usually dull, chiefly brownish or olivaceous. Vertex at its narrowest point between the eyes more than twice the width of second joint of antennæe. Sub-genital plate of male without a sub-apical tubercle.

d. Dorsal surface of pronotum never twice as long as the arerage breadth, generally only half as long again; the sides more or less coustricted in the middle. Antenne of male, less than twice the length of pronotum. Sub-genital plate of male with the apex rounded.

c. Head not large in proportion to pronotum, but little longer than the prozona. Pronotum not enlarged in front to receive the head. Cerci of male exceedingly variable, but very rarely styliform ..... XXXviII. Melanoplus, p. 298

ee. Head swollen; large in proportion to the pronotum, nearly half as long again as the long prozona. Pronotum feebly flaring in front to receire the head. Cerci of male styliform....

XXXIX. Phottaliotes, p. 334

dd. Dorsal surface of pronotum twice as long as average breadth; the sides parallel. Antennæe of male twice or more times as long as pronotum. Sub-genital plate of male broad, the apex truncate..........

XL. PAROXYa, p. 335

\section{Leptysma Stal (1873).}

Body slender, sub-cylindrical. Head as long as pronotum; the vertex prominent, projected in front of the eyes in the form of an equilateral triangle; the lateral carinæ low, the median carina wanting. Face very oblique, the frontal costa low, a little narrowed below the ocellus, shallowly sulcate throughout; eyes longer than wide, set very obliquely on the head. Antennæ shorter than head and 
pronotum, tapering; the joints flattened. Pronotum almost cylindrical, the metazona a little the wider, the front margin truncate, the hind margin broadly rounded; the median carina very low; distinct only on the metazona; lateral carinæ obsolete. Lateral lobes of pronotum longer than wide; the front margin oblique, the hind margin concave, the lower margin sinuate. Prosternal spine short and rounded. Tegmina fully developed, the apical third gradually narrowed. Hind femora very slender, a little shorter than abdomen in both sexes. Cerci of male slender, tapering and bent abruptly upward and forward near the base. Sub-genital plate narrow, upturned and tapering to a point. Upper valves of ovipositor much longer than lower ones, their upper margins with a row of prominent teeth.

But one species of the genus occurs in the United States.

54. Leptysma marginicollis (Serville). The Slender-bodied Locust.

Opsomala marginicollis Serv., 196, 18:39, 591.

ripmala marginimollis Thom., 206, V, 1873, 66, 196.

Laptysmu marginicollis Stal, 200, 1873, 86; Comst., 41, 1888, 111,

Fig. 102; Id., 42, 1895, 111, Fig. 12:3 B1., 6, XXIV, 1892, 28;

Id., 11, XXVI, 1894, 221 ; Id., 16, 1899, 241, Fig. 68; Scudd., $188,1900,47$; Id., $190, \mathrm{IX}, 1900,116$.

Ground color of living specimens light yellowish brown or fawn; unbroken except by a narrow, yellowish stripe, extending from the hind border of eye along the lower edge of pronotum to coxa of hind leg. In living specimens this line is bordered above by one of dark hrown. When the insect is dried the brown and the tips of tegmina become darker.

Face. vertex, occiput and pronotum, densely punctured. Tegmina exceeding the abdomen by 3 to $5 \mathrm{mms}$. Wings transparent, equal to tegmina in male, slightly shorter in the female.

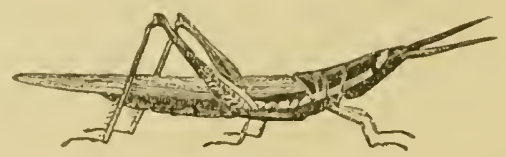

Fig. 61. Leptyma marginicollis (Serv.). (After Comstock).

Measurements: Length of body, male, $28 \mathrm{~mm}$., female, $32 \mathrm{~mm}$; of antennæ, male, $8 \mathrm{~mm}$., female $6 \mathrm{~mm}$.; of pronotum, male, $5 \mathrm{~mm}$., female, $6 \mathrm{~mm}$; of tegmina. male, $20 \mathrm{~mm}$., female, 26 ; of hind femora, male, $14 \mathrm{~mm}$., female, $17.5 \mathrm{~mm}$.

This slender bodied, graceful species, has as yet been taken only in Vigo County, where, in October, 1892, it was found to be common on 
the tall sedges and rushes which grew near the margin of a large pond in the Wabash River bottoms, nine miles below Terre Haute. Its range before that time had been supposed to be a strictly southern one, it having been recorded only from Florida and North Carolina. Since then it has been found to extend across the southern United States from the Atlantic to the Pacific. Its occurrence in numbers as far north as central Indiana is, therefore, of especial interest, and ean only be accounted for by the presence of the broad and sheltering valley of the Wabash, within the confines of which it finds a climate and a regetation congenial to its taste.

In 1893 and 1894 the insect was still present, though in rapidly decreasing numbers as the pond was partially drained. I was much surprised to find, on May 21, 1893, a fully developed male with soft flabby wings, as though just moulted, though no other's of any age were seen on that date. In October, 1902, I again visited the former site of the pond, but found only a vast cornfield, with no signs of this or other rare Orthoptera, which formerly dwelt in numbers in that locality. If still a member of the Indiana fauna, marginicollis will probably be found only about the margins of the larger ponds in the lower Wabash Valley.

At the locality mentioned, marginicollis was never seen on the grass or ground and never hopped when disturbed, but moved with a quick and noiseless flight for 20 or more feet to a stem of sedge or rush, on which it alighted. The instant it grasped the stem, it dodged quickly around to the side opposite the intruder. Then holding the stem firmly with its short front and middle legs, it drew its slender hind femora close up against the body, and folding the tibix into position, hugged its support as closely as possible, and remained perfectly motionless. Its body is almost cylindrical, and being of the same general color as the stalk of the plant on which it rested, it was almost impossible to detect it, unless one saw exactly where it alighted. Eight times out of ten a person, by approaching quietly, could reach his hand about the plant stem and grasp the insect. Its habits excellently illustrated the so-called "protective mimicry" of form and coloring, as it always seemed to choose a cylindrical object, and one similar to its own color before alighting.

\section{Schistocerca Stal (1873).}

Locusts of large size. Vertex with the front sloping downward and passing insensibly into the frontal costa; the lateral carinæ low and indistinct, the median carina wanting, the foveolæ very small, 
often obsolete. Face nearly vertical. Eyes oblong, oval, prominent. Antennæ of medium length, filiform. Disk of pronotum with the sides sloping on the prozona, the metazona usually flat or nearly so; the front margin truncate, the hind margin either broadly rounded or, in some males, obtuse angled; the median earina low but distinct, cut three times by the transverse sulci; the lateral carinæ wanting. Lobes of mesosternum longer than broad. Tegnina always fully developed. Inner wings of large expanse, transparent or nearly so. Hind femora slender, usually equaling or exceeding tip of abdomen. Hind tibiæ with smooth margins, and with numerous spines in regular rows on each side. but with no apieal spine on the outer margin. Second tarsal joint only half as long as the first. Male with cerci oblong and of nearly equal breadth throughout; the sub-genital plate strongly upcurved, its apex deeply notched. Valves of ovipositor strongly exserted.

Eleven species of the genus occur in the United States. Of these, four have been taken in Indiana.

\section{KEY TO INDIANA SPECIES OF SCHISTOCERCA.}

a. Antenna of male not more than one-fourth longer than head and pronotum together.

b. Size very large. Tegmina of female much exceeding the abdomen. Disk of pronotum flat or nearly so, the median stripe broad ......................55 amcricana, p. 290

$b$. Size small. Tegmina of female but little if any exceeding the abdomeu. Disk of pronotum with sides distinctly sloping, the median stripe confined to the cariua......56 damnifica. p. 293

an. Size, medium. Antenma of male one-third or more longer than the head and pronotum together.

c. General color yellowish brown or olive green; a distinct pale yellow mid-dorsal stripe on head, pronotum and closed tegmina ..................57 alutacca, p. 294

cc. General color rusty brown. No yellow stripe on dorsal surface ..................58 rubiginosa, p. 296

55. Somistocerou americaxa.(Drury). The American Locust.

Gryllus americanus (Drury), 48, I, 1770, 128, Plate 49, Fig. 2.

Acridium americanum Scudd., 14 1, VII, 1862, 466; Rathv., 109, 1862, 385, Fig. 25; Thom., 202, V, 1865, 448, 452; Id., 206, V, 1873, 172, Fig. 8; Id., 21 1, IX, 1880, 91, 129, Fig. 10; Glov., 62, 1872, Plate I, Fig. 15; Riley, 117, VIII, 1876, 103, Fig.40; Id., 118 , IX, 1877 , 84, Fig. 17; Id., 214 , I, 1878, 236, 448, Fig. 6; Id., 122, II, 1884, 194, Fig. 269; Comst., 41, 1888, 106, Fig. 96; Bent., 3, VI, 1894, 304, Plate IX, Fig. 3. Arridium (Schistocerra) americunum Stal, 200 I, 1873, 66. 
Schistocerca americana Brun., 22, I, 1885, 136; Id., 28, XXVIII, 1893, 10, Fig. 1; Id., 30, 1893, 462, Fig. 106; Id., 3 1, 1894, 163, 204, Fig. 66; Id., 34, 1896, 122, Fig. 24; Id., 35, 1899, 133, Fig. 75; Id., 36, 1899, 270, Fig. 63; Bl., 4, XXIII, 1891, 79; Id., 9, VI, 1893, 465; Id., 16, 1899, 238, Fig. 63; How., 75, VII, 1895, 220, 429, Figs. 19-22; Weed, 222, 1897,67, Figs. 21-25; Lugg., $84,1898,174$, Figs. 105, 106; Morse, 100 , VIII, 1898, 255, 271; Scudd., 184, XXXIV, 1899, 447, 474; Id., 188, 1900, 47.

Size large, the female often two inches or more in length. Vertex hexagonal, the disk a little depressed. Frontal costa prominent, sulcate in the middle below the ocellus; a little narrowed below point

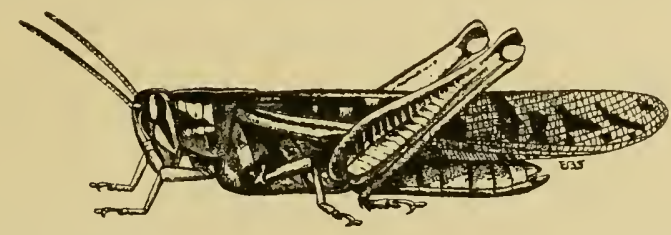

Fig. 62. Schistocerca americana (Drury). Male. (After Lugger).

of union with the vertex. Antennæ but little, if any, longer than head and pronotum together. Disk of pronotum flat on metazona, the sides rounded and sloping on prozona, the surface marked with minute shallow cells, or densely punctate, the hind margin broadly rounded. Tegmina exceeding the abdomen one-fourth or more their length in both sexes. Hind femora slender, reaching tip of abdomen. Spine of prosternum large, curved somewhat backward. Notch of sub-genital plate of male narrow but deep.

Color, reddish brown, often with a slight vermilion tint. A yellow stripe extends from the vertex along the middle of head, pronotum and closed tegmina as far as the tip of the abdomen. A dark brown line runs from the lower side of eye down the cheek. Sides of pronotum with a broad yellowish stripe on upper third and a short and narrow yellow dash near the center; the lower margin yellowish. Tegmina with numerous large dark brown spots, separated by light interspaces; the costal or lower margin whitish yellow, mottled with darker. Wings transparent, the nerres of basal portion yellowish. Outer face of hind femora reddish brown, with one or two dark streaks along the upper third. Hind tibiæ vermilion red, duller in dried specimens; the spines yellow, tipped with black.

Measurements: Length of body, male, $42 \mathrm{~mm}$., female, $50 \mathrm{~mm}$; of antennæ, male, $13 \mathrm{~mm}$., female, $14 \mathrm{~mm}$; of pronotum, male, 9 mm., female, $11 \mathrm{~mm}$; of tegmina, male, $43 \mathrm{~mm}$., female, $53 \mathrm{~mm}$; of hind femora, male, $24 \mathrm{~mm}$., female, $30 \mathrm{~mm}$. 
This is the largest locust found in the State, and when freshly moulted, one of the most handsome. It probably occurs in all the counties but is much less common in the northern half, though I have taken it in Fulton, Starke, Lake and Porter. Freshly moulted, mature specimens, from eggs hatched in spring, have been taken in Vigo County on June 13th, and on three different occasions numerous specimens hare been seen as late as November 22d. On this date, in Marion Connty, when the government thermometer registered $17^{\circ}$ in the morning, several were flushed in the afternoon, though a cold raw wind was blowing. In central and sonthern Indiana it is more abundant in mid-autumn than in summer. There occasionally may be two broods in one season, as I have found the nymphs common in Vigo County on October 15th and 21st.

This species is noted for its extended migrations and when a second brood appears, they are doubtless from eggs laid by mature specimens which have entered the State in early spring. About 3 o'clock in the morning of April 11, 1893, the city of Terre Haute, Indiana, was visited with a severe storm of rain and wind from the southwest. A number of buildings were unroofed and many shade and forest trees twisted and broken off. While on my way to the High School building several persons informed me that they had, that morning, seen specimens of "gigantic grasshoppers" on the strect, but were unable to capture them. About 10 o'elock one of my former pupils brought me two living specimens of $S$. americana which she had picked up from the sidewalk near her home. They had come sailing in on the wings of the wind from some distant point in the sonthwest, where they had passed the winter in the mature state or as an advanced form of the young. Mature individuals which had doubtless migrated have also been taken in Lake County on May 13th.*

In the southern portion of Indiana, americana is always found in dry, mpland localities, such as the borders of roads, old meadows, weed and stubble fields, prairies, and especially in old abandoned fields which have grown up to oak and other shrubs. In the northern portion it occurs in damper localities, being found in the tall grasses and sedges along the borders of sloughs and marshes and in the meadows bordering lakes and tamarack marshes. When flushed it rises quickly and with a fluttering noise, makes a long, wavering, jerky flight, and alights upon the bole or branch of tree or shrub, a fence, or some other object some distance above the earth; seldom,

At Oruond, Florila, this locust was abundant and mature in carly March, 1899, and it may pass the winter in the mature stage in some of the States unch farther north. 
if ever, settling on the ground. If then approached, it dodges around the object upon which it rests, much as does a squirrel under the same circumstances.

Of the distribution of the American locust Scudder has written: "Excepting S. peregrina, which has crossed the ocean and colonized another world, $S$. americana is the most widely distributed member of the genus, and merits its name, ranging as it does from North America east of the Great Plains and south to about latitude $40^{\circ}$; through the West Indies, Mexico and Central America to South America, where it occurs as far as Columbia in the west and Argentina in the east, though the records of its occurrence in South America are few. North of north latitude $40^{\circ}$ or thereabouts, sporadic cases of its appearance are recorded, notably in Massachusetts and southern Ontario; these are doubtless accidental visitants, flying from their proper home farther south."

\section{Schistocerca Damnifica (Saussure).}

Acridium damnificum Sauss., 128 , II, 1861, 14.

Schistocerce damnifice Scudd., 184, XXXIT, 447, 475; Id., 188, 1900, 47 ; Bl., 18, 1902, 48, 222.

Cyrtacanthaeris unilineata Walk., $219, \mathrm{IV}, 1870,611$.

Acridium unilineatum Thom., 188, V, 1873, 170.

Acridium appendiculatum Scndd., 162, XIX, 1877, 86; Id., 161 , VI, 1878, 27.

Acridium intriginosum Thom., 206, V, 1873, 170; Id., 21 1, IX, 1880, 91, 128 (not Harris).

Size of malc small; of the females medium and more bulky. Head small; the disk of vertex hexagonal. Frontal costa sulcate, and with the sides parallel below the ocellus, a little expanded and flat just above, then narrowed at point of union with vertex. Antennæ of male stout, but little, if any, longer than head and pronotum together. Disk of pronotum with the surface very rough with small pits and impressions, the sides strongly sloping, the median carina relatively high, and a little arched, the hind margin right angled in the male, obtuse angled in the female. Tegmina of male usually equaling or slightly exceeding the abdomen; those of female a little shorter; broader than in alutacea. Hind femora of female shorter than abdomen. Notch of sub-genital plate of male deep and narrowly V-shaped.

Color, a nearly uniform dark rust red. A narrow brownish yellow line on occiput and carina of pronotum. Tegmina often with small, dim dusky spots. Outer facc of hind femora sometimes whitish, with dark narrow oblique lines arranged herring-bone fashion. 
Measurements: Length of body, male, $25 \mathrm{~mm}$., female, $42 \mathrm{~mm}$.; of antennx, male, $10 \mathrm{~mm}$., female, $11 \mathrm{~mm}$; of pronotum, male, 7 $\mathrm{mm}$., female, $9.5 \mathrm{~mm}$; of tegmina, male, $22 \mathrm{~mm}$., female, $27 \mathrm{~mm}$; of hind femora, male, $16 \mathrm{~mm}$., female, $19 \mathrm{~mm}$.

This is a locust of southern range, which in Indiana has been taken only in Crawford County. A single female was secured May 10, 1899. This was probably a migrant, as this is a very early date for eggs hatched in spring to mature, and it is not known that the species winters in the nymph stage. Other specimens were taken in June and July, 1902. It frequents old fields and roadsides on the crests of the higher hills near Wyandotte, and is probably to be found in similar localities in the southern third of the State. When flushed they fly long distances and often alight on the limbs of trees or fence posts, around which they dodge, and from which they may often be taken with the hand.

Thomas has taken damnifica in southern Illinois, and Scudder says that it "is a common southern species, occurring in the United States east of the Great Plains, from Pennsylvania, Indiana, Illinois and Arkansas to the Gulf." He gives no Indiana locality. In 1899 I found it abundant at Ormond, Florida, on March 11th and later.

57. Sohistocerca alutacea (Harris). The Leather-colored Locust. Acridium alutaceum Harr., 71, 1811, 139; Id., 72, 1862, 173; Scudd., 141, VII, 1862, 466; Rathv., 109, 1862, 384, Fig. 25; Glov., 62, 1872, Plate VIII, Fig. 13; Plate X, Fig. 13; Thom., 206 , V, 1873, 171; Comst., 41, I, 1888, 106; Fern., 53, 1888, 30; Bl., 4, XXIII, 1891, 79; Beut., 3, VI, 1894, 304, Plate IX, Fig. 2.

Schistocerca alutaceu Brun., 29, III, 1893, 26; Lugg., 84, 1898, 172; Morse, 100, VIII, 1898, 255, 270, Plate 7, Fig. 32; Scudd., 184 , XXXIV, 1899, 445, 464; Id., 188, 1900, 47.

Acrilium smarginatum Dodge, 44, IV, 1872, 15; Scudd., 147, 1872, 250; Thom., 206, V, 1873, 172; Id., 211, IX, 1880, 91, 128.

Schistocerca umarginata Brun., 29, III, 1893, 26; Id., 33, II, 1895, 7, Fig. 46; Lugg., 84, 1898, 173, Fig. 104.

Size medium, the female much the larger, with more robust body. Vertex rather prominent, narrow, the disk sub-rhomboidal, but little depressed, the lateral carine low, distinet only on front half. Frontal costa narrow, sulcate below the ocellus. Antenne of male one and a half times as long as head and pronotum together, the joints a little flattened. 1)isk of pronotum flat on metazona, the sides higher and sloping on prozona, the hind margin broadly obtuse angled; the surface densely punctate: the median carina low but distinct. Prosternal spine large, cylindrical, the apex rounded. 
Tegmina exceeding the abdomen about one-fourth their length in both sexes. Hind femora slender, reaching the tip of abdomen in female, exceeding it slightly in male. Cerci of male short oblong, the upper edge concave or broadly notched; the notch of sub-genital plate U-shaped, about as broad as deep.

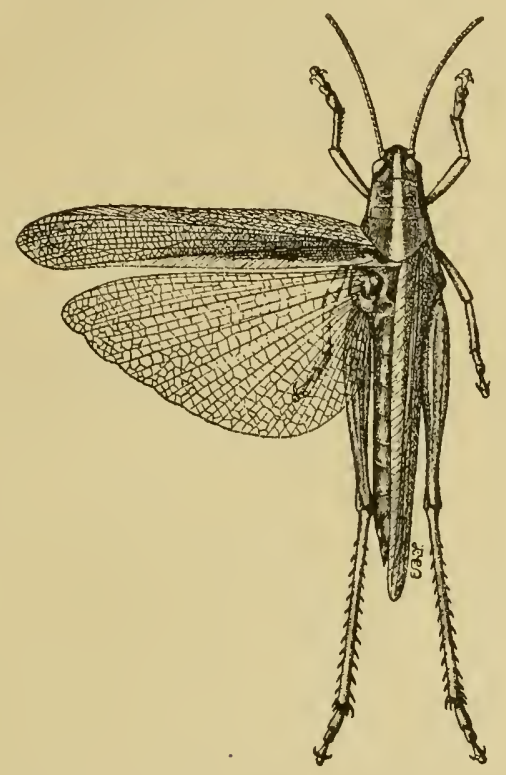

Fig. 63. Schistocerca alutacea Harris. Female. (After Lugger.)

Color, yellowish brown to olive green, darker in old or dried specimens. A narrow bright yellow line runs from the front of vertex back over head, pronotum and middle of closed tegmina. Sides of tegmina with often a few minute fuscous spots. Wings transparent yellowish, the veins darker. Sides of abdomen with a row of black dots on the hind margin of each segment. Outer face of hind femora reddish brown or yellowish with a row of black dots along the upper and lower margins. Hind tibix reddish; the spines yellowish, tipped with black.

Measurements: Length of body, male, $30 \mathrm{~mm}$., female, $45 \mathrm{~mm}$; of antennæ, male and female, $16 \mathrm{~mm}$; of pronotum, male, $7 \mathrm{~mm}$., female, $10 \mathrm{~mm}$.; of tegmina, male, $26 \mathrm{~mm}$., female, $38 \mathrm{~mm}$.; of hind femora, male, $18 \mathrm{~mm}$., female, $25 \mathrm{~mm}$.

This species has been taken only in the western half of the State from Monroe County northward. It is abundant about the marshy meadows and sloughs in Fulton, Lake and Starke counties, where it 
has been taken on August 15 th in numbers. There it makes its home in the rank grasses, weeds and rushes which grow in such places. The males are everywhere much more abundant and more active than the females, though they usually fly a shorter distance. In Vigo County it is frequent in patches of raw prairie and along the edges of thickets bordering them; also in many places along the railways, especially where they pass through prairie regions. Both sexes, when flushed, arise with a whirring noise which, however, is not a true stridulation. The males usually fly about 50 feet and settle down on the grass or on a low shrub. This locust will doubtless be found to inhabit suitable localities throughout the State, as it has been taken from New England to California.

58. Schistocerca rubininosa (Harris-Scudder). The Rusty Locust.

Acrilium rubiginosum Scudd., 14 1, VII, 1862, 467; Glov., 62, 1872, Plate T, Fig. 5; Riley, 122 , II, 1884; 194; Comst., 4 1, 1888, 106; Fern., 53, 1888, 30; Bent., 3, VI, 1894, 304, Plate LX, Fig. 1.

Thehisturema rubiginosa Morse, 93, VII, 1894, 105; Id., 100, VIII, 255, 269, Plate 7, Fig. 31; Scudd., 184 , XXXIV, 1899, 445, 462; Id., $188,1900,48$.

Schistorerea alutaren Rehn., 11 1, XIII, 1902, 89; Id., 112, 312.

Size, medium; the body of the female especially bulky. Head and pronotum wider than in alutacea, but the vertex less prominent. Frontal costa wider and flatter than in alutacca, sulcate below the ocellus. Antennæ of male a third longer than head and pronotum together. Pronotum with the sides sloping on both prozona and metazona; the median carina more prominent than in alutacea, otherwise the same. Tegmina exceeding the abdomen in both sexes. Notch at apex of cerci of male less evident than in preceding species; that of sub-genital plate narrower, more $\mathrm{V}$-shaped.

Color a nearly uniform rusty brown, without median yellow stripe on head and pronotum; the tegmina usually with numerous dim, rounded fuscous spots on the sides. Wings transparent and glassy, slightly reddish toward the tip.

Measurements: Length of body, male, $30 \mathrm{~mm}$., female, $43 \mathrm{~mm}$; of antennx, male, $13 \mathrm{~mm}$., female, $15 \mathrm{~mm}$; of pronotum, male, $\gamma$ mm., female, $10 \mathrm{mmn}$.; of tegmina, male, $27 \mathrm{~mm}$., female, $37 \mathrm{~mm}$.; of hind femora, male, $1 \% \mathrm{~mm}$., female, $22 \mathrm{~mm}$.

This seems to be a scarce locust in Indiana, having been taken only in Porter County. It prefers dry upland pastures and woodland, especially those with a soil of sand, where scrub oaks abound. Its liabits are the same as those of alulucea. Rehn, loc. cit. has placed 
it as a synonym of that species; but, aside from the color, the shorter antemnx, less prominent vertex and frontal costa, and more sloping disk of pronotum are sufficient to show its distinctness. The mere fact that on one or two oceasions, opposite sexes of it and alutacea were found in copulation is no proof of their identity in species, for such widely diversified forms as Melanoplus bivittatus and Meldnoplus differentialis have been noted thus. Rubiginosa ranges over the United States east of the Great Plains and will doubtless be found to inhabit dry sandy localities in many portions of the State.

\section{Hesperotettix Scudder (18\%6).}

Size small; the sides nearly parallel; not greatly compressed. Head small, the vertex opposite the middle of eyes but little wider than second joint of antennæ; the portion in front with a slight median furrow or depression. Face but little oblique, the frontal costa narrow, sulcate throughout, punctate. Antennæ of female equaling the head and pronotum together; a fourth longer in the male. Pronotum longer than in allied genera except Paroxya, the prozona half as long again as metazona, the sides of disk broadly sloping; the median carina low, not cut by the first and second sulci; the hind margin very obtusely angulate. Lateral lobes of pronotum with the front and hind margins nearly straight, oblique; the lower margin with its front half directed upward. Tegmina usually equaling or slightly exceeding the tip of abdomen. Fore and middle femora of male swollen; hind femora slender, much surpassing the abdomen. Subgenital plate of male entire, but with a more or less distinct subapical tubercle.

Seven nominal species are known from the United States, mostly from west of the Mississippi River. One has been taken sparingly in northern Indiana.

59. Hesperotettix PRatensis Scudder.

Hesperotettir pretensis Scudd., 181, 1897, 57, 64, Plate V, Fig. 3; Id., 188, 1900, 50; Lugg., 84, 1898, 177, Fig. 107; Brun., 36, 1899, $247,271$.

Ommatolampis viridis Thom., 206, V, 1873, 156 (in part).

Pronotum slightly increasing in size from in front backward. Tegmina equaling or slightly exceeding the abdomen in both sexes. Supra-anal plate of male triangular, the middle of either half with a distinct ridge, which converge and enclose a basal groove, in which lie the minute, rounded furcula. Cerci, shorter than supra-anal 
plate, conical, tapering to a rather sharp point. Tuberele on subgenital plate indistinct. (See lig. 1, Plate I.)

Color, bright pale green. A short fuscous bar below each eye and on middle of sides of pronotun; also one along middle of oeciput.

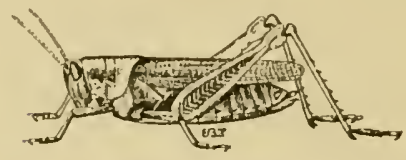

Fig.64. Hesperotettix pratenois Scudd. Female. Natural size. (After Lugger). Antemna pinkish. Disk of pronotum with a pinkish or purplish stripe along its middle, extending back along median line of closed tegmina, and fading insensibly into the green of their sides. Hind femora green, more or less tinged with purplish. Hind tibia, pale bluish green; the spines whitish, tipped with black. Abdomen greenish yellow.

Measurements: Length of body, male, $17 \mathrm{~mm}$., female, $24 \mathrm{~mm}$.; of antennæ, male, $8 \mathrm{~mm}$., female, $9 \mathrm{~mm}$.; of pronotum, male, $5 \mathrm{~mm}$., female, $6 \mathrm{~mm}$.; of tegmina, male, $12 \mathrm{~mm}$., female, $17 \mathrm{~mm}$.; of hind femora, male, $11 \mathrm{~mm}$., female, $13.5 \mathrm{~mm}$.

This dainty and prettily colored species has been noted only in Lake County, where it has been taken in two localities. On September 19,1898 , a single pair were secured from the long grasses bordering the margin of a swale north of Millers. Though careful search was made there and elsewhere in the northern counties, no others were secured until July 24, 1902, when I found them rather common in a long, low, marshy trict, a mile sontheast of Hammond. Here the males were especially active, leaping from one grass stem to another sereral times in snecession, and dodging around the stem the instant they elasped it with their legs. The females were oftentimes easily picked up by the fingers from their resting places. No attempt was made by either sex to use the wings in escaping.

Pratensis ranges, according to Sendder, from the "Mississippi River westward to California;" though he also names southern Illinois as one of its localities. It should be looked for along the edges of prairies and marshes throughout the western half of Indiana.

\section{XXXViII. Melanoplus Stal (18\%3).}

Body moderately stout; generally fecbly compressed. Head not prominent,* lout little if any longer than the prozona. Face almost vertical. Vertex between the eyes but little wider than the frontal costa; the front half sloping downward, and always more or less sulcate, especially in the male. Frontal costa of average width and

\footnotetext{
* Except in punctulatus.
} 
prominence, usually sulcate below the ocellus. Antennæ slender, filiform, never more than twice as long as the pronotum. Disk of pronotum usually only half as long again as the average breadth; the prozona distinctly longer than the metazona, its edges parallel, its surface a little convex and faintly punctate; metazona with its edges more or less diverging backward, its surface flat and densely punctate; front margin truncate, hind margin obtuse angulatc; the median carina low but distinct on the metazona, often faint or obsolete on the prozona; the lateral carinæ obsolete. Lateral lobes of pronotum vertical or nearly so, and usually marked on their upper half with a blackish band. Tegmina always present, in some species being mere oval or lanceolate scales, but little, if any, longer than the pronotum; in others fully developed and then attaining or a little surpassing the tips of the hind femora.* Wings either represented by minute scales or fully developed, transparent, colorless. Hind femora moderately long and slender, usually equaling the tip of abdomen in the female and surpassing it in the male. Cerci of male exceedingly variable in form, often enlarged at apex, never styliform, and usually about the length of the sub-genital plate. Furcula usually developed and to a variable extent and also variable in form; so that they and the cerci furnish characters much used in separating the species one from another.

This genus comprises more species than does any other of the North American Orthoptera, no less than 146 being listed by Seudder from the United States and Canada. Of these 17 have been taken in Indiana. Some of these, to the casual observer, may seem very similar in size, color and general appearance, but a close examination of the abdominal appendages of the male will at once prove their distinctness. The tyro will probably have much difficulty in separating the females of the different species; in fact, he can only do so by taking the two sexes in the field, where they are nsually to be found associated together. While dull colored and uninteresting to most people, the members of this genus form the most characteristic group of our Acrididæ. To it belong our most common locusts and the ones which do the most injury. From mid-Mray until late November they leap from our pathway in numbers, whether we stroll through open woodland, sunny meadow, or along the roadside; while in the back yards and on the lawns of our eity homes they swarm in great profusion.

\footnotetext{
"None of our species, unless it he fusciutus, are dimorphic as regards wing length. I have seen only the short winged form of fasciatus, in Indiana, though a long winged one is known.
} 
The Kansas or Rocky Mountain grasshopper, Melanoplus spretus (Uhler), belongs to this genus, but does not occur in Indiana. Contrary to the general belief, it is not a large, robust speeies, being but about the same size as our red-legged grasshopper, M. femur-rubrum (DeG.), and bearing to the latter a close general resemblance; so

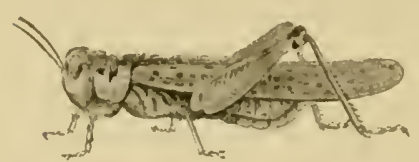

Fig. 641/2. Melanoplus spretus (Uhler). Male. Natural size. close, in fact, that only specialists can readily tell them apart. Millions of dollars of damage was done in the Western States by these small insects in the summers of $18 \% 3$ and 18\%5. Migrating in vast clouds from one part of the country to another they would fall upon a cornfield and convert, in a few hours, the green and promising acres into a desolate stretch of bare, spindling stalks and stubs. In the words of the prophet Joel: "The land was as the garden of Eden before them, and behind them a desolate wilderness; yea, and nothing did escape them."

The following key will aid in the separation of the 17 Indiana species of the genus:

\section{KEY TO TIIE INDIANA SPECIES OF MELANOPLUS.}

a. Tegmina much sluorter than the abdomen; often no longer than the plonotum. Fureula of male almost always feebly developed, usually no longer tlian the last dorsal segment to which they are joined.

b. Cerei of male either equal or tapering beyond the midale, no broader at apex than at the middle, usmally laminate. Tegmina ovate, about the length of the pronotum.

c. Literal lobe of pronotum a nuiform yood brown in the îmale; with a faint dusliy lar on upper lalf in male. Hind femora of male not barred witl blackish. Hind

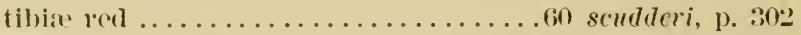

re. Iatcral lolve of pronotum in both sexes with a moad slinind black lan along the mpper half; the lower half yellowish white. Hind fenora of male with two distinct oblique hlackish bars. Hind tibiae palo green..........

(31 riridipes, 1). :30.5

bh. Corci of male with the apex more or less expanded, broader at olovate or nalrowly olsong. or longer than pronotum and lanceolate.

d. Tremina slortor than pronotum. and with a wide intreval betwerell their inucy extges.

c. Hind marerin of pronotmm without a trace of median notell. Crrei of male trumeate at tip. Fureula cylindrical, taperius ............. 
ce. Hind margin of pronotum with a minute but distinct notch in the middle. Cerei of male rounded at tip. Furcula not eylindrical or tapering.

$f$. Tegmina narrowly oblong. All the femora green. Furcula minute, rounded.......

63 gracilis, p. 308

ff. Tegmina broadly ovate. All the femora brown. Fureula well developed, very broad at base, more or less angled or bifid at middle .......64 morsei, p. 309

dd. Tegmina lanceolate, longer than pronotum, their inner edges overlapping.

g. Subgenital plate of male distinctly narrower than long. its extremity strongly elevated. Middle of male cerci but little narrower than base. Tegmina covering two-thirds or more of abdomen ..............

65 fasciatus, p. 311

gy. Sub-genital plate of male short and broad, its extremity but little clevated. Niddle of male cerei distinctly narrower than the base. Tegmina covering but one-half the abdomen ......66 blatchlcyi, p. 313

"u. Tegmina (exeept in the female of extrcmus) as long as or longer than the abdomen. Fureula usually either well developed or obsolete.

$h$. Cerci of male either equal or tapering beyond the middle, the tip usually slender or acuminate, never forked.

i. Apex of sub-genital plate or male with a median notch. Cerci short and nearly equally broad throughont, their length not more than twice as much as the middle breadth .................67 atlanis, p. 314

ii. Apex of sub-genital plate of male entire. Cerci at least three times as long as the middle breadth, generally slender, the apical half sometimes much narrower than the basal.

j. Sub-genital plate of the male nearly as broad at apex as at hase; the apex elevated above the lateral margins, and terminating in a tubercle. Cerci of male narrowing but little in apieal half.............

68 impuliens, p. 316

ji. Sub-genital plate of male distinctly narrower at apex than at hase, the apex not elevated above the lateral margius. Apical half of eerei distinctly narrower than the hasal half.

l. Tegmina much surpassing the hind femora; hind tibire bright red. Apical half of male cerci mueh less than half as broad as the extreme base .........69 femur-rubrum, p. 317 
$k k$. Tegmina shorter than hind femora; those of female shorter than abdomen. Hind tibixe pale red or yellowish. Apical half of male cerci distinctly mole than lialf as broad as the extreme base .......... 70 extremus, p. 319

hh. Cerei of male with the apex mole or less expanded so as to be broader at some point beyond the middle than at the middle; the tip spatulate or suls-spatulate or forked.

l. Cerci of male not forked, the tip no broader than the base. Furenla well developed, at least a third as long as supraanal plate .............. 11 angustipenuis, p. 821

1l. Cerei of male either distinctly forked or with a sub-median process or angle; or else expanded so as to be very much broader at the till than at the base. Furcula wanting or minute.

$m$. Size small, the male being less than $20 \mathrm{~mm}$. in length. Cerci always forked or with a sub-median angulation:

n. Lower fork of cerei merely an angle or median process. Furcula consisting of slender spines. Bases of lateral margins of sub-genital plate incured .............. 72 minor, p. 322

ni. Forks of cerci nearly equal, distinct. Furcula consisting of short triangular lobes. Lateral margins of sub-genital plate nowhere incurved .............. T3 luridus, p. 324

$m m$. Size larger, the length of male being more than 20 mm. Cerci with the apical half much enlarged, but never distinetly forked.

o. Tegmina withont distinct roundish fuscous spots. Length of body of male more than 25 $\mathrm{mm}$. Front marerin of pronotum not flaring to receive the head.

p. Pronotum without light colored lateral stripes. Hind tibia yellow. Furcula of male wholly absent...............

74 differcutialis, p. 320;

pl. Pronotum with light colored lateral stripes along the margin of the disk. Hind tibia red or purplish. Furcula present Jut small ........ T5 biritattus, p. 329

oo. 'Tegmina with distinct roundish fuscous spots. Length of hody of male less than $23 \mathrm{~mm}$. Front marin of pronotum slightly flaring to remive the prominent heal..............

7) pmelulatus, 1). 3281

60. MELaNoplu's sCUDDERI (Uhler). S'ndder's Short-winged Locust.

Pezolettir smulteri Uhl., 212 , II, 1864, 555; 'Thom., 206, V, 1873, 152; Id., $211, \mathrm{IX}, 1880,95,121$; Comst., 41, 1888, 107; B1., 4, XXIII, 1891, 80; Bent., 3, VI, 1894, 309, Plate VIII, Fig. 6. 
Melanoplus scudderi Scudd., 179, XXXVI, 1897, pp. 8, 33; Id., 181 , 1897, 125, 212, Plate 14, Figs. 5, 6; Id., 188, 1900, 63; Lugg., 84, 1898, 184, Fig., 108; Morse, 100 , VHI, 1898, 256, 280, Plate 7, Fig. 37.

Pezotettix unicolor Thom., 206, V, 1873, 151; Id., 208, V, 1875, 888, Plate XLV, Fig. 4; Id., 211 , LX, 1880, 95, 118; Glov., 62, 1873, Plate XIII, Fig. 9.

Size medium or small. Vertex but little elevated above the pronotum, the interspace between the eyes of the female, about as broad as frontal costa, narrower in the male; its front half strongly sloping downward; the median sulcus shallow. Frontal costa feebly sulcate at and below the ocellus. Antemne about three-fourths (male) or less than two-thirds (female) as long as hind femora. Pronotum with the disk broadly convex; the prozona from a fourth to a half longer than the densely punctate metazona, the median carina distinct, but low and equal thronghout; front margin truneate or nearly so, and often faintly notehed in the middle; hind margin obtuse-angled. 'Tegmina about as long as the pronotmm, broad ovate in shape, their inner edges a little separated or just fouching in the male, often overlapping in the female. Wings not half the length of the tegmina. Cerci of male sub-falcate, about twice as long as their basal breadth; the rounded apex about half as broad as the base. Furcula minute, triangular. (See Fig. 2, Plate I.)

Color: Dull reddish or wood brown, nearly uniform in the female. The male, and sometimes the female, with an indistinct dusky bar reaching from the eye back along the upper half of each lateral lobe of pronotum as far as the metazona. Hind femora with two faint dark bars on their upper face, the knees blackish. Hind tibia bright red, often paler at base, the spines black.

Measurements: Length of body, male, $19 \mathrm{~mm}$., female, $24 \mathrm{~mm}$; of antennx, male and female, $8 \mathrm{~mm}$.; of pronotum, male, $6 \mathrm{~mm}$., female, $7 \mathrm{~mm}$.; of tegmina, male, $6 \mathrm{~mm}$., female $7 \mathrm{~mm}$.; of hind femora, male, $11 \mathrm{~mm}$., female, $13 \mathrm{~mm}$.

This short-winged, dull colored locust occurs throughout the State, but is more common southward. On account of its short tegmina, persons who are interested in Orthoptera are very apt at first to regard it as a nymph of some other species. In the central counties it begins to reach maturity about August 5th, and has been taken as late as November 22d. It is one of the most common of the late autumn locusts, frequenting the borders of open woods, fence rows and roadsides, especially in dry situations where blue-grass abounds. On warm sunny afternoons in November, it may often be seen resting quietly on the sides of logs, or the lower part of rail or board fences, 


\section{EXPLANATION OF PLATES I AND II}

\section{PLATE I.}

Fig. 1. IIexperotettir matensis Seudder.

2. Melunoplus semderi (Uhler).

3. Velunoplus viridipes (Walsh).

4. Melunoplus oboraliyemis (Bl.).

5. Melunoplus grarilis (Brun.).

6. Melronoplus morsei $\mathrm{Bl}$.

7. Volunoplus fuspiutus (Walker).

8. Velemolus blutehlemi Scudd.

9. Melunoplus utlunis (Riley).

10. Melanoplus impurlicus Scudder.

\section{PLATE II.}

Fig. 11. Velentrplus femur-velum (DeG.).

12. Mclunoplus sitremes (Walker).

13. Melanophs anyustipemmis (Dodge).

14. Melenoplus minor (Scudder).

15. Melunoplus luridus (Dodge).

16. Velunoplus differentiulis (Uhler).

17. Melamoplus bivitutus (Say).

18. Melumoplus punctulutus (Uhler).

19. I'hetuliotes nelureserensis (Thom.).

20). Prerongu hoosieri (Bl.). 
Plate I.
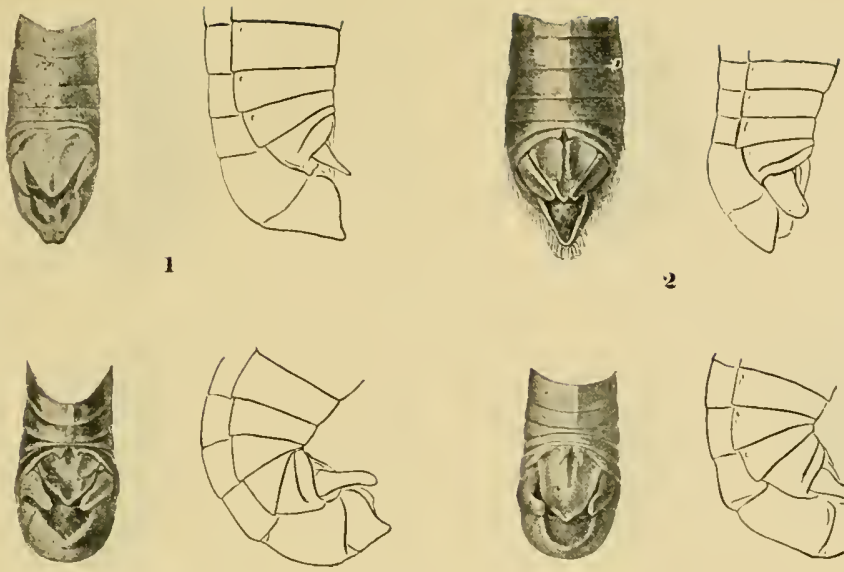

3
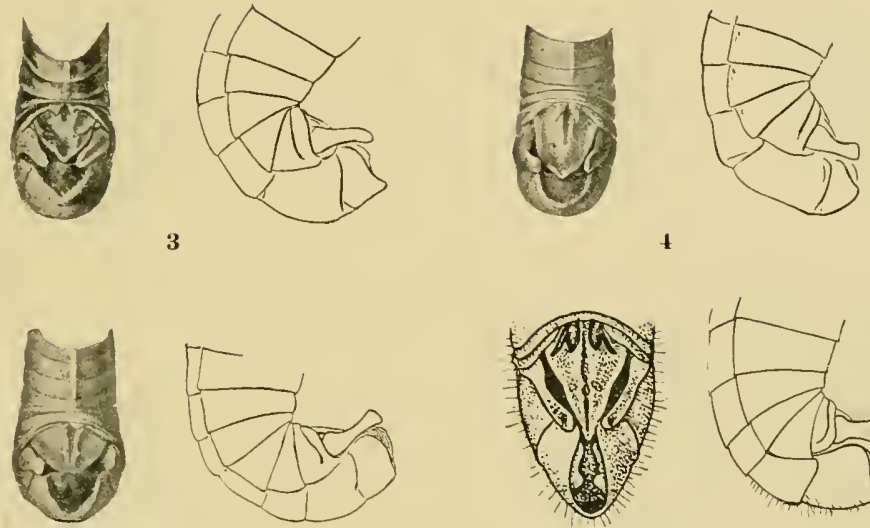

5
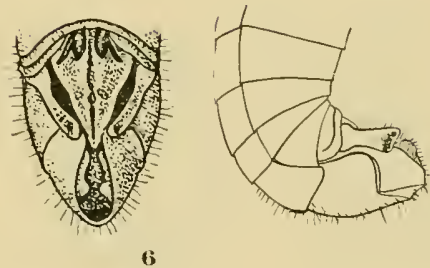

6
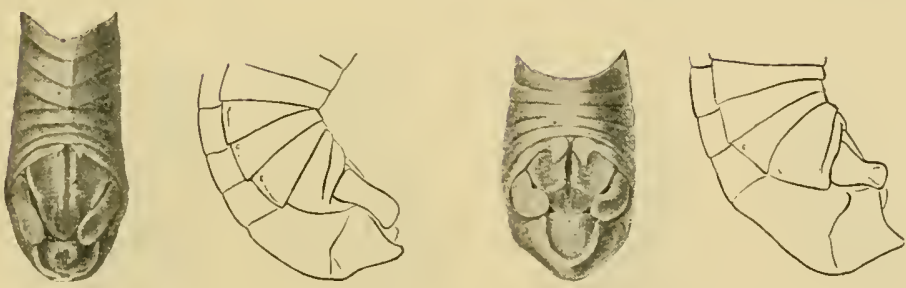

7

s
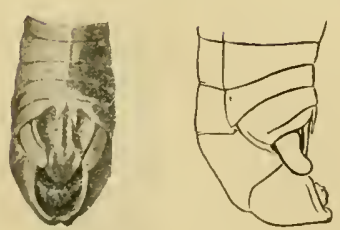

9
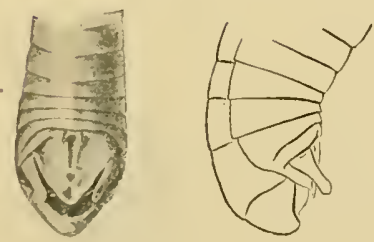

10

Male Abdoninal Ippendages of Hesperotettix and Melanoplus. 

Plate II.
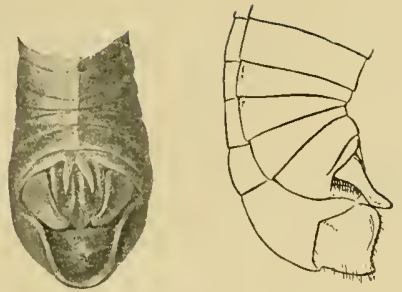

11
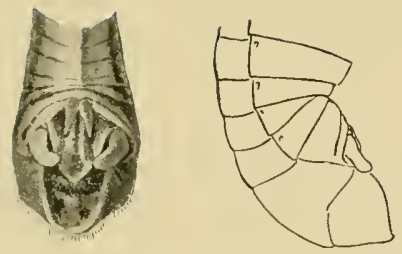

12

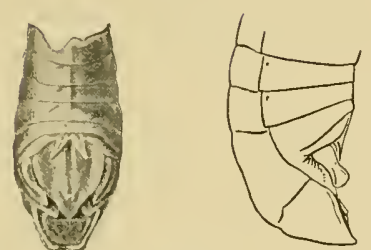

13
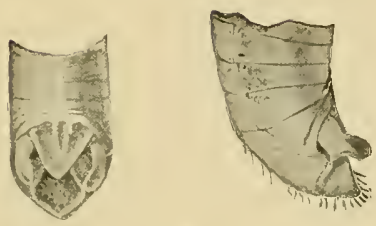

14
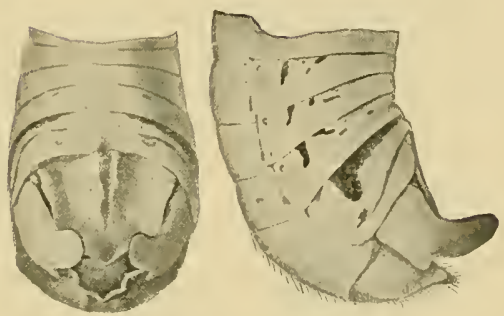

15
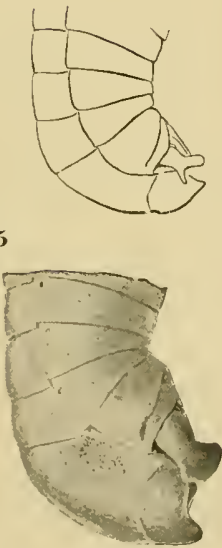

17
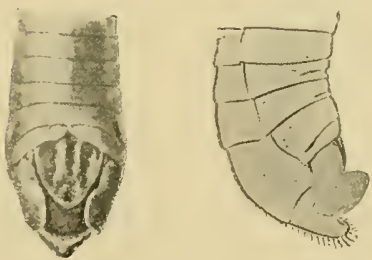

18
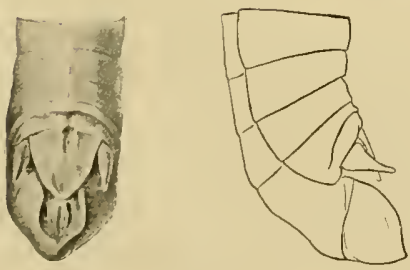

19
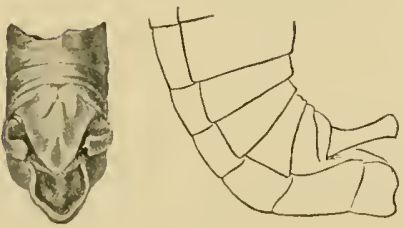

20

Male Abdominal Appendages of Melanoplus, Phetaliotes and Paroxya. 

and apparently enjoying the sunshine. It is able to withstand quite severe frosts and has been seen in copulation as late as November 15th. The general range of scudderi is over the United States east of the Great Plains.

61. Melanoplus viridipes (Walsh-Scudder). The Green-legged Locust. Pezotettix rimidipes Walsh, MS, 1865; Bl., 4, XXIII, 1891, 80; Id., 6, XXIV, $1892,34$.

Melanoplus viridipes Scudd., 179, XXXVI, 1897, 13, 33; Id., 181 , 1897, 128, 255, Plate 17, Fig. 4; Id., 18 8, 1900, 65.

Pezotettix viridulus $\mathrm{McN}$., 88, VI, 1891, 75; Bl., 6, XXIV, 1892, 34; Id., 11 , XXVI, 1894, 245.

Size, medium. Vertex moderately swollen, but little elevated above the pronotum, the portion between the eyes, half as broad again (male) or twice as broad (female) as the basal joint of antennæ; the front half sloping downward and distinctly suleate, especially in the male. Frontal costa narrowed slightly above the ocellus, shallowly sulcate in the male. Antennæ of male equaling or slightly exceeding the hind femora in length; those of female relatively shorter. Pronotum with the disk faintly expanding on posterior half, the median carina distinet on metazona, less so on prozona; the hind margin broadly rounded; prozona about half as long again as the densely punetate metazona. Tegmina equaling (female) or a little longer (male) than the pronotum, elliptical, the apex rounded, the inner edges slightly overlapping in the male, often a little separated in the female. Extremity of male abdomen much recurved; the cerci long and rather slender, erect and a little incurved, tapering gradually from base to apex. Furcula consisting of a pair of minute, widely separated, triangular lobes. Apex of sub-genital plate elevated and terminating in a conical tubercle. (See Fig. 3, Plate I.)

Color, brownish fuscous above, yellowish brown below. Occiput of male darker. A broad, shining black band extends backward from

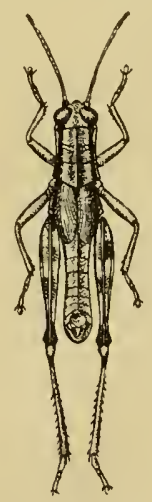

Fig. 65. Melanoplus viridipes (Walsh). Male. One and one-third times natural size. (Original). the eye along the upper half of lateral lobe of pronotum, and is bordered below by an ivory white or yellowish hand. Disk of pronotum and tegmina wood brown. Fore and middle femora greenish; hind femora yellowish brown, with two oblique dark bars on outer face, more distinct in male. Hind tibiæ pale green, the spines black.

Measurements: Length of body, male, $18 \mathrm{~mm}$., female, $23 \mathrm{~mm}$.; of antennæ, male, $9.5 \mathrm{~mm}$., female, $8.5 \mathrm{~mm}$.; of pronotum, male, 
$5 \mathrm{~mm}$., female, $6 \mathrm{~mm}$.; of tegmina, male and female, $6 \mathrm{~mm}$.; of hind femora, male, $9.5 \mathrm{~mm}$., female, $12 \mathrm{~mm}$.

This handsome, short-winged form seems to be rather limited in distribution, having been noted only at two or three points in Illinois and in I'osey, Monroe, Vigo, Marion and Lake counties, Indiana. With us, it is the first locust to reach maturity from eggs hatched in spring, a mature male haring been taken in Vigo County on May 11th, and a number of both sexes in Posey County on May 12th. By June 1st it is common locally, and by August 1st has mostly disappeared. It frequents rather low, flat woods and clearings, being found about the margins of burned or bare places.

On Jume 3, 1900, I happened upon a large colony of viridipes in the upland woods just west of the State Fair Grounds, in Marion County. They were in an open, rather bare tract near the center of the woods, which was surrounded by beech and black maple trees. I took with the fingers, 40 of them in 20 minutes, and could have sceured as many more. The males, when first disturbed, would leap two or three feet, almost perpendicularly, for several times in rapid succession, then give one or two sidewise leaps, and if still pursued, endeavor to hide the head beneath a dead leaf. The females were more clumsy, and after giving one or two short leaps would squat close to the ground, when they were readily taken. One pair were mating and a number were yet in the nymph stage. On June 1, 1902, I found the species abundant in the same place. In Lake County it was taken in a similar woods just back of the hotel on the west side of Cedar Lake. MeNeill says that in Illinois "it shows a deeided preference for open grassy ravines." It probably oceurs in suitable localities over the greater portion of Indiana.

62. Melanoplus obovatipexis (Blatchley). The Obovate-winged Locust.

Przotettir cobneatipemis Bl., 11, XXVT, 1894, 241.

Melanophus whocatipemis Seudd., 179, XXXVI, 1897, 14, 34; Id., 181 , 1897, 129, 26it, Plate 17, Fig. 10; Id., 188, 1900, 61; Bl., 15, XXX, 1898, 62.

l'eztettir mtundipumis Bl., 4, XXIII, 1891, s0 (nee. Sendder).

Male below the medinu in size; female mueh larger and more robust. Thead prominent, the oceiput and rertex elevated a little above the pronotum, the interspace between the eyes nearly twice (male) or more than twice (female) the breadth of basal joint of antenne: the front half strongly sloping downward, narrowly and shallowly sulcate in the male, broadly depressed with distinct raised margins in the female. Frontal costa about the width of the inter- 
space between the eyes; distinctly sulcate in the male; a little depressed about the ocellus in the female. Eyes, large, prominent. Antennæe as long (male) or three-fourths as long (female) as hind femora. Pronotum rather long, faintly (male) or distinctly (female) widening on the posterior halt; median carina distinct and equal throughout; front and hind margins truncate in the female, the latter a little rounded in the male; prozona twice as long as the densely punctate metazona. Tegmina shorter than the pronotum, obovate or broadly ovate in outline, a little longer than their greatest breadth, their inner edges widely separated in the female, less widely but never touching in the male. Wings represented by a slender oblong scale. Male abdomen well recurved; the cerci rather slender, the middle third but little more than half the width of base, the apical third again somewhat widened and slightly excavated on the outer face, the apex truncate. Furcula, consisting of a pair of tapering, cylindrical, diverging lobes, about one-third the length of supra-anal plate. Sub-

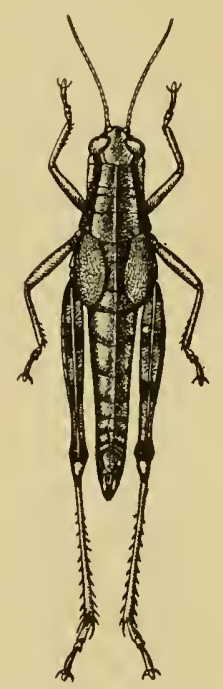

Fig. 66. Melanoplus obovatipennis Bl. Female. One and one-half times natural size. (Original.) genital plate almost as broad as long, the apex not elevated. (See Fig. 4, Plate I.)

Color: Above, dull grayish brown or tan. - A dark fuscous band starts from the middle of hind margin of each eye, and passes back, covering the upper half of lateral lobe of pronotum, then narrows and curves downward to coxa of middle leg. Below, this is bordered by an ivory white band which extends back from the cheek and covers the lower half of the lateral lobe, and then curves down between the front and middle coxa. Metaplenrite ivory-white. Below, the general color is a dirty yellowish brown, with the lower face of the femora orange yellow. The hind femora with their knees black, and with two indistinct blackish bars on the upper and outer faces. Hind tibiæ olive green, annulate with whitish near the base, the spines black. Antennæ with the basal half reddish-brown, the apical half fuscous.

Measurements: Length of body, male, $16 \mathrm{~mm}$., female, $24 \mathrm{~mm}$; of antennæ, male, $10 \mathrm{~mm}$., female, $9.5 \mathrm{~mm}$.; of pronotum, male, 4.5 mm., female, $6 \mathrm{~mm}$.; of tegmina, male, $3 \mathrm{~mm}$. , female, $4 \mathrm{~mm}$.; of hind femora, male, $10 \mathrm{~mm}$., female, $12.5 \mathrm{~mm}$. 
This olive brown, short-winged locust probably oceurs throughout the southern two-thirds of the State, but has been taken only in Crawford, Washington, Monroe, Franklin, Wells, Marion and Vigo countics. In central Indiana it reaches maturity about September 1st, and frequents, for the most part, high, dry, open woods, especially those in which beech and oak trees predominate. On the tops of the hills, in the coal district of Vigo County, where the soil is a clay, and the herbaceous vegetation somewhat limited, it is the prevailing, and often only, representative of the family. In late October, if the season is dry, it is often found in company with Dicromorpha viridis and 'T'ruxalis brericornis among the reeds and tall rank grasses near the borders of marshes, and as late as November 22d, has been noted enjoying the afternoon sunshine from a perch on the bottom plank or rail of a fence. The females are always much more numerous than the males, the ratio being about eight to one. Their larger, robust form renders them more clumsy, and hence more readily caught by the hand, the males being active leapers, and requiring quick movement on the part of the collector to effect their capture. The range of the species is given by Scudder as "Indiana to Arkansas and 'Texas."

63. Melanoplus gracilis (Bruner). The Graceful Locust.

Pezotettir grucilis Brum., 20, VIII, 1876, 124; Scudd., 165, XII, 1880, 75; Bl., 4 XXIII, 1891, 81; Id., 11, XXVI, 1894, 223.

Yelanoplus grecilis Scudd., 179, XXXVI, 1897, 16, 35; Id., 181, 1897, 130, 327, Plate 22, Fig. 3; Id., 188, 1900, 59; Lugg., 84, 1898, 188.

Pezotetti. miuntipennis Thom., 209, I, 1876, 66; Id., 211 , LX, 1880 $90,119$.

Size below the medium. Vertex not swollen nor elevated abore the pronotum; the interspace between the eyes very narrow, about equaling the width of first antennal joint (male) or nearly twice as broad (female); the front half strongly sloping downward and narrowly but distinetly sulcate (male) or broadly and shallowly sulcate (female). Frontal costa prominent, slightly wider than the interspace between the eyes; feebly or not at all sulcate. Antennæ about three-fourths the length of hind femora. Pronotum, sub-cylindrical, faintly expanding on posterior half; the disk with the sides sloping; the median carina low but distinet and equal throughout; front margin truncate, hind margin broadly rounded, with a median shallow notch; prozona twice the length of metazona. Tegmina about the length of the prozona, narrowly oblong, their inner edges widely separated. Hind femora very slender. Extremity of male abdomen 
moderately recurved; the cerci long, narrow, the middle third but half as broad as the base, the apical third a little expanded and flattened. Furcula consisting of a pair of minute rounded lobes. (See Fig. 5, Plate I.)

Color: Dull ash or wood brown above; greenish yellow beneath. Head greenish yellow except on occiput, where it is brownish. A dull blackish bar extends backward from eye along the upper half of lateral lobe of pronotum; the lower half of the lateral lobe greenish yellow. Hind femora bright green (becoming dark in drying) except the knees, which are black. Hind tibiæ green, the spines black.

Measurements: Length of body, male, $16 \mathrm{~mm}$., female, $20 \mathrm{~mm}$.; of antennæ, male, $9 \mathrm{~mm}$., female, 8 $\mathrm{mm}$; of pronotum, male, $4.5 \mathrm{~mm}$., female, $5 \mathrm{~mm}$.; of tegmina, male, $3 \mathrm{~mm}$., female, $4 \mathrm{~mm}$; of hind femora, male, $9.5 \mathrm{~mm}$., female, $11 \mathrm{~mm}$.

This is, next to Mr. scudderi, our most common of the short-winged members of the genus. It probably occurs throughout the State, but has not been noted in the counties south of Monroe and Knox. It frequents rather low, wooded blue-grass pastures and is especially fond of resting and mating upon the foliage of the iron weeds (Vernonia) which grow abundantly in such places. It is also partial

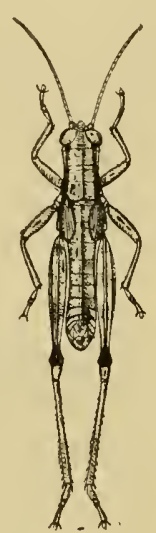

Fig.67. Melanoplus gracilis (Bruner). Male. One and one-half times natural size. (Original.) to the tall grasses growing in ravines and along the border's of sloughs and marshes. In central Indiana the males begin to reach maturity by June 15th, the females about a week later. By July 5th they are mating in numbers. They have also heen noted mating as late as November 10th, and it may be possible that in favorable seasons, a second brood matures. Like most other wingless species, they are active leapers, the males, especially, being noted for their somersaults while endeavoring to escape capture. The range of gracilis is given by Scudder as "Indiana and Kentucky to Nebraska and Dakota."

\section{Melanoplus morset sp. nov.}

Male below the medium in size; female larger and more robust. Head not prominent, the vertex but little swollen, and not at all (male) or a little (female) elevated above the pronotum; the interspace between the eyes very narrow, about as wide (male) or less than one and one-half times as wide (female) as the basal joint of 
antenna; the front half gently sloping and distinctly angulate on the midale of each side, sulcate in the male, plane in the female. Frontal costa a little wider than basal joint of the antenne, very feebly sulcate below the ocellus in male. liyes of male very prominent. Antenne as long (male) or two-thirds as long (female) as hind femora. Pronotum faintly expanding on posterior half in male, or distinctly throughout in the female; the median carina low but distinct except on postcrior third of prozona, where it is sub-obsolete; the sides of disk distinctly sloping downward; the front margin truncate, the hind margin sub-truncate with a broad but shallow median notch or emargination; the prozona twice the length of the rather coarsely punctate metazona. 'Tegmina broadly ovate or sub-rounded, as broad as long, a little shorter than pronotum, their inner edges separated

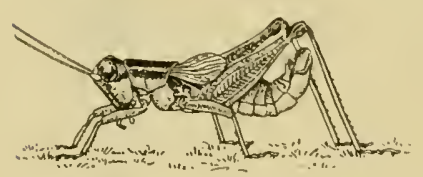

Fig. 68. Melrinoplus morsei sp. nov.

Male. One and one-half times natural size. (Uriginal.) by a space equal to two-thirds their breadth. Extremity of male abdomen strongly recurved; the cerci rather broad, sub-falcate, the middle third more than half the width of base, the apical third expanded and curved upward or forward, excavated on the outer face, the apex obliquely rounded.

Furcula consisting basally of a pair of broad, flat lobes, whose inner edges meet and overlie the median sulcus of supra-anal plate; about the middle they suddenly narrow and become slightly bifid, the outer fingers, slender, a little divergent, reaching nearly to middle of supra-anal plate, the inner ones forming a very short process or angulation. Sub-genital plate longer than broad; distinctly narrowing from below upward. (Sce Fig. 6, Plate I.)

Color grayish or purplish brown above, greenish yellow below. Face greenish yellow more or less sprinkled with fuscous. $A$ broad shining black bar extends back from eye along the upper half of pronotal lobe; this bordered below with greenish yellow. 'Tegmina wood brown. Hind femora reddish brown, or with a fuscous tinge in female, the knees shining black. IHind tibia pale green, the spines black.

Measurements: Length of body, male, $18 \mathrm{~mm}$., female, $24 \mathrm{~mm}$.; of antenmx, male, $11 \mathrm{~mm}$., female, $8 \mathrm{~mm}$; of pronotum, male, 4.5 mm., female, $5.5 \mathrm{~mm}$.; of tegmina, male, $4 \mathrm{~mm}$., female, $5 \mathrm{~mm}$.; of hind femora, male, $11 \mathrm{~mm}$., female, $12 \mathrm{~mm}$.

In color and general appearance this locust bears a close resemblane to $M$. oboratipennis and it was not until $\mathrm{I}$ came to study them critically that I foum them distinct. On comparing the two, morsei 
is easily distinguished by its less prominent head, larger eyes, narrower interspace between the eyes, more feebly sulcate frontal costa, longer antenne of male, more coarsely punctate metazona, broader tegmina and especially by the form of the male cerci and furcula. So far it has been noted only along roadsides and in bare limestone glades on the crests of high wooded hills near Wyandotte, Crawford County. It probably occurs in similar situations throughout the southern third of the State. It reaches maturity some time in June, the first specimens having been taken on the 24th. Nothing distinctive of its habits is known, as when in the field it was thought to be obovatipennis; which, however, is a much later maturing insect.

Since the above was in type I found (July 15, 1903) morsei to be rather common among the underbrush of high wooded slopes on the State University farm, three miles sontheast of Mitchell, Lawrence County. Here the soil was very sparsely vegetated, sedges and wild asters being the prevailing herbs. The ground was covered with the dead leaves of last season, with whose colors the hues of the locusts so blended that they were invisible while motionless. The males leap briskly when approached, but only for a short distance. The heavier bodied females are more clumsy, and are easily eaught with the hand.

I take pleasure in naming this locust in honor of Prof. A. P. Morse, of Wellesley, Massachusetts, a special student and collector of Orthoptera, who has kindly shown me many favors during the preparation of the present paper.

65. Melanoplus fasciatus (Bamston-Walker).

Acritium fusciutum Barn., MS., 1870.

Culoptenus fusciutus Walk., 219 , IV, 1870, 680; Thom., 206, V, 1873, 224.

Melenoplus fasciutus Scudd., 179, XXXVI, 1897, 14, 23, 34; Id., 181 , 1897, 129, 134, 267, Plate 18, Figs. 2-4; Id., 188, 1900, 57; Lugg., 84, 1898, 210, Fig. 136! ; Morse, 100, VIII, 1898, 257; 260, 281, Plate 7, Fig. 39.

Pezotettix borealis Scudd., 141 VII, 1862, 464; Thom., 206, V, 1873. Melanoplus borealis Beut., 3, VI, 1894, 308.

Molconoplus rectus Scudd., 163, XIX, 1878, 284; Id., 16 1, VI, 1878, 43; Id., 164, 1879, 60; Fern., 5 3, 1888, 31.

Melanoplus curtus Scndd., 164, 1879, 59.

Size, medium. Head not prominent, the vertex distinctly elevated above the pronotum, the interspace between the eyes as broad (male) or nearly twice as broad (female) as the basal joint of antennæ; the front half strongly sloping downward, shallowly sulcate, the lateral margins distinct. Frontal costa as broad as the interspace between 
the eyes. feebly or not at all suleate. Eyes relatively small, not prominent. Antenna about as long (male) or two-thirds as long (female) as hind femora. Pronotum feebly expanding on its posterior half; the disk rounded on prozona, flat on metazona; the front margin truncate, the hind margin broadly rounded or obtuse angled; the median carina distinct only on metazona, faintly visible on portions of the prozona; the latter about one-fourth longer than the metazona. Tegmina rovering half (female) or three-fourths or more (male) of the abdomen,* sub-lanceolate, their inner edges overlapping. Extremity of male abdomen well upturned; the cerci straight, about four times as long as broad, the middle third but slightly narrowed, the apical third concave or suleate, the tip rounded. Furcula consisting of a pair of minute, widely separated tubercular teetli. Sub-genital plate longer than broad, the apical margin somewhat elevated. (See Fig. 7, Plate I.)

Color: Dull grayish brown above, clay yellow below; the male the darker. Occiput fuscous. The usual black band behind the eye, extending along the upper half of lateral lobe of prozona. Tegmina, dull reddish brown, with often a few small fuscous spots on the discoidal area. Hind femora dull brownish yellow, with two broad oblique blackish bars on the upper and outer faces; the lower face dull red; the knees black. Find tibia either red or pale green, with a lighter ring near the base; the spines black.

Measurements: Iength of borly, male, $17 \mathrm{~mm}$., female, $21 \mathrm{~mm}$.; of antennæ, male, $9.5 \mathrm{~mm}$., female, $8 \mathrm{~mm}$.; of pronotum, male, 4.5 $\mathrm{mm}$., female, $5 \mathrm{~mm}$.; of tegmina, male, $7.5 \mathrm{~mm}$., female, $8 \mathrm{~mm}$; of hind femora, male, $10 \mathrm{~mm}$., female, $15 \mathrm{~mm}$.

This much described locust is a species of northern range, which has been taken in Indiana only in Marshall and Lake comnties. In the former it has been noted only in a low sandy oak woods, bordering Lost Lake, and just west of the station of Arlington at Lake Maxinkuckee. Here anong low luckleberry and other bushes it is common from July 1.5th on, the females, however, far outnumbering the males. Both sexes leap rigorously when disturbed, but often squat close to the ground after being flushed once or twice. In Lake County a few specimens have been taken in the sand dune region near Millers.

- A form (M.f. volaticus) oecurs in which the tegmina are broad, sub-equal, and far surpass the hind femora. It has been taken in Miehigan, but is not, as yet, known in Indiana. 
66. Melanoplus blatchleyi Scudder.

Melanoplus blatchleyi Scudd., 179, XXXVI, 1897, 15, 34; Id., 181 , 1897, 129, 322, Plate 21, Fig. 10; Id., 188, 1900, 55; Bl., 15 , XXX, 1898, 62; Lugg., 84, 1898, 186, Figs. 112-114.

Pezotettix occiclentalis Brun., 20, VIII, 1876, 124; Bl., 11, XXVI, 1894, 243.

Pezotettix viole Bl., 4, XXIII, 1891, 81.

Size, above the medium. Vertex scarcely elevated above the pronotum, the interspace between the eyes nearly (male) or fully (female) twice as broad as the first joint of antennæ; the front half moderately sloping, broadly sulcate in the male, faintly in the female. Frontal costa short, not reaching clypeus, sulcate at and below the ocellus. Antennæ scarcely shorter than (male) or two-thirds as long as (female) the hind femora. Pronotum feebly expanding on the metazona; the disk flat or nearly so; the median carina distinct

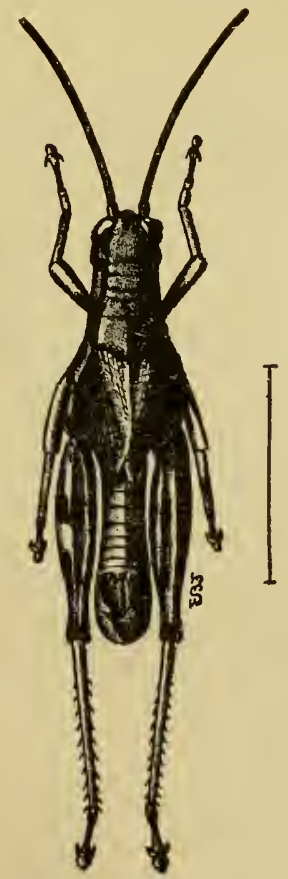

Fig. 69. Melan'plus blatchleyi Scudder. Male. Twice natural size. (After Lugger.)

only on the metazona; the front margin truncate, the hind margin broadly obtuse angled; the prozona abont one-third longer than the closely punctate metazona. Tegmina about one-fourth longer than the pronotum, sub-lanceolate, their inner edges slightly overlapping. Fore and middle femora much swollen in the male. Extremity of 
male abdomen strongly recurved; the cerci coarse and heavy, the middle third, two-thirds as broad as base, the apical third slightly enlarged, curved abruptly inward, compressed, the tip broadly rounded. Furcula consisting of a pair of short, rather broad and flat triangular teeth whose bases almost touch. Sub-genital plate broader than long, the apex a little elevated. (See Fig. 8, Plate I.)

Color: Dark grayish brown above, yellowith below. Face dull brown, the occiput darker. A rather narrow black bar runs back from each eye along the upper third of lateral lobes of prozona, often indistinct or wanting, especially in the female. 1)isk and lower half of lateral lobes of pronotum and tegmina grayish brown, often more or less flecked with fuscous. Ilind femoral reddish or yellowish brown, with two crossbars of black on mpeer and onter faces, these sometimes indistinet in female; the lower face pale or vermilion red, the knees back. Ilind tibia red, with a pale ring on basal third, the spines black.

Measurements: Length of body, male, $21 \mathrm{~mm}$., female, $21 \mathrm{~mm}$.; of antennx, male, $12 \mathrm{~mm}$. female. 9.5 $\mathrm{mm}$.; of pronotum, male, s mm., female, $6 \mathrm{~mm}$.; of tegmina, male, $8 \mathrm{~mm}$., female, $9 \mathrm{~mm}$.; of hind femora, male, $13 \mathrm{~mm}$., female, $14 \mathrm{~mm}$.

This dumsy bodied insect is among the least common of our Indiana Melanopli, having been taken only in Crawford, Knox, Monroe, Vigo, Putnam and Marion counties. Scldom more than a dozen or two are seen each season. It frequents, for the most part, upland woods and thiekets, though it is sometimes found along the borders of marshes and swamps, but never close to the water. It is more arboreal than many of our locusts, having been taken in antumn on prickly ash and buttonbush shrubs, several fect above the ground, and also from the boles of hacklorry and oak trees. where it was probably sunning. Lugger states that in Minnesota "it is very common, preferring the edges of forests or places overgrown with bushes and vines. The graperine, especially, is preferred by these locusts, and they soon destroy its folinge by eating big holes in the leaves."

In central Indiana hlatchleyi begins to reach maturity by .June 1.th, and ragged, forlorn looking specimens have been seen as late as Norember 3d. Its general range is west of the Mississippi. Marion Commty, Indiana, being the most easterly point from which it has been recorded.

67. Melanoplis atianis (Rilet). The Lesser-Locust.

(aloptems. allemis Riley, 116, VII, 1875, 169; Id., 117, VIII, 1876, 113,153 ; Id., 12 , VI, 1881, 89, 90; Id., 122, II, 1884, 194; Id., 127, XXY, 1891, 26, Figs. 4a-c; Pack., 2 16, III, 1883, 273, Plates XX, XXI. 
Culoptenus atlantis Thom., 209, I, 1876, 68; Id., 211 , IX, 1880, 92, $96,124$.

Melunophus atlantis Scudd., 163, XIX, 1878, 286; Id., 16 1, VI, 1878, 45. Melchoplus atlunis Scudd., 2 1 5, II, 1880, 2t, Plate XVII, Fig. 6; Id., 179 , XXXVI, 1897, 20, 32; Id., 181 , 1897, 132, 178, Plate 12, Fig. 7; Id., 188, 1900, 54; Fern., 53, 1883, 31, 33; Bl., 4, XXIII, 1891, 98; Brun., 26, XXVII, 1892, 12; Id., 28, XXVIII, 1893, 29, Figs. 14a-c; Bent., 3, VI, 1894, 306; Morse, 100 , VIII, 1898, 256, 259, 279, Plate 7, Fig. 36; Lugg., 84, 1898, 190, Figs., 116-118.

Size, medimm. Vertex somewhat elevated above the pronotum, the interspace between the eyes nearly (male) or fully (female) twice as broad as the basal joint of antenna; the front half strongly sloping, distinctly sulcate in the male, shallowly in the female. Frontal costa short, not reaching clypeus; feebly or not at all sulcate below the ocellus, the upper third a little narrowed. Antennæ three-fourths

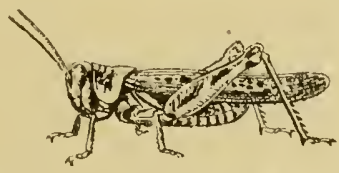

Fig. 70. Melanoplus atlanis Riley. Male. Natural size.

(male) or two-thirds (female) as long as hind femora. Pronotum rather short, distinctly expanding on the metazona, the disk flat or nearly so, the lind margin obtuse angled, the median carina distinct only on the metazona; the latter densely punctate and equaling the prozona in length. Tegmina fully developed, surpassing the hind femora. Extremity of male abdomen but little recurved; cerci about twice as long as broad, the apical half slightly upturned and somewhat inbent; the apex well rounded. Furcula consisting of a pair of moderately diverging slender, tapering spines, about onethird the length of the supra-anal plate. Sub-genital plate narrowing regularly from below upward, the apex somewhat thickened and elevated, and with a distinct median notch. (See Fig. 9, Plate I.)

Color, either dark grayish or reddish brown. Hfead olive brown mottled with darker. The usual black band belind eye is confined to the prozona and in the reddish brown specimens and the females is often indistinct or broken into smaller spots. Tegmina grayish brown, flecked distinctly with fuscons along the discoidal area. Hind femora reddish yellow, with two obliqne dark bars across the upper and outer faces; the lower face usually pinkish, the knees blackish. side of abdomen yellow. 
Measurements: Length of body, male, $20 \mathrm{~mm}$., female, $24 \mathrm{~mm}$; of antennw, male, $9 \mathrm{~mm}$., female, $8 \mathrm{~mm}$.; of pronotum, male, $5 \mathrm{~mm}$., female, $5.5 \mathrm{~mm}$. ; of tegmina, male and female, $20 \mathrm{~mm}$.; of hind femora, male, $12 \mathrm{~mm}$., female, $13 \mathrm{~mm}$.

'This is a very eommon locust throughout the State, having been taken in every county in which collections have been made. It begins to reach maturity the latter part of May-May 2ith and 30th, Vigo County; May 31st, Marion County-and from then until late November may be noted almost anywhere in open blue-grass pastures and woods, borders of roadsides and cultivated fields, meadows and lawns. Numerous examples have been found pairing as late as November $22 \mathrm{~d}$, and it may be that there are two broods each season. In late spring and early summer they are often seen resting on ironweeds and thistles in company with M. gracilis, M. luridus and other species. The cast off skin of their final moult is often noted on such weeds, showing that the nymph climbs thereon to ehange its garment of youth for one of maturity.

Allanis is very often found associated with the more common $M$. femur-rubrum and is considered that species by most persons who deign to notice such a thing as a locust. The male, however, may be readily distinguished from that of femur-rubrum by the notched apex of sub-genital plate, the shorter and less tapering cerci, and by the greater relative length of the tegmina, which extend one-fourth or more their length beyond the tip of abdomen. The dark spots on tegmina are also larger and more distinct in atlanis. The female of atlanis may be known by the ycllow color of the under side of abdomen which in femur-rubrum is reddish brown; and also by the more distinctly banded hind femora. The earlier specimens of allanis are, in general, lighter eolored and liave relatively longer tegmina than those of late autumn, which are very dark gray in hue. The species ranges over most of the United States and Canada.

68. Melanoplus impudicus Scudder.

Helcunoplus impulimes Scudd., 179, XXXVI, 1897, 22, 32; Id., 181 , 1897, 1:3t, 204, Plate 14, Fig. 1; Id., 188, 1900, 60.

Size, medium. Tertex slightly swollen, distinctly elevated above the pronotum; the interspace between the eyes as broad (male) or one and a half times as broal (female) as the first joint of antennæ; the front half strongly sloping, feebly suleate in both sexes. Frontal costa short, not reaching clypeus. narrow, feebly or not at all suleate. Antenne short, two-thirds as long as hind femora. Pronotum expanding but little (male) or more distinctly ( female) on metazona, 
the disk feebly convex; median carina visible thronghout, distinct on metazona; hind margin obtuse angled; the prozona but little, if any longer than the finely punctate metazona. 'Tegmina* reaching the tip of hind femora in both sexes, moderately broad and tapering. Extremity of male abdomen but little recurved; the cerci narrow, compressed, straight, the middle third about half as broad as the extreme base, the apical third but little expanded, the tip rounded. Furcula consisting of a pair of short, triangular spines which lie upon the bases of the ridges of the supra-anal plate. Sub-genital plate scarcely longer than broad, sub-conical, terminating in a blunt tubercle. (See Fig. 10, Plate I.)

Color: Reddish brown above, yellowish below. Face yellowish brown, dotted with fuscous; occiput and disk of pronotum darker. Antennæ reddish, the apical fourth fuscons. An indistinct black band extends from eye back across the upper half of the lateral lobe of prozona; this often nearly obsolete in the female. Tegmina grayish or reddish brown, with a number of dark spots along the discoidal area. Hind femora reddish brown, with two more or less distinct oblique black bars on upper and onter faces; the lower face orange red; the knees dusky. Hind tibiæ bright red, the spines black.

Measurements: Length of body, male, $18 \mathrm{~mm}$., female, $22 \mathrm{~mm}$.; of antennæ, male and female, $8 \mathrm{~mm}$; of pronotmm, male, $5 \mathrm{~mm}$., female, $5.5 \mathrm{~mm}$.; of tegmina, male and female, $15 \mathrm{~mm}$.; of hind femora, male, $11 \mathrm{~mm}$., female, 12.5.

This is a southern species, heretofore recorded only from Georgia, Mississippi and Arkansas. On July 10, 1902, I found it plentiful on a sandy wooded slope in Gibson County, Indiana, about 10 miles southeast of MIt. Carmel, Illinois, and at a point where the terrace on the Indiana side of the Wabash River meets the sandy uplands. Here, among the sciant grass and weers the insect had found a suitable abiding place. The males take to wing readily when disturbed, but the females seem to depend only on their short hind legs to take them out of sight of their pursner. Specimens were sent Professor MIorse, who kindly verified my determination by comparing them with Scudder's types. It is probable that the species will be found over most of the sand-covered area of the lower Wabash River.

69. Melanoplus femur-Rubrum (De Geer). Common Red-legged Locust. Icridium femu-iubrum DeG., 57, III, 1773, 498, Plate XLII, Fig. 5;

Harr. , 70, 1833, 583; Id., 7 1, 1841, 141; Id., 72, 1862, 174.

Caloptenus femm-rubrum Burm., 40, II, 1838, 638; Scudd., 141, VII, 1862, 464; Id., 147, 1872, 250, 253; Glov., 60. 1870, 76, Fig.

* Seudder, in his original description, gives them as "surpassing a little (male) or considerably (female) the hind femora," but this is not true of Incliana specimens. 
32; Icl., 62, 1872, Plate Y, Fig. 11, Plate VII, Fig. 2; Thom., 206, T, 1873, 163; Id., 211 , IX, 1880, 91, 95, 124, Figs. 22, 23; Riley, 116 , VII, 1875, 126, Figs. 26, 29; Id., 117 , VIII, $1876,114-118,153$; Id., 119, 1877, 14-17, 27, Figs. 1, 4; Id., 127, XXV, 1891, 27, Fig. 5.

Protettic (Melanophes) fomu-rentrim Stal, 200, I, 1873, 79.

Melanoplus femen-2ninum Scudd., 148, I, 1874, 375; Id., 163, XIX 1878,285 , 287; Id., 161 , VI, 1878, 44, 46; Id., 181, 1897, 134, 278. Plate XIX, Figs. 1-t; Id., 188, 1900, 58; Comst., 41 , 1888, 108, 110, Figs. 83, 98; Id., 42, 1895, 110, Fig. 120; Fern.. 53, 1888, 31, 33; Bl., 4, ХXII, 1891, 98; Id., 16, 1899, 239, Fig. 65; Bru11., 30, 1893, 458, Fig. 98; Id., 28, XXYIII, 1893, 30-32, Fig. 15; Id., 31 , 1894, 16:3, 205, Fig. 68; Id., 35, 1899, 133, Fig. 77; Beut., 3, VI, 1894, 306, Plate VII, Fig. 7; Lugg., $84,1898,195$, Figs. 121, 122; Morse, 100, VIII, 257, 281, Plate 7, Fig. 40 .

Size, medium. Vertex but little elevated above the pronotum, the interspace between the eyes a fourth wider than (male) or fully twice as wide (female) as the first antennal joint; the front half strongly sloping, distinctly suleate in the male, fecbly in the female. Frontal

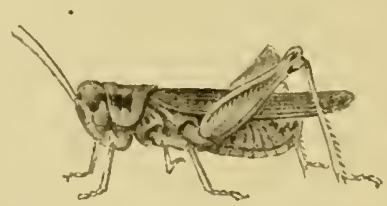

Fig. 71. Melanoplux femur-rubrum (DeGeer). Male. Natural size.

costa as broad as the interspace between the eyes, deeply sulcate below the ocellus in the male. Antennæ about three-fourths (male) or two-thirds (female) as long as lind femora. Pronotum feebly expanding on posterior half, the disk flat or nearly so; the hind margin obtuse angled, more so in the female; the median carina visible thronghout, more distinet on the metazona; the prozona about equal to the latter in length. T'egmina slightly surpassing the tip of hind femora, distinetly though very gradually tapering. Extremity of male abdomen well recurved; the cerei sub-falcate, tapering rapidly from hase to middle, the apieal third but little expanded, the apex very obliquely trumcate and somewhat incurved. Furcula consisting of a pair of tapering cylindrical spines, about half as long as the supra-anal plate, their apical two-thirds well separated and lying just outside the ridges forming its median suleus. Sub-genital plate with its apex less than half the hrealth of the base. not elevated, truncate, and distinctly rounded. (Sec Fig. 11, Plate II.) 
Color: Reddish brown, or brownish fuscous. Head olive to brownish yellow, the occiput darker with usually a pair of widening fuscous stripes on its sides. Disk of pronotum generally darker than the lower half of lateral lobes; the upper half of these lobes with a broad black bar on the prozona, often sub-obsolete in the fenale. Tegmina brownish fuscous, sometimes without spots, but more often with fuscous dots of varying size along the basal half of discoidal area. Hind femora reddish brown, the upper half of outer face usually more or less clonded with fuscous which often forms two oblique crossbars on the upper face; lower and inner faces dull yellow or orange. Hind tibia deep red, rarely palc yellowish green, the spines black.

Measurements: Lengtlı of body, male, $23 \mathrm{~mm}$., female, $25 \mathrm{~mm}$; of antenme, male, $10 \mathrm{~mm}$., female, $8.5 \mathrm{~mm}$; of pronotum, male, 4.5 mm., female, $5 \mathrm{~mm}$.; of tegmina, male, $20 \mathrm{~mm}$., female, $21 \mathrm{~mm}$.; of hind femora, male, $12.5 \mathrm{~mm}$., female, $14.5 \mathrm{~mm}$.

This is the most common and the most injurious of our Indiana Jocusts. It occurs everywhere in blue-grass pastures and meadows, along roadsides and borders of cultivated fields. In central Indiana it begins to reach maturity about. June 5th, and has been seen in numbers and mating as late as November 22d. Those which occur in low damp places are usually darker than those in dry upland localities. The second crop of clover is, in a dry season, often almost wholly destroyed by these insects. When disturbed they either hop rigorously to one side, or fly swiftly and noiselessly straight ahead for 30 or more feet and then suddenly drop to the ground. The species ranges over most all of North America.

70. Melanoplus extremus (Walker).

Culoptenus extremus Walk., 2 19, IV, 1870, 681 ; Thom., 206, V, 1873, 225.

Melenoplus extremus Scudd., 179, XXXVT, 1897, 24, 34; Id., 181 , 1897, 135, 287, Plate 18, Fig. 10; Id., 188, 1900, 57; Bl., 15, XXX, 1898, 57; Morse, 100, VIII, 1898, 257, 259, 292, Plate 7, Fig. 41.

Pezotettix junius: Dodge, 45, VIII, 1876, 9.

Melfonoplus jmius Scudd., 163, XIX, 1878, 286; Id., 16 1, VI, 1878, 45. Culoptenus junims Scudd., 165, XII, 1880, 75.

Size, small to medium. Vertex stightly elevated above the pronotum; the interspace between the eyes nearly (male) or more than (female) twice as wide as the hasal joint of antenne: the front half steeply sloping, distinetly (male) or broadly and shallowly (female) sulcate. Frontal costa not reaching clypeus, faintly widening from above downward; feebly suleate at and below the ocellus. Antennæ 
four-fifths (male) or two-thirds (female) as long as the hind femora. Pronotum widening on the metazona, especially in the femalc; the median earina visible throughout, more distinct on metazona; the hind margin strongly obtuse angled, the angle romded in the fenale; the prozona one-third (male) or one-sixth (female) longer than the closely punctate metazona. Tegmina (in Indiana specimens) reaching nearly to tip of abdomen in the male, covering onehalf to three-fourths of abdomen in female, rather broad at base, but rapidly tapering to a sub-acuminate apex. Extremity of male abdomen but little reeurved; the eerei short and broad, slightly falcate, the basal third feebly tapering, the apical third but little, if any, wider than the middle; the apex obliquely rounded. Fureula consisting of a pair of parallel, tapering, cylindrical spines, about half as long as supra-anal plate, and resting upon the ridges bordering its median sulcus. Sub-genital plate half as broad at apex as at base, the apical margin well rounded, and not elevated. (See Fig. 12, Plate II.)

Color: Dark greenish yellow, tinged with fuscous. Head, greenish yellow, darker above. The usual black bar behind eye extends along the upper half of lateral lobe of prozona; below which the lobe is greenish yellow. Disk of pronotum and tegmina dull olive brown, the latter sometimes with a few small fuscous spots along the discoidal area. Hind femora dull yellow, tinged with reddish brown, usually without traces of dark crossbars; the lower face generally pale orange; knees feebly infuscated. Hind tibiæ pale red, or dull yellow, the spines black.

Measurements: Length of body, male, $18 \mathrm{~mm}$., female, $22 \mathrm{~mm}$.; of antennæ, male, $9 \mathrm{~mm}$., female, $7 \mathrm{~mm}$.; of pronotum, male, $4 \mathrm{~mm}$., female, $5 \mathrm{~mm}$; of tegmina, male, $10 \mathrm{~mm}$., female, $9.5 \mathrm{~mm}$; of hind femora, male, $10 \mathrm{~mm}$., female, $11.5 \mathrm{~mm}$.

This species first came to my notice in the State on August 6, 1897, when it was found near Delong, Fulton County, in an open peat bog which was surrounderl on all sides by a heary growth of tamarack, Larix americana Michx. But about a dozen specimens were secured, all of which were of the short winged form Mr.e. junius. When disturbed they gave sereral short, quick leaps, and then burrowed as far as they could into the dense mass of sphagnum moss which everywhere covered the bog. It has since been taken sereral times in the same place; also in a marsh near the south end of Take Naxinknekee; and probably occurs about the most of the peat hogs and marshes of the northern third of the State. Mr. C. H. Bollman evidently found it near Bloomington. Monroe County, since Scudder mentions a specimen so labeled as oecurring in the U. S. National Mnseum. 
Extremus is an insect of northern range, Walker's type being recorded from Aretic Amcrica. According to Scudder "it probably occurs throughout the larger part of Canada and the northermmost United States. It has also been recorded from several points in Alaska."

71. Melanoplus angustipennis (Dodge). The Narrow-winged Locust.

Culoptenus angustipemis Dodge, 46, IX, 1877, 111.

Melanoplus angustipennis Brum., 22, I, 1885, 138; Id., 28, XXVIII, 1893, 24, Fig. 12; Id., 34, 1896, 121, Fig. 23; Id., 36, 1899, 270, Fig. 58; Scudd., 179, XXXVI, 1897, 26, 34; Id., 181 , 1897, 136, 305, Plate 20, Fig. 6; Id., 188, 1900, 53; Bl. 15 , XXX, 1898, 58; Lugg., 84, 1898, 198, Fig. 123.

Melrmoplus coccimsipes Scudd., 179, XXXVI, 1897, 26, 34; Id., 181 , 1897, 136, 303, Plate 20, Figs, 3-5; Id., 188 , 1900), 56.

Size, medium. Vertex feebly swollen, slightly elevated above the pronotum; the interspace between the eyes one and a half times (male) or twice (female) as broad as the basal joint of antennæ; the front half strongly sloping, distinctly and broadly (male) or feebly (female) sulcate throughout. Frontal costa rather wide and equal throughont, faintly sulcate at and below the ocellus. Antenna about five-sixths (male) or two-thirds (female) as long as the hind femora. Pronotum with the disk feebly enlarging on posterior lralf, the median carina distinct only on the metazona; the hind margin broadly obtuse angled; prozona distinctly (male) or scarcely (female) longer than the closely punctate metazona. Tegmina reaching or slightly surpassing the tips of hind femora, slender, tapering. Extremity of male abdomen scarcely recurved, the cerci rather short, spatulate, incurved, the middle third narrowest, the apex broadly rounded and hollowed on the outer face. Furcula consisting of a pair of diverging, tapering, cylindrical spines, about a third as long as the plate on which they rest. Sub-genital plate longer than broad, the apex a third narrower than base, and with a slight notch or emargination in the middle. (See Fig. 13, Plate II.)

Color: Dark grayish brown or fuscous; often with a reddish brown tinge. The occiput and disk of pronotum fuscous; the lower halves of lateral lobes lighter. The usual dark bar behind the eye covers the upper half of the sides of prozona. Tegmina brownish fuscons, either without spots or with small, indistinet fuscous ones along the middle area. Hind femora dull yellowish brown, obscurety and obliquely banded with fuscous; the lower face dull yellow; the knees blackish. Hind tibia either pale greenish blue or bright red, the spines black. 
Measurements: Jength of body, male, $20 \mathrm{~mm}$., female, $22 \mathrm{~mm}$; of antenna, male, $9.5 \mathrm{~mm}$., female, $8 \mathrm{~mm}$; of pronotum, male and female, $5 \mathrm{~mm}$.; of tegmina, male, $17 \mathrm{~mm}$., female, $16 \mathrm{~mm}$; of hind femora, male and female, $12 \mathrm{~mm}$.

This is one of the most common locusts about the south shore of Lake Michigan occurring in company with $M$. atlanis (Riley), Spharagemon wyomingianum (Thos.), and others over a large part of the sandy area within five miles of the lake. It seems to prefer such barren loealities to those more promising in plant foorl, since Bruner mentions its partiality for "old lreakings and well-fed pastures of many years' use." It probably begins to reach maturity some time in June, as numerous specimens have been found mating in late July.

'The hind tibie of at least a third of the specimens noted were red instead of blue. Seudder* has based his separation of his nominal species coccineipes on the color of the tibia and degree of maculation of the tegmina, two extremely variable characters. The cerci and furcula of the red-legged male are the same in form as of the bluelegged one, and I have therefore combined the two species. In this view I am supported by Prof. A. P. Morse, who has kindly compared speeimens from northern Indiana with Seudder's types.

Angustipennis is a western species, and has not been noted east of Kansas and Iowa, except in the sand dune region of northwestern Indiana. According to Bruner, it ranges from North Dakota to 'Texas, and west to Yellowstone, Montana. He also states that it is increasing rapidly in numbers, and is likely in places to become a serious pest. 'The regetation of the area which it at present inlabits in Indiana is not suffieient in quantity and value to enable it to do much damage. Several successive favorable seasons might, however. enable it to so increase in numbers as to eause it to migrate into the richer agricultural regions to the south and cast.

72. Melaxoples misor (Scudder).

Culoptemus minor Scudd., 152, XVII, 1875, 478; Id., 153, IV, 1875, 77 ; Id., $164,1879,22$.

Yelamplus minor Scudd., 164, 1879, 84; Id., 179, XXXVI, 1897, 29, 35 ; Id., 181 , 1897, 137, 337, Plate 22, Fig. 9; Id., 188, 1900, 61; B1., 4, XXIII, 1891, 81; McN., 88, VI, 1891, 74; Bent., 3, VI, 1894, 307; Lugg., 84, 1898, 201, Fig. 127; Morse, 100, TIII, 1898, 256, 259, 293, Plate 7, Fig. 42.

Size, merium. Vertex but little elevated above the pronotum; the interspace between the eyes nearly twice (male) or three times

* "Rerision of the Melanopli," p. 136 . 
(female) as wide as the first joint of antennæ; the front half but little sloping downward, distinctly and widely sulcate in the male, depressed but searcely sulcate in the female, the lateral margins sharp. Frontal costa faintly narrowed between the antennæ, feebly sulcate at and below the ocellus. Antennæ about two-thirds the length of hind femora in both sexes. Pronotum short, distinctly widening on the metazona; the disk broadly convex; the hind margin obtuse angled; the median carina low, but visible throughout, a little less distinct on the prozona; the latter a fourth longer than the finely punctate metazona. Tegmina reaching the tips of hind femora in the female, slightly surpassing them in the male; of nearly equal width throughout. Fxtramity of male abdomen but little recurved; the cerci with the basal portion stout, four-sided, the apical portion nearly as long, but narrower, bent upward and inward; an inferior angle or process at point of bend; the apex broadly rounded. Furcula consisting of a pair of well separated parallel cylindrical spines, about a fourth the length of the supra-anal plate and overlying the ridges of its median sulcus. Sub-genital plate very short, the apex rounded, the lateral margins incurved near the base. (See Fig. 14, Plate II.)

Color: Above, dark brownish or fuscous, often with a reddish brown tinge, below yellowish. Occiput and disk of prozona darker than the metazona. A shining black bar behind eye extends back along the upper third of lateral lobes of prozona; this bordered below with brownish yellow. Tegmina brownish fuseous, more or less distinetly spotted with darker along the median area. Hind femora brownish yellow, indistinctly and obliquely barred with fuscous on the upper and outer faces; the lower face reddish orange; the knees black above. Hind tibir usually pale blue, pinkish at tip, but sometimes red or dull yellow; the spines black.

Measurements: Length of body, male, $18 \mathrm{~mm}$., female, $24 \mathrm{~mm}$.; of antennæ, male, $8 \mathrm{~mm}$., female, $9 \mathrm{~mm}$.; of pronotum, male, $4.5 \mathrm{~mm}$., female, $5 \mathrm{~mm}$.; of tegmina, male, $15 \mathrm{~mm}$., female, $16 \mathrm{~mm}$.; of hind femora, male, $11.5 \mathrm{~mm}$., female, 13.5 .

This seems to be one of the rarest of our Melanopli, but a half dozen or so specimens having been taken in the State during my collecting, and they only in Vigo, Monroe and Marion counties. It frequents blue-grass pastures, roadsides, and borders of cultivated fields in upland or sandy regions, and when disturbed, flies noiselessly for a short distance. A mature male was taken in Marion County on June 1, 1902. The species resembles $I I$. femur-rubrum and allanis in general appearance and is very likely to be confounded 
with them. It is probably, therefore, more numerous than my observations would denote, and is to be looked for throughont the State, its general range covering "the northern half of the United States and bordering parts of Canada."

\section{Mela Noplus luridus (Dodge).}

Culoptemis luridus Dodge, 4 5, VIIT, 1876, 11 ; Riley, 122, II, 1884, 195. Helanoplus Imritus: Brun., 216 , III, 1883, 60; Id., 22, I, 1885, 138; Scudd., 179 , XXXYT, 1897, 29, 35; Id., $181,1897,137,344$, Plate XXIII, Fig. T; Id. 188, 1900, 61 ; Lngg., 84, 1898, 203, Figs. 128, 129.

Melemoplus collimes Sendd., 163, XIX, 1878, 285; Id., 161, VI, 1878, 44; Id., 179, XXXVI, 18:17, 28, 35; Id., 181, 1897, 138, 346, Plate XXIII, Fig. 6; Id., 188, 1900, 56; Fern., 53, 1888, 31 ; Bl., 4, XXIII, 1891, 99; Id., 11, XXVT, 1894, 244; McN., 88, VI, 1891, 7t; Beut., 3, VI, 1894, 306; Morse, 100, VIII, 1898, 256, 259, 294, Plate 7, Fig. 43.

Size, medium. Vertex somewhat swollen, distinctly elerated above the pronotun; the interspace between the eyes slightly wider than (male) or fully half as wide again (female) as the first antennal joint; the front half moderately sloping, shallowly and broadly sulcate in the male, plane in the female. Frontal costa of nearly equal width throughont, faintly sulcate at and below the ocellus in the male. Antemne about three-fourths (male) or two-thirds (female) as long as the hind femora. Pronotum fecbly and regularly widening on posterior half: the disk flat or nearly so: the median carina distinct only on the metazona; the hind margin feebly obtuse angulate, the angle rounded; the prozona one-third (male) or but slightly (female) longer than the distinctly punctate metazona. 'Tegmina reaching tips of hind femora in the male, often a little shorter in the female, moderately broad, distinctly tapering. Extremity of male abdomen but little recurved; the basal half of cerci gently tapering, about twice as long as the greatest breadth; the apical half distinetly forked, the lower liranch a little shorter and much narrower than the upper. Furcula consisting of a pair of well scparated mimute triangular denticulations. Sub-genital plate as loroad as long, the apex broadly rounded. (See Fig. 1., Plate II.)

Color: Dark gravish brown raried with fuscous. Face dull bluish gray, with mottlings of hrownish purple. Occiput and disk of prozona fuscous. A broad blackish bar extends from eye baek along the upper half of lateral lobe of prozona: this often sub-obsolete, especially in the female. 'Tegmina hrownish fusens, often grayish in the female. with nsmally a row of fuscous spots along the discoidal area; though sometimes immaculate. Ilind femora brownish yellow, 
indistinctly and obliquely barred with fuscous on the upper face, the lower face dull orange or yellowish; the knees black. Hind tibia bright coral red, the spines black.

Measurements: Length of body, male, $19 \mathrm{~mm}$., fomale, $23 \mathrm{~mm}$; of antennæ, male, $9 \mathrm{~mm}$., female, $8 \mathrm{~mm}$.; of pronotum, male, $5 \mathrm{~mm}$., female, $6 \mathrm{~mm}$.; of tegmina, male, $14 \mathrm{~mm}$., female, $16 \mathrm{~mm}$; of hind femora, male, $12 \mathrm{~mm}$., female, $14 \mathrm{~mm}$.

This is the species which, in my former papers I have called $M$. collinus Scudd. In his "Revision of the Melanopli," Scudder has said that collinus "is very closely allied to Mr. luridus, but differs in its lack of any projecting part of the furcula, the less divergent forks of the cerci, less elevated apical margin of the sub-genital plate and greater maculation of the tegmina." In all Indiana specimens the furcula are visible, and I therefore sent representatives to Prof. A. P. Morse to compare with Scudder's types of both species. This he kindly did and answered as follows: "Trom an examination of the material in Mr. Scudder's collection and in mine, I believe $M$. collinus Scudd. and M. luridus Dodge to be one species. My reasons for so thinking are these: First. The furcula of the male is equally as well developed in collinus as in luridus. It is as pronounced in one of the type specimens of collinus from Vermont as in typical luridus, and it occurs very frequently in other New England examples of collinus. Second. The other differences stated (Rev. Mel., p. 348) as distinguishing these species, viz., divergence of forks of cerci and degree of maculation of tegmina, are quite as inconstant and valueless as the degree of development of the furcula. Third. The geographical range of each species naturally and adequately supplements that of the other." I have, therefore, combined the two species under Dodge's name, which has priority.

$M$. luridus probably occurs in all parts of Indiana, though it has been taken only in Crawford, Monroe, Vigo, Putnam, Marion, Wells, Marshall, Laporte and Porter counties. It frequents open, blue-grass pastures and the borders of gravelly and sandy terraces and prairies; and like $M$. gracilis and $M$. biviltalus, delights to carry on its courtship among the leaves and branches of the iron weeds. They begin to reach maturity about July 20th, and may be taken until late November. While of about the same length, the females of luridus are much more robust than those of either $M$. femur-rubrum or $M$. atlanis, and the tegmina just reach the tip of or are a little shorter than the abdomen, instead of exceeding it as in those species. 
74. Melasoples differentialis (Uhler). The Lubberly Locust.

Coloptenus differentiralis Uhl., MS., 1863; Thom., 206, V, 1873, 166; Id., $211,1880,91,96,127$, Fig. 24; Glov., 62, 1872, Plate VIII, Fig. 12; Palte IX, Fig. 4 ; Plate XI, Fig. 6; Riley, 119, 1877, 89, 194, 198, Fig. 34; Id, 214 , I, 1878, 220, 22:3, 225, 298, Figs. 32. 110. Plate IT, Fig. 1; Id., 122, II, 188t, 194, Fig. 271; Id., 127, XXV, 1891, 30, Fig. 8.

Arridium diffirentiul Thom., 202, T, $18(5,5,450$.

Melanopllıs differmlialis. Brun., 22, I. 1885, 139); Ir., 23, 1888, 88, Fig. 4; Id., 26, XXYII, 1892, 32; Id., 28, XXVIII, 189:3, 15, Fig. 5; Id., 30, 189:3, 461, Fig. 103; Id., 3 1, 1894, 163, 204, Fig. 67; Id.. 35, 1899, 1333, Fig. 76; Ir., 36, 1899, 247, 270, Fig. 53; Comst., 41, 188s, 108, Fig. 100; Bl., 4, XXIII, 1891, 99; Id., 15, XXX, 1898, 62; Id., 16, 1899, 238, Fig. 6t; Scudd., 179 , XXXTI, 1897, 30, 35; Id., 181 , 1897, 138, :349, Plate XXII, Figs. 3, 4; Id., 188, 1900, 57; Lugg., 84, 1898, 204, Figs. $1: 30-1: 3:$.

Size, large. Vertex gently arched, but little elevated above the rronotum; the interval between the eyes three times or more as broad as the first antennal joint; the front half gently sloping, broadly but not deeply impressed. Frontal costa broad, but narrower than the interspace between the eyes, broadly and shallowly sulcate at and below the ocellus. Antemme more than twice as long (male)

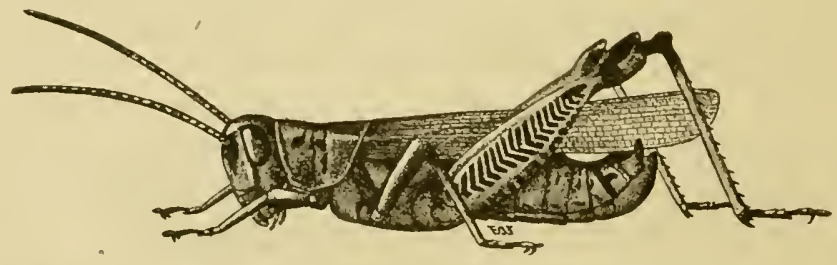

Fig. 72. Melanoplus differntialis (Uhler). Male. One and one-half times natural size. (After Lugger.)

or fully lialf as long again (female) as the pronotum. Disk of pronotum expanding feebly on the metazona, flat or nearly so; the front margin slightly convex, the hind margin obtusely and roundly angulate; the median carina distinct and sharp on the metazona, less distinet but visible on the front half of prozoua; the metazona a little shorter than the prozona and finely rugulose. 'Tegmina exeeeding the tips of hind femora in both sexes, the narrowest apical portion about half as wite as the broadest hasal portion. Hind femora stout and rather short, slightly exceeding the abomen in the male. Extremity of male abdomen but little reenred, the eerci boot-shaped, the basal half oblong; the apical half expanding and feebly forked, the strongly meurved mpper prong being as long and more than 
half as wide as the basal half; the lower prong (heel of the boot) being only a rounded, downward projecting lobe. Furcula absent. Sub-genital plate short and broad, the apical margin thickened. (See Fig. 16, Plate II.)

Color: A nearly mniform dark brownish green, or olive brown above, yellow beneath. The transverse sulci of pronotum and pleural incisions black, as are also one or two small patches on the upper half of lateral lobes of pronotum. Tegmina olive brown, immaculate. Hind femora, either dull or bright yellow, the outer face with narrow black marks arranged herring-bone fashion, the upper, inner face with three oblique black bars. Hind tibia yellow, with a narrow black basal ring, the spines black.

Measurements: Length of body, male, $30 \mathrm{~mm}$., female, $44 \mathrm{~mm}$.; of antennæ, male, $17 \mathrm{~mm}$., female, $15 \mathrm{~mm}$; of pronotum, male, $\%$ mm., female, $10 \mathrm{~mm}$; of tegmina, male, $29 \mathrm{~mm}$., female, $32 \mathrm{~mm}$.; of hind femora, male, $18.5 \mathrm{~mm}$., female, $22 \mathrm{~mm}$.

This is the largest and at the same time one of the most common and destructive of our Melanopli. It ocenrs thronghout the State, having been taken in every county in which collections have been made. In central Indiana it begins to reach maturity about July 25 th, and may be found in favorable seasons until December 1st. In late antumn the females are always worn and bedraggled, while many of the males are bright colored and evidently freshly moulted. The species becomes darker with age and those which mature in autumn are darker than those of midsummer.

In Indiana, the lubberly locust delights in low, damp waste places, such as the margins of lakes and ponds, the borders of streams, fence rows and the margins of low-land cultivated fields. It is especiaily fond of the greater rag weed, Ambrosia trifida L., of the river bottoms, and is often seen by scores feeding npon its leaves, or mating among its foliage. The various species of smartweed, Polygonum, which grow in shallow water, are also much frequented by it in early autumn. On October 2, 189t, vast numbers were seen along the edge of a field of low-land corn, the leaves of the marginal rows of which they had almost wholly destroyed. When a stalk was approached they did not desert it but dodged quickly around to the opposite side, much as does a squirrel around the trunk of a tree when pursued. If, however, one took alarm and jumped, all the others in the immediate vicinity did likewise.

On one occasion a specimen of differentialis was found feeding upon a dead example of Dicromorpha viridis, half or more of the abdomen of the latter having been devoured. The Logger-head 
shrike, Lanius indoricianus I., catches many of these and other loeusts and often impales them on the barlss of wire fences. On one October day I gathered fully a pint of snch impaled insects from a fence row half a mile long, and found that they represented sixteen species; eight of grasshoppers, two of katydids, and six of bectles, all injurious, so that this bird, although savage and bloodthirsty, is of great benefit to the farmer and fruit grower.

M. differentialis, according to Seudder, "inhabits the Mississippi Valley from as far north as latitude $43^{\circ}$ to the Gulf, and the region to the west as far as the Pacific, from a somewhat lower latitude to central Mexico. I do not think it occurs above 6,000 feet. It certainly is occasionally one of the most destructive pests in the west. particularly in Kansas, Missouri and Illinois, and it has been noted as injuring grass, alfalfa, Indian corn, bects, orchard trees, mulberry, poplar and catalpa trees, and even grape vines; also dahlias, hollyhocks and other garden flowers have been specified as its food, not to mention the rag-weed, Ambrosia trifida." Riley states that "in the vicinity of St. Louis, Missouri, the first specimens of this locust were observed to become winged July 19th. Eggs were laid September 9th. As a deviation from the usual egg-laying habits of the genus *** the eggs are sometimes very numerously placed under bark of logs that have been felled on low lands. 'The eggs of this species, unlike those of sprelus, allanis and femur-rubrum, are not quadrilinearly but irregularly arranged. *** The head ends of the eggs in the pod point mostly outward. One hundred and seventy-five eggs have been counted in a single mass." Bruner gives the following summary of its destruetiveness and habits: "This insect has very frequently multiplied in such numbers in limited areas over its range as to do considerable injury to eultivated crops growing upon low, moist ground; and has even been known very frequently to spread over higher and drier lands adjoining these, its customary haunts. It is one of the few species of locusts that has thus far shown a tendency toward civilization. This it has done readily, since its habits are in unison with the cultivation of the soil. It is only since the settlement of the country where it originally occurred that it hias multiplied so as to become sufficiently mumerous as to become a serious pest. *** *

"The eggs are laid in cultivated grounds that are more or less compact, preferably old roals, deserted fields, the edges of weed patches and well grazerd pastures adjoining weedy ravines. Egg laying begrins about the middle of August and continues into Oetober, varying, of course, according to latitude and climatic conditions. Us- 
ually, but not always, only a single cluster of eggs is deposited by each female. Frequently there are two, and in extreme cases perhaps even three, of these clusters deposited by a single female."

75. Melanoplus bivitiatus (Say). The Yellow-striped Locust.

Gryllus bivittatus Say, 138, IV, 1825, 308; Id., 139, II, 1859, 237.

Caloptenus bivittatus Ulıl., in Say, 139, II, 1859, 238; Pack., 104 , 1869, 570; Glov., 62, 1872, Plate I, Fig. 16; Thom., 206, V, 1873, 166; Id., 211, IX, 1880, 91, 96, 126; Riley, 119, 1877, 89, 194, Fig. 38; Id., 214 , I, 1878, 220, 226, 327, 459, Fig. 111; Id., 122, II, 1884, 194, Fig. 272; Id., 127 , XXV, 1891, 31, Fig. 9. Melanoplus bivittatus Scudd., 148, I, 1874, 376; Id., 179, XXXVI, 1897, 31, 35; Id., 181 , 1897, 138, 363, Plate XXIV, Fig. 5; Id., $188,1900,54$; Bl., 4, XXIII, 1891, 99; Id., 1 !, XXVI, 1894, 244 ; Id., 16, 1899, 244, Fig. 70; Brun., 28, XXVIII, 1893, 19, Fig. 8; Id., 30, 1893, 461, Figs. 104-105; Id., 31, 1894, 163, 205, Fig. 71; Id. 35, 1899, 133, Fig. 80; Id., 36, 1899, 247, 270, Fig. 50; Beut., 3, VI, 1894, 308, Plate VH, Fig. 8; Lugg., 84, 1898, 206, Figs. 133-135.

Caloptenus jemoratus Burm., 40, II, 1838, 638.

Melanoplus femoratus Scudd., 163, XIX, 1878, 284, 288; Id., 161 , VI, $1878,43,47$; Id., 179, 1897, XXXVI, 31, 35; Id., 181,1897 , 138, 360, Plate XXIV, Fig. 4; Id., 188, 1900, 58; Comst., 41 , 1888, 108, 110, Fig. 99; Fern., 53, 1888, 31, Fig. 13; Morse, 100, VШI, 1898, 257, 258, 294, Plate 7, Fig. 45.

Acridium flavovittatum Harr., 7 1, 1841, 140; Id., 72, 1862, 173; Emm., $49, \mathrm{~V}, 1854,147$; Rathv., $109,1862,384$.

Size, large. Vertex gently swollen, but little elevated above the pronotum; the interspace between the eyes about three times the width of first antemnal joint; the front half feebly sloping, broadly and shallowly sulcate. Frontal costa broad, sub-equal, feebly sulcate at and below the ocellus. Antennæ about as long (male) or two-thirds as long (female) as the hind femora. Pronotum enlarging feebly on posterior half, more distinctly in female, the disk nearly flat, the hind margin broadly rounded; the median carina low but visible throughout; the prozona fully a half (male) or about onethird (female) longer than the closely and delicately punctate metazona. Tegmina reaching or a little surpassing the hind femora, sometimes a little shorter in the female, tapering regularly and gradnally from base to tip. Hind femora rather long and moderately stout. Extremity of male abdomen but little upcurved; the cerci very stout, large and broad, the basal half narrowing gently, and beyond the middle expanding into two lobes; an upper, ovate, compressed one, nearly as long as the basal half, directed upward and backward; and a lower, short triangular one, broader than long, directed downward. Furcula consisting of a pair of short, much swollen, triangu- 
lar, widely separated lobes. Sub-genital plate narrow, the apex a little elevated and ending in an obtuse tubercle. (See Fig. 17, Plate II.)

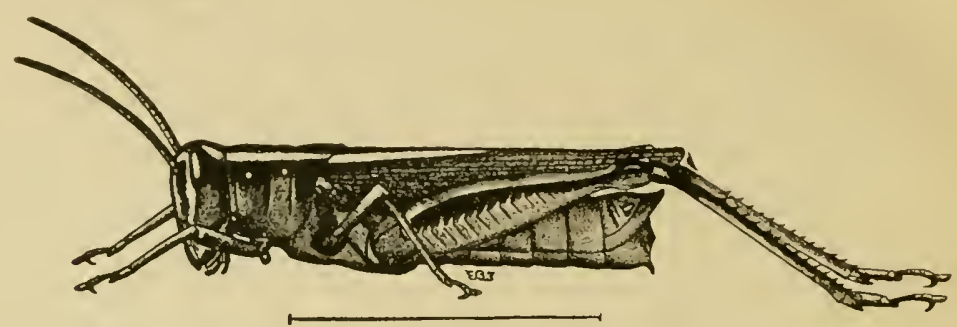

Fig. 73. Melanoplus bivitatus (Say). Female. One and one-quarter times natural size. (After Lugger.)

Color: Dull olive brown above, yellowish beneath. Face either yellow or olive green. Occiput and disk of pronotum reddish or olive brown. A narrow yellowish stripe extends back from the upper angle of each eye along the lateral carinæ of pronotum nearly to the tips of the tegmina; this usually bordered below with blackish on head and lateral lobes of pronotum. Tegmina with often a few fuscous dots along the discoidal area, but sometimes immaculate. Hind femora dull yellow, more or less infuscated along the upper half of outer face; the lower face yellow; the knees partly infuscated. Hind tibiæ usually bright coral red, with black spines; sometimes purplish or greenish yellow.

Measurements: Length of body, male, $28 \mathrm{~mm}$., female, $3 \% \mathrm{~mm}$.; of antennæ, male, $16 \mathrm{~mm}$., female, $14 \mathrm{~mm}$; of pronotum, male, 7 mm., female, $9 \mathrm{~mm}$.; of tegmina, male, $22 \mathrm{~mm}$., female, $24 \mathrm{~mm}$; of hind femora, male, $16 \mathrm{~mm}$., female, $21 \mathrm{~mm}$.

This is also a very common locust throughout the State. It begins to reach maturity about June 15th, perhaps earlier in the southern counties, and has mostly disappeared by mid-September. It frequents clover fields, open blue-grass pastures, prairies and roadsides, and is to be found in both moist and dry localities. When flushed, it usually leaps vigorously; seldom flying; and then noiselessly and for a short distance. It delights to rest on the branches and foliage of the iron weeds and other Compositx, and is often found after death, clinging to them and to tall grasses, where it has fallen a prey to the locust fungus. More than any other of our Melanopli it seems to be subject to the attacks of the red locust mite, Trombidium locustarum Riley. In August I once noted, in Putnam County, a large male with a dozen or more of the mites in different stages, attached to the membrane of the inner wings. A female near 
by, with both tegmina and wings absent, had more than 20 of the mites clinging to the thin membrane beneath the metathorax. Old and worn examples of this locust usually have the wings badly damaged.

I have combined the red-legged form femoratus with Say's older yellow-legged bivittatus, as I have taken the two forms in copulation, and have seen numerous specimens in which the tibiæ were brown at base, greenish or glaucous in the middle and red on the apical third. Specimens from New England labeled femoratus by A. P. Morse, differ in nowise from those from Indiana, called bivittatus by Prof. Lawrence Bruner.

The yellow striped locust ranges from Hudson Bay to North Carolina, and from the Atlantic to the Pacific. It sometimes occurs in such numbers as to be highly injurious. Bruner, in one of his accounts of this species says it is a "lover of rank and succulent vegetation, such as is found upon bottom lands, along the edges of cultivated fields, at the margins of woodlands and on the shaded mountain slopes." When "it develops in large numbers, then these haunts are forsaken, to a greater or less extent, and it spreads over cultivated fields, eating the choicest of everything."

76. Melaxoplus puxctulatus (Uhler). The Grizzly Locust.

Caloptenus punctulatus Uhl., MS., 1862; Scudd, 141, VII, 1862, 465; Thom., 206, V, 1873, 163.

Melanoplus aunctulatus Scudd., 148, I, 1874, 376; Id., 163, XLX, 1878, 285; Id., 161 . VI, 1878, 44; Id., 179 , XXXVI, 1897, 32, 35; Id., 181, 1897, 139, 374, Plate XXT, Fig. 4; Id., 188, 1900, 63; Fern., 53, 1888, 31; Beut., 3, VI, 1894, 252, 307; Bl., 1 5, XXX, 1898, 62; Id., 16, 1899, 187; Lugg., 84, 1898, 208, Fig. 136; Morse, 100, VIII, 1898, 257, 258, 295, Plate 7, Fig. 45 .

Caloptenus griseus Thom., 205, V, 1872, 454; Id., 206, 1873, 165; Glov. 62, 1872, Plate XII, Fig. 14.

Melcnoplus grisens: Bl., 6, XXIT, 1892; 30; Id., 11, XXVI, 1894, 245. Caloptenus heliluo Scudd., 152, XVII, 1875, 476; Id., 153, IV, 1875 , 75 ; Id., $164,1879,20$.

Melrenoplus helluo Scudd., 163, XIX, 1878, 285; Id. 16 1, VI, 1878, 44.

Size, medium. Head prominent; the vertex swollen and distinctly elevated above the pronotum; the fastigium or front half rapidly sloping and sulcate throughout, the margins much raised between the eyes which are separated by a space twice as wide as the basal joint of antennæ. Frontal costa prominent above, of equal width throughout, sulcate below the ocellus. Eyes large and, in the male, very prominent. Antennæ about as long as (male) or a fourth shorter than (female) the hind femora. Pronotum with its front 
border slightly flaring to receive the head; the posterior half widening but little; the median carina usually visible throughout but more distinct on the metazona; the hind margin broadly obtuse angled; the prozona about a third (male) or scarcely (female) longer than the finely rugulose metazona. Tegmina slightly surpassing the hind femora in both sexes; very gradually tapering to a well rounded apex. Extremity of male abdomen moderately recurved; the cerci large, broad; the basal half oblong; the apical half expanded to double the width of the basal, the upward expansion being twice or more as large as the downward. Furcula wholly wanting. Subgenital plate of moderate width, the apex rather abruptly elevated and thickened. (See Fig. 18, Plate II.)

Color: Dark gray, much mottled with blackish. Head and face greenish gray mottled with fuscous; the occiput and disk of prozon: darker. The usual black bar behind eye on upper half of lateral lobes is broken and somewhat indistinct. The disk and sides of metazona and the tegmina are thickly sprinkled with numerous rounded or quadrate fuscous spots, which give to the insect a grizzly appearance, quite distinct from any other of our Melanopli. IIind femora alternately and plainly barred with blackish and dull yellow on the upper and outer faces; the lower face and basal third of inner face coral red. Hind tibiæ either dull red or gray, or a mixture of both: the spines black. Abdomen clay yellow beneath.

Measurements: Length of body, male, $24 \mathrm{~mm}$., female, ?i $\mathrm{mm}$.; of antennx, male, $1 . \mathrm{mm}$., female, $12 \mathrm{~mm}$; of pronotum, male. 5.) mm. female, $6 \mathrm{~mm}$.: of tegmina, male, $20 \mathrm{~mm}$., female. $22 \mathrm{~mm}$.: of hind femora, male, $13 \mathrm{~mm}$., female, $15 \mathrm{~mm}$.

This prettily mottled locust has been taken in Crawford, Monroc. Vigo, Putnan, Montgomery, Marion, Marshall and Fulton counties. but is nowhere common, seldom more than half a dozen being seen each season. It is preëminently an autumn insect; the first mature specimen having been taken on August 20th, while most of those seen were in October and November after heary frost.s. In central Indiana it frequents for the most part low wooded tracts alongr streams, where it may often be noted resting on the trunks of tree.. two or three feet above the grount. In the northern part of the State it has been found only in the depths of the tamarack swamps of Fulton and Marshall counties. While other Aerididare are common up to the very borter of the tamarack growth, this and two species of grouse locusts were the only ones found within this border. Several pairs of punclulalus were taken in coitu on September 24 th. It is not an active insect; usually after one or two short leaps, 
squatting close to the earth, and seemingly depending upon the close similarity of its hnes to the grayish lichens about it to aroid detection. The general range of punclulatus is given by Scudder as Maine to Virginia and westward to Texas and Nebraska. In most places it frequents the vicinity of pine or coniferous trees, and Walker has recently given an interesting account of its habits as follows: "I found them most numerous on dead stumps and logs, in a wood of second growth white pine, at De Grassi Point, Ontario. They were sometimes seen on the trunks and branches of living trees, but most often on the stumps and fallen trunks of the old forest, and on the pine rails of a snake fence enclosing the wood. They were found only on the borders and more open parts of the woods, where they were to be seen upon almost every stump. I have seen ten females on a single stump. It is in these dead stumps and logs that the females deposit their eggs, in which operation I have observed them repeatedly. The female chooses a crack in the wood or an old beetle boring of suitable size and lowers her abdomen down this, sometimes nearly as much as an inch. Sometimes when the hole is of a large size. only the head and legs of the insect can be seen above it. Unlike Chloallis conspersa, the female of $M$. punctulatus apparently never bores herself, unless merely to make her way through any loose rubbish that might be obstructing the hole. She generally chooses sound or only partly decayed wood.

"I managed to obtain several fragments and one complete packet of eggs. The latter was fixed by the cement substance at its lower end to the wall of the bectle-boring three-eighths of an inch in diameter. It was attached at a distance of about three-quarters of an inch down the hole, and except at the lower end, which was imbedderl in a depression in the wall, the packet was quite free. It was corered with a rather thick coating of a porous or vesicular cement substance, which also filled all the spaces between the closely packed eggs. The latter were twenty-three in number, and their arrangement was in general in a longitudinal direction, the anterior ends pointing toward the free end of the packet, but was otherwise irregular. The eggs are 4 to $4.8 \mathrm{~mm}$. long, elongate-elliptical in form, finely and densely punctate, reddish brown."*

"Can. Ent., XXXIII, 1901, 22. 


\section{XXXix. Phetalio'tes Scudder (1897).}

Body elongate, rather slender, a little compressed. Head large, prominent, nearly half as long again as the prozona. Vertex prominent; the narrowest portion one and one-half times as wide as the frontal costa, the front half sloping downward, with a broad, median furrow or depression. Frontal costa with the lower half much wider than the upper; the region just below the ocellus concave. Antennæ about three-fourths the length of hind femora. Pronotum enlarged a little in front to receive the head; the disk with the sides a little sloping, the hind margin broadly obtuse angled; the median carina rather sharp, of equal height throughout, cut by all three of the transverse sulci. Lateral lobes of pronotum with the lower margin obtuse angled near the middle. Tegmina either abbreviate or fully developed. When the former; a little longer than the pronotum, broadly lanceolate, the inner margins touching about the middle. When developed, surpassing the hind femora in both sexes. Hind femora slender, surpassing the tip of abdomen in male, a little shorter in female. Abdomen compressed, carinate above, its apical fourth thickened and curved upward in the male. Cerci depressed, styliform. Furcula minute, triangular. (See Fig. 19, Plate II.)

One species is known from the United States; the short-winged form of which occurs in northern Indiana.

77. Phataliotes nebrascensis (Thomas).

Perotettix nebrascensis Thom., 205, V, 1872, 455; Id., 206, T, 1873, 151; Glov., 62, 1872, Plate XIII, Fig. 2.

Phoctatiotes nebrascensis Scudd., 177 , XXXII, 1897, 205; Id., 181 , XX, 1897, 377, Plate I, Fig. 9, Plate 25, Figs. 6, 7; Id., 188, 1900, 65. Pezolettix autumnalis Dodge, 45, VIII, 1876, 10; McN., 88, VI, 1891, 76.

Caloptenus volueris Dodge, 46, IX, 1S77, 112.

Color: Olive green, more or less marked with fuscous. Face olive green, darker above. A broad blackish band back of eye extends along side of pronotum to posterior transverse sulcus. Disk of pronotum and tegmina wood brown. Abdomen of male with the sides greenish, the posterior third of each segment fuscous; in the female the fuscous predominates. Hind femora greenish tinged with reddish brown; the lower face reddish yellow; the knees black. Hind tibiæ dull green, the spines black. The structural characters are given above under the generic heading.

Measurements: Length of body, male, $22 \mathrm{~mm}$., female, $26 \mathrm{~mm}$; of antennæ, male, $9.5 \mathrm{~mm}$., fenale, $7 \mathrm{~mm}$.; of pronotum, male, $5 \mathrm{~mm}$., 
female, $6 \mathrm{~mm}$.; of tegmina, male, $6 \mathrm{~mm}$., female, $7 \mathrm{~mm}$.; of hind femora, male, 13 mm., female, $14 \mathrm{~mm}$.

Only the short-winged form of this dull colored locust has been taken in Indiana, and those only in Lake and Porter counties on October 11 and 12, 1898. Just east of Hammond, they were found in a long, low, marshy tract among the leaves of blue flag. The next day they were more abundant about some marshes northwest of Dune Park. The males were strong and active leapers, oftentimes giving several great jumps to a tuft of bunch grass or weeds and gliding down it to the ground, where they squatted close until picked up with the fingers. The females were more sluggish and several were taken from between the stems of grass where they were standing on their heads, after endeavoring to escape by diving downward. This is the most eastern point from which the species has been recorded, its range, as given by Scudder, being from the Rocky Moun-

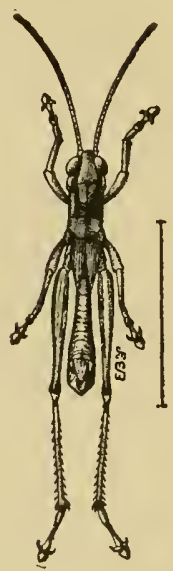

Fig. 74. Phretaliotes nebrascensis (Thos.). Nale.

(After Lugger.) tains to the Mississippi River, though McNeill has taken it in Rock Island and Henry counties, Illinois.

\section{Paroxya Scudder (1877).}

Size, medium. Body straight, sub-cylindrical. Head of average size, the eyes very large and prominent. Vertex narrowed between the eyes, but less so than in Hesperolettix, the narrowest portion, in the male, being about as broad as the frontal costa, broader in the female; the widened portion in front with a broad lengthwise furrow. Frontal costa prominent above the ocellus, flattened below, scarcely sulcate in the male, more strongly in the female. Antennæ of male usually more than half as long again as head and pronotum together. Disk of pronotum twice as long as average breadth, its edges nearly parallel, the surface flat or nearly so; the prozona half as long again as the metazona, the surface of the latter finely and densely punctate; the hind margin obtusely and bluntly angulate; the median carina low, of equal height throughout, cut only by the last transverse sulcus. Lateral lobes of pronotum vertical, longer than deep, the lower margin with its front half strongly directed upward. Tegmina and wings variable in length, but in our species always much longer than the pronotum. Hind femora of average stoutness, equaling or more usually surpassing the tip of abdomen. Sub-genital plate 
of male short, the apex more or less truncate; the cerci long, spoonshaperl, the apex incurved.

Four species are known from the United States, two of which have been described from Indiana.

KEY TO INDIANA SIEE'IES OF PAROXYA.

a. Length of body of male, 20 or more mm. Antenna of male longer than hind femor: 'Tegmina reaching middle of abdomen in both

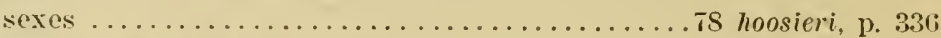

au. Lengtli of hody of male not over $17.5 \mathrm{~mm}$. Antenna of male but three-fonrths the length of hind femora. Tegmina nearly as long as abdomen in female, slightly surpassing abdomen in male......

79 scudderi, p. 339

78. Paroxya hoosieri (Blatchley). The Hoosier Locust.

Peroteflix honsieri Bl., 6, XXIV, 1892, 31.

Prionge hoosieri Scudd., 177 , XXXII, 1897, 205; Id., 181 , XX, 1897, 381, 382, Plate 25, Fig. 9; Id., 188, 1900), 66; Bl., 15, XXX, $1898,63$.

l'arriya, allantica, Bl., 11, XXVI, 1894, 244.

Antennæe of male very long, exceeding the length of posterior

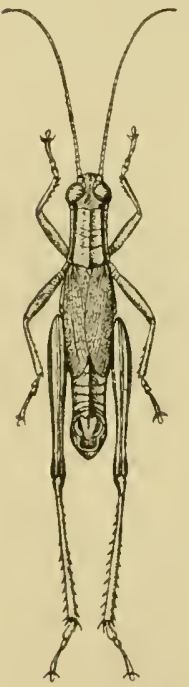

Fig. 75. Paroxya hoosieri (B1.). Hale. One and one-third times natural size. (1)riginal.)

fomora. Foreole present, almost twice as long as. wirle, more distinct in the female. Pronotum broadening slightly on posterior half (more noticeable in the female); median carina distinct and equal throughout, the transverse sulci scarcely noticeable in the female, distinct but shallow in the male; the lateral carine present but ronnded obtusely off; the disk and sides of pusterior lobe densely and rather coarsely pumetate. 'legmina oblong. two and a half times as long as liroad, reaching to middle of abdomen and slightly overlapping on the median dorsal line. the wings but little shorter. Sub-genital plate of male broader than high, the lateral edges higher and flaring slightly outward. Cerci long and slender, gently incurred, narrowed at the middle, with the apical third flattened and slightly hollowed on the exterior face. Fureula consisting of a pair of oblong, parallel, flattened plates, whose inner alges touch: their apical third somewhat tapering and blunt. (See Fig. 20, Plate II.)

Color of living specimens: Male, antenna, light reddish brown, infuscaterl at tip, and with the apical sixth of each segment yellow- 
ish. Face, green; clypens and mouth parts yellow. Tertex, disk of pronotum and tegmina, plain olive, immaculate. Lateral lobes of pronotum greenish-yellow below; above with a broad, shining black line reaching from the eye to their posterior edge. The under side of abdomen pale yellow, and the metapleura with an oblique yellow line. Femora, green; knees, black; hind tibiæ, greenish, yellowish brown at base, with black spines.

Female: Duller; the disk of pronotum and tegmina sometimes with minute fuscous spots; a black stripe on the sides of abdomen, above which are numerous small black blotches.

Measurements: Length of body, male, $22 \mathrm{~mm}$., female, $31 \mathrm{~mm}$; of antennæ, male, $15 \mathrm{~mm}$., female, $11 \mathrm{~mm}$; of pronotum, male, 5 mm., female, $6 \mathrm{~mm}$.; of tegmina, male, $10 \mathrm{~mm}$., female, $13 \mathrm{~mm}$; of hind femora, male, $14 \mathrm{~mm}$., female, $17.5 \mathrm{~mm}$.

This species was first noted in Indiana about the margins of the "Goose Pond," Vigo County, on October 11, 1901. It at once attracted attention on account of the length of the male antennæ, and the black stripes on the sides of the abdomen of the female. The pond was then almost dry, and the dense growth of sedges and rushes which had filled its shallow margins, were, in some places, burned away. Over the burned spots had sprung up a dense green vegetation, and here this Paroxya flourished in company with Truxalis brevicornis and Dicromorpha viridis, while a few feet away Leptysma marginicollis found a suitable home among the rushes and sedges still standing. Both sexes of $P$. honsieri were very active, leaping vigoronsly when approached, and difficult to capture except by throwing the net over them as they rested on the ground. The females were exceedingly difficult to kill in the cyanide bottle, "coming to" after having been kept in it for several hours, although the males were killed in a few minutes. On October 27 th, the spot was again visited, and, although several heary frosts had occurred, yet the species was still fairly common. At this time, however, they were all found in the small patches of grass which grew among the fallen leaves a few yards from the edges of the pond proper.

Since then the species has been found to be rather common in the western and northern portions of the State, having been taken in Gibson, Fulton, Starke, Lake, Kosciusko, Steuben, Whitley and Wells counties, and also by Mr. Lynds . Tones near Oberlin, Ohio. In all these localities it occurs about the borders of marshes, especially those bordering the lakes and tamarack bogs of the north. In Gibson County it was fomnd mature on . July 10 th. 
On one occasion I found a female of this species and also one of Chlcaltis conspersa Harr., a few inches apart on the stump of a downy poplar, Populus heterophylla I., each with the abdomen buried to the full length in the soft wood, but no eggs could be discovered. Nothing has been recorded concerning the habits of oviposition of the members of the genus Paroxya, and it would be surprising if they, like the Chloaltis mentioned, should seek wood rather than earth as the receptive matrix for the eggs.

I at one time considered hoosieri a short winged form of $P$. atlantica, but, on account of distinctive characters pertaining to the abdominal appendages of the male, Scudder regards it as a valid species.

79. Paroxya soudderi Blatchley. Scudder's Paroxya.

Paroxya scudderi Bl., 15, XXX, 1898, 59; Scudd., 188, 1900, 66.

The smallest known member of the genus, the body of the male averaging but $17 \mathrm{~mm}$. in length. Antennæ relatively short, being but $9 \mathrm{~mm}$. in length in both sexes. Tegmina reaching slightly be-
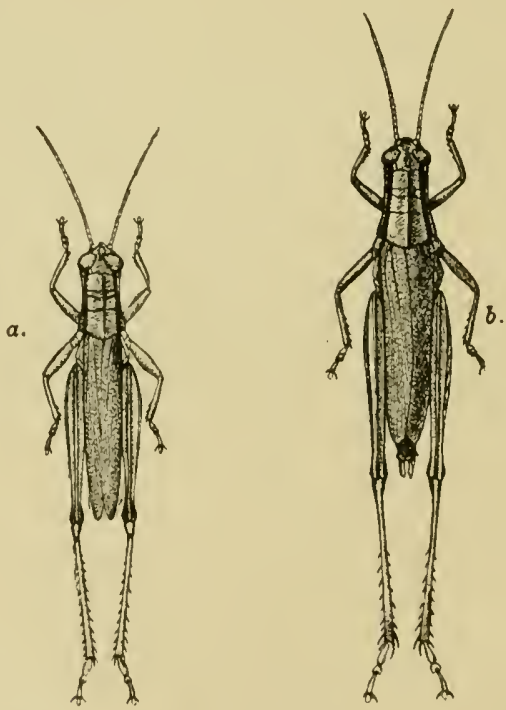

Fig. 76. Paroxya aculderi Bl. a, Male. 6, Female. One and one-third times natural size. (Original.)

yond tip of abdomen in male, a little shorter than abdomen in female. Supra-anal plate of male very short, triangular, with a short, basal, triangular sulcus, in which rest the furcula. These consist of a pair of flattish, oblong. sub-equal plates with their inner edges 
touching except at the apices, where they slightly diverge. Cerci strongly incurved, narrowed at the middle, the basal half stouter than in $P$. hoosieri, the apical third flattened and rounded at the end.

Color: Metazona, tegmina, and upper and outer faces of all the femora of male a uniform light wood brown; occiput and prozona darker. A broad black stripe extends from the eye along the upper half of the lateral lobes of pronotum as far as the posterior transverse sulcus, where it ends abruptly, the posterior lateral lobe being uniform in color with the disk. Below this black stripe is one of ivory white, brightest on the head. Metapleura also ivory white. Face grayish olive, flecked or tinged with yellowish. Basal twothirds of antennæ the color of the tegmina; apical third darker. Palpi and prosternal spine yellow. Sternites of thorax olive brown; those of abdomen yellow as also the lower faces of all the femora. Hind tibiæ dull, pale green (basal third sometimes light brown), with a black spot at knee; the spines eleven in number in the outer series, with their apical thirds black.

Female darker; the tegmina sometimes obscurely and sparingly flecked with fuscous; the yellow of under side dull or wanting.

Measurements: Length of body, male, $17 \mathrm{~mm}$., female, $24 \mathrm{~mm}$; of antennæ, male and female, $9 \mathrm{~mm}$; of pronotum, male, $5 \mathrm{~mm}$. female, $5.5 \mathrm{~mm}$; of tegmina, male, $13 \mathrm{~mm}$., female, $14.5 \mathrm{~mm}$.; hind femora, male, $11.5 \mathrm{~mm}$. female, $13.5 \mathrm{~mm}$.

This graceful-bodied species was first found in small numbers on July $2 \%, 189 \%$, about the grassy margins of a pond in the sand dune region north of Millers, Lake County, and within one-half a mile of the shore of Lake Michigan. On the following day a single pair were taken from a similar locality near Tolleston, in the same county, and about four miles from the lake, but still within the sand covered area. It was nsually found clinging to the stems of the tall rushes and grasses common in such locations, and when disturbed the males used the wings in a noiseless flight, while the females depended upon their leaping powers to escape. When closely followed, they would attempt to hicle by burrowing in the fallen grass.

No others were secured until July 24, 1902, when a single male was taken from low ground along a railway southeast of Hammond. On August 20th it was found in numbers in the tall grasses along a lobe of Bass Lake, Starke County.

$P$. scudderi is more closely allied to $P$. allantica than to either of the other two known species of the genus, but its smaller size, shorter antennæ of male, longer cerci, and the different shape of the male furcula at once distinguish it. It will probably be found to occur 
about low moist places in many of the counties of the northern third of the State.

\section{Family LOCUSTIDE.}

As already noted the sub-order, Sallatoria or Jumpers, includes three families of Orthoptera, one of them being the Locustidee. This family comprises those insects commonly called katydids, green or long-horned grasshoppers and stone or camel crickets.

The distinguishing characters of the members of the family Locustida, as given in the key, p. 210, are the long, slender, tapering, many-jointed antennæ; the almost universal absence of ocelli or simple eyes; the four-jointed* tarsi or feet; and the sword-shaped or falcate ovipositor of the females, which is made of four flattened plates. The head in many of the species is wedge-shaped and the mouth parts are well developed, the mandibles, especially, being long and sharp pointed. This enables the inseet to dig into plant tissue or to eat the seeds of grasses, as many of them do. The males hare, in many instances, abdominal appendages corresponding to the parts of the ovipositor, which are used as clasping organs. The tegmina or wing covers, when present, slope obliquely downwards, instead of being bent abruptly, as in the Gryllide or true erickets; and in most cases, the wings are longer than the tegmina.

'The stridulating or musical organ of the males is quite similar in structure to that of the male cricket, being found at the base of the overlapping dorsal area of the tegmina and nsually consisting of a transparent membrane, of a more or less rounded form, which is crossed by a prominent curved vein, which, on the under side, bears a single row of ininute file-like teeth. In stridulating, the wing covers are moved apart and then shuffled together again, when these teeth are rubbed over a vein on the upper surface of the other wing cover, produeing the familiar, so-ealled "katydid" sound. Each of the different species makes a distinet call or note of its own, and many of them have two ealls, one which they use by night and the other by day. Any one who will pay close attention to these different (alls can soon learn to distinguish each species by its note as readily as the ornithologist ean recognize different species of birds in the same manner. The ear of these insects, when present, is also similar in structure and position to that of the ericket's, being an oblong or oral eavity covered with a transparent or whitish membrane and situated on the front leg, near the basal end of the tibix.

* The members of the genus Daihinia, no one of which occurs in Indiana, have the fore and hind tarsi three jointed. 
The young of Locustida, like those of the other families of the Orthoptera, when hatched from the egg resemble the adults in form but are wholly wingless. As they increase in size they moult or shed the skin five times, the wings each time becoming more apparent, until after the fifth moult, when they appear fully developed, and the insect is mature or full grown, never increasing in size thereafter. Throughout their entire lives they are active, greedy feeders, mostly herbivorous in habit; and where present in numbers necessarily do much harm to growing regetation.

In the number of species in any given locality, the Locustide far outrank the Gryllidce, being excelled in this respect among the other Orthopteran families only by the Acrididae or Locusts. According to Scudder, 194 species of the family are known from the United States. Of these, 40 have been taken in Indiana and are described in the present paper, specimens of all being in my private collection. This is seven more than are known in any other State from which lists have been published except Nebraska, where Bruner records the presence of 58 species. McNeill has listed 27 from Illinois; Smith 33 from New Jersey; Osborne 24 from Iowa, and Scudder 23 from all New England.

Six sub-families of Locustida occur in the United States and all are represented in the Indiana fauna. They may be separated by the following table:

A SYNOPSIS OF THE SUB-FAMILIES OF LOCUSTIDA KNOWN TO OCCUR IN INDIANA.

a. Tegmina and wings present.

b. Prosternal spines absent; vertex rounded or deflexed without spine, tubercle or cone; tegmina always shorter than wings; hind tibire with an apical spine on each side.............

Phaneropterina, p. 342

$b b$. Prosternal spines present; vertex either terminating in a sharp flat spine or produced upward and forward in a rounded tubercle or prominent cone; hind tibiæ with an apical spine on outer side only or on neither.

c. Wing covers leaf-like, broadly expanded in the middle, concave within, longer than the wings; vertex terminating in a sharp, flat spine; pronotum crossed by two distinct transverse sulci........PSEUdOPHYLLIN $\approx$, p. 358

ce. Wing covers narrow, expanded but little, if any, in the middle, often shorter than the wings; vertex terminating in a rounded tubercle or prominent cone; pronotum without, or with only one, transverse sulcus...... 
aa. Tegmina and wings absent, or the former rudimentary.

d. Pronotum extending back to the abdomen; prosternal spines present; fore tibine with a hearing organ near the base: tegmina rudimentary ............... Decticin

dd. Pronotum short, not covering the whole top of thorax; prosternal spines absent; fore tibiæe without a hearing organ near the base; wholly wingless.

$e$. Eyes ovate, vertical, situated on the side of the basal joint of antennæ; ovipositor ensiform, curved strongly

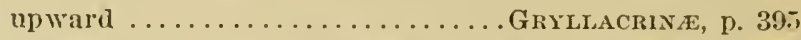

ee. Eyes sub-rotund, situated partly above the basal joint of the antenna; oripositor nearly straight............

Stexopelatate, p. 396

\section{Sub-family PHANEROPTERINA.}

The species of this sub-family are among the largest of our Locustidæ, and, with those of the Pseudophyllinæ, are commonly known as "Katydids." The apex of the head is obtuse or rounded, without cone or spine, and the prosternum is unarmed. The wing covers are shorter than the wings, usually expanded in the middle, and of a bright uniform green color. The wings are folded like a fan and are long and strong, the insects being flyers rather than leapers. The hind limbs, being seldom used except to give themselves an upward impetus at the beginning of flight, while long and slender, are proportionally much smaller in diameter than in the sub-family Conocephatina, whose members leap rather than fly.

The "katydids" are the most arboreal of all of the Locustido, the great majority of them passing their entire lives on shrubs and trees, where they feed upon the leaves and tender twigs, and, when present in numbers, often do excessive injury. The color and form of their wings serve admirably to protect them against their worst foes, the birds; and as they live a solitary life, i. e., do not flock together in numbers as do the green grasshoppers, they are but seldom noticed by man. Their love calls, or songs, however, make the welkin ring at night from mid-August until after heary frost, and though but one or two of the eight species found in the State make a mote in any way resembling the syllables "Katy did, she did," yet all are accredited with this sound by the casual observer, and hence the common name usually given to the members of this sub-family. Their call is seldom made by day for the obrious reason, that it might attract the attention of the birds and so lead to the destruction of the songster. As twilight approaches, however, the male of each species begins his peculiar note, which is kept up with little or no 
intermission until the approach of day warns him that his feathered enemies will soon be on the alert, and that silence will be, for a time, the best policy to pursue.

From the other Locustidæ, the katydids differ widely in their habits of oviposition. The eggs are not deposited in the earth or in twigs, but are usually glued fast in double rows to the outer surface of slender twigs, or are inserted in the edges of leaves. The eggs of the most common species appear like small flattened hemp seeds, and usually overlap one another in the row in which they are placed. On account of this method of oviposition, the ovipositors of the katydids are broader, more curved, and more obtuse at the end than in the other sub-families whose members oviposit in the earth, in rotten wood or in stems of grass. This sub-family is represented in Indiana, so far as known, by three genera, which may be separated by the following table:

\section{KEY TO GENERA OF INDIANA PHANEROPTERINA.}

a. Wing covers of nearly equal breadth throughout; fastigium of vertex no broader than the first antennal joint; supra-anal plate of male with a long decurved spine which is notched at the end.....

XLI. SCUDDERIA, p. 343

aa. Wing covers widest in the middle; fastigium of vertex much broader than the first antennal joint; supra-anal plate of male not as above. b. Hind femora but little, if any, shorter than wing covers; ovipositor well developed, curved gradnally upward...........

XLII. AMBLyCORYPHA, p. 350

$b b$. Hind femora much shorter than wing covers; ovipositor very

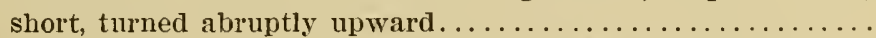

XiliII. Microcentrum, p. 353

\section{Xli. Scudderia Stal (1873).}

This genus includes katydids of medium size, with wing covers long, narrow, of nearly equal width throughout, and rounded at the ends. The fastigium of vertex is acuminate, scarcely deflexed and very narrow, while the vertex itself is compressed, and hollowed out on either side for the better accommodation of the eyes, which are nearly hemispherical. The fore and middle femora are unarmed beneath, while the hind femora are long and slender, almost equaling the length of the wing covers in some of the species. The ovipositor is short, broad, curved sharply upward, and has the apical third finely crenate on both margins. The males are readily distinguished from those of the other genera by having both anal plates 
projected into long curved processes; the one from the supra-anal plate curving downard and notched or forked at the end, that from the sub-anal ('urving upward, and likewise notehed. The form of these processes, together with that of the notches, serve as valuable characters in distinguishing the species. Eight species have been described from the United States, four of which are known to occur in Indiana.

\section{REY TO INDIANA SPECIES OF SCUDDERIA.}

11. Length of posterior femora $28 \mathrm{ol}^{\circ}$ more $\mathrm{mm}$.

b. Notch of supra-anal spine of male square with a minute median tooth, the notch as wide as the middle of the upturned suban:l spine, and embracing the latter when in natural position: the lateral processes slender and compressed...........

So terensis, p. 344

b. Notch of sulpra-anal spine of male acute, without median tooth, and much narrower than the middle of the upcurved subanil spine: the lateral processes (at side of notch) broadly roundel with the lower margin thinner, touching only and not

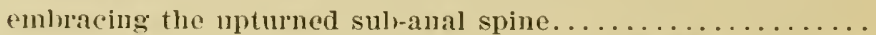

81 curvicatuda. 1). 345

au. Length of postrrior femora less than $25 \mathrm{~mm}$.

c. Notch of supra-anal spine of male very similar to that of curirumlu; tegmina mucl broader than depth of body.......

82 pistillate, p. 347

(r. Notch uf supra-inal spine of male deep and rounded, forming a curions fork-like appendage, the lateral processes of which are much swollen: tegmina no broader than depth of body...

S:3 fureata, p. 348

80. Soudderia trexexsis Saussure-Pictet. The Texas Katydid,

Sculderia texensis Sauss-Pict., 1 36, 1897, 328, Plate 15, Figs. 18-19;

Scudd., 182, 1898, 27:3, 277, Fig. 1; Id., 188, 1900, 69.

Sculderia curvicauda B1., 7, 1893, 99: Bent. 3, VI, 1894, 275, Plate V'II, Figs. 5, 6; Lugger, 84, 1898, 216, Fig. 138.*

T'egmina, wings and legs bright wrass green; borly and face somewhat paler, approaching a whitish in dried specimens. Promotmm much longer than broad, narrower in front than behind, and with a vellowish line along the lateral carina. Posterior femora very slender, armel beneath on inmer carina with three or four minute spines.

Measurements: Tength of body, male, $22 \mathrm{~mm}$., female, 2.; nm.; of pronotum, male, 6.5 mm.; of tegmina, male, $3 \% .5 \mathrm{~mm}$.: of wings

"The synonymy of the spocies of Scudderia has, in the past, heen so badly mixed, that it is difficult to say just what species was referred to by any writer. Mr. Scudder, in his monograph entitled, "The Orthopteran Group Scudderia" (Proceedings Amerieau Academs" Arts and Science, X.XIII, 1898, finally brought order out of chaos, and fixed the present standing of each speeies. 
beyond tegmina, $6 \mathrm{~mm}$.; of hind femora, male, $30 \mathrm{~mm}$., female, 32 $\mathrm{mm}$; of ovipositor, $7 \mathrm{~mm}$. Width of tegmina, $6.5 \mathrm{~mm}$.

Texensis is, in Indiana, one of the most common of the katydids. It has been taken in Crawford, Vigo, Putnam, Henry, Wells, Fulton, Marshall, Porter, Starke and Lake counties. According to Scudder, it ranges over the United States east of the Great Plains. In sonthern Indiana it probably reaches maturity about July 15th. The earliest date on which I have taken it was July 22d, in Putnam County.

The eggs of texensis are laid in the edges of leaves between the upper and lower epidermis, and at first are so thin that they are not

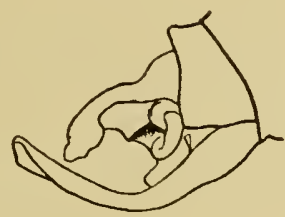

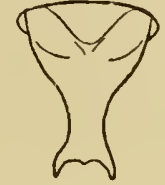

b

Fig. 77. $a$. Extremity of male abdomen of Scudderia texensis Sauss.-Pict. $b$. Dorsal view of anal segment of same. (After Scudder.)

noticeable except when the leaf is held between one's self and the light. They are loosely inserted in these pockets made by the ovipositor of the mother, and as they swell in coming in contact with the ruptured tissnes of the plant, they are held tightly in place. The winter of this, as well as of the other species of the genus, is passed in the egg stage, the young appearing about the last of April.

This insect is probably less arboreal than any other species of katydid, as it is often found clinging to the tall, coarse grasses and sedges which grow near the borders of lakes, ponds and in damp ravines, and to the coarse weeds along the margins of prairies and meadows. When approached, it flies rapidly in a zigzag, noiseless manner for a long distance to another clump of grass or weeds, or to the lower branches of an oak, a tree in which it delights to dwell.

81. Scudderia Curvicauda (De Geer). The Curve-tailed Katydid.

Scurlderia rumicumla De G., 57, UI, 1773, 446, Plate 38, Fig. 3; Brumn., 38, 1878, 240; Sauss.-Pict., 136, 1897, 331, Plate 15. Fig. 20; Scudd., 182, 1898, 274-278, Fig. 3; Id., 188, 1900. 68.

Phaneroptere angustifulic Harr., 7 1, 1841, 129.

Sculderire angustifoliu Scudd., 168, 1892, 67 (note of set to music).

Scudderia furculatu Bl., 7, 1893, 100; Beut., 3, VI, 1894, 275; Lugger, 84, 1898, 217, Figs. 139-140.

$52-$ Geol. 
This species closely resembles $S$. texensis in size and general appearance, and the females of the two are diffieult to distinguislı; the males, however, are readily separated by the different form of the notch of the supra-anal spine. The general color of the two species is the same, but the yellow carinal lines of the pronotum are less dis-
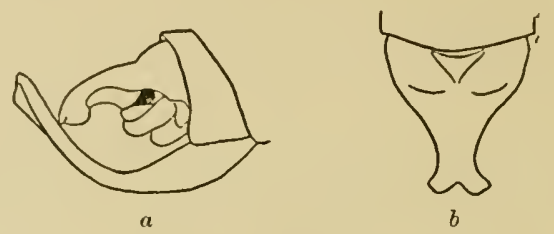

Fig. 78. (a) Extremity of male abdomen of Scudderia curvicauda (De Geer).

(b) Dorsal view of anal kegment of same. (After Scudder.)

tinct or wholly wanting in curvicauda. The wing covers vary in width, but are usually broader than in texensis; and longer and much less broad, proportionally, than in the next species, $S$. pistillata. The females of curvicauda are more robust, and have the serrations on the margins of ovipositor less prominent than those of texensis.

Measurements: Male-Length of body, $23 \mathrm{~mm}$.; of tegmina, 35-37 $\mathrm{mm}$.; of posterior femora, 28-30 $\mathrm{mm}$.; of pronotum, $6 \mathrm{~mm}$. Width of tegmina, $7-8 \mathrm{~mm}$. Female-Length of body, $25 \mathrm{~mm}$.; of tegmina, $38 \mathrm{~mm}$; of posterior femora, $32 \mathrm{~mm}$; of ovipositor, $7 \mathrm{~mm}$. Width of tegmina, $8.5 \mathrm{~mm}$.

Curvicauda probably occurs in all portions of the State, but is less common than texensis. It has been taken in Lake, Starke, Fulton, Marshall, Kosciusko, Putnam, Vigo and Posey counties and is especially common about the marshy meadows bordering some of the lakes and tamarack swamps of northern Indiana. The earliest date on which a mature specimen was taken was July 10th, in Knox County. The general range of curvicauda is the same as that of texensis. The habits of flight, as far as noted, are also essentially the same as in that species.

In New Jersey, according to J. B. Smith, both curvicauda and texensis are very common on cranberry bogs, and destroy many of the berries. They eat into the fruit to get at the seed, which they devour, and leave the berry to dry up. A flock of turkeys which will destroy the young of these katydids and drive off those that are winged is probably the most effective remedy.

Mr. S. H. Scudder, who has studied carefully the songs of many species of Orthoptera and has even set a number of them, including that of curvicauda, to music, has given a pleasing account of its 
song, from which I take the following extract: "It is more noisy by night than by day; and the songs differ considerably at these two times. The day song is given only during sunshine, the other by night and in cloudy weather. I first noticed this while watching one of the little creatures close beside me; as a cloud passed over the sun he suddenly changed his note to one with which I was already familiar, but without knowing to what insect it belonged. At the same time all the individuals around me, whose similar day song I had heard, began to respond with the night cry; the clond passed away, and the original note was resumed on all sides. Judging that they preferred the night song to that of the day, from their increased stridulation during the former period, I imitated the night song during the sunshine, and obtained an immediate response in the same language. The experiment proved that the insects could hear as well as sing. * * * The note by day is bzrwi and lasts for onethird of a second. The night song consists of a repetition, ordinarily eight times, of a note which sounds like tchw. It is repeated at the rate of five times in three-quarters of a second, making each note half the length of the day note."

\section{Soudderia Pistillata Brunner.}

S'enddcria pistilluta Brumu., 38, 1878, 240; Beut., 3, VI, 1894, 276; Sauss. Pict., 136, 1897, 328, 332; Lugg., 84, 1898, 220, Figs. 144, 145; Scudd., 182, 1898, 273, 277; Id., 188, 1900, 69.

This species is closely allied to S. curvicauda but is shorter bodied, broader winged and shorter legged. The notch of supra-anal spine of male is very similar to that of the male curvicauda, but the lateral processes are sub-triangular and distinetly tapering instead of well rounded and of sub-equal breadth as in the latter species. The sub-

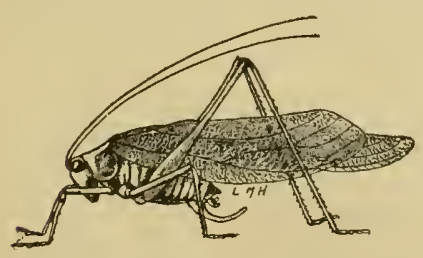

Fig. 79. Scudderia pistillata Brunn. Male. (After Lugger).

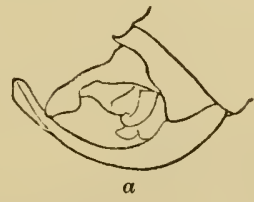

Fig. 80. (a) Extremity of male abdomen of Scudderia pistillata Brunn. (b) Dorsal view of anal segment of same. (After Scudder).

anal spine is also shorter than in curvicauda. The short, broad tegmina and the short hind femora of pistillata are the characters which most readily distinguish the two. 
Measurements: Male-Length of body, $19 \mathrm{~mm}$; of tegmina, 32 $\mathrm{mm}$; of hind fenora, $21 \mathrm{~mm}$; of pronotum, $5.5 \mathrm{~mm}$.; width of tegmina, $10 \mathrm{~mm}$. Female-Length of body, $19 \mathrm{~mm}$; of tegmina, $25 \mathrm{~mm}$.; of hind feunora, $20 \mathrm{~mm}$.; of pronotum, $5.5 \mathrm{~mm}$.; of ovipositor, $6.5 \mathrm{~mm}$; width of tegmina, $9 \mathrm{~mm}$.

Pistillata is a species of northern range, its general distribution being "Northern United States and Canada east of the Great Plains." It is a scarce inseet in Indiana, having, up to the present, been taken in small numbers only about the peat bogs and borders of lakes in Fulton and Koscinsko counties. Mr. Seudder, in his revision of the group, was mistaken in referring the species described in my former paper under the name of furculata to pistillata; as the measurements in my paper will prove. They belonged to curvicauda as at present limited, and are so placed in this paper.

83. Scudderia Furcata Brumner. The Fork-tailed Katydid.

Sćculderie furcetu Brann., 38, 1878, 239, Fig. 72; B1., 7, 1893, 101 ; Beut.. 3, VI, 1894, 275; Sauss.-Pict., 136, 1897, 328, 331, Plate 15, Figs. 16, 17; Scudd., 182, 1898, 275-284, Fig. 8; Id., $188,1900,68$.

Scudderia angustifolia B1., 7, 1893, 102.

Themeroptera curvicuda Riley, 11 5, 1874, 164, Figs., 50, 51. (Text in part.)

This is the smallest, and at the same time, our most common species of the genus. The general color is a dark leaf green, the head and pronotum paler; the latter without trace of yellow on its earinæ. The anterior margin of the pronotum is but slightly narrower than the posterior, whereas in the three preceding species the difference in width is plainly perceptible. The notch of the supraanal spine of the male is deep and rounded, forming a curious forklike appendage, the lateral processes of which are much swollen.

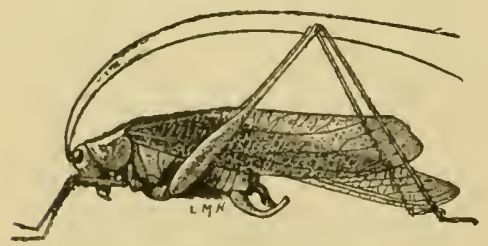

Fig. 81. Sculderia furcata Brunn. Male. (After Lugger.)

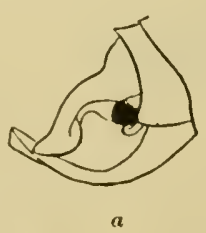

Hig. 82. (a) lixtremity of malo abdomen of Scudderia furcata Brunn. (b) Dormal view of anal segment of same. (After Sculder.)

Measurements: Male-Length of body, 14-16 mm.; of tegmina, $26-31 \mathrm{~mm}$; of posterior femora, 19-22 mm.; of pronotum, $5 \mathrm{~mm}$. 
Width of tegmina, $6 \mathrm{~mm}$. Female-Length of body, 18 to $20 \mathrm{~mm}$.; of tegmina, 26-30 mm.; of posterior femora, $22 \mathrm{~mm}$.; of ovipositor, $5 \mathrm{~mm}$.

Furcata occurs in all portions of the State, haring been taken in every county where collections have been made. Its general range includes the United States and southern Canada east of the Great Plains. In central and southern Indiana the first mature specimens appear about July 15th, but they do not become plentiful before the first of August, and I have seen the nymphs in Vigo County as late as September 18th. It is most frequently seen on the low bushes and trees about the margin of thickets and along fence rows, but in the prairie country north it frequents coarse grasses and weeds in company with the preceding species. Its flight is noiseless and seemingly without direction, and is not so prolonged as that of $S$. texensis. I have seen the adult of this species captured and borne away by the sand wasp.

Dr. C. V. Riley (loc. cit.), gives the following account of the egg laying habits of furcata: "The female stations herself firmly by the middle and hind legs on twigs or leaves contiguous to the one selected to receive the eggs. This leaf is then grasped by the front feet and held in a vertical position, while the edge is slightly gnawed or pared off by the jaws to facilitate the entrance of the point of the ovipositor. When this is done the abdomen is curved under and brought forward, and the ovipositor is seized on its convex edge by the mandibles and maxillæ, which, with the aid of the palpi, guide the point to that portion of the leaf prepared to receive it. After gentle, but repeated efforts, the point of the instrument is finally inserted between the tissues of the leaf, and gradually pushed in to more than half its length. As soon as the cavity is formed, the egg is extruded, and passed slowly between the semi-transparent blades of the ovipositor. As the egg leaves the ovipositor the latter is gradually withdrawn, while the egg remains in the leaf, retained in place, probably, by a viscid fluid that is exuded with it. As many as five of the eggs are sometimes deposited in one row in the same leaf, but more often they are single.

Of the call note of furcata Riley also states: "The shrill of the male is by no means so loud as that of the oblong-winged katydid, Amblycorypha oblongifolia DeGeer, in which its sound is always drowned in the woods. It consists of a softer zeep, zeep, sometimes uttered singly, but generally thrice in succession. The call is occasionally responded to by a faint chirp from the females, produced by stretching out their wings as if for flight, and is as often heard in the day as at night." 


\section{Amblycorypha Stal (1874).}

Head with the vertex flat and without spines; its fastigium deflexed, much broader than the first antennal joint; eyes elliptical or oblong oval. Wing covers broad and rounded at the tip. Stridulating organ of the male, brownish, opaque, traversed by a strong green cross-vein. Supra-anal plate of male short, truncate; sub-anal plate short and broad at base, narrower at apex, with a broad triangular notch, the tips at side of which end in a short, blunt, spine-like process. Ovipositor, broad, of medium length, curved gradually upward from the middle; obtuse or rounded at the end, and with the apical half sharply and strongly serrate on both edges. Six species are listed by Scudder from the United States. Of these, three are known to occur in Indiana.

IEEY TO INDIANA SPECIES OF AMBLYCORYPHA.

a. Size, large; tegmina, it to $37 \mathrm{~mm}$. in length; those of the male exceeding the tip of posterior femora..........St oblongifolia, p. 350

aa. Tegmina not more than $30 \mathrm{~mm}$. in length: those of the male sometimes reaching but not exceeding the tip of the posterior femora.

b. Size, medium; greatest breadth of tegmina contained less than three times in their length; oripositor strongly curved........

85 rotundifolia, p. 352

b6. Size, small; greatest breadth of wing covers contained from three and one-fourth to three and one-half times in their lengtl, ovipositor but moderately curred.... S6 uhleri, p. 353

84. Amblycorypha Obloxgrfolia (DeGeer). The Oblong Leaf-winged Katydid.

Locustu whlongifolin DeG., 57, III, 1773, 445, Plate 38, Fig. 2.

I'hylloptere oblomgifolin Harris, 72, 1862, 159 (Text only); Scudd., 141 , TII, 1862, 444.

Amblycorypha oblongifoliu Brunner, 38, 1878, 266; Bl., 7, 1893, 104; Beut., 3, IT, 1894, 278; Lugger, 84, 1898, 222. Fig. 147; Seudd., $188,190(), 70$.

This is the largest of the three species occurring in the State, measuring about $45 \mathrm{~mm}$. to the end of the wing covers, which are 3.3 times as long as wide. The wings exeed the wing corers by 5 to 6.5 mm. Anterior margin of pronotum much narrower than the posterior, the lateral carine sharply defined; the hind margin of deflexed lateral lobes broadly rounded. The inner, lower carina of posterior femora armed with six to 12 rather strong teeth. General color a bright pea-green, the shrilling organ of the male brownish, with a heavy green cross-vein. The abdomen yellowish or brownish green. Specimens sometimes occur which are wholly pink or rose color. 
Measurements: Male-Length of body, $21 \mathrm{~mm}$; of tegmina, 38 $\mathrm{mm}$; of posterior femora, $30 \mathrm{~mm}$.; of pronotum, $6.5 \mathrm{~mm}$. FemaleLength of body, $23 \mathrm{~mm}$.; of tegmina, $36 \mathrm{~mm}$; of posterior femora, $31 \mathrm{~mm}$.; of ovipositor, $11.5 \mathrm{~mm}$. Width of tegmina of male, 11.5.

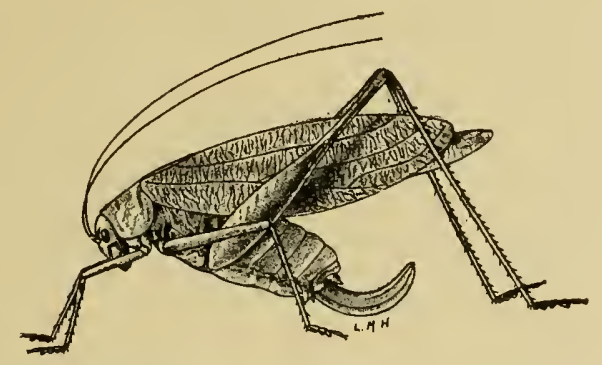

Fig. 83. Amblycorypha oblongifolia (DeG.) Female. (After Lugger).

The oblong-winged katydid is a common species throughout the State, its general range including the northern United States and Canada, east of the Great Plains. In southern Indiana it becomes mature about July 20th, and in the northern counties probably a fortnight later. A number of pink specimens have been taken from low meadows near Bass Lake, Starke County, by Mr. Frank Hay. Two of these are in my private collection. They were taken in a large marshy meadow in the lowlands bordering Yellow River. The canses which produce this curious "sport," by which a grass green is changed to a delicate pink, are, as yet, unknown. Scudder has said that "One thinks at once of autumn leaves and their change from green to red and notices that these pink katydids all occur in the autumn." In Indiana the pink specimens have been taken in early August, long before frost and before any noticeable change in the surrounding vegetation.

Oblongifolia frequents the shrubbery and flowers of the golden-rod and other Compositæ along fence rows and the edges of thickets and woods, especially in damp localities; and when flushed, flies with a kind of whirring noise, alighting on fence or the lower branch of tree. I have often located the male by its note, which to nwe is a creaking squawk-like the noise made by drawing a fine-toothed comb over a taut string. It is usually but once repeated, thongh sometimes three times. On several occasions it has been made after the insect was in my fingers. McNeill says that it is a "quick, shuffling noise which resembles 'katy' or 'katydid' very slightly." 
8i. Amblycorypha Roturdifolia (Scudder). The Round-winged Katydid.

Phylloptere rotumlifwlic Scudder, 141 , VII, 1862, 445.

Imblycmiphe rotumlifolin Brunner, 38, 1878, 268; Bl., 7, 1893, 105; Beut., 3, IT, 1894, 277, Plate VI, Fig. 2; Lagger 84, 1898, 222, Fig. 146; Scudd., $188,1900,70$.

I'hylloptere ublongifolin Harris, 72, 1862, Fig. 75 (Not text); Riley, 115 , 1874,169 , Fig. 55 (Text in part).

The length of .1. rolundifolia is about $32 \mathrm{~mm}$. to the end of tegmina, which are proportionally much broader than those of oblongifolia. 'The posterior femora reach the tip of tegmina in the male, a little longer in the female; armed on the lower, inner carina with four or five minute teeth. Anterior margin of pronotmm, especially

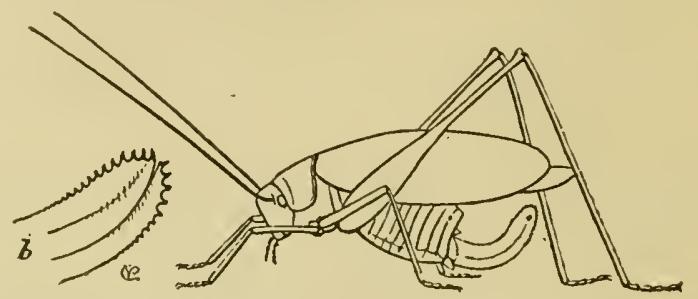

Fig. 84. Amblycorypha rotundifolia (Seudd.) Female. b Enlarged end of ovipositor. (After Riley.)

in the female, but little narrower than posterior; the hind margin of reflexed lateral lobes oblique and less broadly rounded than in oblongifolia. 'The ovipositor is more eurved and more strongly serrate than in either the preceding or the following species. The color is essentially the same as that of oblongifolia. Pink specimens have been recorded from Pennsylvania, but they alpear much more rarely than in the preceding species.

Measurements: Male-[ength of hody. 19) mun.: of tegmina. or mmm.; of posterior femora, $2 j \mathrm{~mm}$.; of pronotum, i $\mathrm{mm}$.; width of tegmina, $10 \mathrm{~mm}$. Female-Lengtl of boly, $20 \mathrm{~mm}$; of tegmina, ?: mm.; of pronotum, $6 \mathrm{~mm}$.; of ovipositor. $10 \mathrm{~mm}$.: width of tegmina. $10 \mathrm{~mm}$.

The round-winged katydid is also a common insect throughout Indiana, though more abundant in the southern half of the State. It is more of a terrestrial species than oblongifolia, being often seen on the ground, or on the rlumps of tall grass and weeds, which grow in (lamp ravines. Its fliglit is comparatively moiseless and less prolonged than that of the preceling speries. In southern Indiana the males beenme mature about the fifth of July; the females a week later. of its note. Mr. Scudder says: "This insect stridulates hoth hy day 
and by night, and withont variation. The song consists of from two to four notes-sounding like chic-a-chee-repeated rapidly so as to be almost confounded, and when three requiring just one-third of a second; the song is repeated at will, generally once in about five seconds, for an indefinite length of time."

86. AMBLyCorypha uhleRi Brumner. Uhler's Katydid.

Amblyeorypha uhleri Brunn., 38, 1878, 267; Bl., 7, 1893, 106; Lugg., 84, 1898, 223; Scudd., 188, 1900, 70 .

Uhler's katydid is our smallest species of the genus, measuring but about $27 \mathrm{~mm}$. to end of tegmina. The posterior femora are armed as in rotundifolia, and slightly exceed the tegmina in both sexes. Pronotum narrower in front, the anterior half of lateral earinæ rounded, the posterior rather sharp; the hind margin of lateral lobes as in rolundifolia. The male has longer wings and narrower tegmina than the female. Ovipositor less curved than in either of the other species, the apical half with emparatively strong serrations on both margins. General color a light grass green.

Measurements: Male-Length of body, $14 \mathrm{~mm}$; of tegmina, 23 $\mathrm{mm}$; of hind femora, $20 \mathrm{~mm}$; of wings beyond tegmina, $5 \mathrm{~mm}$. Female-Length of body, $17.5 \mathrm{~mm}$.; of tegmina, $22 \mathrm{~mm}$.; of hind femora, $23 \mathrm{~mm}$.; of wings beyond tegmina, $3 \mathrm{~mm}$.: of ovipositor. $8.5 \mathrm{~mm}$.

This species is much less common than either of the preeeding, having been taken only in Vigo County. where it frequents the tall sedges and willows bordering the large ponds in the Wabash River bottoms; and in Crawford County near Wyandotte Cave, where a number were secured, on grass and herbs. The young feed upon the leaves of the black and scarlet oaks, Quercus velutina Lam. and $Q$. cocrinea Wang, and the perfect insect is often found on or beneath these trees. It has been recorded before from New Jersey, Maryland and the District of Columbia, and ranges southwest to Texas.

\section{Microcentrum Scudder (1862).}

Size, large. Wing covers moderately expanded in the middle, much longer than the posterior femora, and with the outer border sloping off quite sharply, thus causing the tip to be more pointed than in Amblycorypha. Tertex much as in that genus, slightly furrowed. Eyes broadly oral, very prominent. Hind legs slender and very short, the femora but little more than half as long as the tegmina. Anal plates of male not prolonged; the supra-anal bluntly rounded: the sub-anal forked at the tip as in Amblycorypha. Ovipositor very 
short, bent abruptly upward, bluntly pointed, and with the apical third finely serrate above.

Two species occur in the United States, but one of which has, as yet, been taken in Indiana. Since the other, $M$. retinerve Burm., may in time be found in the southern half of the State, the following key will enable the student to separate the two:

KEY TO THE SPECXES OF MYROCENTRUM.

a. General color bright green; front border of pronotum sinuate, with a slight rounded median projection; hind femora one-half the length of tegmina ...................... laurifolium, p. 354

aa. General color yellowish green; front border of pronotum truncate, without median tooth; hind femora more than one-half the length

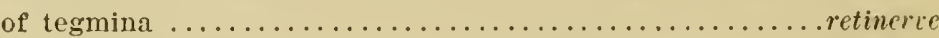

87. Mrorocentrum Laurifolium (L.) The Larger Angular-winged Katydid. The Oblique-winged Katydid.

Gryllus leurifolius L., 81 , II, 1767, 695, 17.

Phylloptera laurifolin Burm., 40, II, 1838, 693; Serv., 196, 1839, 404.

Nirrocentrum lamifolinm Brumn., 38, 1878, 334, 339; B1., 7, 1893, 107; Id., 1 5, 1899, 215, Figs. 47, 49; Beut., 3, VI, 1894, 278, Plate IT, Fig. 3; Lugg., 84, 1898, 224, Figs. 148, 149, 150; Scudd., 188 , 1900, 70 .

Mierocentrum affilictum Scudd., 14 1, VII, 1862, 447, Fig. 5.

Hicrocentins retineris Riley, 115, 1874, 155, Figs. 43.47.

This is the largest species of "katydid" found in the State, both sexes measuring two inches and more to the tip of the wings. The general color is light, grass green, the body yellowish green, lighter beneath. The vertex is quite broad, with its center hollowed out so as to form a shallow pit, which is more prominent in the male. The pronotum is about as broad as long, its anterior margin a little sinuate and usually possessing a slight median tooth, though this is

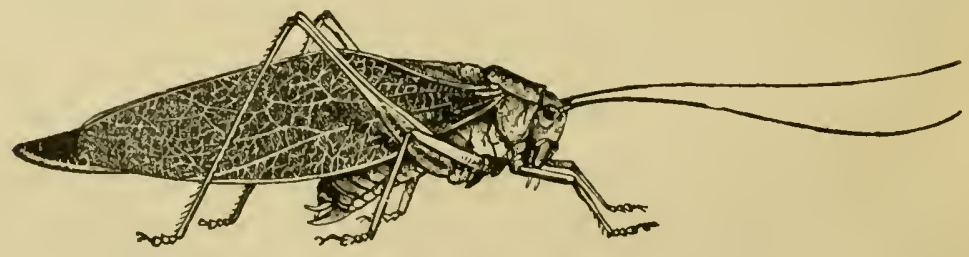

Fig. 85. Microcentum laurifolium (L.) Male. (After Riley).

sometimes obsolete, or is replaced with a shallow notch. The overlapping dorsal surface of the wing covers form a sharp and prominent angle with the lateral portions, whence the common name. 
Measurements: Male-Length of body, $25 \mathrm{~mm}$; of tegmina, 42 $\mathrm{mm}$.; of posterior femora, $22.5 \mathrm{~mm}$.; of pronotum, $6 \mathrm{~mm}$.; width of tegmina, $13 \mathrm{~mm}$. Female-Length of body, $30 \mathrm{~mm}$; of tegmina, $46 \mathrm{~mm}$.; of posterior femora, $24 \mathrm{~mm}$; of ovipositor, $5 \mathrm{~mm}$.; width of tegmina, $14 \mathrm{~mm}$.

In the country it is this insect which is most commonly called "the katydid," and the note of Cyrtophyllus perspicillatus L. is usually attributed to it, but its true note may be represented "by the syllable 'tic,' repeated from eight to twenty times at the rate of about four to the second." However, M. laurifolium is probably less common in Indiana than the broad-winged katydid, with which it is confused. I have taken it in but three counties, viz., Putnam, Vigo and Marion. It is evidently attracted by light, being occasionally found in the gutters beneath electric lights. It, perhaps, occurs throughout the State, as its general range is given as the "United States east of the Rocky Mountains," but it is nowhere in Indiana so common as to be injurious.

The eggs of $M$. laurifolium are usually glued in double rows on the sides of slender twigs, which have been previously roughened with the jaws and otherwise prepared for a place of deposit. The two rows are contiguous and the eggs of one alternate with those of the other. Those of the same row overlap about one-fourth their length. They are of a grayish brown color, long oval in shape, very flat, and measure $5.5 \times 3 \mathrm{~mm}$. They are usually deposited in September, hatch the following May, and th: young, in central Indiana, reach maturity during the first half of August. These eggs have, tember, hatch the following May, and the by persons who found them on their fruit trees, and thought they were the San Jose scale or some other injurious scale insect.

Prof. C. V. Riley has written (loc. cit.) a pleasing description of the egg laying habits and call note of the angular-winged katydid, from which I quote at length as follows:

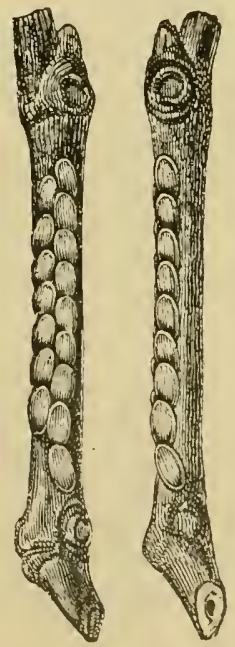

Fig. 86. Eggs of the Angular-winged Katydid. (After Riley).

"The females commence to oviposit early in September, and continue to lay at intervals until the first severe frost. The eggs are occasionally deposited during the day, but the operation usually takes place at night. Selecting a twig of about the size of a common goose 
quill, this provident mother prepares it for the reception of the eggs by biting and roughening the bark with her jaws for a distance of two or three inches. 'This bite is not gradual like that made when feeling, but is sudden and vigorous, the inseet ehewing and pressing the twig each side so as to form an edge. This operation is accompanied by a sudden nervous shake of the body from side to side, and lasts sometimes but two or three minutes. sometimes more than ten. When the operation is accomplished to her satisfaction, she elutches with her front feet the stem to be used, and anchors the middle and hinchmost feet for the most part upon contiguous leaves or branches, and often quite wide apart. Then, if she has her head in an upward direction (for it seems to be immaterial to her whether the eggs are placed from below up or vice versa), she begins at the lower end of the roughened portion of the twig, and, after fretting it anew with her jaws and measuring and feeling it over again and again with her palpi, as if to assure herself that all is as it should be, she slowlywith inmeh apparent effort, and not without letting it partly fall several times-curls the abdomen under until the lower edge of the curved ovipositor is brought between the jaws and palpi, by which it is grasped and guided to the right position. It is then worked slightly up and down for from four to six minutes - all the time guided by the jaws-while a shiny viseid fluid is given out apparently from the ovipositor. Finally, after a few seconds rest or suspension of this work, the egg gradually rises, and, as it passes between the ovipositor, turns so that the one end appears almost simultaneously. from between the convex elge, with the other from the lower tip. of the b)ades. 'The egg adheres to the roughened bark in an oblique position. It is at first almost black and highly varnished, but it aequires its normal gray color within eight or ten hours. After the egg is placed, the abdomen is straightened out and the inseet rests for a few moments, soon, however, to resume her efforts and repeat the like performance, in every particular, except that the second egg is placed on the opposite side of the twig and a little above the first one. The third egg is pushed in between the top of the first one and the twig. the fourth between the top of the second, and so on, one on each side, alternately. Thus these eggs are not laid, as we might naturally imply, one over the other, but rather, one under the other; i. e., each succeeding pair having their ends thrust in between the tops of the preecding pair, the teeth at the end of the oripositor helping to crowd the end into place.

"The length of time required from the commencement of the fretting of the twig to the proper placing of the egg varies all the 
way from five to 20 minutes. Sometimes, as for instance where a bud comes in the way, the preparation of the twig will require a comparatively long time, and after the ovipositor is brought up and a futile attempt made to place the egg, it will be let down again and the work of preparing the twig more vigorously prosecuted a second time.

"The number of eggs laid at one time varies from two to 30 , the first batches containing more than those deposited later in the season. Each female produces from 150 to 200, or perhaps more, and I have known them to lay on the edge of a leaf, or of a piano-cover, or along a piece of cord.

"These eggs, as already remarked, are rather flat when laid, but become more swollen, so that they have a narrower look as they approach the hatching period in spring. During the early part of May, the embryo larva-which lics straight in its egg, completely filling it, with the legs bent up as in a pupa, and the long antennæ curling around them-attains its full development, and after hours of tedious contracting and expanding movements, manages to burst the egg open at its top or exposed end, along the narrow edge, and generally about half way down. Through this opening young Katy slowly emerges, undergoing a moult during the process, and leaving its first skin, in a crumpled white mass, attached to the empty biralvular egg shell. Including hind legs and antenna it measures at this time, rather more than an inch in length, the body alone being one-eighth of an inch long; and in contemplating it, one can not but wonder how the long, stiff legs and great length of antennx, together with the plump body, could so recently have been compressed into the comparatirely small shell to which we see it clinging.

"In from ten to twenty minutes after hatching, these little being: essay their first leaps, and soon begin to eat with avidity. They feed with almost equal relish upon a great variety of foliage, but I have found that when reared upon very succulent leaves, such as lettuce, cabbage, purslain and the like, they are less hardy, and do not attain so great an age as when nourished upon more ligneous food, as the leaves of oak, apple or cherry.

"The first notes of this katydid are heard about the middle of July. and the species is in full song by the first of August. The wing covers are partially opened by a sudden jerk, and the notes produced by the gradual closing of the same. The song consists of a series of from $2 j$ to 30 raspings, as of a stiff quill drawn across a coarse file. There are about five of these raspings or trills per second, all alike, and with equal intervals, except the last two or three, which. 
with the closing of the wing covers, run into each other. The whole strongly recalls the slow turning of a child's wooden rattle, ending with a sudden jerk of the same; and this prolonged rattling, which is peculiar to the male, is invariably and instantly answered by a single sharp 'chirp' or 'tschick' from one or more females, who produce the sound by a sudden upward jerk of the wings.

"Both sexes are for the most part silent during the day, but during the period of their greatest activity their stridulations are never for an hour remitted, from the time the great setting sun hides behind the purple curtains of the west till he begins to shed his scarlet rays in the east- the species being so numerous that the sound as it comes from the woods is one continuous rattling, not unlike the croaking of frogs, but set to a higher key."

\section{Sub-family PSEUDOPHYLLINA.}

This sub-family is represented in Indiana by only one genuscharacterized as follows:

\section{Cyrtophyllus Burmeister (1838).}

Tegmina broad and leaf-like, longer than the wings, obtuse and rounded at the ends, and concave or hollowed within. The vertex extends forward between the eyes in the form of a small triangular spine which is grooved above and crowded by the basal joints of the antennæ. Eyes small, globose. Prosternum armed with two short spines. Pronotum crossed by two transverse sulci; its "surface rugose; its posterior third highest. Anterior pair of legs long and rather stout and well adapted for climbing. The "shrilling" organ of the male is brown in color, with the central portion as transparent as glass, and is sêt in a strong half-oval frame. Sub-anal plate of male produced into a long paddle-shaped appendage which is grooved on the upper side. Ovipositor of female broad, with the apieal half up-curved and denticulate below; apex rather sharply pointed. One species which occurs throughout the eastern United States is common in Indiana.

88. Crrtopirlle's perspiciliates (L.) The True Katydid. The Broadwinged Katydid.

Gryllns perspicillutus L., 80, 1763, 15.

Ciyptophyllus perspicillatus Burm., 40, II, 1838, 697; Brumu., 39ª, 1895, 239 ; Sculd., $188,1900,71$.

Plutyphyllum concuim Harris, 72, 1862, 158, Fig. 74; Riley, 115, 1874, 167. Figs. 52-54. 
Cyrtophyllus concarus Scudder, 14 1, VII, 1862, 444; Bl., 7, 1893, 109; Id., 16, 1899, 214, Fig. 48; Beut., 3, VI, 1894, 279, Plate VI, Fig. 1; Lugger 84, 1898, 226, Figs. 151-152.

The broad-winged katydid is readily known by the characters of the genus given above. The wing covers and wings of living specimens are dark green; the body, pronotum and head lighter, with a tendency to turn yellowish when dried. The main veins of the wing

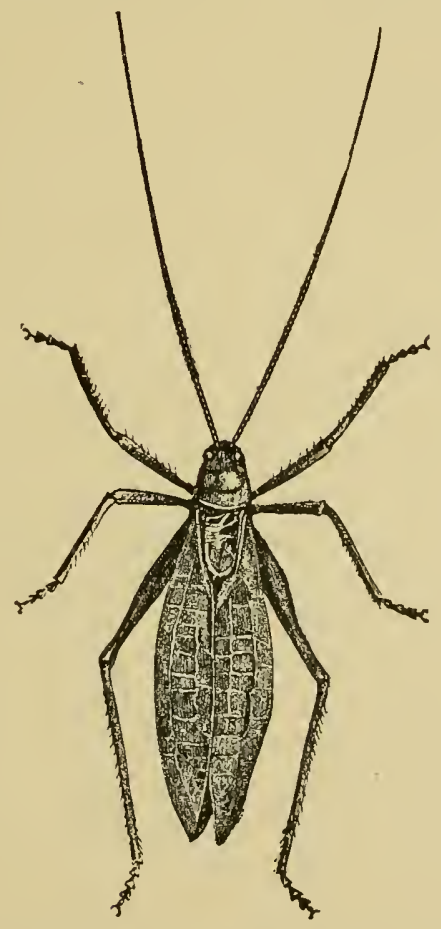

Fig. 87. Cyrtophyllus perspicillatus (L.) Male. (After Harris).

cover are very prominent with many reticulating branches, giving that organ much the appearance of a leaf. Posterior femora short, slender, and armed on apical half of lower outer carina with about six small spines. The ovipositor is almost as long as the abdomen, cimeter-shaped, sharp pointed, and with but slight serrations on the lower edge of apical third. The anal cerci of the male are broadly forked, and when in natural position the lower branch curves beneath the projecting sub-anal plate.

Measurements: Male-Length of body, $30 \mathrm{~mm}$; of tegmina, 37 $\mathrm{mm}$; of posterior femora, $21 \mathrm{~mm}$; of sub-anal spine, $11 \mathrm{~mm}$. Width of tegmina, $18 \mathrm{~mm}$. Female-Length of body, $29 \mathrm{~mm}$; of tegmina, 
$36 \mathrm{~mm}$; of posterior femora, $22 \mathrm{~mm}$; of ovipositor, $14 \mathrm{~mm}$. Width of tegmina, $16 \mathrm{~mm}$.

The broad-winged katydid is found in considerable numbers throughout the State, lut is much more commonly heard than scen. as it dwells in small colonies in the densest foliage which it can find, weh as the tops of shade trees and the entwining vines of the grape arbor. It is more domestic in its habits than any other species of the "liatydid" group, frequenting, for the most part, the shrubbery" of yards and orchards and the trees along fenee rows, being seldom. if erer, heard in extensive wooded tracts. Its note is the loudest made by any member of the family, the male having the musical organ larger and better developed than in any other. The call is almost always begum soon after dusk with a single note uttered at intervals of about five seconds for a half dozen or more times. This preliminary note gives the listener the impression that the musician is tuning his instrument, preparatory to the well-known double eall which is soon begum and kept up almost continuously from dark till dawn. Occasionally, in warm cloudy weather, this eall is made by day; and if the musician is located he will sometimes be found resting on the topmost leaf of a shrub; swinging to and fro as the breezes blow, and sounding his cymbals in seeming unison with the movement. This liatydid probably reaches maturity in southern Indiana by mid-July. The song has been heard in Putnam County as early as July 22d, and a single female was captured in Laporte County as late as October 15 th.

In a Putnan County farmyard I listened for hours, one August night, to the serenade of a band of katydids. They scemingly tried to outdo themselves for my benefit. But to them I was a nonentity -an unknown being. No thought of me or of my attentive ear lurked in or passed through their brains, as they clashed their cymhals in every shrub and tree around the old farm house. One idea alone possessed the minds of the male musicians. That idea was lore-passion-"that greatest thing in the universe." Long and loud the cymbals sounded, each shuffle, each note. doubtless accompanied by the wish that the next would call from the skies, from the branches above or about them-from anywere, it mattered notone of their form and kind. One to whom they could "whisper sweet nothings" -one whom they could caress tenderly with long antenna -one whom, in time, they conld clasp loringly with their slender limbs and forget eymbals, calls, skies, food, earth, everything in that long embrace which to them is the acme. the one. the highest object of their mature existence. 
The serenade continued thus, almost unbroken, from dusk till dawn. A serenade it was in truth - a song of love - of passion, poured out to the listening ears of the other sex. At times a single player dropped out of the chorns. His work, his love-calls had not been in vain. From some leafy retreat, where she had been hidden by day, a lady katydid slowly emerged, and, entranced by the songby, to her ears, the tender wooing notes-drew nearer and nearer unto the charmed circle whence the cymbals clanged and shuffled. Their notes beeame less vigorous. More suftly they fell upon her ear, until finally. as she coyly adranced they ceased and the caress of the antennæ took their place. The other musicians noted the absence of one of their chorus, and sounded their drums the louder, but for most of them their lahor was in vain. Many of them doubtless go through life unblessed by the presence of the gentler sex, ('langing their nightly calls from mid-J uly to the coming of the hoarfrost, and to its loiting nips finally succumbing, possessed by the thought - if a katydid ean think-that this earth is a desolate and cruel abiding place for such as they. So have the most of bachelors -human and otherwise-doubtless thonght, as in the past they yielded up the ghost:

Of the call of this species Mr. Scudder has written: "The note, which sounds like $x r$, has a shocking lack of melody; the poets who have sung its praises must have heard it at the distance that lends enchantment. In close proximity the sound is excessively rasping and grating, londer and hoarser than I have heard from any other of the Locustarians in America or in Europe, and the Locustarians are the noisest of all Orthoptera. Sinee these creatures are abundant wherever they occur, the noise produced by them, on an evening specially farorable to their song, is most discordant. Usually the notes are two in number, rapidly repeated at short intervals. Perhaps nine out of ten will ordinarily give this number; but oceasionally a stubborn insect persists in sounding the triple note-("Katy-shedid'); and as katydids appear desirons of defiantly answering their neighbors in the same measure, the proximity of a treble-roiced songster demoralizes a whole neighborhood, and a curious medley results; notes from some individuals may then be heard all the while, scarcely a moment's time intervening between their stridulations, some nearer, others at a greater distance; so that the air is filled by these noiny troubadours with an indescribably confused and grating elatter."

According to Riley the eggs are thrust, by means of the sharp ovipositor, into crevices and soft substances, and probably, in a state of 
nature, into the crevices of loose bark, or into the soft stems of woody plants. They are of a dark slate color, about $6.5 \times 2 \mathrm{~mm}$. in size, very flat, pointed at each end, and with the edges beveled off or emarginate.

\section{Sub-family CONOCEPHALINAE.}

Vertex projecting forward and upward in the form of a tubercle or cone, sometimes blunt, sometimes much prolonged. Prosternum toothed or with two slender spines. Fore tibia without apical spines. Front coxæ (in our genera) with a spine on the outside. Wing covers seldom expanded in the middle, often shorter than the abdomen, and in color either green or brown. Shrilling organ of male well developed, the cross-vein prominent, the color light brown, with the central portion transparent (except in the genus Conocephalus). Hearing organs present near the base of fore tibiæ. I Iind legs usually stout and much thickened at the base, as the insects seldom fly, but are active leapers, and very difficult to capture.

The cggs are deposited between the stems and root leaves of grass, in the pith of twigs, or sometimes in the turnip-shaped galls so common on certain species of willow. The ovipositor, being thus used as a piercer, has in time developed into a slender and sharp-pointed. instrument which is but little curved and is frequently of excessive length, in some species being over twice as long as the remainder of the body.

To this sub-family belong those slender-bodied green grasshoppers, with long, tapering antennæ which are so eommon in summer and early autumn in damp meadows and prairies and along the margins of streams, ditches and ponds. They are mostly terrestrial in their habits, but one or two of the larger oncs ever being found in trees.

The color of their bodies corresponds elosely with that of the stems and leaves of the sedges and grasses among which they dwell, and so proteets them from the sight of the few birds which frequent a like locality. Their songs, produced in the same manner as those of their larger cousins, the katydids; are as frequent by day as by night, but are usually soft and low in comparison with those of the former. Their day song differs from that of the night, and, says Scudder, "It is curious to observe these little creatures suddenly changing from the day to the night song at the mere passing of a cloud and returning to the old note when the sky is clear. By 
imitating the two songs in the daytime the grasshoppers can be made to represent either at will; at night they have but one note."*

This sub-family is represented in Indiana by three genera which may be separated by the following key:

KEY TO GENERA OF INDIANA CONOCEPHALINE.

a. Fore and middle femora spined beneath; vertex produced forward into a loug sharp cone; stridulating organ of male green and

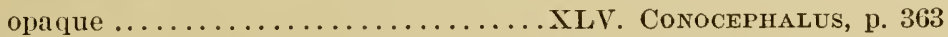

aa. Fore and middle fenora unarmed beneath; vertex terminating in a rounded tubercle which is hollowed out on the sides; stridulating organ of male light brown and partly transparent.

b. Prosterual spines very short; ovipositor slender, straight or nearly so; insect small..........XLVI. Xipundum, p. 371

bb. Prosternal spines longer and more slender; ovipositor stout, usually upcurved; insect of medium size..............

XLVII. ORChelimuM, p. 381

\section{Conocephalus Thunbergh (1815).}

THE CONE-HEADED GRASSHOPPERS.

The nembers of this genus are readily known by having the vertex prolonged forward and upward into a cone which much exceeds in length the first segment of the antennæ, and bears a pointed tooth beneath. Face very oblique. Eyes sub-rotund, rather prominent. Spines of prosternum long and slender. Wing covers long, narrow, rounded at the end, much exceeding the abdomen and slightly exceeding the wings in all our species. The stridulating organ of the male is opaque and of a coarse texture in the left wing cover, but transparent at the center of the right. Hind femora of moderate length, rather slender, the insects often using the wings as locomoters. Ovipositor rather narrow; nearly straight, oftentimes of excessive length; the eggs of those species in which the oviposition has been noted, being deposited between the stem and the root leaves of plants. Anal plates of male not produced; the cerci much swollen, recurved and toothed.

Although these insects are said to be rather common by those writers who have prepared lists of Orthoptera from other states, yet in Indiana they are the least abundant of all the winged Locustida, ten years' collecting having yielded less than twenty specimens. They appear to be more common in the northern than in the southern half of the State.

* American Naturalist, II, 1868, 116. 
Of the habits of the species found in Illinois, McNeill has written: "All the species of Conorphlulus seem to possess more intelligence than is usual among the Orthoptera, and they are about the most diffienlt of the order to amproach. In escaping they usually slip or fall into the grass instear of jumping or flying; but they seem to fully understand that they are very well protected by their color and form. If approached rery cutionsly they often remain quite still upon the stem of grass mon which you have surprised them with the usually well founded expectation that you will not be able to distinguish them from the green herbage around. If they think it worth while to make some aetive morement to escape they will frequently slip around on the other side of the stem and walk down the stem to the ground or off "upon another plint. Unlike most Orthoptera they do not use their front legs in holding to the mouth the thing upon which they feed. Instead of biting they seem to wrench or tear away pieces from the stems or leares."*

The genus is a large one. 101 species being inchuded by Redtenbacher in his monograph. Only sixteen, howerer, are listed by Scudder as occurring in the United States, and but five have, up to the present, been taken in Indiana. These may be distingnished by the following table:

- KeY to iNDiNa species of coxoceptialus.

a. Cone of yertex slender, extending $3 \mathrm{~mm}$. or more in front of eyes, and with either the margin or lower face black.

b. Each margin of cone with a hlack line extending from the alex half way or more to hase: innere lower carina of posterior fenora with four or five minute spines. . . . . . . . .

S!) chsiger. p. 36 is

bb. Lower face of cone wholly liack from apex to inferior basal tooth; posterior femora armed on both the lower carine with a number of plainly visible spines.

r. Length of hody of femile less than 36 mmin; of cone of

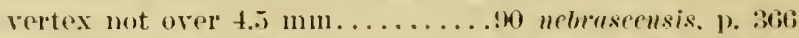

ce. Iength of bosty of female more than t.5 mm.; of cone of

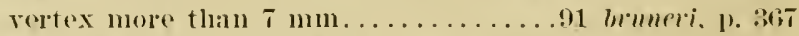

aa. Cone of vertex lather stont, extenting less than $3 \mathrm{~mm}$. in front of ayes, devoid of black markings.

d. Lateral "in rina of pronotum with a yellow line: wing covers with irregulary distriluted llack dots; ovipositor exceeding

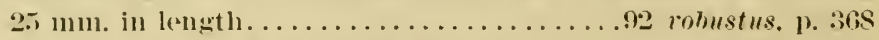

d7. Lateril carina of pronotum without trace of yellow: wing corers a loright glass green. immaculate; ovipositor less than 20 num. in longth.................. palustris, 1), 369

\footnotetext{
* Psyche, VI, 23.
} 
89. Conocephalus ensiger Harris. The Sword-bearer.

Conocephalus ensiger Harris, 72 1862, 163, Fig. 79; Riley, 122, II, 1884, 187, Fig. 263; Comstock, 4 1, I, 1888, 115; Redtenb., 110 , 1891, 67, 89; Scudd., 168, XXII, 1892, 72 (note of tó music); Id., 188, 1900, 72; Bl., 7, 1893, 114; Beut., 3, VI, 1894, 281, Plate VI, Fig. 8; Lugger, 84, 1898, 230, Figs. 153, 154.

A slender bodied species, the general color of which is grass green (rarely brown), the body and face paler; the posterior tibir and tip of ovipositor infuscated. Lateral carina of pronotmm sometimes with a faint yellow line, more plainly visible in the dried specimens. Tegmina very long and slender.

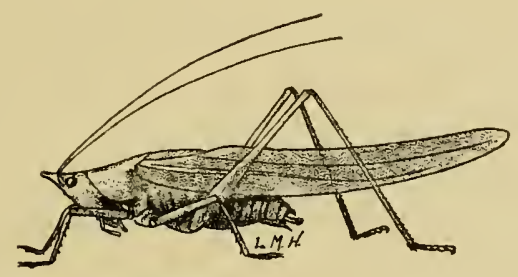

Fig. 88. Conocephalus ensiger Harris. Male. (After Lugger.)

Measurements: Male-Length of body, $26 \mathrm{~mm}$.; tegmina, $42 \mathrm{~mm}$; of posterior femora, $21 \mathrm{~mm}$. Female-Length of body, 28-30 mm.; of tegmina, $4 \% \mathrm{~mm}$.: of posterior femora, $23 \mathrm{~mm}$.: of cone of vertex, $3.25 \mathrm{~mm}$.; of pronotum, $.5 \mathrm{~mm}$.; of ovipositor, $28-31 \mathrm{~mm}$.

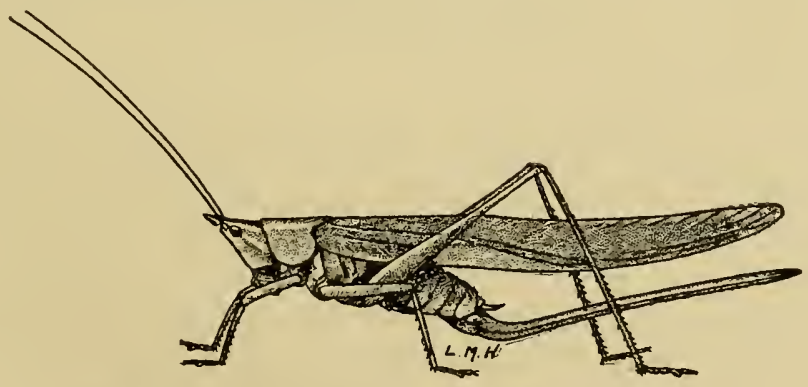

Fig. 89. Conocephalus ensiger Harris. Female. (After Lugger.)

Ensiger is probably the most widely distributed species of Conocephalus occurring in the eastern United States, having been recorded from Maine to the Rocky Mountains. It is the most common one occurring in northern Indiana, where it frequents the tall grasses along ditches and the borkers of damp prairies. In the central and sonthern counties it is scaree, being replaced by the next species. 
The female of ensiger has been recorded as depositing her eggs between the stem and the root leaves of Andropogon, a genus of tall, coarse grasses which grow in dry, sandy localities. The young, hatehed in May, reach maturity in eentral Indiana about July 20 th. Mr. Seudder, who has set the note of the male to music, says of the song: "This insect has but a single song and stridulates only by night, or during eloudy weather. It begins its song as soon as the sky is obseured or the sun is near the horizon. It commences with a note like $b r w$, then pauses an instant and immediately emits a rapid succession of sounds like chwi at the rate of about five per second, and continues them for an unlimited time. Another writer likens its note to the syllable ' $i z_{-}-i k$-ik;', as if sharpening a saw, enlivening the low bushes, and particularly the cornpatch, as it seems to especially delight in perching near the top of a cornstalk and there giving forth its rather impulsive song."

90. Conocepinalus nebrascexsis Bruner. The Nebraska Cone-head.

Conocephalus nebraseensis Bruner, 25, XXIII, 1891, 72; Scudder, 168, XXIII, 1892, 72; Id., 188, 1900, 72; Bl., 7, 1893, 115; Lugg., $84,1898,2: 31$.

This is a heavier bodied and shorter winged species than the preceding. The cone of the vertex projects upward more strongly and has the apieal half more tapering than in ensiger; the basal tooth is also more prominent. The anal cerci of male are stout, with strong internal hooks. Ovipositor long and slender, lanceolate, a little curved upward and extending about one-fourth of an inch beyond the closed tegmina.

General color either bright grass green or a yellowish brown or tan with narrow, yellowish lines along the lateral carinæ of the pronotum. Posterior tibiæ together with all the fect more or less infuscated.

Measurements: Male-Length of body, $28 \mathrm{~mm}$; of tegmina, 37 mm.; of pronotum, $8 \mathrm{~mm}$.; of cone of vertex, $3.5 \mathrm{~mm}$.; of posterior femora, $21 \mathrm{~mm}$. Females-Length of body, $33 \mathrm{~mm}$.; of tegmina, 42 $\mathrm{mm}$.; of posterior femora, $23 \mathrm{~mm}$.; of ovipositor, $29 \mathrm{~mm}$.

The above measurements are very nearly the same as those given by Mr. Bruner in the original deseription of the species, and are the average of a half dozen specimens in my collection. I have one female, however, which is so much larger that at first I was inclined to think it a diflerent species, but the color and structure, except the measurements, agree in every particular with those given above of nebrascensis. The following are the measurements of the specimen 
in question: Length of body, $36 \mathrm{~mm}$.; of cone, $4.5 \mathrm{~mm}$.; of tegmina, $49 \mathrm{~mm}$.; of posterior femora, $30 \mathrm{~mm}$.; of ovipositor, $39 \mathrm{~mm}$.

In central Indiana this is the most common of the three species of Conocephalus there occurring. A number of specimens have been taken in Putnam County by Mr. W. A. Riley, and in Vigo, Fulton and Starke counties by myself. When approached it often attempts to escape by burrowing beneath the fallen grass. It frequents the same localities as $C$. ensiger and is very liable to be mistaken for that species by the casual observer, but may at once be distinguished by the characters given in the key.

91. Conocephalus bruneri sp. nov. Bruner's Cone-head.

A large but comparatively slender bodicd species, having the cone of vertex excessively long, flat rather than convex above, and with its under side a shining black as far back as the basal tooth.

General color: A light pea green tinged with yellowish on the head, pronotum and fore femora. A narrow yellowish line along the lateral carinæ of pronotum, absent on the head but present on the

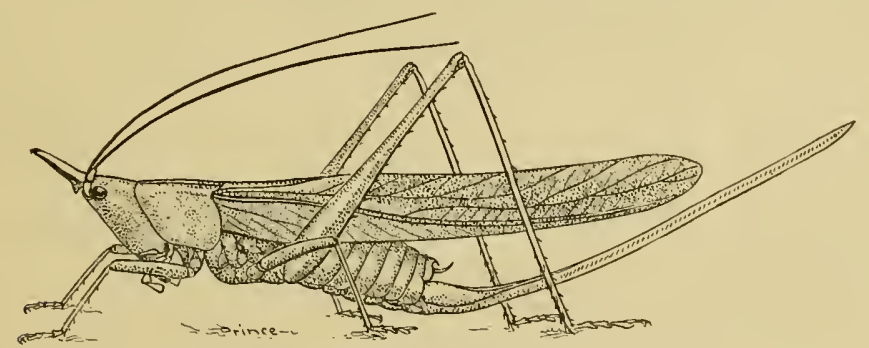

Fig. 90. Conocephalus bruneri sp. nov. Female. Natural size. (Original.)

lateral margins of cone of vertex. A very narrow and oblique yellowish line also extends a short distance back from each eye. Mandibles yellow. Feet and apical joints of palpi more or less infuscated.

Cone of vertex very prominent, extending $7.5 \mathrm{~mm}$. in front of eyes, flattened above, with a slight median furrow in its basal half, gradually tapering from the base forward, its apical half curved slightly upward, the apex rounded and rather blunt; the lower basal tooth small and blunt. Pronotum the same length as the fore femora, of more than average breadth, the lateral carinæ evident but dull, the hind margin broadly rounded; the sides flaring noticeably outward, rather than at right angles to the dorsal field as in most species, their surface a little rugose. Tegmina reaching a little beyond the middle of ovipositor, their basal third rather broad, the apical two-thirds tapering very gradually to the rounded apex. Wings equaling the 
tegmina in length. Fore and middle femora short and stout, unarmed beneath, the former one-third the length of hind femora, the latter a little longer. Hind femora short but slender, armed on both margins of lower carinæ with about nine small but sharp teeth, those on inner carina a little longer and more distant, one from another, than those on outer. Hind tibia a little shorter than the femora. Ovipositor slender, of more than average length, of equal width to within $5 \mathrm{~mm}$. of the apex, from whence it tapers gradually to a rather dull point.

Measurements: Female-Iuength of body, $44 \mathrm{~mm}$; of pronotum, $9.5 \mathrm{~mm}$.; of tegmina, $50 \mathrm{~mm}$; of fore femora, $9.5 \mathrm{~mm}$.; of hind femora, $30 \mathrm{~mm}$.; of hind tibiæ, $29 \mathrm{~mm}$.; of ovipositor, $45 \mathrm{~mm}$.

This large and odd appearing Iocnstid is represented in my collection by a single female, taken in September, 1900, by Mr. Arthur Dransfield in the campus of the "Working Men's Institute," at New Harmony, Posey County, and kindly presented to me. It is quite distinct from any other speeies in this country, approaching most closely the Brazilian species C. Iruncalirostris described by Redtenbacher. The fastigium of the vertex is, howerer, even longer than in that species. Professor Lawrence Bruner, to whom the specimen was sent for examination, writes that he has a single female of the same insect taken from the Potomac bottoms, D. ('., some years ago. The male is, as yet, unknown. The speeies is eridently southern in its range, and should be looked for throughout southern Indiana.

I take pleasure in naming this large Locustid in honor of Prof. Lawrence Bruner, of Lincoln, Nebraska, an anthority on North American Orthoptera, who has shown me many courtesies during the preparation of this paper.

92. Conocephalus robustus Scudder. The Robust Cone-head.

Conocephutus robustus Scudd., 141, VII, 1862, 449; Id., 168, XXII, 1892, 72 (song of); Id., 188, 1900), 72; Riley, 122, II, 1884, 187; Comstock, 4 1, I, 1888, 115; Redtenb., 110, 1891, 89, Plate III, Fig. 36; Bl., 7, 1893, 116; Bent., 3, VI, 1894, 280, Plate VI, Fig. 9; Lugg., 84, 1898, 232.

General eolor bright green or pale brown: sometimes a mixture of both; the wing covers usually speckled with black. Cone of vertex much like that of $C$. ensiger but shorter, with the apex more obtuse; rarely with a black spot at apex, its sides often with a narrow yellowish line; the frontal basal tooth distinct but blunt. Posterior femora armed bencath on both earina with a number of rather weak spines. Wings of male equaling the tegmina in length, in the female a little shorter. Ovipositor shorter than in any of the preceding species. 
Measurements: Male-Length of body, $30 \mathrm{~mm}$; of tegmina, 44 $\mathrm{mm}$.; of hind femora, $23 \mathrm{~mm}$.; of pronotum, $8 \mathrm{~mm}$; of cone, $2 \mathrm{~mm}$. Female-Length of body, $31 \mathrm{~mm}$.; of tegmina, $48 \mathrm{~mm}$; of hind femora, $26 \mathrm{~mm}$.; of ovipositor, $26 \mathrm{~mm}$.

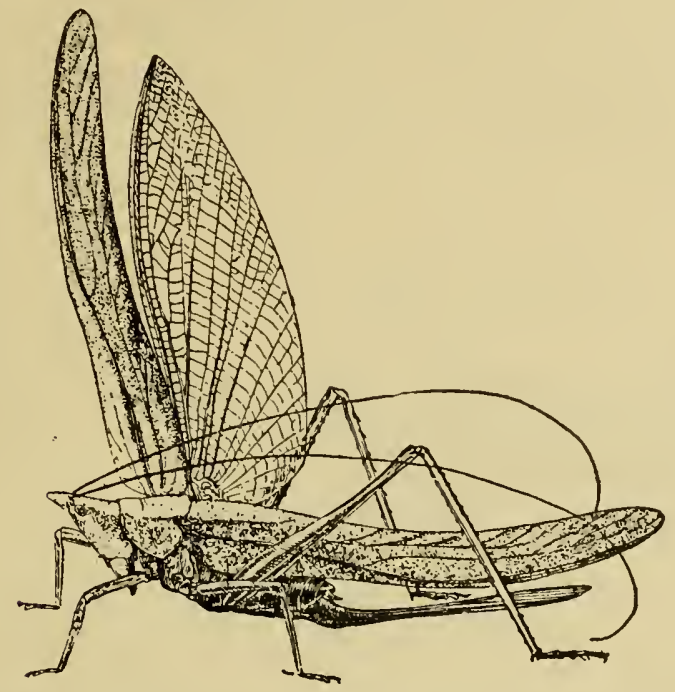

Fig.91. Conocephalus robustus Scudd. Female. Natural size. (After Beutenmuller).

This species seems to be an inhabitant of sandy districts and occurs only along the Atlantic seacoast and the shores of the Great Lakes. In Indiana it has been noted only in Laporte County, where Prof. E. E. Slick found it quite frequently along the shore of Lake Michigan during September and October. Of the specimens sent to me-a half dozen males-he wrote: "They were caught off the trees, in the dusk of the evening, as they were singing. They sang ('whetted') continuously for ten minutes or longer while I watched them."

Mr. Scudder thus describes the note as heard in New England: "Robustus is exceedingly noisy and sings equally, and I believe similarly, by day and night. The song resembles that of the harvest fly, Cicada canicularis. It often lasts for many minutes, and seems, at a distance, to be quite uniform. On a nearer approach one can hear it swelling and decreasing in volume *** and it is accompanied by a buzzing sound, quite audible near at hand, which resembles the humming of a bee or the droning of a bag-pipe." 
93. Coxocephalus Palustris Blatchley. The Marsh Cone-head.

Conocephalus palustris Bl., 10, XXV, 1893, 89; Id., 7, 1893, 118; Scudd., $188,1900,72$.

A small but comparatively heary-bodied species, having the cone of the vertex devoid of black markings and without a basal tooth; ovipositor very short and more than usually broad; posterior femora armed beneath on both carinæ. Cone of rertex short and stout, the tip round, the deflexed front with a dull median carina. Pronotum short, broad. the posterior margin regularly rounded, the lateral

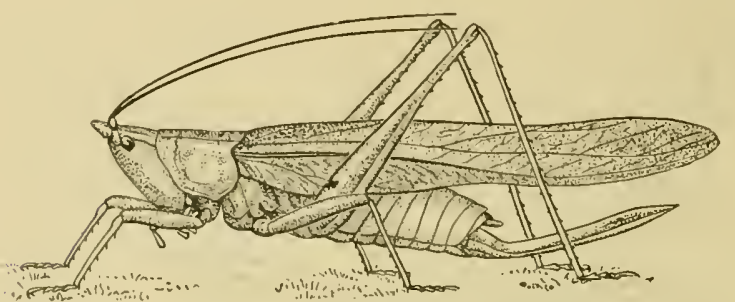

$a$

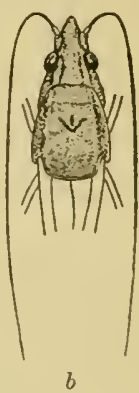

$b$

Fig. 92. Conocephalus palustris Bl.

(a) Female. One and one-third times natural size.

(b) Head of same from above. (Original).

carinæ well defined, the entire surface thickly and rather deeply punctate. 'Tegmina long and rather narrow, regularly rounded tó the apex; of a more delicate texture than in either $C$. ensiger Harris or $C$. robuslus Scudder. Fore and middle femora with two short spines on the apical third of the lower outer carina. Hind legs short, the tibiæ but little more than half as long as the closed teginina; the femora with plainly risible spines on both of the inferior carinæ, eight on the outer and six on the inner. Ovipositor a little shorter than the hind tibix, broadest at a point about two-thirds the distance from the base, thence tapering regularly to a sharp apcx.

Gencral color a very bright grass green. Fastigium tipped with dull yellow, which extends half way down the sides. Labrum and apieal segments of all the palpi a rose red tinged with violet. Tarsi somewhat infuscated. Antennæ and apical third of ovipositor reddish-brown.

Measurements: Female-Length of body, $27 \mathrm{~mm}$; cone of vertex, $2.75 \mathrm{~mm}$.; of pronotum, $7 \mathrm{~mm}$.; of tegmina, $37 \mathrm{~mm}$; of hind femora, $20 \mathrm{~mm}$; of hind tibix, $19.5 \mathrm{~mm}$;. of ovipositor, $19 \mathrm{~mm}$.

This handsome species of Conocephalus belongs to the same group as $C$. robustus and $C$. crepitans Scudder, but is smaller and of a more uniform and brighter green than either of those speeies, besides having shorter legs, ovipositor, ete. It is described from a single female 
taken October 24, 1891, from the fallen grasses on the margins of a large lowland pond in Vigo County. This pond, now extinct, was surrounded on all sides by heavy timber, and its margins yielded a number of interesting Orthoptera found nowhere else in the county. Among them were Leptysma marginicollis Serv., Paroxya hoosieri Bl., Anaxipha exigua Say, Phylloscirtus pulchellus Uhler, and Xiphidium nigropleura Bruner. The first four mentioned are insects of a southern range, and perhaps $C$. palustris will, in time, be found to be more common southward.

\section{Xiphidium Serville (1831).}

This genus includes our smallest winged Locustidæ. The vertex projects forward and slightly upward in the form of a rounded tubercle which is hollowed out on the sides for the reception of the basal joint of the antennx. Face rounded, somewhat oblique. Eyes rather large, sub-globose. Spines of prosternum very short and weak; often mere cone-shaped protuberances. Wing covers narrow, straight, rounded at the end, often varying much in length in the same species, but for the most part shorter than the abdomen. Wings usually a little shorter than the wing covers. Stridulating organ of male well developed, the veins prominent, light brown in color, and with the middle transparent. Hind femora of medium length, stout at base; mostly unarmed beneath. Ovipositor narrow, straight or but slightly curved, oftentimes of excessive length. Anal plates of male not prolonged; the cerci usually much swollen, and toothed at base on the inner margin. Eight species are known to occur in Indiana.

These insects are more variable in color and in the length of wings than those of any other genus of Orthoptera known to me. The variations, however, seem to be abrupt.with no intervening forms. There are long-winged and short-winged forms of the same species but none with the wings of medium length; and when a brown form is tinged with green, or vice versa, the amount of the different color varies but little. Four of our eight species are thus dimorphic' as regards the length of the wings, the short-winged individuals, as far as my observation goes, far outnumbering those with the wings fully developed; and at least three of the eight are variable with respect to color.

KEY TO INDIANA SPECIES OF XIPHIDIUM.

a. Ovipositor shorter than the body.

b. Ovipositor straight.

c. Body very slender; wings a little longer than the tegmina; the latter always fully developed and longer than abdomen ....................... fasciatum, p. 372 
cc. Body stonter; wings in the common form shorter than the tegmina; the latter usullly abbreviated, not reaching tip of abdomell. . . . . . . . .5. brevipenne. 1). $37: 3$

b). Ovipositor a little curvel; texmina (anstant ln length, covering about two-thirds of the ablomen in the male; shorter in the female ...................... nif nemorule, p. 3 it

at. Ovipositor equal to or longer than the hody.

d. Length of posterior femora almost equal to that of the ovipositor.

e. Body rather stout: the temmina always corering more than half the abdomen.

f. Abdomen with dorsal surface light brown, the sides green, or yellowish green; ovipositor no longer than body .............97 ensiferum, 1). 375.

ff. Abdomen with the dorsil surface a fuscous brown, the sides shining black; ovipositor plainly longer than body ...............9s nigroplemr, p. :3it;

ce. Body very slender; the tegmina exceedingly short, padlike, covering only one-thind of abdomen, the sides of latter dull reddish brown...........99 soltans, p. 37т

dd. Posterior femora much shorter than the ovipositor, the latter of excessive length.

\%. Under side of hind femora marmed; the sides of the body green .................. 10n strictmm, 1. 3is

gy. Under side of hind femora armed on the onter carina with serelial slort black spines; the sides of the body dull reddish bown...........101 attrmutum. 1. 379

94. Xrphidium fasciatum (DeGeer). The Slender Meadow Grasshopper. Locusta fcsciata DeG., 5 7, III, 1778, 458, Plate XL, Fig. 4.

Xiphidium fusciatum Burm., 40, II, 1839, 708; Pack., 104, 1883, 567; Riley, 122, II, 1884, 186; Comst., 4 1, I, 1888, 114; Redtenb., 110 , 1891, 192, Plate IV, Fig. 82; Scudd., 168, XXIII, 1892, 75 (song of); Id., 183, XXX, 1898, 184; Id., 188, 1900, 74; Brun., 27, III, 1892, 265; B1., 7, 1893, 119; Beut., 3, VI, 1894, 283, Plate VI, Fig. 7; Lugg., 84, 1898, 238, Figs. 157, 158.

Fasciatum is one of the most slender bodied Locustids belonging to our fauma. It is the only species of Indiana Yiphidium whose wings are never shorter than the body. Posterior femora reaching to or slightly beyond the tip of tegmina in the female, distinetly shorter in the male. Face, sides of pronotum and abdomen, and basal portion of ovipositor green; tegmina and apical third of ovipositor light reddish brown; upper side of abdomen, and stripe on oceiput and disk of pronotum darker brown; legs green, brownish on the knees and tarsi.

Measurements: Male-Length of body, $13.5 \mathrm{~mm}$; of tegmina, $17.5 \mathrm{~mm}$.; of hind femora, $11.5 \mathrm{~mm}$.: of pronotum, $3.5 \mathrm{~mm}$. Female 
-Lengtlı of body, $1 \pm \mathrm{mm}$.; of tegmina, $16 \mathrm{~mm}$; of hind femora, 13 $\mathrm{mm}$; of oripositor, $8 \mathrm{~mm}$.

This handsome meadow grasshopper is abundant throughout the State in timothy and clover meadows and especially so about small streams in low ground, blue-grass pastures. It is one of the first of the Locustida to reach maturity, specimens having been taken in Vigo County as early as July 5th, and it may be found until midOctober. 'The note of the male is very faint-a kind of $z r-r-r-r$ long drawn out.

Fasciatum has, perhaps, the widest distribution of any of our Anerican Locustidx, its. range, according to Redtenbacher, being from British Anerica to Buenos Ayres, S. A.

The Orchelimum gracile of Harris, usually quoted as a synonym of I. fasciatum, has been shown by Bruner (lor. cil.) to be a distinct and valid species.

95. Xiphidium BRevipenne Scudder. The Short-winged Meadow Grasshopper.

Xiphidium brevipennis Scudd., 14 1, VII, 1862, 451; Beut., 3, VI, 1894, 283, Plate VI, Fig. 6.

Yiphidium brevipenne Scudd., 148, 1874, 368; Id., 183, XXX, 1898, 184 ; Id., 188, 1900, 74; Riley, 122 , II, 1884, 186; Comst., 41 ‘ I, 1888, 114; Redtenb., 110 , 1891, 206, Plate IV, Fig. 91; Bl., 7, 1893, 121 ; Lugg., 84, 1898, 239.

A little shorter and thicker bodied species than $T$. fasciatum. Posterior femora rather short and stout, marmed beneath, or rarely with one to four minute spines. Cerci of male swollen, the apex strongly compressed and obtuse, armed below the middle with a rather flat, sharp pointed tooth.

General color: Light reddish brown; the face and sides of pronotum usually green; stripe on occiput and disk of pronotum a very dark brown, margined on each side with a narrow yellow line; tegmina and wings a light reddish brown; ovipositor reddish brown throughout, darker toward the apex.

Measurements: Male-Isength of body, $11 \mathrm{~mm}$.; of tegmina, $\%$ mm.; of posterior femora, $10 \mathrm{~mm}$; of prono-

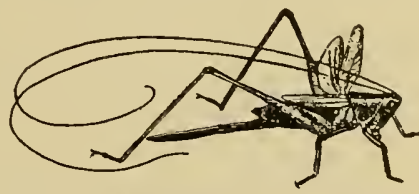

Fig. 93. Xiphidium brevipenne Scudd Female. Natural size. (AfterBeutenmiiller.) tum, 3 mm. Fenale-Length of body, 11-13 mnı; of tegmina, short winged form, 7 mm.; of posterior femora, $11 \mathrm{~mm}$; of pronotum, 3 mm.; of ovipositor, $10 \mathrm{~mm}$.

This is also an abundant species thronghout the State, frequenting the same localities as fasciatum and reaching maturity about a fort- 
night later. Long winged forms of brevipenne oceasionally occur, but in Indiana they are very scaree, but one or two having come under my notice. Of the variations in the length of the wing eovers of it and allied species, Professor Bruner has well said: "That in the genera Xiphidium and Orchelimum wing length is a character not to be relied upon as specific or even varietal difference;" yet liedtenbacher, in his "Monographie der Conocephaliden," has separated a number of his speeies by this character alone, and I can find no mention in his work of the fact that such a variation exists.

96. Xiphidium nemorale Scudder.

Xiphidium nemorule Scudd., 151 , XTII, 1875, 462; Id., 153, IV, 1875, 65; Id., 164, 1879, 15; Id., 168, XXIII, 1892, 75 (song of); Id., 183, XXX, 1898, 184; Id., 188, 1900, 75; Bl., 7. 1893, 122; Beut., 3, VI, 1894, 284; Lugg., 84, 1898, 240.

Siphirlium curtipenue Redtenb., 110, 1891, 208.

A rather robust species with the general eolor a dark, greenish brown; tegmina light reddish brown with the front or lower area fuscous. Dorsal stripe of occiput and pronotum a lighter grayish brown margined with a narrow yellowish line on each side. All the femola punetate with reddish dots. the tarsi and tip of hind femora dusky. Tegmina with the reins and cross-veins unusually prominent, giving them a coarse and scabrous look; the tympanum of male stout and elevated. Cerci conical, the apex obtuse, but little compressed. Ovipositor as long as the abdomen, the apical half with a gentle but evident upward curve.

Measurements: Male--Length of body, $14 \mathrm{~mm}$; of tegmina, 8 $\mathrm{mm}$; of hind femora, $12 \mathrm{~mm}$; of pronotum, $3.5 \mathrm{~mm}$. FemaleLength of body, $15 \mathrm{~mm}$; of tegmina, $5.5 \mathrm{~mm}$; of hind femora, 13 $\mathrm{mm}$.; of ovipositor, $9 \mathrm{~mm}$.

Nemorale is a common insect in central and southern Indiana, but has not as yet been taken north of Marion and Wells counties. It reaches maturity about August 1st, and from then until after heavy frosts may be found in numbers along the borders of dry, upland woods, fence rows, and roalsides, where it delights to rest on the low shrubs, blackberry bushes, or coarse weeds usually growing in such localities. On sunny afternoons of mid-autumn it is especially abundant on the lower parts of the rail and board fences, the male uttering his faint and monotonous love call-a sort of ch-e-e-e-e-

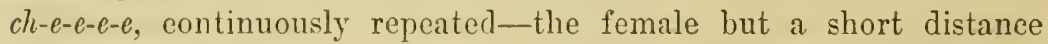
away, a motionless, patient, and apparently attentive listener. When in coitu the male does not mount the back of the female, but, with his body reversed, is dragged about by her, this being the com- 
mon practice of all the species of Xiphidium and Orchelimum. The females at times evidently oviposit in deeaying wood, as on several occasions I have found them on old fence posts and rails with their ovipositors inserted the full length in the wood.

Nemorale has been recorded from Nebraska, Iowa, Illinois and New York, and seems to be confined to the northern half of the middle United States.

97. Xiphidium ensiferum Scudder.

Tiphidium ensifer Scudd., 141 , VII, 1862, 451.

Tiphidium ensiferum Scudd., 166, 1880, Appen., II, 23; Id., 183, XXX, 1898, 183; Id., 188, 1900, 74; Riley, 122, II, 1884, 186 ; Comst., 41, I, 1888, 114; Wheel., 223, II, 1890, 222 (oviposition of); Redtenb., $110,1891,209 ;$ Bl., 7, 1893, 123; Lugg., 84, 1898, 240.

Very similar in general appearance to $X$. brevipenne Scudder, and may be only a large variety of that species. Typical examples are larger, with a longer ovipositor, which is equal in length to the body and equals or slightly exceeds the length of hind femora. Tegmina of the common short-winged form covering about two-thirds of the abdomen in the female; usually reaching its tip in the male. Hind femora usually unarmed, though sometimes bearing one to four small teeth on their lower outer carina. Cerci of male rather stout, with the apical half curved slightly outward and depressed. Ovipositor slender, straight.

The general color is more of a green than in brevipenne; the face, sides of pronotum and abdomen, and usually the four anterior femora, being of that hue. The tegmina and wings are light reddish brown, as are also the tibiæ and ovipositor.

Measurements: Male-Length of body, $12.5 \mathrm{~mm}$; of tegmina, 10 $\mathrm{mm}$.; of hind femora, $13 \mathrm{~mm}$.; of pronotum; $3.5 \mathrm{~mm}$. FemaleLength of body, 12-14 mm.; of tegmina, short winged, $8.5 \mathrm{~mm}$; long winged, $14 \mathrm{~mm}$.; of hind femora, $13.5 \mathrm{~mm}$.; of ovipositor, $12-14 \mathrm{~mm}$.

Although found in Indiana wherever collections have been made, this species appears to be less common than either fascialum or brevipenne. It differs from them occasionally in the manner of oviposition, as, instead of always depositing its eggs in the stems of grasses, it sometimes seeks the turnip-shaped galls so common on eertain species of Salix (willow), and oviposits between their scales. The gall is not formed by the Locustid, but by a Dipterous insect belonging to the faniily of Cecidomyide. Although I have never seen the eggs deposited I have on a number of oceasions found them within the galls, but did not know to what insect they belonged until 
Mr. Wheeler published (loc. cit.) his excellent account of the oviposition of this species. From that I quote as follows: "On September 8th I observed a female in the act of oviposition. She was perched with her head turned toward the apex of the gall. Slowly and sedately she thrust her sword-like ovipositor down between the leaves, and, after depositing an egg, as slowly withdrew the organ in order to recommence the same operation, after taking a few steps to one side of where she had been at work. She soon observed me and slipped away without completing her task. The number of eggs found in a gall varies considerably. Sometimes but two or three will be found, more frequently from 50 to 100 . In one small gall I counterl 1io." The egg is cream-colored, very thin, elongate oval in outline, and measures $4 \times 1 \mathrm{~mm}$.* The young emerge about the middle of May and reach maturity about Angust 10th. Long winged forms of this species are occasionally met with.

Ensiferum was first described from Illinois, and, as yet, has not been recorderd east of the Alleghany Mountains. One which was still in the nymph stage on October 21st, was found to have a white hairworm (Gordius sp?) eight and a half inches long in its abdomen. The development of the nymph had probably been retarded by the presence of the parasite.

98. Xiphidium nigropleura Bruner. The Black-sided Grasshopper.

Tiphidium nigropleum Bruner, 25, XXIII, 1891, 58; B1., 7, 1893, 125; Lugg., 84, 1898, 241.

Tiphidium nigropleura Scudd., 183, XXX, 1898, 184; Id., 188, 1900, 75.

A medinm sized, rather rolmst species, easily distinguished from all others of the gemus by its peenliar coloration. In Indiana dimorphic forms occur; one having the pronotum, tegmina and legs bright grass green, the other with these parts brownish yellow, the green wholly absent. Both forms have the stripe on the occiput and the sides of the abdomen shining black; the former narrowing in front to the width of the tubercle, and bordered on each side with yellowish white. In the green forms the nsual brown stripe on the disk of pronotum is but faintly defined, in the other it is very evident.

The tegmina are msually alsbreriated, reaching only four-fifths of the length of the abdomen, but an occasional specimen is to be found in which they are fully developed and then reach beyond the middle

\footnotetext{
Mr. B. D. Walsh, in the Proc. Ent. Soc. Plil., III, 1864, 232, rocorded the finding, on numerous occsions, of the eggs of an Orchelimum in the turnip-sbaped galls of Salix cordata. Their shape and proportional dimensions, as given by bim, differ much from those of $X$. ensiferum, as thes were cylindrical, .16 to .17 of an inch long, and seven times as long as wide.
} 
of the ovipositor in the female. Ovipositor straight, quite broad and heavy. Male cerci of medium length, rather stout, tapering gently toward the apex, and with a strong sub-basal tooth.

Measurements: Male-Length of body, $14 \mathrm{~mm}$.; of tegmina, 9 $\mathrm{mm}$; of hind femora, 13.5; of pronotum, 3.5. Female-Length of body, $15 \mathrm{~mm}$; of tegmina, short-winged form, $8.5 \mathrm{~mm}$.; of tegmina, long-winged form, $17 \mathrm{~mm}$.; of hind femora, $14 \mathrm{~mm}$.; of ovipositor, $16 \mathrm{~mm}$.

In Indiana this handsome insect has been taken in Gibson, Vigo, Fulton, Narshall, Starke, Lake, Kosciusko, Wells and Steuben eounties, and probably occurs in suitable localities throughout the State. It appears to be a semi-aquatic species, inhabiting only the margins of ditches, large ponds and lakes, where it abides in the tall, rank grasses and sedges growing in the shade. It reaches the perfeet stage about July 1st in southern Indiana, and in Fulton County has been taken as late as October 24 th. The males leap actively when approached. The females are more clumsy and usually dive headlong into a bunch of fallen grass. They can then be most readily captured by clasping the hand about a bunch of grass stems or branches of shrubs, on the under side of which the insects have taken refuge.

Nigropleura has been recorded only from Iowa, Nebraska and Ithaca, New York, specimens having been sent me from the latter locality by one of my correspondents, thus extending eastward its known habitat by more than 700 miles.

Of its habits in Nebraska, Bruner (7oc. cit.), has written as follows: "It is quite plentiful among the rank vegetation on low moist ground, and is especially eommon in wet places where the "cut grass" (Leersia oryzoides Swartz) grows. The supposition is that this grass offers a better place than usual for the deposition of its eggs, which are deposited between the leaves and stems of grass. Grapevines and other creeping plants which form matted clusters that afford shelter from the noonday sun and the bright light of day are farorite haunts of this and other species of our nocturnal grasshoppers and a few of the arboreal crickets."

99. Xiphidium Saltans Scudder.

Xiphidium saltans Scudd., 147, 1872, 249; Id., 183, XXX, 1898, 184; Id., $188,1900,75$.

Xiphidium modestum Brun., 2 5, XXIII, 1891, 56; B1., 7, 1893, 126.

This is the smallest and most slender-bodied Loenstid found in the istate. It is a dull, reddish brown in color, except the stripe on the 
occiput and disk of pronotum, which is a dark, chocolate-brown, the two colors being separated by a rather wide yellowish line which in living specimens is very distinet.
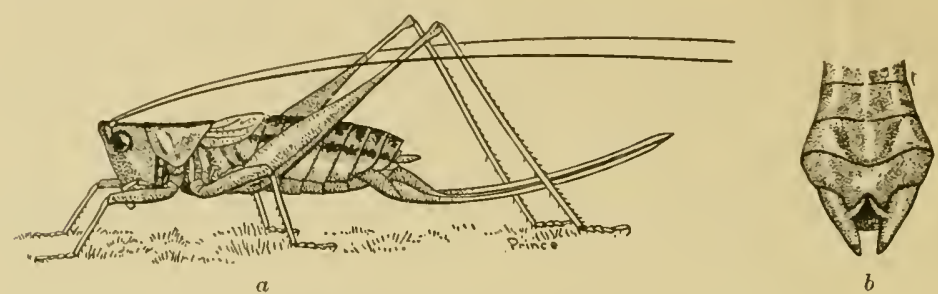

Fig. 94. Xiphidium saltans Scudder.

(a) Female. Two and one-half times natural size.

(b) Tip of uale abdomen, showing form of cerci. (Original.)

The cone of the vertex is short and rather narrow. Tegmina, especially those of the female, very short and obtusely rounded. The shrilling organ of the male is narrower and farther removed from the base of the wing cover than in the male of $X$. strictum, its nearest ally. The tip of male abdomen is but slightly enlarged, cerei elongate, tapering, a little curved outward and armed with a rather long sub-basal tooth. Ovipositor equaling the body in length, very slender and tapering, with its apieal half slightly upcurved.

Measurements: Male-Length of body, $10 \mathrm{~mm}$; of tegmina, 3 $\mathrm{mm}$; of hind femora, $9 \mathrm{~mm}$; of pronotum, $3 \mathrm{~mm}$. Female-Length of body, $11 \mathrm{~mm}$.; of tegmina, $2.5 \mathrm{~mm}$.; of hind femura, $9.5 \mathrm{~mm}$.; of ovipositor, $11 \mathrm{~mm}$.

Saltans as yet has been noted only at one point in the State, namely, the border of a raw prairie near Heckland, Vigo County, where it was found in small numbers on October 21, 1893, and in September, 1894. It appears to be less active than any other Xiphidium, leaping a shorter distance when disturbed, and frequenting the surface of the ground rather than the stems of the tall prairie grasses among which it malies its home. It will probably be found, by close search, to inhabit most of the few remaining patches of raw prairie in the western part of the State. However, it has not been noted elsewhere than in Vigo County, east of the Mississippi River, although it is said by Bruner to be very plentiful in Nebraska, Iowa and Kansas.

100. Xiphidum Strictum Seudder.

Xiphidium strictum, Scudd., 15 1, XVII, 1875, 460; Id., 153, IV, 1875, 63; Id., 164, 1879, 13; Id., 183, XXX, 1898, 183; Id., 188 , 1900, 75; Redtenb., 110, 1891, 205; Bl., 7, 1893, 127; Lagg., $84,1898,242$. 
In this species the body is rather slender and of more than average length; constant in color but dimorphic as respects the length of wings, the long-winged forms, however, being very scarce. Sides of head and body, together with all the femora, green. The usual reddish brown stripe on occiput and pronotum narrowly edged with whitish, especially on the fastigium of the vertex. Tegmina reddish brown; in the females exceedingly short and pad-like, or well developed and reaching almost to knees; when the former, a little longer than the wings, when the latter, $5 \mathrm{~mm}$. shorter than the wings. In the short-winged males (the only ones I have seen) the tegmina are somewhat less than half the length of the abdomen. There is a reddish brown band on dorsal surface of abdomen, darker where it meets the green on sides. Ovipositor pale red, straight, one and a half times the length of the posterior femora. Cerci of male, long, the apical half acuminate, curved slightly inward near the tip.

Measurements: Male-Length of body, $14 \mathrm{~mm}$; of tegmina, 5.5 $\mathrm{mm}$.; of pronotum, $3.5 \mathrm{~mm}$.; of hind femora, $13.5 \mathrm{~mm}$. FemaleLength of body, $17 \mathrm{~mm}$; of tegmina, short-rvinged form, $3.5 \mathrm{~mm}$; long-winged form, $16 \mathrm{~mm}$.; of hind femora, $15.5 \mathrm{~mm}$.; of ovipositor, $23 \mathrm{~mm}$.

Strictum is a common species in the western and northern parts of the State, where it frequents, for the most part, dry upland meadows, open pastures and prairies, and reaches maturity about August 1st. The mature females are usually much more abundant than the males and vary much in size. It is an active leaper and tumbler and like several of its allies, often strives to escape detection by burrowing beneath fallen weeds and grasses. The general range of strictum is to the west and southwest, it having been first described from Texas, and not heretofore recorded east of Illinois, except in my former paper on Indiana Locustidæ.

101. Xiphidium attenuatum Scudder. The Lance-tailed Grasshopper.

Tiphidium attenuatum Scudd., 146, II, 1869, 305; Id., 183, XXX, 1898, 183; Id., 188, 1900, 74; Brun., 25, XXIII, 1891, 57; Id., 27, III, 1892, 265; Redtenb., 1 10, 1891, 191; Bl., 7, 1893, 128; Id., 16, 1899, 219, Fig. 51. (Long winged form).

Xiphidium scudderi Bl., 5a , XXIV, 1892, 26; Scudd., 183, XXX, 1898, 183 ; Id., 188, 1900, 75. (Short-winged form).

General color a dull testaceous or reddish brown, in some specimens tinged with greenish. Antennæ with the basal third reddish, the remainder fuscous, longer than in any other member of the genus belonging to our fauna, measuring $73 \mathrm{~mm}$. in one specimen at hand. Tegmina and wings either abbreviated or fully developed; 
when the former covering about thre-fourths of the abdomen in the female and reaching or slightly surpassing its tip in the male; when dereloped, fully twice the length of abdomen: the wings cxtending 4 mm. beyond the tegmina. Femora gereenish brown, very rarely bright green, the tibia and tarsi darker. Abdomen tapering but slightly posteriorly, with the base of oripositor but little enlarged. Posterior femora heary on their basal two-fifth.s. slender lierond, armed on their lower onter carina with two to four minute blackish

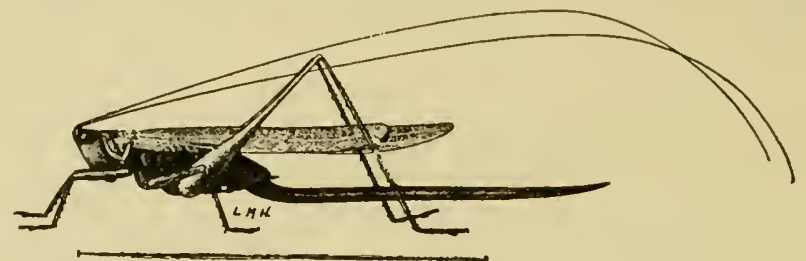

Fig. 95. Xiphidium attenuatum Scudd. Female. (After Lugger.)

spines. Cerei of male long. hroad, with the apical third gently tapering, the basal tooth minute, slender. Oripositor excessively long, slender, straight or but gently curved, the ajex very acmunate.

Measurements: Male-Length of body, 12-1; mm.; of antenna, i3 $\mathrm{mm}$; ; of pronotum, $2.6 \mathrm{~mm}$.; of tegmina, short winged form. 8.5 $\mathrm{mm}$; of long winged form, $19 \mathrm{~mm}$; of hind femora, $14 \mathrm{~mm}$. Female-Length of body, $13-16 \mathrm{~mm}$; of pronotmm, 3 mm.: of tegmina. short winged form, $10 \mathrm{~mm}$. long winged form. $19 \mathrm{~mm}$.: of hind femora, $1+\mathrm{mm}$.; of ovipositor, $26 ;-30 \mathrm{~mm}$.

The short winged form of this species has proven much more abmudant locally in Indiana than the long winged form. In Vigo C'ounty it was, ten years ago, very plentiful about the borders of two large ponds in the Walash River bottoms. In Knox County a few specimens were secured in 1901 from the margin of a similar pond bordering a large cypess swam], while in Koscinsko County it was found to be quite eommon in some marshes near Tippecanoc and Turkey lakes. In all these places the insects dwell among the tall rank grasies and rushes growing in shallow water. The males are, as far as my experience goes, the most arotive leapers among the winged locustida, jumping a half dozen or more times without pause when flushed, and in the net leaping so rapidly from side to side as to prevent eapture with the fingers. The females are evidently handicapped in their leaping powers by the exeessive length of the oripositor. and so more often endearor to escape hy burrowing beneath the dense masses of fallen grass and reed stems which are always found in their aceustomed haunts. 
The long winged form was first taken in Indiana in August, 1902, when it was found in some extensive low ground meadows in Kosciusko Comnty. Here the long and short winged forms were about equally abundant. The former flew readily when approached, but to no great distance. A few of the long winged ones were also taken near Bass Lake, Starke County. The specimens from these northern counties are more slender bodied than those from the south, where only the short winged form has been found. Attenualum was first described from Illinois, though it is not mentioned in McNeill's "List of Orthoptera of Illinois." Outside of Indiana it has been recorded from Nebraska, Iowa and Minnesota.

I find that the length of the ovipositor among the different species of Xiphidium is not at all dependent upon the age of the insect. In both attenuatum and scudderi it is almost as long after the third, and fully as long after the fourth moult as it is in the adult; while a female of strictum has been taken, with no vestige of tegmina, in which the ovipositor measured $18 \mathrm{~mm}$. The eggs of attenuatum, as the length of the ovipositor indicates, are laid between the stems and leaves of tall rank grasses among which the insects live.

\section{XlviI. Orchelimum Serville (1831).}

Locustidx of medium size, but with a short and stout body. Tertex, face and eyes much as in Xiphidium. Spines of the prosternum well developed, cylindrical and slender. Antennæ slender and tapering, usually of excessive length. Wing covers narrow, the apical half often much less in width than the basal, exceeding the abdomen in all our species; almost always shorter than the wings. Stridulating organ of the male as in Xiphidium, but proportionally larger. Ovipositor stout, broad, with the apical half usually upcurved; when straight the apical third tapers rather abruptly on the under side to a fine point. Anal plates and cerci of males as in Tiphidium.

This genus is very close to Xiphidium, and is, by some writers, united with it. Redtenbacher places it as a sub-genus of Xiphidium, separating its members from those of Yiphidium proper by the same characters as did Serville. As scientists differ in opinion as to what characters are necessary to constitute a genus, and as, at best. it is but an artificial and arbitrary grouping of species for the sake of convenience, I follow Serville, Scudder and Bruner in separating the two, believing that the prime idea of convenience can thus be better subserved. 
As noted in the Key to the Genera of Conocephalina, the larger, heavier body, longer prosternal spines, and shorter and broader falcate ovipositor are the chief distinguishing characters of Orchetimum. The wing covers are more uniform in length, and the color, while of slightly different shades of brown or green in the same species, according to season and habitat, does not run to the extremes of variation as in Xiphidium.

The generic name, Orchetimum, the literal meaning of which is "I dance in the meadows," is a most appropriate one, for low, moist meadows everywhere swarm with these insects from July to November; and though waltzes and quadrilles are probably not indulged in, yet the music and song, the wooing and love-making which are the natural accompaniments of those amusements, are ever present, and make the short season of mature life of the participants a seemingly happy one.

Eight species of the genus have been taken by the writer within the State. 'These may be separated by means of the following key:

KEY TO THE INDIANA SPECIES OF ORCHELIMUM.

a. Ovipositor with a very evident curve, its length less than $10 \mathrm{~mm}$.

b. Face without a median brown stripe.

c. Hind femora not armed witl small spines ou the under side.

d. Tegmina broxdest at base; the apical third narrower; body robust.

e. Tegmina and wings sub-equal in length; not much exceeding the hind femora; size, medium.

102 vulgare, p. 353

ec. Tegmina distinctly shorter than wings; plainly exceeding the hind femora; size, large........

103 glaberrimum, p. 385

dd. Tegmina of nearly equal width throughout; body slender; size, small.........104 campestre, p. 396

cc. Apical half of posterior femora armed beneath with sereral small spines; all the tibia and tarsi black or dark brown ....................105 nigripes, p. 357

bb. Face with a dark reddish brown stripe down the center........

106 indianense, p. 388

aa. Oripositor straiglut or nearly so; its length 10 or more mm.

f. Posterior femora unarmed beneath.

g. Body slender; pronotum short, not more than $4 \mathrm{~mm}$. in lengtl; tegnaina narrow, shorter than the wings........

107 delicatum, [. $3 S 9$

gg. Body stout; pronotum 5 or more mm. in lengtl; tegmina and wings sub-equal in length.......10s gladiator, p. 390

ff. Posterior femora armed on the outer lower carina with several

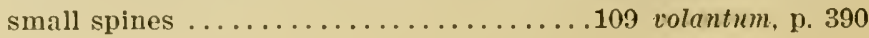


102. Orchelmum vulgare Harris. The Common Meadow Grasshopper. Orchelimum vulgare Harris, 72, 1862, 162, Fig. 77; Scudd., 142, I, 1868, 117 (note of set to music); Id., 168, XXII, 1892, 73 (note of set to music); Pack., 104, 1883, 567; Riley, 122, II, 1881, 187; Comst., 4 1, I, 1888, 114; Bl. 7, 1893, 130; Id., 16, 1899, 220, Fig. 52; Beut., 3, VI, 1894, 282, Plate VI, Figs. 4 and 5; Lugg., 84, 1898, 234, Figs. 155, 156; McNeill, 90, XXXII, 1900, 78, 81 .

Xiphidium agile Redtenb., 110, 1891, 186. (In part.)

Orchelimum agile Scudd., 188, 1900, 73.

A medium sized, robust species, with the general color green or light reddish brown. Face light green or light brown without fuscous marks. The occiput and disk of pronotum with a reddish brown band, widening on the latter, where it is often, especially in the male, bordered on each side with a darker line. The male (as in most of our species) with two short, black dashes on each wing cover, the four forming the angles of an assumed square, enclosing the tympanum. The legs usually pale brown, the tarsi dusky: Pronotum

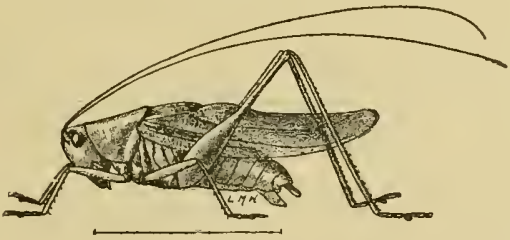

Fig. 96. Orchelimum vulgare Harris. Male. (After Lugger.)

long, its posterior lobe but slightly, if at all, upturned above the plane of the anterior, its hind margin broadly rounded. Tegmina reaching to or very slightly beyond the apex of hind femora, and equaling or very little shorter than the wings: Cerci of male rather long, the apex bluntly rounded, a little depressed; sub-basal tooth somewhat flattened, with the tip sharp and decurved.

Measurements: Male-Length of body, $18 \mathrm{~mm}$.; of pronotum, 6 mm.; of tegmina, $21 \mathrm{~mm}$.; of hind femora, $17 \mathrm{~mm}$. Female-Length of body, $19 \mathrm{~mm}$.; of pronotum, $6.2 \mathrm{~mm}$.; of tegmina, $21 \mathrm{~mm}$.; of hind femora, $18 \mathrm{~mm}$.; of ovipositor, $7.5 \mathrm{~mm}$.

This meadow grasshopper is probably the most abundant member of the family Locustidx found in Indiana. It begins to reach maturity in the central part of the State about July 10th, and more frequently than any other of our species of Orchetimum it is found in upland localities, along fence rows, and in clover and timothy meadows. In early autumn it seems to be very fond of resting on 
the leaves and stems of the ironweed, Vernonia fasciculata Michx., so common in many blue-grass pastures.

"The poetry of earth is never dead:

When all the birls are faint with the hot sun,

And hide in cooling trees, a roice will run

From hedge to hedge about the new mown mead;

'That is the grasshopper's-he takes the lead

In summer luxury, he has never done

With his delights; for when tired out with fun

He rests at ease beneath some pleasant weed."

Vulgare seems to be somewhat carnivorous in habit, as, on two occasions, I have discovered it feeding upon the bodies of small moths which in some way it had managed to capture; while on another date I surprised a female on the flowers of a golden-rod, feasting upon a soldier beetle, Chauliognathus pennsylvanicus DeG.

Of the call note of the male vulgare Seudder has written: "When about to sing on a hot. smmy day, the male mounts a stalk of grass to about a foot from the ground where it clings with its four front legs. allowing its hind legs to dangle on either side of the stalk that they may not interfere with the movements of the tegmina. Beyimning with $t s$ it changes almost instantly to a trill of $z r$; at first there is a crescende movement which reaches its volume in half a secound; the trill is then sustained for a period varying from one to twenty seconds (generally from six to eight seconds), and eloses abruptly' with $p$. 'This strain is followerl by a series of very short statcato note: somnling like jip, jip, jip, repeated at half second intervals: the staceato notes and the trill alternate ad libitum. The staciato notes may be continned almost indefinitely, but are very rarely heard more than ten times in direct suecession; it ordinarily occurs three or four times hefore the repetition of the phrase, but not more than two or three times when the phrase is not repeated. The night song differs from that of the day in the rarer oceurrence of the intermediate notes and the less rapid trill of the phrase; the pitch of both is at B flat."

Rerltmbacher places rulyare as a symonym of DeGeer's Xiphidium agile, stating as his reason for so doing that Harris and Scudder have separated the two "on aecount of small differences in the color and size of the wing corers, as well as in the length of the ovipositor." He may be right in thus combining them, but his relative measurements of $X$. agile as given. do not agree with the specimens of undonbted rulgare in my possession. Sendiler, who has had ample opportunity to eompare the two, says (Bost. Journ. Nat. Hist. VII 
453) that the pronotum is shorter in agile than in vulgare. Redtenbacher's measurements of this organ, as well as those of the hind femora, are much less than the average measurements giren above. Harris, as well as Burmeister, states that the tegmina of agile are $2.5 \mathrm{~mm}$. shorter than the wings, while McNeill (loc. cit.) says that agile has the hind femora armed beneath. Taking all these facts into consideration, though having no typical examples of agile for comparison, I have concluded not to follow Redtenbacher but to retain for the species at hand the name vulgare, by which it is best known to the entomologists of the United States.

\section{ORChELIMUM GLABERRIMUM (Burmeister).}

Xiphidium glaberrimum Burm., 40, II, 1838, 707; Redtenb., 110,1891 , 187.

Orchelimum glaberrimum Scudd., 141 , VII, 1862, 453; Id., 188, 1900, 73; Riley, 122, II, 1884, 186; Comst., 4 1, I, 1888, 114; Bl., 7, 1893, 133; Lugg., 84, 1898, 235; McNeill, 90, XXXII, 1900, 78,81 .

Very close to and perhaps only a larger form of $O$. vulgare. The general color is the same, but the brown line on the disk of pronotum is, in the female, more plainly margined with black, while in the male the black dashes at ends of tympanum are larger and more completely enclose that organ. The tegmina of the male exceed the hind femora by about $4 \mathrm{~mm}$., and are exceeded by the wings about the same distance; those of the female are proportionally a little shorter.

Measurements: Male-Length of body, $22 \mathrm{~mm}$; of pronotum, 6 $\mathrm{mm}$; of tegmina, $26 \mathrm{~mm}$; of hind femora, $19 \mathrm{~mm}$. Female-Length of body, $23 \mathrm{~mm}$.; of pronotum, $6.5 \mathrm{~mm}$.; of tegmina, $24-2 \mathrm{rmm}$; of hind femora, $20 \mathrm{~mm}$; of ovipositor, $8.5 \mathrm{~mm}$.

Burmeister's original description of this species is very short and not distinctive. It is as follows: "Verticis et pronoti medio fulvo, nigro-marginato; elytris ab alis dimidia linea superatis. Long. corp., $11^{\prime \prime \prime}$." Burmeister knew but two species from the United States, and this short description was sufficient for him to distinguish these, but of the twenty or more species now known it is difficult to say just which one he had in mind when he wrote the above.

Glaberrimum is not a common species in Indiana. I have taken it in Vigo, Fulton, Marshall and Starke counties, but only one or two examples from each locality. All were secured from tall grass growing near the margins of ponds or lakes. It is evidently attracted by electric and other lights, as Dr. Robert Hessler took one from his office window near the center of the city of Logansport on the night 
of August 3, 1900. Its general range is given by Scudder as "United States from Rocky Mountains eastward."

104. Orcielinum Campestre Blatchley.

Orehelimum canpestre Bl., 10, XYT, 1893, 91; Id., 7, 1893, 133; Lugg., 84, 1898, 236; Scudd., 188, 1900, 75; MeNeill, 90, XXXI, $1900,78,81$.

A species of less than medium size, with wing covers narrow and of almost equal width throughout; the posterior femora unarmed beneath, and the ovipositor short, narrow, moderately upcurved, and tapering to a delicate point.

Cone of the vertex prominent, narrow, rounded at the apex; the sides of the frontal, deflexed portion rapidly converging to form a very acute wedge. Wing-covers long, slender, not narrowed in the middle as in 0 . vulgare, tapering slightly on the apical third to a rounded end; their length a little shorter than the wings in both sexes. Posterior femora with the basal half quite stout, the length less than that of the tegmina. Cerci of male slender, cylindrical, somewliat pointed, the apical half curved slightly outward, the basal tooth short and weak.

Color: Tegmina and wings almost uniform tranșparent olivaceous brown. The usual dark reddish brown band upon the occiput and disk of pronotum is margined on the latter with two very narrow and darker brown stripes, which extend back to the middle of the posterior lobe of the pronotum. Face, and usually the hind femora, a dirty olive brown; the latter, when dry, with a blackish longitudinal band on the exterior face. In the female the only green on the body is on the lower part of the sides of the pronotum and on the anterior femora. The males usually have the outer face of the posterior femora green, but otherwise are colored like the females. Ovipositor light reddish brown.

Neasurements: Length of body, male, $17.5 \mathrm{~mm}$., female, $19 \mathrm{~mm}$; of pronotum, male, $4.5 \mathrm{~mm}$., female, $5 \mathrm{~mm}$.; of tegmina, male, 20.5 $\mathrm{mm}$., female, $24.5 \mathrm{~mm}$.; of antennæ, male, $46 \mathrm{~mm}$.; of posterior femora, male, $17 \mathrm{~mm}$., female, $17.5 \mathrm{~mm}$; of ovipositor, $7 \mathrm{~mm}$.

This modestly colored grasshopper is very common in the northern half of the State, where it abides in the tall grasses of the low prairie meadows. It has not, as yet, been taken south of Marion and Vigo counties. It is a smaller and more slender bodied insect than the common $O$. vulgare Harris, and has a shorter and narrower pronotum and a much smaller ovipositor than that species. 
105. ORChelimum NIGRIPES Scudder. The Black-legged Grasshopper.

Orchelimum nigripes Scudd., 15 1, XVII, 1875, 459; Id., 153, IV, 1875, 62 ; Id., $164,1879,12$; Id., 168, XXIU, 1892, 73; Id., 188, 1900, 74; McNeill, 88, VI, 1891, 25; Id., 90, XXXII, 1900, 79, 83; Bl., 7, 1893, 135; Lugg., 84, 1898, 236.

Xiphidium nigripes Redtenb., $110,1891,188$.

Somewhat smaller than $O$. vulgare; the body moderately robust. Pronotum short, the posterior lobe, especially in the male, rather strongly upturned. Tegmina equaling the wings in male, a little shorter in the female, surpassing slightly the hind femora. The shrilling organ of the male is unusually large and prominent with strong crossveins, and behind it the tegmina taper rapidly on both margins, their shape and the size of the tympanum causing the male to appear somewhat peculiar and much more robust than it really is. Hind femora armed on apical half of lower outer carina with one to four small spines. Cerci of male slender, tapering, the apex a little obtuse; the sub-basal tooth long, slender and a little curved. Ovipositor rather long, broadest in the middle, tapering to a delicate point. The males vary much in size.

General color green or reddish brown, the former prevailing in the male, the latter in the female. Occiput and disk of pronotum with the usual brown markings. Front and sides of head, and four front femora, reddish yellow. All the tibiæ and tarsi, together with the apical third of hind femora, black or dark brown at least on the upper side; in one specimen at hand the whole body, except the wing covers and femora, black.

Measurements: Male-Length of body, $18 \mathrm{~mm}$; of antennæ, 66 $\mathrm{mm}$.; of pronotum, $5 \mathrm{~mm}$.; of tegmina, $21 \mathrm{~mm}$; of hind femora, 16 mm. Female-Length of body, $19 \mathrm{~mm}$; of tegmina, $22 \mathrm{~mm}$; of hind femora, $17 \mathrm{~mm}$; of ovipositor, $9 \mathrm{~mm}$.

The "black-legged grasshopper" is a lowland species, which has been taken in numbers in Vigo, Putnam, Posey, Starke, Fulton, Lake and Wells counties, and probably occurs in suitable localities througlout the State. It reaches maturity about July 20th, and is usually abundant about the margins of the larger ponds and lakes, where it frequents the tall grasses and especially the stems and leaves of the different species of Polygonum, or smartweed, growing in the shallow water. Examples of the parasitic hairworm (Gordius $s p$ ?) have been taken from the abdomens of a number of specimens.

Nigripes was described from Texas and was first recorded east of Illinois in my former paper. It has been taken by myself at Celina, Ohio, though Scudder gives its range as "Rocky Mountains to the 
Misissippi liver." Its song is much more faint than that of rulgare. the z-e-e-e-e being much less prolonged.

106. Orchelimum indianense Blatchley.

Orchelimum indienerse B1., 10, XXV, 1893, 90; Id., 7, 1893, 137; Scudd., 188, 1900, 7:3; McNeill, 90, XXXII, 1900, 79, 82.

1 stender borlied inseret, with a dark median streak down the face, ant having the posterior femora mamed beneath. The cone of the vertex is short, rather narrow, with a rounded apex. The tegmina, narrow, tapering, a little shorter than the wings, and of a delieate. almost ganze-like texture. Posterior femora slender, shorter than the closed tegmina. Anal cerej of male of medium size. longer than

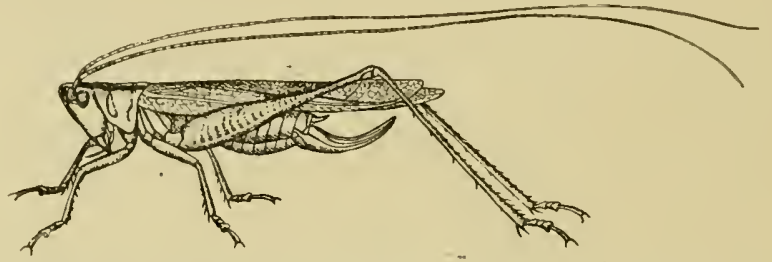

Fig. 97. Orchelimum intianense Bl. Female. One and one-half times natural size. (Uriginal.)

the sul-genital plate, tapering to a dull point; the basal tooth short, with a broarl base and a very sharp point. The ovipositor of female of les: than average width and length, the apical half with a gentle upward curve.

Color: Tegmina and wings a transparent whitish tinged with green on the front or lower iongitudinal nerres; the cross-nervules of the latter darker. Sides of pronotmm and abdomen, and all the femora, light green; the tibia and tarsi of a brownish hue. Face rellowish white, with a dark reddish brown stripe the width of the labrum, starting with the mouth and passing upward to the vertex, where it marrows to the width of that organ; then, broadening on the oceiput, it passes back to the front border of the pronotum, where it divides into two narrow streaks. which enclose a whitish area and extend a little beyond the posterior transverse suture, where they taper to an end. Sub-genital plate of male yellow. Basal third of oripositor dark brown, the remainder light reddish brown.

Neasurements: Je'ngth of body, male, $18 \mathrm{~mm}$., female, $18.5 \mathrm{~mm}$; of pronotum, male and feuale. 4 mm.; of tegmina. male. $21 \mathrm{~mm}$, female, $19 \mathrm{~mm}$; of hinel femora, male, $14 \mathrm{~mm}$., female, 15.5 mm.; of oriphsitor, $2.5 \mathrm{~mm}$. 
This graceful and prettily marked species is quite common among the rank grasses and sedges growing abont the margins of tamarack swamps and lakes in Fulton, Marshall, Starke, Lake, Koscinsko and Steuben counties, where it reaches maturity about July 20th. It is probably a species of northern range which does not oceur in southern Indiana. It is the smallest and most slender of the eight species of the genns so far known to occur in the State, and its markings are very distinct from those of any of the others.

107. Orchelmium delicatum Bruner.

Oichelimum gracile Brun., 25, XXIII, 1891, 70.

Oichelimum delicutum Brun., 27, III, 1892, 264; Scudd., 188, 1900, 73; McNeill, 90, XXXII, 1900, 77, 80.

"A slenderer and somewhat smaller insect than O. vulgare, from which it differs in the form of its pronotum and of the oripositor. The tubercle of the vertex is short, broad, and has the apex rounded. The tegmina and wings are of moderate length, very delicate in texture, and in the male furnished with an inconspicuous musical apparatus. Legs slender, the posterior femora not quite reaching the tips of the closed tegmina. Terminal segment of the male abdomen quite broad; the anal cerci stout and acuminate, with the internal tooth minute; sub-genital plate broad and long, reaching beyond the tips of the cerci. The ovipositor unusually long, broad, nearly straight and fine pointed.

"In color it is a pale transparent green with a broad reddish brown band upon the head and pronotum, continnous from the tip of the vertex to the posterior transverse indentation of the pronotum, somewhat paler in the middle; upon the latter, rather broadly bordered by yellowish white throughout. Face and mouth parts together with the genital armature of the male odhreous; ovipositor light reddish brown. Tarsi and sometimes also the tibix a trifle infuscated."

"Length of body, male, $16 \mathrm{~mm}$., female, $17.5 \mathrm{~mm}$.; of antennæ, male and female, about $50 \mathrm{~mm}$; of pronotum, male, $3.8 \mathrm{~mm}$., female, $4 \mathrm{~mm}$.; of tegmina, male, $19 \mathrm{~mm}$., female, $20 \mathrm{~mm}$.; of hind femora, male, $14 \mathrm{~mm}$., female, $15 \mathrm{~mm}$.; of ovipositor, $11-12 \mathrm{~mm}$."

This species was deseribed from West Point and Lincoln, Nebraska, where Bruner found it common about the margins of ponds and along the edges of streams, also at electric lights. In Indiana it has been noted only in Marshall and Starke counties, where a half dozen specimens were secured in lowland meadows near large lakes on July 30th and Angust 20, 1902. It probably occurs throughout the lake region of the northern third of the State. It has not before been recorder east of Nebraska. 
108. Orchelimug Gladitor Bruner.

Orchelimum gladiator Brun., 25, XXIII, 1891, 71; B1., 7, 1893, 138; Scudd., 188, 1900, 73; McNeill, 90, XXXII, 1900, 77, 81.

In its general structure this species resembles the more robust forms like $O$. glaberrimum and $O$. nigripes. It differs from these, howerer, in having shorter legs and antennæ, and in the shape of the ovipositor. The posterior femora are rather slender and unarmed beneath; the cone of the vertex is short and obtuse, with the extreme tip shallowly sulcate: the inner wings are the same length as the tegmina in the maie, a little longer in the female, where they do not quite reach the tip of the ovipositor. The latter organ is broad, nearly straight and of more than ordinary lengtls. Cerci of male stout, the basal tooth long, tapering gradually to a sharp point, iis apical third a little curred.

Color: Pale transparent grass-green throughout, save the usual markings upon the occiput and disk of pronotum, which are dark brown; on the latter composed of two well defined, narrow, slightly diverging lines. Antenne rufous, feet and extreme tip of the ovipositor tinged with rufous.

Measurements: Length of body, male, $17 \mathrm{~mm}$., female, 18-20 $\mathrm{mm}$; of antennæ, male, $43 \mathrm{~mm}$., fernale, $35 \mathrm{~mm}$; of pronotum, male, $5 \mathrm{~mm}$., female, $4.75 \mathrm{~mm}$; of tegmina, male and female, 19 $\mathrm{mm}$.; of hind femora, male, $14 \mathrm{~mm}$., female, $15.5 \mathrm{~mm}$.; of ovipositor, $10 \mathrm{~mm}$.

This species has been found to be quite common in some of the northern counties, having been taken in low, damp meadows and marshes in Fulton, Starke, Marshall, Kosciusko and Steuben. It probably irhabits low damp prairies and meadows throughout the northern half of the State. It evidently begins to reach maturity about July 25th, perhaps a week sooner. A pair in coitu were secured in Marshall County on July 29th. It was described from Nebraska and has been recorded only from that State and Indiana.

109. Orchelmus volantum MeNeill.

()rchlimum coluntum McNeill, 88, VI, 1891, 26; Id., 90, XXXII, 1900, 80, 83; Scudd., $188,1900,74$.

Orchelimum bruneri B1., 10, XXT, 1893, 92; Id., 7, 1893, 139; Scudd., 188, 1900, 73; McNeill, 90, XXXII, 1900, 80, 83.

A species of medium size and rather slender body with the posterior femora armed beneath, and the ovipositor very broad, nearly straight and of more than average length.

Cone of the vertex narrow, moderately elevated, rounded at apex. Tegmina long and narrow, a little shorter than the wings; strongly 
reticulate in the female. Posterior femora rather stout, the apex, when appressed, just reaching the tip of ovipositor; armed beneath on the apical half with three or four small spines. Cerci of male stout, tapering to a point, with the internal tooth, rather broad and flat at base. Ovipositor very similar to that of O. gladiator Bruner, being very long and stout, nearly straight above, and with the under side of apical third sloping rapidly to the acute apex.

Color: With the exception of the ovipositor, which is a light reddish brown, and the usual stripe on occiput and disk of pronotum, the whole body is a pale, transparent brownish green, the green showing plainly only on the lower half of the side of the pronotum and on the meso- and meta-pleura.

Measurements: Length of body, male, $18 \mathrm{~mm}$., female, $20.5 \mathrm{~mm}$; of tegmina, male, $21 \mathrm{~mm}$., female, $25-28 \mathrm{~mm}$; of pronotum, male and female, $4.75 \mathrm{~mm}$; of hind femora, male, $16 \mathrm{~mm}$., female; 19 mm.; of ovipositor, $10.5 \mathrm{~mm}$.

As shown by the synonymy, this is the 0 . bruneri of my former paper, a comparison of type specimens of volantum, kindly loaned me by Professor McNeill, having proved the two to be identical. The Indiana specimens, however, do not show the character to which McNeill calls especial attention, namely, "the distinct angle formed by the anal area with the lateral field in the female tegmina."

In Indiana volantum has been taken in Vigo, Fulton, Marshall and Starke counties. It is found most abundantly during August and September on the leaves and stems of a tall, broad-leaved knot-weed, Polygonum amphibium L., which grows luxuriantly in the shallow waters about the margins of the larger ponds and lakes. Several other "green grasshoppers," notably among which are Xiphidium attenuatum Scudd. and Orchelimum nigripes Scudd., frequent this plant in large numbers. Keeping company with them an occasional specimen of $O$. bruneri is seen, but, being an active leaper, it often escapes amidst the dense foliage of the knot-weed before its capture can be effected.

Its less robust body, longer armed posterior femora and long tegmina will readily distinguish this species from $O$. gladiator, the only other one which, to my knowledge, has an ovipositor shaped like that of volantum.

Outside of Indiana, volantum has been taken only near Cleveland, Henry County, Illinois, where McNeill found it in small numbers on the semi-aquatic plant, Sagittaria variabilis Engelm, one of the arrow-heads. "Their song," says McNeill, "has a new note in it. It may be represented as follows: zip-zip kr-ze-e-e, kr-ze-e-e, the last part 
of the song not lasting more than half to three-quarters of a second and is alwas preceded by the sound which I represent imperfectly by $k r . "$

\section{Sub-family DECTICIN A:}

All known North American representatives of this sub-family are apterous or sub-apterous, their tegmina never cxtending orer morethan two abdominal segments. The antenne are inserted between the eyes, nearer the summit of the oceiput than the upper margin of the labrum. Slit-like foramina (hearing organs) are present near the base of the fore tibia, and these tibie bear an apical spinc on their onter upper side. The tarsi are all more or less depressed; and their first two joints are sulcate lengthwise on the sides; while the first joint of those of the hind legs bears a free plantula beneath its base.

The sub-family is represented in the Western States by mumerous genera and a large number of species, but east of the Misisippi River but two genera and four species belonging to it have as yet been found. In Indiana but one of these genera, Allanticus scudder, represented by two species, is known to ocem. However. members of the other eastern genus, Orcheslicus Saussure, may in time lie found within the State, since one of its species is known from 'T'ennessee and another from Missouri. From other Declicint the species of Orcheslicus may be distinguished by the armed prostermum, the yresence of four terminal spines on the lower side of hind femora. and an oripositor which curves upward. This last character is the principal one separating them from Allantirus. whose members have the ovipositor straight.

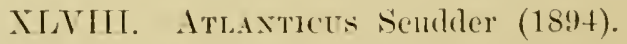

The members of this gemus are Loenstidax of large size, in which the pronotum extends back over the first joint of the abdomen, thus forming a buckler or shield for the back. Face broad, romnded. but slightly oblique. Fyes small, sub-glohose. Vertex with a blunt decurved projection between the antemma. l'ronotmm trumeate in front, rounded behind, flattened above, bent abruptly downard on the sides. l'rostermm arned with two slender, sub-acute spines. 'Tegmina of the females rudimentary, wholly covered by the promotum; those of the males fairly well developed, extending in om most common species five or more mm. back of the promotmm. The shrilling organ, which is covered by the promotum, is cirenlan, and 
rather large for the size of the tegmina. Wings very rudimentary or wanting. Hind femora long and rather slender, extending, in our species, beyond the abdomen in both sexes, notably so in the males. Ovipositor as long as the body, very stout at the base, straight.

The "Shield-back Grasshoppers," so called on account of the large protective pronotum, are often quite numerous from April 1st to September 15th in dry upland woods and on sloping hillsides with a southem exposure, but are seldom, if ever, found in damp localities.

On the first warm days of early spring the young begin to emerge and in suitable places for a month or more are among the most common Orthopterans seen. They are much more active during early life than in the mature state when they crawl rather than leap. In captivity they feed as readily upon animal as upon vegetable food, and in the natural state probably feed upon the dead bodies of such small animals as they can find. The earliest hatched reach maturity in central Indiana about the first of June, and may then often be found resting on the leaves and stems of low shrubs and weeds, but seldom climb over two or three feet from the ground. The adults are far less numerous than the young, the vast majority of the latter probably falling a prey to the many ground-frequenting sparrows and other birds, as they do not hide by day as do the members of the genus Ceuthophilus. The two Indiana species may be separated by the following key:

KEY TO INDIANA SPECIES OF ATLANTICUS.

a. Pronotum more than half as long as hind femora, its front margin in the female much narrowed, but little more than half as wide as hind margin; exposed portion of male tegmina almost as ample as the pronotum ..................110 pachymerus, p. 393

a $a$. Pronotum not more than half as long as hind femora, its front margin in the female but little narrowed, about three-fourths the width of the hind margin; exposed portion of male tegmina less than one-third as ample as the pronotum.......111 dorsulis, p. 394

110. Atlanticus Pachymerus (Burmeister).

Dectints pachymerus Burm., 40, II, 1838, 712.

Thyreonotus pachymerus Scudd., 14 1, VII, 1862, 453; Coms., 4 1, I, 1888, 118, Fig. 106; Davis, 43, XXV, 1893, 108 (song of); Bl., 7, $1893,150$.

Atlanticus pachymerus Scudd., 170 , XXVI, 1894, 179; Id., 188, 1900, 76; Lugg., 84, 1898, 245, Fig. 160.

Color: Male-Grayish or fuscous brown; the sides of pronotum and tegmina black, the former often shining, especially in the young; a narrow, curved yellowish line above the posterior lateral angle of $55-\mathrm{Geol}$. 
promotom: the exposed dorsal fichl of loumina light brown: the fomolat with mmmeroms mimute pale spots. Fomale-l'sually grayish

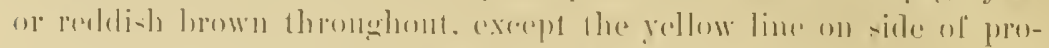
notum, which is bordereml aluse with a dash of hlack.

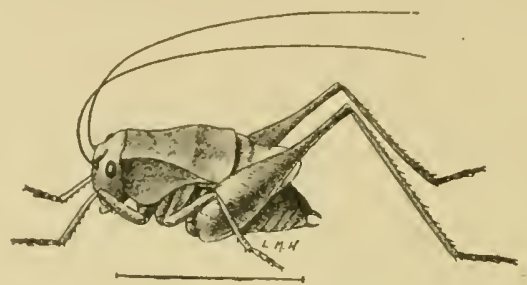

Fig. 98. Atlunticus pachymerus (Burm.). Nale. (After Lugger.)

The lateral carrine ol the foronotum are sharper in this species than in the next; the pronotum itself is proportionally a little longer, and appears more so than it really is on aceount of the broadly rounded posterior lobe. The hind femora, as rell as the ovipositor, are a little shortere than in elorsatis. and the apex of the ovipositor is more blumbly romeded from abore.

Measurement: Male-Lenerth of borly, 19 mm.; of pronotum, 9.5 mm.; of hind f(moral, 1 (i., mm. Female-Lemeth of borly, 21 mm.: of pronotmm, 9.5 mmm; of hind femora, 18 mm.; of ovipositor. 18 mm.

Pachymerus is, in Indiana, by far the more (onmmon of the two species. It has heen taken in lake, Marshall, Marjon, Prutnam, Viggo

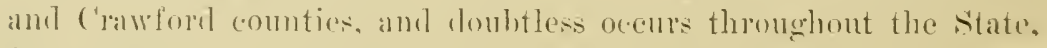
frepuenting the localities mentioned above moler the generic de-

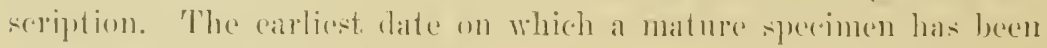
moted was Jume bith, in Tigro ('omenty.

Th a pleasing aceonut of the notes and habits of the suecies. Mr. II. 'T'. Davis, for ril., has witten as follows: "Its someg much resembles that of Orchelimmm rulfure, with the proliminary zip, zip. omitted. It is a contimuns :-e-e-e, with an oceasional short iti, cautsed ly the juscet. gettimer its wing rovers ready for action after a period of silene. * * * Starting with rasplocries, one kept in captivity lat the rest of the fruits in their season, including waternelon, of which he showed a marked apprexiation. If I otferes him a rasploery and then gratually drew it away, he would follow in the direction of the departing fouit, and would finally eat it from my hand."

111. Artaxticts DoRsalis (Burmeister).

Therlens dorealis Burm., 40, II, 1s:3s, 71:3.

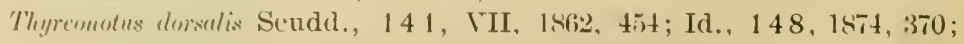

Comst., 122, I, 1685, 11\&; B1., 7, 18:33, 151.

Allunticus dursalis Scudd., 170 , XXVI, 1894, 179; Id., 188, 1900, 75. 
Color: Male-Usually a dark sooty brown flecked everywhere with grayish; the apical third of hind femora lighter; the yellow line on lower border of pronotum inclistinct or wanting. Female-Dull, yellowish brown; the posterior lobe of pronotum, dorsmm of abdomen and ovipositor dark brown. I blackish spot on the face below each eye; the sides of the pronotum with obsolete fuscous markings.

The chief structural distinctions between this insect and pachymerus are given above in the key and under the latter species. It may be added that the hind lobe of the pronotum in dorsatis is quite short and has its posterior margin nearly truneate; whereas in pachymerus it is much longer with the hind margin broatly rounded.

Measurements: Male-Length of body, $19 \mathrm{~mm}$; of pronotum, 9 mm.; of hind femora, $19 \mathrm{~mm}$. Female-Length of body, $24 \mathrm{~mm}$; of pronotmm, $9.5 \mathrm{~mm}$; of hind femora, $20.5 \mathrm{~mm}$.; of ovipositor, $23 \mathrm{~mm}$.

Dorsatis has been taken in the State in Putnam, Vigo, Knox and Crawford countics. In the two last named counties it is more common, than the other species. 1ts general range is more southern and it will probably be found to inhabit only the southern half of Indiana.

Sub-family GRYLIACRINA.

This sub-family is represented in the State by the single genus,

\section{Canitonotis Uhler (1864).}

Form similar to Centhophitus Sendd. Head large, oval, much broader than the prothorax and not deeply smnken into it. Eyes ovate, rertical, situated on the sides but little behind the basal joint of the antennx, and exceeding it a little in length. Maxillary palpi long, the last joint as long as the preeeding one, a very little inflated at the tip. Antenne at least five times the length of the body without the oripositor. Pronotum trapezoidal, the sides not carried downarts as far as the lower line of the eyes, the lateral margins somewhat broadly reeurved; meso- and meta-notmm very small, confined to the dorsum and not prolonged downwarl npon their sides. Oripositor ensiform, curved upurards. its valyes compressed, acute. Legs very short, moderately stout: the anterior and midille tibie slightly incurved near the hase, having a row of four long spines each side beneath; posterior femora amed beneath with a fer short teeth. 'Tarsi stout, four-jointerl, with split cushions bencath, the first joint equal in length to the two following ones conjoined.

A single species is known from the eastern United States. 
112. Camptonotus Caliolinensis (Gerstacker).

Cimplacris earolinensis Gers., 59, XXVI, 1860, 276.

Nentus eremolinensis Brumu., 39, 1888, 381.

Camptonotus cormlinemsis Scudd., 188, 1900, 79.

Camptonotus senderi Uhler, 2 12, II, 1864, 549; Glov., 62, 1872, Plate VIII, Fig. 15; Riley, 122 , II, 1881, 186.

A medium sized wingless Locustid, reddish brown above, yellowish white beneath. Face and all the tibia and tarsi yellowish, the femora, especially the two hind pair, mottled with dark lirown, and a transverse bar of the same color on the three posterior dorsal scements of abdomen.

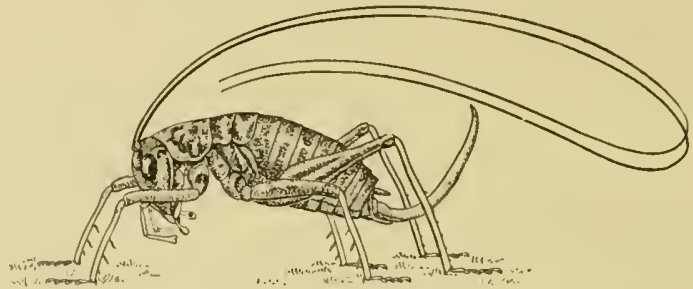

Fig. 99. Cumptonotus carolineusis (Gerstacker). Femule. Twico natural size. (1)riginal.)

Measurements: Female-Length of body, $12 \mathrm{~mm}$; of posterior femora, $7.5 \mathrm{~mm}$; of ovipositor, $8 \mathrm{~mm}$.

A single female of this curions Tocustid was taken October 11, 1902, near Millersville, Marion County, by Philip Baker, of Indianapolis, who kindly presented it to me. I had scen one in Vigo County ten years before but had failed to effect its capture. It has been heretofore taken only in Maryland, Delaware and the Carolinas. Near Baltimore, according to Uller, it appears in the larval state as carly as the first of August and reaches maturity the latter part of September. It is there found upon oak trees, where it is said to spend the day time curled up in the leaves. It will probably be found to oceur in small numbers on oaks throughout the sonthern half of Indiana.

Since the above was in type, two pairs of the half grown young of C. carolinensis have been taken, one pair from near Mitehell, Lawrence Comnty, on . July 15th; the other from near Montezuma. Parlie County, on July 22d. Both pairs were beaten from oak bushes while collecting beetles.

\section{Sub-family S'TENOPEIATITIN.}

The Tndiana members of this sub-family comprise those insects which are eommonly called "stone" or "camel crickets," and. so lar as known, belong to the single genus Ceuthophilus, which is charaeterized below. 


\section{Ceuthophilus Seudder (1862).}

Wingless Locustidæ of medium or large size with a thick body and arched back. Head large and oval, bent downward and backward between the front legs. Antennæ long, slender, cylindrical and tapering to a fine point. Eyes sub-pyriform, the narrow end downward, placed a little above and close to the basal joint of the antennæ. Maxillary palpi long and slender; the apical joint longest, somewhat curved, split on the under side three-fourths of its length, which is nearly equal to that of the two preceding taken together. Pronotum short, not extending over the meso and meta-notum. Prosternum unarmed. Hind femora thick and heavy, turned inward at the base, channeled beneath, with the margins of the channel either serrate or spined in the males, seldom armed in the females. Ovipositor well developed, nearly straight, a little upturned at the tip, the inner valves usually strongly serrate on the under side of the apical fourth. Cerci of males long, slender, usually very hairy.

These insects arc seldom seen except by the professional collector. They are nocturnal in their habits, and during the day hide beneath stones along the margins of small woodland streams, or beneath logs and chunks in damp woods, in which places seldom less than two, nor more than three or four, are found associated together. Being wingless they make no noise, and, like most other silent creatures, are supposed to be deaf, as no trace of an eardrum is visible.

That they are well-nigh omnivorous in their choice of food, I have determined by keeping them in confinement, when they fed upon meat as well as upon pieces of fruit and vegetables, seemingly preferring the latter. The majority of the species evidently reach maturity and deposit their eggs in the late summer or early autumn, as the full grown insects are more common then, but have been taken as late as December 1st. The eggs, which are supposed to be laid in the earth, usually hatch in April, but some are hatched in autumn and the young live over winter, an anomaly among the Locustidæ, as I have taken them on a number of oceasions throughout the winter. Several of the species inhabit eaves and are usually of larger size, with longer antennæ and smaller compound eyes than those found above ground.

The adnlt males of these insects are quite readily separated by the size. number and relative position of the spines on the under side of the hind femora, as well as by the degree of curvature of the corresponding tibix. The females, having neither the spined posterior femora nor the curved tibix, are less readily distinguished by 
the color and the relative measurements of the different organs. As the two sexes are colored alike anil are nsmally found in close proximity there will be little difliculty in placing the female after determining the male by the key given below, which mainly pertains to that sex alone.

Seren species have, up to the present, been taken by the writer in Indiana.

\section{BEY TO INUIAA SPIEUS OF CEUTIOPIILUS.}

a. Fore femora but little, if any. losker than the pronofmm.

t) Hind tiblite of male aremate or sinmate in hasal lualf: the himb femora of male with aloout 13 small, meryul spines on the onter lower centrina. . . . . . . . . . . . . 113 maculutus. p). 399

bb. IIme tibia oi male strajerlit; limel femorat of adult male witl

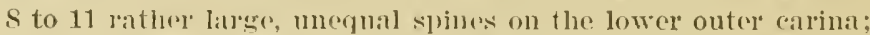
a biond, datr brown or harrkish stripe on cither sicle of dor-

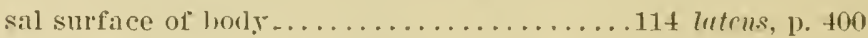

ar. Fore femora one-thirel or more longer than tiro pronotum.

c. Hind fomor:a distinctly shorter than the corresponding tiliae; care inhahitiug species. . . . . . . . . . . 11. styyius, p. 401

re. II ind femora lut little, if aly, shorter than the corresponding tibias: species living albore sround.

d. Lower outer carius of hind fomora of male conspicuously spined.

c. Inferior suleus of hinc femora of male quite derp and of nuiform widtls; the outer carimal with seren to nine slines of nneguil length and not equidistant .................116 blutchleyi, 1) 40.3

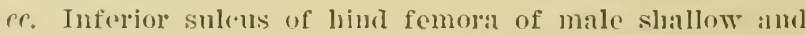
Jreirl; widel at loase than at distal eml: the suines

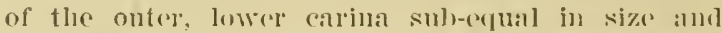

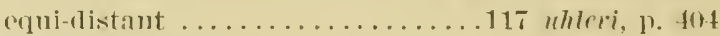

dr. Iower oufre carima of lind femola ot male nevel conspicuonsly spincel.

f. Gencral color cloir rectlish browm, mottled with fraler: hind femoral of male more that twion as long as the fole femora: each of the lower carinate witl alwut 25 clowher mimute teeth...........

118 tertostis. 11. 4111

ff. General eolor dull sooty brown with mmorous puler spots: hind femora of male about twice as long as the fore femola, witl seven to 1.5 small hut distinct teetle on earls of the earina .............

119 breripes. 1. 406 
113. Ceuthophlus maculatus (Say). The Spotted Camel Cricket.

Rephidophom maculetr (Say MS.), Harris, 71 1841, 126; Scndd., 140 , VIII, 1861, 7, 11, 14 .

Phelangopsis meculata Harris, 72, 1862, 155, Fig. 73.

Ceuthophilus maculatus Scudd., 141, VII, 1862, 434; Id., 171 , XXX, 1894, 27, 68; Id., 188, 1900, 82; Glov., 62, 1872, Plate III, Fig. 5; Pack., 104, 1883, 565; Riley, 122, II, 1884, 18t, Fig. 259; Brumn., 39, 1888, 307; Bl., 7, 1893, 142; Id., 16, 1899, 222, Fig. 53; Lugg., 84, 1898, 249, Fig. 163.

General color: Above, dark sooty brown, with often a median stripe of lighter brown on the thoracic segments: below a yellowish brown. The abclominal segments bear on their dorsal surface a number of small yellow dots, often confluent and sometimes in regular transverse rows. Antenne and legs light reddish brown, the hind femora cross-barred with narrow darker brown bars arranged in parallel rows.

Anterior femora a little longer than pronotmm, the inner carina with one or two rather long sub-apical spines. Hind femora about the length of the body; the lower sulcus narrow and of medium depth, its outer carina in the male with twelve to fifteen unequal, rather coarse spines; the inner (arina with about the same number

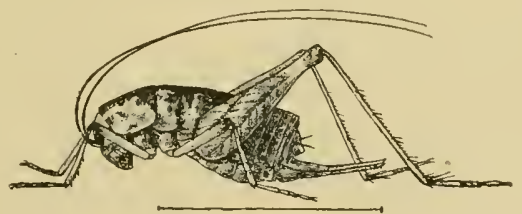

Fig. 100. Ceuthophilus maculatus (Say). Female. (Afer Lugger).

of smaller and sub-equal spines; the female with a number of small, inconspicuous spinules on each carina. Hind tibia a little longer than the femora, the basal third distinctly arcuate or bowed in the male. Cerci with the basal half stont, tapering beyond. Ovipositor two-thirds as long as the hind fenora, gently tapering to the tip, which is slightly upturned, the tecth of the imner valve sharp.

Measurements: Male-Iength of body, $14 \mathrm{~mm}$; of pronotum, 5 mm.; of front femora, $6 \mathrm{~mm}$.; of hind femora, $15 \mathrm{~mm}$.; of hind tibia, $12 \mathrm{~mm}$. Female-Length of body, $16 \mathrm{~mm}$.; of pronotum, $5 \mathrm{~mm}$.; of front femora, $6 \mathrm{~mm}$.; of hind femora, $16 \mathrm{~mm}$; ; of ovipositor, $10 \mathrm{~mm}$.

This "spotted wingless grasshopper" has the widest range of any of the 56 species of ceuthophilus listed by somdler, having been recorded from nearly every State east of the Great Plains. In In- 
diana it is, as far as my observation goes, much less common than some of the other species of the genus, having so far been taken only in Crawford and Putnam counties. In the former county a number of specimens were secured in June and July from beneath logs and chunks in dry upland woods. In Putnam County it was found on August 1st beneath a $\log$ in a damp ravine. It probably occurs sparingly in like situations throughout the State.

114. Ceuthophilus latens Scudder. The Black-sided Camel Cricket. Ceuthophilus tatens Scudd., 141, VII, 1862, 437; Id., 171, XXX, 1894, 29, 64; Id., 188, 1900, 82; Bl. 7, 1893, 143.

General color: Light reddish brown; two broad bands of dark fuscous or blackish along the thorax and one or more of the basal segments of abdomen, extending half way down the sides and separated from one another by a median stripe of light reddish brown. Below the black stripes the sides are pale yellowish brown; while the greater part of the abdomen, as well as the outer face of the hind femora, is dotted with brownish yellow, the dots sometimes confluent, sometimes in apparently regular rows. The legs are light brown, the tips of the hind femora infuscated.

The fore femora a little stouter than the middle pair, nearly a third longer than the pronotum in the male; but little longer in the female, the inner carina with two or three spines. Middle femora with two to four spines on each carina beneath. Hind femora thick and stout, the inferior sulcus of average width and depth, the margins with several minute spines in the females; the outer earina of adult males with eight or nine spines, the four or five middle ones of which are quite strong and prominent, the inner carina with 11 to 14 small and sub-equal spines.

IIind tibie straight, very little, if any, longer than the femora; the inner ealcaria much longer than the outer, and as long as the first tarsal joint. Cerci slender, gently tapering throughout, longer than the greatest width of hind femora. Ovipositor nearly twice as long as fore femora, straight, the tip a little upturned and acute.

Measurements: Lengtl of body, male, $22 \mathrm{~mm}$., female, $24 \mathrm{~mm}$.; of pronotum, male and female, $6.5 \mathrm{~mm}$.; of front femora, male, $8.5 \mathrm{~mm}$., female, $7 \mathrm{~mm}$.; hind femora, male and female, $19 \mathrm{~mm}$.; of hind tibia, male, $21 \mathrm{~mm}$., female, $20 \mathrm{~mm}$; of ovipositor, $11 \mathrm{~mm}$.

Mr. Seudder has evidently described this species from immature specimens of both sexes. As a consequence, his measurements are much less than those given above. The spines on lower onter carinæ of males are more numerous and more prominent in the 
adults than in the two-thirds grown young, where they are sub-equal in size. The black markings at base of tibial spines, used by Scudder in his key, are seldom present in the adults and are therefore of no value as a distinguishing character. I have, in recent years, taken numerous specimens of the large form mentioned in my former paper, and described herewith, in company with the immature forms described by Scudder, and there is no doubt but that the two are the same.

$C$. latens has proven to be a rather common species in Indiana, having been taken in Vigo, Putnam, Crawford, Kosciusko and Steuben counties. It is most commonly found beneath small chunks or flat stones in rather dry sandy localities. Sometimes a half dozen will be found in company beneath the same shelter. It reaches maturity about July 20th, probably from specimens hatched in spring, though I have taken the young on two different occasions in February. The species is sometimes affected by the parasitic hairworm, Gordius sp.? According to Scudder, it ranges from "New York to Texas."

115. Ceuthophilus stygrus (Scudder). The Cave Camel Cricket.

Retphidophome stygiu Scudd., 140 , VIII, 1861, 9.

Ceuthophilus stygius Scudd., 141, VII, 1862, 438; Id., 171 , XXX, 1894, 24, 33; Id., 188, 1900, 84; Pack., 104, 1869, 565; Id., 106 , IV, 1888, 70, 83; Riley, 122, II, 1884, 184; Brunn., 39, 1888, 309; Bl., 7, 1893, 148; Id., 14, 1897, 198; Id., 16, 1899, 175.

Ceuthophilus sloanii Pack., 105, V, 1873, 93; Id., 106, IV, 1888, 71, 83.

Pale, reddish brown, the hind border of each segment with a dark brown band, the pronotum with a similar band on the front margin, and an indistinct, dark median band connecting the two. Face pale with usually a black dash below each eye, and a shorter median one. Antennæ brownish yellow, paler toward the tip, of excessive length, averaging four times the length of body. Legs all very long and slender. Front femora, in the specimens at hand, double the length of the pronotum, with two to five spines on the lower front carina. Middle femora shorter than the anterior with both of the lower carinx armed with three or four distinct spines. Hind femora rather slender, nearly as long as the body, the lower, outer carina prominent; the inferior sulcus narrow and of average depth; both margins armed with numerous small spines, those on the outer carina of male double the size of those on the inner. Hind tibix straight, longer than the corresponding femora. Hind tarsi two-fifths the length of the tibiæ. Cerci slender and tapering, nearly half as long as hind femora. Ovi- 
prositor straight, the apical two-thirds of nearly the same tiameter. the tip sarecely upturnerl; the teeth of inner valve feebly crenate.

Neasmements: Length of boty, male, $30 \mathrm{~mm}$, female, 26 mm.; of pronotums, male, 8.5 mm., female, 6.5 mm,; of front femorit, male, 15 mm., lemale, 1\%,5 mm.; of hind femora, male, 26 mm., female,

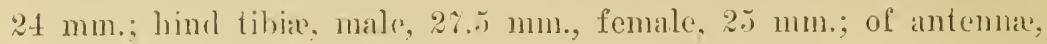
male, $103 \mathrm{~mm}$., female, $96 \mathrm{~mm}$.; of oripositor, $16 \mathrm{~mm}$.

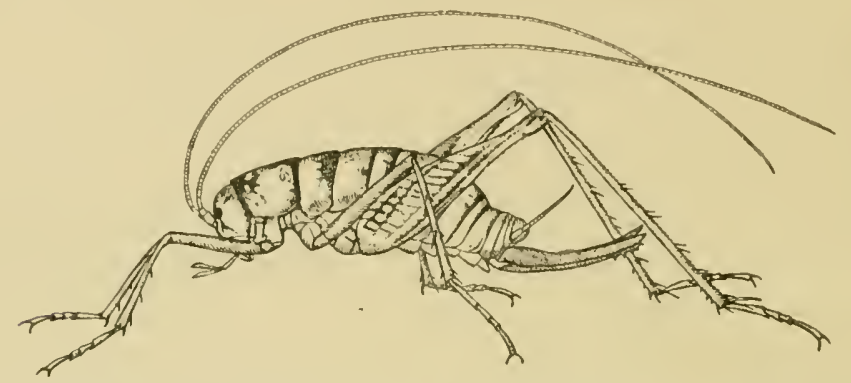

Fig. 101. Ceuthophilus stygius (Sender). Female. One and one-fourth times natural size. The antenna are half as long again as shown in the cut. (Original.)

This "cave cricket" occurs abundantly in crevices in the walls and roof near the mouths of Iryandotte. Litle Wrandotte. Siberi"s Wull Care and saltpetre Cave, Crawford County, and a ferw immature specimens, pronounced by Mr. S. II. Scudder to be the same species, have been taken in Porter's Cave, Owen County and 'Truett's and Strong's cares, Monme County, 80 miles farther nortlu. In the Crawford County caves no specimens were found further back than 250 fect from the mouth, except in Wyandotte, where a few lave been taken on "Nomment Mountain," one-half mile from the mouth. In the other aves they were found back beyond the reach of any rays of light.

The artults of this specirs are the largest "stone" or "('anel crickets" ocrurring in the state and seem to be more or lesis grengarions. In one instance, in Siberts Well cave, more than 20 were. found in a small cranny in the wall. 'They were grouped in a circle, in a space about six inches square, with their antenna prointing toward the center of the cirele, and appeared to he holing a conference or cricket convention.

In regard to the life history of this insect. but little is known. I found a number of specimens of half grown young in Siburt: care on May 16, 189\%. 'The adults were common in July, 18!6: and in November. the young about one-thirt the size of mature specimens wre frepuent in Saltpetre Care. but could not be found clsewhere. 
The species may be represented in winter by the eggs as well as by the young, as is the case among some other members of the genus.

In Saltpetre Cave, where in July stygius was very plentiful, all were found within 100 feet of the entrance. They were never scen on the floor, mnless they leaped there when disturbed, but were found resting on the sides of small projections and in small carities of the walls or roof, with their antemne spread ont before them. If a lighted candle was held close to them they paid no attention to it, but were very sensitive to its heat and to touch. When disturbed they leap with agility, sometimes to a distance of six feet, but with a little care can usually be readily picked up with the fingers before they become frightened.

The immature specimens from caves in Monroe and Owen counties were darker than typical stygius, and were found on the floors of the caves-in one or two instances beneath loose rocks. From their habits I am somewhat inclined to doulbt their being stygius, since it is quite difficult to name correctly the young of any species of Ceuthoplitus.

116. Ceuthophilus blatchleyi Scudder.

Centhophilus blatchleyi Scudd., 171 , XXX, 1894, 26, 57; Id., 188, 1900, 81; Lugg., 84, 1888, 249.

Ceuthophilus uhleri Bl., 7, 1893, 144. (Not C. uhleri Scudd.)

General color: Jight reddish brown, the meso and meta-notum usually darker. The pronotum rather thickly and irregularly motthed with paler spots; the other segments with the pale spots for the most part in a transverse row near the hind margin. The legs yel-

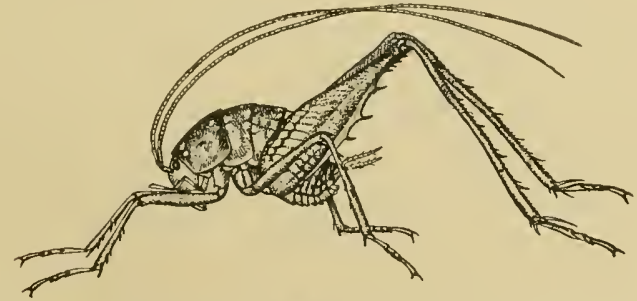

Fig. 102. Ceuthophilus blatchlevi Scudd. Male. One and one-fourth times natural size. (Original.)

lowish brown, the hind femora with the apex a little dusky above and with numerous oblique transverwe dusky bar's on the outer face. In a few specimens the general color is much darker and the outer face of the hind femora is a fuscous brown almost black in hue. 
The anterior femora are but little longer than the pronotum; the lower front margin armed with from one to four spines. IIind femora of the male of average width but rather slender and tapering; the inner surface of the upper portion of the apical half with numerous raised points; the lower outer carina prominent, with the inferior sulcus rather narrow and very deep, the sides meeting at an angle above. The spines of the outer carina are usually arranged in three sets, the basal set containing two to four equidistant gradnated spines, the distal one largest; the middle set contains but a single strong spine equal in size to the one before it and separated from it as well as from the first one of the apical set, by a space almost twice as great as between the members of the basal set; the apical set of four small, sub-equal spines. The inner carina is armed with about 16 small sub-equal spines. The female has the inner carina also armed in like manner with still smaller spines. Hind tibiæ of male straight, a little longer than the femora; distinetly longer in the female. Cerci gradually tapering from a rather stont basc, about as long as the breadth of the hind femora. Ovipositor about two-thirds the length of hind femora.

Measurements: Length of body, male, $14 \mathrm{~mm}$., of female, $16 \mathrm{~mm}$.; of pronotum, male and female, $5 \mathrm{~mm}$.; of fore femora, male, $6.5 \mathrm{~mm}$., female, $6 \mathrm{~mm}$; of hind femora, male, $15 \mathrm{~mm}$., of female, $13.5 \mathrm{~mm}$.; of hind tibix, male and female, $16 \mathrm{~mm}$; of ovipositor, $9 \mathrm{~mm}$.

This species may be readily known from the next, its elosest ally, by the more slender hind femora of the male, the narrower inferior sulcus of these femora, and by the different armature of their lower outer carina.

In central Indiana, blatchleyi is the most common species of Ceuthophilus. It is usually found from July to November in small colonies of three to six or more, beneath rails and logs in rather dry situations. It is especially fond of low, open second bottom woods, with a loamy or sandy soil. The young have been taken in similar places in December and February, but evidently the larger number of eggs do not hatch until spring. It has not, as yet, been taken in either the northern or southern third of the State, but probably occurs throughiout as it lias been recorded from New York, Minnesota and Iowa.

117. Ceuthophiles unlen Scudder. Uhler's Camel Cricket.

Ceuthophilus uhleri Scudd., 141 , VII, 1862, 435; Id., 171 , XXX, 1894, 26, 56; Id., 188, 1900, 84; Glov., 62, 1872, Plate VIII, Fig. 8; Riley, 122, II, 188t, 18t; Brumn., 39, 1888, 6t, Fig. 33b. Ceuthophilus latisulcus Bl., 7, 1893, 146. 
General color: Light brownish or clay yellow, irregularly flecked with fuscous, especially on the pronotum and abdomen; the female somewhat darker. Legs light brown, more or less infuscated on the apical portions of the femora. The anterior femora more than a third longer than the pronotum in the male, shorter in the female, with two sub-equal spines near the apex of the lower front carina. The intermediate femora with three spines on each of the lower carinæ. The hind femora shorter and not so broad as in the preceding, the outer lower carina much less prominent; the upper half of the exterior face very scabrous, with small projections. The inferior sulcus exceptionally broad and shallow, about twice the breadth and one-half the depth of that of $C$. blatchleyi; the sides not meeting in an angle as there, but the top of the sulcus flat. The outer carina with seven or eight sub-equal spines borne at equal distances apart on the apical half; the middle two slightly the larger but much less strong than the corresponding one of $C$. blatchleyi. The inner carina armed with 16 to 20 very small teeth. In the female the inferior 'sulcus is much less broad and the carinæ bear only a few small teeth on their apical half. The hind tibiæ of male with a very slight curve just below the base; a little longer than the corresponding femora in both sexes. Cerci rather stout, shorter than the femoral breadth. Ovipositor but little more than half as long as hind femora, the tip considerably upturned and finely acuminate.

Measurements: Length of body, male, $15 \mathrm{~mm}$., female, $16 \mathrm{~mm}$; of pronotum, male and female, $5 \mathrm{~mm}$; of front femora, male, 7.5 $\mathrm{mm}$., female, $6 \mathrm{~mm}$; of hind femora, male, $1 \% .5 \mathrm{~mm}$., female, 13.5 $\mathrm{mm}$.; of hind tibiæ, male, $18.5 \mathrm{~mm}$., female, $15.5 \mathrm{~mm}$.; ovipositor, $8 \mathrm{~mm}$.

From C. blatchleyi, which it most resembles, this species may at once be known by the longer anterior femora, the much broader and shallower sulcus of the hind femora, as well as by the difference in size and arrangement of the teeth upon the latter. The adult male is larger, with shorter and broader hind limibs than those of blatchleyi, though the males of both these species are much more robust when mature than those of $C$. maculalus and $C$. terrestris which have come under my notice.

In Indiana, uhleri is much less common than the preceding species, having been taken in small numbers only in Vigo and Marion counties, where it occurs mature in August beneath logs and rubbish in dry sandy localities. It has been recorded from the Middle States, Maryland and Georgia. 
118. Celthophlle's terkestis Scudiler.

Centhophitus terrestris Scudd., $171,1894,26,46$; Id., 188, 1900, 84.

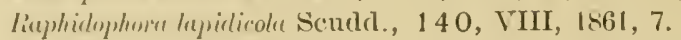

(énthrphilus luppilimolus Scudd,, 141, TII, 1862, 435; Glov., 62, 1872, Plate VII, ligs. 4, 5; Riley, 122, II, 1884, 184; Bl., 7, 1893, 147.

Clear rerdish brown, mottled with small pale spots, especially on the abdomen, where the spots have a tendency to arrange themselves in longitudinal rows. Often, but not always, a median light stripe on the dorsal portion of the pronotum, bordered by darker fuscous Wotches. 'The legs paler, the exterior face of the hind femora with the nsual darker transererie bars, but not so prominent as in $C$. muculatus.

Anterior femora a little longer than pronotum, unarmed beneath. Intermediate femora also vinarmed or with a single apical spine on front margin. IFind femora ahout equaling the boty, rather stout. the inferior suleus of average width, rather deep; both carine of male bearing numerous small serrations, like the fine teeth of a saw. about 2.5 in number and erowded on the apical two-thirds of the segment; those of the fomale marmed or with a few very fine teeth on the apical third. Hind tibie straight, a little shorter than the femora. (Ovipositor less than three-fifths the length of hind femora. the tip upturned a little and pointed.

Measurements: Maln-Length of hody; $1: 3 \mathrm{~mm}$.: of pronotum, 5 mm.; of front femoral, $6 \mathrm{~mm}$.; of hind femoral, $14 \mathrm{~mm}$.; of hint tibia, 1.) $\mathrm{mmm}$. Female-Length of body, $16 \mathrm{~mm}$.: of fore iemora, $6.5 \mathrm{~mm}$.; of himet femora, $15 \mathrm{~mm}$.: of oripositor, $8 \mathrm{~mm}$.

C. Ierestris is in Indiana less common than any other species of the gemns, having been taken only in Pntnam and Vigo counties. The most of those seenred were in $A$ pril and the specinuens were probaloly only about half grown. Its general range includes the northern I'nited states and Camada, east of the Mississippi River.

119. Ceutuphimus Brevtpes Scudder.

Couthephiles bripers scudd., 141, VII, 1862, ti3t; Id., 171 , XXX, 1894, 26,$49 ; \mathrm{Il} ., 188,1900,81 ; \mathrm{Bl} ., 7,1893,148$.

1)11l sooty brown. a little darkere on the dorsum of the thorax where there is mally a natrow median line of clay yellow. Tery profusely spotted with dull yellow spots, especially on the posterior margins of the abrominal segments. Near the apex of the hind femora, these spots nearly form an ammulation of yellow. more noticeable on aceomt of the more or less dark band beyourl. 
Body robust; fromt femora a third or more longer than the pronotum, with a single spine on lower front earina. Tlind femora short and stout; the inferior sulcus of arerage width and deptle: both carina of male armed on apical half with seren to 1 s small saw-like tectlı; those of female with similar hut smaller serrnlations. Ilind tibia straight, distinctly longer than the femora, the imner calcaria considerably longer than the onter, but shorter than the first tarsal joint. Cerci tapering from a rather stout base, a little longer than the femoral breadth. Ovipositor rather slender, two-thirds the length of hind femora, its apical third very slightly arcuate, the tip but little upturned; teeth of the inmer valve small and distant from one another.

Measurements: Male-Tength of body. 16.j mm.: of pronotum. $5.5 \mathrm{~mm}$.; of front femora, $8.5 \mathrm{~mm}$.; of hind femora, $16 \mathrm{~mm}$.; of hind tibix, 18.5 mm. Female-length of body, $16 \mathrm{~mm}$.; of pronotum, $5.5 \mathrm{~mm}$.; of fore femora. 6.5 mm.; of hinel femora, 1.5.5 mm.; of hind tibia. 1 s $\mathrm{mm}$.; of ovipositor, $10.5 \mathrm{~mm}$.

This is another species where the measmoments of Indiana specimens greatly exeeel those given by Mr Seudder in his Nonograph. It is not common in the State, heing represented in my collection only by specimens from Tigo and Orange counties: those from the former county, taken in Feptember and October, being full grown, while those from Orange Comnty, taken in May, are but little more than half as large.

Aside from these Indiana localitics, the species has been recorted only from Maine and New Brunswick.

\section{Family GRILLID:E.}

The thire family of Orthoptera belonging to the sub-order Saltatoria comprises the Gryllider or arickets. From the other Orthopterous insects they may be distinguished by having the wing corers flat above and bent abruptly downward at the sides: the tarsi or feet. three jointer. without pads between the daws; the fore coxa longer than broad. Ocelli or simple eyes are present in the majority of species; while the antennx, like those of the Locustider, are long, slender and many jointed. The hearing organ, when present. is, as there, situated on the Jase of the fore tibix.

The tympanum or calling organ of the male is also, as in the Locustide, locater near the base of the dorsal surface of the tegmina, but is wider and hroader than in the precering fanily, extending across both anal and median areas of the tegmina. The chirps or 
love ealls of the different species of crickets make up the greater part of that ceaseless thrill which fills the air, usually at night, from mid-Angust until after frost. These sounds are made only by the males, and are not rocal, as most persons suppose; but are produced by the tympanum. the insect rubbing the veins in the middle of one wing cover over those of the other. It is often difficult to locate one of these chirpers hy its song. The distanee and even the direction are often most deceiving; the crickets being exceedingly shy, mueh more so than katydids and grasshoppers. Those which live in the ground generally chirp near the entranee to their burrows, and retreat thereto at every approaching footstep. T'hose which live upon

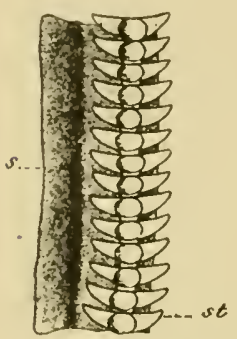

Fig. 103. Stridulating ridges in a house-cricket; 8 , stridulating ridge; st, stridulating toeth. (After Landois.)

trees or shrubs resemble elosely the hues of bark or foliage, and are therefore difficult to find even when close at hand; while the majority, dwelling as they do, among grasses and beneath logs and chips, find alio a safe protection in their color, which is usually closely like that of the objects beneath whichl they rest while somnding their cymbals.

The inner wings of the erickets are, for the most part, short, weak, and comparatively useless as flying organs, thongh sometimes they are nearly twice as long as the outer pair. Like their nearest relatives, the grasshoppers and katydids, these insects, therefore, travel mostly by leaps and, in the course of time, their hind femora have thus become greatly enlarged.

The ovipositor of the female, when exposed, is nsually a long; cylindrical spear-sluaped organ, consisting apparently of two pieces. Each of these halves, however, when closely examined, is seen to be made up of two pieces so united as to form a groove on the inner side, so that when the two halves are fitted together, a tube is produced, down which the eggs pass to the repository in the earth or twig, fitted to receive them.

The eggs of most erickets are laid singly in the ground. A few of the burrowing speeies deposit them in irregular masses in undergromnd carities. The tree crickets place them uniformily in a single row in the pith of twigs. Most species are represented in winter by the eggs alone. A few, howerer, pass the cold season as nymphs, or as adults. The mole erickets are saicl to exist for several years.

Among the families of Orthoptera the Gryllide and Locustider-take a rank superior to all other's. The high specialization of the ovipositor of the female and the perfection of structure of the stridulating 
organ of the male place these two families above all others in the scale of Orthopteran life. That the two are very closely related can be readily seen by any one who will carefully compare them, organ with organ. The Gryllida are placed first, however, by most entomologists, as the great variety of form of almost any given organ among them, when compared with its relative uniformity of structure among the Locuslida, scens to indicate the higher rank of the former.

About $6 \%$ species of Gryllidx are known from the United States. These are divided among six sub-families and 17 genera. All of the sub-families and 12 of the genera are represented among the species known to occur in Indiana. The sub-families may be distinguished by the following table:

A SYNOPSIS OF TIIE SUB-FAMILIES OF GRYLLIDE KNOWN TO OCCUR IN INDIANA.

a. Tarsi compressed, the second joint minute, compressed.

b. Fore tibice enlarged, fitted for digging; female without exposed oripositor (Mole and sand erickets).... GRYLlotalpin 2, p. 410

bb. Fore tibixe not enlarged; female with well developed external oripositor.

c. Hind tibia bearing two rows of minute teeth and a few morable spines. Body very small, sub-spherical; hind femora short, much swollen. (Our species living in ants'

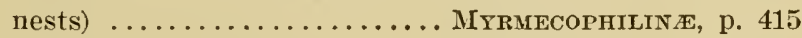

cc. Hind tibia bearing two rows of spines; body of larger size, sub-elongate, with longer and more slender hind femora.

d. Hind tibire rather stont, armed with stout spines withont teeth between them. (Ground and field crickets) .................GRYLLin E, p. 418

dd. Hind tibiae slender, armed with delicate spines (except in the genus $\mathrm{X} a b c a)$, with minute teeth between them. (White tree crickets).............

CEANTHine, p. 443

aa. Second tarsal joint distinct, depressed, cordiform.

c. Hind tibia bearing two rows of spines without teeth between them. Ovipositor in our species compressed and curved upward. (Small black or brown tree crickets)..............

Trigonidines, p. 454

ee. Hind tibixe bearing two rows of spines with small teeth between them. Ovipositor in our species cylindrical, but little

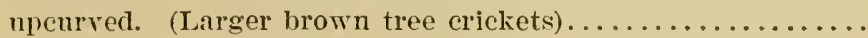

ENeopterinde, p. 457

56-Geol. 


\section{Sub-family GRYTIOOTALPIN.}

This sul-family includes the burrowers among our erickets. The -pecies have the fore limbs so modified that they ean make their way readily bencath the surfice. The antemare are much shorter and less tapering than in the species living above ground. 'The ovipositor of the female is not visible externally.

Three genera are represented in Indiana which may be sceparated by the following key:

IEE TO GEXEIIA OE INUIANA GISLIOTALIINA.

1. Species of latre size; fore tible broadly expanded, the daws prominnt: two large ocelli present; hind femora slender": tarsi thee-

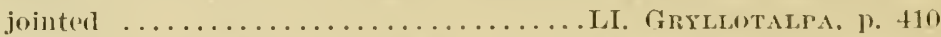

(11. Spreies of small size; fore tihix not broadly expanderl hut bearing three or four spines at the apex; three small ocelli present; hind femor:] much swollen: tarsi one-jointed or wanting.

b. Sperefes more than 5.5 mm. in length: pronotum with a wask transverse suleus; hind tiluie with four pairs of long slender plates userl in swimming; hind tarsi one-jointed...........

I.II. TRIDACTYLI', p. 418

b1. Species less than 5.5 mm. in length; pronotum witl no transverse sulens; hind tilice with a single pair of short plates usel in swimming: hind tarsi wholly wanting............

LIII. Ellifes, 1\% 41 .

\section{Li. Grithotalipa Timmens (1\%6\%).}

Among all the Gryllide found in Indiana the mole crickets rank first in size and singularity of stmeture. When full grown they measure from an inch and a fourth to an inch and a half in length; are light brown in color and have the body covered with very short hairs, giving it a soft, velvety appearance. The females have no visible ovipositor, and, extermally, may be separated from the males only by the differenee in the reining of the uppermost of the wing covers, due to the presence of a tympamm in the latter sex. By their hahit of burrowing bencath the soil in search of such food as the tender roots of plants, earthworms and the larva of various insects, the anterior tibie of these crickets have, in the course of ages, become so modified in structure as to closely resemble the front feet of the common mole, whence the generie name. Cryllotalpa, from "gryllus." a cricket, and "lalpa." a mole. The dactyls or claws of these tibiar are four in mumber, the upper two, the larger, being movable; the others immovable. The compound eyes have, on account of the undergromel life, become much aborted, being not more than one-fourtls the size of those of the common ficld crickets, of 
the genus Gryllus. As the mole crickets crawl rather than leap, the hind femora are but little enlarged, and are always shorter than the pronotum. The hind tarsi are short, seldom exceeding half the wilth of the pronotum. But one species occurs in Indiana.

120. Gryllotalpa borealis Burmeister. The Northern Mole Cricket.

Ginglotalpa borealis Burm., 40, II, 1838, 740; Scudd., 14 5, I, 1869, 25, Plate I, Figs. 9, 34, 35; Id., 148, 1874, 363, Plate A, Fig. 7; Id., $154, \mathrm{X}, 1876,97$ (note of to music); Id., 168, XXIII, 1893, 63 (note of to music); Id., 188, 1900, 86; Glov., 62, 1872, Plate VII, Fig. 13; Id., 63, 1874, 143, Fig. 17; Pack., 104, 1883, 563; Comst., 4 1, I, 1888, 120, Fig. 121; Fletch., 54, XXIV, 1892, 23, Fig. 1; Doran, 47, XXIV, 1892, 270; B1., 5, 1892, 130; Id., 16, 1899, 223, Fig. 54; Bent., 3, VI, 1894, 264; Lugg., 84, 1898, 257, Fig. 167b.

Giryllotalpa brevipennis Serv., 196, 1839, 368; Harris, 62, 1862, 149, Fig.

68; Rathv., 109, 1862, 378, Fig. 12.

Gryllotalpa longipenn is Scudd., 141 , VII, 1862, 426.

Givllotalpa columbia Scudd., 145, I, 1869, 26, Plate I, Figs. 15, 36; Beut., 3, VI, 1894, 264, Plate V, Fig. 5; Lugg., 84, 1898, 257, Fig. 167.

Giryllotalpa columbiana Bl., 5, 1892, 131.

Color: Cinnamon brown, eovered with short, fine hairs of the same hue; claws and veins of tegmina darker.

Tegmina covering one-half to three-fourths of abdomen. Inner wings slightly exceeding tegmina in short winged form, extending beyond tip of abdomen in long winged form (columbia Scudd.).

Measurements: Length of body, $30 \mathrm{~mm}$; of pronotum, $9 \mathrm{~mm}$; ; of tegmina, $9-12 \mathrm{~mm}$.; of hind femora, $7.5 \mathrm{~mm}$.; of cerei, $11 \mathrm{~mm}$.

The northern mole ericket has been taken by the writer in Marshall, Starke, Kosciusko, Putnam, Clinton, Vigo, Tippecanoe, Marion and Monroe counties. and donbtless occurs throughout the State, as it is found over the United States and Canada east of the Rocky Mountains. About one-third of those noter in the State are of the long winged form. On one occasion a $\log$ deeply buried in the sand on the sonthern shore of Lake Maxinknckee was overturned

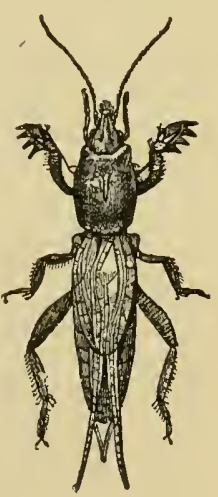

Fig. 104. Gryllotalpa borealis Burm. Longwinged Male. and nine specimens were secured. Of these, however, six were long winged and three short winged.

In the moist mud and sand along the margins of the smaller streams and ponds the runs or burrows of this ericket, exactly like those of a mole though much smaller, can in late summer and early 
autumn be seen by those interested enough to search for them. The burrows are, in the main, very superficial, lying just bencath the surface and running in very irregular directions. They frequently fork, and often end beneath a stonc or small stick. The insects themselves are seldom seen, as they are nocturnal, forming their burrows by night, and scarcely ever emerging from beneath the ground. Moreover, like a mole, they move backward as readily as forward, and so easily escape their cnemies. Apparently one inscct, or a single pair occupy these burrows; the males, though several are often heard at the same time, being usually at quite a distance apart.

The burrows occasionally enlarge into side cavities large enough for the insect to turn around, and in such lateral chambers the eggs are sometimes found in masses of 60 to 100 , adhering to the rootlets of various plants. These eggs are spherical, white or almost colorless, and have a diameter of $0.7 \mathrm{~mm}$. The young are active leapers, and are said to be about three years in reaching maturity. On July 19,1894 , a hundred or more of the half-grown young were captured in a small meshed seine while collecting fishes in a small strcam in Montgomery County. They were evidently burrowing in the soft mud close to shore or perhaps in the mud beneath the shallow water. Just a year later a number of young were also taken in a seine from the waters of the outlet of Lake Wawasee, Kosciusko County. Since they feed, during their lives, mainly upon the tender roots of various plants, they are necessarily very injurious and it is fortunate that with us they are not more common than they are.

The note of the male mole cricket is a sharp di-syllabic chirp, continuously repeated and loud enough to be heard several rods away. It is usually attributed, by those who have given little attention to insect sounds, to the field cricket or to some of the smaller frogs. The cricket is very difficult to locate by this note, and the writer has on several occasions approached cautiously, on hands and knees, a certain spot, and has remained silent for several minutes while the chirping went on apparently beneath his very eyes; yet, when the supposed exact position of the chirper was determined and a quick movement was made to unearth him, he could not be found. Indeed, it is only by chance, as by the sudden turning over of a $\log$ in a soft mucky place, that a person can happen upon one of them unawares. Even then quick motion is necessary to capture him before he scrambles into the open mouth of one of the burrows which he has ever in readiness. I have heard their note in the forenoon of cloudy days, but it is much more common in the afternoon, and Mr. Scudder, who has given especial attention to the sounds of insects, 
has written of it as follows: "Our common mole cricket usually begins its daily chirp at about four o'clock in the afternoon, but stridulates most actively at about dusk. On a cloudy day, however, it may be heard as early as two or three o'clock; this recognition of the weather is rather remarkable in a burrowing insect, and the more so as it does not appear to come to the surface to stridulate, but remains in its burrow, usually an inch below the surface of the ground. Its chirp is a guttural sort of sound, like grü or greeu, repeated in a trill indefinitely, but seldom for more than two or three minutes, and often for less time. It is pitched at two octaves above middle $\mathrm{C}$, and the notes are usually repeated at the rate of about 130 or 135 per minute; sometimes, when many are singing, as rapidly as 150 per minute. Often, when it first begins to chirp, it gives a single prolonged trill of more slowly repeated notes, when the composite character of the chirp is much more readily detected, and afterward is quiet for a long time. When most actively chirping, however, the beginning of a strain is less vigorous than its full swell, and the notes are then repeated at the rate of about 120 per minute; it steadily gains its normal velocity. It sounds not unlike a feeble distinct croak of toads at spawning season."

\section{Tridactylus Olivier (1789).}

To this genus and the next belong the "sand crickets" which are among the smallest of the Gryllidx, no one of the three species found in the United States being more than $10 \mathrm{~mm}$., or two-fifths of an inch in length. The principal distinguishing characters of the genus are given in the key to the genera of Gryllotalpince.

The fore tibia of the males of Tridactylus has been shown by Morse to vary much in structure. It is usually more "or less irregularly ovate in outline and terminating apically in four prominent equidistant teeth, with the convex outer face thickly set with hairs, *** the tarsus being inserted between the first and second teeth and lying on the anterior face." From this normal form it varies in progressive degree to a remarkably bifurcate organ in which the inner limb is elongated and devoid of hairs, the innermost tooth nearly disappears, the second is greatly prolonged into a claw-like organ, while the femur acquires tooth-like projections on its upper, inner ventral angle and becomes greatly enlarged. The outer wings or tegmina are horny and opaque and do not reach the end of the abdomen, while the inner wings are longer and folded lengthwise like a fan. The hind femora are much enlarged and the insects are active leapers. 
"These sand cridkets," salys Ficudder, "are in gemeral appearance, miniature ciryllotalpas, though, mot being loary bodied, they cam lapl vigorously, bommling high in the air. Nothing is more curious than these lirely amel pigmy mole-erickets: they live in similar places, and make burrows like the mole-colekets, hut their foreleg's, thomgh construeted for burrowing, are rery different in detail. They are not, howerer, found in quite such wet spots as the mole-cricket. hannts, prefering the sumbly margins of ponds rather than muddy ones. Their burrows are at first rertical, but immediately turn, runming not mole than an inch below the surface of the gromme and are very uarow, as would be expected of such little creatures: one measured was hardly a fwentieth of an inch in diameter. 'The males a not provided with any tambourine upon the wings, and therefore ranti not siner."

But one species of Tridactylus is kmom from lndiana.

121. Triddctylus apicalis Say. The Larger Sand Cricket.

Triductylus apicalis Say, 138 , IV, 1825, 310; Id., 139, II, 1854, 239; Scudd., 141 , VII, 1862, 425; Ir., 188,1900 , 86; Irl., 195. IX, 1902, 309; Pack., 104, 1883, 5633; Riley, 122, II, 188t, 180; Bl., 5, 1892, 129; Lugg., 84, 1898, 259, Fig. 168.

Nye mixtus Hald., 65, VI, 1853, 36t.

This is the largest of the three species of sand crickets occurring

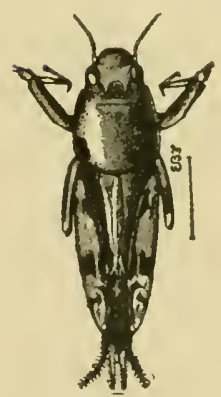

Fig. lo), L'ridactylus apicalis Say. (After Lugger.) in the Truited States, its length being 8 or $9 \mathrm{~mm}$. 'The boty is black or dark lrown, the hear aud thorax with some white markings, and the tegmina with their outer edge and a spot hebind the midello white. 'The hind lemora are whitish with the uperer lalf of outer face brownish or with three dark crosslalls. The wings of the male extend $3 \mathrm{~mm}$. beyond the tip of the abtomen. The fore tibia of the males of Indiana specimons I find to vary in like mamner as those of T'. Lerminatis mentioned by Morse.

Measulements: Length of boty, $9 \mathrm{~mm}$; of tegrmina, is mm.; of immer wings, $x .5 \mathrm{~mm}$; of posterior femora, ; 1 mm.

Apicatis has been noted in Indiana only in P'utnam and Tigro comnties. In the former it was taken in numbers in Ingust. 1s!93, and again in .Jum( 18!) from a damp samthar aloug Walnut C'reck, two miles east of Bainbrigge. lioth here and in Vign Coment it was in company with the next speries. It occupied small pits or burrows in the sand, and would somotimes be seen lesting with the head and half the body ontside the opening of the pit, into which it backed as 
one drew near. Usually, however, it was at a distance from any risible pit and would then leap rigoronsly when approached, often to a height of five feet and a distance twice as great. By close search it will probably be found to occur along damp sandbars in all portions of the State, as its general range includes the United States east of the Great Plains.

\section{ELtures Scudrler (1902).}

This gents was but recently separated from Tridaclylus. The main distinguishing characters are giren in the key. But one species, E. minula (Sondder), ranging from Minnesota to Cuba and Mexico, and from Indiana to California, is known from the United States.

122. Ellipes ainuta (Scudder). The Smaller Sand Cricket.

Tridactylus minutus Scudd., 141, VII, 1862, 425; Id., 188, 1900, 87; Lugg., 84, 1898, 259.

Eillipes minute Scudd., 195, IX, 1902, 309; B1., 18, 1902, 129, 223.

General color a dark brown or hack: middle femora and tibia and posterior femora with narrow white crossbars. Pronotum and segments of abdomen with their hind margins whitish. The wings corer about three-fourths of the abdomen: the tegmina, half of the wings.

Merasurements: Tength of borly, of mm.: of hind femora, 3.5 mm.

In Indiana this small sand cricket has been taken in Spencer", Vigo, Putnam and Lake comties. It frequents damp sumly places which are sparsely covered with griss or other vegetation. where it is often found in company with the grouse locusts or with the larger sand cricket, Tridaclylus apicalis Say. While more active in its morements it does not leap as high nol as far as that species. 'The best way to capture them, after discovering a colony, is to sweep rapidly just above the ground with a net of cheese clotl or other rose meshed material.

\section{SUb-fimily MYRMECOPIILINE.}

The Indiana members of this sub-family are very small, subspherical crickets, which bear a general resemblance to the young of enckroaches but leap actively when disturbed. They live with colonies of ants in or beneath rotten stumps and logs and mder stones. They belong to the single genus, Myrmecophila, characterized as follows: 


\section{MrrmecophiLa Iatreille (1807).}

Body sub-spherical or ovate, greatly convex above, wingless. Fyes very small, resembling ocelli. Antenne rather stout, as long as the body. Occiput almost hidden by the pronotum, which is large, wider behind than in front, the anterior and posterior margins straight; meso and metanotum, similar to the segments of the abdomen, sometimes a little wider. Anterior tibie without hearing organ, unarmed. Hind femora, ovate, greatly enlarged. Hind tibix stout, shorter than femora, compressed, the upper margin ciliate; the inner carina with four movable spines, the outer with two; the apex with three or four rather long, terminal spurs. Cerei as long as or longer
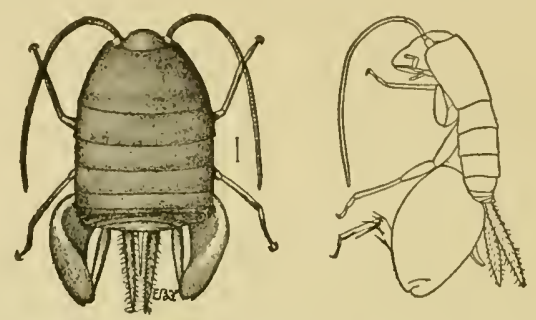

Fig. 106. Myrmecophila nebraseensis Brun. (After Lugger.)

than the abdomen. Ovipositor short and stout. The male is more slender and smaller in size than the female.

A very interesting account of the habits of these little crickets has been published* by W. M. Wheeler, of Austin, Texas, from which I quote at length as follows: "My observations on the habits of Myrmecophila began early in the March of the present year. The little crickets were taken from the Formica or red ants' nests and placed in artificial nests of the agricultural ant, an insect of much larger size, slower movements and in many other respects more satisfactory for purposes of observation than the Formica.

"On $\Lambda$ pril 3d I placed in the artificial nest twenty Myrmecophilas, eight or ten of which had been squeezed or had lost one or both saltatory legs during eapture. All the disabled individuals were at once seized and dispatched in so vindictive a manner, that I could not doubt that the ants were irritated by the pungent red ant nestodor still clinging to the crickets. In an instant all the ants in the compartment of the nest had gathered in little groups, each devouring a Myrmecophila. The uninjured crickets made not the slightest attempt to escape, but felt themselves perfectly at home as soon as

"Psyche, IX, 1900, p. 111, et seq. 
they set foot on the floor of the nest. Their adaptation to a new nest and to an ant of a larger size and belonging to an entirely different sub-family from their former host, was immediate and complete. With constantly vibrating antennæ they began dodging in and out among the little groups of assembled ants. From time to time one of them would be seen cautiously approaching an ant, that was busy with its dinner of Myrmecophila, and fall to nibbling at its legs or the tip of its abdomen. There could be no doubt that the cricket derived some benefit from the oily secretion covering the surface of the ant's body. At first the ant disregarded this nibbling, which probably resembles the attentions of the toilet habitually received from sister ants, but the cricket's scraping mandibles and maxillæ soon grew annoying and the ant would either move away or turn its head, open its mandibles and make a lunge at the Myrmecophila like a large dog annoyed by a puppy. But before the huge mandibles had closed, the cricket was far away, already nibbling at the abdomen of some other ant. The cricket can get at only the legs and abdomen of its host, since the spreading legs prevent it from reaching the thorax. It often stands on its hind legs, and places its forelegs on the ant's leg, in order to reach the femur or tibia. For very obvious reasons, it avoids nibbling at or even approaching the ant's head. It is always alert, as if perpetually aware of danger and ready to dodge at the slightest movement made by the ant.

"Occasionally in the narrow confines of an artificial nest the ants do succeed in capturing and devouring one of their vigilant little guests, but the fact that of the eleven sound erickets left after the above observation was made, eight were still alive June 22d, when I had to discontimue my observations for the summer, shows that the crickets are extremely expert in keeping out of danger. The attitude of the ants during all this time underwent no change as far as I could observe, for they would still occasionally make lunges at the crickets.

"The crickets do not derive all their substance from cleansing their hosts. In earthen nests they are often seen haunting even the galleries that have been abandoned by the ants, scrutinizing the walls and nibbling at them from time to time. There can be no doubt that they find here the same substance which covers the ants, for the walls of the galleries of a populous nest soon become greasy from the attrition of the constantly passing ants. Sometimes the criekets may be seen nibbling at dead ants that have been temporarily abandoned in the galleries or placed on the kitchen-midden of 
the nest. The intretine of a Mymecophila which I dissected ma fomme to contain vil-globules and in gramular whitish substance."

Five species of Myrmecophile are known from the Uniter states. Of these but one ocenrs east of the Mississippi River, and it was: known only from Maryand, Gerovia and the District of Columbia until 1901, whon it was found in numbers in southern Indiana.

123. Myrmecophlla PERGandet Bruner.

Myrmerophiln pergandei Brun., 21 , XVI, 1884, 42, Fig. 4; Riley, 122, II, 1884, 181; Scudd., 187 , VIII, 1899, 424, 425; Id., 188 , 1900,87 .

Color: Dark reddisle brown, the front and hind margins of pronotum, the hind marenins of the other dorsil segnents as well as the apex of oripositor, a darker piceous brown; the legs, cerci and base of antenna and ovipositor a paler brown. 'The young are generally paler tham the achults.

Body broad oval, depressed; nearly twice as long as broad: hind femora pyriform, more arcuate below than above. Ovipositor rather stout, straight, the inner valves a little shorter than the outer.

Measuements: Length of body, male 3-t mum., of female, t-.; mm.; of hind femora, female, 3 mm.; of ovipositor, 2.5 mm.

'This small ant-loving gryllid was first taken in Indiana near New Jarmony, l'osey Comiy, on April 26, 1901. It was afterward foum to be rather common in the region thereabouts as well as in Knox: Perry, Dubois, Crawford, Orange and Lawrence counties: the northcrmmost point at which it has leen olserred being near Mitrhell. Lawrence Comntr. Since its known general range is southern it probably does not ocemr in the northern laalf of the State. With us it is lomel in comprany with a lualf dozen species of ants, the most common of which is a rather large pellowish-led form, probalbly ('amponolus melleus siy. The cricket seems to be always on the move. and when distmbed lages with great agility. Those taken in Crawfort Comity in September were almost double the size of those noted in the spring and probahly more accurately represent the mature insect. But little is as get known of the life habits of these interesting insects and the subject is well worthy of prolonged observation.

\section{Sub-fimily GIYLIIN.T.}

This sub-family comprises the ground and field crickets. 'They' are among the most common members of the order Orthoptera; abounding everywhere in temperate and torrid clinates. The main 
distinguishing characters of the sub-family are given in the key. Many of the species are dimorphic as regards the length of the wings, and on this account much confusion in synonymy has resulted in the past. But three genera of the sub-family oceiur in the United States, all of which are represented in Indiana. These genera may be distinguished by the following key:

KEY TO GENEIRA OF INUIANA GRTLLIN.E.

a. Species of small size; last joint of the maxillary palpi double the length of the one lreceding; hind tibice furnished with long, movable, pilose spines: first joint of hind tarsi unarmed above or with one row of small teeth................ L . Nenobrus. p. 419

a . Species of medium or large size: last joint of maxillary palpi but little, if any, longel than the one preceding; lind tilliae armed with stont, immorable spines: first joint of hind tarsi sulcate ahove. with a row of teeth on each side.

b. Species of large size; fore tibia provided with a hearing organ on both faces................. Lit. Gryllus, 1. 429

bb. Species of medinm size: fore tibia with hearing organ on onter

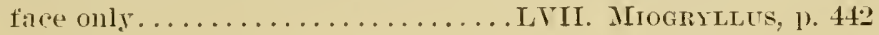

\section{Neмоветs Serville (1839).}

Of all the Gryllidie which occur with ns, the little brown ground crickets of the genus Nemotius are the most numerous and the most social. Unlike their larger cousins, the field erickets, they do not wait for darkness before seeking their food, but wherever the grass has been cropped short, whether on shaded hillside or in the full glare of the noonday sun along the heaten roadway, mature specimens may be seen by hundreds dnring the days of early antumn. Even the tangled masses of sphagnum mosses and other semi-aquatic growth of fen and marsh furnish shelter and food to rertain species which, in the ages of the past, have become adapted to a life of such surroundings.

These ground crickets are all of small size. being never more than half an inch in length. The color is usually a dark brown or pitch black, and the bodies and legs are sparsely clothed with brown hairs. The head and thorax are of nearly equal brealth. The last segment of the maxillary palpus is twice the length of the one preceding it. and enlarged at the outer end. 'The anterior tihia hear near their base a small oval hearing organ on the onter face. The reins of the wing covers of the female rum lengthwise, while in the females of the larger field erickets they run obliquely from both sides. 
While the individuals of Nemobius are so plentiful, their size is so small that they have received but little attention from the average collector. Moreover, so similar in general appearance are they that very close observation by the student is necessary to separate the species one from another. As a consequence but 15 have hitherto been described from the whole United States. Up to May, 1900, when the writer described three new species from Indiana* but three had been accredited to the States north of Florida and east of the Rocky Mountains. MeNeill listed but one from Illinois. Bruner mentions three, two without names, from Nebraska, while Scudder, in his most recent paper on the group, aceredits three, viz: $N$. fasciatus, $N$. cubensis and $N$. carolinus to the central and eastern States.

Within the past ten years many speeimens have been collected in different parts of Indiana. A careful study of these reveals the presence of at lenst eight species. There is little doubt but that the right kind of investigation will show the presence of as many or more in almost any State east of the Rocky Mountains. Those known to occur in Indiana may be separated by the following key:

KEY TO INDIANA SIECIES OF NEMOBIUS.

a. Ovipositor as long as or harely shorter than the hind femora; straight or nearly so.

b. Ovipositor distinctly longer than hind femora; cross-veinlets of tegmina of female very prominent; black of body arranged in lengthwise bars.

c. Color blackish or fuscous; the dark stripes on occiput always visille, thongh sometimes indistinct in very dark specinens ....................... fascintus. p. 421

ce. Color light roddish brown or grayish; withont dark stripes on oceiput . . . . . . . . . 423

b1). Ovijositor no longer than hind femora; cross-reinlets of female tegmina not prominent; Hack of body sattered in blotehes and dashes.....................126 maculatus. p. 424

a11. Oripositor distinctly shorter than hind femora: msmally more or less irruate.

1. Tegmina of female menly or yuite as long as abdomen; wings

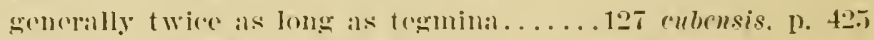

dl. 'legmina of fomale shorter than abdomen, wings wanting.

c. Togmina of males reaching tip of abdomen, their ground color yellowish brown.

f. Dorsal ficld of pronotum and all the legs a miform bownish rellow: tegmina of males wider than abdomen ................

*Psyche, IX, 1900, p. 51, of ser. 
ff. Dorsal field of pronotum and all the legs more or less mottled with black; tegmina of males no wider than abdomen........129 carolimus, p. 427 ce. Tegmina of males covering only two-thirds to threefourths of abdomen, their color wholly black or very dark brown.

g. Length of body of female less than $6.5 \mathrm{~mm}$.; last two joints of maxillary palpi of female dark brown; inner face of hind femora of male not barred with black.........130 palustris, p. 427

gg. Length of body of female more than $7 \mathrm{~mm}$.; last two joints of maxillary palpi of female white; inner face of hind femora of male barred with black...

131 confusus, p. 428

124. Nemobius Fasciatus (DeGeer). The Striped Gromnd Cricket.

Gryllus fasciatus DeG., 57, III, 1773, 522, Plate 43, Fig. 5.

Nemobius fasciatus Scudd., 14 1, VII, 1862, 430; Id., 1 75, IV, 1896, 100, 102 ; Id., 176, VII, 1896, 432; Id., 188, 1900, 88; Glov., 62, 1872, Plate VI, Fig. 13; Sauss., 132, VI, 1874, 389; Id., 133 , II, 1877, 242; Bl., 5, 1892, 136; Id., 16, 1899, 227, Fig. 56; Id., 17. IX, 1900, 51 ; Beut., 3, VI, 1894, 266, Plate V, Fig. 9 ; Lugg., $84,1898,261$.

Acheta vittate Harr., 72, 1862, 152, Fig. 70; Rathv., 109, 1862, 380, Fig. 16.

Nemobius vittatus Scudd,, 14 1, VII, 1862, 430; Id., 142, II, 1868, 115, 120 (song of to music); Id., $148,1874,364$ (chirp set to music); Glov., 62, 1872, Plate III, Figs. 9, 10; Sauss., 132, VI, 1874, 389 ; Pack., 104, 1883, 564; Comst., 41, I, 1888, 121 ; Bl., 5, 1892,135

Nemobius faseiatus rittatus Beut., 3, VI, 1894, 267, Plate V, Fig. 10; Lugg., 84, 1898, 262, Fig. 170; Bl., 17, IX, 1900, 52.

Nemobius exiguus Scudd., 141 , VII, 1862, 429.

'Two forms of this, our largest and most common Nemobius, oceur in Indiana. In one (fasciatus) the tegmina reach to the end of the abdomen while the inner wings extend to the tip of ovipositor. In the other (vittatus) the tegmina of the female corer a little more than half the abdomen and their cross-reinlets are coarser and much more prominent than in $N$. maculatus. Those of the male cover three-fourths of the aldomen. In this form the imner wings are wholly wanting in both sexes. As in most of the other speeies the head and thorax bear many coarse, stifi black hairs. The oripositor is longer than in any other Indiana species, being about one-eighth longer than the hind femora.

The short winged form varies in color from a dusky brown to a rusty black. When of the latter hue the black stripes on the hear, to 
which it owes its varietal name, are very dim or wholly invisible. 'The long winged form is always black.

Measurements: Length of boly, male, $10 \mathrm{~mm}$., female, $11 \mathrm{~mm}$; of pronotum, male and female, :3 mm.; of togmina, male, $5.5 \mathrm{~mm}$., female, $t$ mm.; of wings, long-winged form, $13 \mathrm{~mm}$; of hind femora, male and female, \%.) mm.; of ovipositor, $8.5 \mathrm{~mm}$.

No intermediate short winged forms comnecting

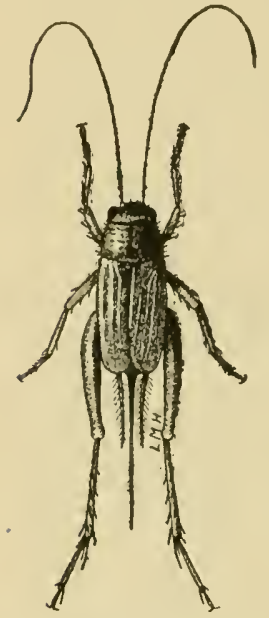

Fig. 107. Nemobius fasciatus (DeG.). Female. Short-winged form. (After Lugger.) fascialus with rillalus have been seen by me, nor have any heen recorded to my knowledge. The two are, howerer, regarded as dimorphic forms of the same species hy the leading authorities, Saussure and Scudder.

1) uring hundrects of days spent in field colleceting not a single sperinen of the long winged form was taken until Angust 1, 1902. when it was found in numbers on the stems of long grass in a marsly hordering Round Lake. Whitley County. Many, however. have been taken from the walks and strects of Indianapolis, Fort Wayne and other cities and towns in the northern part of the State, lut none, as yet, in the sonthern half, not even in I'erre Ilaute, where I resided for seren years. Ithere the insect breeds, and feeds by day is to me unkmown. It appears to reach maturity about July 15th and, at times, as in the first week in Ingust. 1899, swams composed of myviads have appeared about the lights of some of the cities. The newspapers the next day had a column or more devoted to the insects but nothing. except wild gueses, as to whenee they came.

The short winged form rillatus begins to roach maturity in central Indiana about July 1.)th. Living specimens have beerl seen as late as December 1st. Although present in vast mumbers, but little is known of its life babits. When distmberl they are rery difficult to eapture, making enormous leaps with their stout hind legs, no sooner striking the gromel than they are np again, erem if not pursued, until they find a leaf or other shelere beneath which to take rofuge.

They appear to be ommirolons, feething upon sarrion. (ow dung and grasses with equal avidity. 'Though small in size, their enomons numbers as well as the fact that they are constant greedy feeders

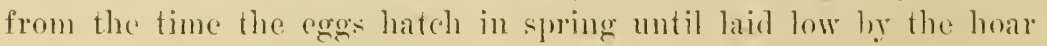
frost of antum, renders them furticularly injurious. The aggregate 
damage which they canse to grass and kindred plants in the course of a single season must be great, and there is little doubt but that this, as well as the other species of the gems, should be classerl among those insects highly destructive to forage plants.*

Mr. S. H. Seudder has given the following pleasing account of the sounds made by this species: "The chirping of the striped cricket is very similar to that of the black field ericket; and may be expressed by $r-r-r-u$, pronounced as though it were a French word. The note is trilled forcibly, and lasts a variable length of time. One of these insects was once observed while singing to its mate. At first the song was mild and frequently broken; afterwards it grew impetnons, forcible and more prolonged; then it decreased in volume and extent until it became quite soft and feeble. At this point the male began to approach the female, uttering a series of twittering chirps; the female ran away, and the male, after a short chase, returned to his old hannt, singing with the same vigor but with more frequent pauses. At length, finding all persuasions unavailing, he brought his serenade to a close."

125. Nemobius Canus Scudder.

Nemobius canus Scudd., 175, IV, 1896, 100, 103; Id., 176 , VII, 1896, 432 ; Id., $188,1900,88$.

Size, large; the head prominent, both it and the thorax sparingly beset with black bristles. Hear reddish or yellowish brown in color; sparingly or not at all marked with fuscous and withont trace of black bars on occiput. Eyes shorter, smaller and more globose than in $N$. fascialus. Antennæ and palpi yellowish brown. Pronotum broader than long, the sides a little convex; yellowish brown in female, larker in male, the sides in latter with a fuscous bar on their posterior half. Tegmina of male covering three-fourths of abdomen, yellowish brown above, darker on basal third, the sides with a shining piceous bar along their upper third; those of female covering half or a little more of abdomen, the stripe on sides narrower and less shining than in male, sometimes with an additional one on dorsal field. Abdomen reddish brown with a median dark stripe on dorsal surface, and a similar one along each side. Hind femora short and very stont, a uniform reddish brown, sometimes darker in the male. Ovipositor distinctly jonger than hind femora, straight or nearly so, the tip acute, the scrrated portion short, the teeth sharp, not crowcled.

\footnotetext{
"For other accounts of the destruction wrought by the species of Nemobins see Rathvon, U.S. Agricultural Report, 1862, p. 380, and Osborne's Bulletin, 23, U. S. Division Entomology, p. 59 .
} 
Measurements: Length of body, male, $8.5 \mathrm{~mm}$., female, $12 \mathrm{~mm}$; of pronotum, male, $2.5 \mathrm{~mm}$., female, $3 \mathrm{~mm}$; of tegmina, male, 6.5 mnl., female, $5 \mathrm{~mm}$; of hind femora, male, $7.5 \mathrm{~mm}$., female, 8.5 mm.; of ovipositor, $9.5 \mathrm{~mm}$.

This is a southern species heretofore known only from Texas, which occurs sparingly throughout southern Indiana, being most abundant in the comnties bordering the Ohio River. Our specimens differ from types from Texas in having smaller eyes, and in being yellowish brown rather than grayish in hue. Specimens were sent to Professor Morse for comparison with Scudder's type, and by him pronounced the same. In Crawford County the species frequents roadsides and high dry open fields and meadows. From the short winged form of fascialus it may at once be separated by the lighter color, unstriped occiput, smaller, more globose eyes and shorter hind femora.

126. Nemobius maculatus Blatchley. The Spotted Ground Cricket. Nemobius maculutus B1., 17, IX, 1900, 52.

Size, medium; head rather prominent, dark reddish brown, more or less dotted with pitch black, especially on forehead and cheeks; eyes rather large, prominent. Antennæ dull yellowish brown, the basal third lighter; maxillary palpi of the same color, the apical half of terminal joint darker. Pronotum broader than long, faintly tapering anteriorly; the dorsal field chestnut brown with numerous dark points; the front margin and lateral field sparingly beset with stiff black bristles. A black stripe starts back of the eye and covers the upper two-thirds of lateral field of both pronotum and tegmina. The latter with a yellowish vein separating the dorsal and lateral fields, more prominent in the male. The dorsal field brownish yellow, sometimes witl blackish dots; in female covering one-third of abdomen, in male, two-thirds; wings absent. Legs and dorsal surface of abdomen brownish yellow sprinkled with fuscous, which on dorsal surface of hind femora is sometimes in crossbars. Oripositor almost straight, equaling in length or very slightly shorter than hind femora: the apieal blades rather long, tapering evenly to a fine point; above, erenly and sharply serrulate.

Measurements: Length of body, male, i mm., female, $8 \mathrm{~mm}$.; of pronotum, $2.5 \mathrm{~mm}$; of tegmina, male, $4 \mathrm{~mm}$. female, $2.8 \mathrm{~mm}$; of hind femora, male, $5.5 \mathrm{~mm}$., female, $6.5 \mathrm{~mm}$.; of oripositor, $6.5 \mathrm{~mm}$. Width of pronotum, $3 \mathrm{~mm}$.

X. maculatus is readily distinguished from the short winged form of $N$. fusciatus by its average smaller size. shorter tegmina of female, 
shorter and straighter ovipositor, fewer hairs on head and pronotum and finer cross-veinlets of female tegmina. The serrulations of the ovipositor are sharper than in fasciatus. The two also differ in color, the ground of maculatus being lighter and the piceous more generally sprinkled where in fasciätus it is in lengthwise bars. Maculatus has, as yet, been taken in small numbers only in Marion and Vigo counties. It is found in low open woods, nsually in the vicinity of or beneath logs.

\section{Nemobius cubexsis Saussure.}

Nemobius cubensis Sauss., 132, VI, 1874, 384, Plate 7, Fig. 5; Scudd., 175, IV, 1896, 100, 105; Id., 176 , VII, 1896, 432; Id., 188 , 1900, 88; Bl., 17, IX, 1900, 54.

Nemobius volaticus Scudd., 160, XIX, 1877, 36; Id., 16 1, VI, 1878, 14.

Head rather full and convex, projecting above the surface of the pronotum, black, with bristly hairs; antennæ dark brown, the margins of its segments paler; palpi varying irregularly from pallid to dusky, the terminal joint nearly twice as long as the third, and about three times longer than the fourth. Pronotum black, broader than long, slightly broader behind than in front, the anterior half or more with a distinct median furrow, the whole surface with scattered black bristles. Tegmina narrow, nearly as long as the abdomen, pitch black in color; wings very long, the tip of the closed tegnina lying midway between the tip of the wings and the front of the head. Legs brownish yellow, more or less infuscated, especially above, the hind femora rather slender, the tibial spines slightly paler at tip. Cerci slender, dusky, about as long as the hind tibix; ovipositor very much as in $N$. carolinus; dark brown, similarly armed at tip.

Measurements: Length of body, male, $6.5 \mathrm{~mm}$., female, $6.75 \mathrm{~mm}$.; of antennæ, male, $13 \mathrm{~mm}$., female, $14 \mathrm{~mm}$; of tegmina, male, $4 \mathrm{~mm}$., female, $4.4 \mathrm{~mm}$.; of hind femora, male, $5 \mathrm{~mm}$.; of hind tibix, male, $3.75 \mathrm{~mm}$., female, $3 \mathrm{~mm}$.; of ovipositor, $3 \mathrm{~mm}$.

I have not seen the females from Indiana and the above description is therefore copied in part from Scudder. Two males distinct from any others found in the State were taken October 9, 1893, from the sandy bed of the old canal north of Terre Haute, Indiana. They were sent to Mr. Scudder, who pronounced them the short winged form of $N$. cubensis. In life they were shining black with a bright yellow line separating the dorsal and lateral fields of the tegmina. The general range of cubensis is southward; it having been recorded from a number of the Gulf States as well as Cuba and Brazil, South America. Scudder records two females as having been taken in Illinois. 
128. Nemolitus extritus Blatchley.

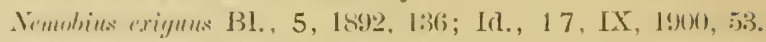

Size, mediun; borly, slender: head rather larewe, but slightly tumid. Eyes small but prominent. Antenne, head. pronotum and femora brownish yellow. Maxillary palpi light yellow throughout or with the apical third of terminal joint infuscated. T'ergmina of male reaching tip of abelomen; the forsal field expanded so that they extend beyond the sides of abdomen: brownisl yellow in color with a narrow piceous bar on upper third of lateral field and with basal third of dorsal fich ofien more or less pitch black. Tegmina of female covering one-half or more of abdonen. the dorsal field usually harily shated with blackish; wings absent in both sexes. Upper surface of abetomen blackish, lower surface brownish yellow or luteous. Ovipositor a third or more shorter than hind femora, distinctly arcuate, the apical blade not enlinged at the bace, armed above with very small and rather dull teeth, which are irregularly distant one from another.

Measurements: l.engtl of body, male, i mm.. of female, r..5 mm.; of tegmina, male, s mm., of female, $t$ mm.; of hind femora, male, 5.2 mm., of femile, $6.3 \mathrm{~mm}$.; of ovipositor. $3.5 \mathrm{~mm}$.

This is the "N. reriguus Sendder" of my paper on the "Gryllide of Indiana," Toc. cil. It appears, however, that Scndder had not described a species as exiguus but had merely mentioned a form of N. fascialus under the name. Bentenmuller afterwards* described N. affinis from New York. which he stated was the inseet mentioned by we, but whish, aceording to Seudder, $\uparrow$ is $\lambda^{\gamma}$. carolinus.

Exiguus is longer and proportionally more slender than the next species, $N$. carolinus scudt., thongh the tegmina of the male are broader. The pronotum and femora are not mottled or marked with fuscous as in that species. The serrations of the oripositor of carolimus are smaller, sharpere and more evenly scparated than in exiguus. The latter species oceurs in all parts of the state and is fully onehall als common as the short winged form of $X$. frescialus. Its habits, time of appearame and local habitat are also essentially the same. Howerer, the smalle size, short ovipositor, yellowish maxillary palpi, and other differences in color. readly distingnish it from that insect.

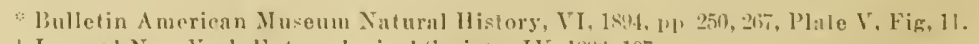

tJournal New York Entomological Sorioty, IS, 18yi, 107. 
129. Nemobius Carolinus Seudder.

Nemolins artimus: Scudd, 160, XIX, 1877, 36; Id., 161 . VI, 1878, 11; Id., 175 , IT, 1896, 100, 107 ; Id., 176, VII, 1896, 433; Id., $188,1900,88 ; \mathrm{Bl} ., 17, \mathrm{IX}, 1900,53$.

('yrtoxiphus meriegutus Brun., 29, III, 1898, 32.

Nemobius affinis Beut., 2, VT, 1894, 249; Id., 3, 267, Plate V, Fig. 11.

Head and antennæe varying from dull yellow to dusky brown, furnished with rather long, curving, distant, black, bristly hairs. Pronotum of the color of the head, but more or less mottled with blackish, a little broader than long, supplied with long. bristly black hairs. its anterior two-thirds with a distinctly impressed median line. Tegmina brownish yellow, the upper third of lateral field with a blackish bar; the dorsal field often with black fleckings; the mottled appearance sometimes due, however, to the black of dorsal surface of abdomen shining through them; those of the male rather ample and reaching the tip of the abdomen, those of the female covering but half of the abdomen; wings wanting. All the legs dull brownish yellow, more or less mottled with blackish; the tibial spines pale near the tip. Dorsal surface of abdomen of female with its basal twothirds black; the last two or three segments brownish yellow with a sprinkling of small black spots. Cerei brownish, very slender, as long as the abdomen; oripositor dark brown, a little upeurved, moderately stout, shorter than the hind tibir, the apical denticular field longer than usual and nearly equaling one-fourth the entire length of the ovipositor.

Measurements: Length of body, male, $7 \mathrm{~mm}$., female, $8.5 \mathrm{~mm}$.: of tegmina, male, $4.2 \mathrm{~mm}$., female, $3.5 \mathrm{~mm}$; of hind femora, male, 5.3 mm., female, $6.2 \mathrm{~mm}$.; of ovipositor, $3.8 \mathrm{~mm}$.

This prettily marked iittle species has been found to be rather common on the grass covered banks of streams and along the fence rows of open woods in Vigo, Putnam and Monroe counties, and it probably occurs in like situations throughout the State. In general appearance it is a diminutive form of $N$. maculatus above described, but its small size and short arcuate ovipositor at once distinguish it. According to Scudder, carolinus ranges from Now England to Nebraska and Texas.

130. Nemobus palustris Blatchley. The Marsh Ground Cricket. Nemobius pelustris B1., 17, IX, 1900, 53.

Size, small; the body of male especially short and broad. Head tumid; eyes large, but not prominent. Pronotum one-third broader than long, the sides sulb-equal, rather thickly beset with stiff black bristles, as are also the forchead and dorsal surface of the two front 
femora. Head, tegmina and body of most specimens a uniform dark piceous; disk of pronotum piceous or fuscous sprinkled with piceous. Antennæ, legs and ovipositor fuscous. Maxillary palpi yellowish except the apical joint which is wholly piceous. Tegmina of female covering a little more than half the abdomen; those of the male hardly reaching its tip. Oripositor almost a third shorter than hind

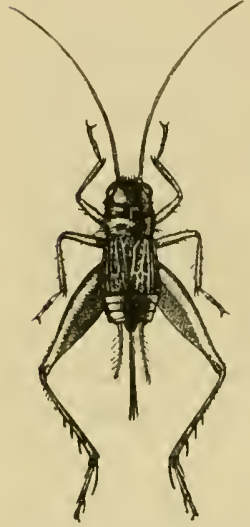

Fig. 108. Nemobius palustris Bl. Female. Three times natural size. (Original.) femora, distinctly though feebly arcuate, the apical blades but little enlarged at the base, very finely serrulate with dull, rasp-like teeth.

Measurements: Length of body, male, $5.8 \mathrm{~mm}$., female, $6.2 \mathrm{~mm}$.; tegmina, male, $4 \mathrm{~mm}$., of female, $3 \mathrm{~mm}$; of hind femora, male $4.5 \mathrm{~mm}$., of female, 5) $11 \mathrm{~m}$.; of ovipositor, $3.5 \mathrm{~mm}$.

This handsome little pitch brown Nemobid has been found only among the tamarack swamps and cranberry bogs of the northern part of the State, where it finds a congenial home in the midst of the dense, damp sphagnum mosses. Sometimes they are so plentiful that a half dozen or more are secn in an area a foot square. Like the other members of the genus they are very active, when disturbed leaping vigorously, a few inches at a time, and finally seeking safety by burrowing in the masses of mosses. It has been taken in Marshall, Fulton and Starke counties and probably occurs wherever peat bogs and sphagnum mosses are present.

\section{Nemobius confusus sp. nov.}

Body broad and rather stout; the head but little prominent; the face and antenna fuscous in color; the vertex, disk of pronotum and two front pairs of femora with scattered, black, stiff hairs. Last two joints of maxillary palpi of the female white, very noticeable in living specimens; the same segments in the males whitish to fuscous, the apical half of terminal joint darker. Pronotum broader than long, with a median impressed line on its front half, more prominent in the female; the disk usually a dark smoky brown in color except along the front half of each lateral carina, where there are some light brown spots; the sides darker. Tegmina of female covering half, those of male, three-fourths of abdoinen, piceous throughout rexcept the carina separating the dorsal from the lateral field, which is fuscous or smoky brown. Dorsal surface of abdomen black, with often a few small dots of yellowish brown on the last three segments. 
All the femora of female and the fore and middle pair of male fuscous, sometimes with a few lighter dots on their upper surface; the hind femora of male blackish on outer face, the dark color passing over the upper side and half way down the inner face where it is broken, thus forming bars or blotches plainly visible on the lighter color. The tibiæ usually reddish brown, more or less mottled with fuscous. The basal joint of front tarsus whitish in the female. Ovipositor but little more than half as long as the hind femora, dark brown in color, its apical third wider and a little upturned; the armed portion longer than in any other Indiana species; the teeth fine, sharp, and more than usually distant one from another.

Measurements: Length of body, male, $7.2 \mathrm{~mm}$., female, $7.5 \mathrm{~mm}$; of tegmina, male, $4 \mathrm{~mm}$., female, $3 \mathrm{~mm}$; of hind femora, male and female, $6 \mathrm{~mm}$.; of ovipositor, $3.3 \mathrm{~mm}$.

This is a larger and broader insect than $N$. palustris. The main differences between the two species are set out in the key. The armed portion of the ovipositor is wider and longer and the teeth more distant and sharper in confusus than in palustris.

$N$. confusus has been taken in Kosciusko and Posey counties. In the former it was found on August 26,1902, to be quite common in some low, damp woods bordering Tippecanoe Lake. Here it had its home among the fallen leaves and beneath small chunks and chips. From Posey County a single specimen was secured also from a tract of low woods.

It seems that the different species of this genus noted above have each a special abiding place. Fasciatus and exiguus are the only ones which may be looked for anywhere in open fields and along roadways. Maculatus occurs in open woods in dry situations; cubensis in sandy districts; carolinus along the banks of streams and on gravelly hillsides; palustris nowhere except among the sphagnum mosses of dense swamps and bogs, while eonfusus likes best the shadows of dense woods which are low and moist. Each species has, therefore, its special habitat where the food on which it thrives is most abundant, and where, during the ages past, it has become so modified in organ and hue as to receive from man a distinctive specific name.

\section{Gryluds Linnæus (1758).}

To this genus belong those dark colored thick-bodied insects known as house and field crickcts. The latter are the best known examples of the family Gryllidie and are abundant from June 1st till after heavy frosts, beneath logs, boards, stones, and especially be- 
neath rails in the cormers of the old-fashioned and rapidly disappearing Virginia rail fences.

All members of the genus Gryllus have the head large and globose; the eyes large and rounded; the antenne thread-like and longer than the body; the pronotum broader than long and about the width of the head; the hind fenora of medium length but much enlarged and well-fitted for leaping: the hind tibix with two rows of strong fixed spines, those nearest the apex being the longer; and the hind tarsi with its first joint sulcate above with a row of minute teeth along each carina. The ovipositor is, in all the species, as long as or longer than the hind femora, and in the same species varies but little in length. Most of the species are, however, dimorphic as regards wing length, though among our Indiana species the short winged forms greatly outnumber the long winged ones. The inner wings vary much more than the outer and sometimes are wholly lacking.

Regarding the general habits of the field erickets Prof. Lawrence Bruner has written: "Tsually most of our North American Grylli live singly or in pairs in burrows which they dig for themselves. These are nsed as retreats during the day time and serve as shelter from ordinary inclemencies of weather. These burrows are generally forsaken about midsummer for some sort of above-ground shelter. From this time on, until fall, they appear to be more social and live in colonies under various sorts of rubbish. Grain shocks are a favorite haunt for them, and since twine has been used for binding, the crickets have been quite troublesome by eutting the bands. During late summer and fall the females eommence preparations for the continuance of their kind, by thrusting their long. slender ovipositors into the loose soil and dropping their eggs. These sometimes hateh the same year, but, as a rule, lic over until the following spring. The young generally live above gromnd, where they hide among fallen leaves, grasses and othor dehris, though sometimes they also creep into chinks and crevices in the earth."

The remarks of $\mathrm{Mr}$. Bruner apply mostly to $G$. abbrevialus, one of our largest and only social species. The young of $G$. pennsylvanicus and $G$. americanus are. for the most part, hatched in antumn and survive the winter in the nymple stages, while $G$. domesticus, the house cricket, passes the winter either as adult or nymph.

The synonymy of the American species of this genus has become greatly confused, due largely to the fact that foreign writers have attempted to monograpls the genus with but a limited number of specimens at hand; and again to the fact that the species, especially the males, are very diflicult to separate. 
Mr. Scudder, in two recent papers," has in part straightened out this difficulty. However, he, as well as the European writers, has written mainly of specimens collected by others, and has not studied the insects in the field. For this reason Mr. Scudder has stated that but three species occur in the northern and central United States, east of the Mississippi River. A long series of observations in the field, coupled with a careful examination of a large number of individuals, has convinced me that at least six species occur in Indiana. $\nmid$ Of these, two are believed to be undescribed. The following key, based largely on the females, may be used in their separation:

KEY TO INDIANA SPECIES OF GRYLLUS.

a. Black species, tlie tegmina and parts of the body sometimes dull reddish brown; first joint of antenna not projecting beyond front of head. (Field crickets.)

b. Very large species, about $25 \mathrm{~mm}$. long; the hind margin of pronotum convex; hind tibia with seven to eight spines on each. side ............................... firmus, p. 432

bh. Medium or small-sized species, the body seldom exceeding 20 mm. in length; hind margin of pronotum truncate; hind tibia with five to six spines on each side.

c. Ovipositor but little, if any, longer than hind femora, never more than $12 \mathrm{~mm}$. in length; tegmina of female with only their basal halves overlapping or attingent, the apical halves spread apart so as to leave a wide Vshaped notch between them.....133 americanus, p. 433

ce. Oripositor plainly longer than the hind femora, always 13 or more mm. in length; tegmina of female with their inner edges either overlapping or attingent their full length.

d. Body slender; the pronotum never more than $5 \mathrm{~mm}$. in width; the tegmina, cerci, ovipositor and legs reddish brown in color.......134 arenaccus, p. 434

da. Heavy bodied species; the prouotum always more than $6 \mathrm{~mm}$. in width; the tegmina, cerci, ovipositor and tibiae black; the hind femora often with the basal half of the under side reddish brown.

c. Ovipositor nearly or fully half as long again as hind femora, always exceeding $18 \mathrm{~mm}$. in length; the male stout, with large and broad head ..............135 abbreviatus, p. 435

*"The Species of Gryllus on the Pacific Coast,"-Psyche, IX, 1901, 267, et seq., and "The Species of Gryllus found in the United States East of the Sierra Nevadas,"-Psyche, IX, 1902, 291, et seq. State.

†Including $G$. firmus Scudder, of which, however, I havo seen no specimen from this 
ce. Ovipositor seldom, if ever, more than $14 \mathrm{~mm}$. or less than $13 \mathrm{~mm}$. in length, rarely more than one-fourth as long again as hind femora; the male more slender, with narrower and less swollen heat ......136 pemsylvanicus, p. 437 1u. Straw-colored species, with some dark brown or blackish markings on heil and thorax; first joint of antenne projecting slightly befond front of head. (IIouse (rickets).......137 domcsticus, p. 439

132. Grylues fikues Sendder.

Ciryllus firmus Scudd., $194, \mathrm{IX}, 1902,295$.

Large and stout, with piceous body. Head large, tumid, with prominent vertex, seareely broader than the pronotum, wholly black. Pronotum stout, black, most delicately margined anteriorly with reddish brown, broadest in advance of the middle, the sides being slightly and not quite uniformly convex, half as broad again as long, the front margin with scarcely perceptible coneavity, the hind margin slightly but distinctly and broadly convex, with a median impressed line searecly or not visible on posterior third, the lower margin of the lateral lobes oblique and nearly straight. Tegmina nearly or quite covering the abdomen, testaceous, more or less infuscated, often in the female with a clear testaceous humeral stripe, the mediastinal vein with three or four branches; wings generally no longer than the body, but sometimes caudate in the female. Legs reddish or yellowish brown, often more or less infuscated, the hind femora stout, the hind tibix with generally six or seren rather long spines on the outer side, the upper inner calcar very long and almost as long as the intermediate calcar. Ovipositor fully a third longer than the hind femora.

Measurements: Length of body, male, $27 \mathrm{~mm}$., female, $26 \mathrm{~mm}$.; of pronotum, male, 5 mm., female, $5.5 \mathrm{~mm}$.; breadth of pronotum, male and female, $\% .5 \mathrm{~mm}$.; length of tegmina, male and female, $14.5 \mathrm{~mm}$.; of hind femora, male, $16 \mathrm{~mm}$., female, $16.75 \mathrm{~mm}$; of ovipositor, $23.5 \mathrm{~mm}$.

This is a species of southern range, specimens in Scudder's collection having come from North Carolina, Georgia, Florida and 'Texas. He also records one specimen from Brookville, Franklin County. Indiana, collected a number of years ago by Dr. Rufus Haymond. I have seen no specimens from this State, but have one from Agricultural College, Mississippi, collected in December by Mr. II. E. Weed. Nothing distinctive of its habits has been noted. It should be looked for throughont the sonthern third of the State. 
133. Gryllus amerionnus sp. nov.

Gryllus neglectus, Bl., 12, VII, 1895, 250. (Nec. Scudd.)

A shining black species, the female short-bodied and thick set, the male more slender. Head no broader than the pronotum, the vertex prominent; but sloping rapidly downward. Pronotum a little narrower in front than behind, its length contained in its greatest breadth 1.3 times; the median impressed line more than usually prominent, except upon its posterior fourth; the front margin truncate or a very little concave, the hind margin slightly sinuate and eiliate with black hairs. Tegmina of female covering two-thirds of abdomen, shining black, sometimes with a reddish brown tinge at base and along the humeral angle; their inner margins straight and overlapping or attingent only on their basal halves; the apical halves with the inner margin oblique or "bias" and when at rest therefore widely separated. Tegmina of male usually covering three-fourths of abdomen, rarely reaching its tip, the mediastinal vein with four branches. Wings represented by narrow thin scales. Hind femora short and stout, their lower and inner sides sometimes tinged with reddish brown on the basal third but never with the large reddish brown spot on lower side, so common in $G$. abbreviatus and $G$. pennsylvanicus. Hind tibir dark chestnut brown, with five or six rather stout spines on the outer side. Ovipositor short, just equaling, or rarely exceeding by 1 $\mathrm{mm}$. the length of hind femora, dark reddish brown in color, the apex paler.

Measurements: Length of body, male, 14 $\mathrm{mm}$., female, $16.5 \mathrm{~mm}$.; of pronotum, male, 3.5 mm., female, $4.2 \mathrm{~mm}$.; of tegmina, male, 7.5 mm., female, $8 \mathrm{~mm}$; of hind femora, male, 10

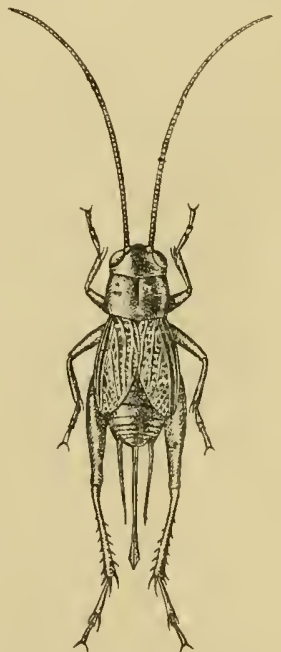

Fig. 109. Grullus americanus sp. nov. Female. One and one-fourth times natural size. (Original.)

mm., female, $11 \mathrm{~mm}$.; of ovipositor, $11 \mathrm{~mm}$. Width of pronotum, male, $5 \mathrm{~mm}$., female, $5.6 \mathrm{~mm}$.

This is the species which I formerly thought to be G. neglectus Scudder, but that authority states in his latest paper on the genus that neglectus is a synonym of pennsylvanicus. Moreover, I find that in his original deseription the average measurements of the ovipositor of neglectus are given as .28 of an inch, or $7 \mathrm{~mm}$., whereas in americanus they are never less than 10 or more than $12 \mathrm{~mm}$. in length. From pennsylvanicus, with which species it has been heretofore confused, americanus may be readily separated by its smaller 
size, narrower pronotum, more uniform shining black color, shorter ovipositor, and the shape, and position when at rest, of the female tegmina. The reticulation of the dorsal field of these tegmina is more noticeable in americanus than in pennsyleanicus, the main diagonal nerves being closer together and the cross-nervules more elerated and prominent. Americanus reaches milurity in the spring about a fortnight the sooner.

Americanus has been taken in Crawford, Posey, Vigo Putnam, Marion, Marshall, Wells and Lake counties, and probably oceurs throughout the State. It is here the first species of Grylus to become mature in the spring, the note of the male-the first Orthopteran song of the season-having been heard on a number of occasions in the central counties as early as May 5th. The young of this speeies, as well as of $G$. pennsylranicus, survive the winter as nymphs. In $\mathrm{S}_{(\mathrm{i})}$ tember and October, after passing the second or third monlt, they seek the shelter of loose bark on log or stmmp, or (rawl heneath chunk or rail where they form for themselves small, inverted coneshaped burrows in the earth, in which they abide until spring. 'Thost which attempt to pass the winter with only a shelter of bark abov them almost always succumb to the changing temperatures of that season, but those which choose more wisely a burrowing place beneath some half buried log or chunk for the most part survive. The temperature of their hibernaculum is much more equable, and the insects becoming sluggish in late autumn remain so until ealled into new activity by the sumshine of spring, unless, meanwhile, they fall a prey to some shrew mouse or other active winter insectivorons mammal. They emerge from their hiding places about April 1st, and after ehanging their garb two or three times. reach the mating stage in early May, when the males begin to greet the passer-by with their merry chirp.

Neither this species nor pennsylvanicus are social criekets. Sometimes two or three of the young have adjacent burrows beneath the same chunk, but more often both they and the adults are solitary. The eggs are laid in June and July, and the newly hatehed young are to be found in numbers during July and August.

\section{Gryllus arexaceus sp. nor. The Sand-Loving Cricket.}

Body very slender, of medium length. Head, black, but little, if any, wider than pronotum, the vertex prominent; the cheeks and palpi reddish brown. Pronotum black; its length contained in its width 1.43 times, the fore and hind margins truneate, very narrowly edged with reddish brown; the median impressed line visible only 
on anterior half. Tegmina reddish brown, lighter along the humeral angle, covering a little more than half the abdomen in the female, three-fourths or more of abdomen in the male. Wings present but very narrow and shorter than the tegmina; abdomen shining black. All the legs reddish brown throughout, except the hind femora which sometimes have the apical half of outer and inner faces blackish. These femora are short and rather slender. Hind tibiæ with six or seven rather long spines on their outer carina. Ovipositor nearly one and a half times longer than hind femora, the average ratio being $1.43: 1$, dark reddish brown in color.

Measurements: Length of body, male and female, $15 \mathrm{~mm}$.; of pronotum, male, $3.2 \mathrm{~mm}$., female, $3.5 \mathrm{~mm}$.; of tegmina, male, $9 \mathrm{~mm}$., female, $7 \mathrm{~mm}$; of hind femora, male, $10 \mathrm{~mm}$., female, $11.5 \mathrm{~mm}$.; of ovipositor, $16.5 \mathrm{~mm}$. Width of pronotum, male, $4.7 \mathrm{~mm}$., female, $5 \mathrm{~mm}$.

This species has been taken only in the sand dune region of Lake County, Indiana, where it is rather plentiful in September and October beneath logs and chunks in bare sandy places. It is more slender bodied than any of our species except the honse cricket, G. domeslicus, which it resembles in form. 'The reddish brown color of tegmina, legs and cerci, contrasts strongly with the deep black of pronotum and abdomen. It will probably be found in sandy localities in the northern half of the State, especially in those counties bordering Lake Michigan.

135. Gryllus abbreviatus Serville. The Common Field Cricket.

Gryllus abbreviatus Serv., 196, 1839, 336; Scudd., 141 , VII, 1862, 427; Id., 188, 1900, 83; Id., 194, IX, 1902, 291; Glov., 62, 1872, Plate VII, Fig. 17; Sauss., 132, VI, 1874, 400, 518; Id., 133, II, 1877, 317; Pack., 104, 1883, 564; Riley, 122, II, 1884, 181 ; Fern., 53, 1888, 15; McNeill, 88, VI, 1891, 5; Bl., 5, 1892, 132 (in part); Id., 12, VII, 1895, 250; Id., 16, 1899, 226, Fig. 55; Beut., 3, VI, 1894, 265; Lugg., 84, 1898, 264, Fig. 172.

Achetu abbreviutu Harr., 72, 1862, 152, Fig. 69; Rathv., $109,1862,380$, Fig. 15.

Gryllus luctussus Serv., 196, 1839, 335; Scudd., 141, VII, 1862, 427; Id., 148, 1874, 363: Id., 188, 1900, 89; Thomas, 205, 1872, 433, Plate I, Figs. 10, 11; Glov., 62, 1872, Plate IX, Fig. 10; Sauss., 1 32, VI, 1874, 396; Id., 133, II, 1877, 317; Pack, 104 , 1883, 564; Fern., 53, 1888, 15; Comst., 41, 1888, 121.

Gryllus rngustu: Scudd., 141 , VII, 1862, 427.

Body large and especially wide. Head of male shining black, mnch swollen, and broader than pronotum; of female less prominent. Pronotum black, broad, its length contained in its width nearly 1.5 times, the median impressed line rather faint; the hind margin truncate or 
very slightly convex. Tegmina usually a very dark reddish brown or black; sometimes dull yellowish brown, covering three-fourths or more of abdomen in female and all of abdomen in male. Wings much shorter than tegmina in the common form (abbrevialus) or nearly as long again in the long winged form (luctuosus). Hind femora very stout, black or dark reddish brown, the hasal third of the under and inner sides almost always brick red. Oripositor very long, equaling or exceeding the body in length, and nearly or fully half as long again as the hind fenora.

Measurements: Length of body, male, $18-20 \mathrm{~mm}$., female, 18-22 nim.; of pronotum, male and fermale, $4.5 \mathrm{~s}$ mm.; of tegmina, male and female, $12 \mathrm{~mm}$.; of hind femora, male, $13 \mathrm{~mm}$., female. 13.5 mm.; of ovipositor, $18-21 \mathrm{~mm}$. Width of tegmina, male and female, $\hat{\imath} \mathrm{mm}$.

This is, in late summer and early autumn, the most common field cricket occurring in Indiana. In a former paper I stated that the young lived over winter, but more careful observation has proven that the young found in winter are those of americanus and pennsylvanicus. Professor McNeill, loc. cit, has given an excellent account of the life history of this species as follows: "The eggs of ablrexiatus hatch in this latitude (northern lllinois) in July, and the first adults appear as early as the seend week in Angust. During every stage of life they are social, feeding together, seeking shelter in conpany and when egg laying time comes, in October. the females collect by hundreds in some suitable locality, an abandoned or little nsed roadway suits them well, and each lays several hundred eggos in an irregular mass. After this duty is performer their business on this planet seems to the finished and they sneemmb to the cold, none surviving the winter. 'The eggs do not hatch until the following July, or if in rare alses they do they probably perish with cold."

In southern Indiana the egrgs hatch in late May or early June and the mature males appear about. July 1st, but in the central and northern parts of the State the first males appear abont a month later.

Gryllus abbreriatus is, in habits. noctumal, omnivorous, and a cannibal. Avoiding the light of day, it rentures forth, as soon as darkness has fallen, in search of food, and all appears to be fish which comes to its net. Of fruit, vegetables, grass and earrion. it seems equally fond and does not hesitate to prey upon a weaker brother when opportunity offers. I have often surprised them feasting on the bodies of their companions, and of about $40 \mathrm{imprisoned} \mathrm{together}$ in a box, at the end of a week but six were living. The heads, wings and legs of their dead (ompanions were all that remained to show that the wealicr had succumbed to the stronger-that the fittest, and 
in this case the fattest, had survived in the deadly struggle for existence.

The long winged form of abbreviatus is seemingly very scarce in this State, but one or two having been taken. There is little doubt but that Scudder is right in referring this form to Serville's luctuosus and placing it as a synonym of abbreviatus, as Serville states that the ovipositor of luctuosus is 9 to 10 lines in length, which is too great for pennsylvanicus of which McNeill thought luctuosus might be the long winged form. According to strict rules of nomenclature the name luctuosus rather than abbreviatus should belong to the insect since the former was described first in Serville's work. However, the short winged form seems to be everywhere the more common and better known, hence I follow Scudder in retaining the name abbreviatus. The range of the species covers the United States east of the Rocky Mountains.

136. Gryluds pennsylvanicus Burmeister. The Pennsylvania Field Cricket.

Gryllus pennsylemicus Burm , 40, II, 1838, 734; Scudd., 14 1, VII, 1862, 429; Id., 188, 1900, 90; Id.; 193, LX, 1901, 268, 269; Id., 194 , IX, 1902, 291; Glov., 62, 1872, Plate I, Figs. 13, 14; Sauss., 132, VI, 1874, 401; MeNeill, 88, VI, 1891, 4, 6; Bl., 12, VII, 1895, 250 ; Beut., 3, VI, 1894, 265, Plate V, Figs. 6, 7 ; Lugg.. 84, 1898, 264, Fig. 173 .

Gryllus luctuosus MeNeill, 88, VI, 1891, 4; Bl., 5, 1892, 133.

Acheta niger Harr., 72, 1862, 152.

Gryllus neglectus Scudd., 14 1, VII, 1862, 428; Id., 188, 1900, 89.

A medium sized but rather broad species; the head of male not so swollen as in abbreviatus, a little wider than the pronotum, shining black in color. Pronotum proportionally a little wider and shorter than in abbreviatus, the length contained in the breadth nearly 1.6 times, the hind margin a little sinuate, the median impressed line plainly visible on anterior half. The tegmina vary in color from a deep black to a smoky or grayish brown, rarely a dull reddish brown, often with a yellowish brown line along the humeral angle; the inner edges straight and overlapping or attingent their full length; those of female reaching nearly to tip of abdomen in short winged form, or slightly exceeding the tip in the long winged form; those of male reaching the tip of abdomen in both forms. Wings either narrow and shorter than tegmina or extending considerably beyond tegmina in the form of tail-like projections. Pronotum, legs, and under side of body in freshly matured specimens often with a minute grayish pubescence which becomes abraded with age, leaving these parts shining black. Hind femora short and stout, its average 
lenerth rontained in that of ovipositor 1.1 times. (Ovipositor always shorter than the body, its average length being 13.5 $\mathrm{mm}$.

Measurements: Length of body, male,

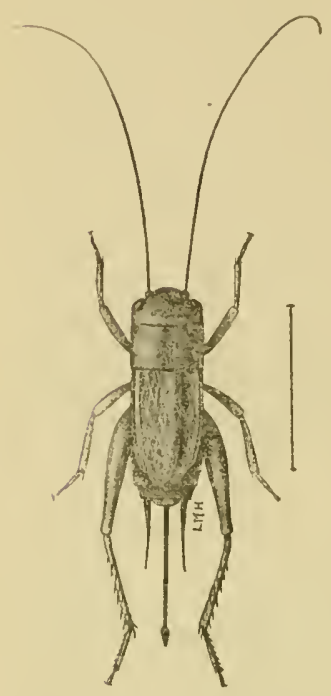

Fig.110. Gryllus pennsylvanicus (Burm.) Short-winged female. (After Lugger.) $1 \% .5$ ninı., female, $1 \% .1 \mathrm{~mm}$; of pronotum, male, $3.9 \mathrm{~mm}$., fenale, $4.2 \mathrm{~mm}$; of tegmina, male. 11.j mm., funale, short winged form. $10 \mathrm{~mm}$., long winged form, 1\%.1 mm.; of hind femora, male, $12.2 \mathrm{~mm}$., female, 12,1 $\mathrm{mm}$.; of ovipositor, $13.5 \mathrm{~mm}$.; width of pronotum, male and female, $6.3 \mathrm{~mm}$.

From abbrevialus this species may be distinguished by the shorter body, the less swollen head of male and especially by the short ovipositor, which in Indiana specimens ranges between 13 and $14 \mathrm{~mm}$. in length. The main distinguishing characters between pennsylianicus and americanus have been set out under the latter species. Another, very noticeablo in the field in the spring, is the dull grityish tinge of pennsytvanicus, especially on the legs and pronotum, the whole body of ameriranus being shining black.

The description of pennsyluanims by Bumeister is als follows: "Fine ahnliche Art (cir. pemsylranicus) findet sich in Nord-amerika; sie ist etwas kleiner, dic Flugeldecken kurzer als der Leib, ohne gelbe Basis, aber mit bramlicher Jauptlang-aker." 'This description is so short and rague that it jo imposible to ascertain from it just what species he har at hanel. Neither Saunsure nor Seudder seem to have seen Bumeister"s type. If so, they have made no record of the fact. Samssure in his latest palper, followed by MeNeill, has asserted his belief that pemsylyanicus is a short wingerl form of luchusus. Howerer, the measurements of body and ovipositor of hurtuosus as given by serville aguee so rosely with those of abluevialus that there can be no doulst of the two being the same. Tha existence of the long wingerl forms of both abbreviatus and the species I call pemsylranicus has dome much to add to the comfusion. I have therefore followed Sendiler. Bentrimiller and others in applying the name pennsylramirus to the folm at hand, though I have no dufinite means of knowing that it is the same insect as that to which Burmeister gave the name. Certain it is, however, that it is distinct from both americanus and abbrerialus described above. 
In Indiana pennsyleanicus, for the most part, survives the winter in the nymph stage, the young, on the approach of cold weather, making for themselves cone-shaped cavitics an inch or two across the top and about as deep, in the mold beneath decaying logs and rubbish. Sometimes the margins of these burrows are surrounded by fragments of grass stems and pieces of decaying leaves. In warm, sheltered localities, some individnals evidently reach maturity in late autumn or early winter; a full grown, freshly moulted female having been taken in a greenhouse in Marion County, on December 14th. The males begin to pass their final moult in central Indiana about May 15th, and from then on through June and July the open woods pastures and the angles of old rail fences echo with the music of their song. The young hatch in . July and Angust, and after the second or third moult form their winter abiding places, while the adults perish with the coming of the hoar frost.

Pennsylvanicus oceur's throughout the State and is said by Scudder to range across the continent. The long winged form is much less common than the short winged and is seldom met with in the field; but may often be found about electric ant other lights during the summer nights. Howerer; on two occasions in June, I have taken a long winged male in company with two short winged females beneath logs.

137. Gryulus Domesticus Limmaus. The House Cricket.

Gryllus (Achetu) domesticus L., 81, I, 1758, 428. Crryllus domesticus Glov., 62, 1872, Plate VI, Fig. 14; Sauss., 132, VI, 1874, 400; Riley, 122, II, 1884, 181; Bent., 3, VI, 1894, 266, Plate V, Fig. 8; Marlatt, 85, 1896, 52, Fig. 20; Lugg., 84, 1898, 266, Fig. 176; Scudd., 188, 1900, 89; Id., 194 , IX, 1902, 291, 294.

Pale yellowish brown or straw color; the head with a dark reddish brown bar on oeciput just in front of pronotum; another between the upper portions of eyes; a third between the bases of the antemnx and a fourth across the labrum, the lower two sometimes united. Pronotum with four or five irregular shaped spots of reddish brown on its dorsal surface, and a narrow bar of the same color on each side; the

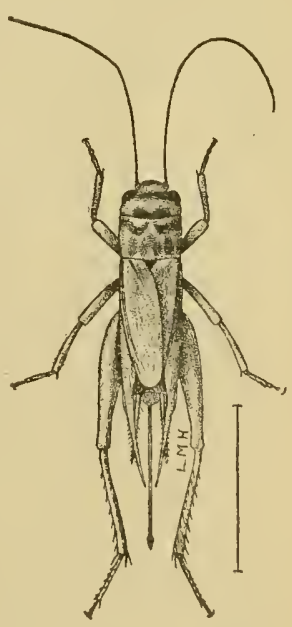

Fig. 111. Gryltus domesticus L. Female. (After Lugger.) posterior margin a little convex. 'Tegmina reaching nearly or quite to the end of abdomen; sometimes with a reddish brown spot on 
their basal third. Juner wings either short and covered by, or extending considerably beyond, the tegmina. Hind femora short and rather slender. Ovipositor one-fifth longer than hind femora, pale brown except the tip, which is darker.

Measurements: Length of body, male, $16.5 \mathrm{~mm}$., female, $15 \mathrm{~mm}$; of pronotum, male and female, $3.5 \mathrm{~mm}$; of tegmina, male and female, $11 \mathrm{~mm}$; of hind femora, male and female, $10 \mathrm{~mm}$; of ovipositor, $12 \mathrm{~mm}$. Width of pronotum, $4.5 \mathrm{~mm}$.

The "house cricket," or "cricket of the hearth," is scarce in Indiana. Until Jamuary 1, 1903. I had in my collection but three specimens, two long winged males and a short winged female, taken by $\mathrm{H}$. McIlroy from beneath rubbish in a gravel pit near West Terre Haute, Vigo County, in October, 1S94. On the date mentioned I secured a dozen or more adults and nymphs in a greenhouse belonging to W. J. Hasselman, situated just north of the city of Indianapolis. The proprietor informs me that the males utter their call note throughout the winter, and that the insect is seemingly most abundant at that season. It is an Old World insect which has been introduced into this country, and occurs sparingly in most of the States east of the Rocky Mountains. Seudder states that he has seen no short winged specimens from the United States though they are common in Europe. The insect is probably less abundant in Indiana than it was a half century ago, when log houses and old fashioned brick and stone fireplaces were most in vogue. Domesticus has also been noted in Putnam County by J. S. Michacls. It is probable that in many instances the so-called "house crickets" of the present country homes are field crickets, especially $G$. abbreviatus, which have striven to prolong their existence by seeking shelter within the domiciles of man.

Marlatt, loc. cit., has given the following pleasing account of the habits of this house cricket: "In Europe, and in some parts of the United States, no insect inhabitants of dwellings are better known than these domestic or house crickets, not so much from observation of the insects themselves as from familiarity with their vibrant, shrilling song notes. These notes, while thoroughly inharmonious in themselves, are, partly from the difficulty in locating the songster, often given a superstitious significance and taken, according to the mood of the listener, to be either a harbinger of good and indicative of cheerfulness and plenty, or to give rise to melancholy and to betoken misfortune. 'The former idea prevails, however, and Cowper expresses the common bulief that the-

“. 'somnds inharmonious in themselves and harsh, Yet heirll in seones whore peace forever reigns, And only there, please highly for their sake.' 
"The house cricket usually occurs on the ground floor of dwellings and evinces its liking for warmth by often occurring in the vicinity of fireplaces, concealing itself between the bricks of chimneys or behind baseboards, frequently burrowing into the mortar of walls. It is particularly apt to abound in bakehouses. It is rarely very abundant but at times multiplies excessively and becomes a very serious nuisance. During cold weather or in cold rooms in winter, it remains torpid, but under the influence of warmth it becomes active and musical. It is easily kept in captivity as a pet, and will reward the possessor by furnishing an abundance of its peculiar melody, and in Spain it is often kept, it is reported, in eages, as we do singing birds. It is in the main nocturnal in its habits, coming out in the dusk of the evening and roaming about the house for whatever food materials it may discover. It feeds readily on bread crumbs or almost any food product to which it can get access, and is particularly attracted to liquids, in its eagerness to get at which it often meets death by drowning. It is a very pugnacious insect and will bite vigorously if captured, and is often predaceous or carnivorous, like most of its outdoor allies. It is supposed to feed on various other house insects, such as the cockroach and is also probably cannibalistic. A pair of native species liept in a cage by the writer, for a short period manifested the greatest friendliness, but the male shortly afterwards made a very substantial meal of his companion.

"These Crickets, in common with most other Orthoptera, will oceasionally in pure wantonness seemingly, cut and injure fabrics, and are particularly apt to eut into wet clothing, evidently from their liking for moisture. Any of the common field grasshoppers or erickets, entering houses, are apt to try their sharp jaws on curtains, garments, etc., and Dr. J. A. Lintner records the case of a suit of clothing just from the tailor which was completely ruined in a night by common black field crickets (Gryllus luctuosus), which had entered an open window in some numbers. There is a popular superstition also to the effect that if a cricket be killed its relatives will promptly ent the garments of the offender.

"The house cricket may be readily destroyed by taking advantage of its liking for liquids, and any vessel containing beer or other liquid placed about will usually result in crickets being collected and drowned in numbers. It may also be destroyed by the distribution of uncooked vegetables, such as ground up carrots or potatoes, strongly poisoned with arsenic. In the use of poisoned baits in dwellings great care, however, should always be excreised." 


\section{Mlogirlutis Sallssure (187\%).}

Areording to Scudter, thi-genus is distinguished from Gryllus by the much smaller size of its representatives, which approximate those of Nemobius in length; in the absence or extremely inconspicuous nature of the loaring organ on the inner side of the fore tibix; in the unbranched or one-bramched mediastinal nerve of the tegmina: in the strictly longitudinal course of the veins on the dorsal field of the female tegmina; in the shortness of the hind tibix which are only two-thirds as long as the hind femora and armed on each side with only four or five spines, and in the striped or banded summit of the head.

Five species of the genus are known to oceur in the United States. of these, one has been found in southern Indiana.

138. Miogr yluus saussurei (Scudder).

Gryllns soussumi Scudd., 160, XIX, 187т, 35; Id., 161 , VI, 1878, 13; Id., $188,1900,90$.

Miogryllus sutsurei Scudd, 192, IX, 1901, 257.

Head rather large, shining black except a yellowish white line on each side of the eyes, extending back to the pronotum; that on the

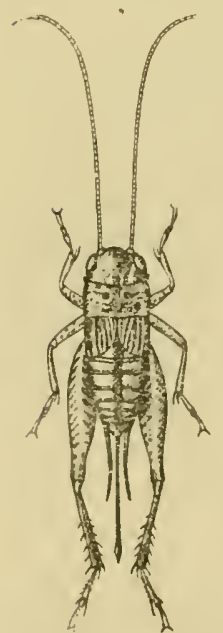

Fig. 112. Miogryllus sausurei (Seudd.) Female. One and one-third times natural size. (Original.) onter sile double the width of the other; in most -pecimens two short whitish lines between these on the occipnt. Palpi yellowish, the apical joint sometimes darker. Antenna dark brown. paler at base. J'ronotmu broader than long, slightly narrow slichtly (oncave, the posterior straight; blackish, laintly mottled with yetlowish brows, the front margin sometines faintly elged with the same: the lower half of the deflected lobes pale yellow solged rejy narrowly below with black. the upper half of the lobes darker than the upper surface and uniform; front and hind margins with a few curved black hristles. 'Tegmina of the female but little longer than the pronotum, covering about one-third of the ablomen; those of the male corering two-thirds of the abdomen; reddish brown or blackish in color, the humeral angle black; the longitudinal veins and marginal area often paler. Wings almost wanting. Legs either yellowish brown or blackish. Hearing organ on the fore tibix fully one-third the length of the tibia on its outer face; wanting on its 
inner face. Abdomen black, with a lighter brown lengthwise band on each side of its dorsal surface. Ovipositor equaling the hind femora in length, yellowish brown in color, the apex darker.

Measurements: Length of body, male, $11.5 \mathrm{~mm}$., femalc, $14 \mathrm{~mm}$; of pronotum, male and female, $3 \mathrm{~mm}$.; of tegmina, male, $4.5 \mathrm{~mm}$., female, $3.5 \mathrm{~mm}$; of hind femora, male and female, $9.5 \mathrm{~mm}$.; of hind tibix, male and female, $6 \mathrm{~mm}$; of ovipositor, $9.5 \mathrm{~nm}$.

This speeies, resembling in general-appearance a large Nemobius, has been taken only in Knox, Gibson and Crawford counties, where it occurs on dry wooded hillsides beneath flat stones and logs. It seems to like best places devoid of grass and other vegetation. In southern Indiana it probably reaches maturity about the middle of June, as it seems to be most abundant by the last of that month. Quite a number of specimens were taken in the vicinity of Wyandotte Cave in 1902. It is a sonthern species which has heretofore been recorded only from Georgia and Florida, and it will therefore probably be found only in the southern third of Indiana.

\section{Sub-family OECANTHINA.}

This sub-family comprises the slender bodied ivory or greenish white'tree crickets. Our Indiana species have the pronotum elongated and narrow, its sides deflexed, the posterior margin somewhat broader than the anterior. The wing covers of the male are flattened, semi-transparent, rather firm in texture and much broader than the body. Those of the female are wrapped close about the body, causing such a difference of appearance between the two sexes that collectors often take them for widely different species. The hind femora are weak and slender. The tibix, in our most common species, are armed with delicate spines between which are minute teeth, visible only under a lens. The tarsi are four-jointed, elongated and compressed, the second joint being very small and compressed. The ovipositor is straight and shorter than the hind femora; its apex a little enlarged and rather blunt.

All our species are strictly arboreal, living mainly on vines, shrubbery and the taller herbaceous plants. They especially frequent the various species of golden-rod and wild sunflowers, and often three or four can be found on a single one of these plants. For the most part they remain quiescent during the day, but are quite active at night.

Scudder recognizes but one gemus, QEcanthus, as belonging to our fanna. One species, however, has no spines on the hind tibix, and since the presence or absence of these spines is deemed of sufficient importance to be used as one of the principal characters in separat- 
ing the sub-families, it is surely of generic value. I therefore separate our species into two genera, which niay be distingnished as follows:

\section{KEY TO GEXERA OF INUINA GEANTHINE.}

a. Hind tibia armed with weak spines, and small teeth between the spines; first joint of antenne smootln; inner wings but little, if any longer than the tegmina.............. IVIII. Gcantius, p. 44

aa. IIind tibia unarmed; first joint of the antemle armed with a stout, blunt tooth in front; inner wings nearly twice as long as the tegmina ........................................ p. 453

\section{Ecanthus Serville (1831).}

The main characters of this genus have been given under the subfamily heading and in the above key. The tegmina of the female are regularly reticulated, with the oblique longitudinal veins plainly visible. 'The mediastinal vein of the male tegmina is not strongly' bowed, and the humeral angle is distinct. The tarsi are imperfectly four-jointed, the division between the third and fourth joints being visible, but the fourth joint is seldom movable by itself. The name CEcanthus, signifying "I dwell in the flowers," is not always true as the insects are as often found upon the foliage of plants as in the flowers proper. Five species occur in Indiana and may be separated by the following table:

KEY TO INDIANA SPECIES OF ECANTIIUS.

a. Antenna without black marks on the under side of the first two joints; tegmina of male more than half as broad as long; front of head and basal joints of antemnie usually pinkish............

139 latipemis, p. 445

aa. Anteuna with one or more black marks or spots on the under side of the first two joints; tegmina of male less than half as broad as long; front of head and basal antenual joints never pinkish.

b. Antenna with but one black mark on each of the two basal joints.

c. Black marks on antenus: in the form of small rounded dots ............................... 440 niveus, p. 446

ce. Mark on first joint of anteunse. long aud hooked at base, that on the second joint oblong; wing covers of male nurowel and tibial spines weaker than in niveus.......

141 angustipennis, p. 450

b). Anteuna eitlee wholly black or with two black marks on each of the two hasal joints.

d. Head and thor:ax, either black or trifasciate with black; antenne usmally black; when pale, the marks on first

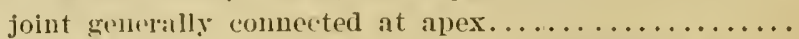


dd. Wholly pale greenish or yellowish, translucent; marks on

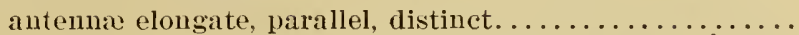

143 quadripunctatus, p. 452

139. CEcanthus Latipennis Riley. The Broad-winged Tree Cricket.

Tecanthus latipennis Riley, 12 1, 1881, 61 ; Ir., 122, II, 1884, 182; Brun., 23, 1888, 120, Fig. 39; Id., 32, 1895, 69, 113, Fig. 40; McNeill, 88, VI, 1891, 6; Hart, 73, III, 1892, 33, Fig. 6; Beut., 3, VI, 1894, 272; Lugg., 84, 1898, 273, Fig. 184; Scudd., 188, 1900, 90.

Size, large. Color of male greenish white; of female, pale yellowish green. Antennæ with basal joints destitute of black markings; these joints and top of head usually roseate or pinkish. Tip of ovipositor dark. Tegmina of male, when unfolded, four-fifths as wide as long, much wider than in any other species. Inner wings of male shorter than tegmina; those of female equaling or slightly exceeding the tegmina.

Measurements: Length of body, male and female, $12.5 \mathrm{~mm}$; of pronotum, male and female, $3.1 \mathrm{~mm}$; of tegmina, male, $15 \mathrm{~mm}$., female, $14.5 \mathrm{~mm}$; of inner wings, male, $12 \mathrm{~mm}$., female, $15 \mathrm{~mm}$; of hind femora, male and female, $10 \mathrm{~mm}$; of ovipositor, 6.5

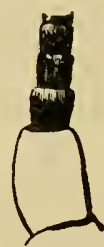

Fig. 113. Four basal joints of antennæ of Ecan$t h u s$ latipennis Riley. (A f ter Lugger). $\mathrm{mm}$. Width of dorsal surface of tegmina of male, $7.5 \mathrm{~mm}$.

This species has been taken only in Vigo and Putnam counties, but probably occurs in all parts of the State, as its range covers the United States east of the Great Plains. It lives mainly on shrubs and vines along the borders of thickets and fence rows, and with us is most abundant from Angust 10th to October 1st.

The eggs of the broad-winged tree cricket are laid in the pith of the smaller twigs of shrubs and vines, preferably in the slender twigs of the wild and cultivated grapes. Dr. Riley has described the method of oviposition as follows: "The jaws are first used to slightly tear the outer bark. With the antennæ stretched straight forward and the abdomen bent up so as to bring the ovipositor at right angles with the cane, the female then commences drilling, working the abdomen convulsively up and down about twice each second. T'he eggs are laid lengthwisc in the pith, but always in two sets, one on each side of the hole. The number varics according to the size of the cane, and the distance between the holes is also variable. The hole is usually filled up with a white mucous secretion, though there is very little of it about the eggs. This secretion also doubtless serves to facilitate the drilling. The same female will lay over $200 \mathrm{eggs}$, and will sometimes puncture the same cane at intervals of one-third of an inch for one and a half feet or more." 
The day note of the male of Talipennis is louder than that of any other species. I have hearl it when fio feet distant; have traced it up, and found the musician beneath a leaf or on a post in the angle of a rail fence, industriously sounding his cymbals. The note is kept up for 20 to 30 seconds, and is then succeeded by a pause of about five seconds, when it is begrm once more. Jr. Riley has written of it, probably of the night song: "The shrill of latipennis is continuous and recalls the trilling of a high-pitched dog-whistle in the distance. The key raries, however, and is sometimes much less high and more musical than at others. The commingled shrill of this species recalls also the distant croaking of frogs in spring. The broad wings are thoronghly elevated during the act, or even bent forward, and the vibration is so rapid that there appears to be no motion."

140. Cecanthus niveus (De Geer). The Snowy Tree Cricket. Gryllus niwes De G., 57, III, 1773, 522, Plate 43, Fig. 6.

(Eronthus niven: Fitch., 56, XVI, 1856, 404; Harr., 72, 1862, 154, Figs. 71, 72; Scudd., 141 , VII, 1862, 431; Id., 148, 1874, 365 (note of set to music); Id., 168, XXII, 1893, Figs. 65, 66; Id., 188 , 1900, 91; Rathv., 109, 1862, 381, Figs. 17, 18; Walsh., 220, I, 1866, 126; Ir., 221 , II, 1867, 54, 94; Riley, 113 , I, 1S69, 138, Figs. 77, 78; Id., 114, V, 1873, 120, Fig. 49; Id., 121 , VI, 1881, 60; Id., 122, II, 1884, 182, Figs. 256, 257; Glov., 62, 1872, Plate IV, Figs. 1, 2; I1., 63, 1874, 143, Fig. 16; Pack., 104, 1883, 5fit, Figs. 561, 562; Id., 107, V, 1890, 230, 591, Figs. 75, 76; Feru., 53, 1888, 17, Figs. 7, 8, 9; Comst., 4 1, I, 1888, 122, Figs. 109, 110; Murtf., 103, II, 1889, 130; McNeill, 88, VI, 1891, 6; Bl., 5, 1s92, 141 ; Il., 16, 1s99, 229, Figs. 57, 58; Hart, 73, UI, 1s92, 33), Fig. 4; Bent., 3, VI, 1894, 269, Plate V, Figs. 12, 13; Bruu., 32, 1895, 110, Figs. 37-39; Id., 35, 1899, 133, Figs. 48, 49; Lugg., 84, 1898, 269, Figs. 177, 178.

both sexes of this specie's are in color ivory white, more or less tinged with a delicate green, especially in the female. The top of head and balal joint of antenne are sometimes suf-

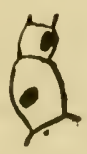

Fig. 114. Basal joints of antennie of Weanthus niveus (1)e(i.) fused with ochre yellow, while on the lower face of cach of the two basal joints of the antenna is a small round black spot. The tegmina are almost twice as long as the aldomen and the imner wings equal or slightly exeed them in length. The oripositor of the female is short, perfectly straight and usually tipped with black. 'The maxillary palpi are longer in this than in any other species of the genns. and the wing covers of the male are broaker in proportion to their length than in any other except. O. latipennis, when $\mathrm{m}$ folded being two-thirds as wide as long. 
Measurements: Male-Length of body, $12 \mathrm{~mm}$; of wing covers, $12.5 \mathrm{~mm}$.; of hind femora, $8.5 \mathrm{~mm}$.; width of wing covers, $5.5 \mathrm{~mm}$. Female-Length of body, $14.5 \mathrm{~mm}$.; of wing covers, $14 \mathrm{~mm}$.; of hind femora, $10 \mathrm{~mm}$.; of ovipositor, $5.5 \mathrm{~mm}$.
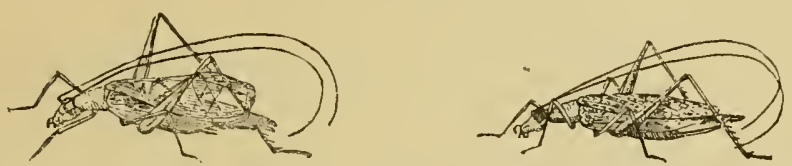

Fig. 115. Ecanthus nivens (DeG.) Male and female. (After Beutenmüller).

While the snowy tree cricket occurs in all parts of Indiana, it appears to be less common in the State than cither $O$. fasciatus or $O$. quadripunclatus, and much of the published literature relating to it has doubtless been of these two species, especially the latter. Like the other members of its genus nireus reaches maturity in southern Indiana about July 1 st, and in the central part a fortnight later, and exists in that stage until aftrr heary frosts. In the writer's experience, the females are more plentiful than the males, the latter being more often heard than seen. During the day they keep themselves hidden among the foliage and flowers of various plants, but as night approaches they come forth and the male begins his incessant, shrill, chirping note, which he continues with little or no intermission till the approach of morning warns him to desist. Professor McNeill, loc. cit., has given an excellent description of the songs of the different species of Ecanthus. "That of nireus," he says, "is the wellknown $t-r-r-r-e-e, t-r-r-r-c-e$, repeated without pause or variation about seventy times in a minute. It is heard only at night and occasionally on cloudy days, but in the latter ease it is only an isolated song, and never the full chorus of the night song produced by many wings whose vibrations in exact unison produces that characteristic 'rhythmic beat.' as Burroughs has happily phrased it."

Fitch, writing of the note of the same insect in New York, has said: "In the southern part of our State the song of the snowy tree cricket begins to be heard as early as the first of August. Perched among the thick foliage of a grapevine or other shrubbery, some feet up from the ground, and remaining in the same spot day after day, its song begins soon after sunset and before the duskiness of twilight arrives. It is distinctly heard at a distance of several rods, and the songster is always farther off than is supposed. Though dozens of other crickets and katydids are shrilling on every side at the same time, the peculiar note of this cricket is at once distinguished from all the rest, consisting of repetitions of a single syllable, slowly ut- 
tered, in a monotonous, melancholy tone, with a slight pause between. The ehildren regard the cricket as no votary of the temperance cause; they understand its song to consist of the words treal, -treat-treat-treat, which words, slowly uttered, do so closely resemble its notes that they will at once recall them to the recollection of almost every reader. And the song is thus continued without the slightest variation and without any cessation, I think, the whole night through. I, however, have sometimes heard it at the first commencement of its evening serenade uttering three syllables resembling the words treat, lreat, two; treat, treat, two-as though the songster was supplicating a libation for his voiceless mate as well

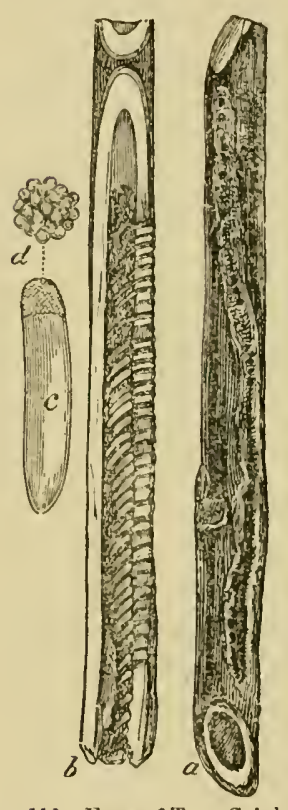

Fig. 116. Eggs of Tree Cricket in raspberry cane.

(a) Cane, showing puneture.

(b) Cane split to show eggs.

(c) Egg enlarged.

(d) Cap of egg enlarged. (After Riley.) as himself-a longer pause following each third note. This prelude is probably performed in limbering or otherwise adjusting his organs, preparatory to performing the regular carol, which is struck into in a few moments."

The females do much harm by ovipositing in the tender canes or shoots of various cultivated fruits, as the raspberry, blackberry, grape, plum, peach, etc.; no less than 321 eggs, by actual count, having been found in a raspberry cane 22 inches in length. So partial is it to the stems of raspberry and blackberry as receptacles for its eggs that in some localities scarcely a cane escapes without being more or less damaged. The eggs are laid in autumn, and at first the injury is shown only by a slight roughness of the bark, but afterwards the cane or branch frequently dies above the puncture, or is so much injured as to be broken off by the first high wind. If the injured and broken canes containing the eggs be collected and burned in early spring the number of insects for that season will be materially lessened.

Professor Bruner, loc. cit., has written of its habits of oviposition in other plants as follows: "In addition to sultivated fruits the snowy tree cricket also deposits its eggs in the stems of a large variety of other plants and trees-the main requirements being a soft fibre and pithy interior to the twigs selected. Among the trees the white willow suffers most. I have seen hedges of this tree so com- 
pletely utilized that scarcely a twig escaped being deposited into. Other species of willow, cottonwood, elm, maple, box elder, cherry, dog-wood, black locust, sycamore, ash, honey-locust, and in fact almost all kinds of trees, are sometimes attacked. Elder is a great favorite, too. After these come weeds, as the artichoke, sunflower, golden-rod, ambrosia, and many others. All of these latter being annuals, or dying to the ground each year, whether attacked by the cricket or not, the conclusion is plain. All the cricket requires is a receptacle for her eggs. It matters but little whether a dead or a living plant furnishes that condition.

"In the case of the honey locust, the thorns as a rule receive the eggs instead of the twigs, and no apparent damage is done. The mature crickets are also said to be met with abundantly upon oaks, hickories, and elms during the egg-laying season, and evidently use these also occasionally for the deposition of their eggs, although I have never obtained or noticed the eggs in the twigs of these trees.

"While woody plants are known to be very commonly used as receptacles for the eggs of this ericket, it is by far the most numerous upon such weeds as those mentioned above during its entire career; but more particularly so during its latter days when looking after the perpetuation of its kind."

Niveus, however, in part, if not wholly, offsets its injurious habit by its carnivorous propensities, as the young which hatch in May or early June, feed, until they reach maturity, upon the various species of aphids or plant lice which infest the shrubbery they frequent. Mr. B. D. Walsh, loc. cit., was the first entomologist to call attention to this carnivorous habit, but it seems little attention was given to the matter. Recently, however, it has again attracted notice, and in Insect Life for November, 1891, Miss Mary E. Murtfeldt, of St. Louis, Missouri, gave an interesting account of some experiments and observations concerning this habit from which the following extract is taken: "Some leaves of plum infested with a delicate species of yellow aphis were put into a jar with the young of $E$ canthus niveus, but attracted no immediate attention. As twilight deepened, however, the crickets awakened to greater activity. By holding the jar against the light of the window, or bringing it suddenly into the lamplight, the little nocturnal hunters might be seen hurrying with a furtive, darting movement, over the leaves and stems, the head bent down, the antennæ stretched forward, and every sense apparently on the alert. Then the aphids provided for their food would be caught up one after another with eagerness and devoured with violent action of the mouth parts, the antennæ meanwhile play- 
ing up and down in evident expression of satisfaction. Unless I had provided very liberally not an aphis would be found in the jar the next morning and the sluggish erickets would have every appearance of plethora."

141. CEcastius angustipexwis Fitch, The Narrow-winged Tree Cricket. Wicunthes angustiprenis Fitch, 56, XVI, 1856, 404; McNeill, 88, VI, 1891, 8; B1., 5, 1892, 143 (in part); Hart, 73, III, 1892, 33, Fig. 5; Acudd., 168, XXIII, 1893, 67; Ir., 188, 1900, 90; Bent., 3, VI, 1894, 251, 270, Tig. 3; Bru1., 32, 1895, 113; Lugg., 84, 1898, 271, Fig., 179.

Pale greenish white, each of the first two basal joints of the antenne with a black mark, that on the first joint being clongate and hooked inwards at the base; the mark on second joint oblong, slightly curved. Head smaller and pronotum narrower

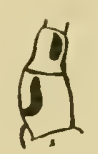

Fig. 117. Basal joints of antennæ of (Eicanthus angustipennis Fitch. anteriorly than in nivcus. Tegmina narrower than in any other species except quadripunctatus. Inner wings slightly surpassing the tegmina in length.

Measurements: Length of body, male, 12 'mm., female, $11.5 \mathrm{~mm}$.; of pronotum, male and female, 2.75 mm. ; of tegmina, male and female, $12 \mathrm{~mm}$; of inner wings, male and female, $13.5 \mathrm{~mm}$; of hind femora, male and female, 8.5 mm.; of ovipositor, $5.5 \mathrm{~mm}$.

The narrow winged tree cricket is not a common insect in Indiana, having so far been taken only in Vigo, Putnam and Crawford counties. It frequents the borders of groves and especially ironweeds in open woods pastures and reaches maturity about July 15th. Scudder gives its range as "New York to Kentucky and Nebraska."

The note of anguslipenuis is fainter than that of niveus and may be represented by receccé, lasting about five seconds, and terminating abruptly, with an equal interval of rest. It usually sings at night only, but sometimes also late in the afternoon in shady places, and on cloudy days.

142. CEcantints Fasciatus Fitch. The Striped Tree Cricket.

(Errenthus fusciutus Fitch. 56, XVT, 1si,6, 414; McNeill, 88, VI, 1891, 6; B1., 5, 1892, 143; Hart, 73, III, 1892, 33, Fig. 1; Scudd., 168, XXIII, 1893, 66; Id. 188, 1900, 90; Brun., 32, 1895, 69, 113; Lugg., 84, 1898, 271, Figs., 180-182.

Fenthus nigpirmenis Walk., 219 , I, 1869, 93; Sauss., 132, VI, 1874, 461 ; Bent., 3, VT, 1894, 250, 270, Fig. 4; Scudd., $188,1900,90$.

Greenish yellow: the head and pronotum either wholly black or with three nore or less ristinct lengthwise black bars. Legs yellow- 
ish with a blackish tinge or wholly black. Body black beneath, yellowish green above. Antenna longer than in other species, often two

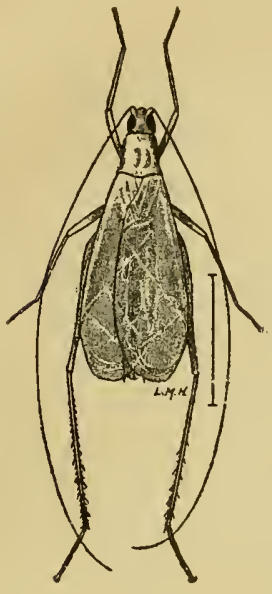

Male.

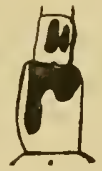

Fig. 119. Basal joints of antennas of Ecanthus fasciutus Fitch.

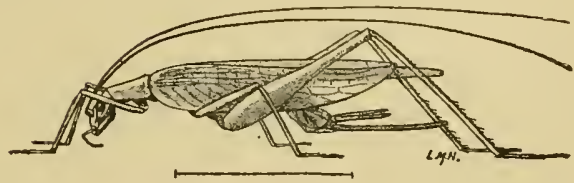

Female.

Fig. 118. QEeanthus fasciatus Fitch. (After Lugger).

and a half times the length of body, either wholly black or with two black marks on each of the two basal joints; the imnermost mark on the first joint twice the length of the other, the two often united at the upper ends. Tegmina slightly narrower than those of niveus. Inner wings equaling or extending a little beyond the tegmina. Spines at apex of posterior tibie stronger and more acute than in allied species. Ovipositor with its apical third slightly but distinctly upcurved.

Measurements: Length of body, male, $12.5 \mathrm{~mm}$., female, $12 \mathrm{~mm}$; of pronotum, male and fcmale, $3 \mathrm{~mm}$.; of tegmina, male and female, $12 \mathrm{~mm}$; of inner wings, male and female, 13.2.; of hind femora, male, $10 \mathrm{~mm}$., female, $9.2 \mathrm{~mm}$; of ovipositor, $5.7 \mathrm{~mm}$. Width of tegmina, male, $5 \mathrm{~mm}$.

The striped tree cricket is the most common member of its kind in Indiana. In August and September, nearly every stalk of goldenrod and wild sunflower along roadsides. in open fields or in fence corners, will have from one to a half dozen of these insects upon its flowers or branches. It is also especially abundant upon the tall weeds and bushes along the borders of lakes and ponds, and in sloughs and damp ravines.

The note of fascialus is a shrill continuous whi-r-r-r-r which is kept up for several minutes with the intervals of irregnlar length. 
It is continued for most of the night and on cloudy days. When the sun is shining brightly it usually begins about mid-afternoon and continues with but little pause until the dawn of the next day, unless the caller is, in the meantime, successful in wooing with his music one of the opposite sex within reaching distance.

On September 18, 1898, I was in late afternoon in a wet prairie near Hammond, Indiana, where $O$. fasciatus was more than usually abundant on clumps of wild sunflower. $\Lambda$ half dozen or more pairs were seen in copulation. In this act it seems that the female mounts the body of the male, the latter first raising the tegmina until they stand at an angle of about 45 degrees, so as to give the female access to a pair of glands which lie immediately beneath the base of wings. The female worked at these glands with her mandibles, the male meantime moving the inner wings gently sideways, in and out. After working over the glands for ten or fifteen minutes, the female would usually leave the body of the male and erawl onto an adjacent head of the sunflowers. The male meantime kept the tegmina raised, seemingly in waiting for her return, which was always at the end of five or six minutes. During the process, no intromittent organ of the male was noticeable, nor was any union of the parts at the end of the abdomen seen. Is it possible that in the mating of these Ecanthids the female removes the semen from the glands whose openings are beneath the tegmina of the male, and then fertilizes her ova?

143. Ecanthus quadripuxctatus Beutenmüller. The Four-spotted Tree Cricket.

Ecanthus quadripunctutus Bent., 2, VI, 1994, 250; Id., 3, 271, Fig. 5; Scudd., 188, 1900, 91 .

Eecenthus fasciatus Hart., 73, III, 1892, 33 (text in part), Fig. 2; Lugg., $84,1898,272$, Fig. 183 (text in part).

Males, greenish white. females yellowish green, in color. Antenne light brown, the basal joints pale green with two black marks on cach; those on the second joint oblong, parallel, the inner about double the length of the outer; the inner mark on lower or basal joint, two-thirds the length of the joint, its upper end curved outward, but not united with the onter mark, which is short and almost round. Wing covers a little narrower than in fasciatus, the inner wings protruding slightly beyoud their tips.

Measurements: Iength of body, male and female, $11.5 \mathrm{~mm}$.; of pronotum, $2.6 \mathrm{~mm}$.; of tegmina, male, $12 \mathrm{~mm}$., female, $10.5 \mathrm{~mm}$; of inner wings, male, $13.5 \mathrm{~mm}$., female, $12.5 \mathrm{~mm}$.: of hind femora, male 
and female, $8.2 \mathrm{~mm}$.; of ovipositor, $5.5 \mathrm{~mm}$. Width of tegmina, male, $4.7 \mathrm{~mm}$.

This is, next to fasciatus, the most common Ecanthus in central and southern Indiana. Specimens are before me from Vigo, Putnam, Marion, Floyd, Crawford and Posey counties. It frequents shrubbery and weeds in fence rows and gardens, and along roadsides; and while often found in company with fasciatus, has never been seen mating with that species. A female was taken in Crawford County on June 28th, an early date for a mature tree cricket. Scudder gives its range as "New York to Indiana." I have specimens from Agricultural College, Mississippi, and from Sherborn, Mas-

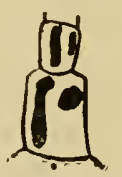

Fig. 120. Basal joints of antenna of Ecanthus quadripunctatus Beut. sachusetts, and have also found it abundant on the north shore of the Niagara River, opposite Buffalo, New York, where it was the only species present on September 4th.

\section{XABEA Walker (1869).}

The members of this genus may be known from those of $\mathscr{E}$ canthus by the following characters: The first joint of antennæ is armed on its under side with a stout blunt tooth. The tegmina of female are irregularly reticulated, the oblique longitudinal veins not being conspicuous; male tegmina with the mediastinal vein strongly arcuated; the humeral angle wanting. Inner wings nearly twice as long as the tegmina. Hind tibiæ with neither spines nor serrations, armed with only four apical spurs, two within and two without. First joint of posterior tarsi unarmed, the tarsi clearly but three-jointed, the second joint very short.

But one species of Xabea is known from the United States, occurring over most of the region east of the Great Plains.

144. Xabea bipunctata (De Geer). The Two-Spotted Tree Cricket.

Gryllus bipunctetus De G., 5 7, 1773, 523, Plate 43, Fig. 7; Burm., 40, II, $1838,732$.

Ecctuthus bipunctatus Serv., 197, XXII, 1831, 135; Glov., 62, 1872, Plate IV, Figs. 5, 6; Sauss., 132, VI, 1874, 458, 462; McNeill, 88, VI, 1891, 9; Hart, 73, III, 1892, 33, Fig. 3; Scudd., 188, 1900, 90.

Xubea bipunctata Riley, 12 1, VI, 1881, 61; Beut., 3, VI, 1894, 272, Plate V, Fig. 14.

Ecanthus punctulatus Fitch, 56, XVI, 1856, 415.

Pale pinkish brown, the tegmina of female with two rather large blackish spots, one near the base, the other at the center. Basal joints of antennæ without black marks, but with the scape of the 
first joint prolonged beneatl, forming an acute blackish tooth. Inner wings much produced beyond the tegmina. Legs pale with a pinkish hue.

Measurements: Length of body, male and female, $13 \mathrm{~mm}$; of pronotum, $3.3 \mathrm{~mm}$.; of tegmina, $11 \mathrm{~mm}$; of inner wings, $20 \mathrm{~mm}$.; of hind femora, $9 \mathrm{~mm}$.; of ovipositor, $6 \mathrm{~mm}$.

This tree cricket is readily recognized by its unarmed hind tibiæ, pinkish brown color, long inner wings and dark spots on female tegmina. It is scarce in Indianta, having as yet been taken only in Vigo County, though it will doubtless be found to occur throughout the State. So far an linown, its habits are the same as those of the more common species of dicanthus.

\section{Sub-family TRIGONIDIIN AE.}

The Indiana members of this sub-family are among the smallest of our native Gryllidx. They are distinguished mainly by the different character of the second tarsal joint, which is depressed and heartshaped, instead of compressed, as in the preceding sub-families. The tympanum or shrilling organ of the male is more simple than in other species, being dividerl by a single oblique vein. The hind tibiæ have no serrations between the spines and bear but two apical spurs on the inner side. 'The ovipositor resembles that of some of the Locustidæ in being short, compressed and saber-like.

Three genera represent the sub-family in the United States. Of these two occur in Indiana.

KEY TO GENERA OF INIIANA TRIGONIDITNA.

a. Last joint of maxillary palpus (chl) shaped; basal joint of antenne sub-depressed, lather lilrge............... AxAxipia, p. 454

(u. Last joint of maxillary palpus very broad, spoon-like; basal joint of antemur narow. minute ........... Lxi. Pirlloscritus, p. 456

\section{JaX. ANaxipha Salusure (1874).}

The members of this genus resemble those of Nemobius in form of borly, breadth of lead. etc., but the females are readily distinguished by the compressed and strongly upenrrerl ovipositor. The antenna are rery long and setaceous. the first joint being rather large and a little flattened. Ocelli present, but small and arranged in a triangle. Maxillary palpi rather long: the last joint dilated in the form of a fumel. 'Tegmini of male almost encasing the abdomen. the speculum or round glassy spot on their apical half prominent and undi- 
vided by a cross nerve; imner wings absent. Hind tibire armed with three pairs of slender spines, of equal length. One species oecurs in the United States, ranging from New York to Texas.

145. Anaxipha exigua ('jay).

Achetr exigur Say, 138, IV, 1825, 309; Id., 139 , II, 1859, 238.

Nemobius exiguu. Sauss., 132, VI, 1874, 391.

Anctiplue exigun Scudd, 162, XIX, 1877, 82; Irl., 168, XXIII, 1893, 67; Id., 188, 1900, 91 ; Beut., 3, VI, 1894, 268.

Gryllus pulicarius Burm., 40, II, 1838, 732.

Anaxiphe pulicerie Sauss., 132, VI, 1874, 371, Plate 7, Fig. 1; Id., 133, II, 1878, 615.

Anaxiplus pulicarius Bl., 5, 1892, 137; Lugg., 84, 1898, 274, Fig. 185.

Head and pronotum dark reddish brown, sparsely covered with long hairs. Tegmina and legs light brown, the former reaching the end of the abdomen in the male, shorter in the female. Abdomen of male blackish; of female pale brown, darker on the sides. Ovipositor dark brown, paler at tip. Cerci very long and slender, elothed with long yellow hairs.

Measurements: Length of body, male, $6 \mathrm{~mm}$., female, $r \mathrm{~mm}$; of antemne, male, $32 \mathrm{~mm}$.; of tegmina, male, $4.5 \mathrm{nmm}$., of female, $3.5 \mathrm{~mm}$.; of hind femora, male and female, $6 \mathrm{~mm}$; of ovipositor, $3.5 \mathrm{~mm}$.

This handsome little ericket has been taken in Vigo, Putnam, Fulton and Kosciusko counties. At Kewanna and De Long, Fulton County, it oceurs in small numbers among the sphagnum mosses

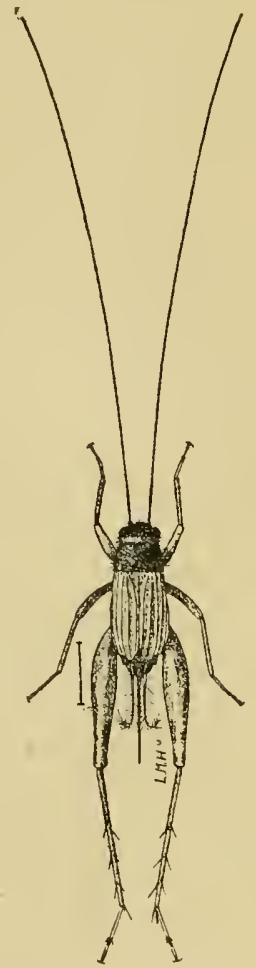

Fig. 121. Anaxipha exigua (Say). $\mathrm{Fe}$ male. Much en. larged. (After Lugger). growing in dense tamarack swamps. In Vigo County it oecurs about the borders of a large pond, and in Koseiusko County in a marsh bordering Tippecanoe Lake. In both these localities it was abundant on the leaves and stems of the arrow alum, eat-tail flags, buttonbush and other semi-aquatic plants. It is very aetive and difficult to eapture, and, on account of its small size, is doubtless overlooked in many localities where it occurs in abundance. In central Indiana it reaches maturity about August 1st, and exists until after heavy frosts. Unlike the Nemobids, which it most elosely resembles, it is never found on the ground, but clings to the stems of bushes and grasses a few feet above the surface. 


\section{Phylloscintus Guerin (1840).}

In this genus the head is noticeably wider than the pronotum, the eyes prominent and protruding; the ocelli indistinct or wanting. The basal joints of antenne are rather small and narrow, and are proportionally farther apart than in most erickets. The apical joint of the maxillary palpus is dilated and spoon-shaped and much longer than the preceding joint, which is triangular. Pronotum sub-cylindrical, narrower in front. Tegmina as long or longer than the body, rather leather-like in texture. Inner wings nearly as long as the tegmina. Ovipositor short, compressed, curved strongly upward.

The genus is exclusively American. But one species is known in the United States, occurring only east of the Mississippi and south of the latitude of central Indiana.

146. Phylloscirtus Pulchellus (Uhler). The Handsome Tree Cricket. Phyllopalpus pulchellus Uh1., 212 , II, 1864, 544; Glov., 62, 1872, Plate VI, Fig. 22.

Phylloscirtus pulchellus Sauss., 132, VI, 1874, 368; Id., 133, II, 1878, 637; Riley, 122, II, 1884, 183; Bl., 5, 1892, 137; Beut., 3, VI, 1894, 268, Plate V, Fig. 16; Scudd., 188, 1900, 91.

Head and pronotum bright crimson red, punctured; antennæ twico the length of the body, blackish at base and at tip, the middle portion yellowish; palpi black. Abdomen shining black; tegmina chestnut brown, the sides darker, with paler nervures. Cerei and legs pale yellow. Ovipositor brown, paler at base.

Measurements: Length of body, female, $7.5 \mathrm{~mm}$.; of tegmina, 5 $\mathrm{rmm}$.; of hind femora, $5.5 \mathrm{~mm}$.; of ovipositor, $3.5 \mathrm{~mm}$.

But three specimens, all females, of this little bright colored cricket are in my collection from Indiana. One of these was taken on September 6th, from a leaf of the button-bush, Cephalanthus occidentalis L., near the border of a large pond in Vige County. When discovered it was motionless, but was vibrating its large maxillary palpi in a very rapid and curions mamner. A second specimen was taken by $\mathrm{Mr}$. Hans Duden from the roadside near Edwardsville, Floyd County, on Angust 16th. It attempted to bite when picked up. The third was taken from the border of a marsh near Grand Chain, Posey County, on September 17th. It probably occurs in low wet woods throughout the sonthern half of the State. According to Uhler it is found in Maryland most frequently "amongst the grass and low bushes near ditches where it jumps about with great rapidity." 


\section{Sub-family ENEOPTERIN A.}

Medium sized Gryllide", having the second tarsal joint flattened and bi-lobed, as in the preceding sull-fanity. 'The hind tibia, however, have serrations between the spines and bear three apical spurs on each side. The tegmina of male in our genera are provided with a sounding organ or tympanmm, and the ovipositor is rylindrical and straight or but little curved. Four genera ocenr in the United States. two of which are represented in Indiana.

KEY TO INDIANA GENERA OF ENEOPTERINA.

a. Body short and hroad: fore tibia with hearing organ on the inner face only: apical segment of the maxillary palpus nearly as lomg as the two preceding tilken together; texmina in both sexes not reaching the tip of abdomen. . . . . . . . . . . . L.XII. ApituEs, 1) 4.5

ut. body rather long and slender; fore tibia with hearing organ on both faces; alical sement of maxillary palpms but little longer than the one-preceding; tegmina axtending much beyond the aldomen in

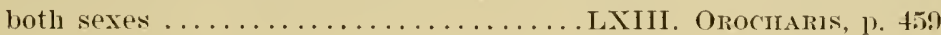

\section{ApItines Thler (1864).}

The main distinguishing characters of this genus have been given in the alove key. In addition it may he stateal that the head is al most globular and narrower than the pronotum; oeelli present; antemes about three times the leneth of the hody, their basal joints much thickened and eylindrical. Maxillary palpi with the iast segment enlarged at tip: obliquely truncated. Pronotum short, narrower in front than behind, the lateral angles romderl, the anterior and posterior margins truncate. 'Tegmina with the humeral vein prominent, forming a earina along the humeral angle. Inner wings very short. Hind femola quite broad, though but little thickened. Hind tibie armed with two rows of spines which are curval at the tip, eight on the imner and five or six on the outer side.

'Two species are known from the castern I'nited States, one of which oecurs in Intiana.

147. Apithes aGitator Uhler.

Hapithus agitutor Uhl., 212 , II, 1864, 546; Glov., 62, 1874, Plate XVI, Fig. 16; Riley, 122, II, 1884, 183, Fig. 23.

A pithis regitutrix Sauss., 132 , VI, 1874, 490.

Apithes agitutor Bl., 5, 1892, 139; Id., 16, 1899, 227; Scudd., 188, $1900,91$.

Irapithes quadratus Scudd., 144, XII, 1868, 140; Id , 164, 1879, 4.

A pithis quedirete Sauss., 132, VI, 1874, 488.

A short, heary hodied aricket; dull redish brown in color. 'Texmina covering about there-founths of ablomen, the rein separating 59-Geol. 
the dorsal field from the marginal, a yellowish white. The top of head and pronotmu, and the surlace of all the femora densely enered with hrownish yellow hairs. ()vipositor a little shorter than hind femora, pale brown, the apical thirt darker, a little upeurred.

Ireasmements: Length of body, male, 10 mm., female, $11 \mathrm{~mm}$; of pronotum, male and female, 2..) 1 mm.; of tegmina, female, $7.5 \mathrm{~mm}$.; of hind femora, male, 8 mm., female, ? mm.; of ovipositor, 8 mm. Width of pronotum, $3.2 \mathrm{~mm}$.

In Indiana this cricket has as yet been taken only in Vigo County, and during the month of september. 'The first ones discovered were on the slender wige of some prickly-ash shrubs which gerew in a damp upland woods. The place was risited a mumber of times and the erickets were always found, perfertly motionless, and immediately above or betow one of the thorns or priekles jutting forth from the twigs. 'The tips of the hind femora were raised so as to project above the body: thus alusing them to resemble the thorns; and the color of the insect, ("orresponding closely to that of the bark, made them very ditficult to discover even when in especial seareh of them. On every dimmp of priekly-ash in the woorls mentioned a number of surerimsos. wore secured, but they could be found nowhere else thereabonts. A second locality was about the roots of a scarlet oak, Quercus roccinea Wang, which grew on a sandy hillside. Ilere they were plentiful, and resting motionless in the depressions of the bark or beneath the leares in the cavities formed by the roots of the tree. A pair were also noterl in another place on the flowers of golden-rorl.

() all the males taken, over thirty in mumber, there was not one with perfect wing covers, and, in almost erery instance, the wing covers as well as the rudimentary wings were wholly absent; while erery female had both pairs malmed. 1 at first alscriber this wing mutilation to the males fighting among themselves, but finally discovared a fanale in the act of derouring the wings of a male. Why this ('urions lablit on the part of one sex? Possibly the females require a wing dict to requite them for their bestowed affections, or, per(hance, they are a jealous set, and, having once gained the aflections of a make, derour his wing cover's to keep him from ealling other females abont him. Quien sabe?

It is more than probalile, howerer. that the mating of the sexes takes place in a similar manner to that of the striped tree cricket Gicanthus fusciulus Fitch, dercribed above; the females gnawing away the tegmina of the males in orier to more readily reach some seminal glands which lie beneath. The openings of these glands, located on the dorsm of the mesothorax, are visible in dried specimens at hand. 
Agitalor is said to be common in the middle and southeastern States, where it inhabits grapevines and dense shrubbery. The eggs of the female are there depositer in twigs of the white elm, Ulmus americuna L., and the insects are very active at night, running and jumping about on the trunks of various trees.

\section{OROCHARIS Uhler (1864).}

The members of this genus have the body flattened and rather slender: the head short, slightly narrower than the nronotum, the front depressed and prolonged between the eyes in the form of a short beak; ocelli present, arranged in a triangle on the short frontal beak; the maxillary palpi with the third segment longest, cylindrical; the apical one a little longer than the one preceding, enlarged gradually from the base, obliquely truncate. Pronotum wider than long, though narrower than the tegmina, the front and hind margins trumate and ciliate. 'Tegmina longer than the abdomen, their texture more membranous than in the preceding genus; strongly reticulated and tapering posteriorly: inner wings a little longer than the tegmina. IInd femora rather short and slender.

Three nominal species occur in the United States; of these one has been taken in Indiana.

148. Orocharis saltator Uhler. The Jumping Tree Cricket.

Orncharis saltator Uhl, , 212 , II, 1864, 545; Riley, 113, I, 1869, 138; Id., 114, V, 1873, 119, Figs. 47, 48; Id., 121 , VI, 1881, 62; Id., 122, II, 1881, 182, Fig. 258; Glov., 62, 1872, Plate III, Figs. 11, 12; B1., 5, 1892, 138; Lugg., 84, 1898, 275, Fig. 186; Scudd., $188,1900,92$.

Oincheris seltutrix Sauss., 132, VI, 1874, 494; Scudd., 174, XCIII, $1896,694$.

Apithes meneilli $\mathrm{Bl}, 5^{\mathrm{n}}$, XXIV, 1892, 27.

Pale brownish yellow. A dark brown stripe reaches from the eye along the side of head and pronotum, and sometimes an irregular fucous line on middle of pronotnm. The tegmina each with a dark lorown or fuscous spot at base, sometimes covering nost of the wing: those of the female with many eross-veinlets which are darker than those runing lengthwise, giving the dorsal field a checkered appearance; those of the male with the vein separating the dorsal field from the marginal, yellow. Inner wings extending 2 to $3 \mathrm{~mm}$. beyond the tegmina. All the femora rather thickly marker with small, dark spot: those on the postrior pair being arranger in regnlar rows. Oripositor a third longer than the hind femora, nearly straight.

Neasurement:: Tength of body, male, 14 mm., female, $16 \mathrm{~mm}$.; of pronotum, male and female, $2.5 \mathrm{~mm}$.; of tegmina, male. $12.5 \mathrm{~mm}$, 
female. 11 mm,; of hincl femora, male, 8 mm., female. 10 mm.; of oripositor, 1\% $\mathrm{mm}$.

'This is a southern species, which in Indiana has so far been taken in suall numbers only in Vign, P'ntmam and Marion comnties; though it douhtless ocenes throughout the southern half of the state. In Tigo Comnty it was fomm in Oetober on the leaves of a golden-rod, śolidngo latifolin l... and on those of prickly-ash, Tanthorylum americammm Mill., both in dense upland woods. In Marion Combtr. Pliblip

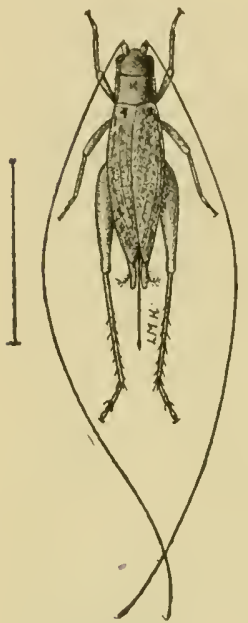

Fig. 122.

Orochuris saltator

Ihler. Female. (After Lugger). biaker brought me sevelul specimens which he found on August 22d, beneath an old coat hanging on a grape arloor, in the back yard of his lather"s residenee near the conter of the city of Indianapolis. When disturbed it often secks salety in flight, and when it alights flattens out its boly-chose against its resting place. Protessor liiley has given an interesting areount of the egglaviuge and songe habits of the jumpling tree (ricket. from which l quote at lenegth as follows: "In Teecember. 18: 8 . I watehed a female of 0 . sollator oripositing in the end of a rlead and rather soft twier of the soft maple at Kirkwoorl, Missomri. 'The twig harl been prunod and the bark was somewhat gnawed loy the ericket and the cares thrust in irregularly from the enel and from the sieles. Both wood and pith were relammed with eress. but all longitudimally inserted. 'Tho'

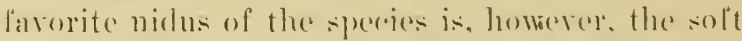
and somewhat rolky, rough hark of the trunk and older bramebes of the American ehm, the egg being thrust in singly or in small hatehes. either longitudinally with, or rery slightly obliquing from, the axis of trunk or branch. The fesmale is rery intent in the act. Workine hor abrlomen leliberately from side to side during the perforation.

"lphe stridulation of this cricket is a rather soft am musical piping of not quite half a secomel's duration, with from four to six trills. but so rapid that they are host in the distance. 'The key je rely high. but varies in different imelividuals and aceoprling to moisture and temperature. It most resembles the vibuting fonch of the finger on the rim of an ordinary tumbler when thee-fourths filled with water - repeated at intervals of from two to four per secomd. and it may

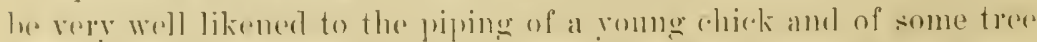

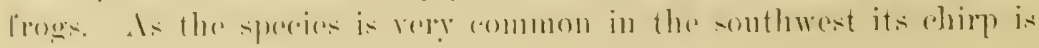


everywhere hearl and is so distinctive that when once studied it is never lost amid the louder racket of the katydids and other night choristers. It is frequently heard during the day time in chomely or damp weather, and I have heard it at St. Louis the first days of November after a slight frost.

"The courting of the sexes is amming. They face cach other and play with their antenna for the best part of an hour or more than an hour. The female is, otherwise, pretty quiet, but the male continmally mouths the twig or the bark mon which the courting is bering (lone, and plays his palpi at a great rate, rery stealthily approaching nearer to his mate meanwhile. It last the antemal fencing coates and those of the female bend back and then the male approaches until their heads touch. II then deliberately turns round, clevates the elytra and slips his abdomen under the female, who virtually mounts and assists him, his elytra overshadowing her head."

THE LIFE ZONES OF INDLANA, AS ILLUSTIATED IBY THE DISTRIBUTION OF ORTHOPTERA WTTHEN THE STA'TE.

The detailed study of the distribution of the Orthoptera of Indiana, made necessary in preparing the foregoing descriptive catalogue, has developed certain facts regarding the life zones of the State which are of especial interest. 1)r. C. H. Merriam, in his "Life Zones and Crop Zones of the Enited States." has made the "[Tper Anstral" life zone cover the entire State, with the exeption of a rery small area of "Tower Austral" in the extreme southwestern corncr. The facts brought out regarling the distribution of Orthoptera ir. Indiana, which are smplenented by numerons ficld notes on other groups of insect and animal life, and on the flowering plants. prove conclusively that the "Transition Zone," represented by the Alleghanian famna and flora, overlaps the northern fourth of the State. while the "Lower Anstral Zone," represented by the Anstroriparian fauna and flora, covers the greater part of the southern third. 'Tho Carolinian fauma and fora of the Tpper Anstral embraces, of course. the prevailing forms of life in the State. 93 of the 1 t8 speries of the preceding catalogue belonging to it. The majority of these range over the entire State mingling with the representatives of the Alleghanian fauna in the north and with those of the Anstroriparian famma in the southern third. To the Carolinian fama belongs also the great majority of the other forms of animal life in the State.

Bulletin No. 10, Division Biological Survey, U.S. Department of Agriculture, 1898 pp. 1-79, map. 
T'me Transiton \%oxl.-The three northern tiers of combies in Indiana embrace serral hundred fresh water lakes within their bounds. 'These lakes range in size from an areal of lialf an acre up to five and a half square miles. Abont their margins are often extensive areas of low, bogrey land. covered with numerous forms of plant life whose main distribution is far to the north. and which have here their sontheru limit. Among the more characteristic plants of the Alleghanian flora, which are found only in the northern fourth of Indiana, are the following: Larch or tamarack, Larir lariciun (Du Thoi); arbor vitu or white cedar, Thuja ocridentalis $\mathrm{T}_{\text {. }}$ : fal=e lily of the valley. In ifolium canarlense (Desf.); moceasin flower. 'ypripedium acaule Ait.; showy lady's slippers, Cypriperlium regiurp IValt.: hog orehis, I relhusa bulbosa T.: fen orchis, Leplorchis laselii (L.); sweet feru, Comptonia peregriua (L.): paper or canoe birch. Belula papyrifera Marsh; speckled or hoary alder, Aluns incana (I..); gold-thread, Coplis trifolia $\left(\mathrm{J}_{\text {s. }}\right)$; round-leaved sundew. Drosera rolundifolin $\mathrm{L}_{\text {.: }}$ black chokeborry, Aronia nigra (Willd.); romuleaved wintergreen, Pyrola rotundifotia $\mathrm{T}_{\text {s. }}$, shin-leaf. Pyrola elliplier Nutt.; trailing arbutus, Epigen repens L.; ereeping wintererecu. Gaullierill procumbens $\mathrm{T}$.; large cranberry. Oxycocens macrocarpus (Air.): chick-weel wintergreen, T'rimlatis americana Pursh.: purple bladderwort, Ltriculuria purpurea $\mathrm{IT}^{\top}$ alt.. and the twin-flower. linnee borcatis $\mathrm{T}$.

Among mammals and reptiles, the following representatives of the Alleghanian famma oceur in the northern fonth of the State: ('inada poreupine, Erethizon dorsatus (I . ) red spluirpel or ehickaree. Srinrus Tutsonirus Frxleben: star-nosed mole. Contylura cristatu (T.): hoary hat. Halapha cimerea (Beaurais): American badger, Taxidea amerirenu (bodlaret); sperkled tortoise, Clemmys gullatu (s'chneid(r), and Błanding's tortoise. Emys meleagris shaw.

Of the Orthoptera described in the foregoing eatalogur, 23 sper.ies. or 15.5 per reent. of the total, may be rassed as helonging to the Nllegrhanian fauma, and as oceupying the sonthern limits of the Transition \%one, which lies between the Boreal and Tpper Iustral zones. 'These truly northeres members of our Orthopteran fama are as follows:

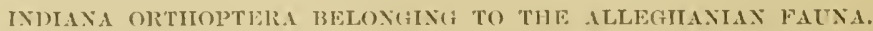
1. (siplinlelln prlilun (Burm.).
6. Mipprisens huldimmmi (Seudd.).
2. (),plunlelle sprerimer (śceurld.).

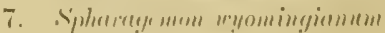
3. Stembuthens endipumis Hamis.
(Thom.).
4. Mressethus lineutus (Scudd.).
8. Trimerofmpis moritime (Harris).
5. ('ummula prllurittı (Scudd.).
9. Srlhiseroren imbiginnen (Harris). 
10. Hesperotettix prutensis Scudd.

11. Melunoplus fusciutus (Walker).

12. Melumoplus extremus (Walker).

13. Melumoplus angustipenmis (Dodge).

14. Phataliotes nelrasensis (Thom.)

15. Prioxya semulderi Bl.

16. Scmelderia pistillata Brumn.
17. Comacepholus robustus Scudd.

18. Orchelimum indiunense $\mathrm{Bl}$.

19. ()relulimmm delicatmm Brun.

20. (),rhelimum gladintor Brun.

21. Temoline palustris Bl.

22. Temobius contusus Bl.

23. Cryglus aremeens B1.

The Lower Austral, Zoxe.-The extreme northern bomndary of the "Lower Austral" life zone passes in a northwest sontheast lirection through the following comnties of Indiana: Vigo, Clay, Owen. Monroe, Jackson, Jennings, Jefferson and switzerland. In the territory south of this line the Austroriparian fauma of that sub-zone overlaps and merges with the Carolinian fauna of the Upper Austral zone. The extension northward on the western line of the State is. without doubt, due to the presence of the broad and shelering valley of the Wabash River, within the confines of which coptain sonthern forms have found a climate mild and suitable to their habits. Within this valley the following members of the Anstroriparian flora grow indigenously, a number of them as far north as Terre Trate: Bald cypress, Trarodium dislichum (I.): mpright burhcad, Echinodorns cordifolius (L.); showy amaryllis. Iymenocallis occidentulis (lee ('onte); pecan, Hicoria pecan (Marsh.): swamp or downy poplar, Populus helerophylta $\mathrm{I}_{\text {.: }}$ chinquapin. ('astanea pumila (L.); Texan red oak. Guercus texana Buckley: pipe vine, Aristolochia tomentosa Sims: American lotus. Nelumbo lulea (Willd.); Carolina moonseed, Cebutha carolina (L.); great bumet, Sanguisorba canadensis L.; water or swamp locust, Gleditsia aquatica Marsh; water ash, Fraxims carotiniana Mill, and crossvine, Bignonia crucigera $\mathrm{I}$.

Amongother characteristic southern plant forms occurring in Indianal south of the northern boundary of the Tower Austral zone are: 'The yellow pine, Pinus eshinala Mill.: mud plantain, Heleranthera reniformis

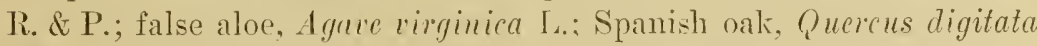
(Marsh): southern hackberry, ('ellis mississippiensis Bose.; American mistletoe, Phoradendron flaressens (Pursh.); cuemulner tree. Magnolia acuminata L.: pencil ftower, s'ylosanthes biflora (L.); ('arolina buekthorn, Rhammus caroliminna ITalt.: yellow passion flower, Passiftora lulea L.: Hercules chub. Aralia spinosa L.; persimmon, Diospyros rivginiana L.; unicorn plant, Marlynia louisiana Mill.: catalpa, Catalpa ratalpa (L.), and the rough hutton-weed, I) iortia teres Walt.

The sonthern norkinghirr, Mimus polyylottos (I.), nests in mumbers as far north as 'T'rie Haute; while among the batrachians and reptiles the hellbender, Cryptobranchus alleghaniensis (Daud.); the southeru cricket frog, Icris gryllus Le Conte; the corn snake, 
Ophibulus dotiulus (L.) ; Sily's dhain smake. O)phibulus rulligester (Say); the beal sllake. Eilnps fulvins (I.): the gromend lizard. Oligosomu laterale (sily): the alligator snapperer, Macrosleslys larerlina (Schweiggere), and the yellow-hellicel terrapin, l'seudemys lroosti (Hollorook). all forms whose main distribution is far lo the somth, find in sonth(r'n Indiana a comgenial alobling place.

11. is not strange, therefore. that we tind, living with these plants and animals. a mumber of (Orthoptera whose range has heretofore been thomght to be confuned to the region mapued by Merriam as the "Lower Anstral." 'Thirty-two of the species listed in the preceding catalogue, or 21.6 per ent. ol the total, may be classed as southeru forms. 'They are as follows:

\section{INDIANA ORTHOPTERA BELONGING TO THE AUSTRORIPARIAN FAUNA.}

1. Temunptery. deropeltifinmis Brumn.

2. Isehneiptere incequalis Sauss. -Zehnt.

3. Ischurptere major (Sauss.-Zelınt.)

4. staymemantis carolina (L.).

5. Cimatiste yrisece (Fab.).

6. Anisommphlu fermginea (Pal. de Beauv.).

7. Tettix arenostes Burm.

8. Neotettix henesocki Bl.

9. Tettigiden spierten Morse.

10. Tettiginter lateralis (Say).

11. Sigrbula admirubilis (Uhıl.).

12. Hippiscus phenicopterns (Germar).

13. Mestubregmu rinctum (Thom.).

14. Trimerotropis ritrina Scudd.

15. Leptysua maryinirollis (Serv.).

16. Sichistorerce demnifiore (Sauss.).
17. Melenoplus morsei B1.

18. Metenophis impudirns Scudd.

19. A whblycorypha uhteri (Brunn.).

20. Conocephalus brueri $\mathrm{Bl}$.

21. Atlentirus domsalis (Burm.).

22. ('muttonotus carolinemsis (Gers.).

23. Centhophilus stygines (Sendd.).

24. Cothophilus uhleri Scudd.

25. Myrmecophila pergandei Brun.

26. Nemobins enus Scudd.

27. Nemobiu: cubensis Sauss.

28. Crigllus firmus Scudd.

29. Mioyryllus somsurei (Scudd.).

30. Ihylloscirtus pulehellus (Uhl.).

31. Aprithes repitator Uhl.

32. (Nocharis sultutor Uhl.

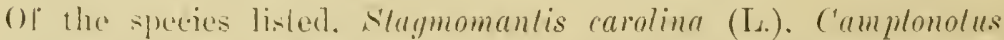
rurolimpnsis (cirs.), syrbula almirabilis (l'hl.) and Orocharis sullator

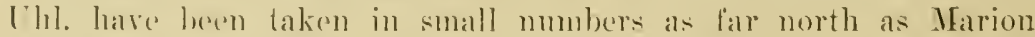
('omentr: all the others onl y soutly of the line mentioned as forming the morthern borter of the Lower Austral. It will be moted that this

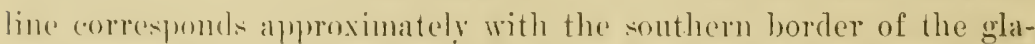
(-ial invasion of Indiana. and it is more than probable that the an(estors of many of thesesouthern forms existed in southern Indiana in presclacial times, when the chimate was momele wamer than now.

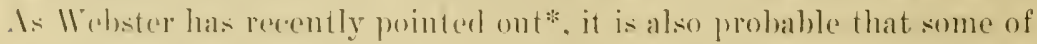

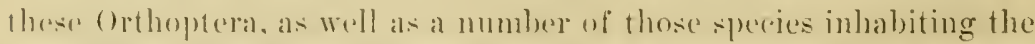
entire sitate. adraneed into the state from the south as fast as it was

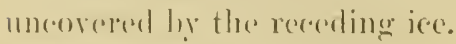

4."The Diffusion of Insecls in North Amcrica." Psyche, X, 1903, pp. ti-58. 
The members of the Alleghanian fauna entered the State, for the most part, from the north or northeast. A number of those which 1 have not classed as Alleghanian or Anstroriparian, and which, therefore, are to be considered (arolinian, evidently came in from the west. Chief among these are Ageneolettix scudderi (Brun.). Melanoplus blatchleyi Scudd., ('onocephulus palustris BI., Tiphidium saltans Sicndd., Tiphidium strictum Scudd., and Orchelimum rolentum IIcN.. all of which appear to be confined to the western half of the State.

\section{GLOSSARY OF' 'TERMS USED IN TLA'T'}

Abbreviated.- Shortened-not reaching the tip of abdomen when applied to tegmina and wings.

Abdomen.-Posterior part of body.

Aborted.--Imperfectly dereloped.

Acuminate-Becoming gradually narrower; tapering to a point.

Acutely.-Sharp: sharply pointed.

Adult.-The imago or winged stage of an insect.

Anal.-Sitnated at or near the anus.

Annulus, annulation, annulate- - Ringed; furnished with ring-like bands.

Antenna.-The jointed organs of touch and smell, attached to the upper part of the face.

Anterior, anteriorly.-Near the head; situated more to the front.

Anus.--The posterior opening of the alimentary canal.

A pex.-The terminal portion of any organ or part of the body.

A piral, apically.-That part of any organ farthest from the body.

A ppressed.-Pressed closely against: fitting elosely to.

A proximate.-Near to: near together.

A pterous.-Wingless.

Arboreal.-Living on or among trees.

Arcuate-Arched; bowed.

Area, areola, areolate. - Wing cells; cellules; the membranaceous spaces between the nervules. 
Arlivelnted.-Divided into distinct joints.

Auditory oryan.- Ear; hearing organ.

Altingent.-Touching; coming in contact with.

Basal.-Next to the body.

Bifil.-Cleft; cloren in two.

Calcaria.-Che spines or spurs at the apex of the tibia.

Carina, carince (pl.).-A kecl or ridge.

Castancons.-Chestuut brown; bright reddish brown.

rerei.-The appendages issuing from the sirles of the last abdominal segment.

Chitine.-The corneons substance of the skin of an insect.

Cimeler-shaped.-Like a short, curved oriental sword.

Cinereous.-Ash-colored; gray tinged with blackish.

Claxale-Having a thickened. club-like extremity.

Clypeus. - A part of the head.

Concave. When the surface gradually declines toward the center, which thus becomes the deepest.

Concex.-When the surface gradually rises toward the center, which thus becomes the highest.

Cordiform, cordale.-Heart-shaped.

Coriacens.-Cieather-like, tough and somewhat rigid.

Corneors.-A horny substance, resembling horn.

Costa.-Median carina of the face.

Costal. - The front margin of tegmina or wing.

Coxa.-The globular or oblong basal piece of the leg.

Crest.-A sharp ridge.

Cristale.-With a prominent longitudinal carina on its upper surface.

Declivent.-Sloping downward.

Derurved.-Bent downward.

Depressed.-Pressed downward; more or less flattened rertically.

Dentale.-Furnished with a tooth or teeth.

Denticulations. - With fine tooth-like notehes.

Dilaled.-Broadened; cxpanded.

Dimorphic.- Existing in two forms.

Disk.-The middle of a surface; the surface within the margins.

Distal.-Farthest distant. opposite of proximal.

Diurnal.-Active during the day.

Dorsal.-Pertaining to the upper surface.

Dorsum. - The upper surface or back of thorax, abdomen, ete. 
Elongate.-More lengthened than usual.

Elytra.-The wing covers: the tegmina.

Emarginate, emargination.-- Eidgerl; notched; terminating in an acute notch at tip.

Ensiform.-Sword-shaped; sharp on both edges and tapering to a point.

Exserted.-Protruding so as to be visible.

Falcate--Sickle-shaped; curved like a sickle.

Fastigium.-The extreme point of the front or vertex of the head.

Fauna.-The animals of a locality.

Femur, femora (pl.).- The thigh or thighs.

Ferruginous.-Rusty brown; brownish red with some yellow.

Filiform.-Slender, thread-like.

Fossorial.-Fit or used for digging or burrowing.

Foveola.-A cavity or small depression.

Front, frons-The upper forward part of the head.

Frontal.-Relating to the front or face.

Fuliginous.-Sooty; dark brown.

Fulvous.-Tawny or light yellowish brown.

Furcula.-The processes of the last abdominal segment of the male.

Fuscous.-Dark brown.

Fusiform.-Spindle-shaped.

Gena.-Cheek.

Gibbous.-Protuberant; swollen.

Glabrous.-Smooth or polished, not hairy.

Glaucous.-Whitish-blue, inclining to gray.

Globose.-Like a ball.

Granulated.-Furnished with minute prominences like grains of sand.

Griseous.-Light gray (white and black).

Gula.-Throat, concave portion below the head.

Habitat.-The place or region which an insect inhabits.

Hemisphercial.-Shaped like half a ball.

Hexagonal.--Six sided.

Hibernate.-To pass the winter in seclusion or sleep.

Host.-The individual furnishing food to a parasite.

Humeral.-Situated on or near a humerus or front corner of the thorax or wing cover.

Hyaline.-Transparent, with a greenish tinge. 
Imago.- In adult ol wingred inseret.

Immarnlale.-Not marlied; nuspotted.

Integumenl.-Onter eorering, -kin.

Intercalary rein. - See p. 136.

Interspace.-Spate between.

Interrupted.-Suldenly stopped or broken.

Labial palpus.-See p. 131.

Labium.-Lower lip.

l.abrum.-[ pper lip.

lanreolate.-lance-shapod.

larea.-The secomel ar worm-lie stage of an inseret.

Lateral lobes of the pronolum.-Tho deflexed portions that correr the sides of thorax.

Linear.- Vory slender.

Longitudinal.- Temglhwise.

Luleous-- Tmmixed yellow: rolor of rlay.

Maculate. - ipotted, marked with spots.

Mandibles.-Marl and horny jaws.

Marginal.—Sitnated on or near the margin.

Median.-Ocrupying the middle.

Membrane, membrameous. - A thin tissue: consisting of a thin tirsue.

IVesonotum. - The upper or dorsal surface of the mesothorax.

Mesosternum.-The uncer surface of the mesothorax.

Vesothorax.-The mirllle part of the thorax, to which the wing corers and middle pair of legs are attached.

Metamorphosis.-Changes an insect undergoes before reaching maturity.

Metanotum.-The mper or dorsal surface of the metathorax.

Metathorax.-The posterior part of the thoras to which the wings and hind pair of legs are attached.

Metazona.-T'lie posterior part of the promotmm.

Millimeter (mmi.).- The thousandth part of a meter, equal to 0.03937 inels, or nearly 1-25th inch.

Nebulous.-Clonded; with uneren, clondy markings.

Nerves. - The large ribs or veins of wing and wing-covers. extending from the base foward the apex.

Nervules. - The sualler connecting veins of the rings and wing covers.

Nocturnal.-Active at night.

$N y m p h$ - An immature insect, active and feering in the larval and pupal stages. 
Obconic.-Conieal, with the vertex pointing downward.

Oblique.-Slanting: when applied to the face, denotes that it slopes under and barkward toward the breast.

Obloug. - With the transwerse dianeter much shorter than the longitudinal.

Obsolete.-Wanting or nearly so; indistinct.

Obtuse.-Blunt.

Ocellus, orelli.-The three simple eyes.

Occiput.-The back part of the head.

Omnirorous. - lating ererything eatable.

Oölheca.-A case concinosing eggs.

Opaque.-Without any hustre: impenetrable by light rays.

Oripositor. - The oroun for depositing egas.

Oriposiliou.-.The act of laying eggs.

Pallid.-Pale or whitish yellow..

Palpus, palpi. - Articulated and movable organs attached to the maxillae and mandibles.

Parasite.- In animal which grows and lives upon another.

P'ellucid.-T'ransjarent: transhueent, but not necessarily colorless

Pentagonal.-Five-sided.

Percureut.-Rumning through the entire length.

Piceous.-Pitchy, the color of piteh.

Pilose.-Having long, sparse hairs.

Plantula.-A cushion-like part between the tarsal hooks or ungues: same as pulvillus.

Plumbeous.-Pale, hlue gray, like lead.

Pronotum.-The shield which covers the front part of the thorax.

Prosternum.-The muter surface of the thorax.

Prosternal spine.-A spine projecting from the under side of the prothorax.

Prothorax.-The anterior division of the thorax to which the hear is joiner?.

Proximal.-Nearest: opposite of distal.

Prozona.-The front dorsal part of the pronotmm.

Pubescent.-Covered with soft, short and not erowded hair, wool or down.

Punclate, punclured.-Containing mumerous small, point-like depressions or punctures.

Pupa, pupal.- The third stage of an inseet; the stage before the imago.

Pulvillus, pulvilli.-The little pads between the claws of the tarsi.

Pyriform.-Pear-shaped. 
Reticulale. - With net-like reins or markings.

Rudimenlary.-Not sufficiently developed to be of use.

lingose.-liomgh, wrinkled; furnished with numerous small elevations.

Rufous.-Dark reddish brown.

Sallatorial.-Fitted for leaping.

Scubrous.-Covered with suall, slight elevations; rough like a file.

Scrobes.-I'its or depressions in which are placed the hases of the antennx.

Segment.-Ring-like division or joint, as of the antenna.

Serrale.-Saw-toothed.

Serralions.-Tecth like a saw.

Serrulate.-Finely serrate; having minute serrations.

Sclaceous.-Bristle-shaped.

Sinuale.-Winding in and out; twice or more curved.

Sinus.-An excaration as if scooped out.

Smoolh.-Without elevations or wrinkles.

Solitary.-Single.

Spalulate-Caddle or spoon-shaped; flattened and broater at the apex than at the base.

spinose.-Armed with spines.

Spinnlose.-Furnished with spinules or diminutive spines.

s'piracle.-An external opening of the respiratory system.

spurs.-Tlie strong spines at the apex of the tibix.

Sternile.-The ventral part of each abdominal segment.

silermum.-The ventral part of a body segment.

Slridulale.-T'o make a shrill sound; to grate, scrape nr creak with

the stridulating organs.

Slyliform.-Shaped like a style.

Sub.-A prefix meaning nearly; almost; somewhat; under, ete.

Sub-costal rein. See p. 13\%.

Sub-median rein. Sce p. 136.

Sulcale.-Grooved, furrowed.

Sulcus, sulci (pl.).- - linear groove or channel: a groove-like cxcavation.

Siulure.-A seam or impressed line: generally used in reference to the junction of two pieces or plates.

Tarsus, tarsi (lar:al).-The jointed foot.

Tectiform.- Ridged in the middle and sloping down on each side.

Tegmina.-Tlue fore wings, upper wings or wing covers. 
Terele.-Sub-cylindrical; straight, without enlargements.

Tergite (tergum).-The dorsal part of a body segment.

Testaceous.-Dull yellowish brown; tile or brick colored.

Thorax.-The part of the body of an insect to which are fastened wings and legs.

Translucent.-Transmitting very little light.

Transparent.-Transmitting light.

Transverse.-Crosswise; signifes that the part or area is broader than it is long.

Tri-carinate.-Having three keels or carine.

Trochanter.-The second joint of the leg.

Truncate.-Cut off squarely at the tip.

Tubercle.-A little solid pimple or exerescence.

Tuberculate.-Covered with tubercles.

Tym panum.-The membrane closing the ear.

Unarmed.-Without a spine.

Ungues.-The curved hooks terminating the tarsus.

Ulnar rein. See p. 136.

Valves.-Four homy appendages forming the ovipositor.

Teins-Nerves; ribs of a wing.

Veinlets.-Nervules: very small eross-veins of the wings.

Tenation.-Method of distribution of veins.

Ventral.-Pertaining to the under surface of the abdomen.

Vertex.-The front portion of the upper surface of the head between and in front of the eyes.

Wing-covers.-Front wings; tegmina.

Wing-pads.-Undeveloped wings, as in the pupa or nymph. 



\section{INDEX TO ORTHOPTERA OF INDIANA.}

(FAMILY AND SUB-FAMLY NAMES ARE IN SMALL CAPITALS; GENERIC AND SPECIFIC NAMES IN ROMAN.)

PAGE

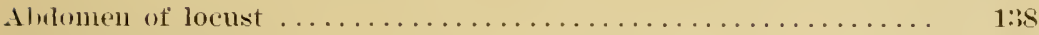

Acknowledgments ........................... 1:7

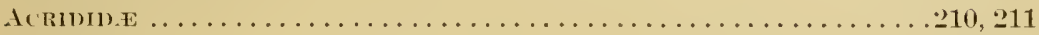

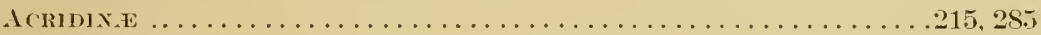

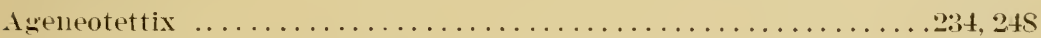

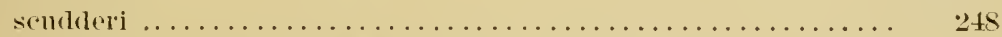

Alleghanian fauna of ludiana. Onthoptera helouging to . . . . . . . 462

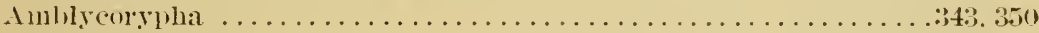

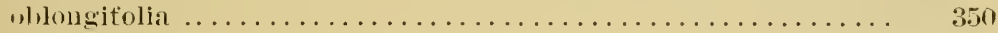

rotundifolia $\ldots \ldots \ldots \ldots \ldots \ldots \ldots \ldots \ldots \ldots \ldots \ldots \ldots \ldots \ldots . .35 .32$

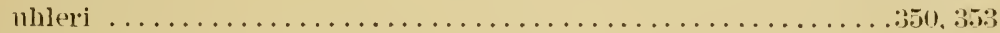

Illatomy, extelual, of a locust.................... 129

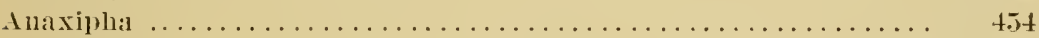

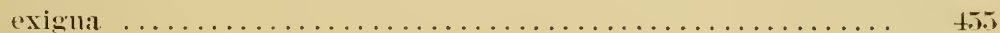

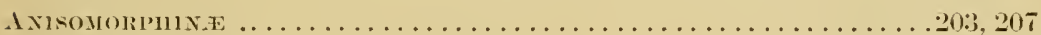

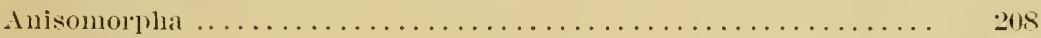

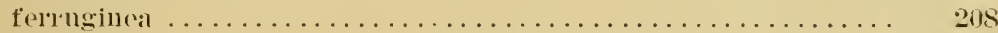

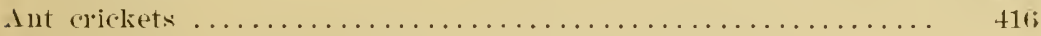

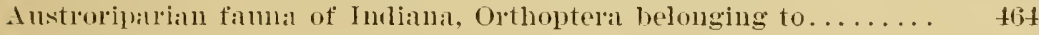

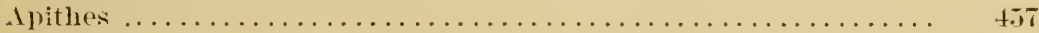

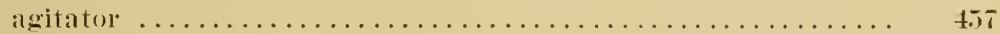

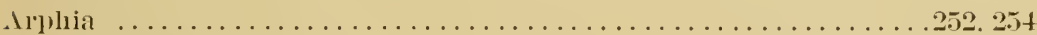

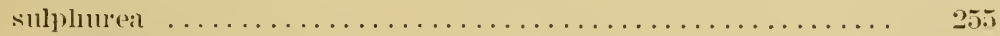

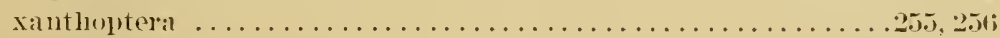

Itlinticus $\ldots \ldots \ldots \ldots \ldots \ldots \ldots \ldots \ldots \ldots \ldots \ldots \ldots \ldots \ldots \ldots \ldots$

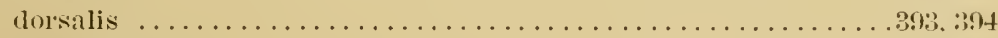

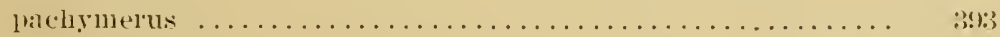

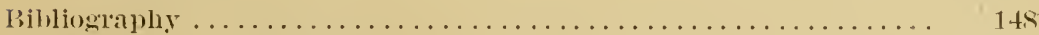

Birls. Indiana, which feed mon orthoptera, list of ........... 14t

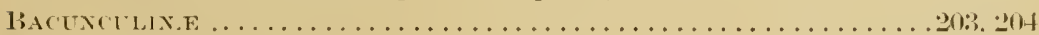

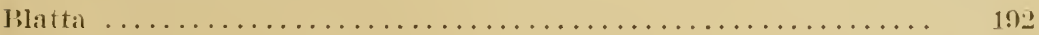

olielltilis . . . . . . . . . . . .

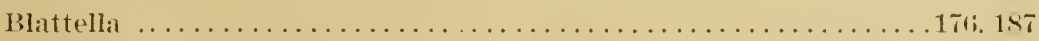

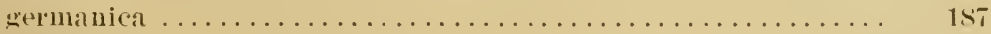

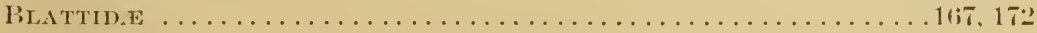

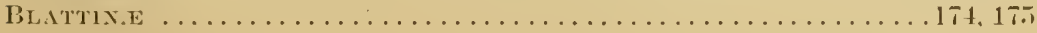




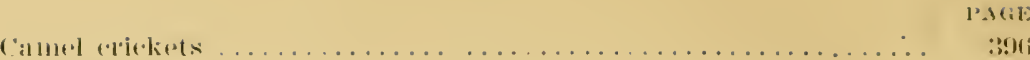

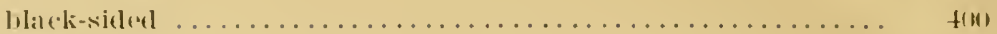

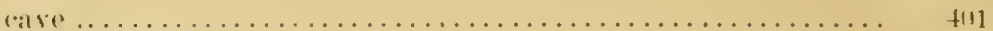

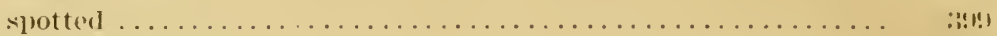

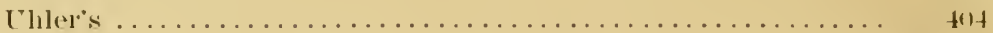

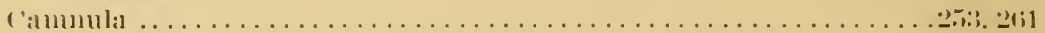

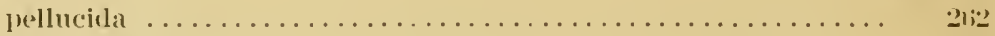

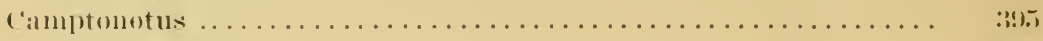

(:)

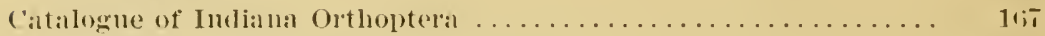

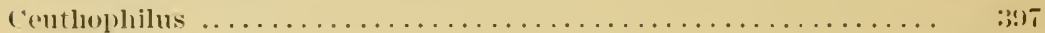

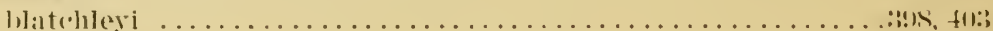

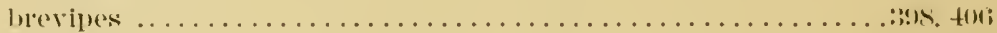

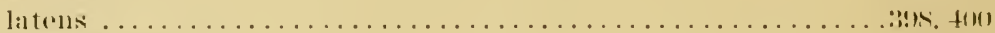

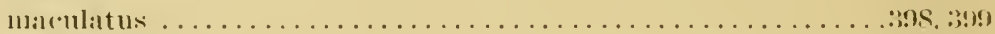

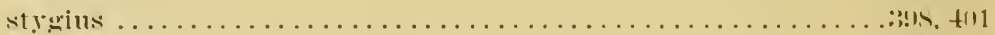

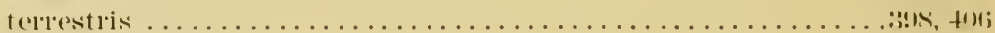

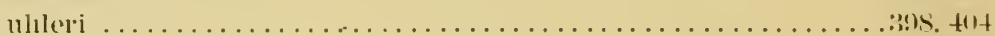

('hitin ............................... 12!)

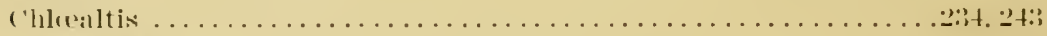

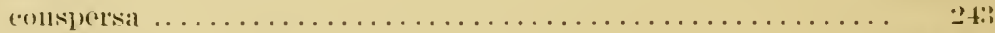

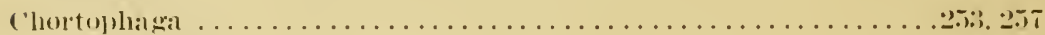

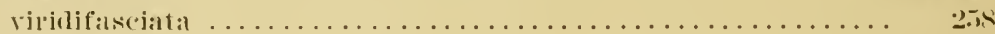

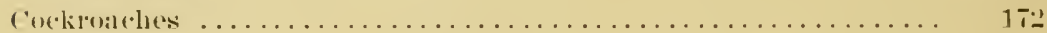

rentedies

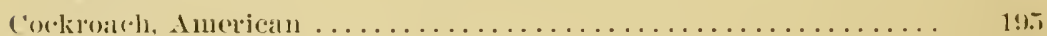

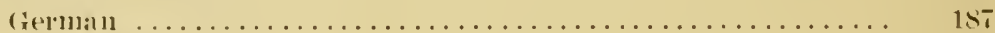

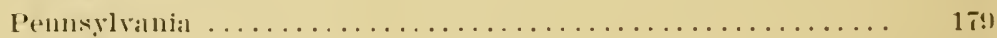

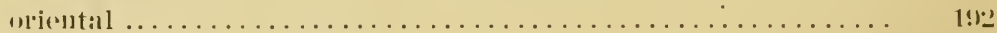

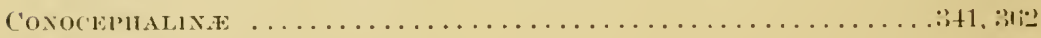

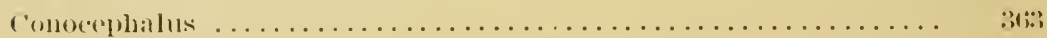

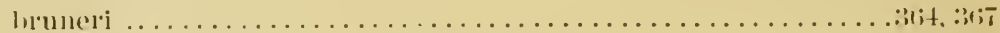

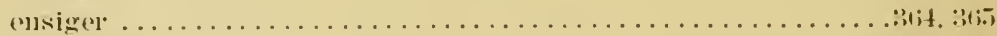

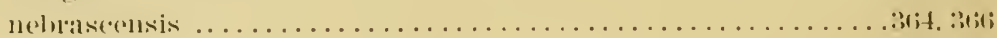

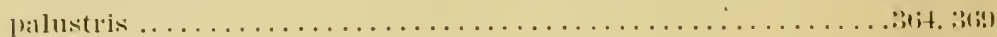

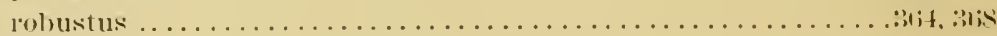

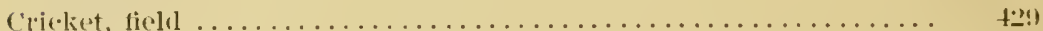

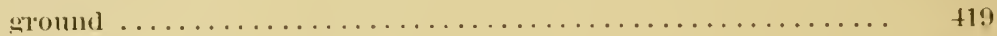

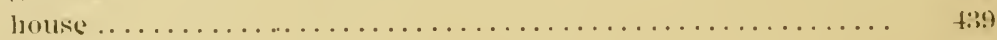

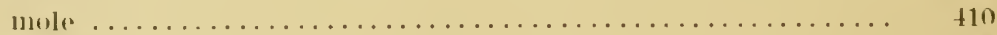

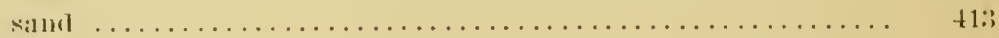

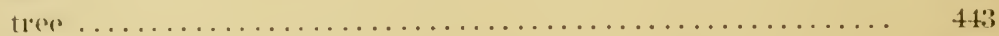

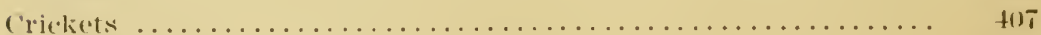

eger-living hahits of ....................... tos

striflulation of $\ldots \ldots \ldots \ldots \ldots \ldots \ldots \ldots \ldots \ldots \ldots \ldots \ldots \ldots \ldots \ldots$ to.

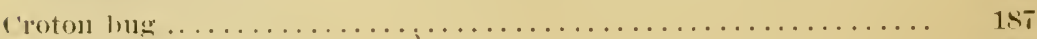

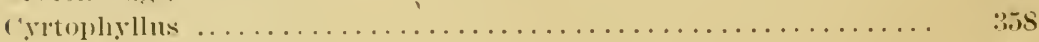

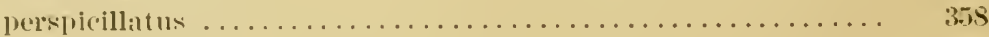


DECTICINE

Diapheromera ................................. 204

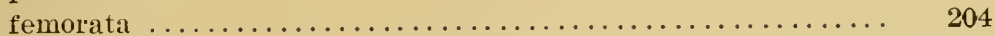

Dicromorpha . . . . . . . . . . . . . . . . . . . . . . . . 234, 238

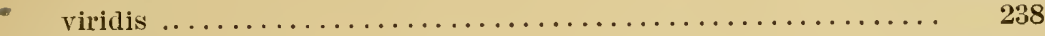

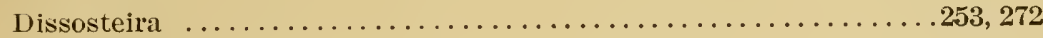

carolina $\ldots \ldots \ldots \ldots \ldots \ldots \ldots \ldots \ldots \ldots \ldots \ldots \ldots \ldots \ldots \ldots \ldots \ldots$

Earwigs $\ldots \ldots \ldots \ldots \ldots \ldots \ldots \ldots \ldots \ldots \ldots \ldots \ldots \ldots \ldots \ldots \ldots \ldots \ldots$

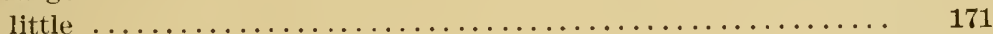

Ellipes $\ldots \ldots \ldots \ldots \ldots \ldots \ldots \ldots \ldots \ldots \ldots \ldots \ldots \ldots \ldots \ldots \ldots \ldots \ldots \ldots \ldots \ldots \ldots \ldots$

minuta $\ldots \ldots \ldots \ldots \ldots \ldots \ldots \ldots \ldots \ldots \ldots \ldots \ldots \ldots \ldots \ldots \ldots \ldots \ldots$

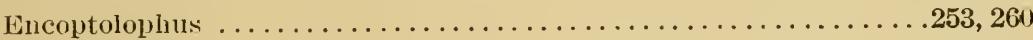

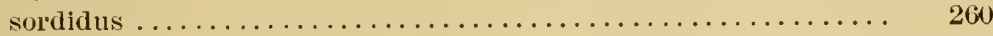

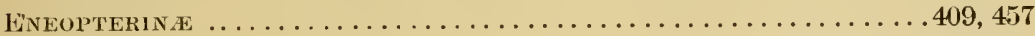

liatunas of Indiana ........................... 461

Alleghanian ............................. 462

Austroriparian ............................ 464

Carolinian $\ldots \ldots \ldots \ldots \ldots \ldots \ldots \ldots \ldots \ldots \ldots \ldots \ldots \ldots \ldots \ldots \ldots$

Field crickets . . . . . . . . . . . . . . . . . . . . . . . . . 429

Americall ............................... 433

Pennsylvalua $\ldots \ldots \ldots \ldots \ldots \ldots \ldots \ldots \ldots \ldots \ldots \ldots \ldots \ldots \ldots \ldots \ldots \ldots$

sand-loving .............................. 434

short-winged $\ldots \ldots \ldots \ldots \ldots \ldots \ldots \ldots \ldots \ldots \ldots \ldots \ldots \ldots \ldots \ldots \ldots$

Forticula .................................. 169

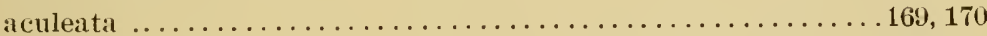

atricularial $\ldots \ldots \ldots \ldots \ldots \ldots \ldots \ldots \ldots \ldots \ldots \ldots \ldots \ldots \ldots \ldots \ldots \ldots \ldots$

Forficulid $\ldots \ldots \ldots \ldots \ldots \ldots \ldots \ldots \ldots \ldots \ldots \ldots \ldots \ldots \ldots \ldots \ldots$

Fungus attacking locusts . . . . . . . . . . . . . . . . . . 142

Glossary .................................. 465

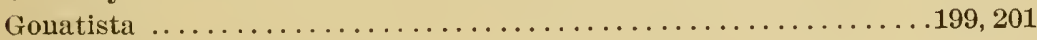

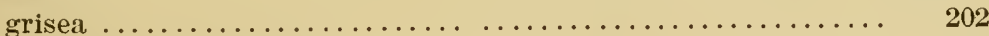

Grasshoppers, black-legged ...................... 387

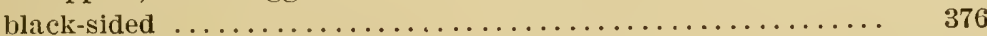

common meadow ........................... 383

cone-headed .............................. 363

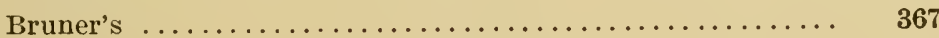

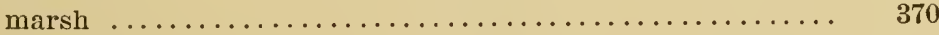

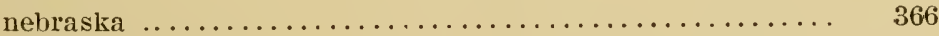

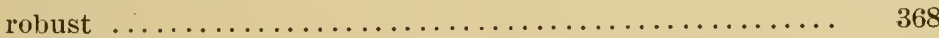

lance-tailed $\ldots \ldots \ldots \ldots \ldots \ldots \ldots \ldots \ldots \ldots \ldots \ldots \ldots \ldots \ldots \ldots \ldots$

shield-backed ............................. 393

short-winged meadow ........................ 373

slender meadow ............................ 372

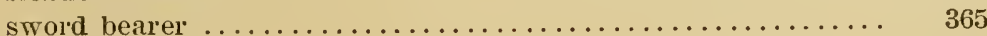

Ground crickets ................................ 419

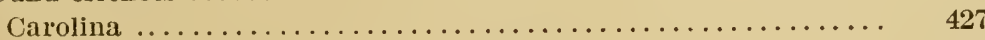

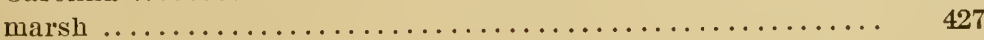

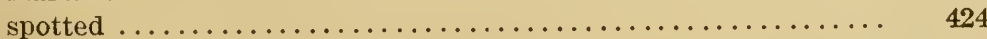

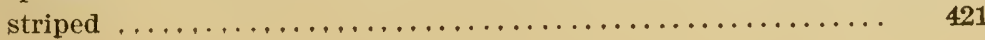


PAGE

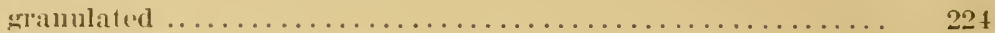

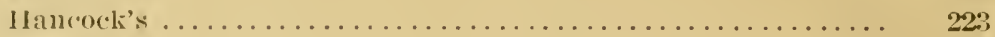

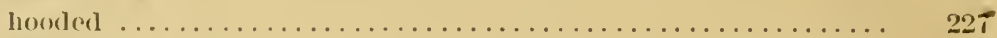

olscure ......................................

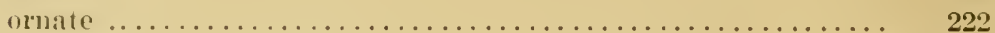

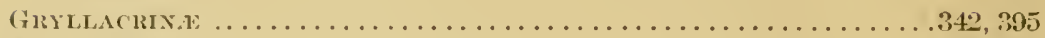

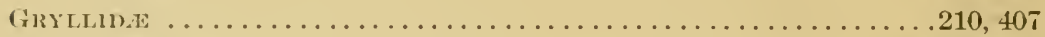

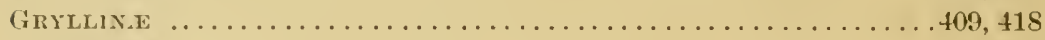

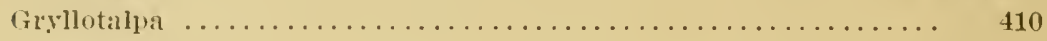

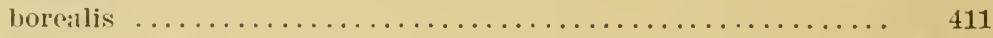

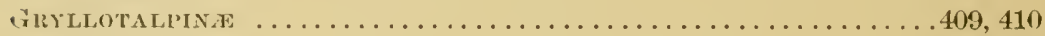

Gryllus . . . . . . . . . . . . . . . . . . . . . . . . 419,429

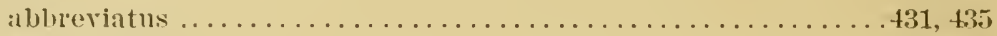

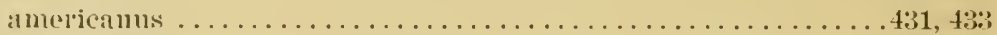

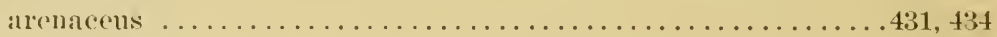

domesticus . . . . . . . . . . . . . . . . . . . . . . .432, 439

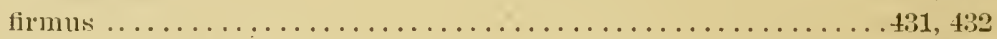

penusylvanicus ..........................432, 437

Hearl of a locust. . . . . . . . . . . . . . . . . . . . . . . . 130

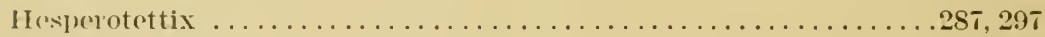

matensis ........................... 297

Irippiscus . . . . . . . . . . . . . . . . . . . . . . . . 253, 26i3

haldemanii ............................... . 264. 269

phonicopterus ...........................264, 267

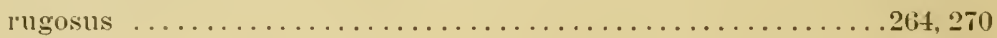

tuberculatus ...........................264, 265

House cricket . . . . . . . . . . . . . . . . . . . . . . 439

Illustrations $\ldots \ldots \ldots \ldots \ldots \ldots \ldots \ldots \ldots \ldots \ldots \ldots \ldots \ldots \ldots \ldots \ldots \ldots$

Indiana Orthoptera, catalogue of ................... 167

Ischmoptela . . . . . . . . . . . . . . . . . . . . . . 176, 178

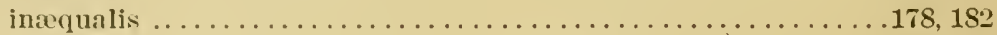

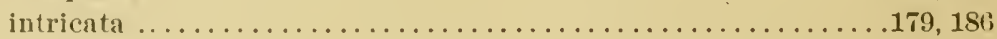

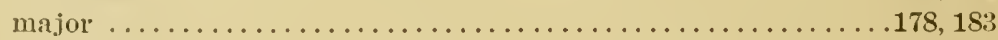

pennsylvanica $\ldots \ldots \ldots \ldots \ldots \ldots \ldots \ldots \ldots \ldots \ldots \ldots \ldots \ldots \ldots \ldots \ldots \ldots \ldots \ldots \ldots$

uhleriana $\ldots \ldots \ldots \ldots \ldots \ldots \ldots \ldots \ldots \ldots \ldots \ldots \ldots \ldots \ldots \ldots \ldots \ldots \ldots$

Katydids, egg-laying lublits of . . . . . . . . . . . . 34:., 345, 349. 355,361 stridulation of $\ldots \ldots \ldots \ldots \ldots \ldots \ldots \ldots \ldots \ldots \ldots \ldots \ldots \ldots \ldots$

Katydid, broad-winged ............................ 358

curred-tailed .............................. 345

fork-tailed ................................ 348

larger angular-winged $\ldots \ldots \ldots \ldots \ldots \ldots \ldots \ldots \ldots \ldots \ldots \ldots \ldots \ldots \ldots$

oblong-leaf winged . . . . . . . . . . . . . . . . . . . . . 350

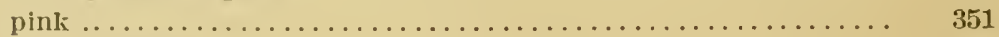

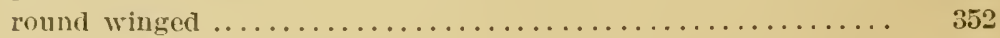

texas $\ldots \ldots \ldots \ldots \ldots \ldots \ldots \ldots \ldots \ldots \ldots \ldots \ldots \ldots \ldots \ldots \ldots \ldots \ldots$

true $\ldots \ldots \ldots \ldots \ldots \ldots \ldots \ldots \ldots \ldots \ldots \ldots \ldots \ldots \ldots \ldots \ldots \ldots \ldots$

Uhler's .................................... 353 
Labia

169,171

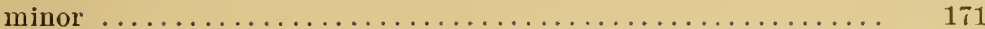

Legs of a locust, parts of $\ldots \ldots \ldots \ldots \ldots \ldots \ldots \ldots \ldots \ldots \ldots \ldots$

Leptysma $\ldots \ldots \ldots \ldots \ldots \ldots \ldots \ldots \ldots \ldots \ldots \ldots \ldots \ldots \ldots \ldots . .287$

malginicollis $\ldots \ldots \ldots \ldots \ldots \ldots \ldots \ldots \ldots \ldots \ldots \ldots \ldots \ldots \ldots$

Life zones of Indiant . . . . . . . . . . . . . . . . . . . . 461

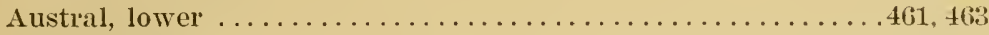

Austral, upper ............................ 461

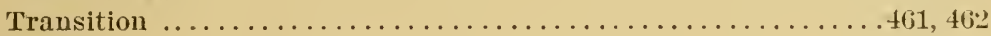

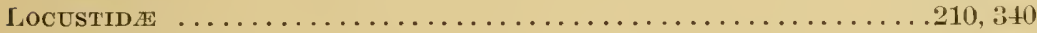

Locust, American . . . . . . . . . . . . . . . . . . . . . . . 290

ash brown .............................. 279

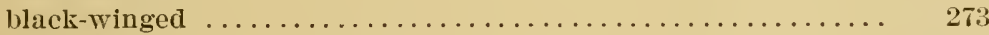

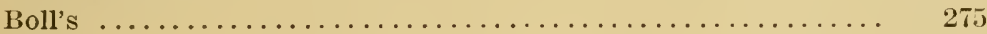

Carolina ............................... 273

clear-winged ............................. 262

clouded ....................................... 260

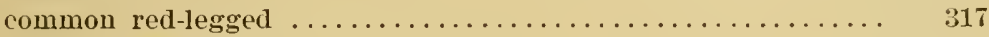

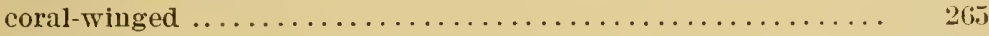

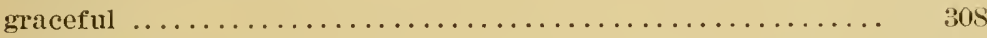

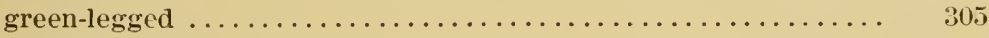

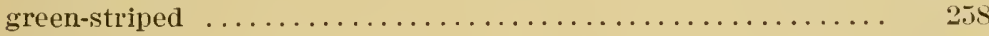

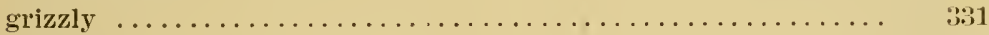

Haldeman's $\ldots \ldots \ldots \ldots \ldots \ldots \ldots \ldots \ldots \ldots \ldots \ldots \ldots \ldots . \ldots \ldots$

haudsome $\ldots \ldots \ldots \ldots \ldots \ldots \ldots \ldots \ldots \ldots \ldots \ldots \ldots \ldots \ldots \ldots$

hoosiel $\ldots \ldots \ldots \ldots \ldots \ldots \ldots \ldots \ldots \ldots \ldots \ldots \ldots \ldots \ldots \ldots \ldots$. $\ldots \ldots \ldots$

Kausas $\ldots \ldots \ldots \ldots \ldots \ldots \ldots \ldots \ldots \ldots \ldots \ldots \ldots \ldots \ldots \ldots \ldots$

leather-colored ............................ 294

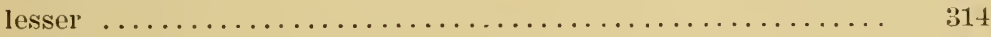

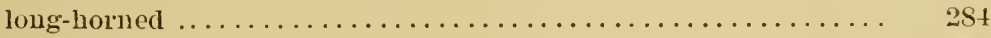

lubberly . .......................... 270,32 ;

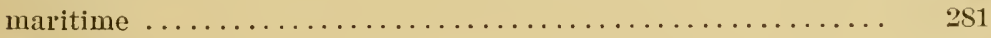

Mlorse's ................................... $30 ! 1$

mottled sand $\ldots \ldots \ldots \ldots \ldots \ldots \ldots \ldots \ldots \ldots \ldots \ldots \ldots \ldots \ldots \ldots \ldots$

narrow-winged $\ldots \ldots \ldots \ldots \ldots \ldots \ldots \ldots \ldots \ldots \ldots \ldots \ldots \ldots \ldots \ldots$

obovate-winged $\ldots \ldots \ldots \ldots \ldots \ldots \ldots \ldots \ldots \ldots \ldots \ldots \ldots \ldots \ldots$

orange-winged $\ldots \ldots \ldots \ldots \ldots \ldots \ldots \ldots \ldots \ldots \ldots \ldots \ldots \ldots \ldots$

Rocky mountain ............................. 300

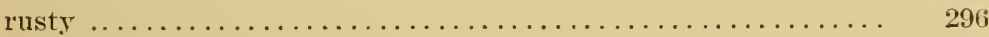

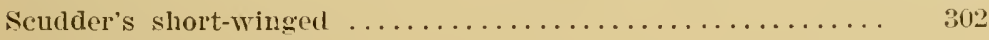

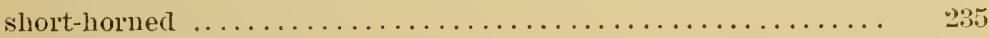

sliort-winged brown ........................ 246

short-winged green ........................ 238

slender bodied .............................. $28 s$

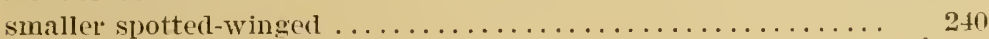

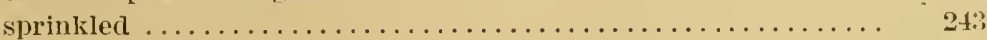

sulphur-winged $\ldots \ldots \ldots \ldots \ldots \ldots \ldots \ldots \ldots \ldots \ldots \ldots \ldots \ldots \ldots \ldots \ldots . \ldots . \ldots . \ldots \ldots$

yellow-striped $\ldots \ldots \ldots \ldots \ldots \ldots \ldots \ldots \ldots \ldots \ldots \ldots \ldots \ldots \ldots \ldots$

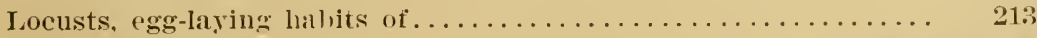

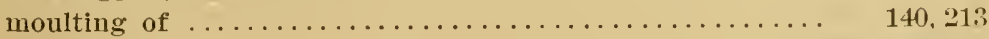

stridulatiou of $\ldots \ldots \ldots \ldots \ldots \ldots \ldots \ldots \ldots \ldots \ldots \ldots \ldots \ldots \ldots$ 
MANTIDA

167,198

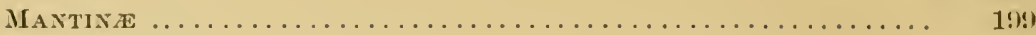

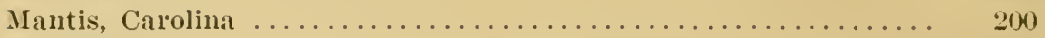

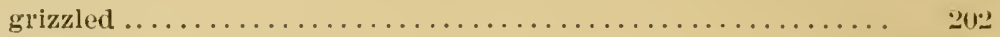

Mecostethus . . . . . . . . . . . . . . . . . . . . . . .234, 249

lineatus . . . . . . . . . . . . . . . . . . . . .

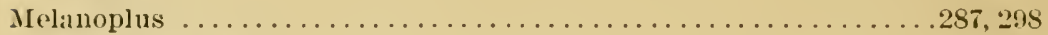

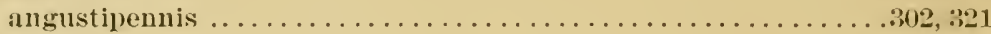

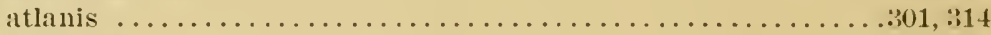

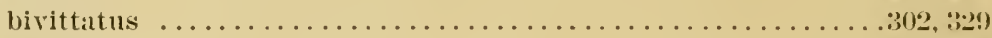

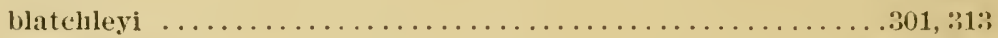

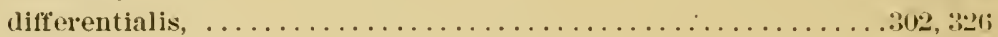

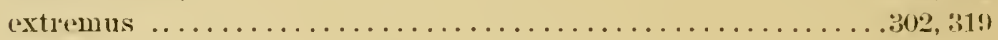

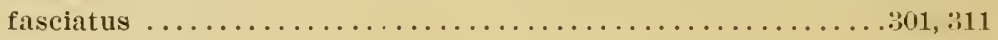

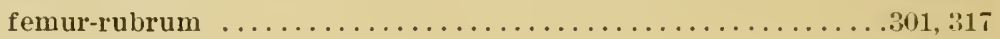

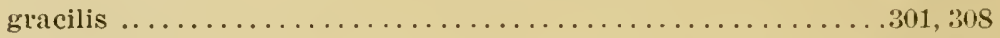

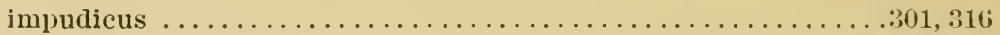

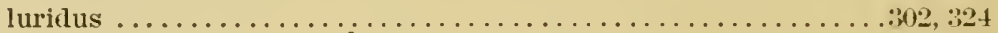

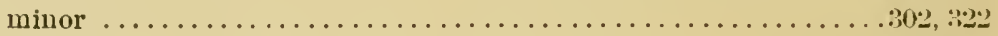

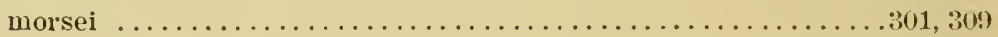

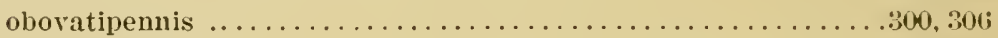

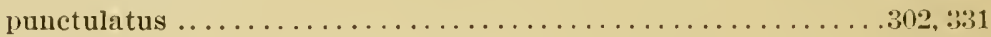

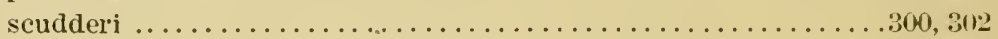

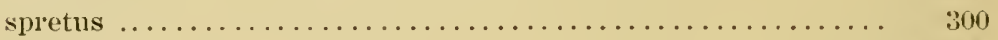

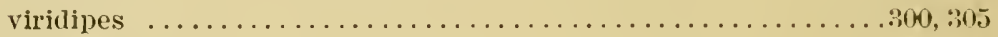

Mestobregma $\ldots \ldots \ldots \ldots \ldots \ldots \ldots \ldots \ldots \ldots \ldots \ldots \ldots \ldots \ldots \ldots \ldots \ldots \ldots \ldots . .254,270$

cinctum .................................. 27

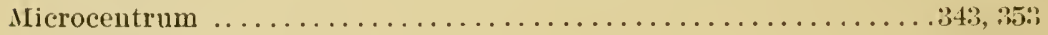

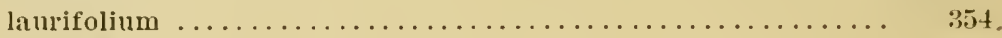

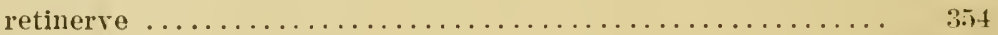

Miogryllus . . . . . . . . . . . . . . . . . . . . . . .419, 44:

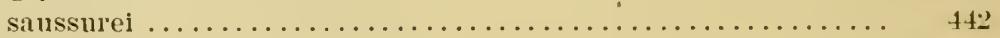

Mole cricket ................................ 410

Myrmecophila $\ldots \ldots \ldots \ldots \ldots \ldots \ldots \ldots \ldots \ldots \ldots \ldots \ldots \ldots \ldots \ldots \ldots \ldots \ldots$

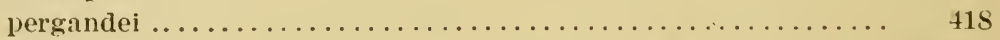

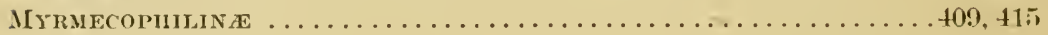

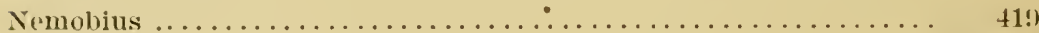

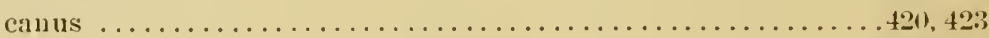

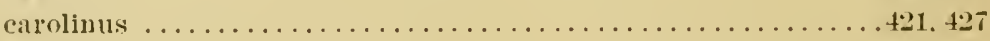

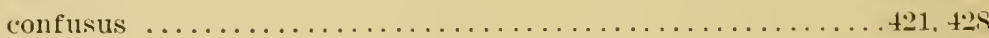

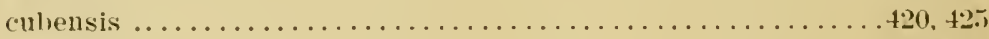

exiguus . . . . . . . . . . . . . . . . . . . . .

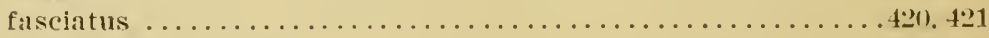

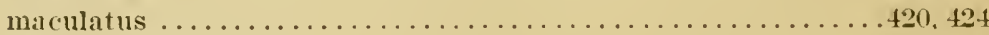

palustris ..............................421, 427

Neotettix ...............................218, 224i

hancocki .............................. 221;

Nomotettix .................................217.218

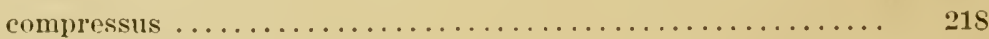

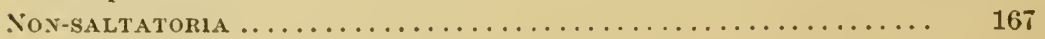


GCANTHIN ...............................409.448

Ecanthus .................................. 444

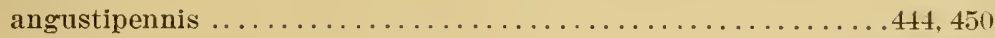

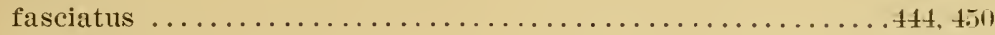

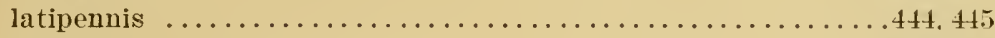

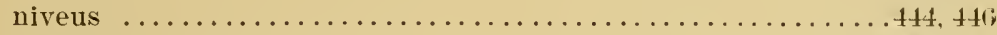

quadripunctatus . . . . . . . . . . . . . . . . . . . . . . . . . . . . . 452

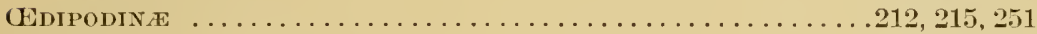

Oötheca ................................. 173

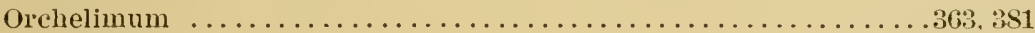

campestre ................................

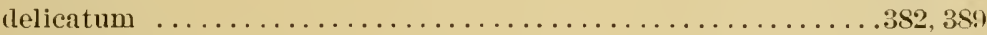

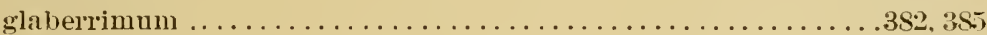

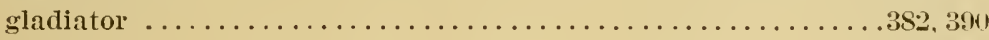

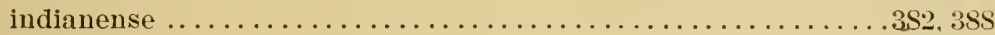

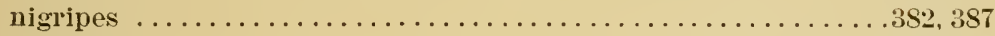

volantum $\ldots \ldots \ldots \ldots \ldots \ldots \ldots \ldots \ldots \ldots \ldots \ldots \ldots \ldots \ldots \ldots \ldots$

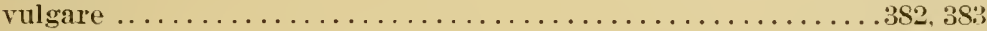

Orchesticus . . . . . . . . . . . . . . . . . . . . . . . 392

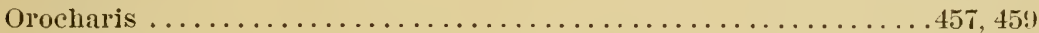

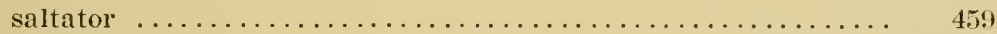

Orphulella . . . . . . . . . . . . . . . . . . . . . . . 284, 289

pelidna $\ldots \ldots \ldots \ldots \ldots \ldots \ldots \ldots \ldots \ldots \ldots \ldots \ldots \ldots \ldots \ldots \ldots$

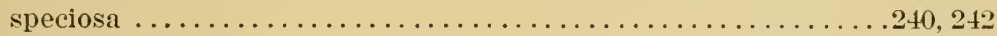

Orthoptera, enemies of ....................... 141

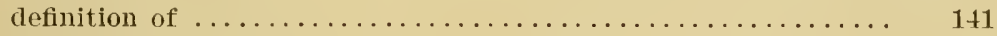

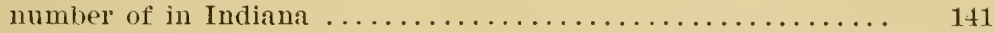

number of in the United States................... 141

Parasites of locusts, animal..................... 143

vegetable ................................ 142

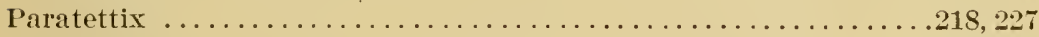

cucullatus ............................ $22 \mathrm{t}$

Paroxya . . . . . . . . .

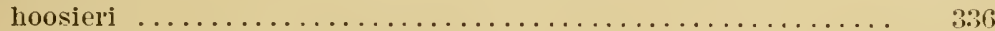

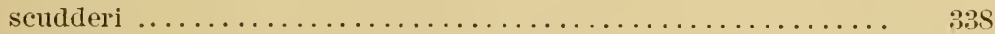

Periplaneta . . . . . . . . . . . . . . . . . . . . . . . 192, 19.

americana .............................. 195

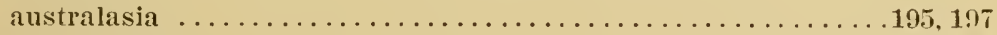

Periplanetinte . . . . . . . . . . . . . . . . . . . . . 175. 1!)1

Pilaneropterina $\ldots \ldots \ldots \ldots \ldots \ldots \ldots \ldots \ldots \ldots \ldots \ldots \ldots \ldots \ldots$

Phasmidat . . . . . . . . . . . . . . . . . . . . . . . . . 168, 203

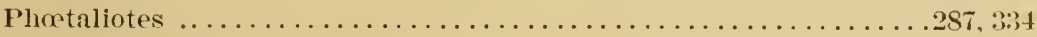

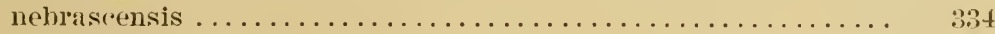

Pliylloscirtus . . . . . . . . . . . . . . . . . . . . . . . . . . . . . . . . 454

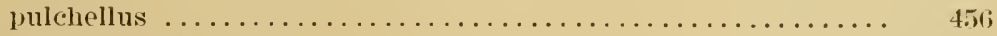

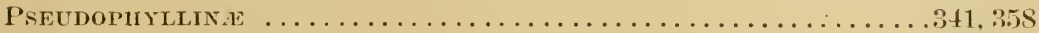

Psinidia $\ldots \ldots \ldots \ldots \ldots \ldots \ldots \ldots \ldots \ldots \ldots \ldots \ldots \ldots \ldots \ldots \ldots \ldots . . \ldots \ldots$

fenestralis $\ldots \ldots \ldots \ldots \ldots \ldots \ldots \ldots \ldots \ldots \ldots \ldots \ldots \ldots \ldots$ 


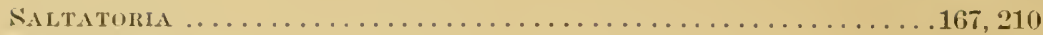

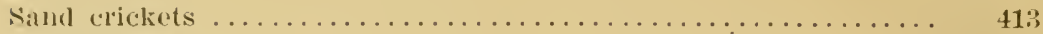

Schistocerea . . . . . . . . . . . . . . . . . . . . . . . 28, 289

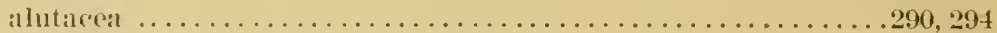

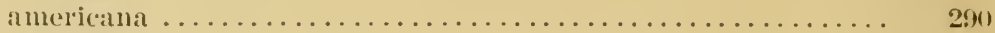

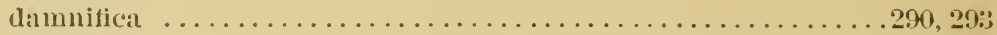

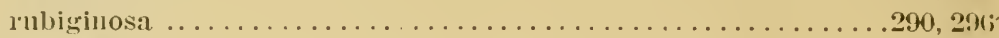

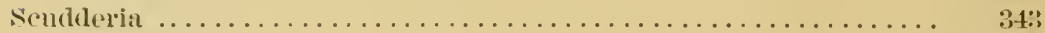

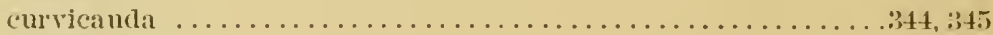

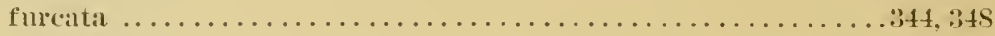

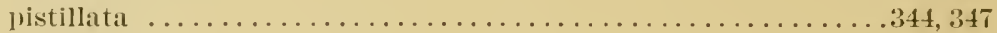

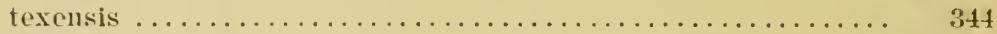

spharagemon $\ldots \ldots \ldots \ldots \ldots \ldots \ldots \ldots \ldots \ldots \ldots \ldots \ldots \ldots \ldots \ldots \ldots \ldots$

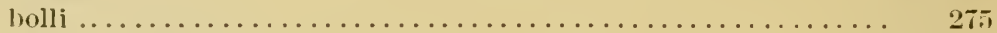

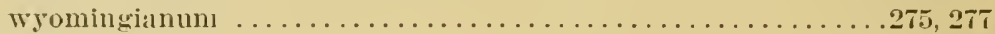

Stagmomantis ........................... 19!

carolinat ............................... 200

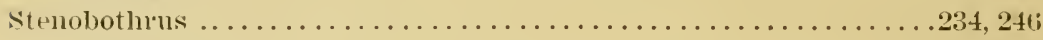

curtipennis ................................... 241

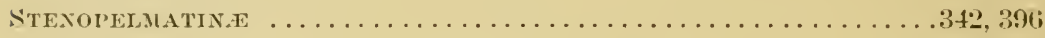

Syobula $\ldots \ldots \ldots \ldots \ldots \ldots \ldots \ldots \ldots \ldots \ldots \ldots \ldots \ldots \ldots \ldots \ldots \ldots \ldots$

almirabilis $\ldots \ldots \ldots \ldots \ldots \ldots \ldots \ldots \ldots \ldots \ldots \ldots \ldots \ldots \ldots \ldots$

Temnopteryx $\ldots \ldots \ldots \ldots \ldots \ldots \ldots \ldots \ldots \ldots \ldots \ldots \ldots \ldots \ldots \ldots \ldots$

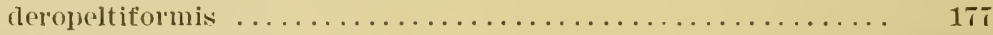

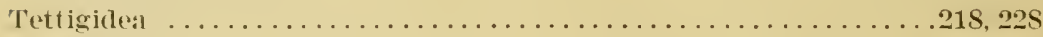

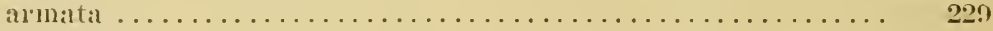

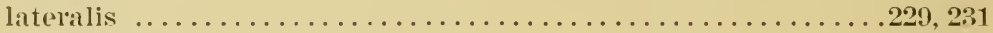

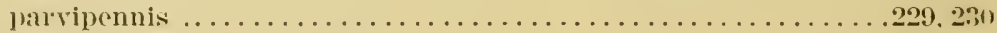

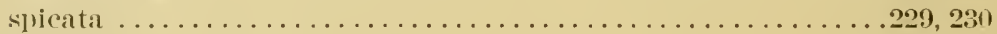

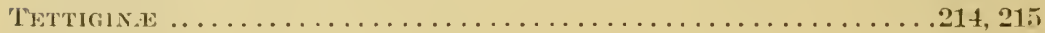

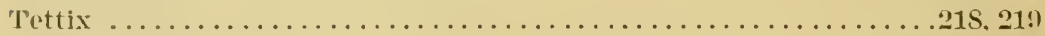

arenosus $\ldots \ldots \ldots \ldots \ldots \ldots \ldots \ldots \ldots \ldots \ldots \ldots \ldots \ldots \ldots \ldots . . \ldots \ldots .224$

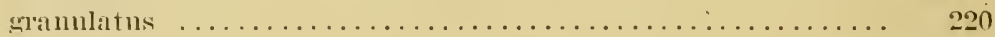

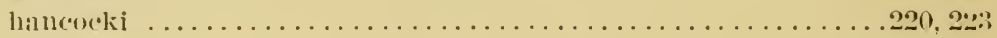

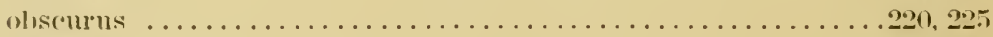

(1)uatus . . . . . . . . . . . . . . 220. 20.2

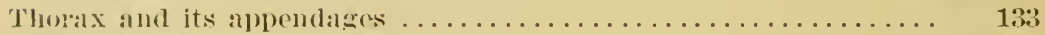

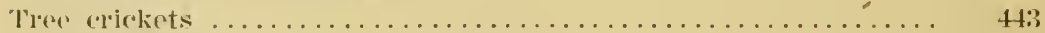

brond-winged . . . . . . . . . . . . . . . . . . . . 44

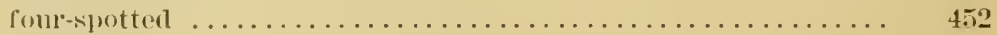

lialudsume $\ldots \ldots \ldots \ldots \ldots \ldots \ldots \ldots \ldots \ldots \ldots \ldots \ldots \ldots \ldots \ldots \ldots \ldots$

jumping . . . . . . . . . . .

natrow-twinged $\ldots \ldots \ldots \ldots \ldots \ldots \ldots \ldots \ldots \ldots \ldots \ldots \ldots \ldots \ldots$

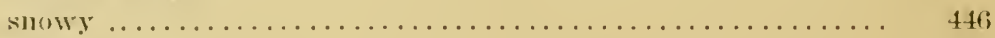

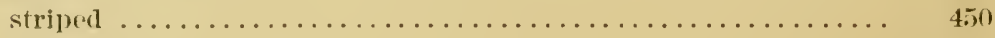

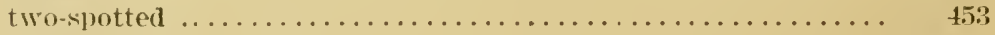

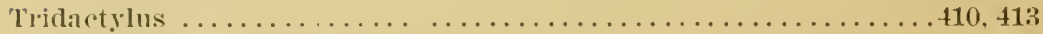

apicalis .............................. 414 
T'Rigonidina

Trimerotropis

citrina

281, 282

maritima

TRysaline

Tryxalis 233,234

brevicolnis

Veins of wings of a locust.

Walkingsticks . . . . . . . . . . . . . . . . . . . . . . . 203

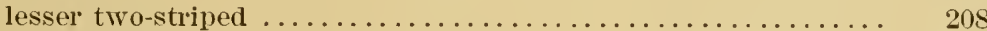

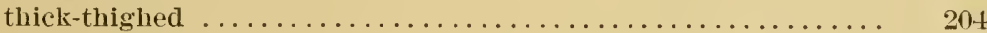

Wings of the locust $\ldots \ldots \ldots \ldots \ldots \ldots \ldots \ldots \ldots \ldots \ldots \ldots \ldots \ldots \ldots \ldots$

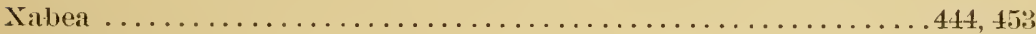

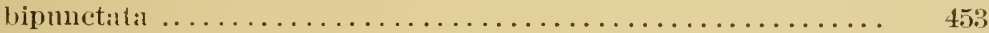

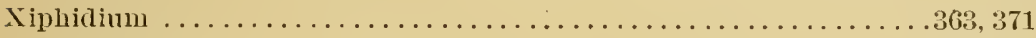

attenuatum . . . . . . . . . . . . . . . . . . . . . 372,379

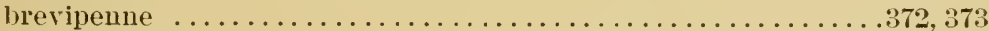

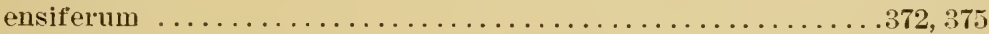

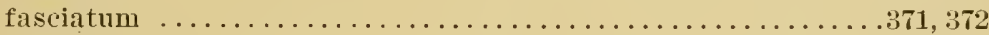

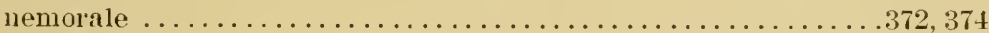

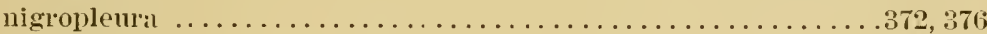

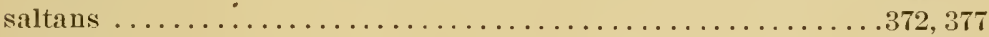

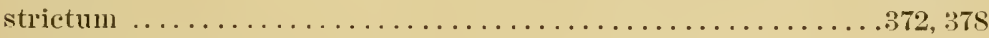

Kones, life, of Indianil.......................... 461 



SMITHSONIAN INSTITUTION LIBRARIES

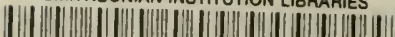

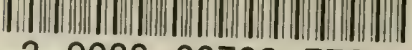

$3908800722 \quad 7762$ 